rapport 2014:4

Folkehelserapporten 2014

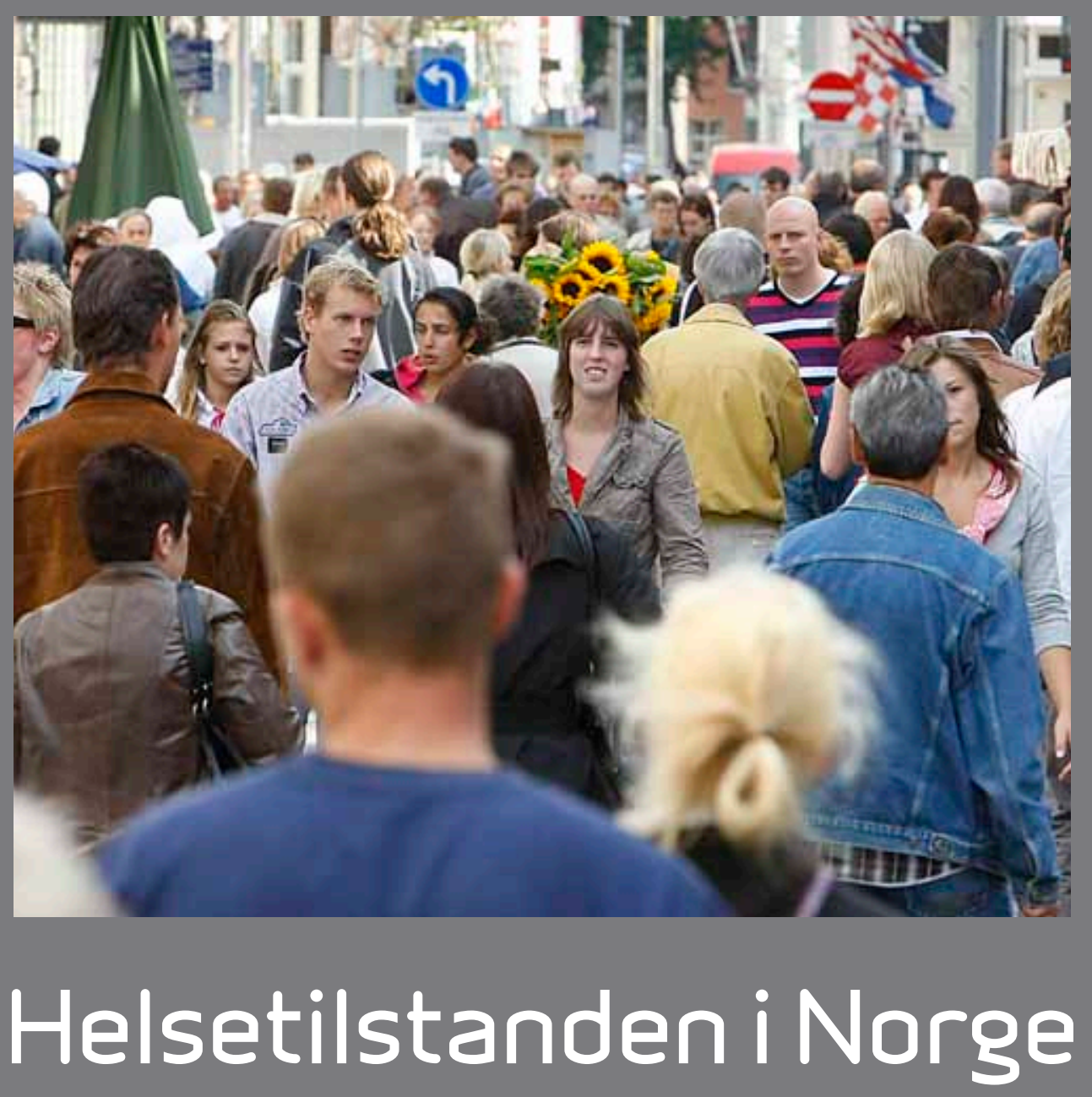

- folkehelseinstituttet 


\section{rapport 2014:4}

Folkehelserapporten 2014

Helsetilstanden i Norge

$\bullet^{\circ}$ folkehelseinstituttet 


\section{Rapport 2014:4}

Nasjonalt folkehelseinstitutt

\section{Tittel:}

Folkehelserapporten 2014

Helsetilstanden i Norge

Ansvarlig redakter for Folkehelserapporten 2014:

Camilla Stoltenberg

\section{Arbeidsredaksjonen:}

Else Karin Grøholt (leder), Hanna Hånes og Anne Reneflot

Utgitt av Nasjonalt folkehelseinstitutt

Postboks 4404 Nydalen

0403 Oslo

Desember 2014

Tel: +47-21 07 7000

E-post: folkehelseinstituttet afhi.no

www.fhi.no

\section{Bestilling:}

E-post: publikasjon afhi.no

Telefon: +47-21078200

Telefaks: +47-21078105

\section{Design:}

Per Kristian Svendsen

Layout:

Grete Soimer

\section{Foto side 15:}

Koppevaksinering i Folkets hus 1907.

Arbeiderbevegelsens arkiv

\section{Foto side 29:}

Historisk arkiv i Bergen, Jimmi Linus/Nasjonalt Folkehelseinstitutt

\section{Illustrasjonsfoto:}

\section{o Colourbox}

\section{Trykk:}

wj.no

Opplag:

1000

ISSN: $1503-1403$

ISBN: 978-82-8082-635-o trykt utgave

ISBN: 978-82-8082-636-7 elektronisk utgave 


\section{Bedre helse for alle!}

Loven om folkehelsearbeid ble iverksatt i 2012 og tar for seg fem viktige prinsipper; medvirkning, bærekraft, helse i alt vi gjør, føre var og sosial utjevning.

Loven pålegger kommuner og fylker å ha oversikt over helsetilstanden til innbyggerne, og følge med på hvordan den utvikler seg over tid. For å støtte kommuner, fylker og nasjonale myndigheter med dette, utarbeider Folkehelseinstituttet årlige folkehelseprofiler for kommuner og fylker. Vi lager også en statusrapport som skal utgis hvert fjerde år, og som skal holdes oppdatert i elektroniske versjoner.

Målene for folkehelsearbeidet ble første gang presentert i Folkehelsemeldingen

«God helse - felles ansvar»:

- Norge skal være blant de tre landene i verden med høyest levealder.

- Befolkningen skal oppleve flere leveår med god helse og trivsel .

- Vi skal skape et samfunn som fremmer helse for hele befolkningen og reduserer sosiale helseforskjeller.

Folkehelserapporten 2014 kan gi oss svar på hvor vi står i forhold til disse målene i dag. I tillegg vil den kunne gi oss en indikasjon på hvilke utfordringer og muligheter som venter oss. Rapporten vil også bli brukt i arbeidet med en ny stortingsmelding om folkehelse som kommer våren 2015.

Helsetilstanden anno 2014 beskrives i Folkehelserapporten ved hjelp av eksisterende data og analyser fra mange ulike kilder. Datagrunnlaget er hovedsakelig registre og helseundersøkelser. Analysene er utført i ulike forskningsmiljøer med forskjellige tilnærminger. Temaene omfatter psykisk og fysisk helse, ikke-smittsomme og smittsomme sykdommer, sosial ulikhet i helse, trivsel og helsefremmende forhold. Påvirkningsfaktorer som kosthold, fysisk aktivitet, tobakk, alkohol og andre rusmidler er også en viktig del av rapporten.

Helsetilstanden i Norge er svært god. Vi har en høy levealder som stadig øker, og vi rangeres på topp i internasjonale sammenligninger om trivsel og velferd. Men vi har sett en økende sosial ulikhet i dødelighet siden 1960-tallet. Det kan se ut som om disse forskjellene er i ferd med å avta, men etter hvert som mange vil leve lenge med sykdom og plager som gir helsetap, kan nye former for ulikhet oppstå. I tillegg får vi nye utfordringer og muligheter i form av et mer mangfoldig samfunn, globalisering og miljøtrusler.

Norge skal være blant de tre landene i verden med høyest levealder, slik vi var på 1950-tallet. Skal vi klare det, må vi vite hvor mulighetene for forebygging og et helsefremmende samfunn finnes. 
Den nye nasjonale strategien «HelseOmsorg21» ble presentert i juni 2014. Visjonen for strategien er kunnskap, innovasjon og næringsutvikling for bedre folkehelse. Strategien peker på behovet for bedre helsedata, bedre tilgang til data, og oppdaterte analyser som når fram til de som skal bruke kunnskapen. For at vi skal få mer kunnskap om helse, er det behov for et kommunalt helse- og omsorgsregister og helseundersøkelser med spørsmål om levevaner og folks opplevelse av egen helse. I tillegg er det behov for mer avanserte analyser, som kan gi et bedre grunnlag for åpne diskusjoner, medvirkning og beslutninger.

Vi trenger kunnskap om

- Forekomst og fordeling av trivsel, sykdom, død og forhold som påvirker dette.

- Årsaker til sykdom.

- Effekten av og kostnadene ved folkehelsetiltak.

I denne rapporten har vi beskrevet mange ulike sykdommer og dødsårsaker, og forhold som påvirker dem. Vi har imidlertid ikke sammenlignet dem systematisk med hverandre, eller rangert deres betydning for å nå folkehelsemålene.

Den første sykdomsbyrdeanalysen for Norge ble publisert av det internasjonale sykdomsbyrdeprosjektet ved Institute of Health Metrics and Evaluation (IHME) i 2013. Våren 2015 vil det bli publisert oppdaterte analyser som vi vil bruke til å gi en mer helhetlig beskrivelse av helsetilstanden og forhold som påvirker den.

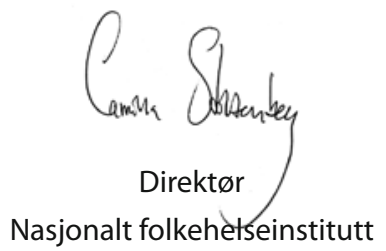




\section{Redaksjonen}

Ansvarlig redaktør for Folkehelserapporten 2014:

Camilla Stoltenberg

\section{Arbeidsredaksjonen:}

Else Karin Grøholt (leder), Hanna Hånes og Anne Reneflot

\section{Fagredaksjonen:}

Toril Attramadal, Divisjon for miljømedisin.

Bjørn Magne Eggen, Divisjon for rettsmedisinske fag.

Ellinor F. Major, Divisjon for psykisk helse.

Hanne Nøkleby og John-Arne Røttingen, Divisjon for smittevern.

Eva Skovlund, Divisjon for epidemiologi.

\section{Hjelp med referanselister:}

Tiril Borge, Grace Lubega, Bo Valentin.

Forfattere er listet opp etter hver enkelt artikkel. Hovedforfatter står først, deretter følger øvrige forfattere alfabetisk. Dersom ikke annet er nevnt, arbeider forfatterne ved Folkehelseinstituttet.

\section{Statistikk:}

Folkehelserapporten 2014 beskriver helsetilstanden i Norge ved hjelp av eksisterende data og analyser fra mange ulike kilder nasjonalt og internasjonalt.

Datagrunnlaget er for det meste registre og helseundersøkelser. Kilde til statistikk framgår av illustrasjoner og tekst.

\section{Webversjon:}

Første del av Folkehelserapporten 2014 ble publisert på www.fhi.no/folkehelserapporten den 30. juni 2014. Andre del ble publisert i september 2014.

Papirversjonen er basert på siste versjon av nettutgaven. For ny versjon av kapitler, retting av feil m.m., se http://www.fhi.no/publikasjoner-og-haandboker/folkehelserapporten/oppdateringer

\section{Kontakt}

For kommentarer og innspill til redaksjonen: kontakt nettredaksjon@fhi.no

Pressehenvendelser rettes direkte til Folkehelseinstituttets medievakt: telefon 21078300. 


\section{Innhold}

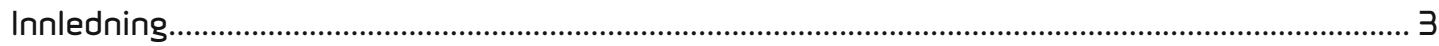

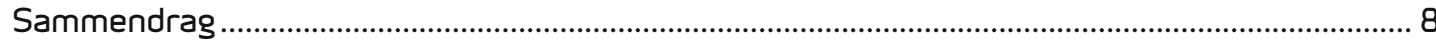

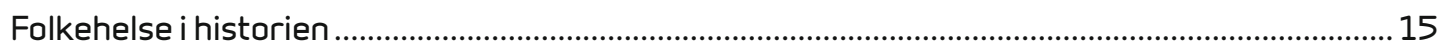

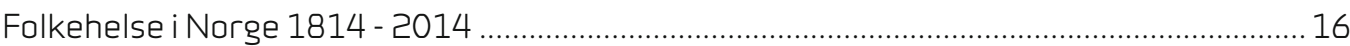

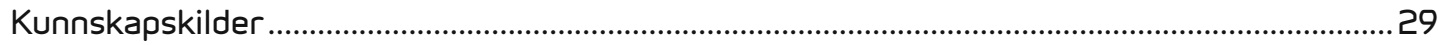

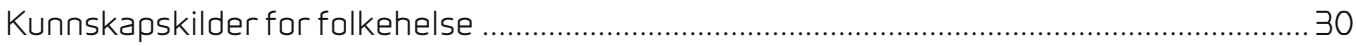

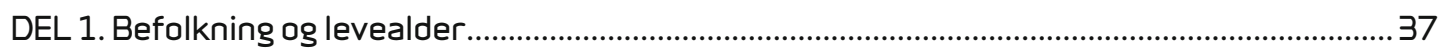

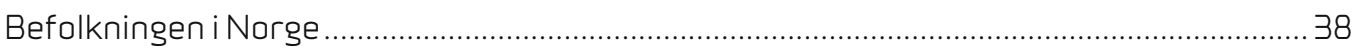

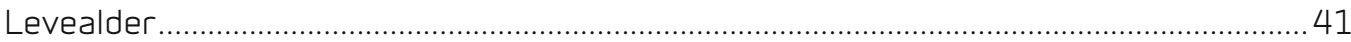

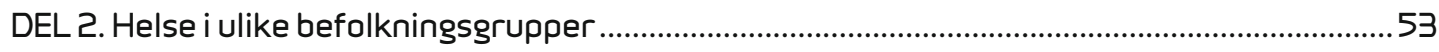

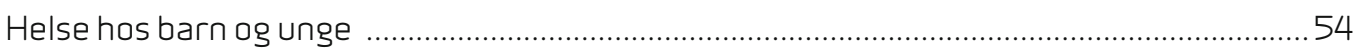

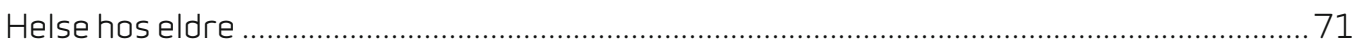

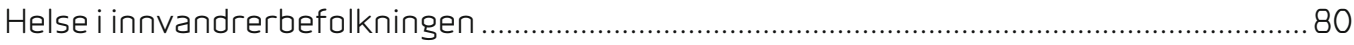

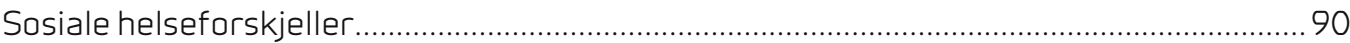

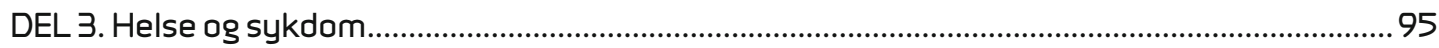

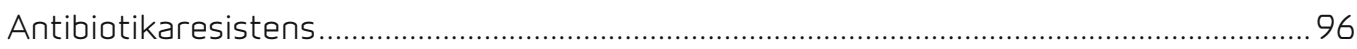

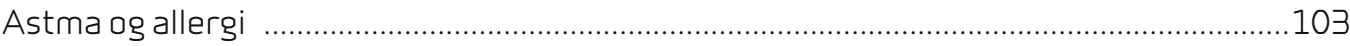

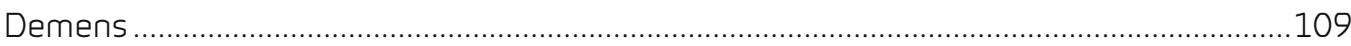

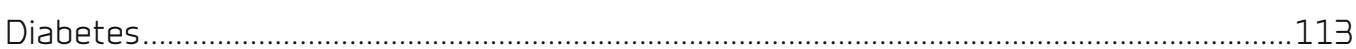

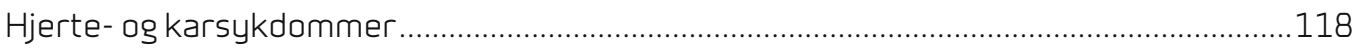

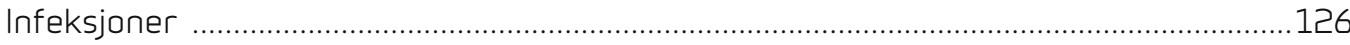

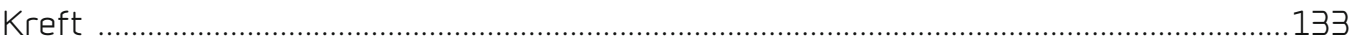

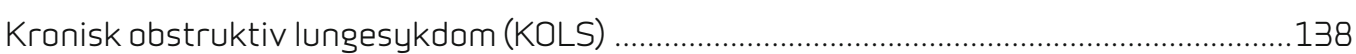

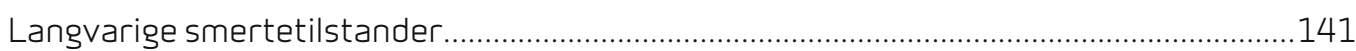

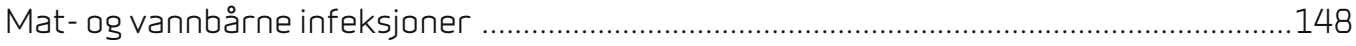

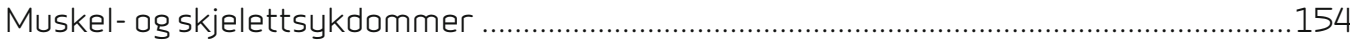

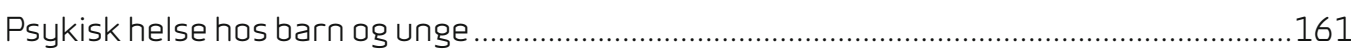




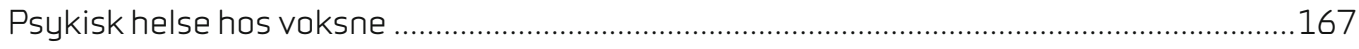

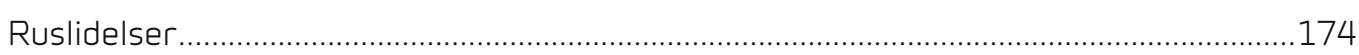

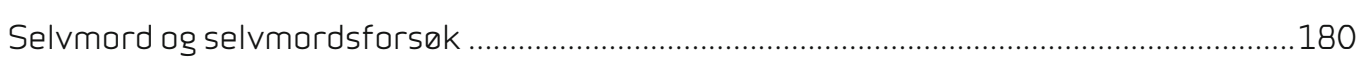

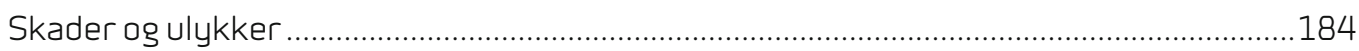

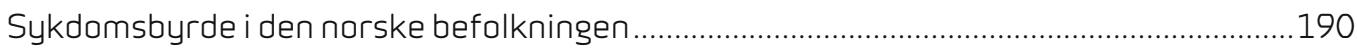

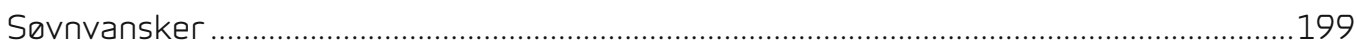

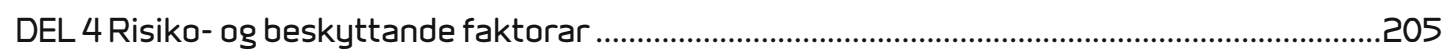

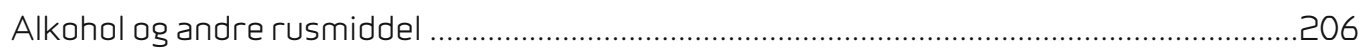

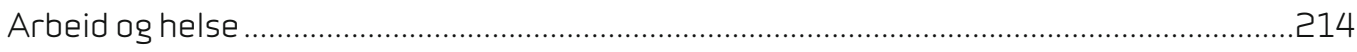

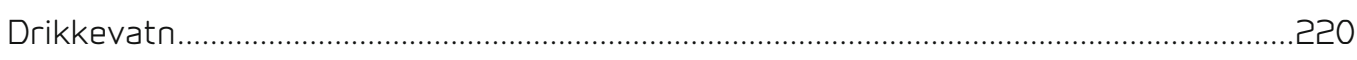

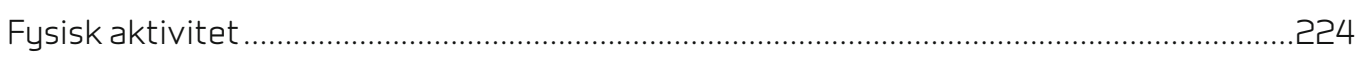

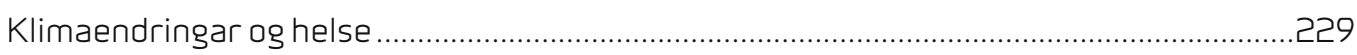

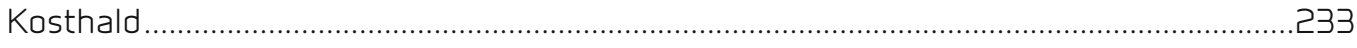

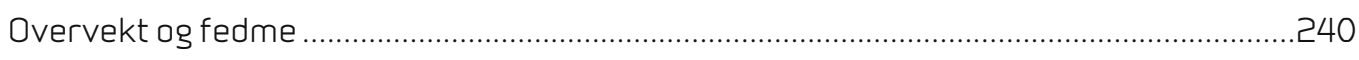

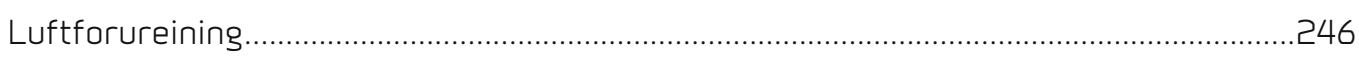

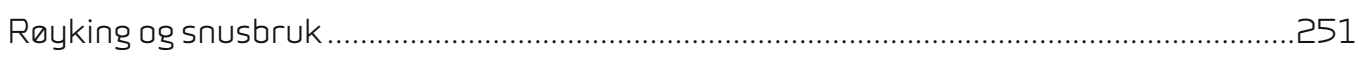

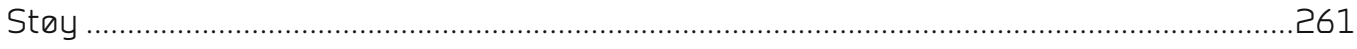

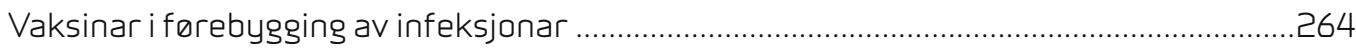




\section{Sammendrag}

\section{Befolkning}

Folketallet i Norge var ved årtusenskiftet i underkant av 4,5 millioner, og i løpet av 2012 passerte vi 5 millioner innbyggere.

Befolkningsutviklingen preges av at fruktbarheten er forholdsvis høy, det er høy innvandring, sterk urbanisering, mange lever alene og andelen eldre øker.

Innvandrere og norskfødte med innvandrerforeldre utgjør rundt 14 prosent av befolkningen. Antallet innvandrere forventes å vokse fra 0,55 millioner i 2012 til rundt 1,3 millioner i 2050. Om lag 320000 innvandrere kommer fra Europa og 240000 fra Afrika og Asia.

Eldre over 70 år utgjør rundt 10 prosent av befolkningen, mens de forventes å utgjøre rundt 20 prosent i 2070.

En mer mangfoldig befolkning vil gi nye folkehelseutfordringer i årene som kommer.

\section{Levealder og sykdomsbyrde}

I 2013 var forventet levealder i Norge 83,6 år for kvinner og 79,9 år for menn. På 1950-tallet hadde Norge den høyeste forventete levealder i verden. I 2009 lå norske kvinner på 12. plass 3,4 år bak japanske kvinner, mens norske menn lå på 9. plass 1,1 år bak australske menn.

Det internasjonale sykdomsbyrdeprosjektet viser at to av tre tapte leveår i Norge skyldes kreftsykdommer eller hjerte- og karlidelser. Hjertesykdom, hjerneslag, lungekreft, tykktarmskreft og KOLS er de fem største årsakene til tapte leveår. Kjente risikofaktorer for disse sykdomsgruppene er usunt kosthold, røyking, skadelig alkoholforbruk og stillesitting.

Sykdomsbyrdeprosjektet viser også at psykiske lidelser, smertetilstander og lårhalsbrudd bidrar til helsetap. De fem ledende årsakene til år levd med helsetap i Norge er korsryggsmerter, alvorlig depresjon, angstlidelser, nakkesmerter og fallulykker med påfølgende bruddskader.

\section{Sosiale helseforskjeller}

I internasjonal sammenheng er den norske folkehelsa god. Men bak gjennomsnittstallene skjuler det seg store forskjeller i sykelighet og dødelighet. Jo bedre utdanning og økonomi, jo bedre helse. De med lengst utdanning og best økonomi har best helse.

Når det gjelder levealder, ser vi for eksempel at den har økt for alle utdanningsgrupper siden 1960-tallet, men gruppene med lang utdanning har hatt den beste utviklingen. For menn ser det ut til at disse forskjellene har blitt mindre etter år 2000. For kvinner øker derimot forskjellene i levealder fremdeles, og kvinner med lav utdanning har hatt den dårligste utviklingen i levealder sammenlignet med andre grupper. Mye av dette kan tilskrives en økende sosial forskjell i dødelighet av de røykerelaterte lungesykdommene lungekreft og KOLS. 


\section{Helse i innvandrerbefolkningen}

Kunnskapen om innvandrerbefolkningens helse er mangelfull. Den kunnskapen vi har tyder på at det er store helsemessige forskjeller mellom ulike innvandrergrupper. Diabetes er utbredt blant innvandrere fra Sri Lanka og Pakistan. Kvinner fra land med høy forekomst av diabetes, har spesielt høy risiko for å utvikle svangerskapsdiabetes. I flere innvandrergrupper er overvekt og fedme utbredt. D-vitaminmangel er utbredt blant innvandrere fra noen lav- og middelinntektsland.

Særlig innvandrere fra lavinntektsland i Afrika og Asia har økt risiko for enkelte infeksjonssykdommer. Dette skyldes økt infeksjonsrisiko i forbindelse med besøk i tidligere hjemland.

Voksne innvandrere og barn og voksne med flyktningebakgrunn rapporterer om mer psykiske helseplager enn etnisk norske.

\section{Helse hos barn og unge}

Andelen barn og unge under 18 år utgjør om lag 22 prosent av befolkningen i Norge og totalt cirka 1125000 personer.

Norske barn har svært god helse i et globalt perspektiv. Sammen med andre nordiske land er vi blant de landene som har aller lavest spedbarnsdødelighet. Det samme gjelder dødelighet for barn under 5 år. Dette er indikatorer som UNICEF benytter som de viktigste når det gjelder barnehelse.

Grunnlaget for god helse i barneårene og voksen alder starter allerede før fødselen. Til tross for god helse i et globalt perspektiv har vi i Norge noen utfordringer. Mindre enn 3 av 10 gravide tar folattilskudd den siste måneden før graviditeten, slik som anbefalt. Tilskudd kan forebygge medfødte nevralrørsdefekter (ryggmargsbrokk). Det er gledelig at stadig færre kvinner røyker i svangerskapet, men vi mangler oversikt over gravides bruk av snus og alkohol.

I barne- og ungdomsårene ser vi utfordringer knyttet til ulykker, for lav fysisk aktivitet, overvekt og kosthold, samt psykisk helse. Ulykker er årsak til om lag 10 prosent av alle dødsfall i aldersgruppen 0-17 år. 15-20 prosent av barn og unge mellom 3 og 18 år har psykiske plager som angst, depresjon og atferdsproblemer.

30 prosent fullfører ikke videregående skole. Frafall i videregående skole har betydning for helsen gjennom hele livsløpet.

\section{Helse hos eldre}

Vi vil få en firedobling av antall 80-89-åringer innen utgangen av dette århundret. Færre vil dø av hjertesykdom, men flere vil leve med kroniske sykdommer i eldre år, slik som hjertesvikt, kreft og demens. Forekomsten av benbrudd er spesielt høy i Norge. 
De individuelle forskjellene i fysisk og psykisk funksjon blant eldre er store. Dersom det legges til rette for at flest mulig eldre får en fin alderdom med god helse og godt funksjonsnivå, kan flere stå lengre i arbeid og ha mindre behov for hjelp. Utdanning og økonomi har betydning også for eldres helse.

Morgendagens eldre kan sannsynligvis ikke direkte sammenliknes med gårsdagens eldre. Bedre levekår, forandret livsstil både med hensyn til fysisk aktivitet og endrede røykevaner, samt bedre helsetjeneste er viktige årsaker til dette. Kanskje er eldre i framtiden samlet sett friskere og mer funksjonsdyktige enn forrige generasjon eldre.

Fire nøkkelfaktorer er viktige for helse i eldre år: høy kognitiv aktivitet, høy fysisk aktivitet, et aktivt sosialt liv og et godt kosthold.

\section{Ikke-smittsomme sykdommer}

Sykdomsbildet i Norge er preget av ikke-smittsomme sykdommer som hjerte- og karsykdommer, type 2 diabetes, overvekt/fedme, KOLS og kreft. Om lag 225000 personer lever med kreft og om lag 200000 anslås å leve med diabetes. Antallet personer som får kreft forventes å øke med 10-20 prosent i årene 2011 - 2016.

Økningen i forekomst av ikke-smittsomme sykdommer har sammenheng med at vi lever lengre, og at samfunnsmessige endringer påvirker levevanene våre.

Det er nå tegn til at økningen i overvekt og fedme har stoppet opp hos barn, og det er tegn til at økningen i fedme er blitt mer moderat hos voksne. Nivået er likevel vesentlig høyere enn på 1980-tallet.

Røyking tar fortsatt mange liv og mange friske leveår, og vi vil i Norge se en fortsatt økning i røyke-relaterte sykdommer som lungekreft og KOLS, spesielt hos kvinner. For menn ser vi en avflating i forekomst, fordi nedgangen i røyking kom tidligere hos menn enn hos kvinner.

Når det gjelder hjerte- og karsykdommer, har det vært en sterk nedgang i dødsfall som følge av hjerte- og karsykdommer totalt sett de siste 40 årene. Vi ser nå en økning i sykehusinnleggelser for akutt hjerteinfarkt hos yngre voksne. De absolutte tallene er ikke store, men økningen gir grunn til årvåkenhet. Dette er en påminnelse om behovet for forebygging.

Ny kunnskap om demenslidelser tyder på at også undergrupper av demens har sammenheng med tilstanden i hjernens blodårer. Tiltak som forebygger hjerte- og karsykdommer kan trolig også forebygge eller utsette enkelte former for demens.

Medisinske framskritt og bedre behandling av akutt hjerteinfarkt og hjerneslag, kreft og diabetes har medført at mange mennesker får mange ekstra leveår. Sammen med økt antall eldre i befolkningen innebærer det samtidig at antallet personer med kroniske sykdommer øker. Et uttrykk for denne sykdomsbyrden er at 7550 pasienter hadde over 10000 sykehusopphold på grunn av hjertesvikt i 2012. 
Spesielt i den eldre delen av befolkningen vil mange ha to eller flere kroniske sykdommer samtidig, for eksempel KOLS og hjertesykdom, eller en psykisk lidelse og hjertesykdom.

Hoftebrudd er hyppigere i Norge enn i mange andre land, men det ser nå ut til at hyppigheten har gått ned. Likevel vil trolig også antallet hoftebrudd øke i årene framover på grunn av et økt antall eldre i befolkningen.

\section{Nikotinavhengighet og nikotin i svangerskapet}

Antallet og andelen i befolkningen som røyker daglig eller av og til har gått betydelig ned, men røyking er fortsatt et stort helseproblem. Om lag 15 prosent av kvinner og menn røyker daglig, og 10 prosent av og til. Røyking hos gravide har gått ned, men det er fortsatt 5 - 8 prosent som røyker i svangerskapet.

Bruken av snus har økt kraftig. Nikotin tilført i form av snus er svært avhengighetsskapende. Fordi mange unge kvinner bruker snus, kan dette bety at det blir flere nikotinavhengige gravide. Nikotin fra snus kan medføre veksthemming hos fosteret.

\section{Kosthold og fysisk aktivitet}

Kostholdet i Norge er godt og maten er trygg sammenlignet med mange andre land.

Kostholdet er i stadig endring. Sukkerinntaket er lavere i dag enn for 10 år siden, men nedgangen har stoppet opp. I gjennomsnitt var inntaket $29 \mathrm{~kg}$ sukker per innbygger per år i 2012, men sukkerinntaket er ikke jevnt fordelt. Spesielt har barn og unge et høyt sukkerinntak, og unge i alderen 16-24 år drikker betydelig mer sukkerholdige drikker enn andre grupper.

Kostholdet er sunnere i grupper med lang utdanning eller høy inntekt enn i grupper med dårligere sosioøkonomiske levekår.

Også saltinntaket i befolkningen er høyt, og tre firedeler kommer fra ferdigmat.

Stillesittende arbeid, bilkjøring og mindre krevende husarbeid bidrar til at den fysiske aktiviteten har gått ned. Elektronikk, PCer, sosiale medier og internett tar større plass $\mathrm{i}$ hverdagen og byr på nye utfordringer også når det gjelder søvn og stillesitting.

Bare om lag 30 prosent av den voksne befolkningen oppfyller anbefalingene om fysisk aktivitet, og 30-åringene er minst aktive. Voksne bruker i gjennomsnitt ni timer per dag på stillesitting.

Den fysiske aktiviteten varierer i ulike grupper. Voksne med høgskole- eller universitetsutdanning har et høyere aktivitetsnivå og tilbringer færre timer med stillesitting enn personer med grunnskoleutdanning. 
Verdens helseorganisasjon (WHO) har anslått at endringer i kosthold, fysisk aktivitet og røykevaner kan forebygge 80 prosent av hjerteinfarkt, 90 prosent av type 2 diabetes og over 30 prosent av kreft. Beregninger fra sykdomsbyrdeprosjektet tyder på at kostholdet er en viktig faktor også for sykdomsbyrden i Norge.

De fleste gruppene i befolkningen får i seg nok vitaminer og mineraler, men det er noen utsatte grupper. Blant disse er enkelte innvandrergrupper som har risiko for lavt D-vitamininntak. Dersom alle kvinner tar forebyggende folattilskudd før og i de første månedene av graviditeten, kan antall barn som fødes med ryggmargsbrokk reduseres, viser beregninger.

\section{Psykisk helse}

Norge har sammen med de andre nordiske landene høyest livskvalitet og lykke i verden. Dette gjelder både voksne og ungdom. Opplevelsen av mestring varierer derimot mer mellom nasjoner, og her ligger Norge på det europeiske gjennomsnittet.

Mange vil oppleve dårlig psykisk helse i løpet av livet. Om lag 15 prosent får minst én episode med alvorlig depresjon, og rundt 10 prosent får en periode med skadelig rusmiddelbruk eller rusavhengighet i løpet av livet.

I takt med et økende antall eldre i samfunnet vil det trolig bli økt behov for helsetjenester for psykiske lidelser, herunder demens. Psykiske lidelser hos eldre kan ha andre kjennetegn enn hos yngre.

Personer med psykiske vansker i barne- eller ungdomsårene har økt risiko for å oppleve psykiske plager og psykiske lidelser senere i livet, men for mange er plagene forbigående.

Av de som har én psykisk lidelse vil halvparten ha minst én psykisk lidelse til. Mange som har psykiske lidelser er ikke i kontakt med helsetjenesten for disse lidelsene.

Personer med psykiske lidelser har høyere forekomst av somatiske sykdommer og lever kortere enn befolkningen for øvrig. Bruk av medikamenter, usunn livsstil og selvmord er viktige forklaringer. Hvert år tar omkring 500 personer sitt eget liv.

\section{Rusmidler og ruslidelser}

Antall mennesker med alkoholproblemer og andre rusmiddelproblemer er høyt, mellom 10 og 20 prosent får problemer som følge av skadelig bruk av alkohol eller andre ruslidelser $\mathrm{i}$ løpet av livet.

Rusmidler er også en viktig årsak til at spesielt unge mennesker skades alvorlig i trafikkulykker og andre ulykker. Det er få bilførere som er ruset, men rusnivået er høyt hos dem som det gjelder.

Personer med samtidig rus- og psykiske lidelser er særlig utsatt for ulykker, voldshendelser og tidlig død, og bruk av rusmidler er vanligere blant personer med psykiske lidelser enn ellers i befolkningen. 
Tilgang til rusmidler er den viktigste risikofaktoren for ruslidelser. Folkehelserapporten 2014 viser at alkoholforbruket har økt med 40 prosent de siste 20 årene, og mest blant kvinner og eldre. Alkoholforbruket hos ungdom har gått ned. Tilgangen til ulovlige rusmidler har økt, og blant disse er nye, syntetiske rusmidler som til dels har ukjente virkninger. Det er registrert hjerteinfarkt hos unge mennesker og dødsfall knyttet til bruk av nye syntetiske rusmidler.

\section{Smittsomme sykdommer}

De smittsomme sykdommene har gått tilbake over hele verden. $\varnothing k \mathrm{kt}$ levestandard og bedre hygieniske forhold er en viktig årsak til dette, i tillegg har bruk av vaksiner bidratt. Innføringen av vaksine mot humant papillomavirus (HPV) vil trolig medføre reduksjon i antall tilfeller av kreft i livmorhalsen fremover.

$\varnothing k t$ globalisering, med reising over landegrensene og økt import av matvarer, medfører økning i enkelte smittsomme sykdommer i Norge. Blant disse er matbårne infeksjoner og ulike infeksjoner med antibiotikaresistente bakterier.

Antall nye tilfeller av seksuelt overførbare infeksjoner har økt de siste årene. Dette har blant annet sammenheng med at for få bruker kondom.

I framtiden kan man forvente nye epidemier av influensa som vi ikke har vaksine for i dag. Også andre epidemier kan oppstå. Vi må være forberedt på at nye virus vil gi sykdom hos mennesker eller øke i utbredelse. Derfor er god beredskap nasjonalt og internasjonalt viktig når det gjelder smittsomme sykdommer.

Drikkevannsledningene i Norge er dårlig vedlikeholdt. Antall tilfeller av mat- og vannbårne sykdommer («matforgiftninger») kan få økt omfang dersom ikke drikkevannsledningene vedlikeholdes bedre. 


\section{Folkehelse i historien}

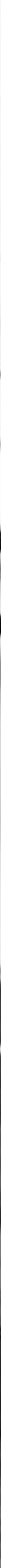




\section{Folkehelse i Norge 1814 - 2014}

Dette kapitlet beskriver utviklingen i folkehelse i 200-årsperioden fra 1814 til 2014.

Første del omhandler 1800-tallet, neste del 1900-tallet og siste del tiden fram til 2014. Fattigdom og smittsomme sykdommer dominerte på 1800-tallet. Utover 1900-tallet økte levestandarden og helseforholdene bedret seg.

\section{Om folkehelse}

Fremveksten av en god folkehelse bygger på utvikling på flere områder:

- Samfunnsforhold og levekår

- Endringer i sykdomspanoramaet og medisinske gjennombrudd

- Organisering av et helsevesen og folkehelsetiltak

\section{0-tallet}

Hungersnød, epidemier, oppdagelse av mikrobene og det første sinnsykeasylet

- Trange kår, stor folkevekst, fattigdom og dårlig ernæring.

- Fra bondesamfunn til industri.

- Levealderen er om lag 40 år, spedbarnsdødeligheten er høy.

- Infeksjonene dominerer sykdomsbildet.

- Et offentlig helsevesen bygges opp.

- Sunnhetsloven, en forløper til dagens lov om folkehelse, vedtas i 1860 .

- Lov om vaksinasjon mot kopper vedtas.

- Gaustad sykehus åpner som første asyl i 1855 og markerer starten på en utbygging av behandlingstilbudet til mennesker med psykiske lidelser

\section{Samfunnsforhold og levekår}

Da utsendingene møttes på Eidsvoll for å vedta Grunnloven i 1814, stod landets folkevalgte overfor store utfordringer. Det stod ikke bra til i landet. De første folkevalgte kom selv fra det bedrestilte lag, men i lavere lag var det stor fattigdom, og skillet mellom fattig og rik var enormt.
Det var ikke lenge siden vi hadde hatt direkte hungersnød, den siste under den engelske blokaden i 1809-12, hvor "... den fattige sultet, den rike led savn..." beskrevet i diktet om Terje Vigen (Ibsen, 1862).

Levekårene var dårlige og spedbarnsdødeligheten høy. Vi har ikke eksakte tall for hele landet, men fra Asker og Bærum finnes det studier. I 1809 var spedbarnsdødeligheten her 40 prosent av alle levende fødte (Fure, 2005). Ernæringstilstanden var dårlig, likeså hygiene og boligforhold. Verst var det i byene.

\section{Befolkning}

Folketallet var litt under 1 million i begynnelsen av 1800, men økte til over det dobbelte i de hundre årene som fulgte, selv om mange valgte å utvandre. Industrialiseringen førte til at folk strømmet til byene for arbeid.

De økonomiske forholdene for landet som helhet bedret seg. Likevel var det grupper som hadde harde kår. Det var perioder med stor arbeidsledighet. Fattigdommen gikk verst ut over arbeidsledige kvinner og barn. De store barnevandringene på Sørlandet er godt dokumentert. Barna måtte vandre lange veier for å ta gjeterjobb om sommeren for å bøte på familienes økonomi. I gruvebyer slik som Røros, måtte selv små barn ned i gruvene som "Vaskarryss".

\section{Helse og sykdom}

\section{Smittsomme sykdommer dominerte}

En målsetting for våre folkevalgte var at man trengte et folk med bedre helse dersom man skulle få en sterk nasjon og økonomisk utvikling (Moseng, 2003).

Sykdommene fikk navn etter symptomer. Man hadde visse forestillinger om smitte og trodde på såkalte miasmer som dunster fra dårlig grunn. Kampen mot smittsomme sykdommer, særlig kolera, var den viktigste saken. 
Vanlige smittsomme sykdommer på 1800-tallet:

- Kolera og tyfus. På 1800-tallet var det flere epidemier, verst var koleraen. De siste epidemiene kom i 1840-årene. Ingen epidemier var så omfattende som Svartedauden og andre pestepidemier på 1300-tallet, men dødeligheten var likevel høy. Det ble beskrevet mange tilfeller av «tyfus»; tyfoidfeber.

- Lepra herjet spesielt på Vestlandet. Pasientene ble isolert i egne leprasykehus med plass til 1000 pasienter totalt.

- Radesyke. På Sørlandet var det stor forekomst av den merkelige radesyken, som man ennå ikke helt har forstått hva var (Lie, 2008). Vi har skjønnlitterære fortellinger om hvordan denne sykdommen herjet (Heivoll, 2012).

- Kjønnssykdommer var utbredt, uten at det ble definert nærmere. Først senere skilte man mellom gonoré og syfilis.

- Tuberkulose. Mot slutten av 1800-tallet ble tuberkulose den store «dreperen», mens lepra og radesyke gikk tilbake.

Utenom sykdommene som er listet opp ovenfor forekom forskjellige magesykdommer, blodgang (dysenteri) og ustanselige diaréer.

Opptil 10 prosent av alle spedbarn døde. Barnesykdommene var ofte dødelige. Da loven om vaksinasjon mot kopper kom i 1810, fikk man kontroll med «barnekoppene», som var den alvorligste barnesykdommen. Loven ble ikke håndhevet strengt til å begynne med, men da det ble innført påbud om å vise vaksinasjonsattest ved konfirmasjon, giftermål og sesjon, økte vaksinasjonen av barn.

Fattigdom, dårlig ernæring og hygiene førte til mange akutte og kroniske infeksjoner. Offentlige ansatte leger hadde plikt til å berette til sentrale myndigheter om helsetilstanden i sine distrikter. De første Medicinalberetningene begynte likevel ofte med at "Sunnhetstilstanden i vårt distrikt må sies å være tålelig god, bedre enn året før". I dag vil vi si at det stod ytterst dårlig til.

Først mot slutten av 1800-tallet ble mikrobene oppdaget, og det åpnet for forebyggende tiltak. Det hadde tidligere vært uenighet blant leger om hva som skyldtes «smitte» og hva som hadde andre årsaker. Begrepene om smitte var uklare, men under koleraepidemiene forstod man at det handlet om smitte eller overføring mellom mennesker.
Et stort norsk bidrag til læren om bakteriene var G. Armauer Hansens (1841-1912) oppdagelse av leprabasillen. Han viste en klar sammenheng mellom sykehusinnleggelse av smittefarlige pasienter og nedgang i antall nye tilfeller. Armauer Hansen var vår første overlege for den spedalske sykdom, som også ble kalt «Hansens sygdom» (Irgens, 1980; Irgens 1984).

På grunn av den høye barnedødeligheten var forventet levealder litt over 40 år i første halvdel av 1800-tallet.

\section{Bedre forhold i Norge enn i naboland}

Det finnes ikke så mange internasjonale sammenlikninger fra 1800-tallet, men Eilert Sundt (1817-1895) har gjort noen beregninger. Han fant at den gjennomsnittlige levealderen i Norge rundt 1855 var høyere enn i Sverige, Danmark og England. Om et kart der land som har lengst levealder er tegnet lysere enn de andre, skriver han:

...på et sådant kart skulle vort land tage sig godt ud. Man betragte engang Norge på et almindeligt kart over vor verdens-del! Er det ikke som Europas høie pande, der freidigt skuer ud mot nord-havet? Og denne pande skulde rimeligvis blive det lyseste parti i det hele billede... (Sundt, 1855).

\section{Helsevesen og folkehelsetiltak på 1800-tallet}

Før mikrobene ble oppdaget kunne legene i praksis tilby svært lite behandling av smittsomme sykdommer. Kvakksalvere og legkvinner drev utstrakt virksomhet, og noen arbeidet på en god måte. «Mor Sæther» (Anne Sæther) virket i Kristiania. Henrik Wergeland skrev et dikt til henne da han lå på det siste:

\section{«Beholder Maanen, Poeter! \\ Dens Væsen er mig for flaut. \\ Min Maane er gamle Moer Sæther \\ i hendes snehvide Skaut»}

Sinnssykehus eller «dollhus» (dårekister) var rene oppbevaringsanstalter for en rekke av samfunnets verst stilte; fattige, forbrytere og psykisk syke. De var ikke under medisinsk tilsyn, og sinnssykehusene var kun egnet til å skjerme resten av samfunnet mot mennesker man ikke ville vite av. Pasientene ble også satt til hardt tvangsarbeid i såkalte tukthus eller sendt på «legd» på forskjellige gårder. 
Legen Fredrik Holst (1791-1871) kan regnes som en forløper for et reformarbeid på psykiatriområdet. Han var statsfysikus i Oslo, og hadde overoppsyn med noen av institusjonene. Holst hadde sett at det var bygd spesielle asyler for de «sinnssvake» $i$ andre land, og at medisinsk tilsyn gjorde det mulig å helbrede noen av pasientene. På grunn av økonomiske begrensninger gikk det imidlertid over 20 år før noe skjedde.

Legen Herman Wedel Major (1814-1854) fikk i oppdrag å sette seg inn i forholdene for de sinnssyke. Hans «Indberetning om Sindsygeforholdende i Norge» i 1846 gav opptakten til Sinnsykeloven av 1848. Det første statlige asylet, Gaustad, ble bygget i 1855. Major regnes som Norges første psykiater og grunnleggeren av norsk psykiatri. (Kringlen, 2007)

\section{Noen milepæler i folkehelsearbeidet på 1800-tallet}

- Offentlige leger skulle skaffe seg løpende oversikt over sykdomstilstanden. Fra 1827 fikk vi offentlige leger over hele landet (Irgens, 1976).

- Opprettelse av provisoriske sunnhetskommisjoner, og fra 1854 faste kommisjoner i distrikter med lepra.

- Sunnhetsloven i 1860 fastsatte at det skulle opprettes sunnhetskommisjoner over hele landet (Larsen, 2010). I lovteksten lød det: «Commissionen skal have sin Opmærksomhed henvendt paa hva der kan tjene til Sundhetstilstandens Fremme og Fjernelse af de Omstændigheter, som især befordre Udvikling af Sygelighed og Utbredelse af Sygdom» (Schjønsby, 2001). I veiledningene som fulgte var det utpenslet en lang rekke oppgaver som gjaldt miljø, vann, næringsmiddelkontroll, sanitærkontroll renovasjon, husdyrhold, etc. (Schiøtz, 2010).

- Da man ved århundreskiftet forstod mer av mikrobenes vesen og smitteveier, kom det lovpålegg om smitteisolasjon, slik som for eksempel ved lepra i 1877 og tuberkulose i 1900. Slik isolasjon skulle hindre videre smittespredning.

- Loven av 1810 som påbød koppevaksinasjon var det første offentlige vaksinetilbudet.

- Sinnssykeloven av 1848 var det første steget mot å få psykisk helse under medisinsk ansvar (Kringlen, 2007).

\section{0-tallet}

Fra infeksjonsbekjempelse til hjerte- og karsykdommer

- Mindre fattigdom, bedre hygiene og bedre ernæring.

- Vaksinasjoner og økte behandlingsmuligheter med antibiotika.

- Røyking øker etter 1945.

- Kroniske sykdommer, spesielt hjerte- og karsykdommer overtar for infeksjonssykdommene.

- Rusproblemer og avhengighet rammer mange

- Hiv-viruset oppdages i 1981.

- Sykehusutbygging og voksende omsorgssektor.

- Helsestasjoner og skolehelsetjeneste bygges ut.

- Nedbygging av institusjoner i psykisk helsevern.

- Kommunehelsetjenesteloven innføres.

- Kunnskapsutvikling.

\section{Bedre levekår - bedre helse}

Levekårene i hele landet bedret seg langsomt i løpet av 1900-tallet. Fra å være et fattig land, ble vi i løpet av 100 år en velstående og rik nasjon. Selv om landet ble satt litt tilbake under andre verdenskrig 1940-1945, var landet i jevn vekst. Fra 1975 var landet selvforsynt med petroleumsprodukter, og Norge gikk inn i «oljeæraen».

\section{Befolkning}

Folketallet var i overkant av 2,2 millioner i begynnelsen av 1900, men økte til om lag 4,5 millioner i løpet av 1900-tallet.

I 1900 bodde 15 prosent av landets befolkning i Oslo og Akershus. Andelen personer tilknyttet jordbruk, skogbruk og fiske gikk ned, mens andelen tilknyttet industrien økte.

De økonomiske forholdene for landet som helhet bedret seg, og velferdsstaten utviklet seg.

\section{Helse og sykdom}

\section{Færre infeksjoner, nye oppdagelser}

Folkehelsen fikk et stort løft på 1900-tallet. Dette skyldtes bedre hygiene og levekår i tillegg til medisinske landevinninger. 


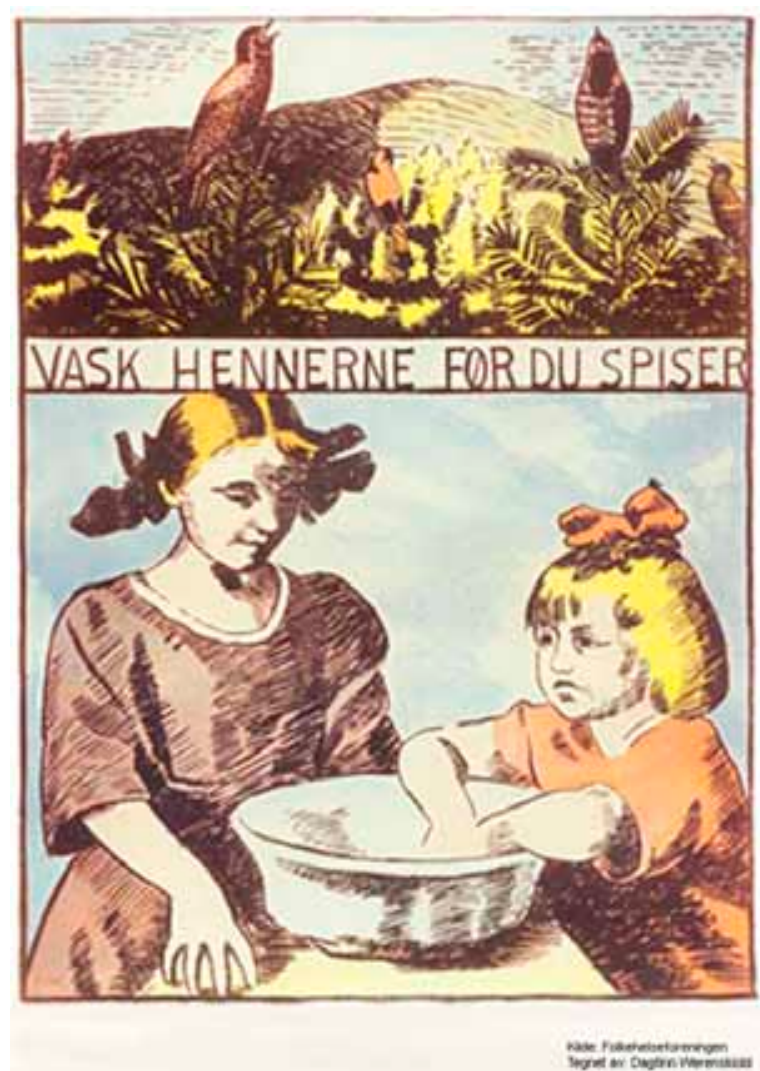

Figur 1: Hygieneplakaten fra Hustavler for mor og barn, 1924. Dette er illustrasjoner utgitt av Folkehelseforeningen, tegnet av Dagfin Werenskiold (Kunsten i Folkehelsens tjeneste).

Begynnelsen av 1900-tallet blir kalt hygieneperioden, der «lys, frisk luft og renslighet» var viktig, se figur 1.

\section{Kosthold og ernæring}

Ernæringssituasjonen bedret seg etter hvert som fattigdommen avtok utover 1900-tallet.
Etter de økonomiske nedgangstidene i 1920-åra, forverret ernæringssituasjonen seg imidlertid på ny. Karl Evang (1902-1981), senere medisinaldirektør (helsedirektør), fikk utført flere kostholdsundersøkelser i «fattige familier» i perioden 1933 -1939. Ernæring ble en viktig del av sosialpolitikken (Nordby, 2009).

\section{Spanskesyken rammet hardt}

Tidlig i hundreåret rammet spanskesyken hardt. Dette var en influensapandemi som oppstod rundt 1918, og som tok mange liv, spesielt unge mennesker som manglet immunitet mot det nye influensaviruset.

\section{Stadig bedring i folkehelsen}

Folkehelsen ble gradvis bedre utover på 1900-tallet, til tross for andre verdenskrig 1940-1945. Spesielt sank antallet infeksjoner betydelig. Et eksempel er tuberkulose, se figur 2. Dødeligheten av tuberkulose var svært høy omkring år 1900, men sank deretter jevnt de neste 50 årene. Mesteparten av nedgangen kom før vi fikk vaksine og medikamentell behandling, og skyldtes i hovedsak bedret levestandard, boforhold, ernæring og hygiene. Figur 2 viser at dødeligheten blant jentene var større enn blant guttene, men forskjellen avtok og var borte etter 1945 .

\section{Vaksiner utryddet barnesykdommene}

I løpet av 1900-tallet kom en rekke vaksiner. Fra 1942 ble difterivaksinen tilgjengelig, og virkningen var umiddelbar. Difteri var en vanlig barnesykdom, og i 1940-43 var det en større epidemi. Et annet eksempel er poliomyelitt. Den siste store epidemien kom i 1951, da ble det registrert 2100 tilfeller (Flugsrud, 2006). Høsten 1956 startet poliovaksinasjonen i Norge.

Etter hvert kom det flere nye vaksiner, spesielt til barn, og barnevaksinasjonsprogrammet vokste. Snart var alle de mest fryktede barnesykdommene

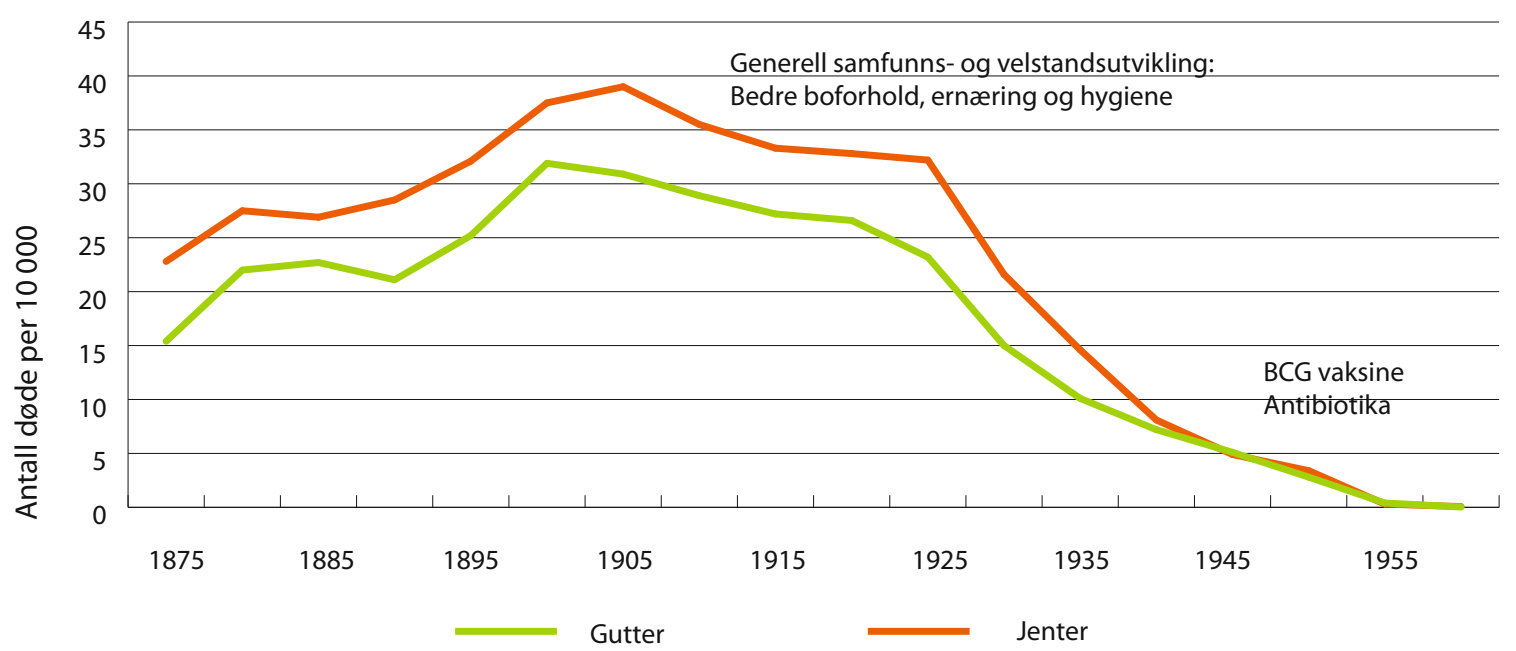

Figur 2: Dødelighet av tuberkulose, jenter og gutter 15-19 år i perioden 1875 til 1960. Kilde: Statistisk Sentralbyrå, Dødeligheten og dens årsaker i Norge 1856-1955, Oslo 1961. 
nesten utryddet. De viktigste var polio og difteri, men også meslinger og kikhoste kunne være dødelige.

Vaksine mot røde hunder (rubella) ble innført i barnevaksinasjonsprogrammet i 1978. Røde hunder er farlig for fosteret dersom mor rammes under svangerskapet.

\section{Medisinsk gjennombrudd: Antibiotika}

Det første antibiotikumet, penicillin, kom i 1940-årene og ble særlig benyttet i behandlingen av barneinfeksjoner. Deretter fulgte en serie lignende medikamenter til ulike typer infeksjonsbehandling.

\section{Hiv/aids}

Aids dukket opp som en tidligere ukjent sykdom tidlig på 1980-tallet. Norge var tidlig ute med forebyggende arbeid i høyrisikogruppene, blant annet med opprettelse av helseutvalget for homofile som drev et utstrakt informasjonsarbeid. Hiv-viruset ble påvist og hivtesten tilgjengelig rundt 1985. Hiv kan i dag behandles med legemidler som bekjemper infeksjonen, men uten at viruset blir helt fjernet fra kroppen.

\section{Vitaminene ble oppdaget}

De fleste livsviktige vitaminene ble oppdaget i løpet av 1920-årene, og tran ble anbefalt som kosttilskudd for D-vitamin. Tidligere hadde rakitt (D-vitaminmangel; engelsk syke) forekommet hos barn. Engelsk syke fikk navn etter barnearbeiderne i engelske kullgruver, som i mangel av sollys utviklet D-vitaminmangel. I statistiske årbøker fra om lag 1900 oppgis engelsk syke som årsak til 0,8 - 0,5 prosent av dødsfallene.

\section{Fra tuberkulose til hjerteinfarkt}

Samtidig som tuberkulosen gikk tilbake, økte forekomsten og dødeligheten av kroniske sykdommer, spesielt hjerte- og karsykdommer. Dette blir ofte kalt den epidemiologiske overgang.

Tobakksbruk er en av de viktigste årsakene til både hjerte- og karsykdommer og flere kreftsykdommer. Tobakksforbruket i Norge var meget lavt under krigsårene 1940-1945 på grunn av streng rasjonering, men da tobakksalget ble frigitt etter krigen, økte forbruket betydelig. Se også kapittel Tobakk.

\section{Psykiatri - nye muligheter}

Den storstilte asylbyggingen fortsatte på 1900-tallet. Behandlingstilbudet var fortsatt sparsomt, men forskjellige opiater og barbiturater ble brukt for å roe de mest urolige og utagerende pasientene. I tillegg til dette var også arbeidsterapi et stort satsingsområde. Hensikten var å finne en beskjeftigelse, og mest vanlig var håndverksarbeid, gårdsdrift og hagebruk. Flere av de største institusjonene, for eksempel Valen og Dikemark, ble storstilte gårdsbruk med stor produk- sjon. De mest urolige pasientene forble likevel innesperret, selv om det ble forbudt med bruk av tvangstrøyer og lignende tiltak.

Rundt midten av hundreåret ble det lansert såkalte eksperimentelle behandlingsmåter, for eksempel elektrosjokk (eller elektrokonvulsiv) behandling som til å begynne med ble gitt uten noen form for narkose. Lobotomier (et spesielt kirurgisk inngrep i hjernen) ble også benyttet som behandlingsmetode. Selv om metoden roet ned urolige pasienter, ble personlighetene radikalt endret. De pasientene som ble utsatt for dette, har senere fått store erstatninger.

Nye medikamenter for alvorlige psykoser kom mot slutten av hundreåret. Dette ga nye muligheter for behandling utenfor institusjonene, som etter hvert er blitt redusert i størrelse.

\section{Over 1000 barn døde unødvendig i krybbedød}

Spedbarnsdødeligheten gikk jevnt nedover på 1900-tallet, men omkring 1970-1980 økte den igjen. Det skyldtes en økning i plutselig spedbarnsdød eller krybbedød. Krybbedød var kjent fra tidligere, men økningen var dramatisk.

De første internasjonale publikasjonene om en mulig sammenheng mellom krybbedød og mageleie kom så tidlig som i 1970, men endringer i praksis kom først på slutten av 1980- og begynnelsen av1990-tallet (Gilbert, 2005). Da norske foreldre ble oppfordret til å legge barna på ryggen, snudde utviklingen i løpet av kort tid, se figur 3. Det er antatt at mer enn 1000 barn døde unødvendig i løpet av perioden (Irgens, 1995; Irgens, personlig meddelelse).

\section{Hjerte- og karsykdommer overtar mot slutten av 1900-tallet}

Mot slutten av 1900-tallet er sykdomspanoramaet preget av kroniske sykdommer. Hjerte- og karsykdommene dominerer. På grunn av økt levealder er det også flere som lever lenge med kroniske sykdommer.

Ved årtusenskiftet har nye behandlingsmuligheter og forebygging gjort at dødeligheten av hjerte- og karsykdommer har gått ned, men disse sykdommene er fortsatt en av våre største folkehelseutfordringer.

Livsstilssykdommer ble et nytt begrep i andre halvdel av 1900-tallet, og spesielt røyking og kolesteroløkende fett kom i søkelyset som risikofaktorer for hjerte- og karsykdommer. 


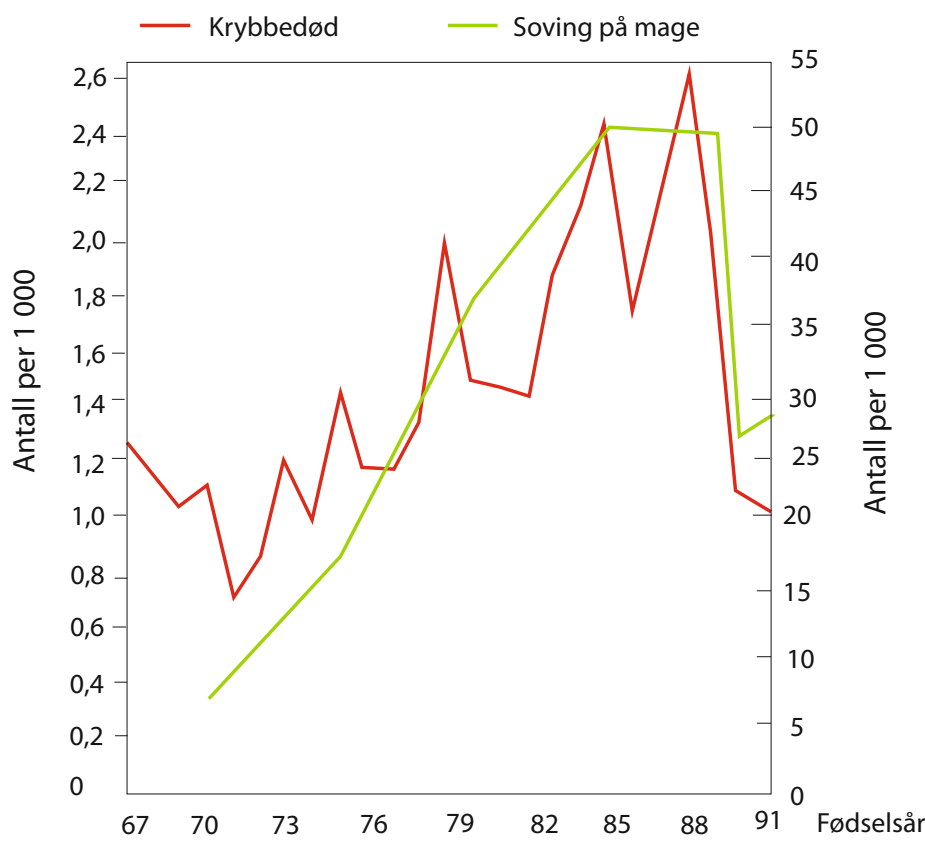

Figur 3: Plutselig uventet spedbarnsdød, utvikling i perioden 1967 til 1991. Kilde: Irgens, 1995.

\section{Spedbarnsdødeligheten blant de laveste i vår del av verden}

Spedbarnsdødelighet er regnet som en god indikator på folkehelse. Rundt år 1900 var spedbarnsdødeligheten høyere i Norge enn i mange andre land i Europa.

Utviklingen av velferdsstaten utover på 1900-tallet har medvirket til at spedbarnsdødeligheten nå er blant de laveste i vår del av verden - under 0,3 prosent.

Dette kan tilskrives flere årsaker: Bedre ernæring og levekår, bedre utdanning og økonomi, bedre behandlingstilbud og i noen grad også forebyggende helsearbeid, spesielt vaksinasjonstilbudet gjennom helsestasjonene. Alle barn får tilbud om gratis vaksiner, og tilbudet er frivillig. Dekningsgraden for de fleste vaksinene er svært høy.

\section{Helsevesen og folkehelsetiltak på 1900-tallet}

\section{Distriktsleger og helseråd}

Utover på 1900-tallet kom det flere distriktsleger, og sunnhetskommisjonene ble erstattet med helseråd i alle kommuner. Distriktslegen var leder for helserådene. Distriktslegeordningen fortsatte helt til 1982. Da fikk kommunene større ansvar for helsearbeidet (Schiøtz, 2003).

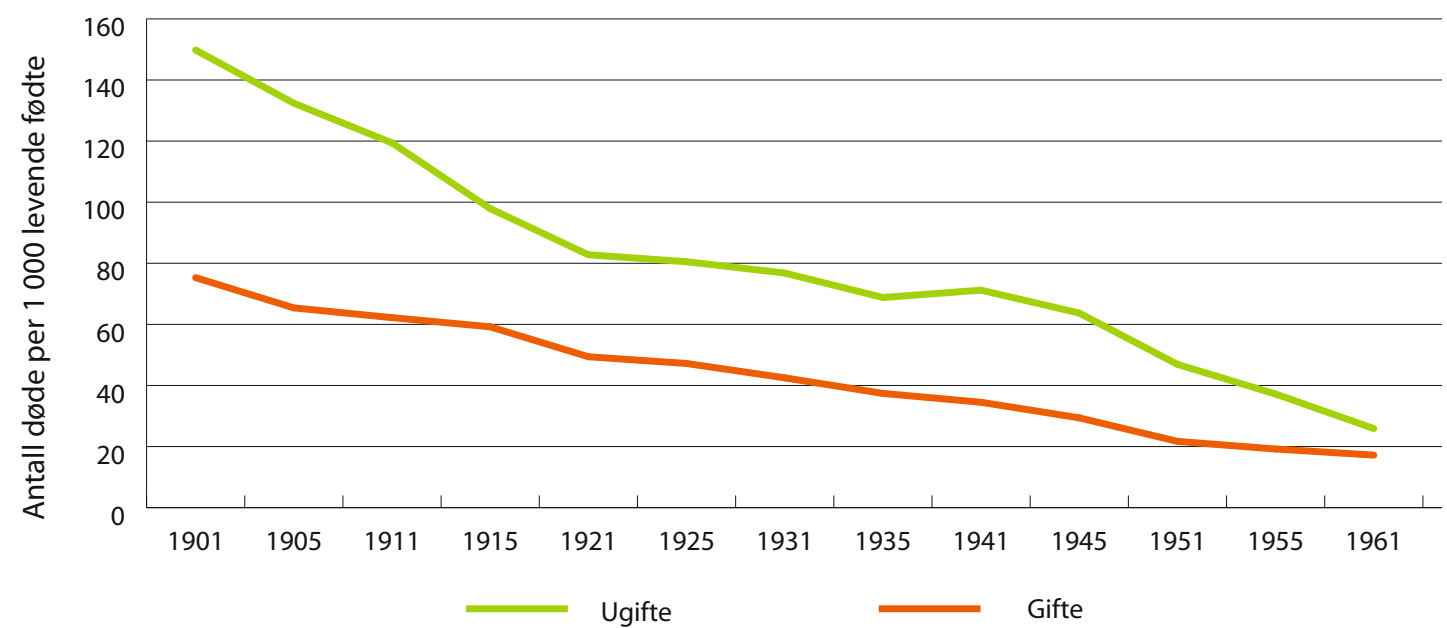

Figur 4: Spedbarnsdødelighet blant barn av gifte og ugifte mødre i perioden fra 1901 til 1961. Kilde: Statistisk Sentralbyrå: Dødeligheten og dens årsaker i Norge 1856-1955. Oslo 1961. 


\section{Helsekontroller for mor og barn}

Den nye kunnskapen om kostholdets betydning for helsen førte til at det ble satt i gang forskjellige helsekontroller, først og fremst av mor og barn, men også av skolebarn. Foregangsmann var Carl Schiøtz (1877-1938). Han var overlege for Oslo skolelegevesen fra 1918 til 1932, og senere professor i hygiene ved Universitetet i Oslo.

Schiøtz var opptatt av hvordan det offentlige kunne fremme skolebarns helse med riktig ernæring, blant annet ved å innføre et skolemåltid for alle. For å holde øye med utviklingen ble alle skolebarn veid og målt regelmessig (Alsvik, 1991).

De Castbergske barnelover som kom i 1915, skulle sikre barn bedre oppvekstforhold.

Helsearbeidet for mor og barn ble forsterket med helsestasjoner for mor og barn, det skjedde spesielt etter initiativ av Katti Anker Møller (1886-1945). Helsestasjonene gav også råd om barnebegrensning (Seip, 1994).

Det var stor forskjell på barnedødeligheten mellom barn av ugifte og gifte mødre, sannsynligvis på grunn av dårlige økonomiske forhold og underernæring, se figur 4.

\section{Kamp mot tuberkulose}

Tuberkuloseundersøkelser ble startet for å oppspore smittekilder og stoppe smittespredning. Statens skjermbildekontroll kom i drift fra 1943. Med spesialinnredete busser og båter med røntgenutstyr besøkte skjermbildeundersøkelsene hver minste krok av landet med regelmessige mellomrom. Undersøkelsene ble opprettholdt frem til 1970-årene.

Etter hvert som tuberkulosen gikk tilbake, skiftet Skjermbildekontrollen navn til Statens helseundersøkelser og rettet seg mot hjerte- og karsykdommer i stedet (Bjartveit, 1997). På lignende vis skiftet også de frivillige organisasjonene arbeidsområde.

Flere organisasjoner engasjerte seg $\mathrm{i}$ arbeidet for bedre folkehelse. Folkehelseforeningen ble stiftet $\mathrm{i}$ 1920-årene og arbeidet for helseopplysning, særlig til mor og barn gjennom sitt tidsskrift.

I kampen mot tuberkulose deltok blant annet Norske Kvinners Sanitetsforening, som ble stiftet allerede i 1896, og ikke minst Nasjonalforeningen mot tuberkulosen, som drev utstrakt opplysningsvirksomhet og stod bak flere tuberkulosesykehus.

\section{Omsorg for funksjonshemmede barn}

Omsorgen for psykisk funksjonshemmede barn er et mørkt kapittel i vår historie. Ofte ble barna sendt fra institusjon til institusjon. Fjermeros kaller dem pleiehjemsnomader (Fjermeros, 2009). Fra 1960-tallet ble de sendt til de store sentralinstitusjonene som da ble bygget opp, blant annet Trastad-hjemmet og Emma Hiorths pleie- og omsorgshjem.

HVPU-reformen (Helsevernet for psykisk utviklingshemmede) i 1991 hadde som mål å skape gode forhold for barn og voksne med psykisk utviklingshemming. Formålet med reformen var at psykisk utviklingshemmede skulle få et normalt liv $\mathrm{i}$ hjemkommunen. De skulle slippe å bli tvangsflyttet til de store institusjonene langt hjemmefra. Kommunene fikk ansvar for å finne boliger og omsorgstilbud.

\section{Nytt årtusen}

\section{God folkhelse, men ikke for alle}

- Velferdsstaten bygges videre.

- Forventet levealder øker til rundt 80 år.

- Det er fortsatt sosiale forskjeller i helse.

- Globalisering øker kravene til smittevernberedskap.

- Befolkningen stiller større krav til helsegoder og behandling.

- Opptrappingsplanen for psykisk helse (19992008) - åpenhet og helhet.

- Lov om etablering og gjennomføring av psykisk helsevern (psykisk helsevernloven) trer i kraft, 2001.

- Endring i røykeloven fra 2004 - forbud mot å røyke på alle offentlige steder.

- Lov om folkehelse i 2012; kommunen får større ansvar.

- Stortingsmelding om folkehelse i 2013.

\section{Samfunnsforhold og levekår}

Norge har i perioden 1990 - 2014 hatt en sterk velstandsvekst. Dette skyldes ikke minst at vi gjennom siste halvdel av 1900-tallet har blitt en rik oljenasjon. Ungdomsskole for alle ble gradvis innført i 1960 årene, og alle har i dag rett til videregående skole. Sysselsettingen er høy, også blant kvinner. Barnehager er bygd ut over hele landet. 
Norge lå på første plass i følge FNs levekårsindeks (Human Development Index-HDI) for 2013. HDI er et mål på et lands samfunnsutvikling ved å kombinere informasjon om forventet levealder, oppnådd utdanning og inntekt (UN rapport, 2013).

Samtidig har vi fått nye utfordringer. God økonomi gjør det mulig å kjøpe tobakk, ferdigmat, søte drikker og mat som de færreste hadde tilgang til eller råd til å kjøpe før 1950. Mange har fått stillesittende arbeid, bil og mindre krevende husarbeid. Den fysiske aktiviteten går ned. Elektronikk, PCer, sosiale medier og internett tar større plass i hverdagen og byr på nye utfordringer når det gjelder søvn, stillesitting og mobbing på nett. Tilgangen til rusmidler i samfunnet øker. Disse «nye levekårene» gir nye utfordringer for folkehelsen.

\section{Befolkning}

Folketallet i Norge var ved årtusenskiftet i underkant av 4,5 millioner og i løpet av 2012 passerte vi 5 millioner innbyggere (Brunborg, 2012).

Den årlige befolkningsveksten i Norge har de siste årene vært på litt over 1 prosent. Omtrent en tredjedel skyldes fødselsoverskudd, mens resten skyldes netto innvandring.

Innvandringen til Norge har økt kraftig de siste tiårene. I dag utgjør innvandrere og deres etterkommere rundt 14 prosent av befolkningen. Denne andelen vil øke sterkt i årene fremover (Brunborg, 2013).

Det er anslått at andelen personer over 80 år i Norge vil øke fra 2020 (Brunborg, 2014). Se også kapittel Befolkning.

\section{Helse og sykdom}

\section{Kroniske sykdommer dominerer}

Sykdomspanoramaet var ved inngangen til det 21. århundret preget av ikke-smittsomme sykdommer som hjerteog karsykdommer, kreft, KOLS og diabetes. Teknologiske framskritt og utvikling innen medisinsk behandling har siden 1970-årene hatt stor betydning for overlevelse av enkeltsykdommer, spesielt hjerte- og karsykdommer.

Hjertekirurgisk behandling med bypass-operasjon og senere mekanisk utblokking av kransarterier og «proppløsende» legemidler er for eksempel blitt vanlig behandling ved akutt hjerteinfarkt. Nye medikamenter til behandling av kreft og andre sykdommer er også under stadig utvikling.

Nedsatt funksjonsevne og kroniske sykdommer som kreft, demenssykdommer og smertelidelser øker sterkt med alderen - særlig blant de aller eldste. Sykdommer som tidligere innebar tidlig $d ø d$, for eksempel hjerteog karsykdommer og kreft blir dermed kroniske sykdommer som folk lever med. Eldre har også ofte flere sykdommer samtidig, som sammen påvirker funksjonsevne, livskvalitet og psykisk helse.

Sykdomsbyrdeprosjektet Global Burden of Disease (GBD) viser at to av tre tapte leveår i Norge er forårsaket av kreftsykdommer eller hjerte- og karsykdommer. Iskemisk hjertesykdom (tette blodårer i hjertet), hjerneslag, lungekreft, tykktarmskreft og KOLS er de fem største årsakene til tapte leveår (IHME, 2013). Sentrale risikofaktorer for disse sykdomsgruppene har sammenheng med endringer i levevaner, for eksempel kosthold, røyking, alkoholforbruk og fysisk aktivitet.

GBD viser også at psykiske lidelser, smertetilstander og lårhalsbrudd bidrar til tapt helse. De fem ledende årsakene til år levd med helsetap i Norge er korsryggsmerter, alvorlig depresjon, angstlidelser, nakkesmerter og fallulykker med påfølgende bruddskader (IHME, 2013).

\section{Sosiale helseforskjeller}

Selv om den norske befolkningens helse generelt er god, og alle grupper i det sosioøkonomiske hierarkiet har fått bedre helse de siste tiårene, er det gruppene øverst på den sosiale rangstigen som har hatt den beste utviklingen. På tross av at levestandarden i befolkningen har økt, er det fortsatt forskjeller mellom utdanningsgruppene. De med best utdanning og $ø$ konomi har best helse.

Temaet sosial ulikhet i helse kom for alvor på den helsepolitiske dagsordenen med Stortingsmeldingen «Resept for et sunnere Norge» som ble lansert i januar 2003 (St.meld. nr. 16 (2002-2003). (I februar 2007 la Helse- og omsorgsdepartementet fram «Nasjonal strategi for å utjevne sosiale helseforskjeller», en stortingsmelding som ga klare føringer for arbeidet med å redusere sosiale helseforskjeller - «....å redusere de sosiale helseforskjellene uten at noen grupper får dårligere helse....» (St. meld nr. 20 (2006-2007)).

Færre innvandrere enn norskfødte oppgir å ha god eller svært god helse (67 prosent mot 86 prosent). I tillegg har kroniske infeksjonssykdommer (for eksempel tuberkulose, hiv og hepatitt B), diabetes, stoffskiftesykdommer, angina pectoris (hjertekrampe), leddgikt, benskjørhet, overvekt og fedme høyere forekomst i noen innvandrergrupper enn i den norskfødte befolkningen. Forekomsten av psykiske plager og lidelser er også høyere blant innvandrere (Abebe, 2010). Kunnskapen om helsen og bruk ave helse- 
tjenester i innvandrerbefolkningen er fragmentert og mangelfull.

\section{Mot et desentralisert psykisk helsevern}

Opptrappingsplanen for psykisk helse (1999-2008) som ble vedtatt av Stortinget var en satsing med mål om en kvalitativ og kvantitativ bedre tjeneste for mennesker med psykiske lidelser. Verdigrunnlaget til planen var basert på et tjenestetilbud som skulle fremme uavhengighet, selvstendighet og evne til å mestre eget liv. Utbygging av kommunalt psykisk helsearbeid, ambulante team, tilpassede boliger og DPS, kampanjer for åpenhet og mot stigmatisering av psykiske lidelser var sentrale mål i planen.

Samtidig med Opptrappingsplanen for psykisk helse, ble det også gjennomført en del andre relevante juridiske og administrative endringer. Foretaksreformen bidro til en organisatorisk tilnærming mellom spesialisthelsetjenesten for somatiske lidelser og psykiske lidelser. Rusreformen i 2004 innebar at staten ved de regionale helseforetakene overtok ansvaret for spesialiserte behandlingstiltak for mennesker med rusmiddelavhengighet (NOU 2011:9).

\section{Folkehelsetiltak ved inngangen til nytt årtusen}

Røykeloven (lov om vern mot tobakksskader) trådte opprinnelig i kraft i 1975. Formålet var å begrense helseskader ved bruk av tobakk, og det ble blant annet innført forbud mot tobakksreklame, aldersgrense ved kjøp av tobakk og påbud om merking av tobakksprodukter med advarsel om helsefare. Loven har senere gjennomgått flere revisjoner, og en viktig endring ble innført fra 1. juni 2004 da de ble forbudt å røyke på alle offentlige steder, blant annet på serveringssteder. Røykeloven har hatt stor betydning for den nedgangen vi ser i befolkningens røykevaner på 2000-tallet (SIRUS, 2009).

Ny lov om folkehelsearbeid (folkehelseloven) trådte i kraft i 2012. Formålet med loven er blant annet å bidra til en samfunnsutvikling som fremmer folkehelse og jevner ut sosiale helseforskjeller.

Gjennom folkehelseloven har landets kommuner og fylkeskommuner fått ansvar for å ha oversikt over helsetilstanden og faktorer som påvirker helsen. Oversikten skal legges til grunn for det langsiktige folkehelsearbeidet i kommunen. Som et ledd i dette arbeidet publiserer Folkehelseinstituttet årlige folkehelseprofiler - en unik rapport for hver enkelt kommune og hvert fylke.
En stortingsmelding om folkehelse ble lagt fram våren 2013 (St. meld. nr. 34 (2012-2013). Den har 3 hovedmål for folkehelsearbeidet:

- Norge skal være et av de tre landene i verden som har høyest levealder.

- Befolkningen skal oppleve flere leveår med god helse og trivsel og reduserte sosiale helseforskjeller.

- Et samfunn som fremmer helse i hele befolkningen.

Folkehelsemeldingen vektlegger behovet for å forebygge sykdom og å fremme helse i alle sektorer i samfunnet - «Health in All Policies».

\section{Norge i det internasjonale bildet}

Norge hadde i perioden 1850 til ut på 1880-tallet den høyeste registrerte levealderen for menn og kvinner i verden. Det samme var tilfellet i perioden fra 19471955 for menn og 1945-1970 for kvinner. Senere har levealderen steget mindre i Norge enn i andre land. I 2013 var forventet levealder i Norge 81,4 år (begge kjønn samlet). Dette plasserte Norge på en 13. plass, bak ledende Sveits og andre land det er naturlig å sammenligne oss med, blant annet Sverige og Island. Les mer i kapittel Levealderen i Norge.

Resultater fra det globale sykdomsbyrdeprosjektet (GBD) i 2010 viser at Norge i stor grad har de samme helseproblemene som andre land. De ikke smittsomme sykdommene dominerer, og utgjør en felles global folkehelseutfordring (Lim, 2012; Lozano, 2012; Murray, 2012; Salomon, 2012; Vos, 2012).

\section{Et friskere folk - men med nye utfordringer}

Da utsendingene møttes på Eidsvoll for å vedta den norske Grunnloven i 1814, stod landets folkevalgte overfor store utfordringer. Levekårene var dårlige og spedbarnsdødeligheten høy.

En av målsettingene for våre folkevalgte var at folkehelsen måtte bedres dersom man skulle bygge en sterk nasjon.

Arbeidet for å bedre befolkningens helse har derfor vært sentral i utviklingen av den norske velferdsstaten. Lover og regler, universelle velferdsordninger, ernæring og hygiene, utdanning og kunnskapsutvikling har hatt stor betydning i denne utviklingen. I tillegg har en offentlig helsetjeneste av god kvalitet vært viktig for å oppnå god helse. I et historisk lys er 
det likevel endringer knyttet til samfunnsforhold og velferd som har hatt størst betydning for folkehelsen. Det er først og fremst forholdene utenfor helsetjenesten som skaper folkehelse.

Målet om et friskere folk er oppnådd, men ved inngangen til det 21. århundret har vi nye utfordringer med sykdommer som i mange tilfeller er knyttet til globalisering, livsstil og levevaner, som igjen har sammenheng med de sosioøkonomiske, kulturelle og miljømessige betingelsene i samfunnet.

\section{Referanser}

Abebe, P.S. Public health challenges of immigrant in Norway: a research review. NAKMI report 2/2010.

Alsvik O. 'Friskere, sterkere, større, renere'. Om Carl Schiøtz og helsearbeidet for norske skolebarn. Historisk institutt, Universitetet i Oslo 1991.

Bjartveit K. Statens helseundersøkelser. Fra tuberkulosekamp til mangesidig epidemiologisk virksomhet. Norsk Epidemiologi 1997; 7 (2): 157-174.

Brunborg G. Vi blir 5 millioner innbyggere 19. mars 2012. SSB, 2012.

Brunborg, H. Hvor mange innvandrere er det - og blir det - i Norge? Samfunnsspeilet 2013; 27(3): 2-9.

Fjermeros H. Åndssvak! Universitetsforlaget 2009.

Flugsrud LB. 50 år med poliovaksine i Norge. Tidsskr Nor Lægeforen 2006; 126: 3251.

Fure E. Spedbarnsdødeligheten i Asker og Bærum på 1700og 1800 tallet. Tidsskr Nor Lægeforen 2005; 125: 3468-71.

Gilbert R, Salanti G, Harden M and See S. Infant sleeping position and the sudden infant death syndrome: systematic review of recommendations from 1940 to 2002. International Journal of Epidemiology 2005; 34: 884-7.

Heivoll G. Kongens hjerte, Tiden 2012.

Ibsen H. Terje Vigen, 1862.

IHME, Institute of Health Metrics and Evaluation. The Global Burden of Disease: Generating Evidence, Guiding Policy - Euroepan Union and European Free Trade Association Regional Edition. Seattle, WA: IHME; 2013.

Irgens LM,Bjerkedal T. Utvikling av informasjonssystemer i helsesektoren og bruken av disse i det forebyggende helsearbeid. Tidsskr Nor Lægeforen 1976;96:295-300.

Irgens LM. Leprosy in Norway. An Epidemiological Study Based on a National Patient Registry. Lepr Rev $1980 ; 51$ Suppl.1:1-130.

Irgens LM. The Discovery of Mycobacterium Leprae. A Medical Achievement in the Light of Evolving Scientific Methods. Am J Dermatopathol 1984;6:337-343.

Irgens LM, Markestad T, Baste V, Schreuder P, Skjærven R, Øyen N. Sleeping position and SIDS in Norway 1967-1991. Arch Dis Child 1995;72:478-82.
Kringlen E, Norsk psykiatri gjennom tidene. N W DAMM \& Søn AS, Oslo 2007.

Larsen $\varnothing$. Sunnhetsloven - mer enn en helselov. Michael; 7;2010: Supplement 8, 11-49.

Lie A. Radesykens tilblivelse. Historien om en sykdom. Det medisinske fakultet, Universitetet i Oslo, 2008. Dr.grads avhandling

Lim SS, Vos T, Flaxman AD, Danaei G, Shibuya K, AdairRohani $\mathrm{H}$, et al. A comparative risk assessment of burden of disease and injury attributable to 67 risk factors and risk factor clusters in 21 regions, 1990-2010: a systematic analysis for the Global Burden of Disease Study 2010. Lancet. 2012; 380: 2224-60.

Lozano R, Naghavi M, Foreman K, Lim S, Shibuya K, Aboyans V, et al. Global and regional mortality from 235 causes of death for 20 age groups in 1990 and 2010: a systematic analysis for the Global Burden of Disease Study 2010. Lancet. 2012;380: 2095-2128.

Moseng OG. Ansvaret for undersåttenes helse (1603-1850). Universitetsforlaget 2003.

Murray CJL, Vos T, Lozano R, Naghavi M, Flaxman AD, Michaud C, et al. Disability-adjusted life years (DALYs) for 291 diseases and injuries in 21 regions, 1990-2010: a systematic analysis for the Global Burden of Disease Study 2010. Lancet. 2012; 380: 2197-2223.

Nordby T. Helsedirektør Evangs planer for velferdsstaten. Michael 2009;6:331-7.

NOU 2011:9 Økt selvbestemmelse og rettssikkerhet. Balansegangen mellom selvbestemmelse og omsorgsansvar i psykisk helsevern. Utredning fra utvalg oppnevnt ved kongelig resolusjon 28. mai 2010. Avgitt av Helse- og omsorgsdepartementet 17. juni 2011.

Salomon JA, Wang HD, Freeman MK, Vos T, Flaxman AD, Lopez AD, et al. Healthy life expectancy for 187 countries, 1990-2010: a systematic analysis for the Global Burden Disease Study 2010. Lancet. 2012; 380: 2144-62.

Schiøtz A. Folkets helse - landets styrke. Universitetsforlaget 2003.

Schiøtz A. Hvordan gikk det med Sunnhetsloven av 1860 ? Michael 2010; 7: 332-44.

Schjønsby HP. Innføring av sunnhetsloven i 1860. Tidsskr Nor Lægeforen 2001; 121: 80-1.

Seip A-L. Veiene til velferdsstaten. Norsk sosialpolitikk 1920-75. Oslo: Gyldendal, 1994

SIRUS, Statens institutt for rusmiddelforskning. Evaluering av myndighetenes samlede innsats for å forebygge tobakksrelaterte sykdommer i perioden 2003 til 2007. Rapport SIRUS, 2009.

SSB, Statistisk sentralbyrå, 1961. Dødeligheten og dens årsaker i Norge. 1856-1955. Oslo: Statistisk sentralbyrå.

St.meld. nr. 16 (2002-2003). Resept for et sunnere Norge. Oslo: Helsedepartementet.

St.meld. nr. 20 (2006-2007). Nasjonal strategi for å utjevne sosiale helseforskjeller. Oslo: Helse- og Omsorgsdepartementet. 
St.meld. nr. 34 (2012-2013). Folkehelsemeldingen. God helse - felles ansvar. Oslo: Helse- og Omsorgsdepartementet.

Sundt E. Om dødeligheten i Norge. Bidrag til kundskab om folkets kaar. Christiania. Hallings bogtrykkeri 1855.

Tønnessen M, Syse A, Aase KN. Befolkningsframskrivinger 2014-2100: Hovedresultater. SSB, 2014. Foreløpig versjon publisert 17. juni 2014.

UNITED NATIONS. Human Development Report 2013. United Nations Development Programme (UNDP). ISBN 978-92-1-126340-4.
Vos T, Flaxman AD, Naghavi M, Lozano R, Michaud C, Ezzati $M$, et al. Years lived with disability (YLDs) for 1160 sequelae of 289 diseases and injuries 1990-2010: a systematic analysis for the Global Burden of Disease Study 2010. Lancet. 2012; 380: 2163-96.

\section{FORFATTERE}

Rannveig Nordhagen, Else Karin Grøholt, Lorentz Irgens, Ellinor Major, Aage Tverdal, Sidsel Graff-Iversen 


\section{Kunnskapskilder}

and
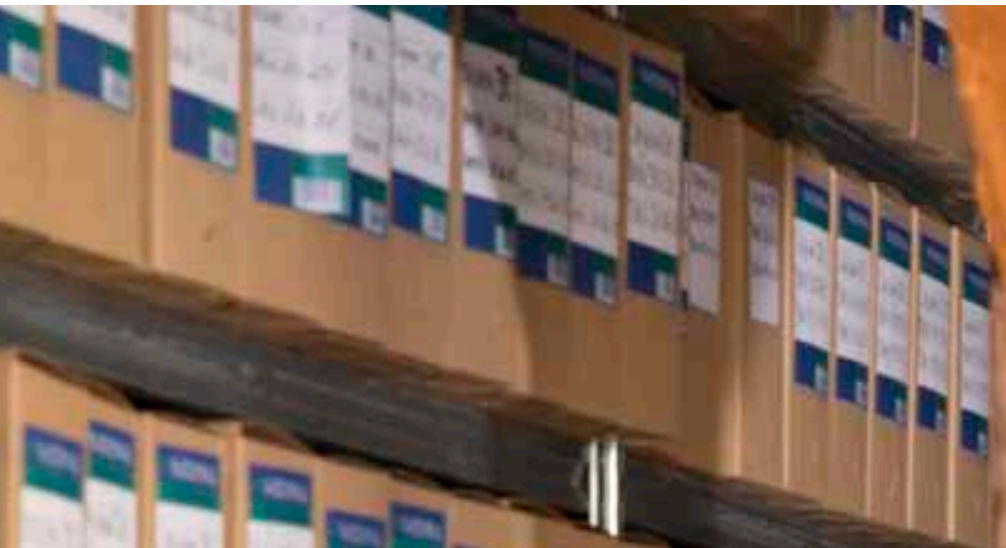

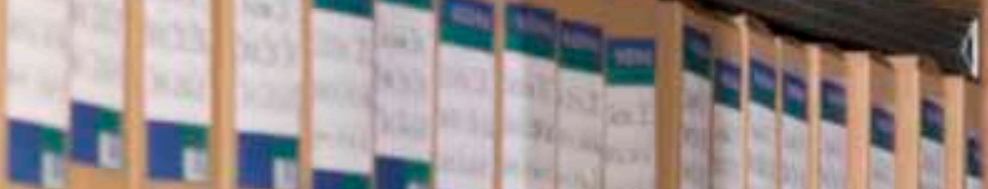

1)
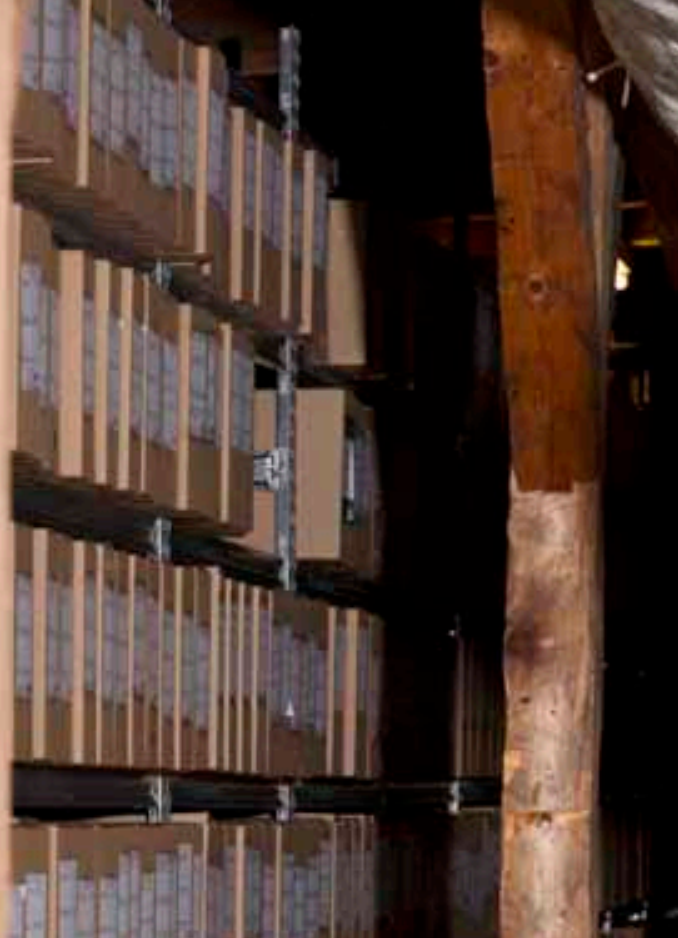

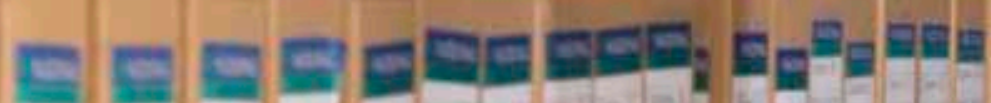
mermmerm

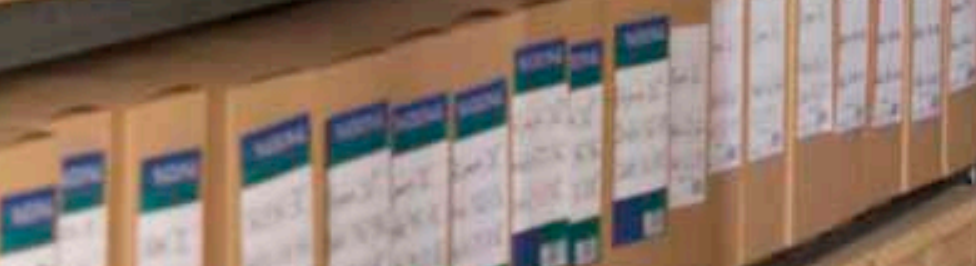


- Data fra helseregistre, helseundersøkelser og biobanker gir verdifull kunnskap om utviklingen i folks helse og påvirkningsfaktorer over tid.

- Norge har i dag 17 sentrale helseregistre og 47 nasjonale medisinske kvalitetsregistre, i tillegg til et ukjent antall lokale medisinske kvalitetsregistre som gir informasjon om helsetilstanden og bruk av helsetjenester i hele befolkningen.

- En stor utfordring er å følge utviklingen i ikke-smittsomme sykdommer og faktorer som påvirker disse. Her er det er blant annet behov for systematiske helseundersøkelser.

- Vi mangler gode data om forekomsten av psykiske lidelser, rusrelaterte sykdommer, og om faktorer som påvirker disse.

- Det er også behov for å forenkle regelverket, modernisere IT-infrastrukturen og bedre tilgjengeligheten til data fra de ulike kildene, samtidig som hensynet til den enkeltes personvern er godt ivaretatt.

\section{Hvorfor trenger vi kunnskap om folkehelse?}

Godt folkehelsearbeid forutsetter løpende oversikt over befolkningens helse og sykdomsforhold, samt forskning og analyser som kan avdekke hvordan sykdom kan forebygges og helse fremmes.

For at helsemyndighetene skal kunne følge med på utviklingen i folkehelse, fange opp trender, oppdage nye risikofaktorer og måle om eventuelle tiltak virker etter hensikten, må vi ha kunnskap som er:

- Nyttig og relevant. Vi bør blant annet kunne utvikle kunnskap om:

o Både smittsomme sykdommer og utbredte ikke-smittsomme somatiske sykdommer som kreft, hjerte- og karsykdom, kronisk obstruktiv lungesykdom (KOLS), type 2 diabetes, samt psykiske lidelser og rusrelatert sykdom

o De viktigste kjente påvirkningsfaktorene for ikke-smittsomme sykdommer; tobakk, alkohol, overvekt, fysisk inaktivitet, høyt blodtrykk, høyt kolesterol, samt viktige kjente påvirkningsfaktorer på psykisk helse som negative livshendelser, stressfaktorer og liten sosial støtte

o Levekår og sosioøkonomiske faktorer
Kunnskapskildene bør videre være:

- Oppdaterte

- Av høy kvalitet

- Pålitelige

- Nasjonalt og internasjonalt troverdige og vel ansett

- Tilpasset brukerne og forvalterne av folkehelsetjenester

Nedenfor tar vi for oss de ulike kunnskapskildene for folkehelse vi har i Norge i dag, og hva de kan levere.

\section{Registre}

\section{Sentrale helseregistre}

Vi har i dag 17 sentrale helseregistre. Disse registrene inneholder relativt få opplysninger, men har til gjengjeld opplysninger om mange individer. Registrene har stor verdi, fordi de omfatter alle i de aktuelle befolkningsgruppene, for eksempel alle fødende, og kan gi viktig informasjon om fødsel, sykdom og død og utviklingen av helsetilstanden over tid.

- Tall fra Dødsårsaksregisteret viser hvordan dødeligheten av hjerte- og karsykdommer økte sterkt fra 1950- til 1970-tallet, og senere hvordan den falt betydelig på 1990-tallet. 
- Tall fra Meldingssystem for smittsomme sykdommer (MSIS) viser at barnesykdommene er under kontroll, mens seksuelt overførbare sykdommer fortsatt er en utfordring.

- I følge det nasjonale vaksineregisteret SYSVAK får 95 prosent av barna de viktigste vaksinene i barnevaksinasjonsprogrammet.

Helseregistre som omfatter alle i de aktuelle befolkningsgruppene er også velegnet til å studere sjeldne sykdommer som det ellers er vanskelig å fange opp. Et eksempel på dette er Medisinsk fødselsregister som ble opprettet i kjølvannet av thalidomidskandalen. Bruk av det kvalmestillende medikamentet thalidomid under svangerskapet ga betydelig risiko for fostre/barn med alvorlige misdannelser. Registret ble opprettet for at man så tidlig som mulig skulle kunne oppdage sjeldne skader og medfødte sykdommer/misdannelser.

Analyser av data fra Medisinsk fødselsregister og Dødsårsaksregisteret har også vist hvordan antall barn som døde i krybbedød falt kraftig da man sluttet å legge spedbarna på magen.

\section{Medisinske kvalitetsregistre}

Vi har i dag 47 nasjonale medisinske kvalitetsregistre. I tillegg har vi et ukjent antall regionale/lokale kvalitetsregistre med kontinuerlig datainnsamling. Disse registrene inneholder oftest opplysninger om avgrensede pasientgrupper med bestemte diagnoser, eller pasientgrupper som mottar spesifikk behandling. Noen kvalitetsregistre er knyttet til sentrale helseregistre i fellesregistere. Kreftregisteret og Hjerte- og karregisteret er eksempler på fellesregistre som består av flere nasjonale medisinske kvalitetsregistre og et basisregister.

Eksempler på kvalitetsregistre er:

- Norsk hjerteinfarktregister har opplysninger om sykehusinnlagte pasienter med hjerteinfarkt og hvilken behandling de får. Registeret har hatt nasjonal dekning siden 2013 og er knyttet til Nasjonalt register over hjerte- og karlidelser.

- Nasjonalt kvalitetsregister for tykk- og endetarmskreft har opplysninger om utredning, behandling og oppfølging av alle pasienter med tykk- og endetarmskreft. Registeret har hatt nasjonal dekning siden 2007, og er knyttet til Kreftregisteret.

Det er et faglig og politisk ønske å innhente pasientrapporterte resultater, såkalte «patient reported outcome measures» (PROMS), som kan inngå i datagrunnlaget for kvalitetsutviklingen i helse- og omsorgstjenesten (Black, 2013). PROMS inkluderer resultater om utredning og behandling, og kan kun innhentes med samtykke fra pasienten.

\section{Administrative registre}

De administrative registrene inneholder demografiske og sosioøkonomiske forhold som ekteskapelig status, landbakgrunn, utdanning, inntekt, bruk av fastlegetjenester og trygdeytelser. Når opplysninger fra disse registrene sammenstilles med opplysninger $i$ helseregistre og helseundersøkelser, kan de gi et mer helhetlig bilde av forhold som påvirker folkehelsen, og hvordan helse- og omsorgstjenestene fungerer.

\section{Sammenstilling av data gir ny kunnskap}

Alle som er bosatte i Norge har et fødselsnummer. Dette gir mulighet til å sammenstille data fra ulike datakilder på individnivå, for eksempel fra helseregistre og administrative registre. Vi kan på den måten følge helsetilstanden i befolkningen over tid, analysere forskjeller mellom grupper i befolkningen og bidra med ny forskningsbasert kunnskap både nasjonalt og internasjonalt.

Noen ferske eksempler på nye forskningsresultater om sjeldne sykdommer, basert på sammenstilte data fra ulike registre:

- Barn født etter assistert befruktning har ikke økt risiko for kreft. Nordisk studie med sammenstilling av ulike sentrale helseregistre (Sundh, 2014)

- Cerebral parese (CP) er delvis genetisk betinget, og det er en opphopning av CP i familier. Norsk studie med sammenstilling av data fra Medisinsk fødselsregister og NAV (Tollånes, 2014)

\section{Helseregistrene trenger modernisering og samordning}

For å bedre kunnskapsgrunnlaget for folkehelse er det nødvendig med en modernisering og samordning av helseregistrene og andre datakilder. Dette arbeidet pågår i dag i regi av Nasjonalt helseregisterprosjekt, og er knyttet til regjeringens eHelse-arbeid (St. Meld. 9 (2012-2013) Én innbygger - én journal). Norges forskningsråd har også gitt støtte til et program for utvikling av sentrale helseregistre som infrastruktur for forskning (NFR, 2014).

Innsamling av data til registrene skjer i dag til dels fragmentert og tungvint, og i mange tilfeller papirbasert eller ved hjelp av gammel informasjons- og kommunikasjonsteknologi. Regelverket for bruk av disse dataene er komplisert og hindrer effektiv utnyttelse av data til helsestatistikk og løpende helseanalyser, forskning, kvalitetsforbedring, pasientsikker- 
hetstiltak, planlegging, styring og beredskap. Det er også et faglig og politisk ønske om å innhente pasientrapporterte resultater av utredning og behandling, slik at disse kan inngå i datagrunnlaget for kvalitetsutviklingen i helse- og omsorgstjenesten.

En revidert helseregisterlov ble vedtatt 20. juni 2014 og er ment å legge til rette for enklere og mer effektiv bruk av data fra helseregistrene.

\section{Helseregistrenes begrensninger}

Datakilder som skal beskrive folkehelsen og påvirkningsfaktorer bør omfatte hele befolkningen .

De fleste helseregistrene får informasjon om individer først når de har oppsøkt helsetjenesten. Norsk pasientregister (NPR) inneholder for eksempel viktige opplysninger om forekomst av tilstander som krever behandling i sykehus eller hos spesialist. Andre helseproblemer, som normalt bare krever behandling hos allmennlege, blir ikke registrert i NPR. For helseproblemer som både behandles i primærhelsetjenesten og spesialisthelsetjenesten, får vi dermed bare registrert de mest alvorlige tilfellene - som er "toppen av isfjellet". I tillegg kan det være skjevheter i hvilke befolkningsgrupper som kommer til behandling.

Både type 2 diabetes og KOLS er eksempler på sykdommer der datagrunnlaget i registrene er ufullstendig. Dette er tilstander som gjerne diagnostiseres og behandles i kommunehelsetjenesten, og som i tillegg oppdages sent i forløpet av sykdommen.

\section{Helseundersøkelser}

Helseregistre er nødvendige, men ikke tilstrekkelige datakilder for å kunne følge helsetilstanden i befolkningen. Systematisk og gjentatte landsrepresentative helseundersøkelser trengs for å samle data om viktige kjente risikofaktorer og andre påvirkningsfaktorer for sykdom og død.

Siden 1973 har for eksempel Statistisk sentralbyrå jevnlig samlet inn data om helse og levekår, herunder data om egenopplevd helse og rusmiddelbruk. Dette er en verdifull datakilde for trender i befolkningen.

Etter den andre verdenskrig, 1940-1945, ble det gjennomført landsomfattende screeningunders $\varnothing$ kelser av store befolkningsgrupper for tuberkulose og etter hvert hjerte- og karsykdommer. Omfattende fylkesvise undersøkelser av landets 40-åringer ble for eksempel gjennomført fra 1985 til 1999 i regi av Statens helseundersøkelser (SHUS), som seinere gikk inn i Folkehelseinstituttet da instituttet ble etablert i
2002. Datainnsamlingen inkluderte biologiske prøver og fysiske undersøkelser av deltakerne.

CONOR er en sammenstilling av data fra regionale helseundersøkelser fra 1990-tallet og framover, og inneholder per i dag informasjon fra om lag 200000 nordmenn (Aamodt, 2010). CONOR inneholder både helsedata og blodprøver, og er et samarbeid mellom Folkehelseinstituttet og universitetene i Oslo, Bergen, Trondheim og Tromsø.

Etter 2003 har det ikke vært gjennomført systematiske, landsrepresentative helseundersøkelser med blodprøver og fysiske målinger blant voksne. Regionale helseundersøkelser har imidlertid vært gjennomført blant annet i Nord-Trøndelag og Tromsø de senere årene. I dag har vi derfor mangelfull kunnskap om hvordan for eksempel blodtrykk, kolesterol, blodsukker, vekt og andre kjente risikofaktorer har utviklet seg i et representativt utvalg av hele den norske befolkningen. Nyere undersøkelser kan gi en indikasjon på denne utviklingen, men det er en økende bekymring både i nasjonale og internasjonale fagmiljø at deltakelsen i slike samtykkebaserte undersøkelser har vært fallende de senere år.

\section{Biobanker}

Noen av de samtykkebaserte helseundersøkelsene er tilknyttet biobanker. Flere av dem har pågående datainnsamling, som for eksempel Den norske mor og barn-undersøkelsen (MoBa), eller har planer om innhenting av nye data, for eksempel Helseundersøkelsene i Nord-Trøndelag (HUNT 4) og Tromsøundersøkelsen (Tromsø 7).

Disse dataene gir mulighet for å analysere miljøfaktorer, for eksempel kostholdsfaktorer, infeksjoner og miljøgifter, og genetiske faktorer i biologisk materiale. De kan på den måten gi verdifull kunnskap om sykdomsårsaker og mekanismer.

Folkehelseinstituttet har også startet arbeidet med å etablere en human miljøbiobank for å overvåke hvordan befolkningen utsettes for miljøgifter. Miljøgiftene finnes i små mengder i mat, drikkevann og luft, samt i forbrukerprodukter som elektriske artikler, møbler, kosmetikk, barneleker og klær. Noen stoffer har vi kjent til i mange tiår, men det kommer stadig nye til. Mange av stoffene kan påvises i biologiske prøver fra mennesker, for eksempel i blod, morsmelk, urin og hår.

Den humane miljøbiobanken vil dels ta utgangspunkt i eksisterende prøver fra Mor og barn-undersøkelsen 
og dels hente inn nye data fra undergrupper av deltakerne.

\section{Framtidig folkehelsearbeid - på hvilke områder er det særlig behov for data?}

Vi mangler gode helsedata på flere områder, blant annet:

- Psykiske lidelser og rusrelatert sykdom

- Kommunale helse- og omsorgstjenester

- Legemiddelbruk blant pasienter i sykehus, sykehjem og døgninstitusjoner

- Ikke-smittsomme sykdommer og faktorene som påvirker disse

- Innvandrerbefolkningens helse

Nedenfor følger omtale av de ulike «kunnskapshullene».

\section{Psykiske lidelser og rusrelatert sykdom}

Vi mangler data om utbredelsen av psykiske lidelser i befolkningen. I tillegg mangler vi befolkningsbaserte data om forekomsten av rusrelatert sykdom. Slike data kan gi grunnlag for løpende helseanalyser og forskning, og de er nødvendige for å kunne planlegge og måle effekter av behandling og folkehelsetiltak. Kvalitetsindikatorer er dessuten viktige for å kunne sammenlikne og sørge for god og lik behandling for psykiske lidelser og rusrelatert sykdom i hele landet. Data om psykiske lidelser og rusrelatert sykdom er avgjørende for forskning på årsaker til og konsekvenser av disse tilstandene.

Verdens helseorganisasjon har gjennomført intervjuundersøkelser med strukturerte diagnostiske intervjuer i representative grupper av befolkningen i land over hele verden (WHO, 2014). En tilsvarende landsomfattende undersøkelse i Norge kan gi verdifulle grunnlagsdata om forekomst av psykiske lidelser i den norske befolkningen.

\section{Kommunale helse- og omsorgs- tjenester}

Kommunale helse- og omsorgstjenester er et annet eksempel på områder der vi mangler helsedata. I tillegg finnes det nesten ikke nasjonale data fra store deler av tannhelsetjenesten, helsestasjons- og skolehelsetjenesten. Slike data vil kunne gi verdifull kunnskap om blant annet eldres helse, tannhelsen i den voksne befolkningen og vekst og utvikling blant barn og unge.
I stortingsmeldingen om kvalitet og pasientsikkerhet (Helse- og omsorgsdepartementet, 2012) varslet Regjeringen at den ville utrede etablering av et register for den kommunale helse- og omsorgstjenesten etter mønster fra Norsk pasientregister. Stortinget sluttet seg til dette i sin behandling av meldingen, og utredningsarbeidet har startet.

\section{Legemiddelbruk blant pasienter i sykehus, sykehjem og døgn- institusjoner}

Vi har gode data om legemiddelbruk basert på resepter (Reseptregisteret), men mangler data om legemiddelbruk i sykehus, sykehjem og andre døgninstitusjoner. Dette er særlig problematisk når det gjelder systematisk og oppdatert kunnskap om eldres helse. En nasjonal arbeidsgruppe ledet av Folkehelseinstituttet har utredet behovet for et fellesregister for legemidler. I rapporten som er levert Helse- og omsorgsdepartementet, anbefales det at Reseptregisteret utvides med informasjon om legemiddelbruk på individnivå i institusjon (FHI, 2013).

\section{Ikke smittsomme sykdommer og faktorer som påvirker disse}

Stadig flere mennesker lever med ikke-smittsomme sykdommer som tidligere var forbundet med tidlig død, for eksempel type 2-diabetes, hjerte- og karsykdommer og kreft. Risikoen for slike sykdommer øker med alderen, og i en aldrende befolkning vil vi måtte regne med flere kronisk syke.

Gjennom Kreftregisteret, Norsk pasientregister og Hjerte- og karregisteret kan vi følge utviklingen i antall tilfeller som er så alvorlige at de behandles i spesialisthelsetjenesten. Men vi har ikke gode datakilder når det gjelder å følge utviklingen i overvekt/fedme, forstadier til type 2-diabetes, kroniske lungesykdommer og demens, for eksempel utviklingen i ulike aldersgrupper,

I tillegg har vi begrenset tilgang på data om utviklingen i risikofaktorer som kolesterol, blodtrykk, blodsukker, vekt, kroppsmasseindeks, samt bruk av alkohol og andre rusmidler. På dette området er det blant annet behov for systematiske helseundersøkelser. Da kan trender lettere fanges opp, og forebyggende tiltak planlegges (se også nedenfor).

Vi mangler kunnskap om utviklingen i rusmiddelbruk over tid, både alkohol og andre rusmidler. For å kunne innhente slik kunnskap, trengs det kartleggingsstudier som må gjøres på en standardisert måte over tid, og det bør brukes både biologiske prøver og spørreskjema. Særlig i planleggingen av det forbyg- 
gende arbeidet er det viktig å få troverdige data fra undersøkelser med høyt deltakerantall (Gjerde, 2014).

\section{Innvandrerbefolkningenes helse}

Flere spørreskjemaundersøkelser er ikke tilpasset innvandrerbefolkningen hverken metodisk eller språklig, og vil derfor ha lav svarprosent i innvandrergrupper. Egne helseundersøkelser for innvandrere kan gi verdifull informasjon, men det at innvandrerpopulasjonen er i stadig endring, avhengig av hvem som til enhver tid kommer til Norge, gjør det vanskelig å planlegge og å få gode nok data fra slike undersøkelser.

Så langt er data fra helseregistre den beste kilden til kunnskap, men likevel lite benyttet i studier av innvandreres helse. MSIS er det eneste av helseregistrene som inneholder fødelandsopplysninger. De andre helseregistrene må koble fødelandsopplysninger fra det sentrale folkeregisteret. Studier som bruker registerkoblinger til undersøkelser av innvandreres helse vil fange opp utfordringer $i$ nye, store grupper, følge utviklingen over tid og for eksempel få kunnskap om hvordan det går med innvandrere og deres etterkommere.

De sentrale helseregistrene er imidlertid avhengige av informasjon fra et oppdatert folkeregister. Folkeregisteret får ikke alltid flyttemelding fra innvandrere som flytter utenlands for kortere eller lengre perioder. Dette betyr at beregning av sykelighets- og dødelighetsrater i innvandrerbefolkningen blir mindre pålitelige enn de ellers kunne vært.

\section{Kunnskap om effekter av tiltak}

Befolkningens helse påvirkes som nevnt av biologiske faktorer (vekt, blodtrykk, kolesterolnivå, blodsukkernivå), livsstilsfaktorer (kosthold, fysisk aktivitet, røykevaner, alkoholbruk og annen rusbruk), nærmiljøfaktorer (støy, helsefarlige stoffer, negative livshendelser, stress, liten sosial støtte) og faktorer på samfunnsnivå (sosial ulikhet, arbeidsledighet).

Sykdomsforebyggende og helsefremmende tiltak kan settes inn på alle trinn i årsakskjedene som virker inn på helse. De samfunnsmessige tiltakene har konsekvenser for folk flest og vil ofte ha stor betydning. Men tiltak på samfunnsnivå er gjerne de som er vanskeligst å evaluere. En viktig utfordring er derfor å utvikle og ta i bruk evalueringsmetoder som kan si noe om effektene av slike tiltak.

Evalueringen av tiltak bør planlegges sammen med planlegging av tiltakene. Hvis evalueringen settes i gang først når tiltakene er iverksatt, vil det være vanskeligere og ofte umulig å få til god evaluering. I Folkehelsemeldingen (Helse- og omsorgsdepartementet, 2013) ble det lagt fram forslag om å opprette et kompetansemiljø for evaluering av folkehelsetiltak ved Folkehelseinstituttet. Arbeidet med å opprette et slikt kompetansemiljø er i gang, og en arbeidsgruppe ved instituttet har foreslått at en i første omgang skal prioritere to områder:

- Evaluering av tiltak som iverksettes eller initieres av Helse- og omsorgsdepartementet, Helsedirektoratet eller andre myndigheter.

- Rådgivning om evaluering av tiltak som iverksettes i kommuner og fylker.

I tillegg til å evaluere enkelttiltak, vil det være en oppgave for Folkehelseinstituttet å benytte data fra helseregistre og helseundersøkelser for å se på endringer i risikofaktorer og helsefremmende faktorer over tid, og for å evaluere det samlede folkehelsearbeidet på sentrale områder.

Innen medisinsk klinisk forskning blir randomiserte, kontrollerte fors $ø \mathrm{k}$ framhevet som den aller beste tilnærmingen til vurdering av effekten av medikamenter og andre intervensjoner eller behandlingsmåter. I slike studier sammenliknes ofte en behandlingsgruppe med en gruppe som ikke får behandling.

I folkehelsearbeidet er tiltakene rettet mot befolkningen, og det kan av praktiske eller etiske grunner være vanskelig å utføre tilsvarende randomiserte forsøk. Det er derfor en særlig utfordring på dette feltet å utforme alternative studier av høy kvalitet.

\section{Muligheter og utfordringer}

Det norske samfunnet har store muligheter til å skaffe seg solide og kontinuerlig oppdaterte kunnskapskilder for folkehelsen, gitt vårt system for folkeregistrering, administrative registre, sentrale helseregistre, medisinske kvalitetsregistre, samtykkebaserte helseundersøkelser med tilknyttede biobanker, samt det pågående eHelse-arbeidet.

En stor utfordring er å følge utviklingen i ikke- smittsomme sykdommer og faktorene som påvirker disse. På dette området er det blant annet behov for systematiske helseundersøkelser og utvikling av gode metoder for evaluering av tiltak.

En annen utfordring er å forenkle regelverket, styrke forvaltningen, modernisere IT-infrastrukturen og bedre tilgjengeligheten til data fra de ulike kildene, samtidig som hensynet til den enkeltes personvern er godt ivaretatt. Klarer vi dette, kan vi ta ut stadig større 
gevinster som kommer den enkelte og hele samfunnet til gode.

\section{Referanser}

Aamodt, G, Søgaard, AJ, Næss, Ø, Beckstrøm, AC \& Samuelsen, SO. CONOR-databasen - et lite stykke Norge. Tidskrift for den Norske Laegeforening 2010;(130).

Black, N. Patient reported outcome measures could help transform healthcare. Br Med J 2013; 346(167).

FHI, Folkehelseinstituttet: K Furu, M Mahic, K Ulshagen et al. Fellesregister legemidler - samordning av oppdrag på legemiddelfeltet. Utredning av behovet for en overordnet samordning av eksisterende registre og nye initiativ på legemiddelområdet i form av et fellesregister for legemiddelbruk. Oslo: Folkehelseinstituttet; 2013.

NFR, Forskningsrådet. 2014. Verktøy for forskning del II: Norsk veikart for forskningsinfrastruktur 2014. [hentet april 2014].

Gjerde, H, Christophersen, AS, Øiestad, EL \& Vindenes, V. Bruk av biologiske prøver til kartlegging av rusmiddelbruk: foredrag ved Forskningsrådets konferanse. I "Psykisk helse og rusmiddelforskning - Sammen om fremtidens forskning!", Trondheim, 3-5. februar 2014., Forskningsrådet; 2014.
Helse- og omsorgsdepartementet. Meld. St. 9 (2012-2013): Én innbygger - én journal: Digitale tjenester i helse- og omsorgssektoren.

Helse- og Omsorgsdepartementet. Meld. St. 34 (20122013). Folkehelsemeldingen. God helse - felles ansvar.

Helse og omsorgsdepartementet. Meld. St. 10 (20122013): God kvalitet - trygge tjenester. Kvalitet og pasientsikkerhet i helse- og omsorgstjenesten.

Sundh, KJ, Henningsen, AK, Kallen, K, Bergh, C, Romundstad, LB et al. Cancer in children and young adults born after assisted reproductive technology: a Nordic cohort study from the Committee of Nordic ART and Safety (CoNARTaS). Hum Reprod 2014; 29(9): 2050-7. Pubmed.

Tollånes, MC, Wilcox, AJ, Lie, RT \& Moster, D. Familial risk of cerebral palsy: population based cohort study. 2014; 349(4294). DOI: http://dx.doi.org/10.1136/bmj.g4294

WHO, World Health Organization. 2014. The World Mental Health Survey Initiative.

\section{FORFATTERE}

Øyvind Næss, Marta Ebbing, Lars Johan Hauge, Vidar Hjelvik, Marta Ebbing, Helle Margrete Meltzer, Anne Reneflot 


\section{DEL 1 \\ Befolkning og levealder}

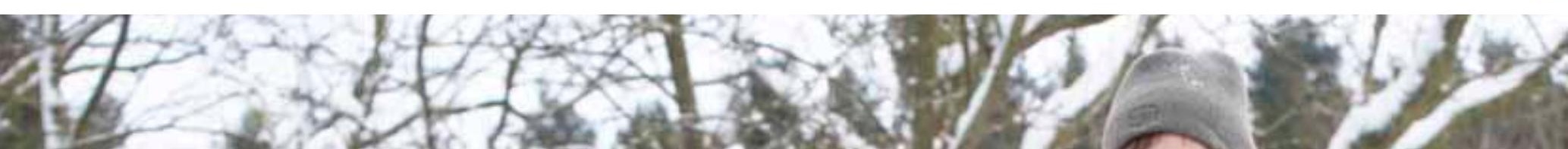

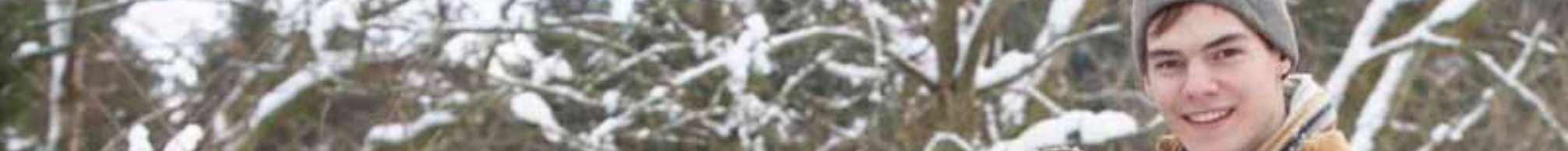
$-1-2.50$ at $(30)$

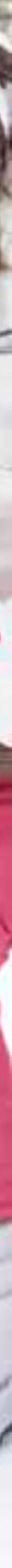




\section{Befolkningen i Norge}

- Befolkningen i Norge har økt fra 2,22 millioner i 1900 til 5,05 millioner i 2013.

- Andelen innbyggere under 18 år har falt fra 40 til 20 prosent de siste 100 årene.

- Andelen innbyggere over 70 år har økt, og er i dag 10 prosent.

- Norge er blant de land i Europa som har høyest fruktbarhet og høyest innvandring.

- Befolkningsveksten i Norge i 2011-13 er den høyeste på 90 år.

- Urbanisering har foregått jevnt over 100 år.

\section{Årlig befolkningsvekst på rundt én prosent}

Den årlige befolkningsveksten har de siste årene vært litt over 1 prosent, omtrent som den globale befolkningsvekst. Befolkningsveksten i Norge i 2011-13 er den høyeste på 90 år. Omtrent en tredjedel av veksten i Norge skyldes fødselsoverskudd, mens resten skyldes netto innvandring. Ifølge Statistisk sentralbyrås (SSB) befolkningsframskrivinger antas det at den raske befolkningsveksten vil fortsette en del år framover for deretter å avta (Brunborg, 2012). Det er imidlertid stor usikkerhet om utviklingen, og usikkerheten er i særlig grad knyttet til anslagene for innvandring, dernest til utvikling forventet levealder og fertilitet. Videre øker usikkerheten ved framskrivningene jo lenger fram i tid vi går, og når framskrivningene brytes ned på kjønns og aldergrupper. SSB presenterer derfor flere alternativer i sin befolkningsframskriving basert på ulike forutsetninger med hensyn til fruktbarhet, levealder, inn- og utvandring (Brunborg, 2012):

- Ifølge hovedalternativet (mellomalternativet) vil det være 6 millioner innbyggere i Norge i 2031 og 7 millioner i 2063.

- Ifølge lavalternativet blir det 5 millioner nordmenn i 2063.

- Ifølge høyalternativet blir det 10 millioner nordmenn i 2063.

\section{Dobbelt så mange eldre}

De siste 15 årene har antall over 70 år vært konstant (figur 1), og andelen vil også holde seg konstant de neste 10 årene. Det forventes at (mellomalternativet) levealderen vil øke jevnt til 87,5 år for menn og 90 år for kvinner i 2070 (Brunborg, 2012). Det vil bety at Norge vil få stadig flere eldre på sikt. I dag utgjør eldre over 70 år rundt 10 prosent av befolkningen, mens $\mathrm{i}$ 2070 vil de utgjøre 20 prosent. De aller eldste vil også utgjøre en stadig større andel av befolkningen. Selv om Norge i likhet med mange andre land vil oppleve en eldrebølge, vil den være langt svakere enn i land som Japan. I dag er 15 prosent av befolkningen i Japan over 70 år og dette forventes å øke til 40 prosent i 2050.

\section{Høy fruktbarhet sammenlignet med andre rike land}

Samlet fruktbarhetstall (SFT) er det mest utbredte målet på fruktbarhet. Det forteller hvor mange barn en gruppe av kvinner får hvis de på hvert alderstrinn opplever de aldersspesifikke fødselsratene som er observert et visst år. I 2012 var fruktbarhetstallet 1,85, som er høyt i forhold til andre rike land. Bare Frankrike og flere engelsktalende land ligger høyere (PRB, 2013). Etter en oppgang på siste halvdel av 1980-tallet (fra bunnivået på 1,66 i 1984) har fruktbarhetstallet holdt seg over 1,80 siden 1988 med unntak av de to årene 2001-2002 (1,78 og 1,75). Nivået har vært over 1,90 i sju av disse årene, blant annet i 2006-2009.

Et annet mål på fruktbarhet er det gjennomsnittlige antall barn et fødselskull av kvinner faktisk har fått. I mange land er dette tallet betydelig høyere enn fruktbarhetstallet i de årene kullet har vært i sin reproduktive alder, noe som henger sammen med at fødealderen har gått opp. 


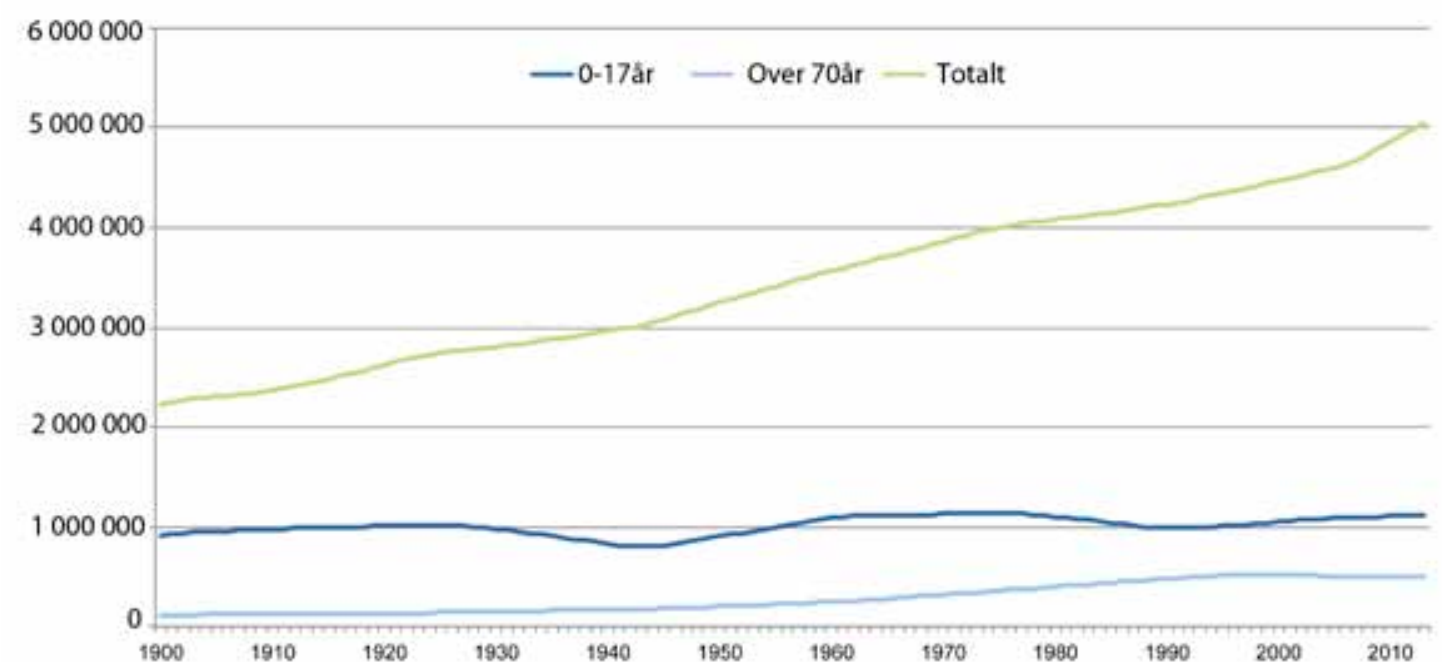

Figur 1: Antall i befolkningen som er under 18 år og over 70 år fra 1900 til 2013.

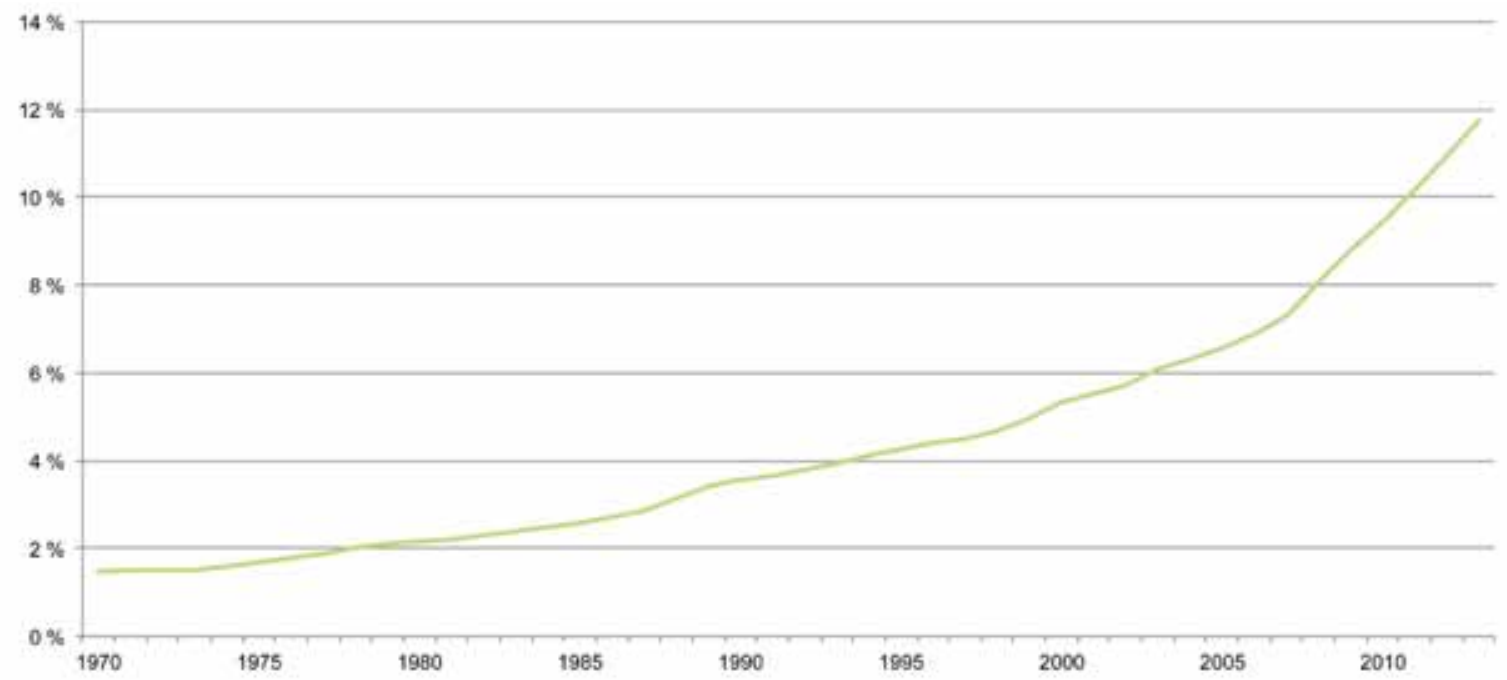

Figur 2: Andel av befolkningen som er innvandrere, 1970 - 2013. Kilde: Statistisk sentralbyrå.

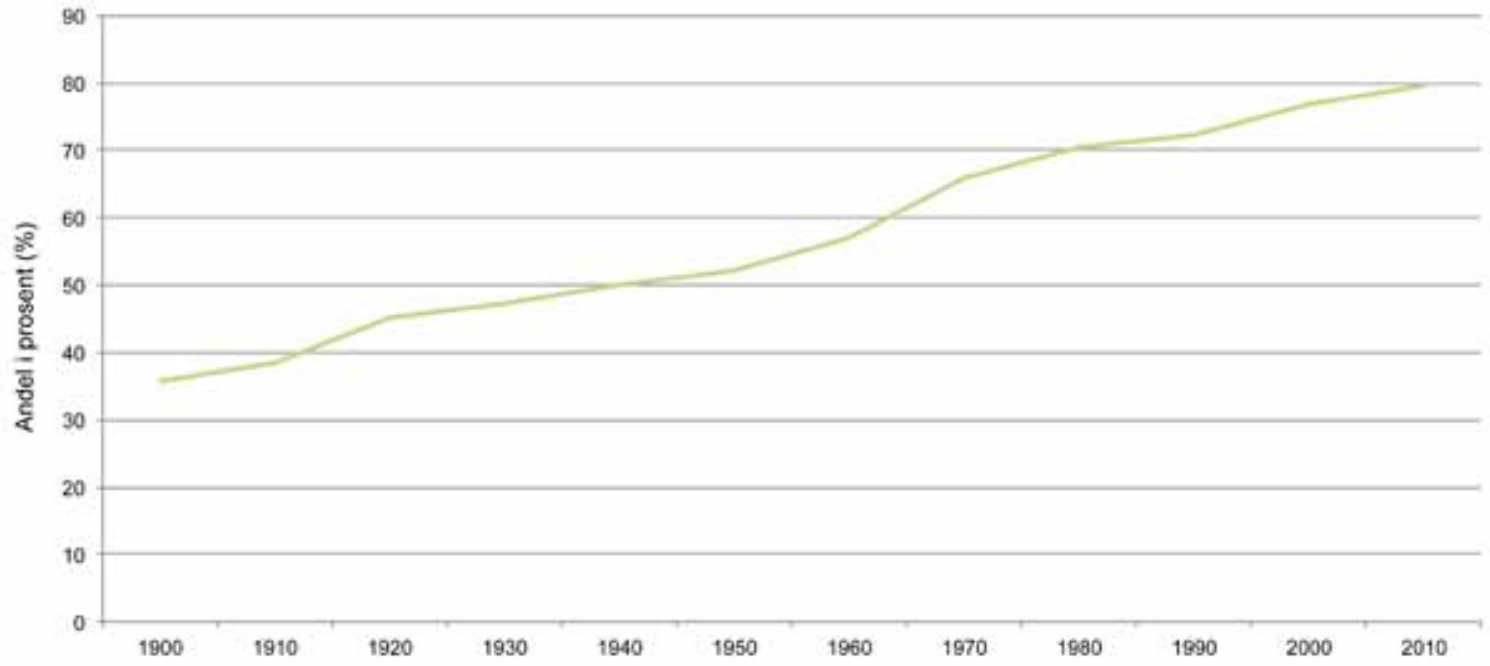

Figur 3: Andel av befolkningen som bor i urbanisert områder 1900-2013. Kilde: Statistisk sentralbyrå. 
Tabell 1: Gjennomsnittlig antall barn ved 45 årsalder for kvinner født i 1935, 1945, 1955, 1960 og 1967.

Kilde: Statistisk sentralbyrå 2014, Statistikkbanken

\begin{tabular}{|c|c|}
\hline Kvinnens fødselsår & $\begin{array}{c}\text { Gjennomsnittlig antall } \\
\text { barn ved 45 år }\end{array}$ \\
\hline 1935 & 2,42 \\
\hline 1945 & 2,19 \\
\hline 1955 & 2,04 \\
\hline 1960 & 2,10 \\
\hline 1967 & 2,03 \\
\hline
\end{tabular}

Tabell 1 viser gjennomsnittlig antall barn ved 45 årsalder for kvinner født i 1935, 1945, 1955, 1960 og 1967. Vi ser at det har vært et fall etterfulgt av et ganske stabilt nivå.

Blant kvinnene født i 1967 var det 12,8 prosent barnløse, mens 14,5 prosent, 40,5 prosent og 32,2 prosent hadde henholdsvis ett, to eller tre eller flere barn (SSB, 2014).

Dette innebærer at 83 prosent av de som ble foreldre, fikk minst to barn. Videre innebærer det at 44 prosent av de som fikk sitt andre barn, også fikk minst ett barn til.

Prognosene for fruktbarheten framover varierer mellom 1,7 og 2 for alle norske kvinner (Brunborg, 2013a).

I 1900 var rundt 4 prosent av befolkningen født i utlandet. Dette var stort sett folk født i Sverige og nordmenn som hadde returnert fra USA. I 1970 var rundt 1,5 prosent av befolkningen innvandrere, se faktaboks. De siste 40 årene har denne andelen økt til 12 prosent, se figur 2. Rundt halvparten av innvandringen til Norge siden 2007 har vært arbeidsinnvandring, og de største gruppene har kommet fra Polen, Sverige og Litauen.

Til sammen utgjør innvandrere og norskfødte med innvandrerforeldre rundt 14 prosent av befolkningen i Norge (Brunborg, 2013b). Det er rundt 320000 innvandrere fra Europa i Norge, og rundt 240000 fra Afrika og Asia. Innvandrerbefolkningen er en sammensatt gruppe. De har kommet til Norge av ulike grunner (eks arbeid, beskyttelse og familiegjenforening), og de representerer mer enn 200 ulike land. Rundt halvparten befinner seg i aldersgruppen 20-44 år, og av norskfødte med innvandrerforeldre er 85 prosent under 20 år. Hvilke grupper som til enhver tid kommer til Norge avhenger av internasjonale konjunktursvingninger, innlemmelse av nye medlemsland i EU og nye krigs- og konfliktområder.

\section{Innvandrerbefolkningen framover}

SSB har siden 2005 også gjort framskrivinger på innvandrerbefolkningen. Ifølge hovedalternativet som ble presentert i 2012 vil antall innvandrere vokse fra 0,55 millioner i 2012 til 1,3 millioner i 2050. Dersom vi tar med barn av innvandrere, vil antallet vokse fra 0,66 millioner i 2012 til 2,03 millioner i 2070.

Tabell 2: Antall innvandrere etter landbakgrunn. Kilde: Statistisk sentralbyrå

\begin{tabular}{|l|c|}
\hline Landbakgrunn & Antall innvandrere \\
\hline Europa & 323260 \\
\hline Afrika & 67566 \\
\hline Asia & 171919 \\
\hline Nord og Mellom-Amerika & 13602 \\
\hline Sør-Amerika & 15024 \\
\hline
\end{tabular}

\section{$\varnothing$ kende urbanisering}

Andelen av befolkningen som bor i urbane strøk har vokst fra rundt 35 prosent i 1900 til rundt 80 prosent $i$ dag, se figur 3. 1940 var et vendepunkt da rundt halvparten av befolkningen bodde i tettbygd strøk.

\section{Sterk vekst rundt Oslo}

De siste 10 årene har halvparten av all befolkningsvekst i Norge vært innen 10 mil fra Oslo (Høydal, 2010).

De siste 110 årene har andelen av befolkningen som bor i Oslo og Akershus vokst fra rundt 15 til rundt 21 prosent. Også Rogaland har opplevd en relativ vekst (fra 5,7 til 8,4 prosent). Andelen av befolkningen som lever i Sør-Trøndelag, Hordaland, Buskerud, Vest-Agder og Vestfold er omtrent uforandret de siste 110 årene, mens resten av fylkene har opplevd en relativ nedgang i befolkningen (SSB, 2014).

\section{Referanser}

Brunborg, H. Vi blir 5 millioner innbyggere 19. mars 2012. Oslo: Statistisk sentralbyrå; 2012.

Brunborg, H \& Tønnessen, M. Befolkningsutviklingen. Økonomiske analyser. 2013a; 32, 3-13.

Brunborg, H. Hvor mange innvandrere er det - og blir det - i Norge? Samfunnsspeilet 2013b; 27(3): 2-9.

Høydahl, E. Befolkningsvekst rundt Oslo. Samfunnsspeilet 2010; 24(5-6): 11-19.

PRB; Population Reference Bureau. World population data sheet. [hentet 30/5/2014].

SSB; Statistisk sentralbyrå. Statistikkbanken. [hentet 30/5/2014].

\section{FORFATTER}

Per Henrik Zahl 


\section{Levealder}

- | 2013 var forventet levealder 83,6 år for kvinner og 79,7 år for menn.

- Forventet levealder er økt mer eller mindre kontinuerlig de siste 170 årene, men med ulik veksttakt.

- Fra om lag 1940 ble kvinners levealder stadig høyere sammenliknet med menns levealder, men de siste 20 årene har denne utviklingen snudd.

- Det er store og vedvarende geografiske forskjeller i levealder.

- I perioden etter 1960 har sosiale forskjeller i levealder økt, men dette ser nå ut til å stagnere eller snu.

- I perioden etter 1960 har Norge gått fra å ha verdens høyeste levealder til å havne et stykke ned på verdensrankingen, særlig for kvinner.

- Sammenlignet med andre OECD- land har Norge hatt en ugunstig utvikling i dødelighet særlig ved lave og høye aldre.

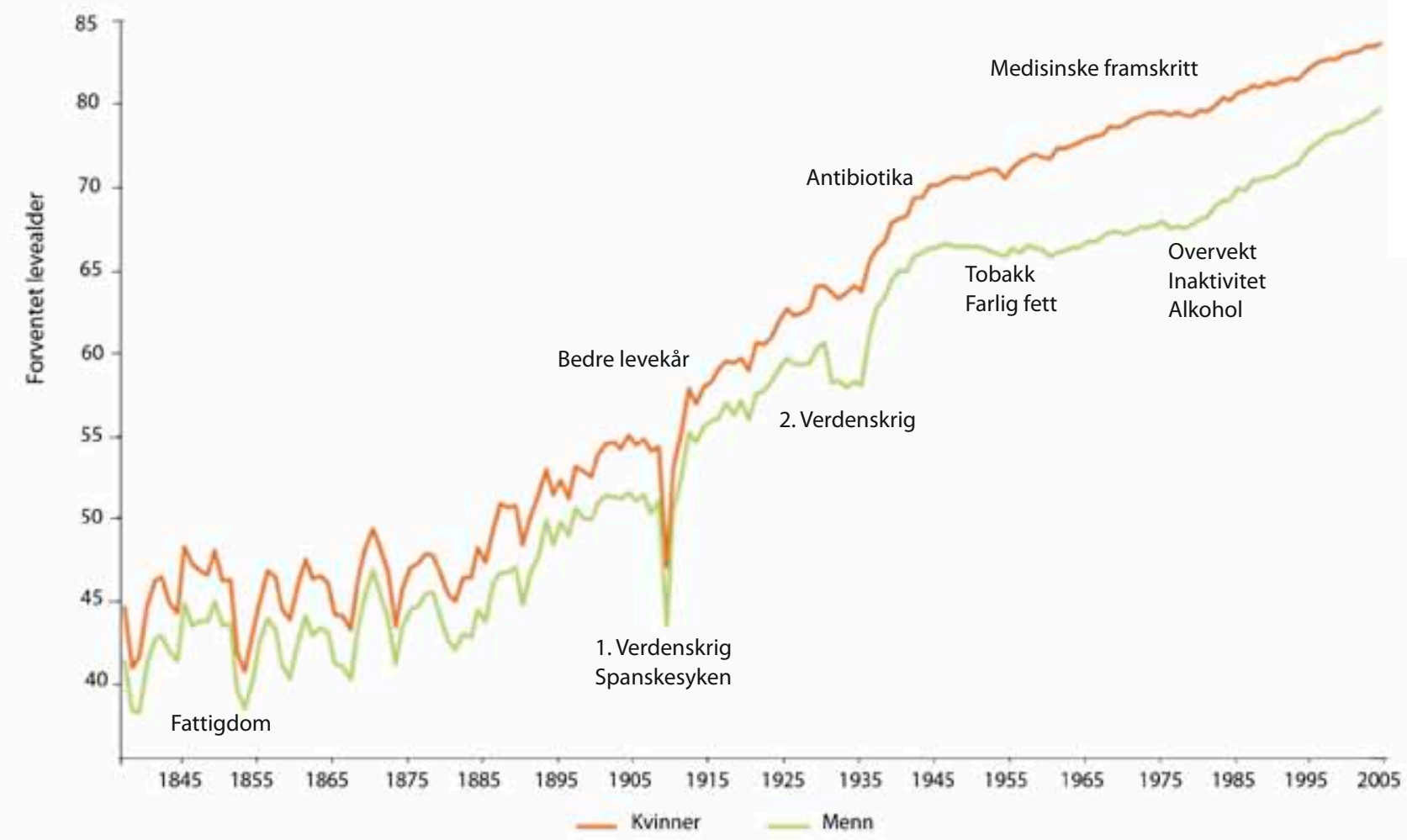

Figur 1: Forventet levealder i Norge 1846 - 2013. Kilde: Human Mortality Database, SSB-tall for 2010-2013. 


\section{Om forventet levealder}

Forventet levealder er et vanlig brukt mål for å oppsummere dødeligheten ved alle aldre i ett enkelt tall. Det gir et mål på hvor lenge en person kan forvente å leve gitt at denne personen gjennom hele sitt liv helt hypotetisk levde under de dødelighetsforhold som gjelder i dag.

Det er viktig å merke seg at forventet levealder i regelen vil være en dårlig prognose for hvor lenge en nyfødt faktisk vil leve fordi han/hun vil leve sitt liv inn i framtiden der dødeligheten trolig vil ha endret seg fra dagens situasjon. Forventet levealder målt i 1900 var for eksempel på rundt 52 år, men personene født i det året levde i gjennomsnitt vesentlig lenger fordi dødeligheten sank betydelig gjennom hele 1900-tallet.

\section{Forventet levealder er høyere for kvinner enn for menn}

I 2013 var forventet levealder 83,6 år for kvinner og 79,7 år for menn (SSB, 2014).

\section{Vi lever lenger enn før}

I Norge kan vi beregne forventet levealder med brukbar presisjon tilbake til 1846. Som vist i figur 1 var forventet levealder omlag 50 år for kvinner og et par år lavere for menn i 1846. I 2013 hadde forventet levealder steget til 83,6 år for kvinner og 79,7 år for menn.

Forventet levealder har steget kontinuerlig gjennom hele perioden fra 1846 til i dag. Fram til omtrent 1890-tallet var veksten ganske svak og med en god del fluktuasjoner. Det er likevel verdt å merke seg at levealderen i Norge var helt i verdenstoppen allerede i 1850.

Som figur 1 viser har forventet levealder vært høyere for kvinner sammenlignet med menn $\mathrm{i}$ hele perioden fra 1846 til 2013.

Veksten i forventet levealder var sterkest i perioden 1920-1950. Etter dette hadde vi en periode der menns levealder stod stille og til dels falt i to-tre tiår før den igjen akselererte. Dette ga seg utslag i en markant økning i forskjellen mellom menn og kvinners levealder.

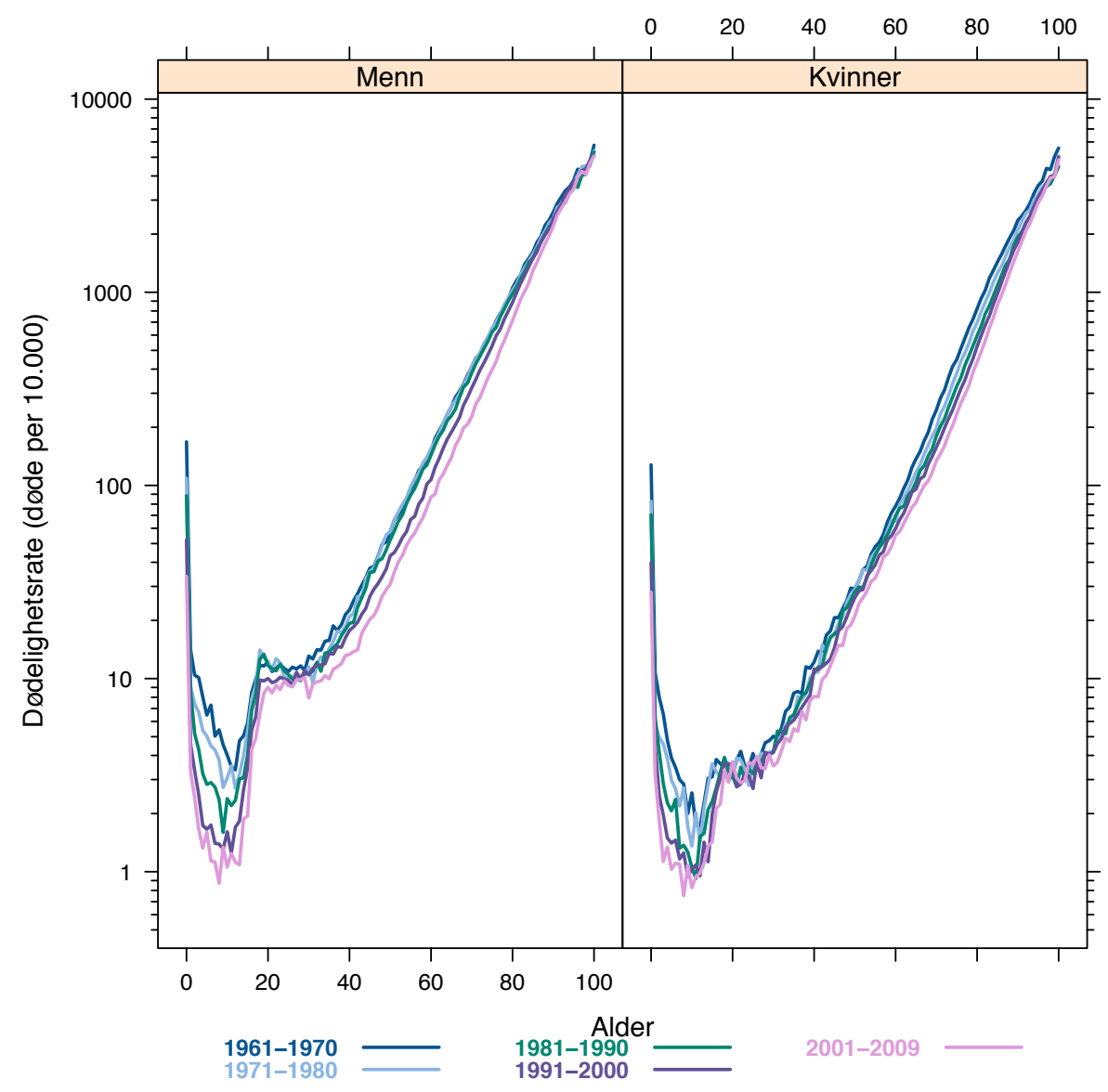

Figur 2: Dødelighetsrater etter alder i Norge 1961-2009 (merk: logaritmisk skala). Kilde: Human mortality database. 
I de siste 20 årene har forskjellen i forventet levealder mellom menn og kvinner blitt mindre. Den ulike utviklingen vi ser for menn og kvinner i figur 1 finner vi i de fleste land det er naturlig å sammenligne oss med. En hovedforklaring på dette er at menn i større grad og tidligere enn kvinner endret livsstilsvaner. Kvinner begynte for eksempel seinere å røyke enn menn, og har derfor hatt en tidsmessig forskyvning i røykerelaterte dødsfall. Tilsvarende effekter kan knyttes til slike forhold som uheldig kosthold og ulykker ved bilkjøring.
Dødeligheten har sunket i alle aldersgrupper

Figur 2 viser dødelighetsrater (døde per $10.000 \mathrm{i}$ ett kalenderår) etter alder i Norge fra 1961-2009. Som figuren viser har dødeligheten spesielt sunket for spedbarn og barn i perioden etter 1960, og tydeligst for gutter.

For voksne menn er det særlig i de siste to tiårsperiodene et markert fall i dødelighet ved alle aldre fra om lag 30 år til om lag 70 år. Fallet i dødelighet avtar etter 70 årsalderen, og forsvinner ved de høyeste aldrene.

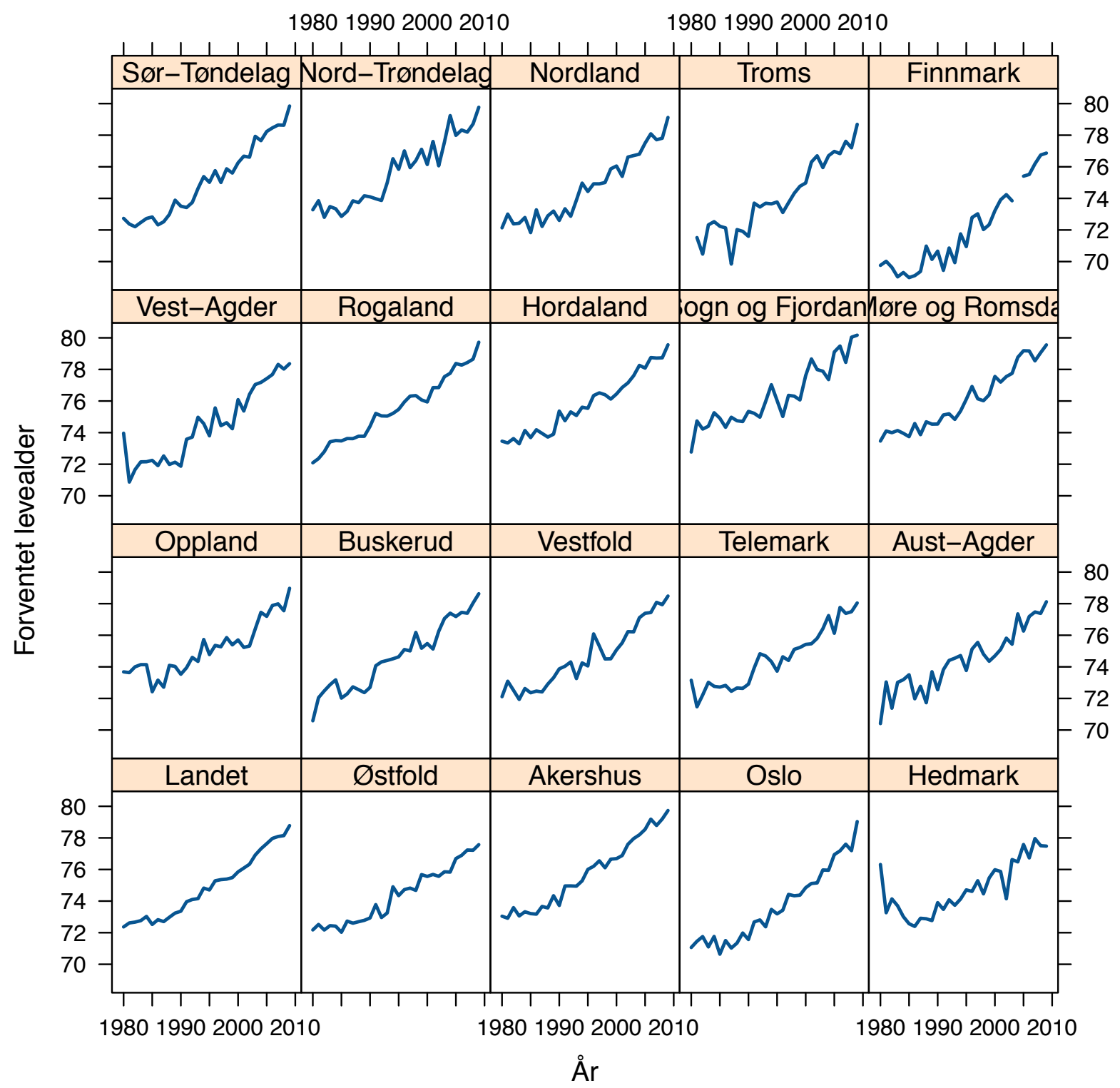

Figur 3a: Forventet levealder for menn i norske fylker 1980-2009. Kilde: Egne beregninger basert på SSBs befolkningsstatistikk. 
For voksne kvinner er fallet i dødelighet jevnere fordelt mellom alle periodene uten at noen enkeltperioder skiller seg ut. Kvinner har som menn et fall som påvirker de fleste aldre over 30 år. Fallet er imidlertid sterkere ved høyere aldre for kvinner sammenlignet med menn, og tydelig helt opp til 90 års alder, se figur 2.

Merk at en prosentvis endring i dødeligheten i alderen 2-40 år betyr ganske lite for forventet levealder, fordi dette angår få dødsfall i utgangspunktet. Motsatt vil et fall i spedbarnsdødeligheten bety mye, både fordi denne har vært høy og fordi spedbarn som dør gir mange tapte leveår.

\section{Store fylkesforskjeller i forventet levealder}

Det er regionale forskjeller i dødelighet og forventet levealder, se figur 3a og 3b som viser forventet levealder blant menn og kvinner i perioden 1980 til 2009.

- Levealderen er høyest på Vestlandet og lavest i Finnmark, Østfold og Hedmark.

- I 2009 var forskjellen mellom ytterpolene Sogn og Fjordane og Finnmark 3,4 år for menn og 2,9 år for kvinner.

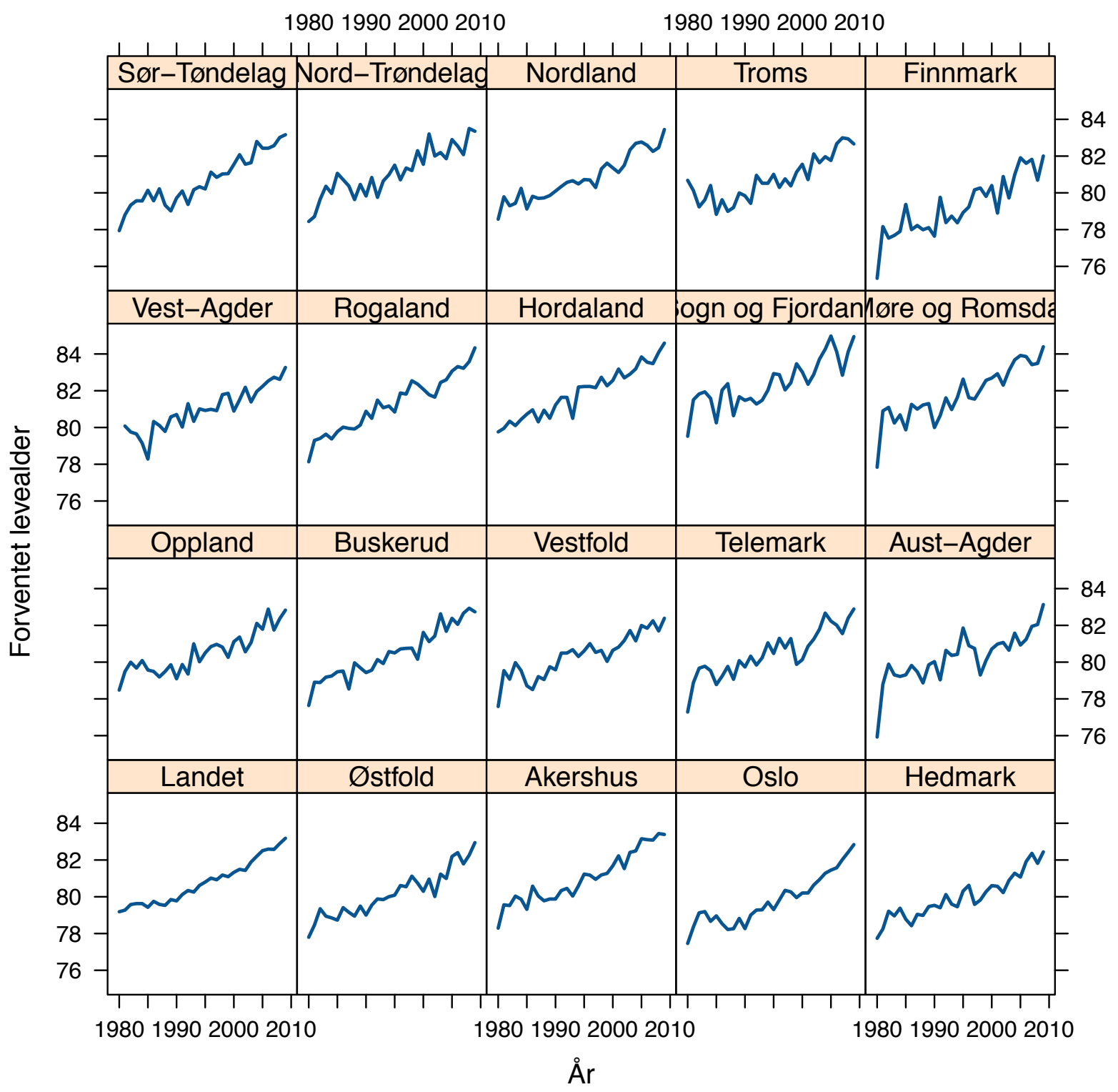

Figur 3b: Forventet levealder for kvinner i norske fylker 1980-2009. Kilde: Egne beregninger basert på SSBs befolkningsstatistikk. 
- Fylkesforskjellene har vært ganske bestandige over tid, men det er en svak tendens til mindre forskjeller der fylkene som starter ut med lavest levealder har sterkere vekst og dermed delvis tar igjen fylkene med høyest levealder.

- Oslo har hatt markant vekst i forventet levealder, mens for eksempel Hedmark bare har hatt svak $ø$ kning.

De geografiske forskjellene er enda mer slående på lavere geografisk nivå. Spriket mellom høyeste og laveste levealder i norske kommuner er om lag 5 år for både menn og kvinner. Denne forskjellen ser vi selv etter å ha ekskludert de mest ekstreme målingene i små kommuner der rene statiske tilfeldigheter spiller en stor rolle. Størst er forskjellene innad i Oslo by. I følge tall fra SSB varierte menns levealder i 2008-2011 fra 73,2 år på Sagene til 82 år i Vestre Aker. Dette er en forskjell som er omtrent like stor som den vi hadde for hele landet i perioden mellom 1960 og 2013, se figur 1.

\section{Høy utdanning - lengre levealder}

Det har lenge vært et betydelig politisk fokus på at det er store sosiale forskjeller i dødelighet i Norge, der personer med høyere inntekt, utdanning og posisjon i arbeidslivet gjennomgående har lavest dødelighet. Det har vært framhevet som et paradoks at slike forskjeller er vel så høye i de nordiske land som ellers i Europa, til tross for velutbygde velferdsordninger med universelle rettigheter (Dahl, 2014).

I figur 4 vises utviklingen i forventet gjenstående levealder for 35-åringer i Norge i perioden 1960-2009 der befolkningen er delt i tre etter utdanningsnivå (grunnskole, videregående og høyere utdanning). For slike sammenligninger er forventet levealder fra fødselen lite egnet siden man ikke kan klassifiseres etter forskjeller i utdanning før en viss alder.

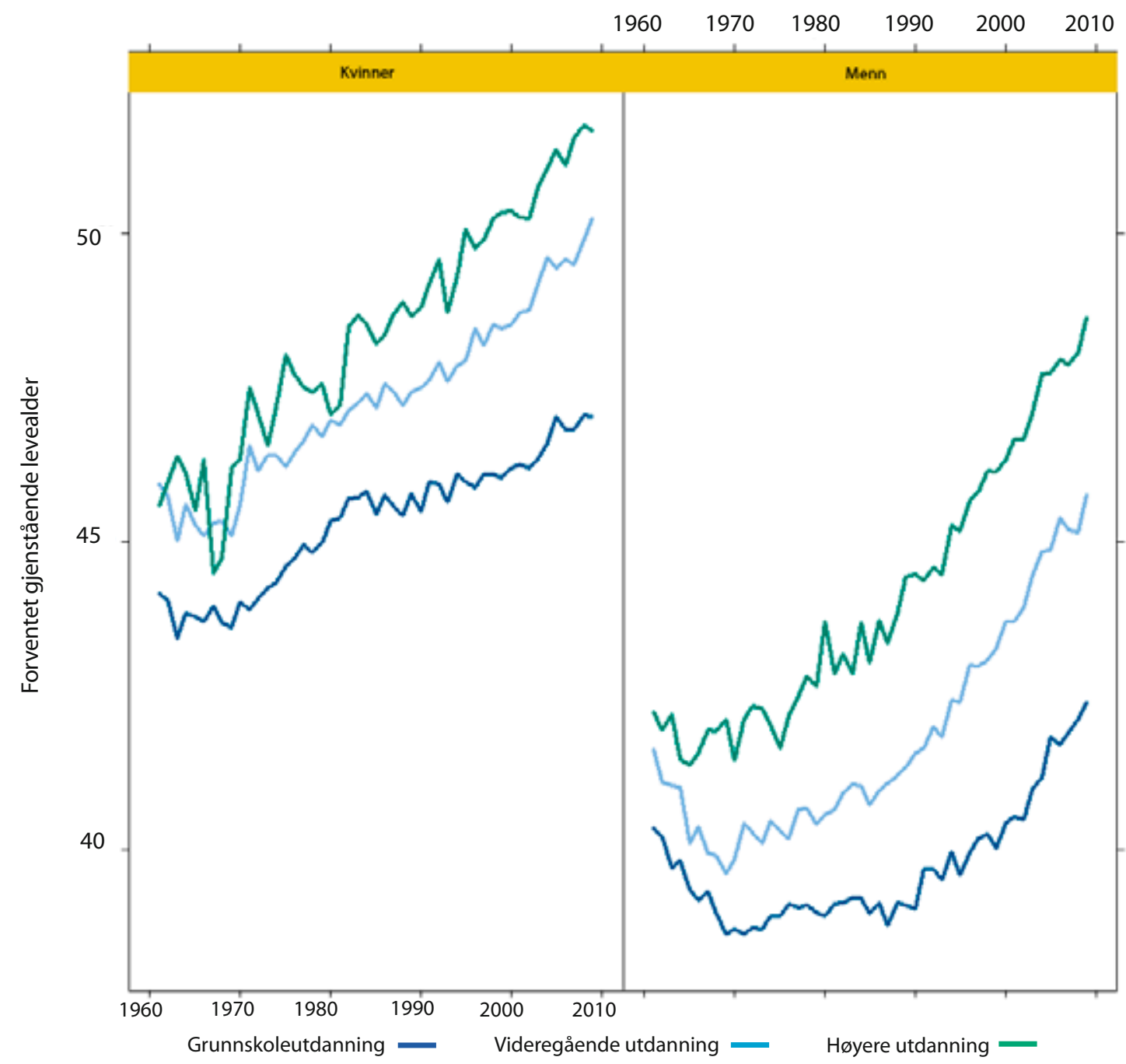

Figur 4: Forventet gjenstående levealder fra 35 års alder i Norge 1960-2009 gruppert etter utdanningsnivå. Kilde: Steingrímsdóttir, 2012. 
Av figuren ser vi at:

- Levealderen steg først i gruppen med høyere utdanning og til slutt i gruppen med grunnskoleutdanning.

- Det er omtrent 10 års etterslep i stigningen i levealder mellom de ulike utdanningsgruppene.

- Levealderen for menn med grunnskoleutdanning stod stille eller gikk noe ned helt fram til midten av 1990-tallet da den begynte å stige.

- De siste årene har særlig lavt utdannede kvinner hatt en lite gunstig utvikling.

Fra 1960 til 2009 økte levealderen betydelig mer i grupper med høyere utdanning enn i grupper med lavere utdanning. Dette gjelder både kvinner og menn. Det er tegn på at denne utviklingen er i ferd med å stagnere og snu.

\section{Andre land har gått forbi Norge}

En av hovedmålsettingene for folkehelsearbeidet er at «Norge skal være blant de tre landene i verden som har høyest levealder» (St.meld. nr 34 (2012-2013)). Figur $5 \mathrm{a}$ og $5 \mathrm{~b}$ viser forventet levealder $\mathrm{i}$ ulike land $\mathrm{i}$ 2009, som er det siste året vi har sammenlignbare data for disse landene. Som vi ser av figurene er forskjellen mellom de første landene små, særlig hvis vi ser bort fra japanske kvinner som har lengst forventet levealder i verden.

Figur 6 viser forventet levealder for de landene som har hatt vedvarende perioder med verdens høyest kjente levealder tilbake til 1850. Både for menn og kvinner hadde Norge den høyeste registrerte levealderen fra 1850 til ut på 1880-tallet. Dette skjedde i en periode da Norge var et av de mindre økonomisk utviklede landene i vår del av Europa.

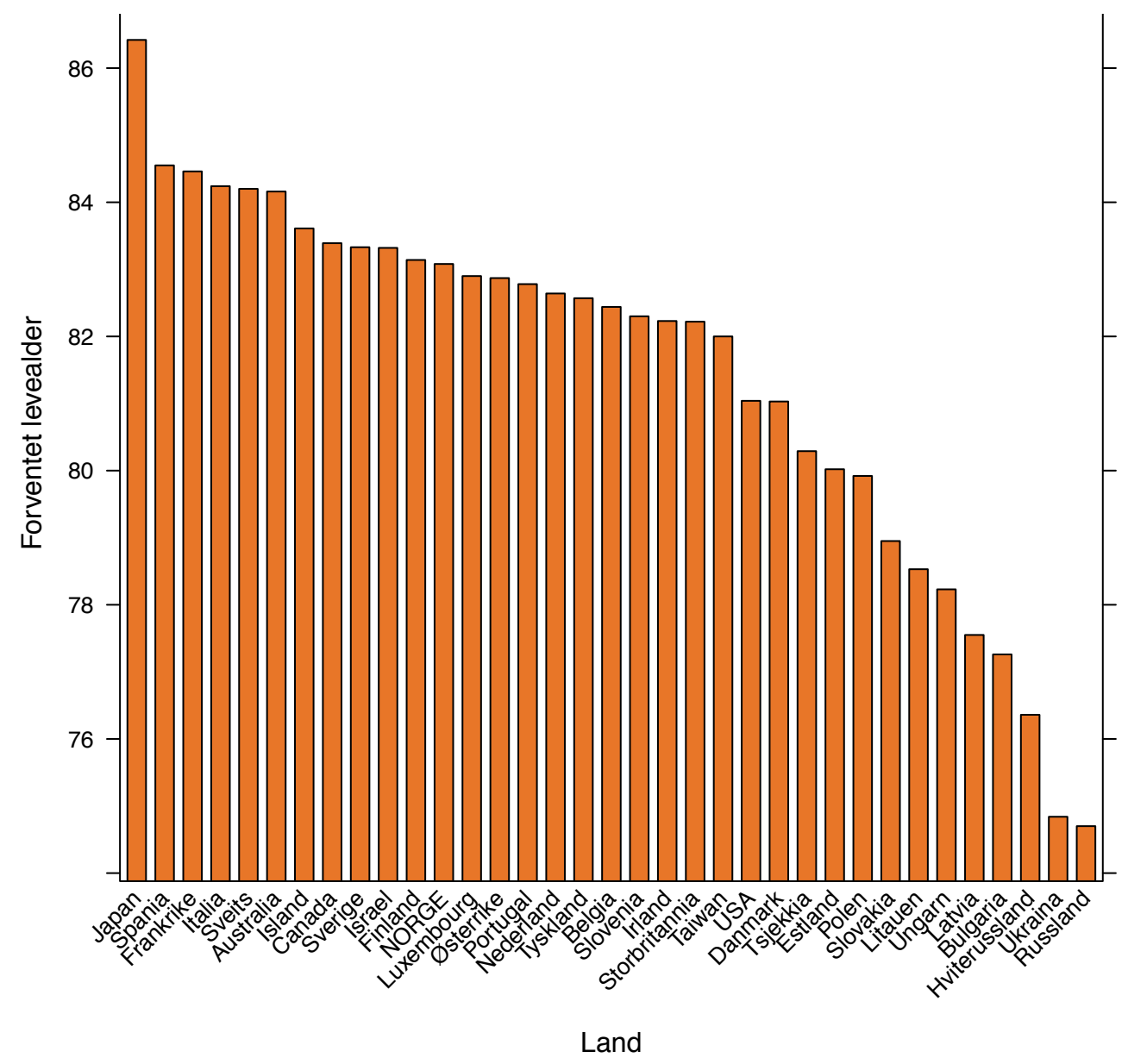

Figur 5a: Forventet levealder for kvinner i ulike land 2009. Kilde: Human Mortality Database. 


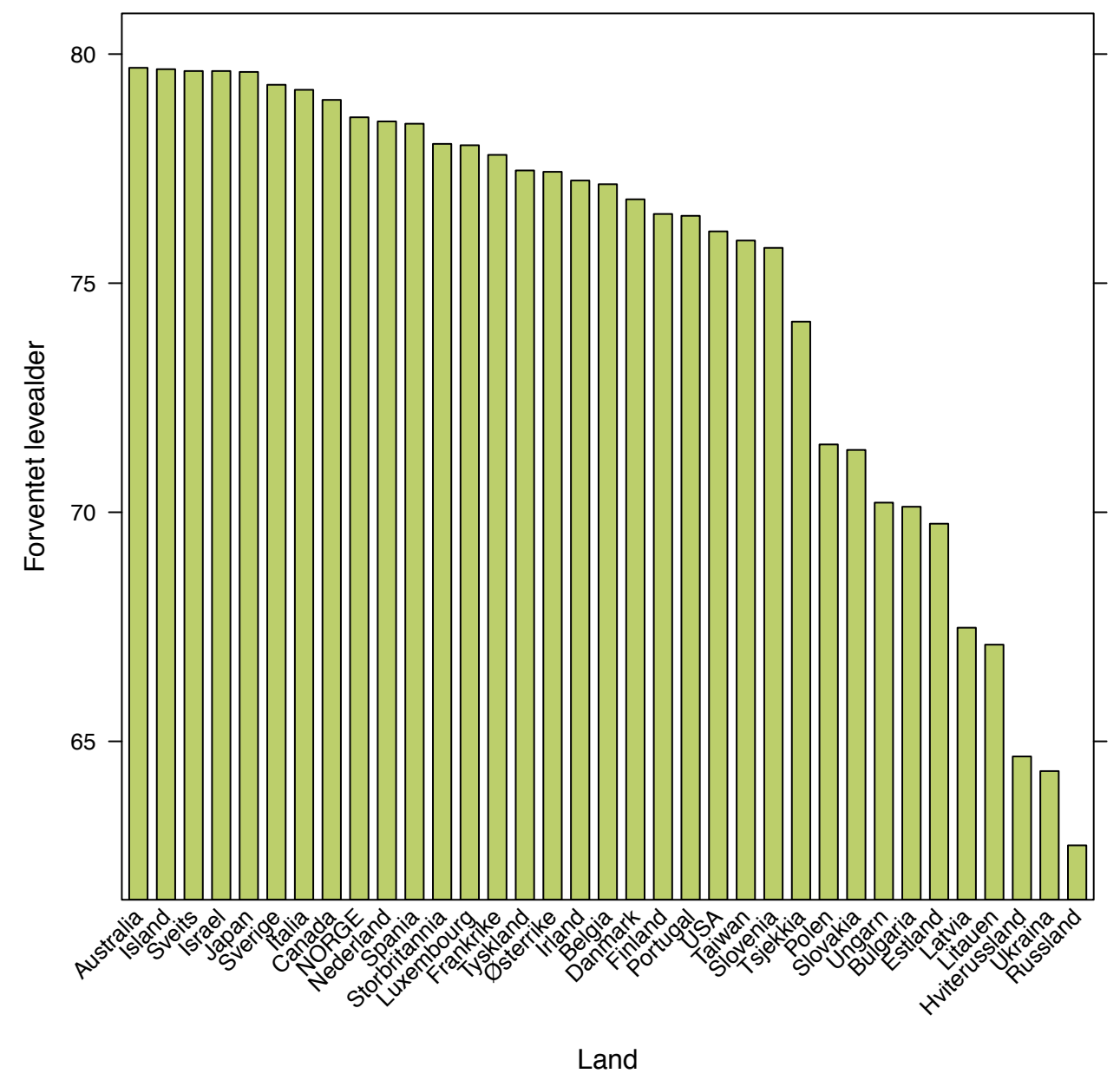

Figur 5b: Forventet levealder for menn i ulike land 2009. Kilde: Human Mortality Database.

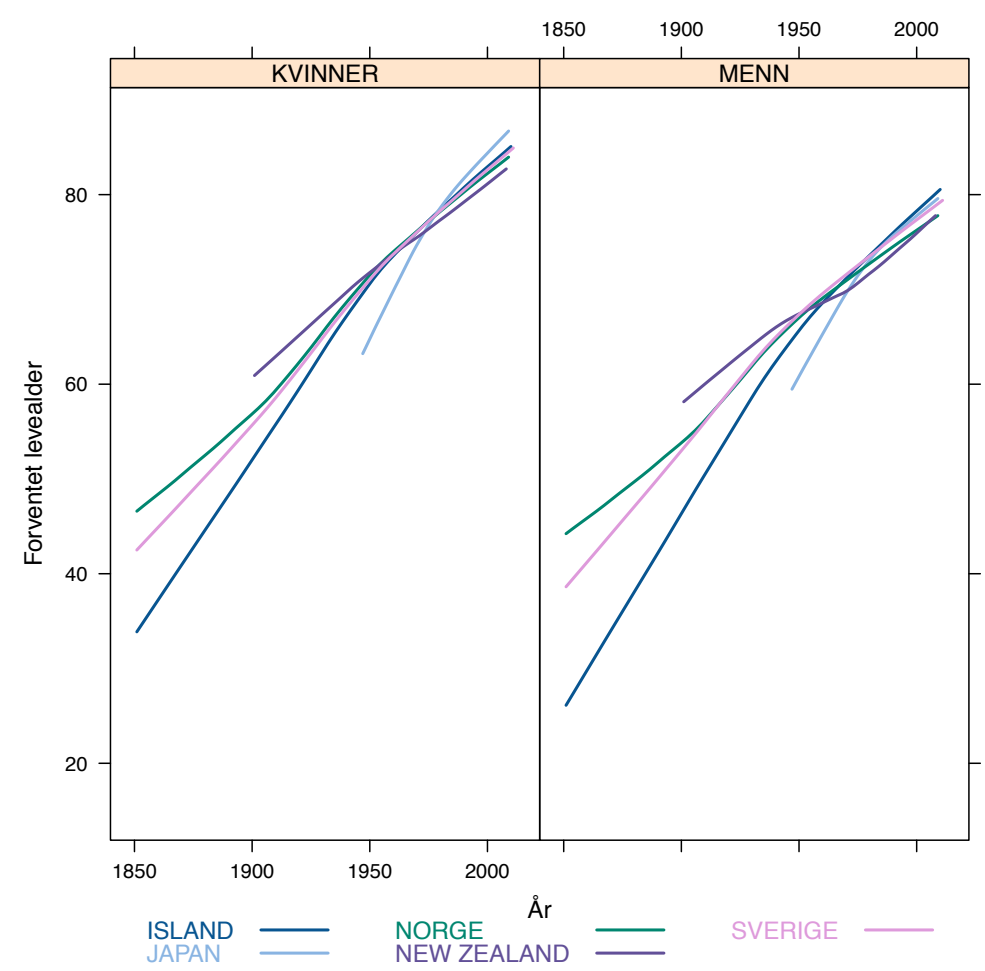

Figur 6: Forventet levealder i land med vedvarende perioder med verdens høyest kjente levealder 1850-2009. Kilde: Human Mortality Database. 
I perioden 1947-1955 for menn og 1945-1970 for kvinner lå forventet levealder i Norge igjen på verdenstoppen, hårfint foran Sverige. Senere har levealderen steget mindre her til lands enn i flere andre land, inkludert Sverige.

I perioden fra 1960 fram til i dag har Norge gått fra å ha verdens høyeste levealder til å havne et stykke ned på lista. Dette betyr at utviklingen i dødelighet i Norge har vært mindre gunstig enn for land vi liker å sammenlikne oss med. For å få en mer detaljert oversikt over dette kan vi se på dødeligheten ved forskjellige aldre. I figur 7 sammenlignes dødeligheten i Norge med et OECD-snitt, og i figur 8 gis samme type figur for Norge sammenlignet med Sverige.

Figurene er tegnet som et kart for hvert kjønn. X-aksen (vannrett) viser kalenderår og y-aksen (loddrett) alder. Rødlige farger angir at dødeligheten er høyere i Norge enn i referansebefolkningen (det vil si OECD i figur 7 og Sverige i figur 8). Gult angir at norsk dødelighet er på nivå med eller marginalt lavere enn referansebefolkningen. Grønne farger angir at dødeligheten er lavere.

Fra Figur 7 ser vi at Norge sammenlignet med OECD går fra lav dødelighet (dyp grønn) tidlig i perioden til en mindre gunstig posisjon (gul til rød) i dag. Dette samsvarer naturlig nok med det vi fant for forventet levealder. Men utviklingen er langt fra uniform. Den mest ugunstige utviklingen i relativ forstand har funnet sted for de eldste og for barn og ungdom, som går fra grønt til rødt.

Utviklingen for barn og unge er veldig markant, men her må man ha i mente at dødelighetsnivået er svært lavt for denne aldersgruppen. Dette innebærer både at høy dødelighet i denne aldersgruppen betyr lite for forventet levealder, og at en slik sammenligning er særlig utsatt for statistiske tilfeldigheter.

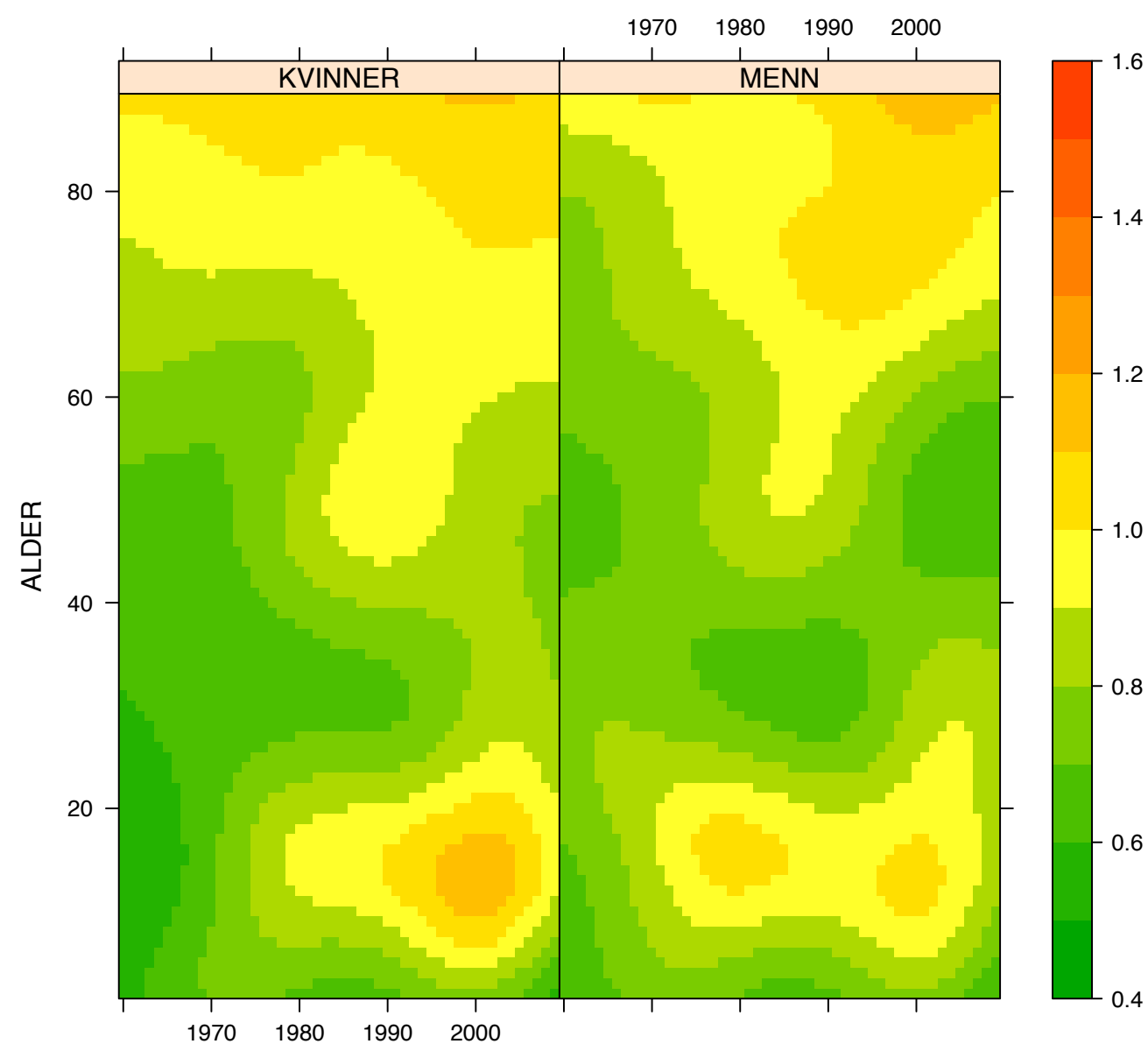

$\AA ̊ R$

Figur 7: Dødeligheten i Norge i forhold til den totale OECD-befolkningen for alle kalenderår 1960-2009 og ett års aldersgrupper 0-89. Rødlige farger angir at dødeligheten er høyere i Norge enn i referansebefolkningen (OECD). Gult angir at norsk dødelighet er på nivå med eller marginalt lavere enn referansebefolkningen. Grønne farger angir at dødeligheten er lavere. 
I sammenligningen mellom Norge og Sverige i figur 8 framkommer mye av det samme bildet. Her er den relativt ugunstige utviklingen for ungdom og unge voksne enda mer framtredende.

\section{Internasjonal sammenligning etter dødsårsak}

Figur 9 viser en sammenligning av dødeligheten i Norge og OECD etter hovedgrupper av dødsårsaker. OECD-snittet er i denne figuren beregnet ut fra de europeiske OECD-land. Figuren viser at norske kvinner har lav dødelighet av hjerte- og karsykdommer relativt til OECD, mens dødeligheten av kreft er like høy eller høyere enn i OECD. For menn er det ikke så klare forskjeller mellom sykdomsgruppene og nivået ligger gjennomgående lavere enn i OECD.

For dødelighet av hjerte- og karsykdommer og kreft kommer Norge generelt bedre ut enn OECD for de lave aldersgruppene (under 60 år) enn for de høye aldersgruppene. Norge har gjennomgående høyere dødelighet enn OECD for ulykker, spesielt ved lave aldersgrupper. Det er særlig verdt å merke seg den uheldige utviklingen for unge kvinner de siste årene.

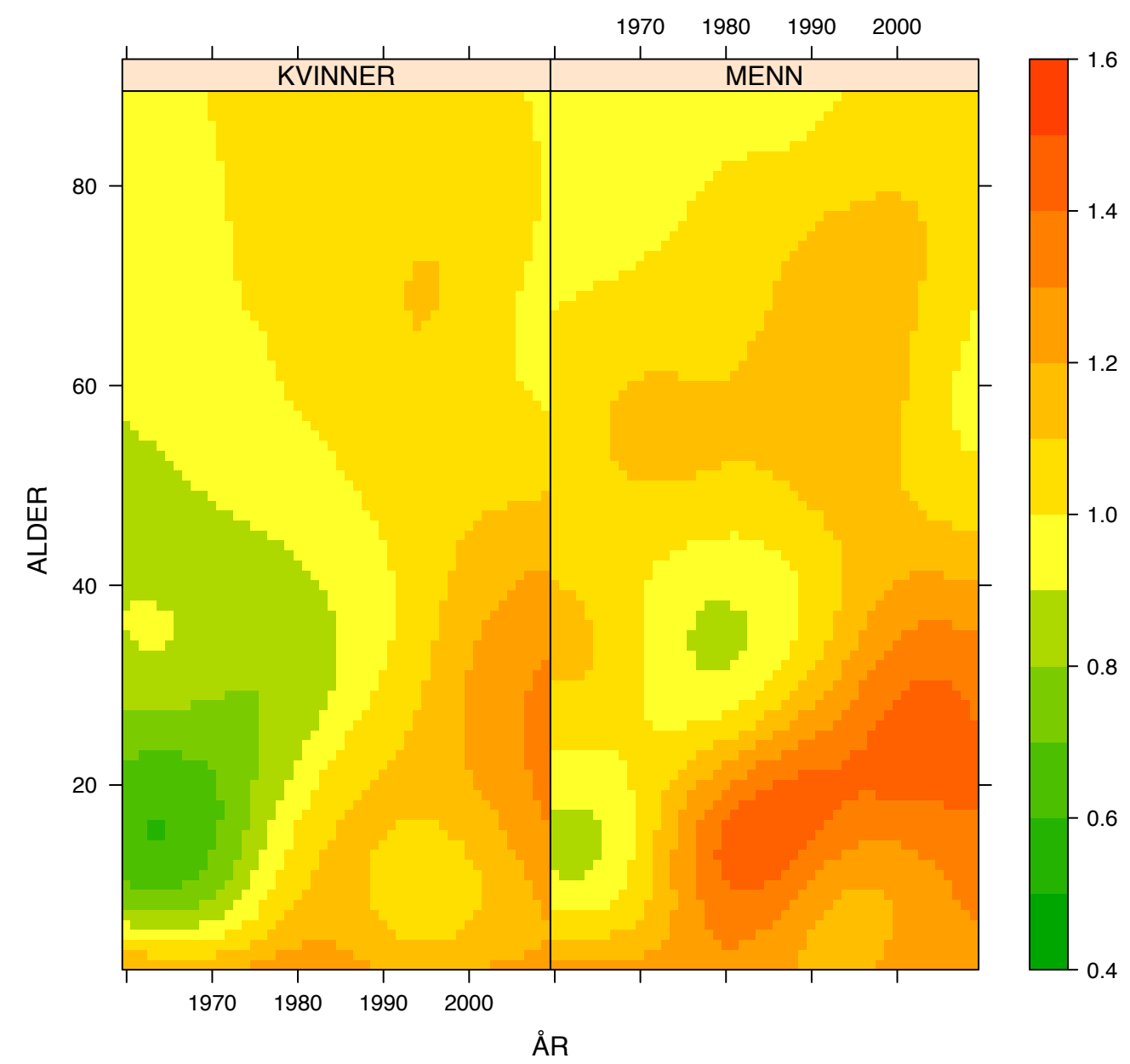

Figur 8: Dødeligheten i Norge i forhold til Sverige for alle kalenderår 1960-2009 og ett års aldersgrupper 0-89. Rødlige farger angir at dødeligheten er høyere i Norge enn i referansebefolkningen. Gult angir at norsk dødelighet er på nivå med eller marginalt lavere enn referansebefolkningen. Grønne farger angir at dødeligheten er lavere. Kilde: Human Mortality Database. 


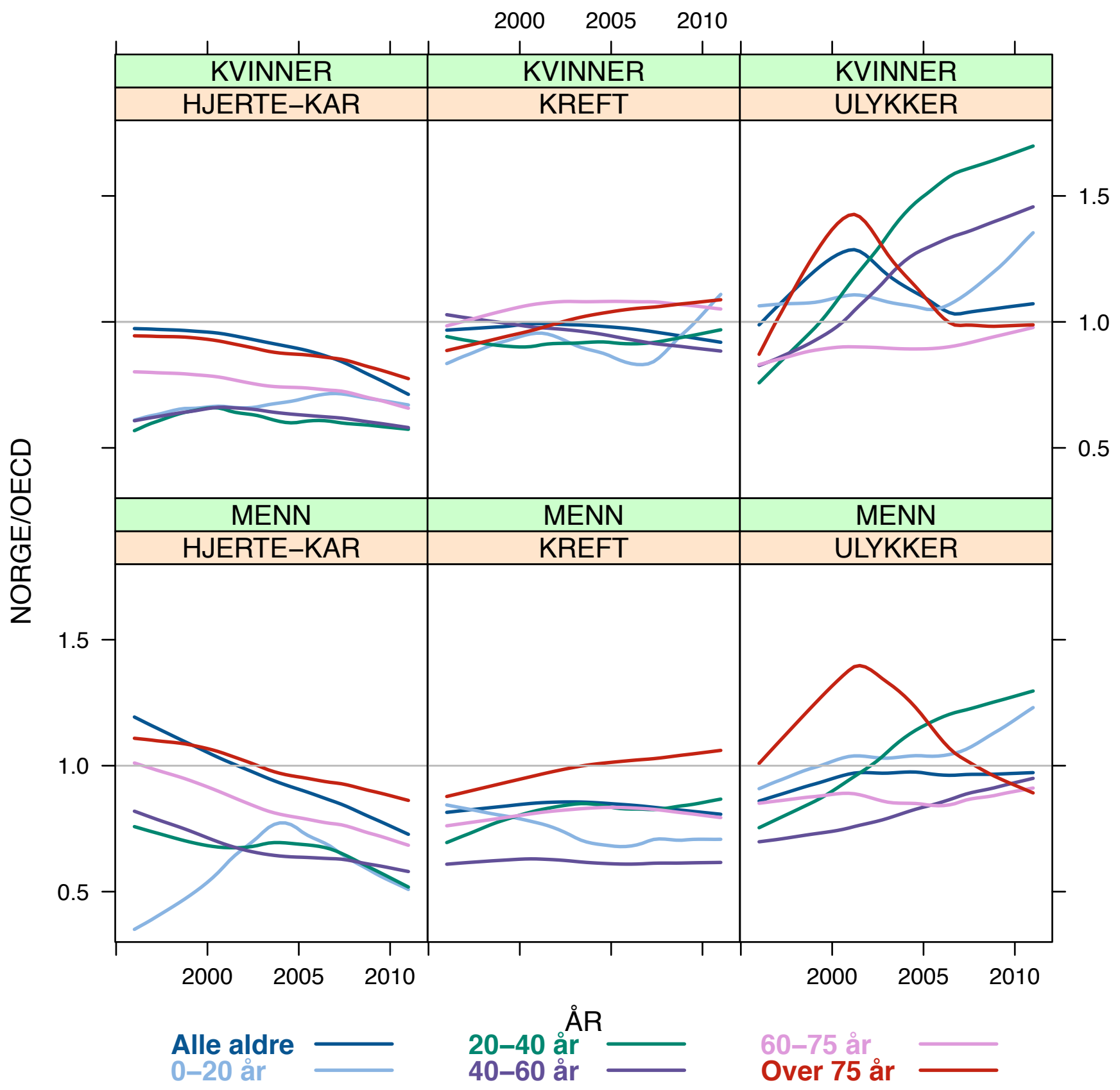

Figur 9: Dødeligheten i Norge sammenlignet med europeiske OECD-land fordelt på hovedgrupper av årsaker. Nivået i $\mathrm{OECD}=1$. Ratene er aldersstandardisert innenfor hver aldersgruppe. Figuren viser hvordan Norge kommer ut i forhold til OECD når det gjelder hjerte- og karsykdommer og kreft i de lave aldersgruppene. Kilde: European Detailed Mortality Database, WHO, 2014. 


\section{Referanser}

Dahl, E, H Bergsli og K. van der Wel (2014): Sosial ulikhet i helse En norsk kunnskapsoversikt, Rapport fra Høgskolen i Oslo og Akershus.

European detailed mortality database (2014), WHO.

Tilgjengelig fra: http://data.euro.who.int/dmdb/ (mai 2014)

Human Mortality Database (2014), University of California, Berkeley, and Max Planck Institute for Demographic Research. Tilgjengelig fra: mortality.org (mai 2014).

Statistisk sentralbyrå (2014). Tilgjengelig fra: SSB.no.
Steingrímsdóttir OA, Ø Næss, JO Moe, EK Grøholt, DS

Thelle, BH Strand BH og K Bævre (2012): Trends in life expectancy by education in Norway 1961-2009, European Journal of Epidemiology, 27(3), 163-71.

St.meld. nr. 34 (2012-2013). Folkehelsemeldingen. God helse - felles ansvar. Oslo: Helse- og Omsorgsdepartementet.

\section{FORFATTER}

Kåre Bævre 



\section{DEL 2 Helse i ulike befolkningsgrupper}

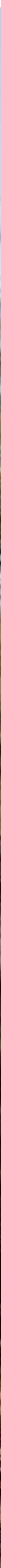


- Mødrenes gjennomsnittsalder ved første fødsel har økt jevnt de siste 40 årene.

- Behovet for assistert befruktning har økt i takt med økende fødealder.

- Mindre enn 3 av 10 gravide har tatt folattilskudd den siste måneden før graviditeten, slik helsemyndighetene anbefaler.

- Vi mangler oversikt over kvinners bruk av snus og alkohol i graviditeten.

- Spedbarnsdødeligheten og andelen dødfødsler har gått betydelig ned de siste 40 årene.

- Ulykker er årsak til om lag 10 prosent av alle dødsfall i aldersgruppen 0-17 år.

- Kroniske smerter er vanlig i ungdomsårene.

- De fleste barn bor sammen med begge foreldrene i oppveksten.

- De fleste barn har minst én fortrolig venn.

- 30 prosent fullfører ikke videregående skole.

- 15-20 prosent av barn og unge mellom 3 og 18 år har psykiske plager som angst, depresjon og atferdsproblemer.

\section{Barnebefolkningen i Norge}

I Norge passerte folketallet 5 millioner i 2012. Barnebefolkningen utgjør om lag 22 prosent av dette, dersom vi følger FN's definisjon på barn: 0-17 år. Det totale antall barn i Norge var 1125160 per 1.januar 2014 (SSB, 2014a).

I 2013 flyttet nær 15000 barn til Norge. De fleste kom fra Polen og Sverige. Barn under 18 år som var innvandrere og norskfødte barn med innvandrerforeldre, utgjorde 14 prosent av den bosatte befolkningen (0-17 år) per 1. januar 2013. Blant barn av innvandrere var hele 72 prosent yngre enn 16 år per. 1. januar 2014 (SSB, 2014a).

\section{Cirka 60000 barn fødes hvert år}

I 2013 ble det født 59914 barn $\geq 500$ gram eller $\geq 22$ uker i Norge (FHI, 2014a).

\section{Helse i fosterliv og første leveår}

\section{Mødrenes fødealder øker}

Mødrenes gjennomsnittsalder ved første barnefødsel har økt jevnt fra 23,1 år i 1967 til 28,5 år i 2013 (FHI, 2014a). Kvinner i Oslo har høyest gjennomsnittsalder ved første barnefødsel, nesten 31 år i 2013.

Befruktningsevnen faller med økende alder. Høy alder før første svangerskap øker derfor behovet for assistert befruktning (se nedenfor). Høy alder hos førstegangsfødende øker også risikoen for komplikasjoner som svangerskapsforgiftning og svangerskapsdiabetes, noe som kan ha uheldige konsekvenser for fosteret både på kort og lang sikt. Risikoen for at fødselen tar lengre tid, og for at barnet må forløses med keisersnitt øker også med økende alder hos den fødende (Herstad, 2014).

\section{Spedbarnsdødeligheten er lav}

Spedbarnsdødeligheten i Norge er i dag under 3 per 1000 levende fødte. Både dødeligheten i første levemåned og hele første leveår har sunket gjennom mange tiår. Andelen dødfødsler har også gått ned og var 3,8 per 1000 fødte i 2013 (FHI, 2014a). 
Nedgangen i spedbarnsdødeligheten skyldes trolig en generell bedring i folkehelse og levekår, samt god omsorg under svangerskap og fødsel. Et viktig bidrag til endringene i spedbarnsdødeligheten er nedgangen i krybbedød fra slutten av 1980-tallet. Denne nedgangen skyldes i stor grad at anbefalt sovestilling for nyfødte ble endret fra mageleie til ryggleie. Dette førte til en nokså umiddelbar nedgang i forekomsten av krybbedød i Norge og resten av Skandinavia (Wennergren, 1997).

\section{Komplikasjoner i svangerskapet og risiko for barnet}

Komplikasjoner i svangerskapet kan øke risikoen for dødfødsel og nedsatt helse hos det nyfødte barnet:

- Morkakeløsning er en sjelden, men alvorlig komplikasjon med betydelig økt risiko for dødfødsel. Forekomsten har sunket fra nesten 8 per 1000 i 1990 til rundt 3 per 1000 i 2012 (FHI, 2014a).

- Svangerskapsforgiftning er en komplikasjon som gir økt risiko for sykelighet for mor og foster på både kort og lang sikt. Globalt er dette en viktig årsak til mødredødelighet (Steegers, 2010; Duley, 2009). Svangerskapsforgiftning påvirker ofte fosterets vekst og øker risikoen for at barnet blir født med "lav fødselsvekt". Andelen gravide med svangerskapsforgiftning gikk ned fra 4,4 prosent 1999 til under 3 prosent i 2012 (FHI, 2014a).

\section{Bedre overlevelse av for tidlig fødte barn}

Lav fødselsvekt (< 2500 gram) kan skyldes dårlig morkakefunksjon eller for tidlig fødsel. Det kan derfor være en indikator på at barnet ikke har hatt et optimalt fosterliv, men lav fødselsvekt kan også skyldes arvelige faktorer.

Barn med lav fødselsvekt har økt risiko for sykdom og død rundt fødselen og for å utvikle visse kroniske sykdommer senere i livet, blant annet hjerte- og karsykdommer og type 2-diabetes (Hediger, 2011; Barker, 1995).

Også for tidlig fødsel kan gi lav fødselsvekt, men denne fødselsvekten er ikke nødvendigvis for lav i forhold til svangerskapslengden. Ofte har imidlertid for tidlig fødte barn også hatt dårligere vekst. Umodne lunger er ofte den største utfordringen for de for tidlig fødte barna.

- Andelen barn som er født før 37 uker, er noe redusert de siste 10 årene (7,1 prosent i 2003 og 6,3 prosent i 2013).
- Andelen barn som er født før 32 uker (to måneder for tidlig eller mer) har ligget relativt stabilt på vel 1 prosent i samme periode (FHI, 2014a).

Overlevelse den første levemåneden er bedret blant de barna som er født altfor tidlig:

- Blant barn som ble født før 32 svangerskapsuker i 2000, døde 12,1 prosent i løpet av første levemåned. Tilsvarende tall i 2013 var 9,2 prosent.

Til tross for en bedring i overlevelse for de mest for tidlig fødte barna, vil de oftere enn andre få problemer når de vokser opp, blant annet har de økt risiko for cerebral parese, lungesykdommer, lærevansker og ADHD (Moster, 2008; Halmøy, 2012).

\section{Færre barn med høy fødselsvekt}

I perioden fra rundt 1998 til 2004 var det er stor økning i andelen barn med høy fødselsvekt (FHI, 2014a). Høy fødselsvekt (>4500 g) er forbundet med problemer i forbindelse med forløsningen. Vanskelige skulderforløsninger, blødninger, skader i fødselskanalen, økt bruk av tang og sugekopp, samt økt bruk av keisersnitt er eksempler på dette (Stotland, 2004).

De siste årene har det vært en nedgang både i andelen av de veldig lette og de veldig tunge barna. Parallelt med dette har gjennomsnittlig fødselsvekt gått ned til det nivået man hadde på 1980-90-tallet. Gjennomsnittlig fødselsvekt var litt under 3500 gram i 2013.

\section{3 av 100 barn fødes etter assistert befruktning}

Siden 2007 er over 3 prosent av barna i Norge født etter assistert befruktning, noe som blant annet har sammenheng med at kvinner er eldre når de får sitt første barn.

Assistert befruktning øker risikoen for tvillinger og trillinger. De siste årene er denne andelen redusert fordi det i dag er vanlig å sette inn bare ett egg.

- Fra 2000 til 2013 ble andelen tvillingbarn født etter assistert befruktning halvert fra cirka 40 til under 20 prosent.

- Andelen trillingbarn ble i samme periode redusert fra 2,0 til 0,3 prosent.

\section{Medfødte misdannelser}

Andelen barn som fødes med alvorlige misdannelser har holdt seg forholdsvis konstant gjennom mange år, og er i dag rundt 3 prosent av alle fostre/fødte, inkludert svangerskapsavbrudd som er utført på grunn av sykdom eller misdannelse hos fosteret (FHI, 2014a). 
En økende andel fostre med alvorlige misdannelser diagnostiseres før fødselen og fører til svangerskapsavbrudd. Svangerskapsavbrudd skjer oftest i tilfeller der fosteret har flere alvorlige misdannelser og/eller kromosomfeil.

Mellom 85 og 90 prosent av misdannelsene er isolerte, det vil i hovedsak si at bare ett organsystem er berørt, for eksempel hjertet. Disse misdannelsene vil likevel kunne være svært alvorlige og kreve omfattende, ofte høyspesialiserte, kirurgiske inngrep.

\section{Livsstilsfaktorer hos mor og barnets helse}

\section{Røyking og snusbruk i svangerskapet}

Tall fra Medisinsk fødselsregister (MFR) i 2013 viser at 8 prosent av gravide kvinner røykte ved svangerskapets begynnelse og 5 prosent ved svangerskapets slutt. Ti år tidligere, i 2003, var tilsvarende tall 20 og 12 prosent.

Vi vet lite om omfanget av snusbruk i svangerskapet. Informasjon om snusbruk vil inngå i nytt elektronisk helsekort for gravide som er under planlegging.

Røyking i svangerskapet er mest utbredt blant (Cupul-Uicab, 2012):

- yngre gravide

- gravide med lav utdanning

- gravide med et ikke-planlagt svangerskap

- døtre av røykende foreldre

- førstegangsgravide

$\varnothing k t$ risiko for dødfødsel er kanskje det mest alvorlige uønskede svangerskapsutfallet for røykende kvinner. Risikoen øker med økende røykedose, og tall fra Medisinsk fødselsregister for de siste 10 årene viser en doblet risiko med 10 sigaretter per dag, og en tre ganger høyere risiko med 20 sigaretter per dag. Den absolutte risikoen for dødfødsel knyttet til røyking er likevel lav.

Noen få sigaretter per dag fører til en dobling av risikoen for vekstreduksjon hos fosteret, og med større røykedoser øker risikoen ytterligere. Det er ellers godt dokumentert at røyking reduserer fruktbarheten hos både menn og kvinner.

Flere studier har vist at også snus øker risikoen for dødfødsel, vekstreduksjon og for tidlig fødsel. Risikoen for dødfødsel dobles, mens risikoen for vekstreduksjon og for tidlig fødsel øker med 30-40 prosent (Wickström, 2011; Baba, 2014; Gunnerbeck, 2014).

\section{Alkohol og andre rusmidler i svangerskapet}

Alkohol er skadelig for fosteret gjennom hele fosterlivet, og man kjenner ikke til noen trygg nedre grense for alkoholbruk i svangerskapet (O'Leary, 2013; Lewis, 2012; Willford, 2006). Helsemyndighetene anbefaler derfor totalavhold i hele svangerskapet (Helsedirektoratet, 2005). Ved stort alkoholbruk i svangerskapet øker risikoen for føtalt alkohol syndrom (FAS) og føtal alkoholeffekt (FAE). Barn med FAS og FAE er født med dårlig fostervekst og hjerneskade, som gir psykomotoriske utviklingsforstyrrelser og lærevansker. Barn med FAS har også karakteristiske ansiktstrekk (Helsedirektoratet, 2005).

Internasjonale studier antyder en forekomst av FAS fra 0,2 til 8 per 1000 (Sampson, 1997; May, 2001; Elgen, 2007 ). I MFR er det kun registrert 7 tilfeller av FAS i perioden 1999-2012. Det er en tydelig indikasjon på at man trenger en bedre registrering. FAS er den alvorligste formen for fosterskade som følge av alkohol, og forekomsten av alkoholrelaterte fosterskader er antagelig flere ganger høyere enn FAStallene tilsier (Sampson, 1997; May, 2001; Elgen, 2007). Disse barna har også ofte psykomotoriske utviklingsproblemer som lære- og konsentrasjonsvansker og hyperaktivitet (Manning, 2007; Elgen, 2007).

Alkohol er den viktigste forebyggbare årsaken til psykomotorisk utviklingshemming hos barn, og det er et paradoks at man har så dårlig registrering av både alkoholbruk i svangerskapet og effektene av dette.

\section{Kosthold i svangerskapet}

Mors kosthold i svangerskapet påvirker barnets helse både i fosterlivet og etter fødselen (Henriksen, 2005). Gravide anbefales å følge de generelle nasjonale kostrådene (Helsedirektoratet, 2011a ). Studier blant annet fra Den norske mor og barnundersøkelsen har vist at et variert kosthold med daglig inntak av grønnsaker, frukt, grove kornprodukter, fisk og melkeprodukter, og begrenset inntak av søte drikker, kaffe og sukker, er forbundet med lavere risiko for både komplikasjoner i svangerskapet og lav eller høy fødselsvekt hos barnet (Englund-Ögge, 2014; Sengpiel, 2013; Brantsæter, 2012; Brantsæter, 2009). 
Kosttilskudd kan ikke erstatte det mangfoldet av stoffer som et sunt og variert kosthold gir, men noen kosttilskudd er nødvendige. I Norge har det siden 1998 vært anbefalt at kvinner som planlegger graviditet, eller som kan regne med å bli gravide, bør ta et daglig tilskudd på $400 \mu \mathrm{g}$ av B-vitaminet folat for å forebygge nevralrørsdefekter. Tilskuddet skal tas den siste måneden før graviditet og de første 2-3 månedene i graviditeten. Imidlertid viser tall fra Medisinsk fødselsregister at bare 27 prosent av norske kvinner tar tilskudd av folat før de blir gravide. Hvert år er om lag 60 kvinner gravide med et barn som har ryggmargsbrokk eller en annen alvorlig nevralrørsdefekt. Tallet kan trolig halveres dersom kvinner tar folattilskudd allerede før unnfangelsen og fortsetter med det i begynnelsen av svangerskapet (FHI, 2013b).

For lite D-vitamin gir rakitt hos barn, osteomalasi hos voksne og øker risikoen for osteoporose. Dersom kostholdet ikke inneholder rikelig med fet fisk, er det svært få som får dekket D-vitaminbehovet gjennom maten alene. Vi er avhengige av sol-eksponering eller kosttilskudd for å få dekket behovet. I Den norske mor og barn-undersøkelsen tok cirka 60 prosent av de gravide tran eller et annet kosttilskudd med D-vitamin (Haugen, 2008), men tallet er trolig lavere blant gravide i den generelle befolkningen.

\section{Amming}

Norske helsemyndigheter anbefaler at spedbarn fullammes i seks måneder, og ammes videre til de er minst 1 år gamle (Helsedirektoratet, 2011b). Om lag 80 prosent av alle norske mødre ammer sine barn opptil 6 måneders alder (Kristiansen, 2010). Dette er en svært høy andel i global sammenheng, selv om andelen som ammer eksklusivt så lenge er mye lavere.

Effekten av morsmelk på barns helse, sammenlignet med morsmelkerstatning, er diskutert i vestlige land. I Norge har Vitenskapskomiteen for mattrygghet (VKM) vurdert forskning om morsmelkens positive egenskaper opp mot mulige negative effekter av at morsmelken også inneholder miljøgifter. VKM konkluderte at nåværende nivåer av miljøgifter $\mathrm{i}$ morsmelk innebærer liten risiko for barnets helse, og at fordelene med morsmelk er langt større for barnet enn risikoen fra miljøforurensninger (VKM, 2013).

\section{Helse og sykdom lkke-smittsomme sykdommer}

\section{Astma og allergi}

Det mangler landsdekkende unders økelser i Norge på antall personer med astma og allergi, det finnes kun studier som dekker mindre geografiske områder. Ulike diagnosekriterier og forskjell i metoder for innsamling av data gjør det vanskelig å sammenligne studier og å finne sikre tall for hvor stor andel av befolkningen som har de ulike sykdommene. Tall fra norske undersøkelser baserer seg også i stor grad på spørreskjema og må tolkes med forsiktighet.

Resultater fra en tverrsnittsundersøkelse blant barn i alderen 7-14 år fra Nordland viste at forekomsten av selvrapportert astma var 18 prosent i 2008 (Hansen, 2013). Dette samsvarer med resultater fra en undersøkelse blant barn i Oslo i 2003 hvor livstidsforekomsten ble funnet å være 20 prosent ved 10 år og 26 prosent ved 16 år (Lødrup Carlsen, 2006; Hovland, 2014). Forekomst er $\mathrm{i}$ alle undersøkelsene beregnet ut fra om barnet noen gang har hatt astma. Basert på ulike undersøkelser og data fra Reseptregisteret ser antallet tilfeller ut til å ha økt de siste 20-30 årene (Hansen 2013, Lødrup Carlsen 2006 ; Hovland, 2014; FHI 2014d).

Hos barn i førskolealder har mange forbigående astmalignende symptomer, men utvikler ikke astma. Denne trenden underbygges av reduksjonen man ser i bruken av astmamedisin hos barn etter førskolealder (FHI, 2014d). Diagnostiseringen kan gjøres med større sikkerhet fra omtrent fem års alder.

Av de som får astma, vil omtrent tre av fire ha utviklet sykdommen før skolealder. En stor andel av disse blir fri for symptomer i løpet av skolealderen, men nye tilfeller dukker opp i løpet av barne- og ungdomsårene, og i voksen alder.

Mange barn og unge har høysnue og atopisk eksem. Flere norske studier finner at livstidsforekomsten av høysnue (rinitt) ligger på omtrent 25 prosent hos barn i skolealder og 30 prosent hos unge i puberteten (Selnes, 2005; Hansen, 2013; Hovland, 2014). Forekomsten av atopisk eksem er 17 prosent hos 2 år gamle barn, og mellom 21 og 35 prosent hos barn i alderen 9-16 år. Dette viser tall fra norske studier i perioden fra 2000 (Selnes, 2005; Smidesang, 2010; Hovland, 2014).

Gutter har høyere forekomst av astma og allergi enn jenter fram til puberteten. Etter puberteten øker forekomsten blant jentene mer enn hos guttene. Årsakene 
til kjønnsforskjellene er usikre, men hormonelle endringer i puberteten og forskjeller i miljøeksponeringer kan ha betydning (Almqvist, 2008; Chen, 2008).

Årsakene til astma og allergiske sykdommer er for det meste ukjente. Det finnes derfor ikke forebyggende tiltak for utvikling av disse sykdommene.

\section{Diabetes}

Type 1-diabetes er den vanligste formen for diabetes blant barn, og om lag 300 nye personer under 15 års alder får type 1-diabetes hvert år i Norge. Dette tallet har vært stabilt fra 2004 (Skrivarhaug, 2014). Det er sannsynligvis lavere insidens av type 1-diabetes blant innvandrere fra India og Pakistan og en del andre land i Asia og Sør-Amerika, i alle fall blant barn. Vi har ikke norske data, men dette er dokumentert i Sverige (Ji, 2010).

Type 2-diabetes rammer oftest voksne personer, men også barn og unge kan få sykdommen. Risikoen for type 2 diabetes øker med økt kroppsvekt.

Både type 1- og type 2-diabetes skyldes i en viss grad arvelige faktorer, men arv alene er sjelden nok til å utvikle diabetes. Et unntak er sjeldne genetiske former for diabetes.

Type 1-diabetes kan foreløpig ikke forebygges, og foreløpig vet vi svært lite om påvirkbare risikofaktorer for denne diabetestypen.

\section{Langvarige smerteplager}

Forekomsten av langvarige smerteplager hos barn og ungdom er dårlig kartlagt i Norge, men forbruket av smertestillende legemidler og tall fra andre land tyder på at kronisk smerte også er vanlig i ungdomsårene (El-Metwally, 2007). I Levekårsundersøkelsen 2005 rapporterte foreldrene at 6 prosent av barna i aldersgruppen 6-10 år hadde kroniske smerteplager og 12 prosent i alderen 11-15 år.

En studie av 12-15-åringer i Sør- og Nord-Trøndelag viser at 17 prosent var regelmessig plaget av hodepine, magesmerter, ryggsmerter eller smerter i armer/bein (Larsson, 2007). Forbruk av smertestillende medisiner blant norske 15-16-åringer er høyt og har steget betydelig siden 2001 (Lagerlov, 2009).

\section{Kreft}

Mellom 140 og 150 barn under 15 år rammes hvert år av en kreftsykdom (Kreftregisteret, 2012). Leukemi og kreft i hjernen/det sentrale nervesystem står for 58 prosent av tilfellene.
- Leukemi (29 prosent)

- Kreft i hjernen/det sentrale nervesystemet (29 prosent)

- Lymfekreft (11 prosent)

Cirka 300 menn får årlig påvist testikkelkreft i Norge, halvparten av tilfellene er i aldersgruppen 15-34 år (FHI, 2013c). Totalt sett er testikkelkreft ingen hyppig kreftform, men det har vært økende forekomst i den vestlige verden gjennom flere tiår (Kreftregisteret, 2014).

I yngre aldersgrupper er det få som dør av kreft, og de siste tiårene har det skjedd en svært gledelig utvikling i overlevelsen av kreft kos barn. I aldersgruppen under 15 år økte overlevelsesprosenten for akutt lymfatisk leukemi fra 75 til 84 prosent i perioden 1985 til 2009 (Kreftregisteret, 2012).

\section{Infeksjoner}

\section{Barnesykdommer}

I Norge er det få sykdomstilfeller av de sykdommene vi vaksinerer mot i barnevaksinasjonsprogrammet. Et unntak er kikhoste. Fra 1997 er det observert en betydelig økning i antall kikhostetilfeller, særlig hos eldre barn og unge. Forklaringen er sannsynligvis at vaksinens effekt avtar etter fem- seks år. I barnevaksinasjonsprogrammet er det derfor innført en oppfriskningsdose ved 7 og 15 års alder.

Vaksinasjonsdekningen for vaksinene i barnevaksinasjonsprogrammet ligger mellom 90 og 95 prosent. For vaksine mot human papillomavirus (HPV) er dekningen så langt noe lavere, fordi denne vaksinen først ble innført i 2009. Les mer om HPV i avsnittene om seksuelt overførbare infeksjonssykdommer og i kapittel om vaksinasjon.

I miljøer med dårlig vaksinasjonsdekning opptrer det noen ganger mindre utbrudd av barnesykdommer. I 2011 var det et meslingutbrudd med utgangspunkt i en bydel i Oslo, hvor vaksinasjonsdekningen for MMR-vaksinen (meslinger, røde hunder og kikhoste) lå klart under landsgjennomsnittet, med bare 85 prosent dekning for barn født i 2008. En relativt høy andel av de smittede var barn fra et innvandrermiljø, hvor skepsisen til MMR-vaksine var særlig høy.

Fra høsten 2014 vil vaksine mot sped- og småbarnsdiaré forårsaket av rotavirus også inngå i barnevaksinasjonsprogrammet. Vaksinen er en drikkevaksine som gis som dråper i munnen til spedbarn. 
Nesten alle barn får rotavirusinfeksjon før 5 års alder, og hvert år blir nær 1000 barn i Norge lagt inn på sykehus for behandling av væsketap som skyldes rotavirusinfeksjon.

\section{Seksuelt overførbare infeksjons- sykdommer}

Antall diagnostiserte tilfeller av klamydiainfeksjoner i Norge økte gjennom en 10-årsperiode fram til 2008, og har siden vært stabilt høyt (om lag 22000 tilfeller årlig). Det er særlig personer i alderen 15-25 år som smittes. Klamydiainfeksjoner gir sjelden plager, og mange infeksjoner blir aldri oppdaget. Ubehandlet kan klamydiainfeksjon hos et fåtall av de smittende føre til redusert fruktbarhet.

Andelen av unge kvinner som blir vaksinert mot papillomavirus har økt siden innføringen av vaksinen i 2009. Vaksinen gis til jenter i 7. klasse. Om lag 75 prosent har fått tre doser og er fullvaksinerte (FHI, 2013d).

Internasjonale studier viser god effekt av HPV-vaksine i vaksinasjonsprogram. Effekten, målt i forekomst av kjønnsvorter og forstadier til livmorhalskreft, har kommet raskt i de landene som ved innføringen tilbød vaksine til flere årskull samtidig (Blomberg, 2013; Baldur-Fjelskov, 2014; Brotherton, 2011; Crowe, 2014). Det vil fortsatt ta tid før tilsvarende effekt kan måles i Norge. Dette skyldes hovedsakelig at vi i Norge bare har tilbudt vaksine til jenter i 7. klasse. Se også kapittel om vaksinasjon.

\section{Skader og ulykker}

Det har vært en betydelig nedgang i ulykkesdødsfall blant barn og unge de siste 60 årene. Særlig blant gutter har det vært en formidabel framgang på dette området. Mens dødeligheten etter ulykker i aldersgruppen 0-17 år var 45 per 100000 gutter i 1951, var tilsvarende tall i 2012 redusert til 2 per 100000 gutter.

Færre jenter enn gutter dør av ulykker, men forskjellen mellom gutter og jenter er i dag mye mindre enn den var ved starten av 1950-tallet. En kraftig reduksjon i antall dødsfall i trafikken har bidratt sterkt til den positive utviklingen i ulykkesdødelighet for barn og unge. Også drukningsulykker tar langt færre liv enn tidligere i denne aldersgruppen.

På tross av nedgangen i ulykkesdødsfall, er ulykker fortsatt en viktig dødsårsak blant barn og unge. Ulykker er årsaken til om lag 20 prosent av alle dødsfall i aldersgruppen 1-17 år (SSB, 2014b). De fleste av disse dødsfallene kan forebygges.
I tillegg forårsaker ulykker et stort antall ikke-dødelige skader med varierende grad av alvorlighet. I befolkningen er ungdom blant de som skader seg oftest. Ulykker blant unge skjer oftest $\mathrm{i}$ hjemmet og i ulike fritidsaktiviteter. Små barn (0-4 år) er spesielt utsatt for brannskader.

Mange dødsfall i trafikk gjelder unge voksne. I perioden 2003-2012 omkom om lag 40 personer i aldersgruppen 18-24 år i veitrafikkulykker årlig. Manglende bruk av hjelm, bilbelte og høy fart er viktige årsaker til disse dødsfallene (FHI: 2014c; Haldorsen, 2013). I mange tilfeller er bruk av forskjellige rusmidler en medvirkende årsak i slike ulykker.

\section{Psykisk helse og psykiske lidelser}

Psykiske plager og lidelser er et stort helseproblem hos barn og unge i Norge i dag. Til enhver tid regner vi med at:

- 15-20 prosent av barn og unge mellom 3 og 18 år har nedsatt funksjon på grunn av psykiske plager som angst, depresjon og atferdsproblemer. Omtrent åtte prosent av barn og unge har så alvorlige problemer at det tilfredsstiller kriteriene til en psykisk lidelse (Heiervang, 2007; Wichstrøm, 2012; FHI, 2009b).

For de fleste barn og unge er psykiske plager forbigående, men hos noen vedvarer plagene. En fjerdedel av barn som ved 18 måneders alder har betydelige psykiske plager, har det også ved 4 års alder (Mathiesen, 2009). Blant fireåringer vil 40 prosent av de med betydelige psykiske plager fremdeles ha dette som 10-åringer (Koot, 1992).

Det er vanlig at flere psykiske lidelser opptrer samtidig:

- Om lag fire av fem fireåringer med depresjon og atferdsforstyrrelser har en annen psykisk lidelse i tillegg (Wichstrøm, 2012). Emosjonelle lidelser (angst- og depresjonslidelser) og atferdslidelser opptrer ofte samtidig.

- Ved 8-10 års alder har mange barn med ADHD, atferdslidelse eller emosjonell lidelse en annen psykisk lidelse i tillegg. Det er vanligst at atferdsforstyrrelsene opptrer sammen med ADHD eller angst- og depresjonslidelser (Heiervang, 2007).

- I ungdomstiden (13-18 års alder) har man funnet at om lag 40 prosent av ungdommene som lider av en gruppe av psykiske lidelser (f.eks. stemningslidelser) også tilfredsstiller kriteriene for en annen gruppe av psykiske lidelser (f.eks. atferdsforstyrrelser) (Merikangas, 2010). Dette gjelder særlig for stemningslidelser. 
Spiseforstyrrelser starter som regel i løpet av ungdomsårene, og anoreksi og bulimi forekommer hyppigere hos jenter enn gutter (Fairburn, 2003; Striegel-Moore, 2007).

\section{Utvikling over tid}

Tall fra tre større ungdomsundersøkelser i Oslo (Ung i Oslo 1996, 2006 og 2012) viser en tendens til økning i depresjonsplager og nedgang i atferdsvansker blant elever i 9. og 10. klasse samt i 1. klasse videregående fra 2006 til 2012 (NOVA, 2012). Det har vært uvisst hvorvidt dette er et enkeltstående funn eller del av en større utviklingstrend. Tall fra den norske levekårsundersøkelsen sammen med nye tall fra Reseptregisteret kan tyde på at dette er en utviklingstrend.

For aldersgruppen 15-19 år viser tall fra Reseptregisteret at det var en sterk økning i antallet som brukte antidepressiva i perioden fra 2004 til 2013, se figur 1. Blant unge gutter økte antallet fra cirka 1300 til 1800 brukere (44 prosent økning) og blant unge jenter fra cirka 2800 til 4100 brukere (48 prosent økning) (FHI, 2014d). Blant de som var 20 år og eldre var økningen på 11 prosent (kvinner) og 13 prosent (menn).

For aldersgruppen 16-24 år viser tall fra Levekårsundersøkelsene at andelen med høy skåre (over 1,75) på psykiske plager økte fra 1998 til 2012, se figur 2. Økningen var sterkest blant unge kvinner der 13 prosent hadde høy skåre i 1998 og 23 prosent i 2012. For unge menn var de tilsvarende tallene 7 prosent og 12 prosent (FHI, 2014e).

$\varnothing$ kningen i psykiske plager som er vist gjennom Reseptregisteret og ulike helseundersøkelser kan skyldes ulike feilkilder, slik som synkende deltagelse

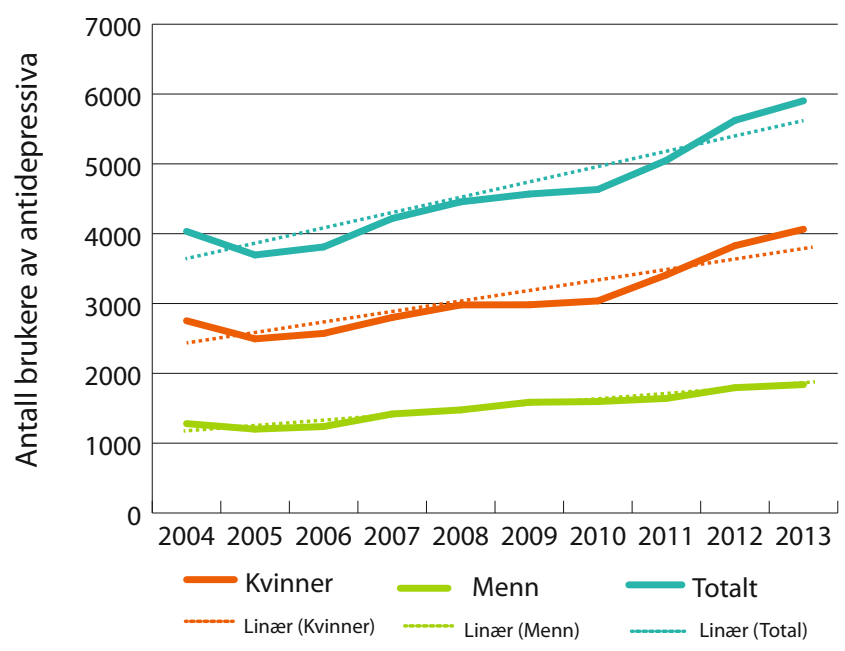

Figur 1: Antall brukere av antidepressiva i aldersgruppen 15-19 år, 2004-2013. Kilde: FHI/Reseptregisteret, 2014. i helseundersøkelser, økt rapporteringsvillighet om psykiske plager eller at leger i økende grad skriver ut resepter på antidepressiva til unge. Det er imidlertid ikke urimelig at deler av den rapporterte økningen i psykiske plager er reell, og at den økte bruken av antidepressiva blant ungdom gjenspeiler en reell økning i depresjon.

\section{Selvmord og selvmordsforsøk}

Selvmord blant barn under 15 år er ytterst sjelden. Når det gjelder annen selvmordsatferd, er villet egenskade først og fremst knyttet til ungdom, mens selvmordsforsøk er knyttet til alle aldersgrupper. I mange studier av villet egenskade er det uklart om ungdommene har skadet seg selv ut fra suicidal hensikt eller ikke. Det er derfor knyttet stor usikkerhet til estimater av villet egenskade med ulik grad av suicidal intensjon.

I en norsk studie av 4000 norske ungdommer oppgav rundt 11 prosent at de hadde skadet seg med vilje (Ystgaard, 2003). Det var omtrent tre ganger så mange jenter som gutter som oppgav at de hadde skadet seg med vilje. De fleste (74 prosent) hadde kuttet seg selv på kroppen (Ystgaard, 2003).

\section{Tenåringsgraviditet}

Det er i dag et fåtall tenåringer som får barn. De fleste tenåringene som blir gravide, velger å ta abort.

Tenåringsmødre. I 2013 var det 19 kvinner i alderen 15 år og yngre og 162 kvinner i alderen 16-17 år som fødte et barn. Dette utgjorde 0,3 prosent av alle fødsler. Rundt 1975 var tilsvarende andel vel 2 prosent. Andelen gikk gradvis ned til om lag 0,3 prosent på

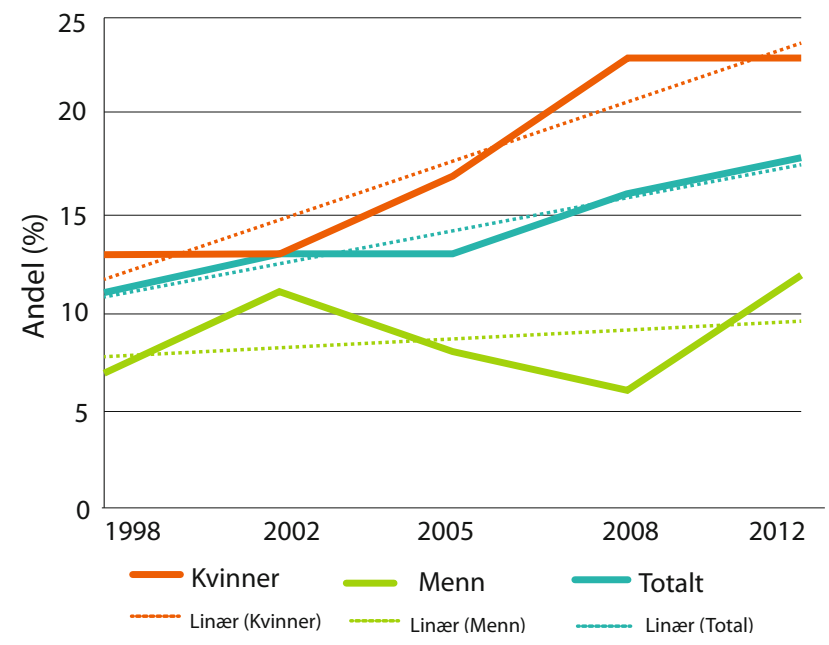

Figur 2: Andelen (i prosent) med høy skåre på HSCL-25 i aldersgruppen 16-24 år, 1998-2012. Kilde: FHI/Norgeshelsa, 2014. 


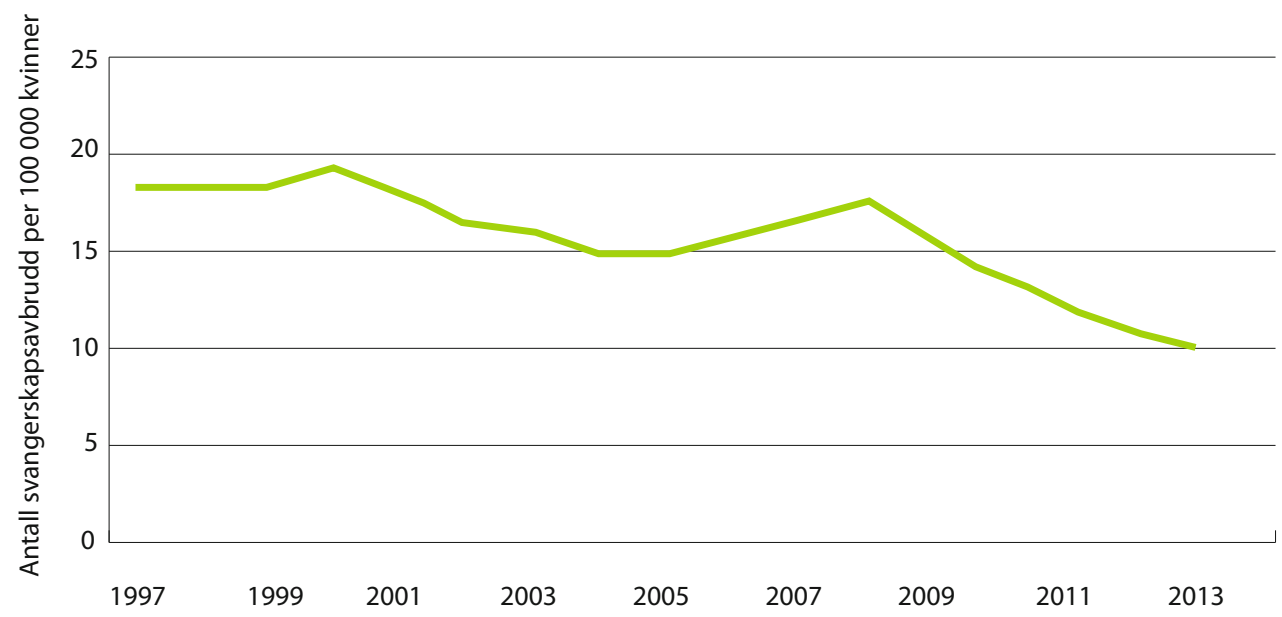

Figur 3: Svangerskapsavbrudd blant kvinner i aldersgruppen 15-19 år fra 1997 til 2013, antall per 1000 kvinner. Kilde: FHI/Norgeshelsa/Register over svangerskapsavbrudd.

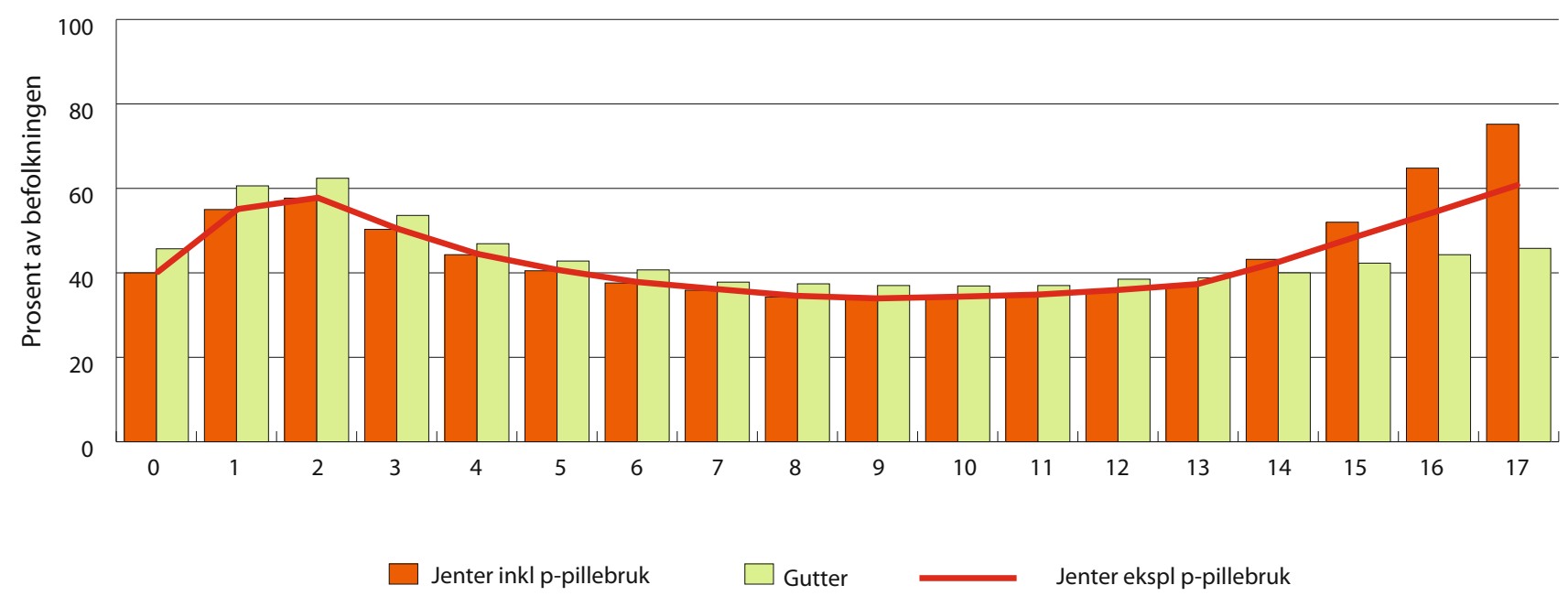

Figur 4: Legemiddelbruk blant barn og unge i alderen 0-17 år, 2013. Kilde: FHI/Reseptregisteret.

begynnelsen av 1990-tallet, og har etter dette ligget på dette nivået (FHI, 2014a).

Abort blant tenåringer. Aborttallene blant tenåringer har sunket gjennom flere år, se figur 3 .

- I 2013 ble det utført 10,1 svangerskapsavbrudd per 1000 kvinner i aldersgruppen 15-19 år. Dette er det laveste tallet siden registreringen startet $i$ 1979. I år 2000 var tallet 20,1 per 1000 kvinner i denne aldersgruppen.

Finnmark har vært fylket med høyest antall tenåringsaborter per 1000 kvinner. Fra 2012 til 2013 var det imidlertid en betydelig nedgang; fra 25,3 til 16,7 per 1000.

\section{Bruk av legemidler}

Reseptregisteret viser at i 2013 fikk 485000 barn og unge i alderen 0-17 år utlevert ett eller flere legemidler på resept. Dette tilsvarer 44 prosent av alle barn i denne aldersgruppen.

Andelen brukere er høyest blant ett- og toåringer (rundt 60 prosent) og lavest hos 8-11 åringer (rundt 35 prosent), se figur 4. De legemidlene som barn og unge bruker mest, er antibiotika, antiastmatika, allergi- og forkjølelsesmidler og øyedråper (Furu, 2011). Bruken gjenspeiler de typiske diagnosene som sees i allmennpraksis i denne aldersgruppen: astma, allergi, ørebetennelse (otitt), øvre luftveisinfeksjoner og øyekatarr (konjunktivitt) (Straand, 1998). 
$\varnothing$ kningen i andelen legemiddelbrukere hos jenter fra 14-årsalderen skyldes bare delvis p-pillebruk, se figur 4. En studie har vist at bruken av sovemidler økte i perioden 2004-2011, hovedsakelig på grunn av en kraftig økning i bruk av melatonin.

Andelen barn i alderen 0-17 år som fikk sentralstimulerende legemidler (brukt ved ADHD), økte i perioden fra 2004 til 2008, men har siden 2010 ligget stabilt på 1,4 prosent (upubliserte data fra Reseptregisteret).

Vi har liten kunnskap om bruken av reseptfrie legemidler, samt hvilke legemidler barn bruker når de er innlagt i sykehus.

\section{Faktorer som har betydning for barn og unges helse}

\section{Familie og omsorg}

De første to leveårene bor 88 prosent av barna sammen med begge foreldrene. Denne andelen synker gradvis til 62 prosent blant 17-åringene. Foreldrenes samlivsbrudd ser ut til å ha sammenheng med både psykiske helseplager, skoleproblemer og frafall fra skolen hos barna (Amato, 2010; Størksen, 2007; Størksen, 2006; Sun, 2002).

Tall fra Helse- og levekårsundersøkelsen i 2005 viser at om lag åtte prosent av barn mellom 6 og 15 år bor i husholdninger der foreldrene er i konflikt med hverandre. Konflikter mellom foreldre kan henge sammen med søvnvansker, kroppslige helseproblemer, endrede fysiologiske reaksjoner og utagerende atferd hos barn (El-Sheik, 2006; El-Sheik, 2001).

\section{Alkoholbruk og psykiske vansker blant foreldre}

Årlig vil om lag 410000 barn ha en eller to foreldre med en psykisk lidelse, og 90000 barn vil ha minst én forelder som misbruker alkohol. Totalt vil omlag 40 prosent av norske barn være i en eller begge gruppene, viser en norsk undersøkelse (FHI, 2011). Imidlertid fører ikke alle lidelser til nedsatt omsorgsevne. Mange foreldre har forholdsvis milde lidelser som hovedsakelig plager dem selv, ikke barna. Det kan eksempelvis dreie seg om fobier, forbigående depresjoner og mild sosial angst. Barn av foreldre som misbruker alkohol eller har psykiske lidelser har en forhøyet risiko for å oppleve ulike vansker, sammenlignet med andre barn (FHI, 2011).

\section{Fritid og venner}

\section{Fritidsaktiviteter}

Tall fra Statistisk Sentralbyrås tidsbruksundersøkelse viser at barn mellom 9 og 15 år i gjennomsnitt hadde 7 timer og 46 minutter til disposisjon til fritid i 2010. Dette er en nedgang på 12 minutter sammenliknet med år 2000, men de har likevel mer fritid enn de hadde for noen tiår siden. Gutter hadde 36 minutter mer fritid enn jenter i 2010.

Både barn og unge brukte i 2010 mye av fritiden til sosialt samvær, elektroniske medier (først og fremst fjernsyn) og på «annen fritid» som blant annet omfattet lek og bruk av dataspill og internett. Gutter brukte gjennomgående mer tid på idrett og dataspill enn jentene, mens jentene brukte mer av fritiden sin til sosialt samvær.

Sammenliknet med barn i familier der foreldrene har høy inntekt og utdanning er det en lavere andel barn i familier med lav inntekt og utdanning som deltar i fritidsaktiviteter (Sletten 2010, Sletten 2011; Thorød 2012; Gustavsen 2011).

\section{Venner}

Den nasjonale Ungdata-rapporten som er basert på et hundretalls lokale ungdoms-undersøkelser, viser at de fleste ungdommer på 8.-10. trinn har minst én fortrolig venn (NOVA, 2014) Nesten én av ti oppgir imidlertid at de mangler en venn som de føler at de kan stole helt på. Dataene tyder på at ungdommer fra familier med dårlig råd, oftere mangler fortrolige venner.

Sosial støtte fra venner beskytter mot psykiske- og fysiske helseplager blant barn og ungdom (Hirch \& DuBois, 1992; Myklestad, 2012; Ystgaard, 1997). Deltakelse i organiserte fritidsaktiviteter kan beskytte mot psykiske- og fysiske helseplager fordi det blant annet gir barn og ungdom mulighet til å være sammen med støttende voksne, utvikle relasjoner med jevnaldrende, oppleve utfordrende erfaringer og jobbe mot et mål (Mahoney, 2000; Samdal, 2012).

\section{Barnehage og skole}

\section{Barnehage}

I 2012 hadde 90 prosent av alle barn i alderen 1-5 år barnehageplass, 80 prosent i aldersgruppen 1-2 år og 97 prosent i aldersgruppen 3-5 år. Antallet og andelen minoritetsspråklige barn som har barnehageplass er også økende (SSB, 2013). I 2012 hadde 34400 minoritetsspråklige barn i alderen 1-5 år barnehageplass. Dette utgjorde drøyt 71 prosent av alle barn i denne gruppen. Dekningsgraden har økt mest for 1-2 åringene. 
Barnehager av høy kvalitet kan fremme god helse (Duncan, 2006). Kvalitet refererer til strukturelle forhold (utdanningsnivå blant personalet, antall barn per voksen, stabilitet i personalet), innholdet i det pedagogiske tilbudet og relasjonen voksen-barn. Barn som går i barnehage med høy kvalitet, har oftere bedre språk og bedre sosial tilpasning enn de som er hjemme eller i et annet barnepasstilbud (Bradley, 2007; FHI, 2008).

Barnehagen har vist seg å ha spesielt gunstig effekt på språkutvikling til barn med lav sosioøkonomisk bakgrunn og barn med innvandrerbakgrunn (VotrubaDrzal, 2004).

\section{Skole}

Skolen er en viktig arena for faglig og sosial utvikling. I skoleåret 2012-2013 gikk om lag 615000 elever i kommunale og private grunnskoler. Det var registrert om lag 273000 elever i videregående utdanning høsten 2012. Blant unge med innvandrerbakgrunn var 72 prosent registrerte elever i 2012, mot 68 prosent i 2011. Deltakelsen er høyest blant innvandrerjenter, men innvandrergutter har økt deltakelsen mest det siste året (SSB, 2012).

Mobbing, faglige vansker, dårlig forhold til lærere, sosial isolasjon og liten støtte fra de voksne på skolen gir økt risiko for å utvikle psykiske helseplager (Froyd, 2008; FHI, 2009a; Myklestad, 2012; Olweus, 2003, Olweus, 2005; Oppedal, 2003; Torsheim, 2001).

\section{Frafall i videregående opplæring}

Frafall i den norske videregående opplæringen er et omfattende problem, 30 prosent av de som startet videregående opplæring i 2006 fullførte ikke (SSB, 2012). Frafall i videregående opplæring reduserer mulighetene i arbeidsmarkedet, øker risikoen for uføretrygd og gir dårligere levekår og helse (Falch, 2009). Flere studier har påvist sammenheng mellom frafall og senere helse, selv om årsakssammenhengene er uklare.

Mentale helseproblemer knyttes til frafall i skolen, slik som ADHD, rusmisbruk, angst og depresjon, samt ulike adferdsforstyrrelser (Breslau, 2010). Det er ikke påvist noen årsakssammenheng mellom kroniske sykdommer som astma og diabetes og frafall i videregående opplæring (Breslau, 2010).

\section{Inneklima}

Vi har begrenset kunnskap om hvor store inneklimaproblemer det er i barnehager, skoler, private boliger og andre bygninger i Norge (FHI, 2013a).
Dårlig inneklima kan gi:

- Nedsatt trivsel, for eksempel på grunn av høy temperatur, mye støv på grunn av manglende renhold, luktplager og «tung luft» med høyt CO2-nivå.

- Hodepine.

- Tørr hud og tørre øyne.

- Forverring av astma og allergi. Det er vist sammenheng mellom det å regelmessig oppholde seg i hus med høy fuktighet, fuktskader eller mugg og økt forekomst av luftveisplager som astma, allergi og luftveisinfeksjoner.

Effektene av dårlig inneklima vil avhenge av type forurensning, den enkeltes følsomhet, ventilasjonsforhold, renhold og antall personer i rommene.

Fordi barn er en stor og særlig følsom gruppe, er inneklimaforholdene i skoler og barnehager viktige for barns helse og trivsel. Selv der helseeffekter av inneklimaforhold ikke kan dokumenteres, vil dårlig vedlikeholds- og bygningsmessig standard kunne medføre at barn, elever og ansatte får utilfredsstillende arbeidsforhold og opplever betydelig nedsatt trivsel.

Inneklimaforholdene i nye skoler og barnehager er i hovedsak gode. Det er imidlertid et stort etterslep når det gjelder utbedringer av eksisterende skoleog barnehagebygg. Ofte skyldes dårlig inneklima i slike bygninger fukt og muggskader. Årsaker kan for eksempel være dårlig drenering, utette tak eller skjulte vannlekkasjer.

Å ta fuktproblemer på alvor og utbedre disse så raskt som mulig, kan gi en stor helsemessig gevinst. Videre er det viktig å sørge for god ventilasjon tilpasset bruken og antall brukere av lokalene.

\section{Overvekt og fedme}

Resultater fra ulike helseundersøkelser blant barn i Norge viser at:

- Mellom 15 og 20 prosent av barn har overvekt/ fedme (Dvergsnes 2009; Juliusson, 2007; Kolle, 2009; FHI, 2014b).

- Åtte prosent av tredjeklassingene har bukfedme (FHI, 2014b).

Mye tyder på at andelen overvektige barn økte signifikant i Norge fram mot begynnelsen av 2000-tallet (Juliusson, 2007). Det siste 10-året ser det imidlertid ut til at andelen skolebarn med overvekt og fedme i gjennomsnitt har forandret seg lite. Resultater fra den nasjonale studien Barns vekst i Norge (Barnevekst- 
studien) ved Folkehelseinstituttet viser følgende for perioden 2008-2012 (FHI, 2014b):

- Andelen tredjeklassinger med overvekt inkludert fedme har holdt seg stabilt med et gjennomsnitt på 16 prosent.

- Andelen tredjeklassinger med bukfedme har endret seg lite med et gjennomsnitt på åtte prosent.

Resultatene viser også en betydelig forskjell i overvekt og fedme blant barn i urbane og rurale områder samt knyttet til foreldrenes utdanning og sivilstatus (FHI, 2014b).

Nye nasjonale målinger i Barnevekststudien i 2015 vil gi sikrere holdepunkter for utviklingen av overvekt og bukfedme blant norske barn.

Når det gjelder ungdom viser Helseundersøkelsen i Nord-Trøndelag (HUNT) i 2006-2008 (Krokstad, 2011) at:

- 22 prosent av guttene og 20 prosent av jentene i ungdomsskolen var overvektige.

- 27 prosent av guttene og 25 prosent av jentene i videregående skole var overvektige.

Vi har ikke systematiske nasjonale målinger som kan vise vektutviklingen over tid blant ungdom. Data fra helseundersøkelsen i Nord-Trøndelag (HUNT) rapporterer imidlertid om en bekymringsfull utvikling av overvekt inkludert fedme blant unge i aldersgruppen 13-18 år i perioden 1968 til 2008.

\section{Fysisk aktivitet}

Barn har et unikt aktivitetsmønster som skiller seg fra voksnes aktivitetsmønster ved at det ofte inneholder periodiske og spontane aktiviteter.

Tall fra kartleggingen av barn og unges fysiske aktivitet i 2011 inkluderte målinger fra 6-, 9- og 15-åringer. Dette var første gang 6-åringene ble inkludert. Fysisk aktivitet i denne studien ble registrert med aktivitetsmålere (Kolle, 2012).

- Barn: I gjennomsnitt bruker 6-årige jenter og gutter henholdsvis 73 og 91 minutter på moderat fysisk aktivitet daglig, mens 9-årige jenter og gutter i gjennomsnitt bruker 64 og 82 minutter.

- Unge: 15-årige jenter og gutter er i gjennomsnitt moderat aktive i henholdsvis 52 og 60 minutter daglig.

I alle aldersgruppene bruker gutter mer tid på fysisk aktivitet totalt sett (lett, moderat og hard sammenlagt) enn jenter. Innad i de ulike aldersgruppene er det ellers stor variasjon i gjennomsnittlig antall minutter brukt på inaktivitet og fysisk aktivitet.
Blant 6-åringene bruker jenter og gutter like mange minutter på hard fysisk aktivitet.

I gjennomsnitt er 15-åringene mest inaktive målt i antall minutter per dag.

\section{Kosthold}

Grunnlaget for våre kostvaner legges i barndommen. Det er derfor viktig at barn fra starten får en sunn og balansert kost, som bidrar til god helse. Forskning viser at kosthold tidlig i livet har betydning både for psykisk og fysisk helse. Kosten bør settes sammen av grove kornprodukter (grovbrød og grove, usøtede kornblandinger), grønnsaker og frukt, magre meieriprodukter (lettvarianter av melk, ost og yoghurt), fisk, fugl, kjøtt, bønner, linser og litt nøtter.

En av de største ernæringspolitiske utfordringene i tiden framover er å redusere inntaket av sukker blant barn og unge (Helsedirektoratet, 2011c).

Utdanning og økonomi har betydning for kostholdet:

- En dybdestudie av 11-åringer fra Oslo-området viste at foreldrenes utdanningslengde har sammenheng med barnas forbruk av sukkerholdige drikkevarer (Totland, 2013).

Sukker som er tilsatt i matvarene er med på å øke risikoen for kroniske sykdommer, spesielt overvekt og fedme. I tillegg øker sukker og søte drikker risikoen for karies og tannerosjon. Barn under 18 år, som ennå ikke har fullt utviklede tenner, er særlig utsatt for erosjonsskader.

\section{D-vitamin}

Unge jenter og ikke-vestlige innvandrere er risikogrupper for vitamin D-mangel, spesielt i vinterhalvåret (Helsedirektoratet, 2011c; Meyer, 2008). Daglig tilskudd i form av tran eller annet kosttilskudd er anbefalt for å dekke D-vitaminbehovet (Helsedirektoratet, 2011c).

\section{Alkohol og rusmidler}

Tall fra Ungdata 2013 viser at 86 prosent av ungdommene i alderen 13-16 år ikke har drukket seg beruset i løpet av siste året, mens rundt 3 prosent har drukket seg beruset mer enn seks ganger eller mer (NOVA, 2014).

Det er liten kjønnsforskjell i bruk av alkohol tidlig på ungdomsskolen, men på siste ungdomskoletrinn er det flere jenter enn gutter som angir at de har vært tydelig beruset det siste året.

Om lag halvparten av elevene på første trinn i videregående skole har vært tydelig beruset. 
Kun 1-4 prosent av ungdomsskoleelevene har prøvd hasj eller marihuana det siste året, økende med alder. Tilsvarende tall for første trinn i videregående skole er åtte prosent. Dette viser tall fra Ungdata 2013 (NOVA, 2014).

\section{Tobakk}

Det har skjedd en svært gledelig utvikling av røykevaner blant ungdom de senere årene. Etter intensiveringen av kampen mot røyking, ser vi at det store flertall unge aldri har røykt (NOVA, 2014).

Resultater fra Ungdata 2013 viser at:

- 87 prosent av ungdommene i aldersgruppen 13-16 år rapporterer at de aldri har røykt.

- Om lag én prosent av åttendeklassingene oppgir at de røyker daglig eller ukentlig, mot 3-5 prosent i 10. klasse.

- Mens kjønnsforskjellene er små blant de yngste, er det litt flere gutter enn jenter på tiendetrinn som oppgir at de røyker daglig eller ukentlig.

- 84 prosent av ungdommene oppgir at de aldri har brukt snus, mens seks prosent bruker snus daglig eller ukentlig.

I aldersgruppen 16-24 år er det 8 prosent av mennene og 6 prosent av kvinnene som oppgir at de røyker daglig. Tilsvarende er det 27 prosent av mennene og 14 prosent av kvinnene i denne aldersgruppen som oppgir at de bruker snus daglig i 2013 (SSB, 2014C).

\section{Sosioøkonomiske forskjeller}

Studier viser at levevaner ofte følger utdannings- og inntektsnivå. Det betyr at grupper med lengre utdanning og høyere inntekt i gjennomsnitt har gunstigere levevaner og bedre helse enn grupper som har kortere utdanning og lavere inntekt. I gruppen med lav utdanning er det en betydelig større andel som rapporterer om generelt dårlig helse enn i gruppen med høy utdanning (FHI, 2007; Kurtze, 2013; Dahl, 2014).

Tilsvarende funn finner vi blant barn og unge. I familier med lav sosioøkonomisk status er det en høyere andel barn og unge som vurderer helsa si som dårlig sammenlignet med barn og unge i familier med høyere sosioøkonomisk status (Elstad, 2012: Dahl, 2014). Barn og unge av foreldre med lav sosioøkonomisk status har også $ø k t$ risiko for langvarige sykdommer og plager, som for eksempel astma, allergi og eksem (Grøholt, 2003).

En dybdestudie av 11-åringer fra Oslo-området har vist at foreldrenes utdanningslengde hadde sammenheng med barnas forbruk av sukkerholdige drikker (Totland, 2013). Inntaket av frukt og grønnsaker er også høyest blant personer med høy utdanning (Helsedirektoratet, 2013c).

Studier har vist at det er sosiale forskjeller i overvekt og fedme blant barn (Grøholt, 2008; Biehl, 2013).

Andelen unge som røyker viser også en sosial gradient (NOVA, 2014; Helsedirektoratet, 2013a).

\section{Norske barns helse i internasjonal sammenheng}

Norske barn har svært god helse i et globalt perspektiv. Sammen med andre nordiske land er vi for eksempel blant de land som har aller lavest spedbarnsdødelighet i verden. Det samme gjelder dødelighet under 5 års alder. Dette er indikatorer som UNICEF benytter som de viktigste når det gjelder barnehelse.

Resultater fra ulike studier viser dessuten at:

- Det går en klar nord-sør gradient i overvekt og fedme blant barn. Land i sørlige deler av Europa har en betydelig høyere andel barn med overvekt (inkludert fedme) sammenliknet med barn i Norge og andre nordiske land. Dette viser resultater fra WHO European Childhood Obesity Surveillance Initiative i ulike land i Europa (Wijnhoven, 2013).

- Atferdslidelser er mindre vanlig hos norske barn enn hos barn i andre vestlige land (Heiervang, 2007; Wichstrøm, 2012). Det samme gjelder depresjonsplager i ungdomsårene (Wichstrøm, 1999; Kessler, 2001). Dette kan komme av kulturelle forskjeller i forståelsen og rapporteringen av problematisk atferd og psykiske lidelser hos barn og unge (Heiervang, 2008).

- Norske 9-åringer er noe mer fysisk aktive enn barn på samme alder i Europa og USA.

- Norske 15-åringer har et aktivitetsnivå tilsvarende det en ser hos jevnaldrende europeere og noe høyere enn hos 12-19-åringer i USA (Kolle, 2012).

- Tall fra helsevaneundersøkelsen blant skolebarn (HBSC-studien) i 2009-2010 viser at andelen 15-åringer som røyker minst én gang per uke, er lav i Norge sammenlignet med andre europeiske land. I denne aldersgruppen oppgav 8 prosent av jentene og 9 prosent av guttene at de røykte minst én gang per uke. Tilsvarende tall for Sverige var 15 og 13 prosent, og for Danmark 13 og 14 prosent. Av de nordiske landene var det 
flest 15-åringer i Finland som røykte minst én gang per uke; 19 prosent av jentene og 20 prosent av guttene (WHO, 2012)

- Norge er, sammen med Finland og Sverige, blant de landene i verden som topper statistikken for nye årlige tilfeller av type 1-diabetes hos barn.

\section{Hva betyr god helse i barne- årene for helse i voksen alder?}

Dagens folkehelse er et uttrykk for de miljøbelastningene som innbyggerne har vært utsatt for tidligere. På samme måte vil framtidig folkehelse bli formet av hvordan sykdomsfremmende og -hemmende faktorer er fordelt i dag.

For 50-60 år siden ble det lansert teorier om at grunnlaget for mange sykdommer ble dannet ved livets begynnelse. Disse teoriene er senere utviklet videre, blant annet gjennom arbeidene til Anders Forsdahl i Norge og David Barker i Storbritannia.

Mens Forsdahl så på sammenhengen mellom faktorer i spedbarnsalderen og helse i voksen alder, hevdet Barker og hans medarbeidere at årsakene til hjerte- og karsykdommene lå lenger tilbake i livsløpet, nemlig i fosterlivet (Forsdahl, 1977; Forsdahl, 2002; Barker, 1995; Barker, 2013).

Barker og medarbeidere har funnet at fødselsvekt og vekst i spedbarnsalderen har sammenheng med blant annet karsykdom i hjertet, type 2-diabetes, høyt blodtrykk og kolesterolnivå i voksen alder (Barker, 2013). De har også vist at vekten ved ett års alder har sammenheng med senere sykdom (Barker, 1989). Det innebærer at også tidlig barndom må betraktes som en kritisk eller sensitiv periode for barnet.

I de senere årene har det vokst fram en livsløpstilnærming til de kroniske sykdommene. Man tenker seg et årsaksforløp fra fosterliv til livets slutt hvor man i tillegg til de antatte påvirkninger i fosterlivet påvirkes av ulike faktorer senere i livet. Til sammen tenker man seg at de ulike faktorene gjennom livsløpet inngår i biologiske og sosiale årsakskjeder for kroniske sykdommer og død (Ben-Shlomo, 2002). Dette er en mer dynamisk tilnærming. Den innebærer at våre livsløp ikke er fastlagt allerede i fosterlivet, men kan endre seg underveis, både i positiv og negativ retning. I stedet for å hevde at uheldige forhold i fosterlivet etter en såkalt latensperiode viser seg som sykdom i voksen/eldre alder, tenker man seg et samspill av alle faktorer gjennom hele livsløpet.
I fosterlivet er muligens sårbarheten størst for de organene som da er i sterk utvikling og vekst. Det kan også finnes liknende følsomme eller kritiske perioder senere, kanskje spesielt i barne- og ungdomsalderen. Disse påvirkningene kan være av biologisk eller psykososial natur, og de kan bestå av samspill mellom arvelige egenskaper og miljø.

\section{Utfordringer og muligheter for forebygging og helsefremming}

Det finnes både samfunnsmessige og individrettede muligheter for forebygging innenfor barn og unges helse, og forutsetningene er blant annet at:

- Data om barn og ungdoms helse innhentes regelmessig gjennom helseundersøkelser og/ eller aggregering av lokalt innsamlede data (helsestasjoner, skoler, registre).

- Forebygging begynner senest i svangerskapet, helst før.

- Forebygging skjer på arenaer der barn og gravide er: Helsestasjoner, barnehager og skoler, skolehelsetjenenesten, fritidsaktiviteter og kulturskoler, fritidsklubber og i media som benyttes av barn og unge. Skolehelsetjenesten har en viktig rolle, både fordi den er et lavterskeltilbud, og fordi den treffer ungdom i en viktig og sårbar alder.

\section{Referanser}

Almqvist, C, Worm, M, Leynaert, B \& working group of, GALENWPG. Impact of gender on asthma in childhood and adolescence: a GA2LEN review. Allergy 2008; 63(1): 47-57.

Amato, PR. Research on Divorce: Continuing Trends and New Developments. Journal of Marriage and Family 2010; 72(3): 650-66.

Baba, S, Wikstrom, AK, Stephansson, O \& Cnattingius, S. Influence of snuff and smoking habits in early pregnancy on risks for stillbirth and early neonatal mortality. Nicotine Tob Res 2014; 16(1): 78-83.

Baldur-Felskov, B, Dehlendorff, C, Munk, C \& Kjaer, SK. Early Impact of Human Papillomavirus Vaccination on Cervical Neoplasia-Nationwide Follow-up of Young Danish Women. J Natl Cancer Inst 2014.

Barker, DJ. Fetal origins of coronary heart disease. BMJ 1995; 311(6998): 171-4.

Barker, DJ \& Thornburg, KL. The obstetric origins of health for a lifetime. Clin Obstet Gynecol 2013; 56(3): 511-9.

Barker, DJ, Winter, PD, Osmond, C, Margetts, B \& Simmonds, SJ. Weight in infancy and death from ischaemic heart disease. Lancet 1989; 2(8663): 577-80. 
Ben-Shlomo, Y \& Kuh, D. A life course approach to chronic disease epidemiology: conceptual models, empirical challenges and interdisciplinary perspectives. Int J Epidemiol 2002; 31(2): 285-93.

Biehl, A, Hovengen, R, Groholt, EK, Hjelmesaeth, J, Strand, $\mathrm{BH}$ et al. Adiposity among children in Norway by urbanity and maternal education: a nationally representative study. BMC Public Health 2013; 13: 842.

Blomberg, M, Dehlendorff, C, Munk, C \& Kjaer, SK. Strongly decreased risk of genital warts after vaccination against human papillomavirus: nationwide follow-up of vaccinated and unvaccinated girls in Denmark. Clin Infect Dis 2013; 57(7): 929-34.

Bradley, RH \& Vandell, DL. Child care and the well-being of children. Arch Pediatr Adolesc Med 2007; 161(7): 669-76.

Brantsæter, AL, Birgisdottir, BE, Meltzer, HM, Kvalem, HE, Alexander, J et al. Maternal seafood consumption and infant birth weight, length and head circumference in the Norwegian Mother and Child Cohort Study. Br J Nutr 2012; 107(3): 436-44

Brantsæter, AL, Haugen, M, Samuelsen, SO, Torjusen, H, Trogstad, $L$ et al. A dietary pattern characterized by high intake of vegetables, fruits, and vegetable oils is associated with reduced risk of preeclampsia in nulliparous pregnant Norwegian women. J Nutr 2009; 139(6): 1162-8.

Breslau, J. Health in Childhood and Adolescence and High School Dropout. California Dropout Research Project Report. Santa Barbara, California: University of California; 2010.

Brotherton, JML, Fridman, M, May, CL, Chappell, G, Saville, AM et al. Early effect of the HPV vaccination programme on cervical abnormalities in Victoria, Australia: an ecological study. The Lancet 2011; 377(9783): 2085-92.

Chen, W, Mempel, M, Schober, W, Behrendt, H \& Ring, J. Gender difference, sex hormones, and immediate type hypersensitivity reactions. Allergy 2008; 63(11): 1418-27.

Crowe, E, Pandeya, N, Brotherton, JML, Dobson, AJ, Kisely, $S$ et al. Effectiveness of quadrivalent human papillomavirus vaccine for the prevention of cervical abnormalities: casecontrol study nested within a population based screening programme in Australia. Br Med J 2014; 348(1458).

Cupul-Uicab, LA, Skjaerven, R, Haug, K, Melve, KK, Engel, $\mathrm{SM}$ et al. In utero exposure to maternal tobacco smoke and subsequent obesity, hypertension, and gestational diabetes among women in the MoBa cohort. Environ Health Perspect 2012; 120(3): 355-60.

Dahl, E, Bergsli, H \& van der Wel, KA. Sosial ulikhet i helse: En norsk kunnskapsoversikt (Hovedrapport). Oslo: Høgskolen i Oslo og Akershus; 2014.

Duley, L. The global impact of pre-eclampsia and eclampsia. Semin Perinatol 2009; 33(3): 130-7.

Duncan, GJ \& Gibson-Davis, CM. Connecting child care quality to child outcomes: drawing policy lessons from nonexperimental data. Eval Rev 2006; 30(5): 611-30.

Dvergsnes, K \& Skeie, G. Utviklingen i kroppsmasseindeks hos fireåringer i Tromsø 1980-2005. Tidsskr Nor Laegeforen 2009; 129(1): 13-6.
El-Metwally, A, Salminen, JJ, Auvinen, A, Macfarlane, G \& Mikkelsson, M. Risk factors for development of nonspecific musculoskeletal pain in preteens and early adolescents: a prospective 1-year follow-up study. BMC Musculoskelet Disord 2007; 8: 46.

El-Sheikh, M, Buckhalt, JA, Mize, J \& Acebo, C. Marital conflict and disruption of children's sleep. Child Dev 2006; 77(1): 31-43.

El-Sheikh, M \& Harger, J. Appraisals of marital conflict and children's adjustment, health, and physiological reactivity. Dev Psychol 2001; 37(6): 875-85.

Elgen, I, Bruaroy, S \& Laegreid, LM. Lack of recognition and complexity of foetal alcohol neuroimpairments. Acta Paediatr 2007; 96(2): 237-41.

Elstad, Jl \& Pedersen, AW. Fører dårlig familieøkonomi til flere subjektive helseplager blant ungdom? Tidsskrift for velferdsforskning 2012; 15: 78-92.

Englund-Ögge, L, Brantsæter, AL, Sengpiel, V, Haugen, M, Birgisdottir, BE et al. Maternal dietary patterns and preterm delivery: results from large prospective cohort study. $\mathrm{Br}$ Med J 2014; 348(1446).

Fairburn, CG \& Harrison, PJ. Eating disorders. The Lancet 2003; 361(9355): 407-16.

Falch, T \& Nyhus, $\mathrm{OH}$. Frafall fra videregående opplæring og arbeidsmarkedstilknytning for unge voksne Trondheim: Senter for økonomisk forskning AS; 2009, rapport: 07/09.

FHI, Folkehelseinstituttet, 2007. $\varnothing$ Næss, M Rognerud and BH Strand. Sosial ulikhet i helse. En faktarapport. Oslo: Folkehelseinstituttet; rapport: 2007:1.

FHI, Folkehelseinstituttet, 2008. S Schjølberg, R Lekhal, MV Wang et al. Forsinket språkutvikling; En foreløpig oversikt basert på data fra Den norske mor og barn undersøkelsen. Oslo: Folkehelseinstituttet; rapport: 2008:10.

FHI, Folkehelseinstituttet, 2009a. MJ Helland and KS Mathiesen. 13-15 åringer fra vanlige familier i Norge hverdagsliv og psykisk helse. Oslo: Folkehelseinstituttet; rapport: 2009:1.

FHI, Folkehelseinstituttet, 2009b. A Mykletun, AK Knudsen and KS Mathiesen. Psykiske lidelser i Norge : et folkehelseperspektiv. Oslo: Folkehelseinstituttet; rapport: 2009:8

FHI, Folkehelseinstituttet, 2011. FA Torvik and K Rognmo. Barn av foreldre med psykiske lidelser eller alkoholmisbruk; omfang og konsekvenser. Oslo: Folkehelseinstituttet; rapport: 2011:4.

FHI, Folkehelseinstituttet, 2013a. R Becher, J Hongslo, J $\varnothing$ vrevik et al. Anbefalte faglige normer for inneklima: Revisjon av kunnskapsgrunnlag og normer. Oslo: Folkehelseinstituttet; rapport: 2013:7.

FHI, Folkehelseinstituttet. 2013b. Fakta om folattilskudd og svangerskap.

Folkehelseinstituttet. 2013c. Fakta om kreft. [hentet 9/5/2014].

FHI, Folkehelseinstituttet, 2013d. L Trogstad, J Stålcrantz, MS Ege et al. Årsrapport for HPV-vaksine i barnevaksinasjonsprogrammet 2012. Oslo: Folkehelseinstituttet; 2013. 
FHI, Folkehelseinstituttet. 2014a. Medisinsk fødselsregister. [hentet 17.07.2014].

FHI, Folkehelseinstituttet. 2014b. Barns vekst i Norge (Barnevektstudien). [hentet 7/4/2014].

FHI, Folkehelseinstituttet, 2014c. I Myklestad, K Alvær, C Madsen et al. Skadebildet i Norge: Hovedvekt på personskader i sentrale registre. Oslo: Folkehelseinstituttet; 2014c.

FHI, Folkehelseinstituttet. 2014d. Statistikk fra Reseptregisteret. [hentet 15/03/2014].

FHI, Folkehelseinstituttet, 2014e. Statistikk fra Norgeshelsa. [hentet 17/11/2014].

Forsdahl, A. Are poor living conditions in childhood and adolescence an important risk factor for arteriosclerotic heart disease? Br J Prev Soc Med 1977; 31(2): 91-5.

Forsdahl, A. Observations throwing light on the high mortality in the county of Finnmark.: Is the high mortality today a late effect of very poor living conditions in childhood and adolescence? Int J Epidemiol 2002; 31(2): 302-08.

Frojd, SA, Nissinen, ES, Pelkonen, MU, Marttunen, MJ, Koivisto, AM et al. Depression and school performance in middle adolescent boys and girls. J Adolesc 2008; 31(4): 485-98.

Furu, K \& Skurtveit, S. Legemidler forskrevet til barn og ungdom i alderen 0-17 år i Norge. En studie basert på data fra Reseptregisteret. Norsk Farmaceutisk Tidsskrift 2011; 119(4): 16-19.

Grøholt, EK, Stigum, H, Nordhagen, R. Overweight and obesity among adolescents in Norway: cultural and socioeconomic differences. Journ Publ Health 2008; 30: 258-65.

Grøholt, EK. Health and Well-being of Children in the Nordic Countries - Influence of Socio-economic Factors in Welfare States. Oslo: Folkehelseinstituttet; 2003.

Gunnerbeck, A, Bonamy, AKE, Wikstrom, AK, Granath, F, Wickstrom, R et al. Maternal Snuff Use and Smoking and the Risk of Oral Cleft Malformations - A Population-Based Cohort Study. PLoS One 2014; 9(1).

Gustavsen, K. Sosiale ulikheter i oppvekst - en humanitær utfordring. TF-rapport nr. 283. Bø: Telemarksforskning; 2011.

Haldorsen, I. Dybdeanalyser av dødsulykker i veitrafikken 2012. Statens vegvesen; 2013.

Halmøy, A, Klungsøyr, K, Skjærven, R \& Haavik, J. Pre- and perinatal risk factors in adults with attention-deficit/ hyperactivity disorder. Biol Psychiatry 2012; 71(5): 474-81.

Hansen, TE, Evjenth, B \& Holt, J. Increasing prevalence of asthma, allergic rhinoconjunctivitis and eczema among schoolchildren: three surveys during the period 19852008. Acta Paediatr 2013; 102(1): 47-52.

Haugen, M, Brantsaeter, AL, Alexander, J \& Meltzer, HM. Dietary supplements contribute substantially to the total nutrient intake in pregnant Norwegian women. Ann Nutr Metab 2008; 52(4): 272-80.

Hediger, ML \& Joseph, KS. Fetal growth: Measurement and evaluation. I: GB Louis and RW Platt (Eds.). Reproductive and perinatal epidemiology. Oxford: Oxford University Press; 2011, 168-85.
Heiervang, E, Goodman, A \& Goodman, R. The Nordic advantage in child mental health: separating health differences from reporting style in a cross-cultural comparison of psychopathology. J Child Psychol Psychiatry 2008; 49(6): 678-85.

Heiervang, E, Stormark, KM, Lundervold, AJ, Heimann, M, Goodman, R et al. Psychiatric disorders in Norwegian 8- to 10-year-olds: an epidemiological survey of prevalence, risk factors, and service use. J Am Acad Child Adolesc Psychiatry $2007 ;$ 46(4): 438-47.

Helsedirektoratet 2005. Alkohol og graviditet. Hva er farlig for fosteret? Hvordan forebygge og behandle? Rapport fra en ekspertgruppe. Oslo: Helsedirektoratet; 2005, rapport: IS-1284.

Helsedirektoratet. 2011a. Kostholdsråd for gravide.

Helsedirektoratet. 2011b. Riktig næring for små mager: Kostholdsråd for spedbarn.

Helsedirektoratet. 2011c. Sunt kosthold for små mager: Kostholdsråd for barn.

Helsedirektoratet, 2013a. RL Lindbak and A Helleve. Tal om tobakk: 1973-2012. Oslo: Helsedirektoratet; 2013.

Helsedirektoratet, 2013b. Utviklingen i norsk kosthold. Oslo: Helsedirektoratet; 2013.

Henriksen, T, Haugen, G, Bollerslev, J, Kolset, SO, Drevon, CA et al. Ernæring i fosterlivet og fremtidig helse. Tidsskr Nor Laegeforen 2005; 125: 442-44.

Herstad, L, Klungsøyr, K, Skjærven, R, Tanbo, T, Forsén, L et al. Maternal age and emergency operative deliveries at term: a population-based registry study among low-risk primiparous women. BJOG 2014: n/a-n/a.

Hirsch, B \& DuBois, D. The relation of peer social support and psychological symptomatology during the transition to junior high school: A two-year longitudinal analysis. Am J Community Psychol 1992; 20(3): 333-47.

Hovland, V, Riiser, A, Mowinckel, P, Carlsen, K-H \& Lødrup Carlsen, KC. Asthma with allergic comorbidities in adolescence is associated with bronchial responsiveness and airways inflammation. Pediatr Allergy Immunol 2014; 25(4): 351-59.

Ji, J, Hemminki, K, Sundquist, J \& Sundquist, K. Ethnic Differences in Incidence of Type 1 Diabetes among SecondGeneration Immigrants and Adoptees from Abroad. The Journal of Clinical Endocrinology \& Metabolism 2010; 95(2): 847-50.

Juliusson, PB, Roelants, M, Eide, GE, Hauspie, R, Waaler, PE et al. Overweight and obesity in Norwegian children: secular trends in weight-for-height and skinfolds. Acta Paediatr 2007; 96(9): 1333-7.

Kessler, RC, Avenevoli, S \& Ries Merikangas, K. Mood disorders in children and adolescents: an epidemiologic perspective. Biol Psychiatry 2001; 49(12): 1002-14.

Kolle, E. Fysisk aktivitet blant 6-, 9- og 15-åringer i Norge: resultater fra en kartlegging i 2011. Oslo: Helsedirektoratet; 2012. 
Kolle, E, Steene-Johannessen, J, Holme, I, Andersen, LB \& Anderssen, SA. Secular trends in adiposity in Norwegian 9-year-olds from 1999-2000 to 2005. BMC Public Health 2009; 9: 389.

Koot, HM \& Verhulst, FC. Prediction of children's referral to mental health and special education services from earlier adjustment. J Child Psychol Psychiatry 1992; 33(4): 717-29.

Kreftregisteret. 2012. Bedret overlevelse på barnekreft over hele landet.

Kreftregisteret. 2014. Kreftstatistikk. [hentet 9/5/2014].

Kristiansen, AL, Lande, B, Overby, NC \& Andersen, LF. Factors associated with exclusive breast-feeding and breast-feeding in Norway. Public Health Nutr 2010; 13(12): 2087-96.

Krokstad, S \& Knudtsen, MS. Folkehelse i endring: Helseundersøkelsen Nord-Trøndelag : HUNT 1 (1984-86) - HUNT 2 (1995-97) - HUNT 3 (2006-08). Levanger: HUNT forskningssenter; 2011.

Kurtze, N, Eikemo, TA \& Kamphuis, CB. Educational inequalities in general and mental health: differential contribution of physical activity, smoking, alcohol consumption and diet. Eur J Public Health 2013; 23(2): 223-9.

Lagerlov, P, Holager, T, Helseth, S \& Rosvold, EO. Selfmedication with over-the-counter analgesics among 15-16 year-old teenagers. Tidsskr Nor Laegeforen 2009; 129(15): 1447-50.

Larsson, B \& Sund, AM. Emotional/behavioural, social correlates and one-year predictors of frequent pains among early adolescents: influences of pain characteristics. Eur J Pain 2007; 11(1): 57-65.

Lewis, SJ, Zuccolo, L, Davey Smith, G, Macleod, J, Rodriguez, $\mathrm{S}$ et al. Fetal Alcohol Exposure and IQ at Age 8: Evidence from a Population-Based Birth-Cohort Study. PLoS One 2012; 7(11): e49407.

Lødrup Carlsen, KC, Håland, G, Devulapalli, CS, MuntheKaas, $M$, Pettersen, $M$ et al. Asthma in every fifth child in Oslo, Norway: a 10-year follow up of a birth cohort study. Allergy 2006; 61(4): 454-60.

Mahoney, J.L. and Stattin, H. 2000. Leisure activites and adolescent antisocial behavior: the role of structure and social context. Journal of Adolescence, 23: 113-127.

Manning, MA \& Eugene Hoyme, H. Fetal alcohol spectrum disorders: a practical clinical approach to diagnosis. Neurosci Biobehav Rev 2007; 31(2): 230-8.

Mathiesen, K, Sanson, A, Stoolmiller, M \& Karevold, E. The Nature and Predictors of Undercontrolled and Internalizing Problem Trajectories Across Early Childhood. J Abnorm Child Psychol 2009; 37(2): 209-22.

May, PA \& Gossage, JP. Estimating the prevalence of fetal alcohol syndrome. A summary. Alcohol Res Health 2001; 25: $159-67$

Merikangas, KR, He, JP, Burstein, M, Swanson, SA, Avenevoli, $S$ et al. Lifetime prevalence of mental disorders in U.S. adolescents: results from the National Comorbidity Survey Replication--Adolescent Supplement (NCS-A). J Am Acad Child Adolesc Psychiatry 2010; 49(10): 980-89.
Meyer, HE, Holvik, K, Lofthus, CM \& Tennakoon, SU. Vitamin $\mathrm{D}$ status in Sri Lankans living in Sri Lanka and Norway. $\mathrm{Br} J$ Nutr 2008; 99(5): 941-4.

Moster, D, Lie, RT \& Markestad, T. Long-term medical and social consequences of preterm birth. N Engl J Med 2008; 359(3): 262-73.

Myklestad, I, Røysamb, E \& Tambs, K. Risk and protective factors for psychological distress among adolescents: a family study in the Nord-Trondelag Health Study. Soc Psychiatry Psychiatr Epidemiol 2012; 47(5): 771-82.

NOVA, 2012. T Øia. Ung i Oslo 2012, Nøkkeltall. Norsk Institutt for oppvekst, velferd og aldring Notat $\mathrm{nr} 7 / 12$.

NOVA: A Bakken. Ungdata: nasjonale resultater 2013. Oslo: Norsk institutt for forskning om oppvekst, velferd og aldring; 2014.

O'Leary, CM, Taylor, C, Zubrick, SR, Kurinczuk, JJ \& Bower, C. Prenatal Alcohol Exposure and Educational Achievement in Children Aged 8-9 Years. Pediatrics 2013.

Olweus, D. Social problems in school. I: JG Bremner and A Slater (Eds.). An Introduction to developmental psychology. Malden, Mass.: Blackwell; 2003, 434-54.

Olweus, D. A useful evaluation design, and effects of the Olweus Bullying Prevention Program. Psychology, Crime \& Law 2005; 11(4): 389-402.

Oppedal, B. Adolescent mental health in multi-cultural context. Oslo: University of Oslo; 2003.

Samdal, O, Bye, HH, Torsheim, T, Birkeland, MS, Disth, ÅR et al. Sosial ulikhet i helse og læring blant barn og unge: resultater fra den landsrepresentative spørreskjemaundersøkelsen “Helsevaner blant skoleelever: en WHO-undersøkelse i flere land". Bergen: HEMIL-senteret, Universitetet i Bergen; 2012.

Sampson, PD, Streissguth, AP, Bookstein, FL, Little, RE, Clarren, SK et al. Incidence of fetal alcohol syndrome and prevalence of alcohol-related neurodevelopmental disorder. Teratology 1997; 56(5): 317-26.

Selnes, A, Nystad, W, Bolle, R \& Lund, E. Diverging prevalence trends of atopic disorders in Norwegian children. Results from three cross-sectional studies. Allergy 2005; 60(7): 894-9.

Sengpiel, V, Elind, E, Bacelis, J, Nilsson, S, Grove, J et al. Maternal caffeine intake during pregnancy is associated with birth weight but not with gestational length: results from a large prospective observational cohort study. BMC Med 2013; 11: 42.

Skrivarhaug, T, Stene, LC, Drivvoll, AK, Strom, H, Joner, G et al. Incidence of type 1 diabetes in Norway among children aged 0-14 years between 1989 and 2012: has the incidence stopped rising? Results from the Norwegian Childhood Diabetes Registry. Diabetologia 2014; 57(1): 57-62.

Sletten, MA. Social costs of poverty; leisure time socializing and the subjective experience of social isolation among 13-16-year-old Norwegians. Journal of Youth Studies 2010; 13(3): 291-315.

Sletten, MA. Å ha, å delta, å være en av gjengen. Velferd og fattigdom i et ungdomsperspektiv. Oslo: NOVA; 2011, rapport: 11/11. 
Smidesang, I, Saunes, M, Storro, O, Oien, T, Holmen, TL et al. Allergy related disorders among 2-yrs olds in a general population. The PACT Study. Pediatr Allergy Immunol 2010; 21 (2 Pt 1): 315-20.

SSB, Statistisk sentralbyrå, 2012. Gjennomstrømming i videregående opplæring, Elektronisk versjon.

SSB, Statistisk sentralbyrå, 2013. Barnehager, 2012, endelige tall.

SSB, Statistisk sentralbyrå, 2014a. Barn og unge i befolkningen; Demografisk bilde av norske barn.

SSB, Statistisk sentralbyrå, 2014b. Dødsårsaker. [oppdatert 2013; nedlastet 2 Desember 2014]. Tilgjengelig fra: http:// www. ssb.no/helse/statistikker/dodsarsak Statistikkbanktabell 08874.

SSB, Statistisk sentralbyrå, 2014c. Røykevaner, 2013; Én av tre bruker snus eller røyker.

Steegers, EAP, von Dadelszen, P, Duvekot, JJ \& Pijnenborg, R. Pre-eclampsia. The Lancet 2010; 376(9741): 631-44.

Stotland, NE, Caughey, AB, Breed, EM \& Escobar, GJ. Risk factors and obstetric complications associated with macrosomia. Int J Gynaecol Obstet 2004; 87(3): 220-6.

Straand, J, Rokstad, K \& Heggedal, U. Drug prescribing for children in general practice. A report from the More \& Romsdal Prescription Study. Acta Paediatr 1998; 87(2): 218-24.

Striegel-Moore, RH \& Bulik, CM. Risk factors for eating disorders. Am Psychol 2007; 62(3): 181-98.

Størksen, I, Røysamb, E, Gjessing, HK, Moum, T \& Tambs, K. Marriages and psychological distress among adult offspring of divorce: a Norwegian study. Scand J Psychol 2007; 48(6): 467-76.

Størksen, I, Røysamb, E, Holmen, TL \& Tambs, K. Adolescent adjustment and well-being: effects of parental divorce and distress. Scand J Psychol 2006; 47(1): 75-84.

Sun, Y \& Li, Y. Children's Well-Being during Parents' Marital Disruption Process: A Pooled Time-Series Analysis. Journal of Marriage and Family 2002; 64(2): 472-88.

Thorød, AB. Deltakelse og valg av organiserte fritidsaktiviteter når familiens økonomi er svak. . Fontene Forskning 2012; 1(12): 19-31.

Torsheim, T, Aaroe, LE \& Wold, B. Sense of coherence and school-related stress as predictors of subjective health complaints in early adolescence: interactive, indirect or direct relationships? Soc Sci Med 2001; 53(5): 603-14.

Totland, TH, Lien, N, Bergh, IH, Bjelland, M, Gebremariam, MK et al. The relationship between parental education and adolescents' soft drink intake from the age of 11-13 years, and possible mediating effects of availability and accessibility. Br J Nutr 2013; 110(5): 926-33.

VKM: HM Meltzer, P Brandtzæg, H Knutsen et al. Benefit and risk assessment of breastmilk for infant health in Norway. Oslo: Vitenskapskomiteen for Mattrygghet; 2013.
Votruba-Drzal, E, Coley, RL \& Chase-Lansdale, PL. Child care and low-income children's development: direct and moderated effects. Child Dev 2004; 75(1): 296-312.

Wennergren, G, Alm, B, Oyen, N, Helweg-Larsen, K, Milerad, $J$ et al. The decline in the incidence of SIDS in Scandinavia and its relation to risk-intervention campaigns. Nordic Epidemiological SIDS Study. Acta Paediatr 1997; 86(9): 963-8.

WHO: C Currie, C Zanotti, A Morgan et al. Sosial determinants of health and wellbeing among young people. Health Behavior among School-Aged Children (HBSC) study: international report from the 2009/2010 survey. Copenhagen, Denmark: World Health Organization; 2012.

Wichstrøm, L. The emergence of gender difference in depressed mood during adolescence: the role of intensified gender socialization. Dev Psychol 1999; 35(1): 232-45.

Wichstrøm, L, Berg-Nielsen, TS, Angold, A, Egger, HL, Solheim, E et al. Prevalence of psychiatric disorders in preschoolers. J Child Psychol Psychiatry 2012; 53(6): 695-705.

Wijnhoven, TM, van Raaij, JM, Spinelli, A, Rito, Al, Hovengen, R et al. WHO European Childhood Obesity Surveillance Initiative 2008: weight, height and body mass index in 6-9-year-old children. Pediatr Obes 2013; 8(2): 79-97.

Wikstrøm, AK, Stephansson, O, Kieler, H \& Cnattingius, S. Snuff during pregnancy no risk-free alternative to smoking. Lakartidningen 2011; 108(29-31): 1430-3.

Willford, J, Leech, S \& Day, N. Moderate prenatal alcohol exposure and cognitive status of children at age 10. Alcohol Clin Exp Res 2006; 30(6): 1051-9.

Ystgaard, M. Life stress, social support and psychological distress in late adolescence. Soc Psychiatry Psychiatr Epidemiol 1997; 32(5): 277-83.

Ystgaard, M. Villet egenskade blant ungdom: nye forskningsresultater og konsekvenser for forebyggende arbeid. Suicidologi 2003; 8(2): 7-10.

\section{FORFATTERE}

Redaktører: Rannveig Nordhagen og Else Karin Grøholt

Bidrag fra: Rune Becher, Berit Granum, Kari Furu, Liv Grøtvedt, Maren Helland, Ragnhild Hovengen, Øystein Karlstad, Anne Kjeldsen, Kari Klungsøyr, Helle Margrethe Meltzer, Ingri Myklestad, Wenche Nystad, Eyvind Ohm, Katrine Owe, Siri Seterelv, Anne Reneflot, Jens Christoffer Skogen, Lars Christian Stene, Lill Trogstad, Per Henrik Zahl. 
- Det er forventet en betydelig økning i antall og andelen eldre framover.

- Levealderen øker.

- Økningen i levealder kan samtidig være en utfordring for det norske samfunnet.

- Flere vil leve med kroniske sykdommer.

- Flere vil leve med kreft, og færre vil dø av hjertesykdom.

- Flere vil få demens.

- Forekomsten av benbrudd er spesielt høy i Norge.

- Utdanning og økonomi er også viktig for eldres helse.

- Både arv og miljø er viktig for å kunne være frisk og aktiv i eldre år.

- Fire nøkkelfaktorer er viktige for helse i eldre år: Høy kognitiv aktivitet, høy fysisk aktivitet, et aktivt sosialt liv, et godt kosthold.

\section{Forventet levealder øker}

Levealderen har økt med om lag 2-3 måneder per år de siste tiårene. Økningen har vært størst blant menn de senere årene. Dette kan blant annet skyldes økt røykerelatert dødelighet blant kvinner, noe som har ført til en delvis utflating av kjønnsforskjellene i forventet levealder.

Prognoser tyder på at levealderen fortsetter å øke i de kommende tiårene både blant kvinner og menn (Brunborg, 2012). En fortsatt økning i forventet levealder i Norge kan først og fremst skje ved at de eldste aldersgruppene lever lengre. Dødeligheten i yngre aldersgrupper er såpass lav at en bedring i disse aldersgruppene vil i mindre grad påvirke den forventede levealderen for den norske befolkningen sett under ett. Beregninger viser for eksempel at hvis ingen døde før 50 års alder, ville befolkningens forventede levealder bare øke med 1 - 2 år i gjennomsnitt (Brunborg, 2012).

\section{Antall eldre i befolkningen øker betydelig fra 2025}

Kombinasjonen av at vi lever lengre og store fødselskull spesielt etter andre verdenskrig 19401945, medfører at vi vil få en større andel eldre de kommende årene.

Før år 2100 vil vi sannsynligvis se følgende utvikling i antall eldre over 70, 80 og 90 år, i følge prognoser for medium vekst i levealder (Brunborg, 2012), se figur 1:

- Antall over 80 år vil øke med 6-7 prosent årlig i perioden 2025-29, og vi vil få en firedobling av antall 80-89-åringer innen utgangen av dette århundret.

- Antall 90-åringer vil vokse spesielt raskt, med en faktor på 10 før år 2100.

- Antall personer som er 100 år og eldre var 736 ved starten av 2012 og vil vokse til 12500 i år 2100. 


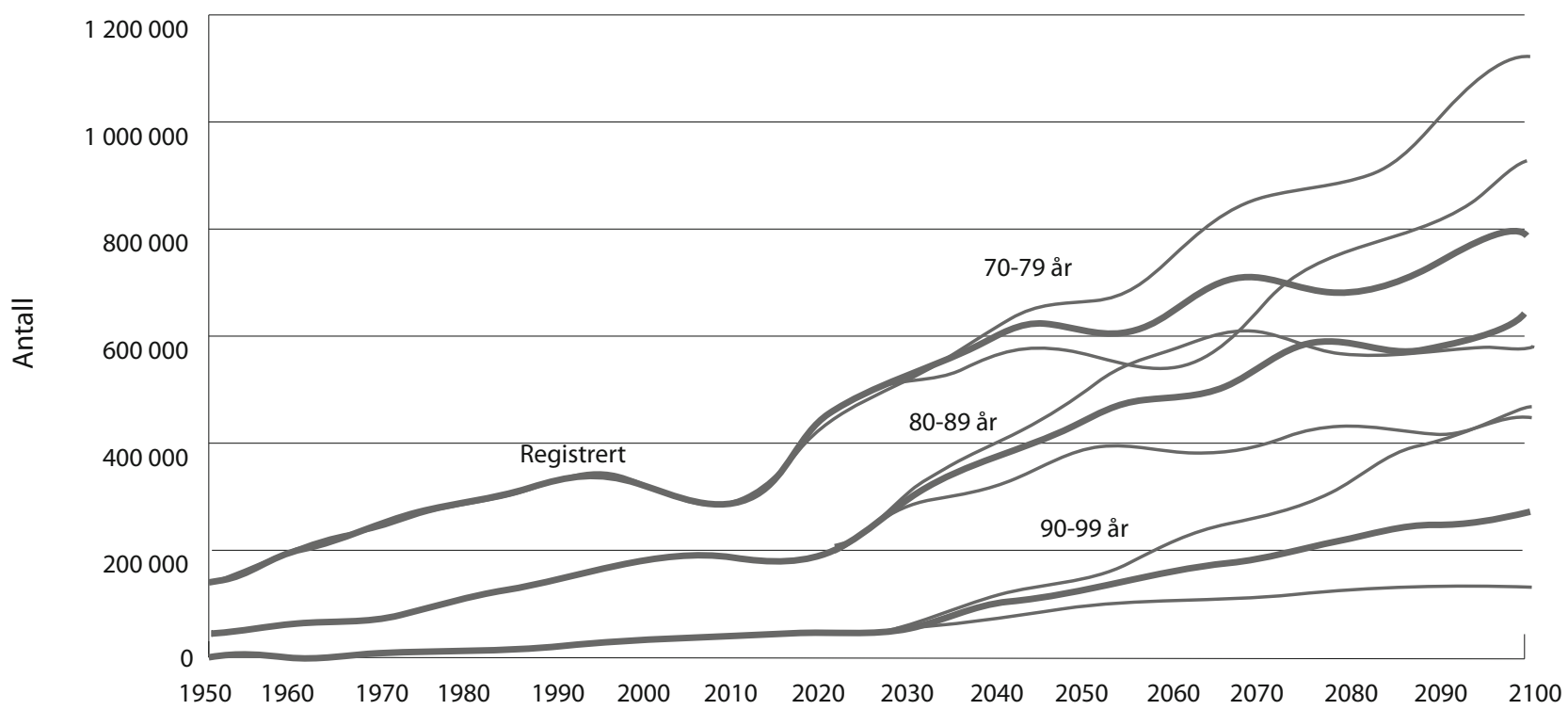

Figur 1: Antall eldre i 10-årige aldersgrupper med tre ulike progosevarianter, 1950-2100. Kilde: Figur 4 (Brunborg, 2012). Publisert med godkjennelse av Norsk Epidemiologi.

\section{Vi lever lengre, men blir helsa i eldre år bedre?}

\section{Litt friskere enn før?}

Vi lever lengre, men det er usikkert om de ekstra leveårene medfører bedret helse blant de eldre. Forskningslitteraturen viser sprikende funn. Dette kan blant annet skyldes forskjeller i hvilken tidsperiode studien dekker, hvilke helsemål som har vært studert og forskjeller i datakvalitet. Spørreundersøkelser blant eldre har dessuten ofte stort frafall, og utvalgene er små. Det er også få studier med objektive mål på helse og funksjonsnivå, og de fleste studiene baserer seg på selvrapportering.

Resultater fra studier i Sverige, England, USA og Norge kan likevel tyde på at eldre er friskere, mer funksjonsdyktige, og har bedre hukommelse enn tidligere (Christensen, 2009; Falk, 2014; Fors, 2013; Moe, 2011; Parker, 2005; Skirbekk, 2013; Vaupel, 2010). En stor landsdekkende helseundersøkelse blant eldre i Sverige (SWEOLD) viste imidlertid det motsatte for en del helseutfall blant de eldste (77 år og eldre) (Fors, 2013).

Data fra norske helse- og levekårsundersøkelser blant hjemmeboende eldre personer viser at andelen som vurderer helsen som god eller meget god økte noe i perioden 1998-2008 (Mørk, 2011). Helse- og levekårsundersøkelser og internasjonale studier viser også at selv om forekomsten av sykdommer øker, har andelen eldre med hjelpebehov gått noe ned, eller vært stabil de siste 20 til 30 årene (Fors, 2013, Mørk, 2011).

\section{Flere vil leve med kroniske sykdommer} Selv om kanskje flere eldre enn tidligere rapporterer god funksjonsevne og i større grad enn tidligere klarer hverdagens utfordringer, er det også mange som lever lenge med kroniske sykdommer. Risikoen for en rekke slike sykdommer øker med alderen.

Sykdommer som tidligere innebar tidlig død, for eksempel type 2-diabetes, hjertesykdommer og kreft hører nå til kategorien kroniske sykdommer. En aldrende befolkning vil derfor medføre flere kronisk syke. Eldre har også ofte flere sykdommer samtidig, som sammen påvirker funksjonsevne, livskvalitet og psykisk helse.

\section{Flere vil leve med kreft}

Kreftrisikoen øker med alderen, og med en aldrende befolkning vil det bli flere eldre med en kreftdiagnose.

Når man justerer for antall eldre, viser statistikk fra Kreftregisteret at antall nye krefttilfeller har vært stabil for de eldste aldersgruppene de siste tiårene, med unntak av brystkreft og prostatakreft som har økt (blant annet som følge av screening) (Syse, 2012).

Andelen som lever med kreft (forekomsten) har derimot økt i befolkningen. Det skyldes at bedre behandlingsmuligheter og bedret overlevelse fører til at flere lever lenge med sin kreftsykdom. Det er beregnet at økningen i kreftforekomst vil fortsette, spesielt fra år 2030.

- Prognoser for antall personer over 80 år med kreft er beregnet til 71000 i 2030 og nesten 100 000 i 2040 (Syse, 2012).

\section{Færre dør av hjerte- og karsykdom}

De siste tiårene har dødeligheten av hjerte- og karsykdommer hos eldre gått ned i Norge (Mørk, 2011). Det er derfor forventet at flere vil leve med hjerte- og karsykdommer på grunn av bedret overlevelse. 
I en svensk studie ble det beregnet at antall nye hjerneslagpasienter årlig vil øke med 59 prosent mot år 2050 hvis antall nye tilfeller av hjerneslag i de ulike aldersgruppene er konstant (Hallstrom, 2008). Årsaken til dette er at det blir flere eldre. Til og med en nedgang i nye tilfeller på 2 prosent innen hver aldersgruppe hvert femte år ville fortsatt gi en økning på 33 prosent i antall nye hjerneslagpasienter årlig frem mot år 2050 (Hallstrom, 2008).

Mange hjerneslagpasienter får nedsatt funksjonsevne og trenger hjelp i hverdagen (Engstad, 2012). Vi mangler norske studier på utviklingen i antall nye tilfeller av hjerte- og karsykdommer blant eldre og hvordan samsykelighet mellom kreft og hjerte- og karsykdom vil påvirke både levealder og funksjonsevne.

\section{Mange brudd som følge av fall og benskjørhet}

I 2012 døde 479 personer som følge av fall med påfølgende brudd, 70 prosent var over 80 år (SSB, 2014).

Hvert år faller om lag en tredjedel av de som er over 65 år, og halvparten av de over 80 år.

Årsakene til fall er sammensatte, men det er noen etablerte risikofaktorer (Bergland, 2012):

- Tidligere fall

- Høy alder

- Dårlig balanse og mobilitet

- Dårlig syn

- Kognitiv svekkelse (demens og forstadier)

- Sykdommer som hjerneslag og Parkinsons sykdom

- Bruk av flere legemidler samtidig

Forekomsten av brudd i Norge er blant de høyeste i verden, og årsakene til dette er stort sett ukjente. Klimatiske forhold kan bare forklare deler av den høye forekomsten (Solbakken, 2014). Hoftebrudd er mest alvorlig, og de fleste skjer etter fall innendørs i hjemmet. Om lag 70 prosent av alle hoftebrudd skjer blant kvinner.

- I 2008 var det 4403 kvinner i aldersgruppen 75 år og eldre som fikk sitt første hoftebrudd, og av disse var 26 prosent døde innen ett år etter bruddet.

Mange brudd skyldes redusert benmasse (osteoporose) kombinert med et fall. Tap av benmasse skjer langsomt og gir ingen symptomer før det oppstår et brudd. Mange vil derfor ha osteoporose uten å vite det.

\section{Infeksjoner og antibiotikaresistens}

Risikoen for å utvikle en infeksjon som trenger antibiotikabehandling, er relativt høy blant eldre. Det er beregnet at antibiotikaforskrivningen ved sykehjem utgjør 6 prosent av antibiotikabruken i Norge, til tross for at under 40000 personer bor i slike institusjoner (Blix, 2007).

Eldre har ofte svekket infeksjonsforsvar på grunn av aldringsprosessen. I tillegg kan kronisk sykdom og mangelfull ernæring svekke immunforsvaret ytterligere.

Infeksjoner medfører ofte alvorlige konsekvenser, blant annet er smitte med antibiotikaresistente bakterier et økende problem.

Alle personer over 65 år anbefales pneumokokkvaksine og influensavaksine som ledd i forebyggingen av infeksjoner. Videre anbefales alle voksne å ta én dose oppfriskningsvaksine mot kikhoste om lag hvert tiende år.

Vaksine mot pneumokokkinfeksjon til barn har redusert forekomsten av denne infeksjonen også hos eldre. Dette er et eksempel på såkalt flokkbeskyttelse, der vaksinasjon har gunstig virkning på hele befolkningen. Pneumokokker er bakterier som blant annet kan gi lungebetennelse.

\section{Psykisk helse og sykdommer i nervesystemet}

Helse- og levekårsundersøkelsene til Statistisk sentralbyrå tyder på at psykiske helseproblemer er mindre utbredt blant eldre enn blant yngre. I 2008 var det 6 prosent av de over 67 år som rapporterte om psykiske plager, mens 9 prosent av de i alderen 50-66 år rapporterte om slike plager (Mørk, 2011).

\section{Angst og depresjon}

Forekomsten av angst- og depresjonslidelser er forholdsvis jevnt fordelt gjennom livet i voksen alder. Forekomsten går litt ned etter pensjonsalderen, og det er en liten økning mot slutten av livet (FHI, 2011). Tap av nære personer, svakt sosialt nettverk og ensomhetsfølelse er risikofaktorer for angst og depresjon som er spesielt viktige blant eldre.

\section{Demens og kognitiv svikt}

Det er anslått at om lag 70000 personer i Norge har demens (Engedal, 2009; Helsedirektoratet, 2014a). Andelen med demens øker med økende alder, se tabell 1. 
Tabell 1: Andel med demens i ulike aldersgrupper. Kilde: (Engedal, 2009; Helsedirektoratet, 2014a).

\begin{tabular}{|c|c|}
\hline Aldersgruppe & Andel (prosent) \\
\hline $65-69$ år & 1 \\
\hline $70-74$ år & 2 \\
\hline $75-80$ år & 6 \\
\hline $81-85$ år & 18 \\
\hline $86-90$ år & 32 \\
\hline 90 år og eldre & 41 \\
\hline
\end{tabular}

Demens gir svekket hukommelse, særlig for det som har skjedd i nær fortid. I tillegg gir demens redusert evne til abstrakt tenkning og dårlig kontroll over følelsene. Sykdommen kan ikke kureres. De samme risikofaktorene som er knyttet til hjerte- og karsykdommer, slik som fysisk aktivitet og kosthold, er også knyttet til demens. Dette gir håp om forebygging. Likevel må vi regne med en kraftig økning i utbredelse som følge av økende levealder.

\section{Parkinsons sykdom}

Parkinsons sykdom rammer om lag én prosent av befolkningen i aldersgruppen 50-70 år, økende til litt over tre prosent i alderen over 85 år. Sykdommen er uhelbredelig og gir skader i hjernen som forverres over tid. Symptomer er rykninger og redusert motorisk kontroll, etter hvert også svekkede kognitive funksjoner. Over halvparten av tilfellene fører etter noen år til demens.

\section{Funksjonsevne og uførhet}

Studier over utviklingen i funksjon og uførhet blant eldre har ikke vist entydige resultater verken i Norge eller i andre land (Christensen, 2009; Falk, 2014; Fors, 2013; Moe, 2011; Vaupel; 2010). Funksjonsevne blant eldre vil påvirke både utgifter til eldreomsorg og alderspensjon, samt etterspørsel etter arbeidskraft. Det er derfor viktig å kartlegge forhold som kan bidra til å bedre funksjonsevnen blant eldre.

\section{Nedsatt syn og hørsel påvirker funksjonsevnen}

Nedsatt syn og hørsel er vanlig i eldre aldersgrupper, og kan redusere sosial kontakt og mulighetene til å fungere godt i hverdagen (Borchgrevink, 2005; Tambs, 2004).

- Nær én av ti over 66 år sier at de har problemer med synet, selv om de bruker briller.

- Én av fem over 66 år oppgir at de har problemer med hørselen selv om de bruker høreapparat.

- Nesten halvparten av befolkningen fra 65 til 74 år og omtrent $3 / 4$ av befolkningen over 74 år har et hørselstap.

- Likevel viser en stor norsk undersøkelse bare svake effekter av hørselstap på psykisk helse og trivsel blant eldre.

\section{Har flere sykdommer samtidig}

Bedre behandling og stigende levealder øker risikoen for at flere sykdommer forekommer samtidig. Mange eldre bruker flere legemidler for å behandle de ulike lidelsene de har, noe som øker faren for bivirkninger og uønskede interaksjoner.

Det ligger store muligheter for forebygging i å redusere risikofaktorer som er felles for flere vanlige sykdommer (Helsedirektoratet, 2014b):

- Mangel på fysisk aktivitet

- Fedme

- Usunt kosthold

- Røyking, rusmiddelmisbruk

- Mobbing og sosial ekskludering

Røyking: Andelen røykere blant eldre har gått ned de senere årene, og det er i dag færre eldre enn yngre som røyker (Mørk, 2011).

Alkohol: Både yngre og eldre drikker mer alkohol enn tidligere (Mørk, 2011).

Fysisk aktivitet: I 2008 rapporterte 69 prosent av de over 50 år at de mosjonerte ukentlig. Dette er en dobling fra ti år tidligere.

I aldersgruppen 66 år og eldre var andelen som mosjonerte ukentlig også høy; 62 prosent mosjonerte en gang per uke eller mer i 2008 (Mørk, 2011).

Fedme: Andel med fedme og overvekt var i 2008 litt lavere blant de over 66 år enn i aldersgruppen 50-66 år (Mørk, 2011).

\section{Forskjeller mellom grupper i befolkningen}

\section{Utdanning og økonomi også viktig for eldres helse}

Det er store sosiale forskjeller i forventet levealder blant eldre. I grupper som har lengre utdanning og god økonomi, er levealderen høyere enn i grupper med lavere utdanning og dårligere økonomi. Dette gjelder både i Norge og andre land (Huisman, 2005).

- Forskjeller i levealder: I perioden 1961-2009 økte forskjellene i forventet levealder mellom utdanningsgruppene, dette gjelder også i gruppene over 70 år (Moe, 2012). 
- Forskjeller i helse: Blant de som bare hadde grunnskoleutdanning, var det 14 prosent som hadde dårlig eller meget dårlig helse i aldersgruppen 67 år og eldre. Blant de som hadde høyskole- eller universitetsutdanning, var andelen derimot bare 9 prosent (Mørk, 2011).

- Forskjeller i helseplager: Tall fra fem fylker i perioden 2000-2003 viser at de med høyere utdanningsnivå hadde færre plager enn de med lavere utdanningsnivå (FHI, 2007). Disse forskjellene fant man både for selvrapportert generell helse, hjerteinfarkt, diabetes, kronisk bronkitt og kroniske smerteplager. Mønsteret var tydelig både for menn og kvinner.

\section{Levealderen varierer mellom fylkene}

Forventet gjenstående levealder etter 65 års alder varierer med bostedsfylke. Både for menn og kvinner er det høyest forventet levealder i Sogn og Fjordane. Ved 65 års alder kan kvinner i dette fylket forvente å leve 22 år til, og mennene i 18 år til, se figur 2. Dette er 2 år lengre enn for menn og kvinner i Finnmark, som har lavest gjenstående forventet levealder i Norge.
Etter Sogn og Fjordane er det 65-åringene i fylkene Akershus, Hordaland, Møre og Romsdal og Rogaland som har lengst forventet gjenstående levealder. Det gjelder både for menn og kvinner.

\section{Hva dør eldre av?}

De samme sykdommene som gir tapt helse mot slutten av livet, er hyppige dødsårsaker.

Resultater fra det internasjonale sykdomsbyrdeprosjektet 2010 viser at kroniske sykdommer tar mange leveår blant eldre i Norge (IHME, 2013).

I aldersgruppen over 70 år tar følgende sykdommer flest leveår:

- Hjertesykdom

- Hjerneslag

- KOLS

- Alzheimers sykdom

- Lungebetennelse

Også i aldersgruppen over 80 år kommer hjertesykdom og hjerneslag på de to øverste plassene, både for menn og kvinner, se tabell 2.

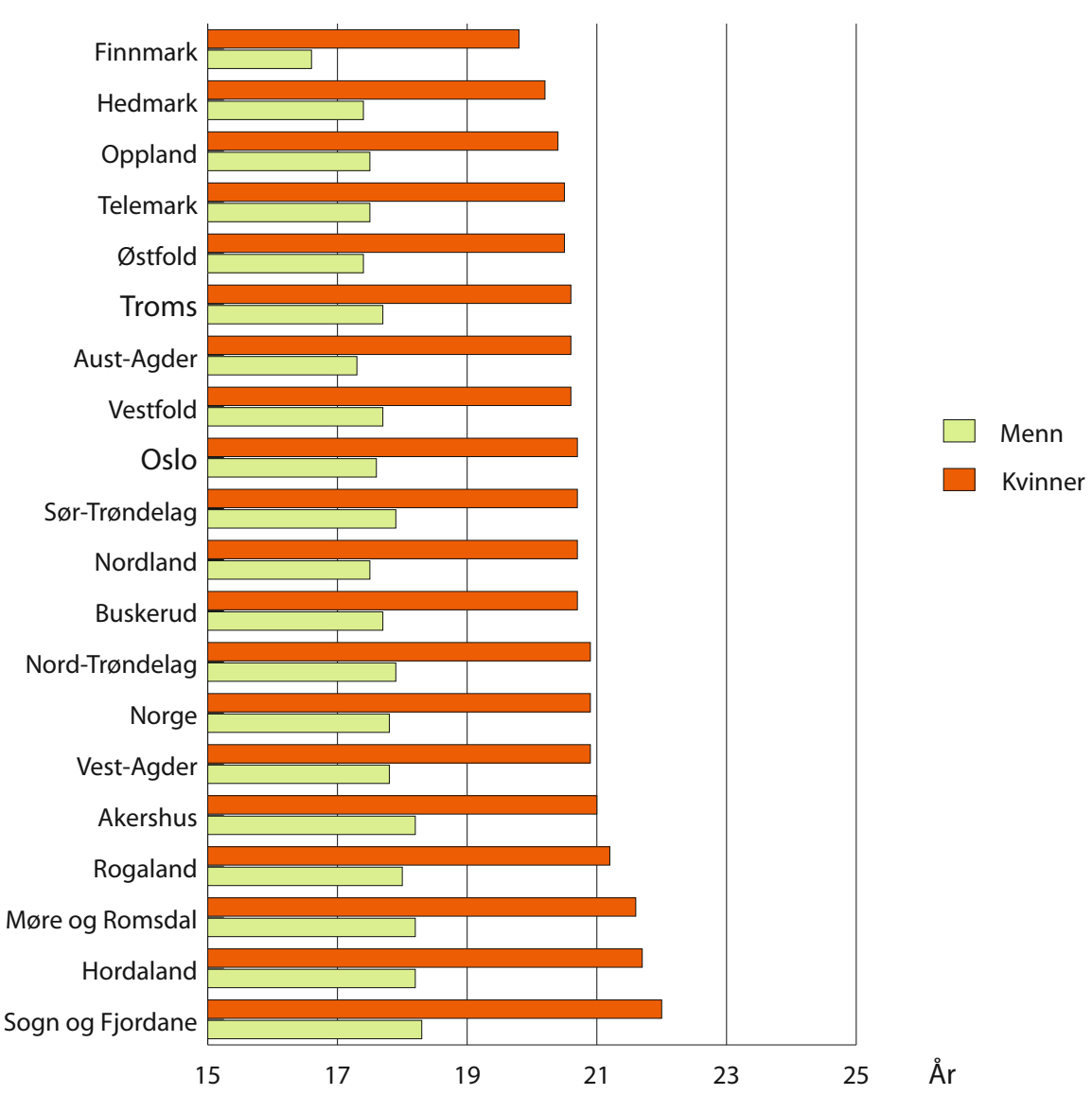

Figur 2: Forventet gjenstående levetid for 65- åringer sortert etter fylke, kvinner og menn i perioden 2006-12. Kilde: Norgeshelsa. 
Tabell 2: Rangering av de 10 viktigste dødsårsakene etter hvor viktige de er for antall tapte leveår (Years of life lost (YLLs) for de over 80 år i 2010 i Norge.

Kilde: IHME, 2013.

\begin{tabular}{|l|l|l|l|}
\hline & Menn & & Kvinner \\
\hline 1 & $\begin{array}{l}\text { Iskemisk } \\
\text { hjertesykdom }\end{array}$ & 1 & $\begin{array}{l}\text { Iskemisk } \\
\text { hjertesykdom }\end{array}$ \\
\hline 2 & Hjerneslag & 2 & Hjerneslag \\
\hline 3 & Lungebetennelse & 3 & Alzheimers sykdom \\
\hline 4 & KOLS & 4 & Lungebetennelse \\
\hline 5 & Prostatakreft & 5 & KOLS \\
\hline 6 & Alzheimers sykdom & 6 & $\begin{array}{l}\text { Annen kardio- } \\
\text { vaskulær sykdom }\end{array}$ \\
\hline 7 & Tykktarmskreft & 7 & Fall \\
\hline 8 & Lungekreft & 8 & Tykktarmskreft \\
\hline 9 & Fall & 9 & Atrieflimmer \\
\hline 10 & Atrieflimmer & 10 & Diabetes \\
\hline
\end{tabular}

\section{Utfordringer og muligheter for forebygging og helsefremming}

De individuelle forskjellene i fysisk og psykisk funksjon blant eldre er store. Et viktig spørsmål er om fysiske og psykiske svekkelser er naturlige konsekvenser av det å bli gammel, eller om de kan påvirkes eller forebygges i større eller mindre grad. Forskningen viser at en del av disse prosessene kan påvirkes, og at de har sammenheng med livsstil og påvirkninger gjennom livet (Morgan, 2011).

Aldringsprosessene styres av både kronologisk alder, biologi og livsstil. Dette betyr at morgendagens eldre sannsynligvis ikke direkte kan sammenliknes med gårsdagens eldre. Bedre levekår, forandret livsstil både med hensyn til fysisk aktivitet og endrede røykevaner, samt bedre helsetjeneste er viktige årsaker til dette. Kanskje er eldre i framtiden samlet sett friskere og mer funksjonsdyktige enn forrige generasjon eldre (Christensen, 2009; Vaupel, 2010)?

\section{Hvordan få flere aktive og friske år?}

Forskningen på eldres helse har stort sett handlet om sykdommer og uførhet. Mindre forskning har blitt gjort på den delen av befolkningen som har god helse og funksjon også i eldre år. Begreper som suksessfull eller optimal aldring ble introdusert av Rowe \& Kahn på 1980-tallet (Rowe, 1987). Vi har ingen entydig definisjon på dette, men vanligvis er begrepene definert som fravær av fysisk og psykisk sykdom, samt at man lever et aktivt liv. Begrepene har fått fornyet interesse i politikk og forskning de senere årene, blant annet $\mathrm{i}$ WHO (WHO, 2002). Året 2012 var det europeiske året for aktiv aldring (Walker, 2012).
Det norske forskningsrådet har aktiv aldring som en av sine hovedprioriteringer i hovedsatsingen «Flere aktive og sunne år (FASE)» (Forskningsrådet, 2013).

Følgende forhold kan trolig påvirke antallet aktive og friske år:

\section{Familiesituasjonen}

Familiesituasjonen kan særlig påvirke helsen eldre menns helse (Grundy, 2008; Tomassini, 2004). Familiestøtte kan også være avgjørende for når eldre flytter til bo- og behandlingshjem.

Eldre spiller ofte en sentral rolle når det gjelder omsorg for barnebarn og avlastning for yrkesaktive foreldre (Daatland, 2011; Herlofson, 2011). Barnebarn er også viktig for mange eldres livskvalitet. Medfallende fruktbarhet og økt gjennomsnittsalder for første fødsel, vil færre oppleve å bli besteforeldre (Lappegård, 2011; Priskorn, 2012).

En betydelig andel av befolkningen vil være enslige når de blir eldre (Christiansen, 2013).

\section{Miljø og levevaner}

Forskning viser at både arv og miljø er viktig for å kunne være frisk og aktiv i eldre år (Stordal, 2012). De eksakte mekanismene for «suksessfull aldring» eller god aldring er imidlertid stort sett ukjente. I den store svenske Betula-studien fant man sammenheng mellom gener og kognitiv funksjon (Nilsson, 1997). I tillegg har tvillingstudier vist at genetiske faktorer bestemmer en betydelig del av den kognitive funksjonen i eldre år, men mye er også uforklart (Daffner, 2010).

Andre studier har funnet at genene betyr mindre og mindre jo eldre man blir (Rowe, 1997). Det er blant annet vist at kognitiv helse i eldre år er påvirket av ytre faktorer gjennom hele livsløpet, slik som fysisk aktivitet, røyking, intellektuelt stimulerende aktiviteter, kosthold og alkoholbruk (Daffner, 2010; Di Marco, 2014). Et aktivt og sosialt liv ser også ut til å forebygge demens (Fratiglioni, 2004).

Mange av de samme livsstilsfaktorene som gir økt risiko for hjerte- og karsykdom, gir også økt risiko for redusert kognitiv funksjon og demenssykdom (Solomon, 2014). Dette er også funnet i nyere norske studier (Arntzen, 2011; Rosness, 2014; Strand, 2013; Strand, 2014). 
Fire nøkkelfaktorer er løftet fram som spesielt viktige med tanke på god aldring:

- Høy kognitiv aktivitet

- Høy fysisk aktivitet

- Et aktivt sosialt liv

- Et godt kosthold

De samme faktorene kan virke beskyttende mot noen former for demens. Også utdanning, mestring og kontroll har vist seg å være viktige beskyttende faktorer (Stordal, 2012).

\section{Fysisk aktivitet og trening}

Fysisk aktivitet er en av nøklene til et langt liv og god helse (Lohne-Seiler, 2012; Voelcker-Rehage, 2011). Effekten av fysisk aktivitet er like god hos eldre som hos yngre. Trening øker muskelstyrken også hos de eldre, og dette kan gi økt balanseevne, forebygge fall og gi økt livskvalitet.

Fysisk aktivitet er også gunstig for kognitiv funksjon (Daffner, 2010) og demens (Rosness, 2014).

En stor internasjonal studie undersøkte effekten av fysisk aktivitet og trening på eldres helse og funksjon. Resultatene viste at trening hadde gunstig effekt på gangfunksjonen og gav redusert uførhet (Pahor, 2014).
Studien er en av de største i sitt slag og inkluderte 1635 personer i alderen 70-89 år som ble fulgt over en fireårsperiode.

\section{Utfordringer}

$\varnothing$ kningen i levealder og andelen eldre i befolkningen er en suksesshistorie. Samtidig kan dette være en utfordring for det norske samfunnet. I 2012 var det om lag fem personer i arbeidsfør alder per pensjonist. Dersom vi får en utvikling med middels økning i levealder, vil antallet synke til 2,1 i år 2100, se figur 3 (Brunborg, 2012). Verken innvandring eller endringer i fruktbarheten kan endre disse utsiktene i noen særlig grad (United Nations, 2007). Dette understreker hvor viktig det er å legge til rette for at flest mulig eldre får en fin alderdom med god helse og godt funksjonsnivå, slik at den enkelte kan stå lengre i arbeid og ha mindre behov for hjelp.

Ved utgangen av 2013 var det 800400 personer som mottok alderspensjon i Norge (Amundsen, 2014). Data fra SSB antyder imidlertid på at det var en viss økning i andelen 62-67- åringer som var i lønnet arbeid i perioden 2008-2012 (Brunborg, 2012).

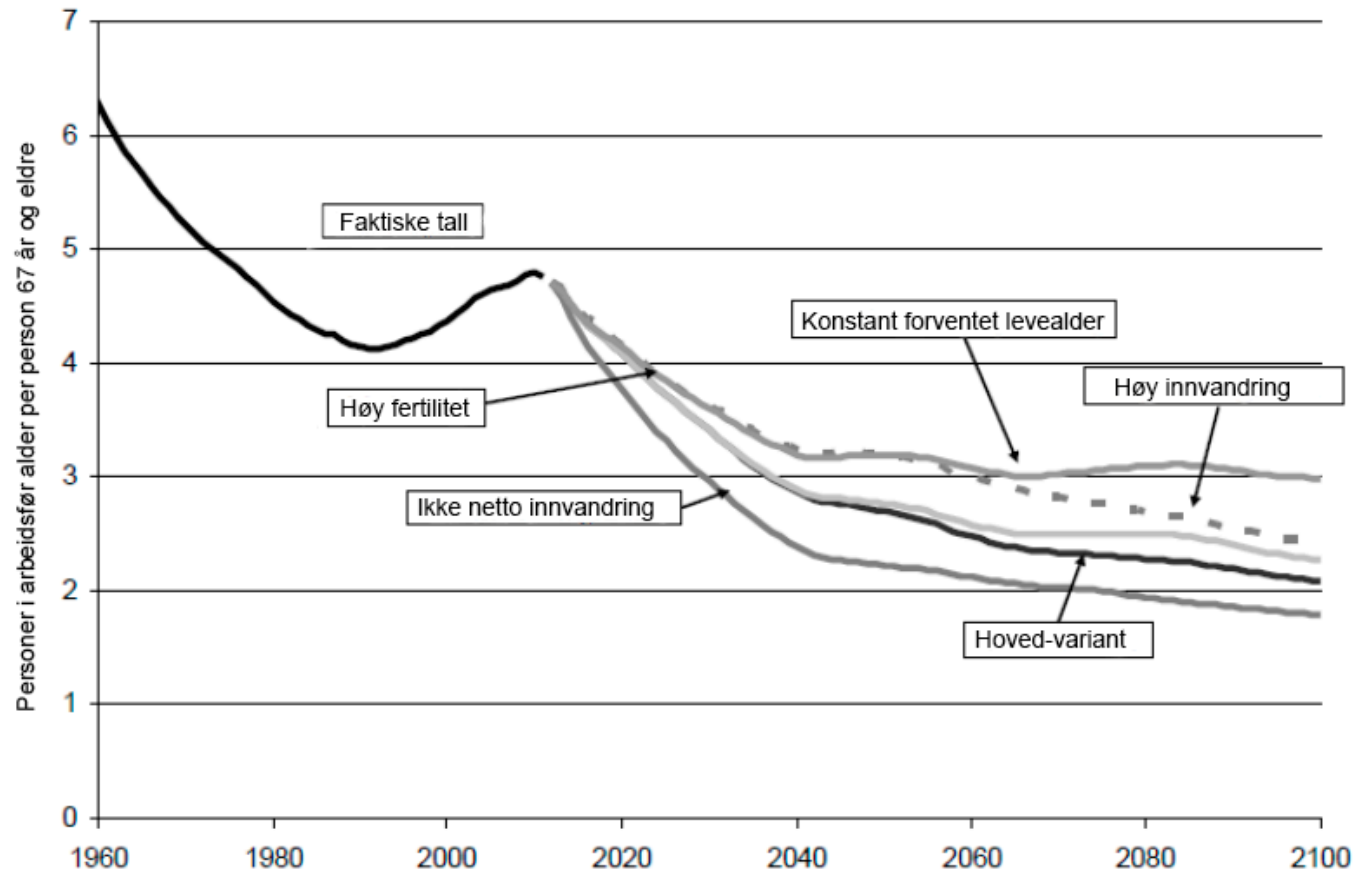

Figur 3: Potential old age support ratio (PSR) 1950-2100. Befolkning 19-66 år I forhold til befolkning 67 år og over. Befolkningsframskrivinger 2012-2100 av Statistisk Sentralbyrå. Kilde: Figur 5 (Brunborg, 2012). Publisert med godkjennelse av Norsk Epidemiologi. 


\section{Referanser}

Amundsen, I, Dahl, ES \& Haga, O. Utviklingen i alderspensjon pr. 31. desember 2013. Oslo: NAV; 2014.

Arntzen, KA, Schirmer, H, Wilsgaard, T \& Mathiesen, EB. Impact of cardiovascular risk factors on cognitive function: the Tromso study. Eur J Neurol 2011; 18(5): 737-43.

Bergland, A. Fall risk factors in community-dwelling elderly people. Norsk Epidemiologi 2012; 22(2): 151-64.

Blix, HS, Roed, J \& Sti, MO. Large variation in antibacterial use among Norwegian nursing homes. Scand J Infect Dis 2007; 39(6-7): 536-41.

Borchgrevink, HM, Tambs, K and Hoffman, HJ. The Nord-Trondelag Norway Audiometric Survey 1996-98: unscreened thresholds and prevalence of hearing impairment for adults $>20$ years. Noise Health 2005; 7(28): 1-15.

Brunborg, $\mathrm{H}$. Increasing life expectency and the growing elderly population. Norsk Epidemiologi 2012; 22(2): 75-83.

Christensen, K, Doblhammer, G, Rau, R \& Vaupel, JW. Ageing populations: the challenges ahead. Lancet 2009; 374(9696): 1196-208.

Christiansen, SG \& Keilman, N. Probabilistic household forecasts based on register data - the case of Denmark and Finland. Demographic Research 2013; 28: 1263-302.

Daatland, SO, Herlofson, K \& Lima, IA. Balancing generations: on the strength and character of family norms in the West and East of Europe. Ageing and Society 2011; 31(07): 1159-79.

Daffner, KR. Promoting successful cognitive aging: a comprehensive review. J Alzheimers Dis 2010; 19(4): 110122.

Di Marco, LY, Marzo, A, Munoz-Ruiz, M, Ikram, MA, Kivipelto, $M$ et al. Modifiable Lifestyle Factors in Dementia: A Systematic Review of Longitudinal Observational Cohort Studies. J Alzheimers Dis 2014.

Engedal, K \& Haugen, PK. Demens. Fakta og utfordringer. 5. utgave. Oslo: Forlaget Aldring og Helse; 2009.

Engstad, T, Engstad, TT, Viitanen, M \& Ellekjær, H. Epidemiology of stroke in the elderly in the Nordic countries. Incidence, survival, prevalence and risk factors. Norsk Epidemiol 2012; 22(2): 121-26.

Falk, H, Johansson, L, Ostling, S, Thogersen Agerholm, K, Staun, $\mathrm{M}$ et al. Functional disability and ability 75 -yearolds: a comparison of two Swedish cohorts born 30 years apart. Age Ageing 2014; 43(5): 636-41.

FHI, Folkehelseinstituttet: E Langballe and M Evensen. Eldre i Norge: Forekomst av psykiske plager og lidelser. Oslo: Folkehelseinstituttet; 2011.

FHI, Folkehelseinstituttet: $\varnothing$ Næss, M Rognerud and BH Strand. Sosial ulikhet i helse. En faktarapport. Oslo: Folkehelseinstituttet; 2007, rapport: 2007:1.

Fors, S, Lennartsson, C, Agahi, N, Parker, MG \& Thorslund, $M$. Interview study on the living conditions of the very old. Elderly acquire more health problems, but they manage everyday life better. Lakartidningen 2013; 110(32-33): 1403-5.
Forskningsrådet. Store satsinger 2015, side 10. Oslo: Forskningsrådet; 2013.

Fratiglioni, L, Paillard-Borg, S \& Winblad, B. An active and socially integrated lifestyle in late life might protect against dementia. Lancet Neurol 2004; 3(6): 343-53.

Grundy, E \& Kravdal, Ø. Reproductive history and mortality in late middle age among Norwegian men and women. Am J Epidemiol 2008; 167(3): 271-79.

Hallstrom, B, Jonsson, AC, Nerbrand, C, Norrving, B \& Lindgren, A. Stroke incidence and survival in the beginning of the 21st century in southern Sweden: comparisons with the late 20th century and projections into the future. Stroke 2008; 39(1): 10-5.

Helsedirektoratet. 2014a. Demens. [hentet 04.07.2014].

Helsedirektoratet, 2014b. Anbefalinger om kosthold, ernæring og fysisk aktivitet. Oslo, Norge: Helsedirektoratet.

Herlofson, K, Hagestad, G, Slagsvold, B \& Sorensen, A. Intergenerational family responsibility and solidarity in Europe. Oslo: NOVA; 2011.

Huisman, M, Kunst, AE, Bopp, M, Borgan, JK, Borrell, C et al. Educational inequalities in cause-specific mortality in middle-aged and older men and women in eight western European populations. Lancet 2005; 365(9458): 493-500.

IHME, Institute for Health Metrics and Evaluation (2013). GBD Profile: Norway. Results 1990-2010. Hentet 1.juni 2014 fra http://www.healthdata.org/results/country-profiles

Lappegård, T, Rønsen, M \& Skrede, K. Fatherhood and Fertility. Fathering: A Journal of Theory, Research, and Practice about Men as Fathers 2011; 9(1): 103-20.

Lohne-Seiler, H \& Torstveit, MK. Viktigheten av fysisk aktivitet og trening blant eldre. Norsk Epidemiol 2012; 22(2): 165-74.

Moe, JO \& Hagen, TP. Trends and variation in mild disability and functional limitations among older adults in Norway, 1986-2008. European Journal of Aging 2011; 8: 12.

Moe, JO, Steingrimsdottir, OA, Strand, BH \& Næss, Ø. Trends in remaining life expectancy at retirement age (65 years) by educational level in Norway 1961-2009. Nor J Epidemiol 2012; 22(2): 85-94.

Morgan, LA \& Kunkel, SR. Aging, society and the life course. 4th ed. New York: Springer Publishing Company, LLC; 2011.

Nilsson, G, Backman, L, Erngrund, K \& Nyberg, L. The betula prospective cohort study: Memory, health, and aging. Aging Neuropsychol Cogn 1997; 4(1): 32.

Pahor, M, Guralnik, JM, Ambrosius, WT, Blair, S, Bonds, DE et al. Effect of structured physical activity on prevention of major mobility disability in older adults: the LIFE study randomized clinical trial. JAMA 2014; 311(23): 2387-96.

Parker, MG, Ahacic, K \& Thorslund, M. Health changes among Swedish oldest old: prevalence rates from 1992 and 2002 show increasing health problems. J Gerontol A Biol Sci Med Sci 2005; 60(10): 1351-5.

Priskorn, L, Holmboe, SA, Jacobsen, R, Jensen, TK, Lassen, $\mathrm{TH}$ et al. Increasing trends in childlessness in recent birth cohorts - a registry-based study of the total Danish male population born from 1945 to 1980. Int J Androl 2012; 35(3): 449-55. 
Rosness, TA, Strand, BH, Bergem, AL, Engedal, K \& Bjertness, E. Association between dementia-related mortality and physical activity in old age: a population based cohort study. Dementia and Geriatric Cognitive Disorders Extra 2014; In press.

Rowe, JW \& Kahn, RL. Human aging: usual and successful. Science 1987; 237(4811): 143-9.

Rowe, JW \& Kahn, RL. Successful aging. Gerontologist 1997; 37(4): 433-40.

Skirbekk, V, Stonawski, M, Bonsang, E \& Staudinger, UM. The Flynn effect and population aging. Intelligence 2013; 41(3): 169-77.

Solbakken SM, Magnus JH, Meyer HM, et al. Impact of comorbidity, age and gender on seasonal variation in hip fracture incidence. A NOREPOS study. Arch Osteoporos 2014;9:191. doi: 10.1007/s11657-014-0191-2.

Solomon, A, Mangialasche, F, Richard, E, Andrieu, $\mathrm{S}$, Bennett, DA et al. Advances in the prevention of Alzheimer's disease and dementia. J Intern Med 2014; 275(3): 229-50.

Mørk, E. Seniorer i Norge 2010. Oslo: Statistisk Sentralbyrå; 2011.

SSB, Statistisk sentralbyrå, 2014. Statistikkbanken. [hentet 07.07.2014].

Stordal, E, Bosnes, I, Bosnes, O, Romuld, EB \& Almkvist, O. Successfully aging elderly (SAE) : a short overview of some important aspects of successful aging. Norsk Epidemiol 2012; 22(2): 103-08.

Strand, BH, Langballe, EM, Hjellvik, V, Handal, M, Naess, O et al. Midlife vascular risk factors and their association with dementia deaths: Results from a Norwegian prospective study followed up for 35years. J Neurol Sci 2013; 324(1-2): 124-30.

Strand, BH, Langballe, EM, Rosness, $\mathrm{TA}$, Bergem, AL, Engedal, $\mathrm{K}$ et al. Age, education and dementia related deaths. The Norwegian Counties Study and The Cohort of Norway. J Neurol Sci 2014.
Syse, A, Veenstra, M, Aagnes, A \& Tretli, S. Cancer incidence, prevalence and survival in an aging Norwegian population. Norsk Epidemiologi 2012; 22(2): 109-20.

Tambs, K. Moderate effects of hearing loss on mental health and subjective well-being: results from the NordTrondelag Hearing Loss Study. Psychosom Med 2004; 66(5): 776-82.

Tomassini, C, Kalogirou, S, Grundy, E, Fokkema, T, Martikainen, $\mathrm{P}$ et al. Contacts between elderly parents and their children in four European countries: current patterns and future prospects. European Journal of Ageing 2004; 1(1): 54-63. http://dx.doi.org/10.1007/s10433-004-0003-4

United Nations, 2007. World Economic and Social Survey 2007: Development in an Ageing World. New York, USA: United Nations; 2007.

Vaupel, JW. Biodemography of human ageing. Nature 2010; 464(7288): 536-42.

Voelcker-Rehage, C, Godde, B \& Staudinger, UM. Cardiovascular and Coordination Training Differentially Improve Cognitive Performance and Neural Processing in Older Adults. Front Hum Neurosci 2011; 5: 1-12.

Walker, A \& Maltby, T. Active ageing: A strategic policy solution to demographic ageing in the European Union. Int J Soc Welfare 2012; 21(S1): 117-30.

WHO, World Health Organization, 2002. Active Ageing: A Policy Framework. Geneva: World Health Organization, 2002.

\section{FORFATTERE}

Bjørn Heine Strand, Hanne Merete Eriksen, Kristian Tambs, Vegard Skirbekk 


\section{Helse i innvandrerbefolkningen}

- Det er store helsemessige forskjeller mellom ulike innvandrergrupper.

- Diabetes er utbredt blant innvandrere fra Sri Lanka og Pakistan.

- Kvinner fra land med høy forekomst av diabetes, har spesielt høy risiko for å utvikle svangerskapsdiabetes.

- I flere innvandrergrupper er overvekt og fedme utbredt.

- Ved besøk i tidligere hjemland har særlig innvandrere fra lavinntektsland i Afrika og Asia økt risiko for å bli smittet med enkelte infeksjonssykdommer.

- Voksne innvandrere og barn og voksne med flyktningebakgrunn rapporterer om mer psykiske helseplager enn etnisk norske.

- D-vitaminmangel er utbredt blant innvandrere fra noen lav- og middelinntektsland.

- Fortsatt er kunnskapen om innvandrerbefolkningens helse mangelfull. Noen av de viktigste datakildene vi har til kunnskap om innvandreres helse er mer enn 10 år gamle.

\section{Om innvandrerbefolkningen i Norge}

Andelen innvandrere (personer født i utlandet med to utenlandsfødte foreldre) i befolkningen har steget kraftig siden 1970 og utgjorde i 2013 om lag 12 prosent av befolkningen, se figur 1 og tabell 1. Til sammen utgjør innvandrere (personer født i utlandet av to utenlandsfødte foreldre) og norskfødte med innvandrerforeldre rundt 14 prosent av befolkningen i Norge (Brunborg, 2013):

- Omlag 320000 innvandrere kommer fra Europa.

- Omlag 240000 kommer fra Afrika og Asia.

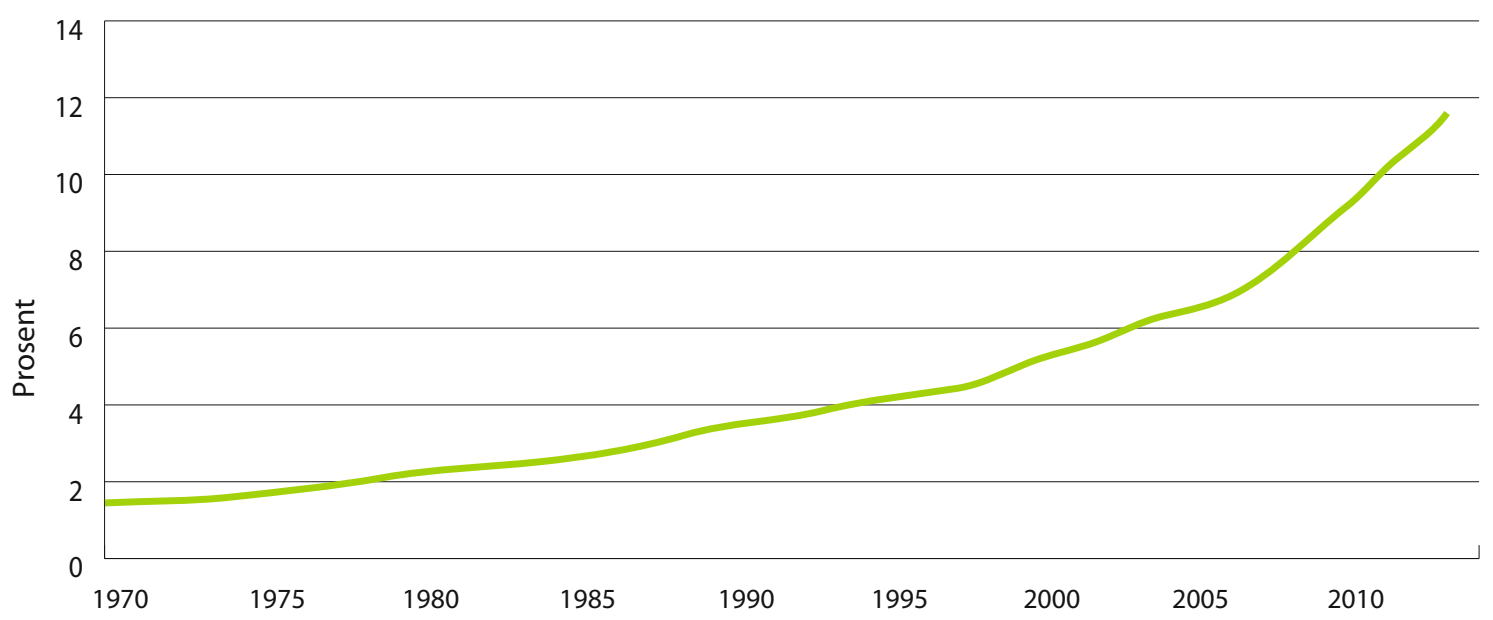

Figur 1: Andel av befolkningen som er innvandrere (personer født i utlandet med to utenlandsfødte foreldre), 1970 - 2013. Kilde: Statistisk sentralbyrå. 
Tabell 1: Antall innvandrere (personer født i utlandet med to utenlandsfødte foreldre) etter landbakgrunn, 2013. Kilde: Statistisk sentralbyrå.

\begin{tabular}{|l|l|}
\hline Landbakgrunn & Antall innvandrere \\
\hline Europa & 323260 \\
\hline Afrika & 67566 \\
\hline Asia & 171919 \\
\hline Nord og Mellom-Amerika & 13602 \\
\hline Sør-Amerika & 15024 \\
\hline
\end{tabular}

Rundt halvparten av innvandrerbefolkningen er i aldersgruppen 20-44 år, og av norskfødte med innvandrerforeldre er 85 prosent under 20 år.

Innvandrerbefolkningen har kommet til Norge av ulike grunner, som for eksempel arbeid, beskyttelse og familiegjenforening, og de representerer mer enn 200 ulike land. Hvilke grupper som til enhver tid kommer til Norge, avhenger av internasjonale konjunktursvingninger, innlemmelse av nye medlemsland i EU og nye krigs- og konfliktområder.

En relativt stor andel personer i enkelte innvandrergrupper har ingen eller liten utdanning. Innvandrere er overrepresentert i lavinntektsgrupper og har statistisk sett lavere sysselsetting enn befolkningen forøvrig.

\section{Innvandrerbefolkningen vil øke i de kommende tiårene}

SSB har siden 2005 gjort framskrivinger på innvandrerbefolkningen. Ifølge det såkalte hovedalternativet som ble presentert i 2012, vil antall innvandrere vokse fra 0,55 millioner i 2012 til 1,3 millioner i 2050. Dersom vi tar med barn av innvandrere, vil antallet vokse fra 0,66 millioner i 2012 til 2,03 millioner i 2050.

\section{Innvandreres helse}

Innvandrerbefolkningen er en sammensatt gruppe når det gjelder alder, kjønn, opprinnelsesland, sosioøkonomisk status, innvandringsgrunn og oppholdstid. Innvandrernes helse er derfor formet av en rekke ulike faktorer, og helsebehovene vil også endre seg med oppholdstiden.

Noen av helseforskjellene mellom de ulike innvandrergruppene har sammenheng med sosioøkonomisk status (Rechel, 2011), men lav sosioøkonomisk status kan også være et resultat av å være innvandrer.

\section{Datagrunnlaget}

Mesteparten av kunnskapen vi har om innvandrerbefolkningens helse i dag er basert på resultater fra noen få helseundersøkelser. De viktigste er:

- Helseundersøkelsen i Oslo 2000-2002 (HUBRO): omfatter voksne innvandrere fra Tyrkia, Iran, Pakistan, Sri Lanka og Vietnam (FHI, 2014).

- Helseundersøkelsene blant ungdom, UNGHUBRO. Gjennomført blant alle 10-klassinger i Oslo i 2000 -2002, og deretter i resten av landet,

- Helse- og levekårsundersøkelser blant voksne innvandrere i 1986, 1993 og 2005. Den siste undersøkelsen omfattet innvandrere fra Tyrkia, Iran, Pakistan, Sri Lanka, Vietnam, Somalia, Chile, Bosnia-Herzegovina, Serbia og Montenegro (SSB, 2008).

Vi har lite kunnskap om helsen til andre innvandrergrupper.

Dataene fra HUBRO og Helse- og levekårsundersøkelsene er 10 år gamle, og det er behov for oppdaterte data både på gruppene som inngår i de to undersøkelsene og om nye store innvandrergrupper, for eksempel innvandrere fra de nye EU-landene. Helse- og levekårsundersøkelsene baserer seg på selvrapportert informasjon om innvandreres helse, mens HUBRO også har kliniske målinger og blodprøver fra sine deltakere.

Datagrunnlaget for barn og unge er enda mer begrenset. UNGHUBRO inneholder kun selvrapportert informasjon om helsen. I UngKul-prosjektet har Folkehelseinstituttet samlet inn data på etnisitet og migrasjon for barn og unges læring, tilpasning og psykiske helse (FHI, 2008a). Også UngData-undersøkelsene vil kunne gi noe informasjon om helse til barn og unge med innvandrerbakgrunn (NOVA, 2013).

Så langt er data fra helseregistre lite benyttet i studier av innvandreres helse. MSIS er det eneste av helseregistrene som inneholder fødelandsopplysninger. Dersom man skal bruke data fra andre helseregistre i analyser og forskning på innvandreres helse, må helseregisterdata sammenstilles med fødelandsopplysninger fra det sentrale folkeregisteret. Slike registerstudier kan bli et verdifullt tilskudd til helseundersøkelser.

\section{Vurdering av egen helse}

Både tall fra HUBRO i 2000-2002 og fra SSBs helse- og levekårsundersøkelser i 2005 fant at færre innvandrere enn etnisk norske vurderte sin helse som god eller 
svært god. I undersøkelsene deltok innvandrere fra Tyrkia, Iran, Pakistan, Sri Lanka, Vietnam, Somalia, Chile, Bosnia-Herzegovina, Serbia og Montenegro.

Data fra helse- og levekårsundersøkelsen i 2005 viste at mens 67 prosent av innvandrerne vurderte sin helse som god eller svært god, var tilsvarende andel i den etnisk norske befolkningen 86 prosent (SSB, 2008). Sammenliknet med innvandrermenn var det en lavere andel av innvandrerkvinnene som vurderte sin helse som god eller svært god, 60 prosent mot 71 prosent. Det var forskjeller mellom innvandrere fra ulike land. Mens 78 prosent av innvandrere fra Somalia vurderte sin helse som god eller svært god, var det kun 60 prosent av innvandrere fra Tyrkia som gjorde det samme (SSB, 2008).

\section{Infeksjonssykdommer}

Innvandrere fra lavinntektsland i Afrika og Asia utgjør en stor del av de som blir diagnostisert med de kroniske infeksjonssykdommene tuberkulose, hiv og hepatitt $B$. Dette er sykdommer hvor innvandrerne smittes i sitt opprinnelige hjemland. Enten blir sykdommen oppdaget etter ankomst til Norge, eller de smittes ved senere besøk i hjemlandet.

- I perioden 1977-2013 sank antallet årlige meldte tilfeller av tuberkulose fra om lag 450 til 50 blant etnisk norske, mens det steg fra under 50 til om lag 350 blant innvandrere, se figur 2.

- I femårsperioden 2009-2013 utgjorde innvandrere 49 prosent av alle meldte tilfeller av hiv-infeksjon, 63 prosent av alle tuberkulosetilfellene og 92 prosent av alle meldte tilfeller av kronisk hepatitt B. Om lag en tredel av de smittede kom fra land på Afrikas horn.

Ved besøk i tidligere hjemland har særlig innvandrere fra lavinntektsland i Afrika og Asia økt risiko for å bli smittet med enkelte infeksjonssykdommer. I de siste årene er om lag halvparten av de meldte tilfellene med malaria, tyfoid- og paratyfoidfeber og hepatitt A smittet i Pakistan eller India. Se figur 3.

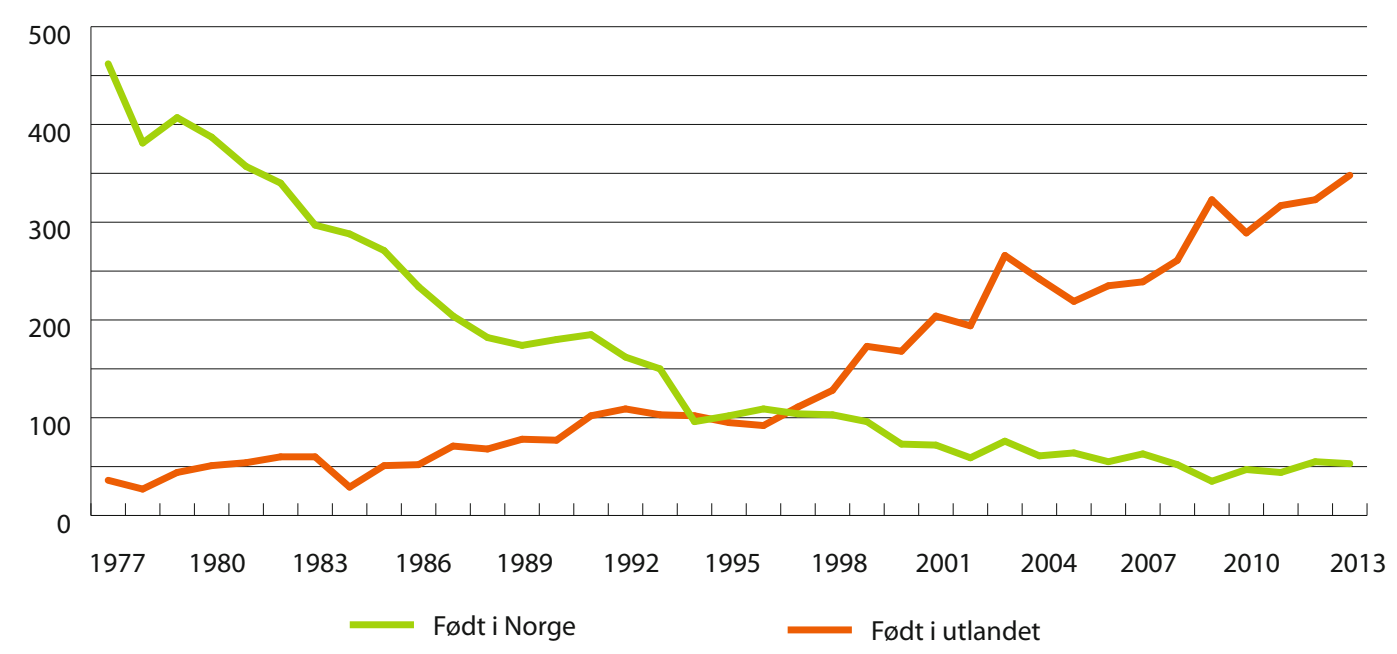

Figur 2: Antall meldte tilfeller av tuberkulose 1977-2013, etter fødeland. Kilde: MSIS.

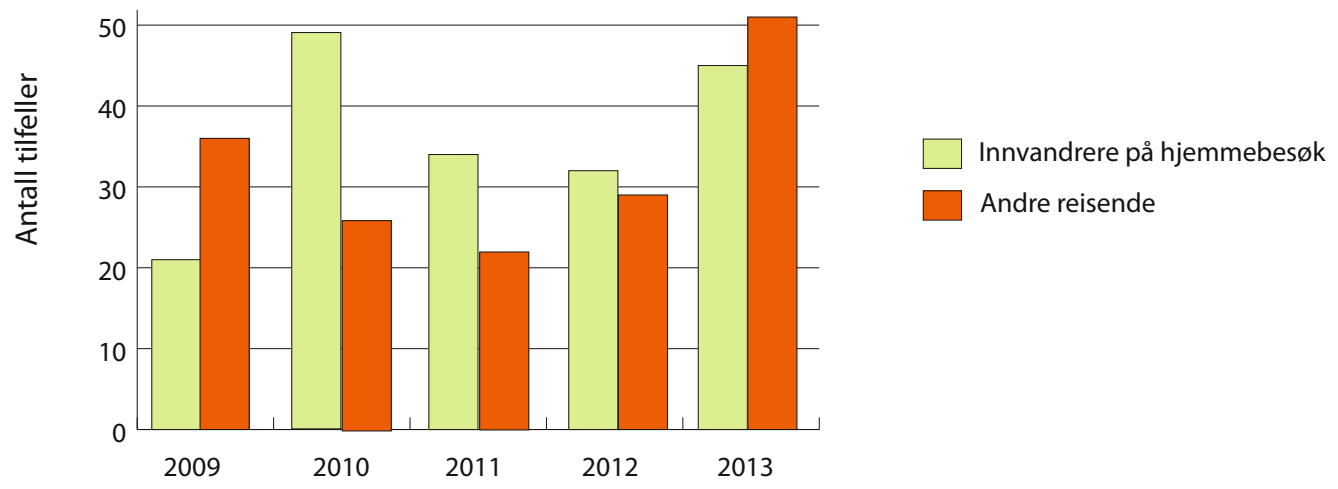

Figur 3: Antall meldte tilfeller av sykdommene hepatitt A, malaria, tyfoidfeber og paratyfoidfeber hos utenlandsreisende i 2009-2013, etter type reisende. Kilde: MSIS. 
Når innvandrere er på besøk i familiens hjemland, kommer de i tett kontakt med lokalbefolkningen. I tillegg tar de i mindre grad enn andre reisende reisevaksiner og malariaprofylakse, og mange er ikke klar over at de etter noen år i Norge mister mye av den delvise immuniteten mot enkelte sykdommer de hadde da de bodde i hjemlandet (FHI, 2014).

\section{Ikke-smittsomme sykdommer}

\section{Hjerte- og karsykdommer}

Fullstendige tall på forekomst av hjerte- og karsykdom hos ulike innvandrergrupper i Norge er per i dag ikke tilgjengelige. Selvrapporterte tall fra HUBRO 2000-2002 viste imidlertid at flere innvandrere enn etnisk norske rapporterte om hjerte- og karsykdommer (Kumar, 2009). For eksempel oppga 2 prosent av norske menn å ha hatt hjerteinfarkt, mens tilvarende andel hos pakistanske menn var 7 prosent. Av de norske kvinnene var det ingen som oppga å ha hatt hjerteinfarkt, mens andelene var 2 prosent blant kvinner fra henholdsvis Sri Lanka og Vietnam. Vi vet ikke hvordan hjerte- og karsykdommer har utviklet seg etter 2002.

\section{Diabetes}

Tall fra MoRo (Mosjon på Romsås) og HUBRO i 2000 2002 viser at innvandrere fra Sri Lanka og Pakistan hadde høy forekomst av diabetes sammenliknet med etnisk norske og andre innvandrergrupper (Jenum, 2012a). I Oslo var forekomsten av diabetes blant innvandrere fra disse to landene $20-26$ prosent. Det ser også ut til å være en sterkere sammenheng mellom overvekt/fedme og diabetes for innvandrere fra Sri Lanka og Pakistan enn for etnisk norske. For alle nivåer av overvekt/fedme var forekomsten av diabetes høyere i de to innvandrergruppene enn blant de etnisk norske (Jenum, 2012a).

Forekomsten av diabetes blant innvandrere fra Sri Lanka og Pakistan er generelt høyere enn forekomsten som har blitt rapportert fra opprinnelseslandene Sri Lanka og Pakistan. Det gjelder både urbane og rurale områder (Jafar, 2004; Katulanda, 2008; Katulanda, 2011; Shera, 2007; Zahid, 2008). Dette kan tyde på at migrasjon har noe å si for risikoen for å utvikle diabetes.

En studie basert på informasjon fra allmennpraktiserende leger tyder også på at innvandrere fra SørAsia har dårligere blodsukkerkontroll og får diabetes i yngre alder enn både andre innvandrergrupper og etnisk norske (Tran, 2010). Dette er en særlig utfordring når kvinner med type 2-diabetes blir gravide. Type 2-diabetes øker risikoen for komplikasjoner i svangerskapet. Risikoen kan i stor grad forebygges ved god planlegging før graviditeten. I planleggingen bør det legges vekt på god blodglukosekontroll (HBA1c-nivå < 7 prosent før konsepsjon), samt livsstilstiltak og medikamentell behandling (Kitzmiller, 2008).

Kvinner fra land med høy forekomst av diabetes har også spesielt høy risiko for å utvikle svangerskapsdiabetes. Dette viser en studie basert på tall fra Medisinsk fødselsregister i perioden 1988-1998 blant innvandrerkvinner fra Sør-Asia og Nord-Afrika (Vangen, 2003). I STORK Groruddalen-undersøkelsen, hvor et utvalg av alle gravide fra Groruddalen i Oslo ble testet, hadde omtrent 15 prosent av de gravide fra etniske minoritetsgrupper svangerskapsdiabetes. Høyest forekomst var det hos kvinner fra Sør-Asia og Midtøsten (Jenum, 2012b). Noe av den økte sårbarheten for svangerskapsdiabetes hos kvinner fra Sør-Asia har blitt knyttet til sosioøkonomiske forhold tidlig i livet, samt lav fysisk aktivitet (Mørkrid, 2012). Å fremme fysisk aktivitet vil derfor være spesielt viktig for gravide kvinner i denne gruppen.

Noe av årsaken til den høye forekomsten av diabetes og andre metabolske risikofaktorer hos innvandrere fra sør-asiatiske land som Pakistan og Sri Lanka, kan være knyttet til sosioøkonomiske faktorer (Helsedirektoratet, 2009). Mors levevilkår tidlig i livet og under svangerskapet kan også spille en rolle (Sletner, 2014; Sletner, 2013). Dårlige ernærings- og vekstforhold i de første leveårene, inkludert fosterlivet, har sammenheng med økt risiko for sykdommer senere i livet (Hales, 1992). Se også kapittel Helse hos barn og unge, første del.

I studien STORK Groruddalen, som så på nyfødte av ulik etnisk opprinnelse i Oslo, fant en at nyfødte fra lav- og middelinntektsland i større grad enn nyfødte med vesteuropeisk bakgrunn hadde en såkalt tynnfet fenotype (Sletner, 2013). Dette gjaldt særlig de med pakistansk bakgrunn, hvor mor enten var født i Pakistan eller i Norge med pakistansk mor. En tynn-fet fenotype innebærer en kroppssammensetning med mer fett i buken og mindre muskelmasse, og kan være assosiert med økt sårbarhet for diabetes og hjerte- og karsykdom senere i livet (Joshi, 2012; Yajnik, 2003).

\section{Kreft}

Vi har liten kunnskap om forekomst av kreft i de forskjellige innvandrergruppene. Hovedårsaken er at landbakgrunn ikke registreres i Kreftregisteret i dag.

\section{Muskel og skjelettplager}

Tall fra HUBRO i 2000-2002 viser at 20-26 prosent av kvinnene med innvandrerbakgrunn hadde muskel- og skjelettplager (FHI, 2008a). Tilsvarende andel i den norske befolkningen var åtte prosent. Om lag 
15 prosent av innvandrermennene svarte at de hadde muskel- og skjelettplager mot to prosent av etnisk norske menn.

\section{Psykisk helse}

\section{Psykiske helseplager blant voksne}

Vi har foreløpig lite kunnskap om utbredelsen av psykiske lidelser blant innvandrere. Flere norske studier har brukt data fra HUBRO i 2000-2002 og Helseog levekårsundersøkelsen for innvandrere i 2005. Disse studiene fant at andelen med psykiske helseplager var høyere i innvandrerbefolkningen enn blant etnisk norske (FHI, 2008a; SSB, 2008), men at det var en del variasjon mellom gruppene. Av de innvandrergruppene som var representert i studien, var det innvandrere fra Iran, Irak og Tyrkia som hadde de høyeste andelene med psykiske helseplager (rundt 40 prosent), mens de laveste andelene var blant innvandrere fra Sri Lanka (16 prosent) og Somalia (16 prosent) (FHI, 2008a; SSB, 2008). Andelene som rapporterte om psykiske helseplager økte med alderen, og de var også gjennomgående høyere blant kvinner enn menn. Etter 2005 er det ikke gjort tilsvarende undersøkelser.

\section{Psykiske plager blant barn og unge}

Forskjellene i psykiske helseplager mellom innvandrere og etnisk norske ser ut til å være mindre blant barn og unge enn blant voksne. Dette viser tall fra en studie basert på data fra de tre undersøkelsene UngKul, Barn i Bergen og Akershusundersøkelsen som ble gjennomført i henholdsvis 2002, 2006 og 2007. I aldersgruppen 10-12 år rapporterte 16 prosent av guttene med innvandrerbakgrunn og 11 prosent av de etnisk norske guttene om emosjonelle plager, atferdsvansker, sosiale plager og/eller hyperaktivitetsproblemer. Blant jentene var det ingen forskjell i den totale forekomsten av slike plager (11 prosent mot 9 prosent) (FHI, 2008b).

Den samme studien som over fant at særlig emosjonelle problemer var mer utbredt blant barn og unge med innvandrerbakgrunn enn blant etnisk norske barn og unge (FHI, 2008b). I aldersgruppen 10-12 år rapporterte 13 prosent av guttene med innvandrerbakgrunn om emosjonelle problemer, mot 5 prosent av de etnisk norske guttene. Blant jentene var tallene henholdsvis 18 og 10 prosent (FHI, 2008b). En nyere studie tyder på at det høye nivået av emosjonelle problemer blant gutter med innvandrerbakgrunn sammenlignet med etnisk norske gutter, dels kan henge sammen med at de har mer skolerelaterte belastninger (Alves, 2011). Det var ikke forskjeller i andelen selv-rapporterte atferdsproblemer mellom barn med og uten innvandrerbakgrunn i aldersgruppen 10-12 år (FHI, 2008b).
Også blant barn og unge finner vi store variasjoner i psykiske helseplager mellom ulike innvandrergrupper (Oppedal, 2005; Oppedal, 2007). En studie basert på data fra UngHubro i 2000-2002 fant at 15-åringer fra Iran og Vietnam hadde mer depressive symptomer enn ungdom fra Somalia og tamilske ungdommer fra Sri Lanka.

I de yngste aldersgruppene (7-10 år) er det ikke funnet forskjeller i psykiske plager mellom barn som er født i utlandet (første generasjon innvandrere) og barn som er født i Norge (andre generasjon innvandrere). Blant ungdom er det imidlertid mer psykiske plager blant innvandrergutter som er født i Norge enn blant innvandrergutter som er født i utlandet. For jentene er det omvendt (Oppedal, 2005).

\section{Psykiske helseplager blant flyktninger}

Flyktninger har mer psykiske plager enn det som er funnet hos andre innvandrere og i majoritetsbefolkningen (Bronstein, 2011; Fazel, 2012; Fazel, 2005; Seglem, 2014). Atskillelse fra og tap av familiemedlemmer, samt fangenskap, tortur og andre krigsrelaterte opplevelser er særlig forbundet med økt risiko for depresjon og post-traumatiske stressplager (PTSD). Belastninger knyttet til asylsøknadsprosessen og til bosetning og tilpasning i tiden etterpå, er også viktige for å forstå stabilitet og forandringer i psykiske plager blant voksne og barn med flyktningebakgrunn.

\section{Risiko- og beskyttende faktorer}

\section{Overvekt og fedme}

Fedme, definert som kroppsmasseindeks (KMI) på over 30 , ser ut til å være et utbredt problem i enkelte innvandrergrupper. Tall fra ulike studier basert på data fra HUBRO i 2000-2002 og MoRo (mosjon på Romsås i Oslo) (Jenum, 2012; Kumar, 2006) viser blant annet at om lag halvparten av kvinner fra Pakistan og Sri Lanka hadde bukfedme (forholdet mellom midjeog hoftemål). Andelen blant etnisk norske kvinner var til sammenlikning en tredel. Andelen menn med bukfedme var lavere både blant pakistanske og etnisk norske menn, henholdsvis 20 og 10 prosent. Innvandrere fra Vietnam hadde lav andel med bukfedme, 21 prosent av kvinnene og ingen av mennene.

En senere studie undersøkte overvekt og fedme blant somaliske innvandrere og fant at til sammen 66 prosent av kvinnene og 28 prosent av mennene hadde overvekt eller fedme, definert som $\mathrm{KMI} \geq 25$ (Gele, 2013). Både generell fedme og bukfedme (midjeomkrets) hadde sammenheng med økende botid i 
Norge og lite fysisk aktivitet, noe som tyder på at tidlig forebygging er viktig for denne innvandrergruppen (Gele, 2013).

\section{Fysisk aktivitet}

Tall fra helseundersøkelser i perioden 1994-2003 tyder på at i innvandrergrupper fra lav- og middelinntektsland er en høy andel inaktive, det vil si 1 time eller mindre lett fysisk aktivitet per uke (Rabanal, 2013). Rundt 50 prosent av mennene fra Øst-Asia, Nord-Afrika og Sør-Øst Asia rapporterte om inaktivitet, mot 20 prosent av de etnisk norske mennene. Blant kvinnene fra Midtøsten, det indiske subkontinentet (slik som Pakistan, Sri Lanka, India og Bangladesh) og fra land i Afrika sør for Sahara og det tidligere Jugoslavia rapporterte over 40 prosent om inaktivitet, mot 16 prosent av de etnisk norske kvinnene.

\section{Kosthold og ernæring}

Noen innvandrergrupper spiser tradisjonelt mye frukt og grønnsaker, og det er forbundet med redusert risiko for flere kroniske sykdommer. En studie av gravide kvinners kosthold basert på data fra STORK Groruddalen fant imidlertid at innvandrerkvinnene i studien spiste mer usunt enn de etnisk norske (Sommer, 2013). Sosioøkonomisk status og integreringsnivå så ut til å kunne forklare en god del av denne forskjellen i kosthold.

D-vitamintilførselen gjennom kosten kan bli mangelfull for dem som er lite ute i sollys. En rekke studier har vist at D-vitaminmangel er utbredt blant innvandrere. Dette gjelder særlig innvandrere fra Pakistan, Sri Lanka, Tyrkia, Iran og Vietnam (Falch, 2000; Holvik, 2005; Meyer, 2004). Særlig utsatt er gravide og fødende pakistanske kvinner (Brunvand, 1996; Falch, 2000; Henriksen, 1995)

\section{Alkohol}

Data fra HUBRO i 2000-2002 viser at innvandrere fra Iran, Tyrkia og Pakistan rapporterte om sjeldnere inntak av alkohol enn etnisk norske (Amundsen, 2012). Innvandrere med lang botid, eldre og kvinner drakk alkohol sjeldnere enn gjennomsnittet, mens innvandrere med høy utdanning og arbeidsdeltakelse drakk alkohol oftere. Muslimske innvandrere drakk sjeldnere enn ikke-muslimske innvandrere. Vi vet ikke om dette har endret seg etter 2000-2002.

Også innvandrerungdommer ser ut å drikke mindre alkohol enn norsk ungdom (Amundsen, 2012; NOVA, 2010). I en nyere studie om Osloungdoms rusbruk fant man for eksempel at mens 45-50 prosent av unge med en eller to norskfødte foreldre hadde drukket $\varnothing$ siste 30 dager, så gjaldt det kun for 20 prosent av unge med innvandrerbakgrunn (Øia, 2012). Tilsvarende hadde
20 prosent av de norske drukket brennevin mot 10 prosent av de med innvandrerbakgrunn. Mellom de etnisk norske og de med én av foreldrene født i Norge, var det bare små forskjeller.

\section{Røyking}

Analyser av data fra HUBRO i 2000-2002 (Vedøy, 2013) viser at 56 prosent av mennene fra Tyrkia, 46 prosent av mennene fra Iran og 36 prosent av mennene fra Vietnam røykte. Blant innvandrerkvinner var røyking mest utbredt blant kvinner fra Tyrkia (28 prosent) og Iran (23 prosent). Den tilsvarende andelen blant etnisk norske menn og kvinner var henholdsvis 27 og 30 prosent. Andelen som røyker har falt i befolkningen som helhet siden 2002 (se kapittel om røyking og snusbruk), men vi har ikke nyere tall for røyking i innvandrerbefolkningen.

\section{Sosioøkonomisk status}

Både den fysiske og psykiske helsen er bedre blant innvandrere som har høy utdanning eller er i arbeid og har god økonomi, enn den er blant innvandrere som har lav utdanning, står utenfor arbeidslivet eller har lav inntekt (FHI, 2008a; SSB, 2008; Syed, 2006). God sosial støtte og sosial integrering er også forbundet med god helse, mens opplevd diskriminering og vold har en negativ betydning for helsen (Dalgard, 2006; SSB, 2008; Syed, 2006).

\section{Migrasjonsprosessen}

Migrasjonsprosessen omfatter både opplevelser i opprinnelseslandet forut for avreise, som eventuell internering, fluktrute eller opphold i flyktningeleir, samt ankomst til bosettingslandet, med derpå følgende søknad om oppholdstillatelse eller asyl. I tillegg omfatter migrasjonsprosessen bosetting og tilpasning til en ny kultur. Alle fasene er forbundet med forhold og erfaringer som kan ha betydning for innvandreres helse. Når det gjelder flyktninger, har forskere særlig fokusert på hvilken betydning tortur, vold og andre krigsrelaterte traumer forut for migrasjonen har for deres psykiske helse, mens forskning på de frivillige migrantenes psykiske helse for det meste har vært rettet mot økonomiske, sosiale og kulturelle faktorer i tiden etter bosettingen.

Mange innvandrere beholder en tilknytning til opprinnelseslandet og til familie og venner som fortsatt bor der. Krig og konflikter i hjemlandet kan også påvirke deres psykiske helse. Flere studier finner at både naturkatastrofer og krig i hjemlandet øker risikoen for psykiske plager hos innvandrere, selv lenge etter flukt og bosetting (Dyb, 2011; Guribye, 2011). 


\section{Bruk av helsetjenester}

I 2012 var det om lag 61 prosent av innvandrere som oppsøkte fastlegen sin minst én gang. Tilsvarende tall i den etnisk norske befolkningen var 69 prosent (SSB, 2014). Mens antall konsultasjoner hos fastlegen er det samme for kvinner med og uten innvandrerbakgrunn, har mannlige innvandrere i gjennomsnitt færre konsultasjoner (1,8 per år) enn etnisk norske menn (2,2 per år). Det er imidlertid store forskjeller mellom ulike innvandrergrupper. Mens arbeidsinnvandrere fra EU/EØS-land ofte har lavere bruk av fastlege, viser andre studier at innvandrere fra andre land oppsøkte fastlegen oftere enn etnisk norske (SSB, 2008). Bruk av fastlege øker også med tid bosatt i Norge.

En ny studie finner at blant innvandrere fra Polen, Sverige, Tyskland, Pakistan og Irak, hadde alle bortsett fra irakiske menn, mindre sannsynlighet for å bruke fastlegen for psykiske helseplager enn etnisk norske (Straiton, 2014). Bruken av fastlege økte med botiden, og flyktninger oppsøkte fastlegen for psykiske helseplager i større grad enn innvandrere som hadde kommet til Norge for familiegjenforening.

Innvandrere bruker legevakten noe mindre enn nordmenn (henholdsvis 24 prosent og 27 prosent), men det er stor variasjon i bruk av legevakt mellom de ulike innvandrergruppene (Sandvik, 2012):

- Innvandrere fra Tyskland eller Polen (som ofte kommer som arbeidsinnvandrere) har lav bruk av legevakt, henholdsvis 7 og 12 prosent.

- Innvandrere fra Irak eller Somalia (som ofte kommer som flyktninger) har høy bruk av legevakt, henholdsvis 34 og 32 prosent.

Helse- og levekårsundersøkelsen fra 2005 finner ingen forskjell mellom innvandrere og etnisk norske i bruk av spesialisthelsetjenesten (SSB, 2008). En studie gjennomført i Oslo tyder imidlertid på at innvandrere i mindre grad enn etnisk norske søker akuttpsykiatrisk hjelp (Berg, 2009).

\section{Bruk av legemidler}

Kultur, religion og språkbarrierer kan påvirke innvandreres bruk av legemidler. To studier av pakistanske innvandrere med livsstilssykdommer fant blant annet at ramadan, misforståelser som følge av kommunikasjonsproblemer og kulturell oppfatning om medisinbruk førte til feil bruk av medisiner (Håkonsen, 2012; Håkonsen, 2011). Nesten halvparten (46 prosent) av de pakistanske innvandrerne svarte at de endret sin medisinbruk under ramadan. Sammenliknet med etnisk norske hadde de pakis- tanske innvandrerne også mindre kunnskap om sin egen medikamentelle behandling (Håkonsen, 2012).

\section{Fragmentert og mangelfull kunnskap om innvandreres helse}

Kunnskap om ulike innvandrergruppers helse og bruk av helsetjenester er mangelfull og fragmentert. Det gjelder både hvilke grupper som er studert og hvilke temaer som er belyst.

- Det er mangel på kunnskap om sykdomsforekomst blant de ulike innvandrergruppene som er bosatt eller oppholder seg midlertidig $\mathrm{i}$ Norge.

- Kunnskapen om barn og unges helse er særlig mangelfull.

Det er flere årsaker til den begrensede kunnskapen:

- Landbakgrunn ligger ikke ligger inne som en fast variabel i norske helseregistre.

- Flere spørreskjemaundersøkelser er ikke tilpasset innvandrerbefolkningen, verken metodisk eller språklig, og vil derfor ha lav svarprosent.

En oversikt over forskningen på innvandrerhelse i Norge viser at de fleste studiene ikke skiller mellom helserelevante faktorer, som eksempelvis landbakgrunn, innvandringsgrunn og botid i Norge.

Norge har svært gode sentrale helseregistre og nasjonale medisinske kvalitetsregistre. De kunne i større grad vært benyttet i analyser og forskning på innvandreres helse.

\section{Barrierer knyttet til bruk av helsetjenester}

Innvandrerbefolkningen kan oppleve ulike barrierer knyttet til bruk av helsetjenester som igjen kan ha betydning for helsen:

- Kulturelle utfordringer knyttet til bruk av helsetjenester; tegn på sykdom og når man bør oppsøke helsetjenestene.

- Kommunikasjonsproblemer kan skape misforståelser og få alvorlige følger for diagnostisering, behandling og rehabilitering.

- Stigma knyttet til psykiske helseplager kan bidra til at færre søker helsehjelp for denne type helseplager. 
- Manglende kunnskap om organiseringen av helse- og omsorgstjenestene og hvilke rettigheter man har. Slik kunnskap er en viktig forutsetning for å kunne nyttiggjøre seg tilbudene som finnes.

- Manglende kunnskap og kompetanse hos helsepersonell om særskilte helseutfordringer hos ulike grupper av innvandrere.

\section{Referanser}

Alves, DE, Roysamb, E, Oppedal, B and Zachrisson, HD. Emotional problems in preadolescents in Norway: the role of gender, ethnic minority status, and home- and school-related hassles. Child Adolesc Psychiatry Ment Health 2011; 5(1): 37. http://www.ncbi.nlm.nih.gov/ pubmed/22093180

Amundsen, E. Low level of alcohol drinking among two generations of non-Western immigrants in Oslo: a multiethnic comparison. BMC Public Health 2012; 12(1): 535. http://www.biomedcentral.com/1471-2458/12/535

Berg, JE. The level of non-Western immigrants' use of acute psychiatric care compared with ethnic Norwegians over an 8-year period. Nord J Psychiatry 2009; 63(3): 217-22. http:// www.ncbi.nlm.nih.gov/pubmed/19034713

Bronstein, I and Montgomery, P. Psychological distress in refugee children: a systematic review. Clin Child Fam Psychol Rev 2011; 14(1): 44-56. http://www.ncbi.nlm.nih. gov/pubmed/21181268

Brunborg, H. Hvor mange innvandrere er det - og blir det - i Norge? Samfunnsspeilet 2013; 27(3): 2-9. http://www. ssb.no/befolkning/artikler-og-publikasjoner/ attachment/121979? ts=142b2393578

Brunvand, L, Henriksen, C and Haug, E. Vitamin D deficiency among pregnant women from Pakistan. How best to prevent it? Tidsskr Nor Laegeforen 1996; 116(13): 1585-7. http://www.ncbi.nlm.nih.gov/pubmed/8685871

Dalgard, OS, Thapa, SB, Hauff, E, McCubbin, M and Syed, HR. Immigration, lack of control and psychological distress: findings from the Oslo Health Study. Scand J Psychol 2006; 47(6): 551-8. http://www.ncbi.nlm.nih.gov/ pubmed/17107504

Dyb, G, Jensen, TK and Nygaard, E. Children's and parents' posttraumatic stress reactions after the 2004 tsunami. Clin Child Psychol Psychiatry 2011; 16(4): 621-34. http://www. ncbi.n/m.nih.gov/pubmed/21565871

Falch, JA and Steihaug, S. Vitamin D deficiency in Pakistani premenopausal women living in Norway is not associated with evidence of reduced skeletal strength. Scand J Clin Lab Invest 2000; 60(2): 103-9. http://www.ncbi.nlm.nih. gov/pubmed/10817396

Fazel, M, Reed, RV, Panter-Brick, C and Stein, A. Mental health of displaced and refugee children resettled in highincome countries: risk and protective factors. The Lancet 2012; 379(9812): 266-82. http://linkinghub.elsevier.com/ retrieve/pii/S0140673611600512
Fazel, M, Wheeler, J and Danesh, J. Prevalence of serious mental disorder in 7000 refugees resettled in western countries: a systematic review. Lancet 2005; 365(9467): 1309-14. http://www.ncbi.nlm.nih.gov/pubmed/15823380

FHI; Folkehelseinstituttet. HUBRO - helseundersøkelsen i Oslo i 2000-2001. [hentet 22/5/2014]. Tilgjengelig fra: http://www.fhi.no/artikler/?id=102755

FHI; Folkehelseinstituttet. BN Kumar. The Oslo immigrant health profile. Oslo: Folkehelseinstituttet; 2008a, rapport: 2008:7. Tilgjengelig fra: http://www.fhi.no/ dav/920ab22ad5.pdf

FHI; Folkehelseinstituttet. B, Oppedal, GE, Azam, SB, Dalsøren et al. Psykososial tilpasning og psykiske problemer blant barn i innvandrerfamilier. Oslo: Folkehelseinstituttet; 2009, rapport: 2008:14. Tilgjengelig fra: http://www.fhi.no/dokumenter/3ef60b2cba.pdf

FHI; Folkehelseinstituttet. Smittevernveileder for helsepersonell. [hentet juni 2014]. Tilgjengelig fra: http://www.fhi.no/ publikasjoner-og-haandboker/smittevernboka

Gele, A and Mbalilaki, A. Overweight and obesity among African immigrants in Oslo. BMC Research Notes 2013; 6(1): 119. http://www.biomedcentral.com/1756-0500/6/119

Guribye, E. "No God and no Norway": collective resource loss among members of Tamil NGO's in Norway during and after the last phase of the civil war in Sri Lanka. International Journal of Mental Health Systems 2011; 5(1): 18. http://www.ijmhs.com/content/5/1/18

Hales, CN and Barker, DJ. Type 2 (non-insulin-dependent) diabetes mellitus: the thrifty phenotype hypothesis. Diabetologia 1992; 35(7): 595-601. http://www.ncbi.nlm.nih.gov/ pubmed/1644236

Helsedirektoratet. Diabetes: forebygging, diagnostikk og behandling. Oslo: Helsedirektoratet; 2009. www.helsedirektoratet.no/publikasjoner/nasjonal-faglig-retningslinjediabetes/Publikasjoner/Nasjonal-faglig-retningslinjeDiabetes-fullversjon.pdf

Henriksen, C, Brunvand, L, Stoltenberg, C, Trygg, K, Haug, E et al. Diet and vitamin $D$ status among pregnant Pakistani women in Oslo. Eur J Clin Nutr 1995; 49(3): 211-8. http:// www.ncbi.nlm.nih.gov/pubmed/77745537

Holvik, K, Meyer, HE, Haug, E and Brunvand, L. Prevalence and predictors of vitamin $D$ deficiency in five immigrant groups living in Oslo, Norway: the Oslo Immigrant Health Study. Eur J Clin Nutr 2005; 59(1): 57-63. http://www.ncbi. nlm.nih.gov/pubmed/15280907

Håkonsen, $\mathrm{H}$ and Toverud, EL. Cultural influences on medicine use among first-generation Pakistani immigrants in Norway. Eur J Clin Pharmacol 2012; 68(2): 171-8. http:// www.ncbi.nlm.nih.gov/pubmed/21837393

Håkonsen, $\mathrm{H}$ and Toverud, EL. Special challenges for drug adherence following generic substitution in Pakistani immigrants living in Norway. Eur J Clin Pharmacol 2011; 67(2): 193-201. http://www.ncbi.nlm.nih.gov/ pubmed/21161197

Jafar, TH, Levey, AS, White, FM, Gul, A, Jessani, S et al. Ethnic differences and determinants of diabetes and central obesity among South Asians of Pakistan. Diabet Med 2004; 21(7): 716-23. http://www.ncbi.nlm.nih.gov/ pubmed/15209764 
Jenum, AK, Diep, LM, Holmboe-Ottesen, G, Holme, IM, Kumar, BN et al. Diabetes susceptibility in ethnic minority groups from Turkey, Vietnam, Sri Lanka and Pakistan compared with Norwegians - the association with adiposity is strongest for ethnic minority women. BMC Public Health 2012; 12: 150. http://www.ncbi.nlm.nih.gov/ pubmed/22380873

Jenum, AK, Morkrid, K, Sletner, L, Vangen, S, Torper, JL et al. Impact of ethnicity on gestational diabetes identified with the WHO and the modified International Association of Diabetes and Pregnancy Study Groups criteria: a population-based cohort study. Eur J Endocrinol 2012b; 166(2): 317-24. http://www.ncbi.n/m.nih.gov/pubmed/22108914

Joshi, SR. Type 2 diabetes in Asian Indians. Clin Lab Med 2012a; 32(2): 207-16. http://www.ncbi.nIm.nih.gov/ pubmed/22727000

Katulanda, P, Constantine, GR, Mahesh, JG, Sheriff, R, Seneviratne, RD et al. Prevalence and projections of diabetes and pre-diabetes in adults in Sri Lanka--Sri Lanka Diabetes, Cardiovascular Study (SLDCS). Diabet Med 2008; 25(9): 1062-9. http://www.ncbi.n/m.nih.gov/pubmed/19183311

Katulanda, P, Rathnapala, DAV, Sherrif, R and Matthews, DR. Province and ethnic specific prevalence of diabetes among Sri Lankan adults. Sri Lankan Journal of Diabetes Endocrionology and Metabolism 2011; 1(1): 2-7. http://www.sljol. info/index.php/SJDEM/article/view/4180

Kitzmiller, JL, Block, JM, Brown, FM, Catalano, PM, Conway, DL et al. Managing Preexisting Diabetes for Pregnancy: Summary of evidence and consensus recommendations for care. Diabetes Care 2008; 31(5): 1060-79. http://care. diabetesjournals.org/content/31/5/1060.short

Kumar, BN, Meyer, HE, Wandel, M, Dalen, I and HolmboeOttesen, G. Ethnic differences in obesity among immigrants from developing countries, in Oslo, Norway. Int J Obes (Lond) 2006; 30(4): 684-90. http://www.ncbi.nlm.nih. gov/pubmed/16130029

Kumar, BN, Selmer, R, Lindman, AS, Tverdal, A, Falster, K et al. Ethnic differences in SCORE cardiovascular risk in Oslo, Norway. Eur J Cardiovasc Prev Rehabil 2009; 16(2): 229-34. http://www.ncbi.nlm.nih.gov/pubmed/19276982

Meyer, HE, Falch, JA, Sogaard, AJ and Haug, E. Vitamin $D$ deficiency and secondary hyperparathyroidism and the association with bone mineral density in persons with Pakistani and Norwegian background living in Oslo, Norway, The Oslo Health Study. Bone 2004; 35(2): 412-7. http://www.ncbi.nlm.nih.gov/pubmed/15268891

Mørkrid, K, Jenum, AK, Sletner, L, Vardal, MH, Waage, CW et al. Failure to increase insulin secretory capacity during pregnancy-induced insulin resistance is associated with ethnicity and gestational diabetes. Eur J Endocrinol 2012; 167(4): 579-88. http://www.ncbi.nlm.nih.gov/ pubmed/22889687

NOVA:T Øia and Å Strandbu. 15-åringer - hvem drikker?: en undersøkelse av tiendeklassinger i Oslo 2009. Oslo: Norsk institutt for forskning om oppvekst, velferd og aldring; 2010, rapport: 1/10. Tilgjengelig fra: http://www. hioa.no/Om-HiOA/Senter-for-velferds-og-arbeidslivsforskning/NOVA/Publikasjonar/Rapporter/2010/15-aaringerhvem-drikker
NOVA: A Bakken. Ungdata: nasjonale resultater 2010-2012. Oslo: Norsk institutt for forskning om oppvekst, velferd og aldring; 2013. Tilgjengelig fra: http://www.ungdata.no/ asset/7229/1/7229 1.pdf

Oppedal, B, Roysamb, E and Heyerdahl, S. Ethnic group, acculturation, and psychiatric problems in young immigrants. J Child Psychol Psychiatry 2005; 46(6): 646-60. http://www.ncbi.nlm.nih.gov/pubmed/15877769

Oppedal, B and Røysamb, E. Young Muslim Immigrants in Norway: An Epidemiological Study of Their Psychosocial Adaptation and Internalizing Problems. Applied Developmental Science 2007; 11(3): 112-25. http://dx.doi. org/10.1080/10888690701454583

Rabanal, KS, Lindman, AS, Selmer, RM and Aamodt, G. Ethnic differences in risk factors and total risk of cardiovascular disease based on the Norwegian CONOR study. Eur J Prev Cardiol 2013; 20(6): 1013-21. http://www.ncbi.nlm. nih.gov/pubmed/22642981

Rechel, B. Migration and health in the European Union. Berkshire: Open University Press; 2011.

Sandvik, H, Hunskaar, S and Diaz, E. Immigrants' use of emergency primary health care in Norway: a registrybased observational study. BMC Health Serv Res 2012; 12 : 308. http://www.ncbi.nlm.nih.gov/pubmed/22958343

Seglem, KB, Oppedal, B and Roysamb, E. Daily hassles and coping dispositions as predictors of psychological adjustment: A comparative study of young unaccompanied refugees and youth in the resettlement country. International Journal of Behavioral Development 2014; 38(3): 293-303. http://jbd.sagepub.com/content/38/3/293.abstract

Shera, AS, Jawad, F and Maqsood, A. Prevalence of diabetes in Pakistan. Diabetes Res Clin Pract 2007; 76(2): 219-22. http://www.ncbi.n/m.nih.gov/pubmed/17005289

Sletner, L, Jenum, AK, Mørkrid, K, Vangen, S, Holme, IM et al. Maternal Life Course Socio-Economic Position and Offspring Body Composition at Birth in a Multi-Ethnic Population. Paediatric and Perinatal Epidemiology 2014; 28(5): 445-54. http://dx.doi.org/10.1111/ppe.12137

Sletner, L, Nakstad, B, Yajnik, CS, Mørkrid, K, Vangen, S et al. Ethnic Differences in Neonatal Body Composition in a Multi-Ethnic Population and the Impact of Parental Factors: A Population-Based Cohort Study. PLoS ONE 2013; 8(8): e73058. http://dx.doi.org/10.1371\%2Fjournal. pone.0073058

Sommer, C, Sletner, L, Jenum, AK, Morkrid, K, Andersen, LF et al. Ethnic differences in maternal dietary patterns are largely explained by socio-economic score and integration score: a population-based study. Food Nutr Res 2013; 57. http://www.ncbi.nlm.nih.gov/pubmed/23843779

SSB; Statistisk sentralbyrå. S Blom. Innvandreres helse 2005/2006. Oslo: Statistisk Sentralbyrå; 2008, rapport: 2008/35. Tilgjengelig fra: http://www.ssb.no/a/publikasjoner/pdf/rapp 200835/rapp 200835.pdf

SSB; Statistisk sentralbyrå. Statistikkbanken - Allmennlegetjenesten 2013. [hentet 1/9/2014]. Tilgjengelig fra: http:// www.ssb.no/helse/statistikker/fastlegetj/aar/2014-09-11 
Straiton, M, Reneflot, A and Diaz, E. Use of GP services for mental health problems: A comparison with Norwegians and immigrants. BMC Health Services Research 2014; 14(31).

Syed, H, Dalgard, O, Dalen, I, Claussen, Br, Hussain, A et al. Psychosocial factors and distress: a comparison between ethnic Norwegians and ethnic Pakistanis in Oslo, Norway. BMC Public Health 2006. http://www.biomedcentral. com/1471-2458/6/182

Tran, A, Diep, L, Cooper, J, Claudi, T, Straand, J et al. Quality of care for patients with type 2 diabetes in general practice according to patients' ethnic background: a cross-sectional study from Oslo, Norway. BMC Health Services Research 2010; 10(1): 145. http://www.biomedcentral.com/1472$6963 / 10 / 145$

Vangen, S, Stoltenberg, C, Holan, S, Moe, N, Magnus, P et al. Outcome of pregnancy among immigrant women with diabetes. Diabetes Care 2003; 26(2): 327-32. http://www. ncbi.nlm.nih.gov/pubmed/12547857

Vedøy, TF. The role of education for current, former and never-smoking among non-western immigrants in Norway. Does the pattern fit the model of the cigarette epidemic? Ethn Health 2013; 18(2): 190-210. http://www. ncbi.nlm.nih.gov/pubmed/22762415
Yajnik, CS, Fall, CH, Coyaji, KJ, Hirve, SS, Rao, S et al. Neonatal anthropometry: the thin-fat Indian baby. The Pune Maternal Nutrition Study. Int J Obes Relat Metab Disord 2003; 27(2): 173-80. http://www.ncbi.nlm.nih.gov/ pubmed/12586996

Zahid, N, Claussen, B and Hussain, A. Diabetes and impaired glucose tolerance in a rural area in Pakistan and associated risk factors. Diabetes \& Metabolic Syndrome:

Clinical Research \& Reviews 2008; 2(2): 125-30. http://www. sciencedirect.com/science/article/pii/S1871402108000222

Øia, T. Ung i Oslo 2012: nøkkeltall: Notat nr. 7/2012. Oslo: Norsk institutt for forskning om oppvekst, velferd og aldring; 2012. Tilgjengelig fra: www.hioa.no/content/ download/45468/674693/file/6066 1.pdf

\section{FORFATTERE}

Anne Reneflot (red), Kjersti Stormark Rabanal, Hans Blystad, Brit Oppedal, Melanie Straiton 


\section{Sosiale helseforskjeller}

- Det er betydelige sosiale forskjeller i helse og levevaner i den norske befolkningen.

- De sosiale helseforskjellene finnes både blant barn og voksne.

- Levealderen øker med økende utdanning.

- Utdanningsforskjeller i røyking antas å være en viktig årsak til de sosiale forskjellene i dødelighet i Norge.

\section{Om sosiale helseforskjeller}

Når man studerer grupper i samfunnet, finner man systematiske forskjeller i helse. Jo høyere utdanning og inntekt en gruppe har, jo høyere andel av gruppens «medlemmer» vil ha god helse (Huisman, 2005; Helsedirektoratet, 2005). Dette kalles sosiale helseforskjeller eller sosial ulikhet i helse.

Å bevege seg oppover på samfunnets rangstige betyr at man også beveger seg oppover når det gjelder helse. Helsen øker for hvert trinn.

De sosiale helseforskjellene gjelder for nesten alle sykdommer, skader og plager, og i alle aldersgrupper.

\section{Sosial ulikhet i helse er et samfunnsproblem}

En kunnskapsoppsummering konkluderer med at det er betydelige forskjeller i helse og levevaner i Norge, og at dette er et samfunnsproblem som det bør være mulig å gjøre noe med (Dahl, 2014). Slike ulikheter er urettferdige og representerer et tap for enkeltmennesker, familier og samfunnet.

Sosiale forskjeller i helse og levealder er også et folkehelseproblem fordi befolkningens totale helsepotensiale ikke utnyttes fullt ut. Arbeidsdager og år med god helse og høy livskvalitet går tapt.

\section{Levealderen øker med utdanningslengde}

Tall fra 2009 viser at menn med universitets- eller høgskoleutdanning kan forvente å leve 6 år lengre enn menn med grunnskole. For kvinner er forskjellen 5 år (Steingrímsdóttir, 2012).

Figur 1 viser gjenstående levealder ved 35 års alder, etter utdanningsnivå. Kvinner til venstre, menn til høyre.

I Norge har levealderen økt for alle utdanningsgruppene siden 1960-tallet, men gruppene med lang utdanning har hatt den beste utviklingen.

- For menn ser det ut til at forskjellene mellom utdanningsgruppene har blitt mindre etter 2000 (Steingrímsdóttir, 2012; Strand 2014).

- For kvinner øker derimot forskjellene i levealder fortsatt. Kvinner i gruppene med lav utdanning har hatt den dårligste utviklingen i levealder sammenlignet med andre grupper (Steingrímsdóttir, 2012; Strand, 2014).

Blant eldre personer er det mindre utdanningsforskjeller i levealder enn hos de yngre, men også her er forskjellene betydelige. Forventet gjenstående levetid ved 65 års alder varierer med om lag 2 år mellom ulike utdanningsgrupper (Moe, 2012). Se også kapittel Levealder.

\section{Forskjeller i helse og sykdom}

I gruppen med lav utdanning er det en betydelig større andel som rapporterer om generell dårlig helse enn i gruppen med høy utdanning (Kurtze, 2013). I gruppene med lavere utdanningsnivå er det også mer selvrapporterte muskel- og skjelettsykdommer og 


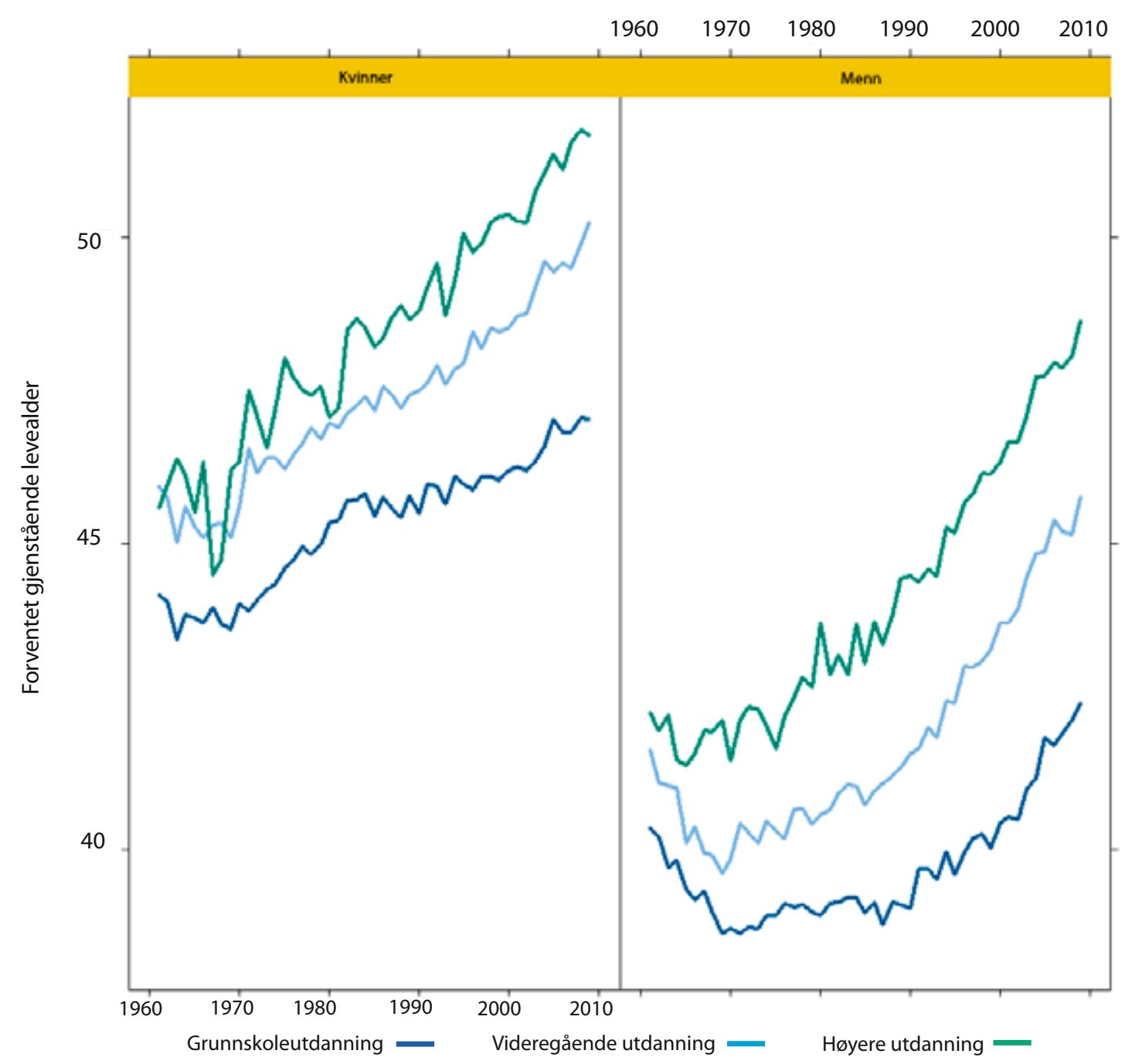

Figur 1: Forventet gjenstående levealder fra 35 års alder i Norge 1960-2009 gruppert etter utdanningsnivå. Kilde: Steingrímsdóttir, 2012.

psykiske plager enn blant de med høyere utdanningsnivå (FHI, 2007; Dahl, 2014).

Tilsvarende funn finner vi blant barn og unge. I familier med lav sosioøkonomisk status er det en høyere andel barn og unge som vurderer helsa si som dårlig sammenlignet med barn og unge i familier med høyere sosioøkonomisk status (Elstad, 2012).

Barn og unge av foreldre med lav sosioøkonomisk status har også økt risiko for langvarige sykdommer og plager, som for eksempel astma, allergi og eksem (Grøholt, 2003).

\section{Forskjeller i levevaner}

Studier viser at levevaner ofte følger utdannings- og inntektsnivå. Det betyr at grupper med lengre utdanning og høyere inntekt i gjennomsnitt har gunstigere levevaner og bedre helse enn grupper som har kortere utdanning og lavere inntekt.
En dybdestudie av 11-åringer fra Oslo-området viste for eksempel at foreldrenes utdanningslengde hadde sammenheng med barnas forbruk av sukkerholdige drikker (Totland, 2013). Inntaket av frukt og grønnsaker er også høyest blant personer med høy utdanning (Helsedirektoratet, 2013a).

Det er sosiale forskjeller i overvekt og fedme blant barn (Biehl, 2013). Det er også funnet at andelen med fedme er lavere blant 40-åringer med høy utdanning enn blant 40-åringer med lavere utdanning (Meyer, 2005).

Andelen som røyker viser også en sosial gradient (NOVA, 2013; Helsedirektoratet, 2013b). I tillegg viser en internasjonal studie av 22 europeiske land at Norge hadde den høyeste sosiale forskjellen i andel dagligrøykere. Blant de med grunnskoleutdanning var andelen dagligrøykere om lag fire ganger større enn hos de med universitet- eller høgskoleutdanning (Mackenbach, 2008). 
Siden midten av 1990-årene har det vært en nedgang i andelen dagligrøykere i alle utdanningsgrupper, men forskjellene mellom utdanningsgruppene er fremdeles store. Mens bare 8 prosent av de med universitetseller høyskoleutdanning røyker, er tilsvarende andel i gruppen med grunnskoleutdanning på hele 34 prosent (Helsedirektoratet, 2013b).

Alkoholbruken øker med økende utdanning og inntekt, men andelen med alkoholavhengighet er likevel høyere blant personer med lav inntekt og utdanning (FHI, 2009).

\section{Røykerelaterte sykdommer forklarer mye}

Ved årtusenskiftet kunne hjerte- og karsykdommene forklare om lag halvparten av forskjellen mellom gruppene med lang og kort utdanning når det gjaldt tidlig død (Strand, 2010). Det var betydelig flere som døde av hjerteinfarkt før 75 års alder i de laveste enn i de høyeste utdanningsgruppene.

Etter år 2000 har det imidlertid blitt betydelig mindre sosiale forskjeller i hjerte- og karsykdommer, både blant menn og kvinner (Strand, 2014). Hjerte- og karsykdommer forklarer i dag bare en femdel av forskjellene hos kvinner og en tredel hos menn. Nedgangen i ulikheter i hjerte- og karsykdommene har bidratt sterkt til at spesielt de sosiale helseforskjellene blant menn har blitt mindre (Mackenbach, 2014).

Hos kvinner har imidlertid økningen i den sosiale ulikheten i dødelighet av lungekreft og KOLS vært større enn tilsvarende nedgang i dødelighet av hjerteog karsykdommer, og dermed har vi totalt sett fortsatt en økning av de sosiale forskjellene i levealder hos kvinner (Strand, 2014).

I tiåret etter 2000 kunne lungekreft og KOLS forklare en tredel av de sosiale forskjellene i levealder blant kvinner. For menn sto disse dødsårsakene for en femdel av forskjellene (Strand, 2014).

- Utdanningsforskjeller i røyking antas å være en viktig årsak til de sosiale forskjellene i dødelighet i Norge (Strand, 2010; Strand, 2014; Machenback, 2008).

Hjertesykdom, KOLS og lungekreft er alle røykerelaterte sykdommer. En viktig folkehelseutfordring er derfor å bekjempe røyking, spesielt i grupper med lav utdanning.

\section{«Årsakene til årsakene» og de sosiale påvirkningsfaktorene}

Helse og levevaner som røyking, kosthold og fysisk aktivitet skapes ikke i et vakuum, men henger tett sammen med samfunnsforhold og levekår i oppvekst, voksenliv og alderdom (Dahl, 2014). Noen årsaksforhold virker antagelig gjennom hele livsløpet (Blane, 2013), og samspillet mellom de ulike påvirkningsfaktorene er derfor viktig.

Sammenhengen mellom sosial posisjon og helse er velkjent, men hvorfor det er slike forskjeller - hva som er de egentlige «årsakene til årsakene» er vanskeligere å forklare. Er det forskjeller i levekår og oppvekstmiljø, arbeidsmiljø og psykosial belastning, eller er det andre faktorer som kan forklare de sosiale forskjellene vi finner i helse?

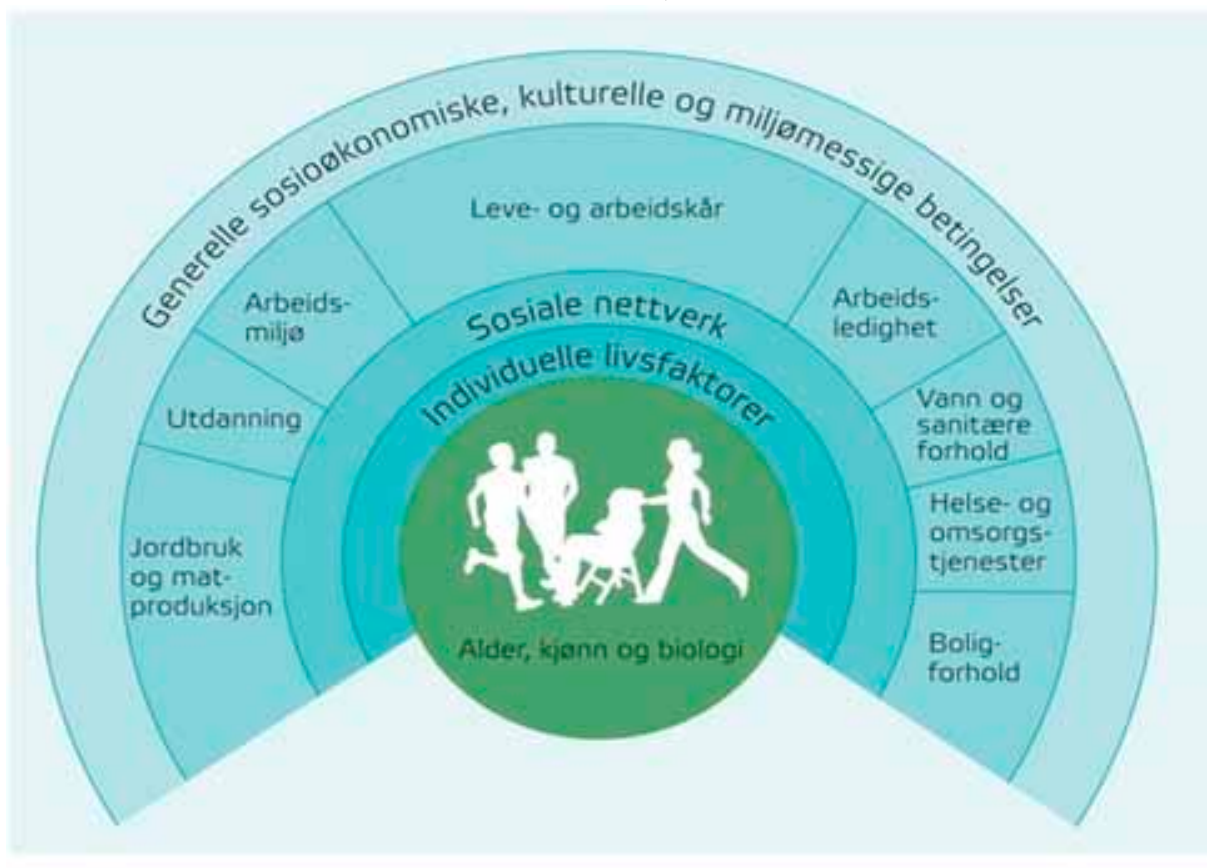

Figur 2: Ulike påvirkningsfaktorer for helse. Kilde: Dahlgren \& Whitehead, 1991. 
Figur 2 viser hvordan ulike lag av påvirkningsfaktorer påvirker folkehelsen og den sosiale fordelingen av denne. Faktorene spenner fra personlige egenskaper som alder og kjønn, til samfunnsforhold som kultur, arbeid, bo- og nærmiljø, utdanning og sosiale nettverk.

Som figuren viser er levevaner ikke bare et resultat av personlige valg. De valgene den enkelte tar er også et resultat av miljø og levekår. De bakenforliggende faktorene kan fremme helsen, eller det motsatte; øke risikoen for sykdom.

Reduserte sosiale helseforskjeller er et viktig mål i folkehelsearbeidet. Innsats for å gjøre noe med levekår, som arbeid og utdanning, kan bidra til å fremme helse og jevne ut sosiale helseforskjeller.

En utjevning av de sosiale helseforskjellene innebærer et stort potensiale for folkehelsen.

\section{Referanser}

Biehl A, Hovengen R, Grøholt EK, Hjelmesæth J, Strand BH, Meyer HE. Adiposity among children in Norway by urbanity and maternal education: a nationally representative study. BMC Public Health 2013; 13: 842. Doi:10.1186/14712458-13-842.

Blane D, Kelly-Irving M, d'Errico A, Bartley M, Montgomery S. Social-biological transitions: how does the social become biological? Longitudinal and Life Course Studies 2013; 4: 136-146.

Dahl E, Bergsli H, van der Wel K. Sosial ulikhet I helse: En norsk kunnskapsoversikt. Høgskolen i Oslo og Akershus. Rapport, 2014.

Dahlgren G, Whitehead M. Policies and Strategies to Promote Social Equity in Health. Stockholm 1991.

Elstad JI, Pedersen AW. Fører dårlig familieøkonomi til flere subjektive helseplager blant ungdom? Tidsskrift for velferdsforskning, 2012; 15: 78-92.

FHI, Folkehelseinstituttet, 2007. Sosial ulikhet i helse. En faktarapport. Folkehelseinstituttet: Rapport 2007:1.

FHI, Folkehelseinstituttet, 2009. Levekårsundersøkelsen 2005: psykisk helse i Norge : tilstandsrapport med internasjonale sammenligninger. Oslo, Nasjonalt folkehelseinstitutt: 2009:6.

Grøholt EK. Health and Well-being of Children in the Nordic Countries - Influence of Socio-economic Factors in Welfare States. Norwegian Institute of Public Health, Oslo, Norway, 2003.

Helsedirektoratet, 2005. Gradientutfordringen. Sosial- og helsedirektoratets handlingsplan mot sosiale ulikheter i helse. Rapport1/2005. ISBN-nr. 82-8081-060-9.

Helsedirektoratet, 2013a. Utviklingen i norsk kosthold. Oslo: Helsedirektoratet.
Helsedirektoratet, 2013b. Tall om tobakk. Tilgjengelig på helsedirektoratet.no

Huisman M, Bopp M, Borgan JK, Borrell C, Costa G, Deboosere P, Gadeyne S, Glickman M, Marinacci C, Minder C, Regidor E, Valkonen T, Mackenbach JP. Educational inequalities in cause-specific mortality in middle-aged and older men and women in eight western European populations. Lancet 2005; 365: 493-500.

Kurtze N, Eikemo TA, Kamphuis, CBM. Educational inequalities in general and mental health: differential contribution of physical activity, smoking, alcohol consumption and diet. European Journal of Public Health 2013, 23: 223-9. Doi: 10.1093/eurpub/cks055.

Mackenbach JP, Stirbu I, Roskam AJR, Schaap MM, Menvielle $G$, Leinsalu L, Kunst AE, for the European Union Working Group on Socioeconomic Inequalities in Health. Socioeconomic inequalities in health in 22 European countries. N Engl J Med 2008; 5 358_2468-81.

Mackenbach JP, Kulhánová I, Menvielle G, Bopp M, Borrell $C$ et al. for the Eurothine and EURO-GBD-SE consortiums. Trends in inequalities in premature mortality: a study of 3.2 million deaths in 13 European countries. J Epidemiol Community Health. doi:10.1136/jech-2014-204319.

Meyer, H. E. and A. Tverdal. Development of body weight in the Norwegian population. Prostaglandines, Leukotrienes and Essential Fatty Acids 2005; 73(1): 3-7.

Moe JO, Steingrímsdóttir ÓA, Strand BH, Næss $\varnothing$. Trends in remaining life expectancy at retirement age ( 65 years) by educational level in Norway 1961-2009. Norsk Epidemiologi 2012; 22: 85-94.

NOVA, 2013. Ungdata: Nasjonale resultater 2010-2012. Norsk institutt for forskning om oppvekst, velferd og aldring. NOVA Rapport 10/13.

Steingrímsdóttir OA, $\varnothing$ Næss, JO Moe, EK Grøholt, DS Thelle, BH Strand BH og K Bævre. Trends in life expectancy by education in Norway 1961-2009, European Journal of Epidemiology 2012; 27(3), 163-71.

Strand BH, Groholt EK, Steingrímsdóttir, OA, Blakely, T, Graff-Iversen, S, Næss, O. Educational inequalities in mortality over four decades in Norway: prospective study of middle aged men and women followed for cause specific mortality, 1960-2000. BMJ 2010; 340. Doi: http://dx.Doi. org/10.1136/bmj.c654.

Strand BH, Steingrímsdóttir OA, Grøholt EK, Ariansen I, GraffIversen $\mathrm{S}, \mathrm{N}$ æss O. Trends in educational inequalities in cause specific mortality in Norway from 1960 to 2010: a turning point for educational inequalities in cause specific mortality of Norwegian men after the millennium? BMC Public Health 2014 Nov 24;14(1):1208. [Epub ahead of print]

Totland, T. H., Lien, N., Bergh, I. H., Bjelland, M., Gebremariam, M. K. et al. The relationship between parental education and adolescents' soft drink intake from the age of 11-13 years, and possible mediating effects of availability and accessibility. Br J Nutr, 2013; 110(5), 926-933. Doi: $10.1017 / \mathrm{s} 0007114512005946$.

\section{FORFATTERE}

Bjørn Heine Strand, Else Karin Grøholt, Ólöf A. Steingrímsdóttir 


\section{DEL 3 Helse og sykdom}

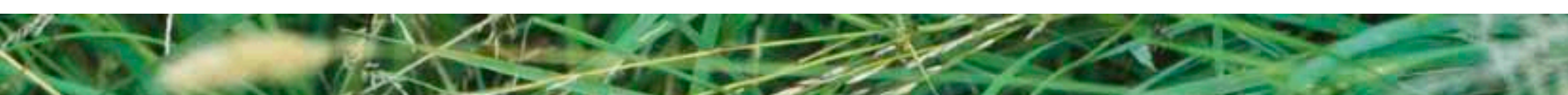

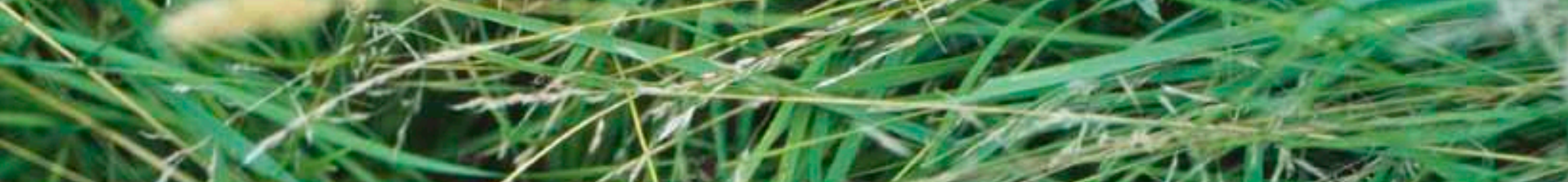

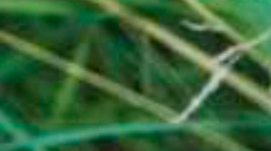

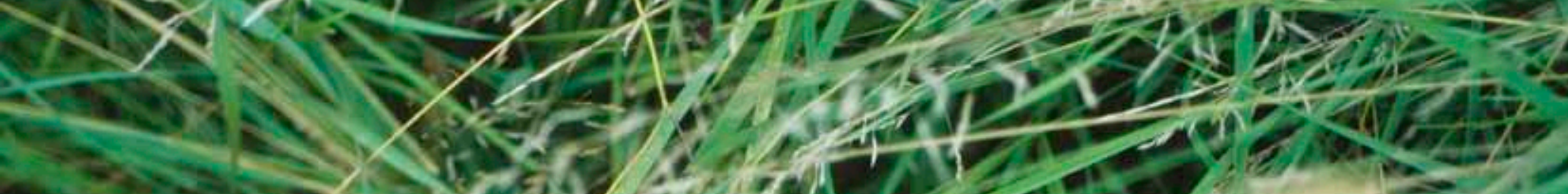

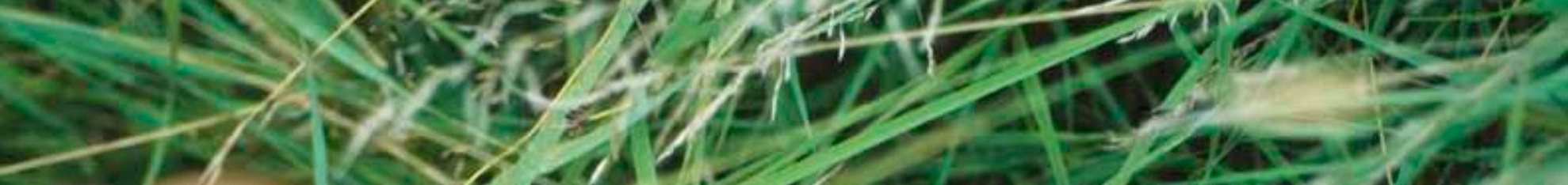

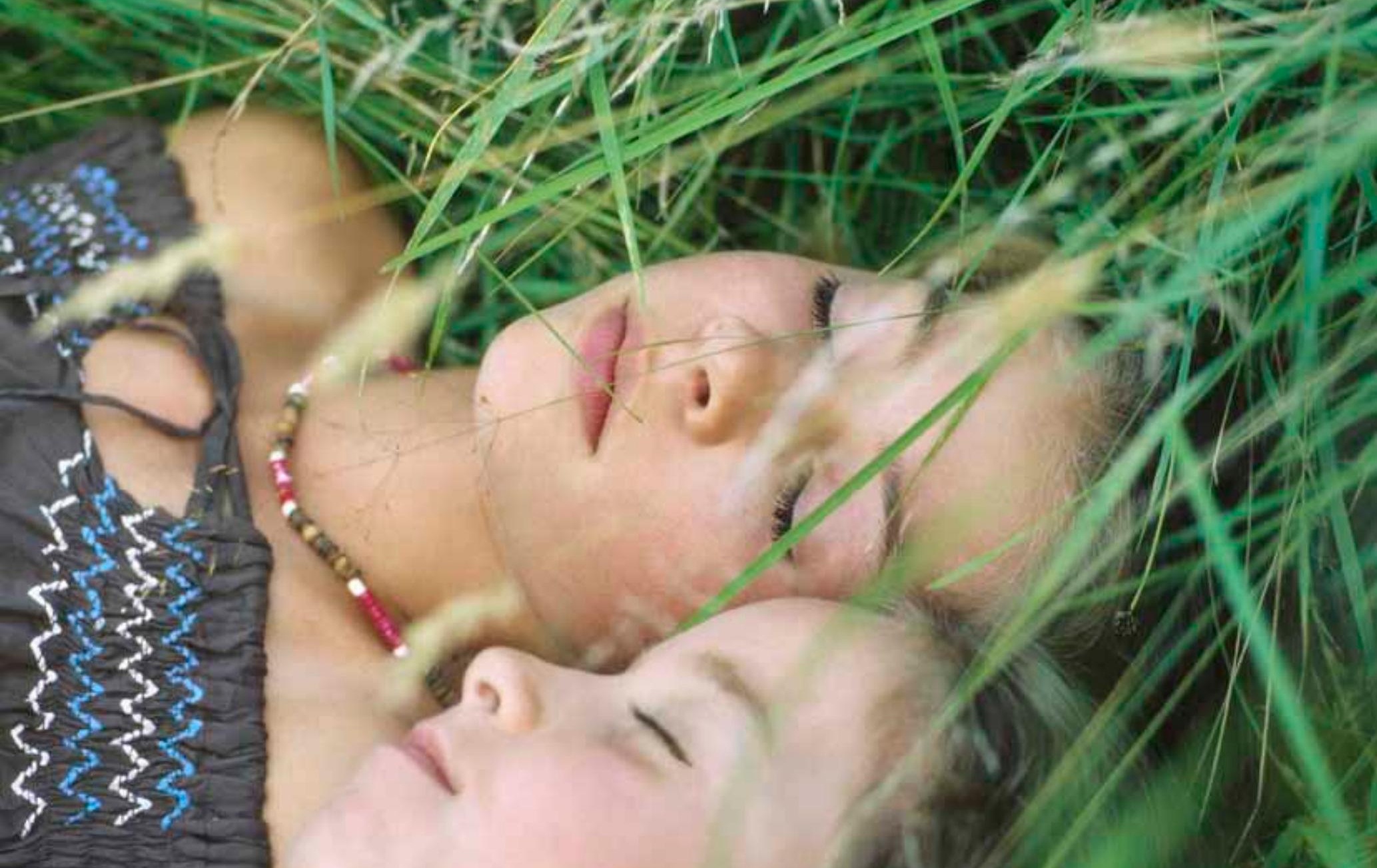


- $\varnothing$ kende antibiotikaresistens hos bakterier er en alvorlig trussel for fremtidig medisinsk behandling.

- Overvåkingen viser en økning i infeksjoner med antibiotikaresistente gule stafylokokker de siste 10 årene i primærhelsetjenesten.

- Fra 2010 har Norge hatt flere større utbrudd med vancomycinresistente tarmbakterier i sykehus.

- Forekomsten av blodforgiftninger og andre infeksjoner med ESBL-resistente bakterier har økt dramatisk internasjonalt og er også økende i Norge.

- Det viktigste forebyggende tiltaket er å begrense antibiotikabruken og velge smalspektrede i stedet for bredspektrede antibiotika.

\section{Om antibiotikaresistens}

Antibiotikaresistens innebærer at bakterier kan leve videre og formere seg selv om de utsettes for antibiotika.

Noen bakterier er naturlig resistente overfor enkelte antibiotika, mens andre kan utvikle resistens når de utsettes for antibiotika. Dette kalles ervervet resistens.

Bakterier kan utvikle resistens mot ett eller flere antibiotika. Bakterier som er resistente mot to eller flere antibiotika, kalles multiresistente.

\section{Hvordan bakterier utvikler resistens}

Bakterier kan bli resistente mot antibiotika på flere måter, først og fremst ved:

- Endringer i arvestoffet (DNA); såkalte mutasjoner. Slike mutasjoner kan oppstå når antibiotika spres i miljøet og påvirker bakterier.

- Å hente resistensgener fra andre bakterier. Dette kalles horisontal genoverføring. For eksempel kan såkalte mobile genetiske elementer med resistensgener overføres mellom bakterier.

Slike endringer kan skje i bakteriene hos den enkelte som bruker antibiotika, og i bakterier i miljø som utsettes for antibiotika.

\section{Hvordan antibiotikaresistens sprer seg}

Antibiotikaresistens sprer seg ved at resistente bakterier smitter mellom mennesker og mellom mennesker og miljø, og ved at resistensgener sprer seg mellom bakterier både hos enkeltpersoner og i miljøet.

Antibiotikaresistente bakterier vil ofte etablere seg $\mathrm{i}$ den normale bakteriefloraen, for eksempel blant bakteriene i tarmen. Personene blir da bærere av antibiotikaresistente bakterier. Bærere blir sjelden syke, men kan bidra til spredning av antibiotikaresistens.

\section{Dagens situasjon og utvikling over tid}

Utviklingen av multiresistente bakterier har særlig vært bekymringsfull hos tarmbakterier de siste årene, men også for andre typer bakterier øker resistensproblemet i Norge og internasjonalt.

Situasjonen i Norge er gunstigere enn i de fleste andre land. Økt antibiotikabruk, reisevirksomhet, import av mat og spredning av resistente bakterier i matproduksjonen kan imidlertid endre bildet.

Nedenfor følger omtale av de viktigste typene antibiotikaresistente bakterier. 


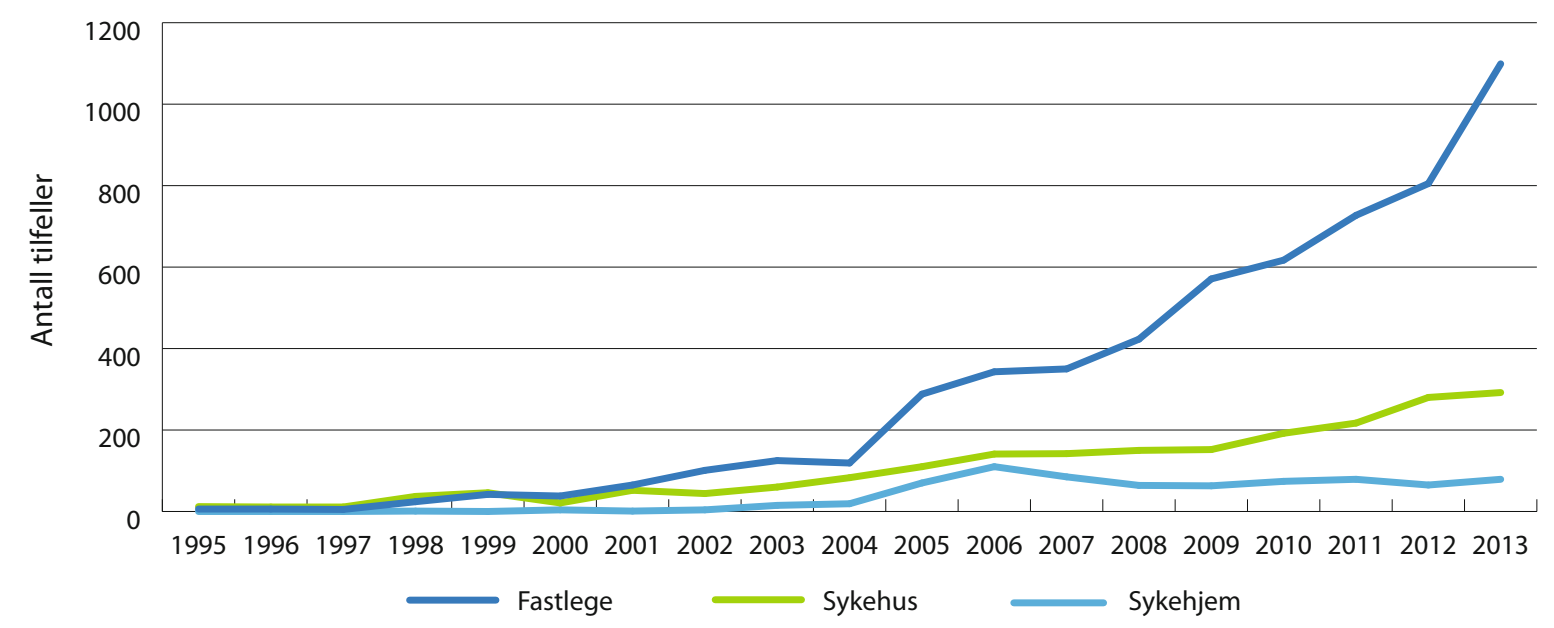

Figur 1: Antall meldte tilfeller av meticillinresistente gule stafylokokker (MRSA) per år, i perioden 1995 - 2013, fordelt på hvor pasientene ble undersøkt. Kilde: Meldingssystem for smittsomme sykdommer (MSIS).

\section{Meticillinresistente gule stafylokokker (MRSA)}

Gule stafylokokokker (Staphylococcus aureus) er bakterier som er vanlige på hud og slimhinner hos mennesker. Mellom 20 og 40 prosent av befolkningen er langvarige, friske bærere, og de fleste av oss kommer i kontakt med gule stafylokokker i løpet av livet. Hos friske personer gir bakteriene sjelden sykdom, men på helseinstitusjoner er S. aureus en av bakterietypene som oftest påvises som årsak til infeksjon.

Meticillinresistente S. aureus (MRSA) skiller seg ikke fra «vanlige» gule stafylokokker når det gjelder smittefare eller evne til å gi sykdom. Men de er resistente mot alle antibiotika som er utviklet fra penicillin, og resistensen gjør det vanskeligere å behandle infeksjoner som skyldes MRSA.

\section{$\emptyset$ kning i meldte tilfeller fra fastleger}

I alt ble det meldt om 1482 tilfeller (infeksjoner og bærerskap) med MRSA i Norge i 2013, se figur 1.

Figuren viser antall meldte MRSA-tilfeller per år, i perioden 1995 - 2013, fordelt på hvor pasientene ble undersøkt:

- Det har kun vært en liten økning i antall tilfeller meldt fra norske sykehus.

- Den største økningen ses i antall tilfeller meldt fra fastlege. Over 40 prosent var smittet i utlandet.

\section{Internasjonalt: Norge har lav forekomst av MRSA}

Norge har en av de lavest registrerte forekomster av MRSA i verden. Ved blodforgiftninger som skyldes gule stafylokokker, er andelen som skyldes MRSA over 20 prosent i de fleste land i Europa, og ofte over 50 prosent $\mathrm{i}$ andre deler av verden. I Norge er andelen fortsatt under én prosent, men forekomsten er økende (EARSS, 2012).

\section{Utfordring å holde kontroll med MRSA i sykehus og sykehjem}

Infeksjoner med MRSA er en særlig trussel for sykehuspasienter, personer med svekket immunforsvar, samt eldre. Disse gruppene er mer utsatte for alvorlige infeksjoner og er avhengige av riktig antibiotikabehandling tidlig i infeksjonsforløpet. Dersom forekomsten av MRSA på helseinstitusjoner øker, kan behandlingen av stafylokokkinfeksjoner bli mindre effektiv og betydelig dyrere.

Om økningen i samfunnet fortsetter og på sikt medfører en høy forekomst av MRSA i befolkningen, er dagens smitteverntiltak ikke hensiktsmessige og nye strategier må utvikles for å hindre at MRSA etablerer seg i sykehus og sykehjem.

\section{Ett utbrudd av MRSA i norsk svineproduksjon} En annen trussel er forekomsten av dyre-assosiert MRSA (LA-MRSA=livestock associated MRSA). I Danmark og andre europeiske land er dette et stort problem i svineproduksjonen. Det har vært ett utbrudd av LA-MRSA i norsk svineproduksjon. Store ressurser og nye overvåkingsprogrammer er satt inn for å hindre videre spredning og etablering av LA-MRSA i Norge.

\section{Vankomycinresistente enterokokker (VRE)}

Enterokokker er bakterier som lever i tarmen. De er vanligvis ikke spesielt aggressive bakterier, men de kan gi alvorlige infeksjoner hos svekkede personer. Enterokokkene har naturlig resistens mot en rekke antibiotika. Dersom det oppstår en infeksjon med vankomycinresistente enterokokker (VRE), blir behandlingen vanskelig fordi det er få alternative legemidler. 
Flere større utbrudd med VRE i sykehus i Norge

Figur 2 viser antall meldte tilfeller av VRE fra 1996 til 2013. Det var få meldte tilfeller fram til 2010. Fra 2010 har Norge hatt flere større utbrudd med VRE i sykehus, og følgelig har det totale antallet VRE-tilfeller økt betydelig. I 2011 ble det meldt om hele 289 tilfeller. I 2013 ble det meldt om 117 tilfeller.

Holdes sykehus med utbrudd utenfor statistikken, er det en liten, men ikke sikker økning i meldte tilfeller av VRE-infeksjoner i Norge.

\section{Strenge smitteverntiltak i sykehus fortsatt nødvendig}

Omfattende tiltak med smitteoppsporing, screening og isolering gjør at VRE-utbruddene i sykehus sannsynligvis kommer under kontroll. Om en kan opprettholde de strenge smitteverntiltakene og fortsatt ha en restriktiv bruk av antibiotika, er det håp om at forekomsten kan holdes på dagens lave nivå.

\section{Bakterier med ESBL-resistens}

ESBL er forkortelse for extendert spektrum betalaktamaser, og er en resistensmekanisme som inaktiverer noen av de viktigste antibiotikatypene vi har for behandling av infeksjoner, særlig infeksjoner som skyldes tarmbakterier som E.coli. Det finnes mange varianter av ESBL-resistensmekanismen.

\section{Økning av blodforgiftninger som skyldes ESBL - produserende bakterier}

Forekomsten av bakterieinfeksjoner som skyldes ESBL- produserende bakterier har økt dramatisk internasjonalt og er også økende i Norge. For eksempel er andelen av E. coli med ESBL i blodforgiftninger de siste 10 årene tidoblet og var i 2013 steget til 5 prosent av alle blodforgiftninger med E.coli i Norge. Dette er alvorlig. De antibiotikatypene man vanligvis bruker til å behandle E.coli-infeksjoner, er ikke effektive mot ESBL-resistente E.coli. I tillegg vil de antibiotikatypene som man må bruke, medføre økt risiko for at enda mer resistente bakterier dukker opp.

Det er kun bakterier med en spesiell variant av ESBL, $\mathrm{ESBL}_{\text {KARBA, }}$ som blir systematisk overvåket i Norge.

Denne formen for ESBL-resistens er den mest omfattende og gir få eller ingen behandlingsmuligheter for rammede pasienter. Overvåkingen startet i 2012, og antall meldte infeksjonstilfeller er svært lavt. I 2013 ble det påvist 24 infeksjoner med slike bakterier. I 2012 var tilsvarende tall 30. Nesten alle var knyttet til pasienter som hadde fått behandling i utlandet.

\section{ESBL er ikke under kontroll internasjonalt}

På verdensbasis er det en dramatisk økning i forekomsten av ESBL, og situasjonen er ute av kontroll. Det er stor risiko for å bli bærer av disse mikrobene ved reiser i Sørøst-Asia og Afrika, men også i Sør-Europa.

Reisevirksomhet er antakelig en viktig årsak til spredningen av disse bakteriene globalt. Det er særlig fryktet at bakterier som har resistensmekanismen ESBLKARBA spres til norsk helsevesen. Disse infeksjonene er meget vanskelige å behandle siden vi ikke har effektive antibiotika. Det er rapportert om stadig flere utbrudd med slike infeksjoner internasjonalt. Dødeligheten er høy (Souli, 2010). Figur 3 viser forekomsten av resistens mot 3. generasjons cefalosporiner i ulike land i Europa. Resistensen er i hovedsak forårsaket av ESBL.

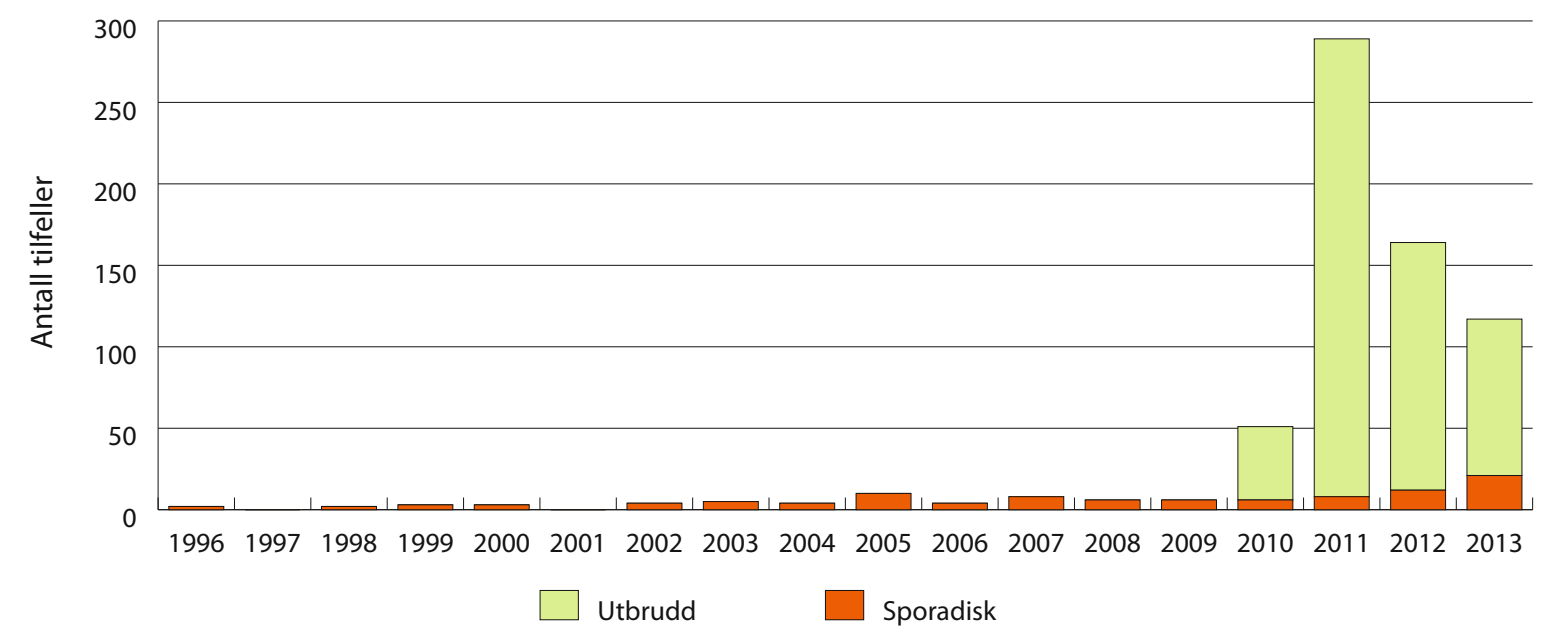

Figur 2. Antall meldte infeksjoner med Vancomycinresistente enterokokker (VRE) per år, i perioden 1996 - 2013, fordelt på utbrudd og sporadisk forekomst. Kilde: Meldingssystem for smittsomme sykdommer (MSIS). 


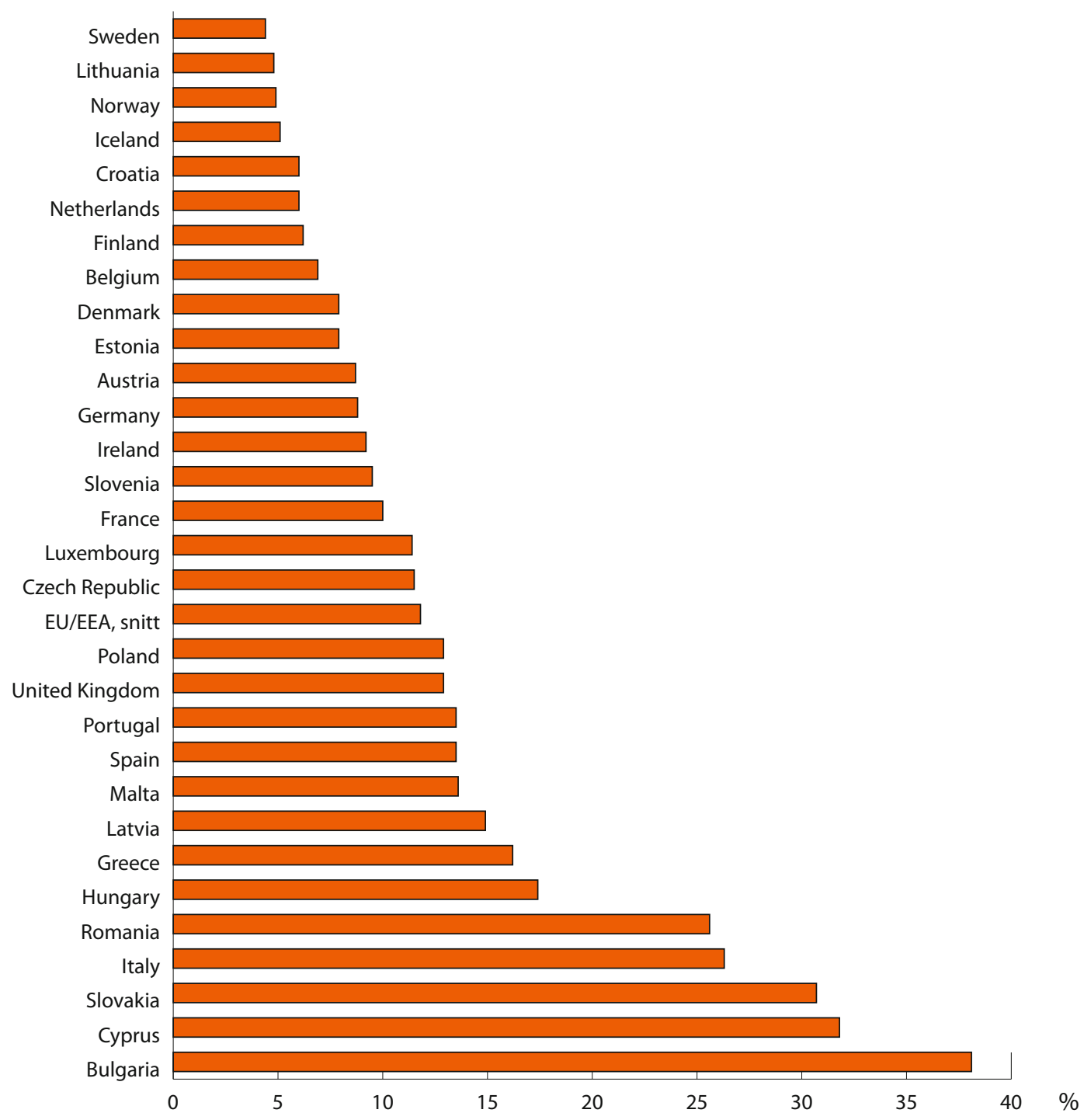

Figur 3. Forekomsten av resistens mot 3. generasjons cefalosporiner i E.coli fra blodkulturer i ulike europeiske land i perioden 2009-2012. Slik resistens er i hovedsak forårsaket av ESBL. Kilde: EARS-Net.

\section{Andre typer antibiotikaresistens} Multiresistent tuberkulose (MDR-TB): I Norge har vi de siste årene behandlet mellom 5 og 8 tilfeller av multiresistent tuberkulose årlig. Ingen tilfeller med multiresistent tuberkulose har så langt oppstått under behandling i Norge.

Internasjonalt er multiresistent tuberkulose et stort og økende problem. Spesielt er problemet stort i land som var en del av det tidligere Sovjetunionen.

For å hindre at tuberkulosebakterien utvikler resistens, er det viktig å behandle pasienten med minst tre medikamenter samtidig. I tillegg må medikamentene tas i en tilstrekkelig lang periode, det vil si 6-12 måneder. WHO anbefaler at tuberkulosemedisiner tas som direkte observert behandling (DOT). Det innebærer at helsepersonell følger opp pasienten gjennom hele behandlingsforløpet, og ser på at pasienten tar medi- sinen sin hver dag. Norge slutter seg til denne anbefalingen, med noen tilpasninger til den enkelte pasient.

Resistens ved gonoré: Forekomsten av gonoré er økende i Norge. I 2013 ble det diagnostisert 506 tilfeller (Folkehelseinstituttet, 2014a).

Bakterien som forårsaker gonoré, Neisseria gonorrhoeae, har vist en forbløffende evne til å utvikle resistens. Det er nå bare noen få behandlingsalternativer tilgjengelige som bakterien ikke er resistent mot eller har nedsatt følsomhet for. I Norge må gonoré i dag behandles med intramuskulær injeksjon med antibiotika.

\section{Virusresistens}

Bare midler mot bakterier går under betegnelsen antibiotika. Men man ser samme type resistensproblemer overfor legemidler mot andre mikrober, slik som midler mot virus (antivirale midler). Det oppstår 
stammer som er motstandsdyktige eller resistente mot disse legemidlene. Dersom resistente virus sprer seg $\mathrm{i}$ befolkningen, innebærer det at virusinfeksjoner kan bli vanskeligere å behandle enn de er i dag.

Eksempler på resistens hos virus er resistens mot influensamiddelet oseltamivir, mot hiv-midler og mot midler som benyttes ved leverbetennelse (virushepatitt).

\section{$\varnothing$ kning i antibiotikaresistens internasjonalt}

Internasjonalt har det vært økende rapportering av tilfeller der pasienter har en infeksjon med bakterier som er motstandsdyktige mot alle tilgjengelige antibiotika. Dette gjelder også i Europa. Det fryktes at slike bakterier skal få fotfeste, særlig i helsetjenesten.

Selv om det har vært en økning i infeksjoner med antibiotika-resistente bakterier i Norge de siste årene, er problemet foreløpig betydelig mindre enn i de fleste andre land, se tall i avsnittene om MRSA, VRE og ESBL.

\section{Forebygging av antibiotikaresistens}

Den viktigste årsaken til antibiotikaresistens er bruk av antibiotika hos dyr og mennesker. Når resistente bakterier har oppstått, vil videre spredning skje:

- Gjennom kontakt mellom mennesker.

- Gjennom kontakt mellom mennesker og dyr.

- Fra vann, mat og miljøet for øvrig til mennesker.
- Ved internasjonal reisevirksomhet og internasjonal handel med matvarer. Dette bidrar til spredning av antibiotikaresistente bakterier fra land med høy forekomst, til land med lav forekomst.

Antibiotikaresistens er et globalt problem, og det er behov for internasjonalt samarbeid hvis verdenssamfunnet skal kunne møte utfordringen. Viktige forebyggende tiltak er å:

- Redusere antibiotikaforbruket både hos dyr og mennesker.

- Velge smalspektrede framfor bredspektrede antibiotika.

- Begrense spredning av antibiotikaresistente bakterier.

- Begrense forurensning av miljøet med antibiotika.

- Utvikle nye antibiotika.

- Overvåke antibiotikaresistens nasjonalt og internasjonalt.

Nedenfor utdypes disse punktene.

\section{Redusere antibiotikaforbruket}

I Norge ble det i 2012 brukt knapt 51,9 tonn antibiotika til mennesker, 6,2 tonn til husdyr og 1,7 tonn til fiskeoppdrett. Bruk av antibiotika har økt gradvis over tid. Nesten 90 prosent av all antibiotikabruk hos mennesker skjer i dag utenfor sykehus og sykehjem (NORM/MORM-VET 2012).

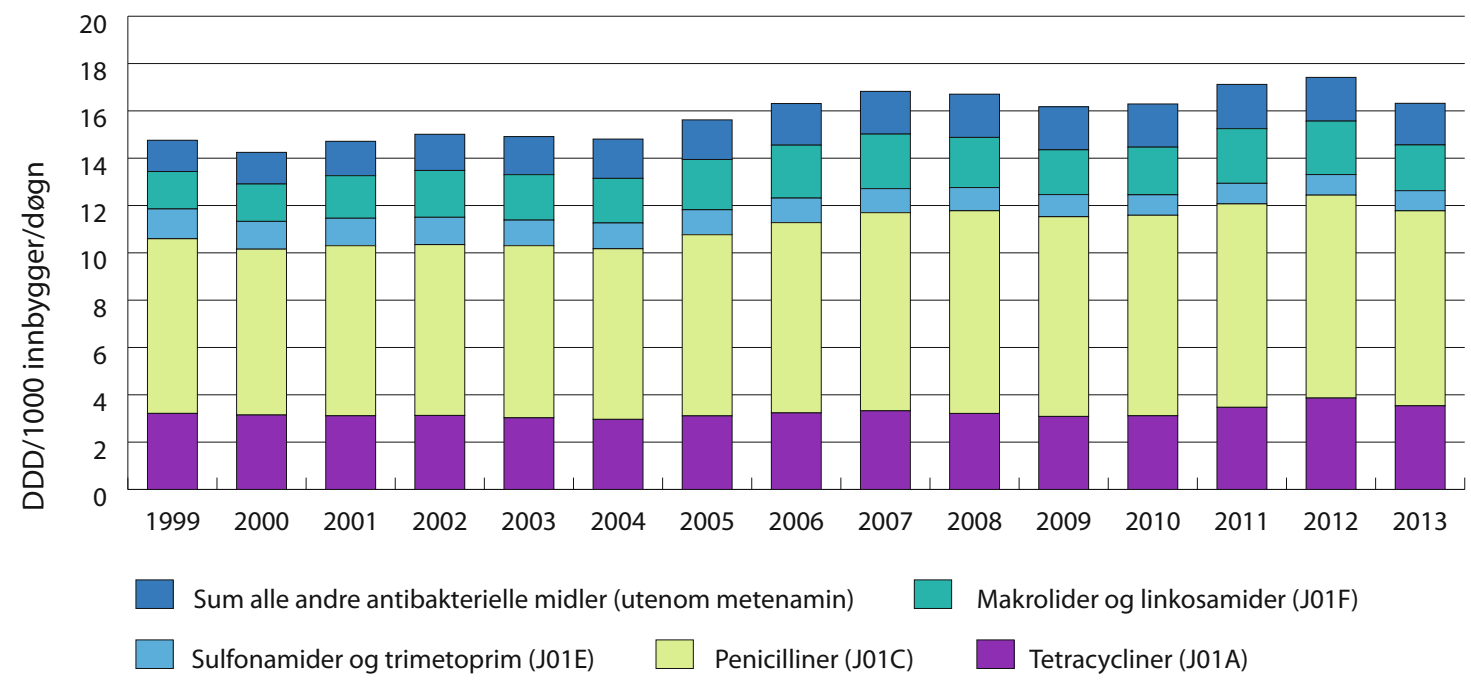

Figur 4. Bruk av antibakterielle midler i Norge i perioden 1999-2013 målt i definerte døgndoser (DDD) per 1000 innbyggere per døgn. Kilde: Folkehelseinstituttet, Legemiddelforbruk i Norge. 
Antibiotikabruken i landbruket er et viktig bidrag til det samlede forbruket globalt. Norsk landbruk har et lavt forbruk sammenliknet med andre land. Særlig nedgangen i forbruk av antibiotika i fiskeoppdrett fra 48 tonn i 1987 til 1,6 tonn i 2012 er et eksempel på en positiv utvikling.

\section{Bruke smalspektrede i stedet for bredsprektrede antibiotika}

Smalspektrede antibiotika påvirker færre bakterietyper og forårsaker dermed mer begrenset resistensutvikling.

Forbruket av antibiotika i Norge har en gunstig sammensetning, med størst forbruk av smalspektret penicillin. Økningen i antibiotikaforbruket fra 2004 til 2013 skyldes i hovedsak økt bruk av penicilliner som er smalspektrede, se figur 4.

\section{Begrense forurensning av miljø og spredning av resistente bakterier} Antibiotikaforbruket i matproduksjonen gir grunn til bekymring, fordi spredning av resistente mikrober til miljøet er svært uønsket, og spredning til mennesker kan forekomme. Særlig er forekomsten av LA-MRSA i husdyr et problem. Vi har allerede hatt utbrudd i dyrebesetninger i Norge, men dette er et mye større problem i andre europeiske land. Det er også påvist E. coli-bakterier med ESBL og resistens mot kinolonantibiotika i norsk kylling (NORM/NORM-VET, 2012).

Reisevirksomhet: Spredning av antibiotikaresistens fra land og områder med høy forekomst av resistens til områder med lav forekomst, kan knyttes til reisevirksomhet (Tängdén, 2010). I områdene med høy forekomst er miljøet forurenset med resistente bakterier. Det kan være svært vanskelig å unngå å få i seg disse gjennom for eksempel mat (Tängdén, 2010).

Det er også en risiko for å bli smittet med antibiotikaresistente bakterier hvis man legges inn eller behandles i helseinstitusjoner i områder med høy forekomst av resistens. Dette gjelder både ESBL-holdige tarmbakterier, MRSA og VRE.

\section{Utvikling av nye antibiotika har stoppet opp}

Kombinasjonen av økende forekomst av resistens og stopp i utvikling av nye antibiotika er årsaken til at WHO og andre internasjonale organer (ECDC) mener at antibiotikaresistens er en alvorlig trussel for framtidig medisinsk behandling. Utviklingen av nye antibiotikaklasser har de siste 30 årene stoppet opp, og kun noen få nye antibiotika er kommet på markedet.

\section{Utfordring i behandling av pasienter}

Allerede i dag innebærer en infeksjon med resistente bakterier at det tar lengre tid for den enkelte pasient å bli frisk. Dette kan medføre forlenget opphold i sykehus, og behandling med dyrere medikamenter enn vanlig. I verste fall risikerer pasienten å få en infeksjon som skyldes en bakterie som er motstandsdyktig mot alle tilgjengelige antibiotika.

I Norge har vi så langt kunnet kontrollere forekomsten av antibiotikaresistens ved iherdige og omfattende smitteverntiltak i helseinstitusjoner, men smittepresset kan etter hvert blir så stort at tiltakene ikke lenger er effektive.

\section{Overvåking av antibiotikaresistens i Norge}

Overvåking av antibiotikaresistens hos mikrober er nødvendig dersom helsetjenesten også i fremtiden skal kunne levere medisinsk behandling på en trygg måte. I Norge overvåkes antibiotikaresistens på flere måter:

- Norsk overvåkingssystem for antibiotikaresistens hos mikrober (NORM) er et nasjonalt helseregister som overvåker resistens mot antibiotika i bakterier hos syke. Registeret overvåker resistens hos de viktigste sykdomsfremkallende bakteriene hos mennesker. I tillegg er det en begrenset overvåking av resistens hos Neisseria gonorrhoeae.

- Norsk overvåkingssystem for antibiotikaresistens hos mikrober - veterinærmedisin (NORM-VET) overvåker forekomsten av antibiotikaresistens blant bakterier fra dyr, fôr og næringsmidler i Norge. NORM og NORM-VET samarbeider nært og lager en felles årsrapport (NORM-VET).

- Meldingssystem for smittsomme sykdommer (MSIS) overvåker ulike infeksjoner og bærerskap forårsaket av resistente mikrober. Dette inkluderer bærertilstand eller infeksjoner med MRSA, penicillinresistente pneumokokker,VRE og mikrober med spesielle resistensmønstre.

\section{Referanser}

EARS-net. Antimicrobial resistance surveillance in Europe 2012. Stockholm: European Antimicrobial Resistance Surveillance Network EARSS-Net; 2012

ECDC. Annual Epidemiological Report 2013; 2.6 Antimicrobial-resistant pathogens and healthcare-associated infections. Sweden: European Centre for Disease Prevention and Control (ECDC); 2013.

Folkehelseinstituttet. Gonoré og syfilis i Norge i 2013. Oslo: Folkehelseinstituttet; 2014a. 
Folkehelseinstituttet: S Sakshaug, H Strøm, C Berg et al. Legemiddelforbruket i Norge 2009-2013. Oslo: Folkehelseinstituttet; 2014b, rapport: 2014:1.

Folkehelseinstituttet/MSIS. 2014. MSIS-statistikk. [hentet 20/6/2014].

NORM/NORM-VET. Usage of Antimicrobial Agents and Occurrence of Antimicrobial Resistance in Norway. Tromsø/Oslo: Norsk overvåkingssystem for antibiotikaresistens hos mikrober (NORM) og Norsk overvåkingsprogram for antibiotikaresistens i mikrober fra fôr, dyr og næringsmidler (NORM-VET); 2012.

Souli, M, Galani, I, Antoniadou, A, Papadomichelakis, E, Poulakou, G et al. An Outbreak of Infection due to $\beta$-Lactamase Klebsiella pneumoniae Carbapenemase 2Producing K. pneumoniae in a Greek University Hospital: Molecular Characterization, Epidemiology, and Outcomes. Clin Infect Dis 2010; 50(3): 364-73.
Tängdén, T, Cars, O, Melhus, Å \& Löwdin, E. Foreign Travel Is a Major Risk Factor for Colonization with Escherichia coli Producing CTX-M-Type Extended-Spectrum $\beta$-Lactamases: a Prospective Study with Swedish Volunteers. Antimicrob Agents Chemother 2010; 54(9): 3564-68.

WHO. The evolving threat of antimicrobial resistance Options for action. Geneva, Switzerland: World Health Organization; 2012.

http://www.fhi.no/artikler/?id=111478

\section{FORFATTER}

Jørgen Bjørnholt, Oliver Kacelnik, Petter Elstrøm og Siri Seterelv 


\section{Astma og allergi}

- Astma og allergi er en hyppig årsak til plager hos barn og unge i industrialiserte land.

- Flere gutter enn jenter har astma og allergi før puberteten.

- Vi vet lite om årsakene til astma og allergi.

- Det er per i dag ingen kjente tiltak som kan forebygge utvikling av astma og allergi hos dem som er friske.

- Luftveisinfeksjoner, allergener og miljøfaktorer som blant annet sigarettrøyk, svevestøv og eksos, samt kjemikalier fra forbrukerprodukter kan forverre symptomene hos de som allerede er syke.

\section{Om astma og allergi}

\section{Astma}

Astma er en kronisk betennelses- eller irritasjonstilstand i luftveiene som kan utløses av ulike faktorer (f.eks. allergener, luftveisinfeksjoner, anstrengelse, luftforurensning). Dette kan gi symptomer som gjentatte episoder med hoste, tetthet i brystet, tung pust eller surkling, særlig om natten eller tidlig om morgenen. Mellom episoder med forverring kan pusten være normal. Det er flere forskjellige typer astma som allergisk og ikke-allergisk, anstrengelsesutløst eller yrkesrelatert astma.

\section{Allergi}

Allergi skyldes en overreaksjon av immunsystemet ved kontakt med ulike proteiner, metaller og kjemikalier. Det finnes mange typer allergi, og de vanligste er høysnue (rinitt), atopisk eksem, allergisk kontakteksem og matallergi.

\section{Høysnue}

Symptomene på høysnue er rennende og kløende nese og øyne. Nedsatt konsentrasjonsevne, tretthet og slapphet kan også forekomme. De fleste med høysnue reagerer på allergener i husstøv, kjæledyr og pollen, samt muggsoppsporer hvis luftfuktigheten er høy.

\section{Atopisk eksem}

Atopisk eksem (ofte kalt barneeksem) er en sykdom med kløende hudutslett som gjerne opptrer i tidlig barndom. De fleste av barna med atopisk eksem blir kvitt eksemet før tenårene. Det er uklart hva som er utløsende årsaker, men barn med allergiske og astmatiske foreldre har en økt risiko for å utvikle atopisk eksem.

\section{Allergisk kontakteksem og elveblest}

Allergisk kontakteksem opptrer ofte som røde og kløende utslett som oppstår noen timer etter kontakt med et allergen. I enkelte tilfeller oppstår kontakteksem kun etter at huden har blitt utsatt for sollys. Dette kalles fotoallergi. Elveblest (urtikaria) opptrer raskt etter eksponering og er karakterisert ved lokale hevelser, rødhet og kløende følelser i huden etter direkte kontakt med et allergifremkallende stoff. Det vanligste kontaktallergenet hos barn og voksne er nikkel, men en rekke konserveringsmidler og duftstoffer er også viktige allergener. Proteiner fra matvarer kan også forårsake allergiske reaksjoner i huden.

\section{Matallergi}

Matallergi er en immunologisk betinget reaksjon og avgrenses til reaksjoner på mat som kan påvises ved spesifikke lgE-antistoffer i blodprøver (serum). Matallergi er forårsaket av proteiner i mat, og gir vanligvis reaksjoner raskt. Det er vanlig at symptomene også kan komme fra andre organer enn mage-tarmsystemet, for eksempel huden, luftveiene og hjerte- og karsystemet.

De vanligste alvorlige reaksjonene hos barn er mot egg, hasselnøtt, peanøtt og melk. De fleste barna vokser av seg egg- og melkeallergi før skolealder. Allergi mot nøtter, og særlig peanøtter, varer ofte livet ut. Hos voksne er det reaksjoner mot hasselnøtter, 
peanøtter og hvete som er vanligst, mens reaksjoner mot fisk sjelden rapporteres.

\section{Forekomst av astma og allergi}

Det finnes ingen landsdekkende undersøkelser i Norge på antall personer med astma og allergi, kun studier som dekker mindre geografiske områder. Ulike diagnosekriterier og forskjell i metoder for innsamling av data gjør det vanskelig å sammenligne studier og å finne sikre tall for hvor stor andel av befolkningen som har de ulike sykdommene. Tall fra norske undersøkelser baserer seg også i stor grad på spørreskjema og må tolkes med forsiktighet.

Basert på ulike undersøkelser ser det ut til å være en høy forekomst av astma og allergiske sykdommer i befolkningen, og antallet tilfeller ser ut til å ha økt de siste 20-30 årene.

\section{Astma}

\section{Astma hos barn}

Resultater fra en tverrsnittsundersøkelse blant barn i alderen 7-14 år fra Nordland viste at forekomsten av selvrapportert astma var 18 prosent i 2008 (Hansen, 2013). Dette samsvarer med resultater fra en undersøkelse blant barn i Oslo i 2003 der forekomsten ble målt til 20 prosent blant tiåringer (Lødrup Carlsen, 2006). Forekomst er i begge undersøkelsene beregnet ut fra om barnet noen gang har hatt astma.
Hos barn i førskolealder har mange forbigående astmalignende symptomer, men utvikler ikke astma. Denne trenden underbygges av reduksjonen man ser i bruken av astmamedisin hos barn etter førskolealder, se figur 1. Diagnostiseringen kan gjøres med større sikkerhet fra omtrent fem års alder.

Av de som får astma, vil omtrent tre av fire ha utviklet sykdommen før skolealder. En stor andel av disse blir fri for symptomer i løpet av skolealderen, men nye tilfeller dukker opp i løpet av barne- og ungdomsårene, og $\mathrm{i}$ voksen alder.

\section{Astma hos voksne}

I behandling av astma har bruken av bronkieutvidende midler og betennelsesdempende midler en sentral plass. Bruk av astmalegemidler kan reflektere andelen av befolkningen som har aktiv astma og som har behov for behandling. Tall fra Reseptregisteret er de beste tallene vi har om forekomsten av astma hos voksne. Bruken av legemidler er relativt stabil fram til 30 års alderen der en ser en liten økning for begge kjønn.

Figur 1 viser andelen av befolkningen som fikk legemidler for astma og astmalignende symptomer i 2005 og 2013. Fra 40-50 års alder brukes disse legemidlene også i behandling av KOLS og vil derfor ikke reflektere behandling av astma.

Det er også vist at toppidrettsutøvere som driver utholdenhetsidretter som ski og svømming har en økt forekomst av astmalignende symptomer og plager.

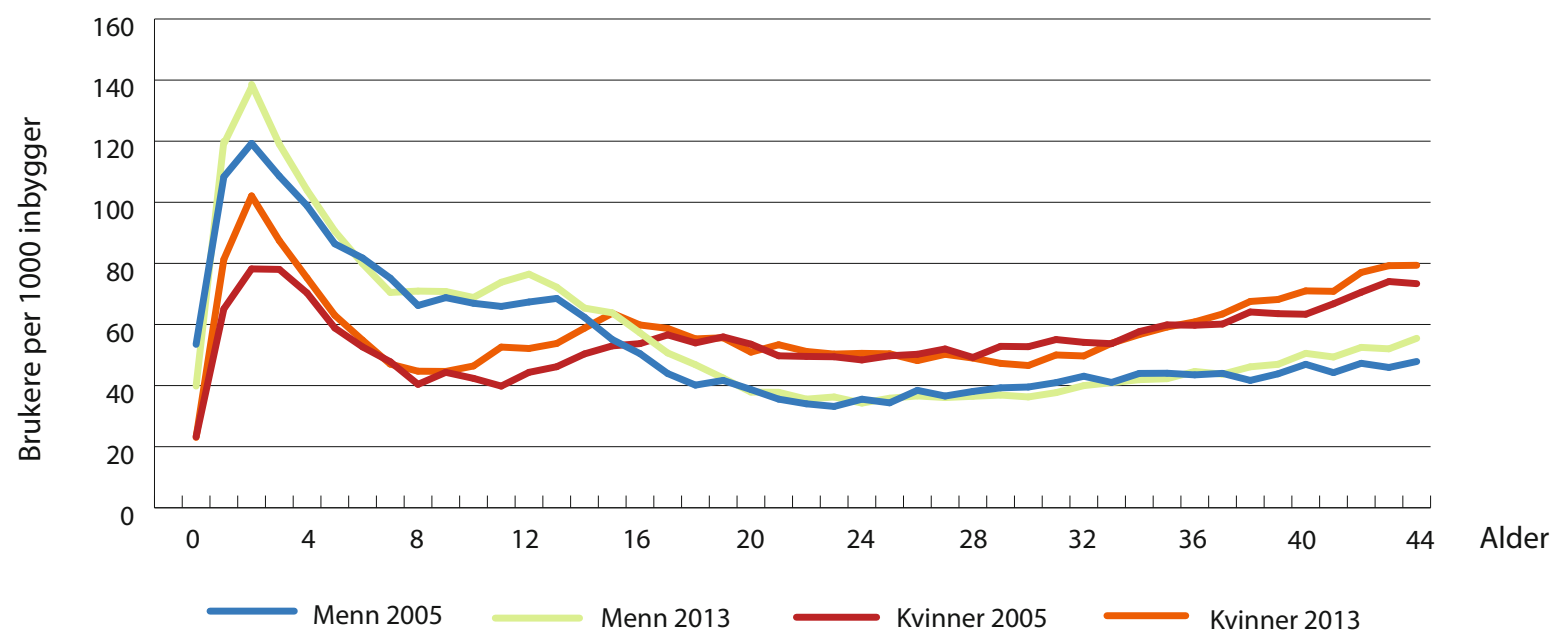

Figur 1: Brukere av astmalegemidler i 2005 og 2013 per 1000 innbyggere, 0-44 år. Legemiddelbrukere er personer som henter minst ett av legemidlene på resept på apotek i løpet av året. Astmalegemidler inkluderer kortikosteroider til inhalasjon, kort- og langtidsvirkende beta2-agonister til inhalasjon, kombinasjonspreparater med kortikosteroider og beta2-agonister til inhalasjon, og leukotriene reseptor antagonister. Kilde: Reseptregisteret. 


\section{Allergi}

Mange barn og unge har høysnue og atopisk eksem Flere norske studier finner at livstidsforekomsten av høysnue (rinitt) ligger på omtrent 25 prosent hos barn i skolealder og 30 prosent hos unge i puberteten (Selnes, 2005; Hansen, 2013; Hovland, 2014). Når det gjelder voksne, er det rapportert om en forekomst på 23 prosent for Vest-Europa (Bauchau, 2004).

Forekomsten av atopisk eksem er 17 prosent hos 2 år gamle barn, og mellom 21 og 33 prosent hos barn i alderen 9-11 år. Dette viser tall fra norske studier i perioden 2000-2009 (Selnes, 2005; Smidesang, 2009; Hovland, 2014). Tilsvarende tall er rapportert fra studier i Sverige og Danmark (Mortz, 2001; Rönmark, 2009).

\section{Én av fem voksne har allergisk kontakteksem} Forekomsten av allergisk kontakteksem varierer både over tid og mellom ulike land. Dette skyldes forskjellig bruksmønster av produkter, samt nasjonale reguleringer for bruk av kjemikalier. I en oversiktsartikkel fra 2001, der studier fra land i Europa, Nord-Amerika og Asia inngikk, ble det rapportert om en forekomst på 7 prosent for allergisk kontakteksem hos 12-16 år gamle barn (Simonsen, 2011). For voksne i Skandinavia (årene 1966-2007) er tilsvarende forekomst på 21 prosent (Thyssen, 2007).

Enkelte yrkesgrupper er spesielt utsatt med tanke på utvikling av hudallergi. Dette gjelder yrker hvor man utfører hyppig håndvask og hvor man arbeider med hudirriterende og allergifremkallende stoffer, for eksempel gummikjemikalier, duftstoffer, konserveringsmidler, hårfarge og metaller.

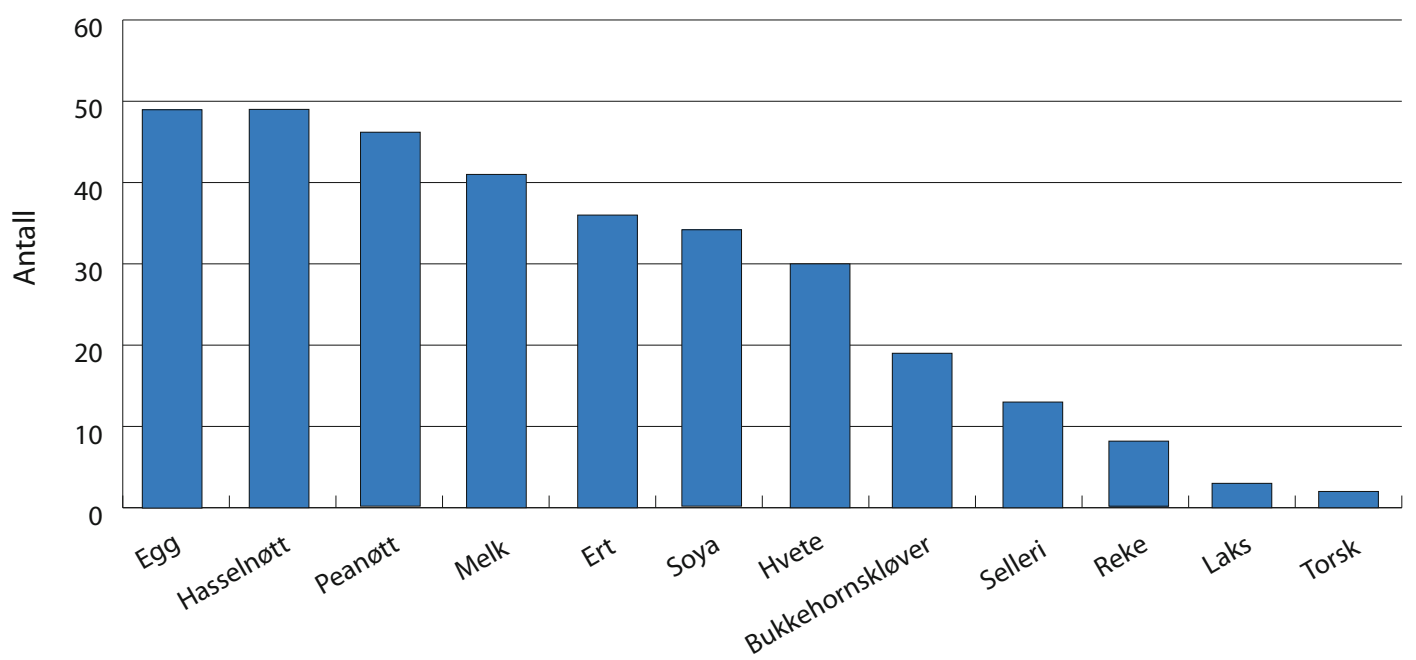

Figur 2a: Matvarer som oftest gir positiv allergitest (spesifikt lgE i serum) i aldersgruppene 0-5 år. Funnene er i samsvar med det som er rapportert for Europa og USA. Kilde: Matallergiregisteret.

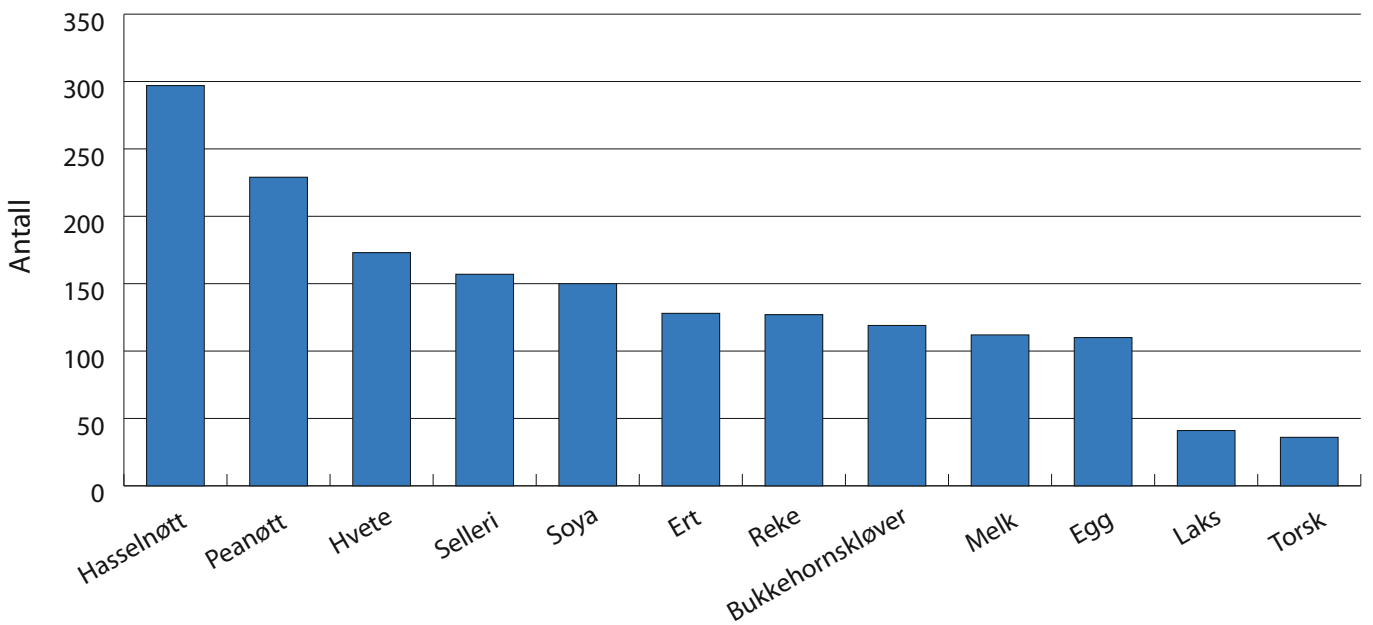

Figur 2b: Matvarer som oftest gir positiv allergitest (spesifikt lgE i serum) i aldersgruppen 6-80 år. Funnene er i samsvar med det som er rapportert for Europa og USA. Kilde: Matallergiregisteret. 
Seks til åtte prosent av barn har symptomer på matallergi

Rapporter fra Europa og USA viser at 6-8 prosent av små barn og 3-4 prosent av voksne har symptomer på matallergi og samtidig positiv allergitest (spesifikt lgE i serum) (Gupta, 2007; Sicherer, 2010; Allen, 2012). Imidlertid er det mange flere som reagerer allergisk på en eller flere matvarer enn det man er i stand til å påvise med de metodene man har tilgjengelig (Sampson , 2005; Ben-Shoshan, 2010).

Figurene $2 \mathrm{a}$ og $2 \mathrm{~b}$ viser matvarer som oftest gir positiv allergitest hos barn under fem år og hos personer mellom 6 og 80 år. Tallene er basert på frivillig innsendte meldinger til Nasjonalt register for alvorlige reaksjoner på mat i 2000 til 2013. Matallergiregisteret mottar mellom 80 og 100 meldinger med blodprøve per år, men man vet ikke om disse tallene er representative for den norske befolkningen (Namork, 2011; Matallergiregisteret).

\section{Mange har både astma og allergi}

Det er en stor grad av samsykelighet mellom astma og allergiske sykdommer. I en norsk studie av 10-åringer hadde hele 87 prosent av barna med høysnue (rinitt) også astma, atopisk eksem eller konjunktivitt (kløende/ rennende øyne), mens 12 prosent av barna hadde alle disse sykdommene (Bertelsen, 2010). I en svensk studie var høysnue forbundet med astma og/eller eksem hos 33 prosent av 12 år gamle barn (Ballardini, 2012). Videre fant de at astma var forbundet med eksem og/eller høysnue blant 67 prosent av barna (Ballardini, 2012).

I en stor europeisk studie fant man at den relative risikoen for samsykelighet ved åtte års alder var på 63 prosent dersom barnet også hadde astma, høysnue og eksem ved fire års alder (Pinart, 2014). Dette tyder på at barn med to eller flere sykdommer i tidlig barndom har økt risiko for fortsatt samsykelighet senere i barndommen.

\section{Utvikling over tid og inter- nasjonal sammenlikning}

Omfanget av astma har økt i Norge. En studie blant barn i alderen 7-14 år fra Nordland viste at forekomsten av selvrapportert astma økte fra 7 til 18 prosent i perioden 1985 til 2008 (Hansen, 2013). I undersøkelsen er forekomsten beregnet ut fra om barnet noen gang har hatt astma. I sterk kontrast til dette viser tall fra samme tidsperiode for andre vestlige land som for eksempel Tyskland, Sverige og USA at forekomsten er i ferd med å stabilisere seg, og i enkelte land går den også ned (Zøllner, 2005; Akinbamia, 2009; Bjerg, 2010).
Resultater fra en undersøkelse i Nord-Norge viser en økning i forekomsten av høysnue fra 17 til 30 prosent i perioden 1985 - 2000, og i forekomsten av atopisk eksem fra 13 til 21 prosent i perioden 1985 - 1995 (Selnes, 2005). Det var ingen ytterligere økning i forekomsten av atopisk eksem fram til år 2000 (Selnes, 2005). Det er vanskelig å avgjøre om disse trendene er landsomfattende da tallene er basert på kun én studie.

Det er store internasjonale forskjeller i forekomsten av høysnue og atopisk eksem blant barn og unge i alderen 6-7 år og 12-13 år (Asher, 2006). Det viser resultater fra ISAAC-studien som inkluderer mange regioner i store deler av verden. Den ble gjennomført i 19921998 og gjentatt i 1999-2004. I løpet av perioden mellom første og andre undersøkelse i ISAAC-studien ble det funnet en svak økning i forekomsten av høysnue på verdensbasis (Asher, 2006). Flere av områdene med høy forekomst ved første undersøkelse hadde imidlertid en lavere forekomst ved neste undersøkelse. For aldersgruppene 6-7 og 12-13 år var det en økning i forekomsten av atopisk eksem ved henholdsvis 84 og 59 prosent av studiesentrene.

Flere rapporter viser til en økende forekomst av matallergi i Europa, men god dokumentasjon mangler (Moneret-Vautrin, 2004; Burney, 2014).

$\varnothing \mathrm{kt}$ forekomst av pollenallergi i Europa og spesielt Skandinavia, vil på grunn av klimaendringer kunne forventes å gi en følgende økning i både høysnue og pollen-relatert matallergi (såkalte kryssreaksjoner) (Eriksson, 2004; Madsen, 2005; Signs of climate change in Nordic Nature, 2009; D’Amato, 2013). Årsaken til kryssreaksjoner er at allergenene i pollen ligner på proteinene i maten.

\section{Forskjeller i befolkningen}

\section{Forekomst endrer seg i puberteten}

Gutter har høyere forekomst av astma og allergi enn jenter fram til puberteten. Etter puberteten øker forekomsten blant jentene mer enn hos guttene. Årsakene til kjønnsforskjellene er usikre, men hormonelle endringer i puberteten og forskjeller i miljøeksponeringer kan ha betydning (Almqvist, 2008; Chen, 2008).

Det er ingen tydelige alders- eller kjønnsforskjeller i forekomsten av allergisk kontakteksem.

\section{Sosioøkonomiske forskjeller}

Publisert litteratur tyder på at det er en høyere forekomst av astma blant personer med lav sosioøkonomisk status (Almqvist, 2005; Hammer-Helmich, 2014). 
Det ser også ut til å være en tilsvarende sammenheng mellom økt alvorlighetsgrad av astma og sosioøkonomisk status (Lang, 2010; Trupin, 2013). Resultatene er imidlertid ikke helt entydige da effekten av sosioøkonomisk status på utvikling av astma ser ut til å kunne variere med alder på barnet (Hafkamp-de Groen, 2012).

Sammenhengen mellom sosioøkonomisk status og allergiske sykdommer er usikker, ulike undersøkelser peker i ulike retninger (Almqvist, 2005; du Prel 2006; Kotz, 2011; Hammer-Helmich, 2014). Årsaken til de motstridende funnene er uviss, men kan ha sammenheng med ulik metode for innhenting av data, ulik definisjon av sosioøkonomisk status eller ulike diagnosekriterier.

\section{Geografiske forskjeller}

Vi har manglende kunnskap om regionale forskjeller i forekomsten av astma og allergi i Norge. En studie av skolebarn bosatt i Oslo, Øvre Hallingdal og Odda i 1997 viste imidlertid at det var liten forskjell i forekomsten av astma, høysnue og eksem (Nystad, 1997).

\section{Risikofaktorer og muligheter for forebygging}

Årsakene til astma og allergiske sykdommer er for det meste ukjente. Derfor finnes det heller ikke forebyggende tiltak for utvikling av disse sykdommene.

Arvelig disposisjon er en viktig faktor. Resultater fra tvillingstudier har vist at 65-67 prosent av variasjonen i tendens til å få astma i stor grad kan tilskrives arv (Nystad, 2005).

Miljøfaktorer kan ha betydning for astma og allergiske sykdommer. Endret mikrobiologisk mangfold (bakteriell sammensetning i kroppen), luftveisinfeksjoner tidlig i livet og eksponering for allergener og miljøkjemikalier er nevnt som mulige årsaker til sykdomsutvikling og/eller forverring av sykdom. Andre mulige risikofaktorer er overvekt og inaktivitet.

\section{Forebygging av plager hos de som er syke}

Det er viktig å skille mellom faktorer som kan påvirke utviklingen av sykdom blant de som i utgangspunktet ikke har astma eller allergi, og faktorer som kan gi økte plager hos personer som er rammet.
De som allerede har utviklet sykdom bør:

- unngå eksponering for det de er allergiske mot

- unngå eller redusere eksponeringen for faktorer som kan forverre symptomene, slik som infeksjoner, allergener, luftforurensning (røyk, svevestøv, eksos) og miljøkjemikalier

\section{Referanser}

Akinbami LJ, Moorman JE, Garbe PL, Sondik EJ. Status of childhood asthma in the United States, 1980-2007.Pediatrics 2009;123 Suppl 3:S131-45.

Allen KJ, Koplin JJ. The epidemiology of IgE-mediated food allergy and anaphylaxis, Immunol Allergy Clin North Am. 2012; 32: 35-50.

Almqvist C, Pershagen G, Wickman M. Low socioeconomic status as a risk factor for asthma, rhinitis and sensitization at 4 years in a birth cohort. Clin Exp Allergy 2005;35:612-8.

Almqvist C, Worm M, Leynaert B; working group of GA2LEN WP 2.5 Gender. Impact of gender on asthma in childhood and adolescence: a GA2LEN review. Allergy 2008;63:47-57.

Asher MI, Montefort S, Björkstén B, Lai CKW, Strachan DP, Weiland SK, Williams $\mathrm{H}$, and the ISAAC Phase Three Study Group. Worldwide time trends in the prevalence of symptoms of asthma, allergic rhinoconjunctivitis, and eczema in childhood: ISAAC Phases One and Three repeat multicountry cross-sectional surveys. Lancet 2006; 368: 733-43.

Ballardini N, Kull I, Lind T, HAllner E, Almqvist C, Östblom E, Melén E, Pershagen G, Lilja G, Bergström A, Wickman M. Development and comorbidity of eczema, asthma and rhinits to age 12 - data from the BAMSE birth cohort. Allergy 2012;67:537-544.

Bauchau V, Durham SR. Prevalence and rate of diagnosis of allergic rhinitis in Europe. Eur Respir J 2004;24:758-764.

Ben-Shoshan M, Harrington DW, Soller L, Fragapane J, Joseph L, St Pierre Y, Godefroy SB, Elliot SJ, Clarke AE. A population-based study on peanut, tre-nut, fish, shellfish, and sesame allergy prevalence in Canada. J Allergy Clin Immunol 2010;125:1327-1335.

Bertelsen RJ, Lødrup Carlsen KC, Carlsen K-H. Rhinitis in children: Co-morbidities and phenotypes. Pediatr Allergy Immunol 2010;21:612-622.

Bjerg A, Sandström T, Lundbäck B, Rönmark E. Time trends in asthma and wheeze in Swedish children 1996-2006: prevalence and risk factors by sex. Allergy 2010;65:48-55.

Burney PG, Potts J, Kummeling I, Mills EN, Clausen M, Dubakiene R, Barreales L, Fernandez-Perez C, FernandezRivas M, Le TM, Knulst AC, Kowalski ML, Lidholm J, BallmerWeber BK, Braun-Fahlander C, Mustakov T, Kralimarkova T, Popov T, Sakellariou A, Papadopoulos NG, Versteeg SA, Zuidmeer L, Akkerdaas JH, Hoffmann-Sommergruber K, van Ree R. The prevalence and distribution of food sensitization in European adults. Allergy 2014;69:365-71.

Chen W, Mempel M, Schober W, Behrendt H, Ring J. Gender difference, sex hormones, and immediate type hypersensitivity reactions. Allergy 2008;63:1418-1427. 
D’Amato G, Baena-Cagnani CE, Cecchi L, Annesi-Maesano I, Nunes $C$ et al. Climate change, air pollution and extreme events leading to increasing prevalence of allergic respiratory diseases. Multidiscip Respir Med. 2013 Feb 11;8(1):12. doi: 10.1186/2049-6958-8-12.

du Prel X Krämer U, Behrendt H, Ring J, Oppermann $\mathrm{H}$, Schikowski T, Ranft U. Preschool children's health and its association with parental education and individual living conditions in East and West Germany. BMC Public Health 2006;6:312.

Eriksson NE, Moller C, Werner S, Magnusson J, Bengtsson $\mathrm{U}$, Zolubas M. Self-reported food hypersensitivity in Sweden, Denmark, Estonia, Lithuania, and Russia. J. Investig. Allergol. Clin. Immunol 2004;14:70-79.

Gupta R, Sheikh A, Strachan DP, Anderson HR. Time trends in allergic disorders in the UK. Thorax 2007; 62: 91-96.

Hammer-Helmich L, Linneberg A, Thomsen SF, Glümer C. Association between parental socioeconomic position and prevalence of asthma, atopic eczema and hay fever in children. Scand J Public Health 2014;42:120-7.

Hansen, R E, Evjenth B, Holt J. Increasing prevalence of asthma, allergic rhinoconjunctivitis and ezcema among school children: three surveys during the period 19852008. Acta Pædiatrica 2013;102:47-52.

Hovland V., A. Riiser, P. Mowinckel, K.H. Carlsen, K.C.L. Carlsen. Asthma with allergic comorbidities in adolescence is associated with bronchial responsiveness and airways inflammation, Pediatr Allergy Immunol, Pediatr Allergy Immunol. 2014;25:351-9.

Hafkamp-de Groen E, van Rossem L, de Jongste J, Mohangoo AD, Moll HA et al. The role of prenatal, perinatal and postnatal factors in the explanation of socioeconomic inequalities in preschool asthma symptoms: the Generation R Study. J Epidemiol Community Helath 2012;66: 1017-24.

Kotz D, Simpson CR, Sheikh A. Incidence, prevalence, and trends of general practitioner-recorded diagnosis of peanut allergy in England, 2001 to 2005. J Allergy Clin Immunol 2011 Mar;127:623-30.

Lang AM, Konradsen J, Carlsen KH, Sachs-Olsen C, Mowinckel $P$ et al. Identifying problematic severe asthma in the individual child--does lung function matter? Pediatr Allergy Immunol 2010;21:945-53.

Lødrup Carlsen KH, Håland G, Devulapalli CS, MuntheKaas $M$, Pettersen $M$ et al. Astmha in every fifth child in Oslo, Norway: a 10-year follow-up of a birth study. Allergy 2006;61:454-60.

Madsen C. Prevalence of food allergy: An overview. Proc. Nutr. Soc. 2005;64:413-417.

Moneret-Vautrin DA, Kanny G, Morisset, M, Rancè F, Beaudouin E. Severe food anaphylaxis:107 cases registered in 2002 by the Allergy Vigilance Network. Eur Ann Allergy Clin Immunol 2004;36:46-51.

Mortz CG, Laurtisen JM, Bindslev-Jensen C, Andersen KE. Prevalence of atopic dermatitis, asthma, allergic rhinitis, and hand and contact dermatitis in adolescents. The Odense Adolescence Cohort Study on Atopic Disease and Dermatitis. Br J Dermatol 2001;144:523-532.

Namork E, Fæste CK, Stensby BA, Egaas E, Løvik M. Severe allergic reactions to food in Norway: a ten year survey of cases reported to the food allergy register. Int J Environ Res Public Health 2011; 8:3144-55.

Nystad W, Magnus P, Røksund O, Svidal B, Hetlevik Ø. The prevalence of respiratory sympotoms and asthma among school children in three different areas of Norway. Pediatr Allergy Immunol 1997;8: 35-40.

Nystad W, Røysamb E, Magnus P, Tambs K, Harris JR. A comparison of genetic and environmental variance structures for asthma, hay fever and eczema with symptoms of the same diseases: a study of Norwegian twins.Int J Epidemiol 2005;34:1302-9.

Pinart M, Benet M, Annesi-Maesano I, von Berg A, Berdel $D$ et al. Comorbidity of eczema, rhinitis, and asthma in IgE-sensitised and non-sensitised children in MeDALL: a population-based cohort study. Lancet Respir Med 2014;2:131-140.

Rönmark E, Bjerg A, Perzanowski M, Platts-Mills T, Lundbäck B. Major increase in allergic sensitization in schoolchildren from 1996 to 2006 in northern Sweden. J Allergy Clin Immunol 2009;124:357-363.

Sampson HA. Food allergy - accurately identifying clinical reactivity. Allergy 2005;60:19-24.

Selnes A, Nystad W, Bolle R, Lund E. Diverging prevalence trends of atopic disorders in Norwegian children. Results from three cross-sectional studies. Allergy 2005;60:894-899.

Sicherer SH, Munoz-Furlong A, Godbold JH, Sampson HA. US prevalence of self-reported peanut, tree nut, and sesame allergy: 11-year follow-up. J Allergy Clin Immunol 2010;125:1322-1326.

Signs of Climate Change in Nordic Nature. Nordic Council of Ministers; Copenhagen, Denmark: 2009. Available online: http://www.norden.org/sv/publikationer/publikationer/2009-551 (accessed on 25 April 2011).

Simonsen AB, Deleuran M, Johansen JD, Sommerlund M. Contact allergy and allergic contact dermatitis in children - a review of current data. Contact Dermatitis 2011;65:254-265.

Smidesang I, Saunes M, Storrø O, Oien T, Holmen TL et al. Allergy related disorders among 2-yrs olds in a general population. The PACT Study. Pediatr Allergy Immunol. 2010 Mar;21(2 Pt 1):315-20. doi: 10.1111/j.13993038.2009.00954.x. Epub 2009 Dec 9.

Thyssen JP, Linneberg A, MennéT, Johansen JD. The epidemiology of contact allergy in the general population - prevalence and main findings. Contact Dermatitis 2007; 57:287-299.

Trupin L, Katz PP, Balmes JR, Chen H, Yelin EH et al. Mediators of the socioeconomic gradient in outcomes of adult asthma and rhinitis. Am J Public Health. 2013;103:e31-8.

Zöllner IK, Weiland SK, Piechotowski I, Gabrio T, von Mutius E et al. No increase in the prevalence of asthma, allergies, and atopic sensitisation among children in Germany: 1992-2001. Thorax 2005;60:545-8.

\section{http://www.fhi.no/artikler/?id=110549}

\section{FORFATTERE}

Berit Granum, Øystein Karlstad, Per Nafstad, Ellen Namork og Wenche Nystad 
- Med økende levealder vil vi få et økt antall demenstilfeller.

- Risikofaktorer for demens ser for en stor del ut til å være de samme som risikofaktorene for hjerte- og karsykdommer.

- Tiltak som rettes mot forebygging av hjerte- og karsykdommer, kan trolig også redusere antall tilfeller av demens.

- Gener spiller en vesentlig rolle for demens.

\section{Kjennetegn ved demens og ulike typer}

Demens er fellesbetegnelsen på flere sykdommer som medfører kognitiv svikt, forbundet med funksjonstap i hjernen. I sjeldne tilfelle kan demens være forårsaket av vitaminmangel, kronisk rusmisbruk, hodeskader, stoffskiftesykdom eller annen sykdom. De aller fleste demenstilfellene er likevel knyttet til høy alder, og tilstanden betegnes da som aldersdemens.

Aldersdemens er en samlebetegnelse for ulike demenssykdommer og omfatter Alzheimers sykdom, vaskulær demens, demens med Levy-legemer, frontotemporal demens og andre typer. Aldersdemens forekommer sjelden før 70-årsalderen og vanligvis ikke før 80 år, mens nesten annenhver person over 90 år har aldersdemens.

Tilstanden utvikler seg langsomt, gjerne gjennom flere år og kan ikke kureres. Forverringen skjer raskere etter hvert som sykdommen utvikler seg. Dersom den demente ikke dør av andre årsaker, vil vedkommende dø av aldersdemens etter anslagsvis 10 års sykdom.

Som oftest er en demensdiagnose basert på ulike tester og på samtaler med pasient og pårørende. En viktig del av diagnostiseringen er å utelukke andre mulige årsaker til den kognitive svikten. I noen tilfeller kan det også være viktig å utelukke andre psykiske lidelser, ettersom alvorlig depresjon av og til kan arte seg som en demensliknende tilstand.

\section{Nesten hver femte person får demens i løpet av livet}

Beregninger basert på et stort antall studier i VestEuropa viser en utbredelse på 6,9 prosent blant personer over 59 år (Prince, 2013). Utbredelsen stiger fra 1,6 prosent i aldersgruppen 60-64 år til 43 prosent i gruppen over 89 år.

- Når disse tallene sammenholdes med statistikk for aldersfordeling i Norge, viser de at omtrent 1,5 prosent av hele befolkningen lider av demens. Nesten hver femte person vil få demens i løpet av livet (Seshadri, 2006).

Den vanligste formen for aldersdemens er Alzheimers sykdom som utgjør anslagsvis 60 prosent av all aldersdemens (Qiu, 2007). Dernest kommer vaskulær demens (rundt 20 prosent) (Qiu, 2007) og demens med Lewy-legemer (10 prosent) (Zaccai, 2005). Estimatene for frontotemporal demens spriker kraftig, men denne typen utgjør neppe mer enn 5 prosent (Bornebroek, 2004). Anslagene over fordelingen av de ulike demenstypene varierer en god del. Se faktaboks om de ulike formene for demens.

Blandingstilfeller er svært vanlige og utgjør kanskje bortimot halvparten av alle demenstilfellene (Jellinger, 2010). Det er også uklare skiller mellom de ulike demenstypene, blant annet fordi symptombildene for de ulike typene overlapper så sterkt at det er vanskelig å gi en sikker diagnose. 


\section{Utvikling over tid}

\section{Vil forekomsten av demens øke i årene framover?}

Det har vært vanlig å anta at omtrent 70000 personer, eller 1,4 prosent av befolkningen lider av demens i Norge (Rapport, Sosial og helsedirektoratet, 2007). Dette tallet er i hovedsak basert på en enkelt undersøkelse gjort i Nederland for ca. 20 år siden og er usikkert (Ferri, 2005), men det er i god overensstemmelse med anslaget på 1,5 prosent basert på resultater fra Vest-Europa (Prince, 2013). Vi har ikke gode data fra Norge.

Beregninger har vist at forventet økning i levealder i Norge vil føre til mer enn en fordobling i forekomst av demens fra 2006 til 2050, dersom aldersspesifikk utbredelse holder seg på dagens nivå (Sosial- og helsedirektoratet, 2007). Andre beregninger har anslått en fordoblet forekomst i Vest-Europa fra 2001 til 2040 (Ferri, 2005). På verdensbasis har det vært beregnet at forekomsten vil fordobles hvert 20. år (Reitz, 2011), mens et noe mer moderat anslag er en drøy tredobling i verden fra 2001 til 2040 (Ferri, 2005).

Dette er imidlertid verstefallsprognoser. Eksponering av en del risikofaktorer kan og vil antakelig bli redusert gjennom forebygging, og en ny undersøkelse fra England har vist en nedgang i demensutbredelse fra 8,3 til 6,5 prosent i perioden fra ca.1990 til 2010. Tallene er korrigert for at levealderen var lavere i 1990. (Matthews, 2013). I tillegg har en dansk studie funnet klart bedret kognitivt funksjonsnivå blant personer i alderen 93-95 år over en tiårsperiode (Christensen, 2013). Selv om forebygging neppe kan forhindre en økt utbredelse av demens som konsekvens av høyere levealder, kan økningen antakelig bremses en god del.

\section{Forskjeller mellom ulike befolkningsgrupper}

\section{Alder}

Som nevnt stiger utbredelsen kraftig med alder, fra anslagsvis 1,6 prosent $i$ aldersgruppen 60-64 år til 43 prosent blant personer på 90 år eller mer (Prince, 2013). Nesten hver femte person dør med demens (Seshadri, 2006).

\section{Flere kvinner enn menn blir demente} En overvekt av kvinner blant personer med demens kan delvis tilskrives høyere levealder blant kvinner (SSB, 2014). Men utbredelsen er også høyere blant kvinner enn menn innen samme aldersgruppe. Den prosentvise kjønnsforskjellen øker med alderen.
Resultater fra en europeisk undersøkelse viser også at mens kjønnsforskjellen var liten fram til tidlig $\mathrm{i}$ 80-årsalder, var den bortimot 50 prosent høyere blant kvinner enn blant menn på samme alder etter 85 årsalderen (Lobo, 2000).

\section{Sosioøkonomiske forskjeller i demens} Forekomsten av demens er høyere blant personer med lav utdanning enn blant høyt utdannede. Resultater fra en metaanalyse av et stort antall studier viser at risikoen økte med 80 prosent fra laveste til høyeste utdanningsgruppe for Alzheimer og med 60 prosent for annen demens (Caamaño-Isorna, 2006). Det er uklart hvor mye av disse forskjellene som skyldes forskjeller i levesett knyttet til utdanning. Det finnes ingen statistikk over mulige forskjeller knyttet til ulike områder av landet.

\section{Internasjonale forskjeller}

Forekomsten av demens ser ut til å være høyest $\mathrm{i}$ Amerika og Europa, og lavest i Afrika. Dette viser beregninger gjort av et ekspertpanel i 2010 (SosaOrtiz, 2012), se figur 1. Et annet ekspertpanel beregnet liknende, men noe lavere tall for 2001 (Qiu, 2007). De regionale forskjellene er sannsynligvis knyttet til forskjeller i levealder (Qiu, 2007, Sosa-Ortiz, 2012), og det er få eller ingen holdepunkter for å anta betydelige forskjeller i utbredelse mellom vestlige land.

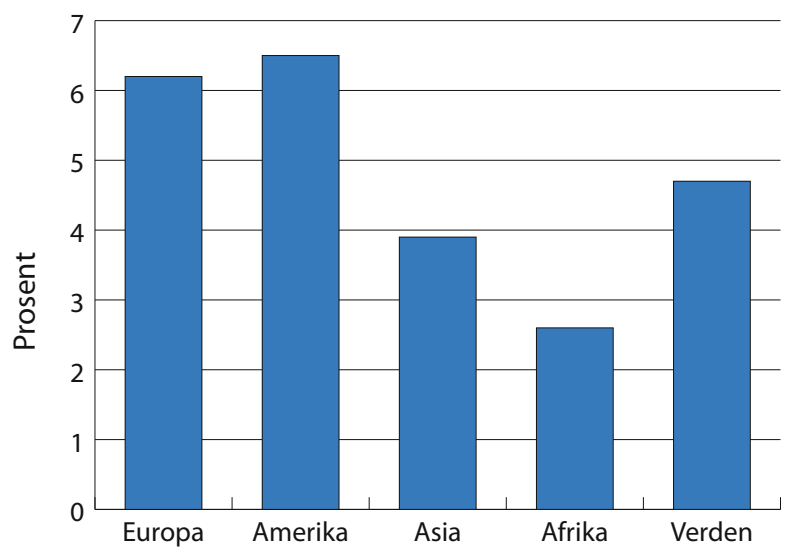

Figur 1. Utbredelse av demens i ulike verdensdeler. Prosent av befolkningen over 60 år. Kilde: Sosa-Ortiz 2012. Klikk på figuren for stor versjon.

\section{Årsaksfaktorer}

Et internasjonalt ekspertpanel konkluderte i $2010 \mathrm{med}$ at det ikke finnes helt sikker viten om modifiserbare risikofaktorer for demens, men at lovende forskning peker ut sannsynlige faktorer (Plassman, 2010). Nye resultater er kommet til, men fremdeles er kunnskapen om spesifikke årsaksfaktorer beheftet med usikkerhet. 
I noen grad er årsaksfaktorene knyttet til valg av diagnose. Dersom pasienten for eksempel har hatt høyt blodtrykk og antas å ha vært rammet av hjerneinfarkt, er dette en indikasjon på at tilstanden er vaskulær demens. Det at antatte risikofaktorer er med å bestemme hvilken diagnose som settes, kompliserer forskningen på hvilke faktorer som faktisk medfører øt risiko for de ulike demenstypene.

Likevel må vi anta at siden vaskulær demens skyldes tilstopping av blodårer, er risikofaktorene til dels de samme som for annen kardiovaskulær sykdom, spesielt hjerneslag (Se kapittel hjerte- og karsykdommer). Disse risikofaktorene omfatter høyt blodtrykk, høyt kolesterolnivå, diabetes, gjentatte betennelser og infeksjoner, hormonerstatninger, røyking, høyt alkoholforbruk, usunt kosthold, fysisk inaktivitet og overvekt. (Plassman, 2010, Grysiewicz, 2008).

Fordi mange demenstilfeller i virkeligheten er blandingstilstander, gjelder risikofaktorene for vaskulær demens også en stor andel av demenstilfellene, herunder blandingstilfeller diagnostisert som Alzheimers sykdom. Noen forskningsresultater har dessuten vist at «ren» Alzheimer også ser ut til å påvirkes betydelig av kardiovaskulære risikofaktorer (Tolppanen, 2012). Kanskje kan faktisk også denne demenstypen forstås som en hjerte- og karsykdom (Tolppanen, 2012).

Bortsett fra alder, er en spesiell variant av apolipoprotein-genet (ApoE, allel \&4 på kromosom 19) den sterkeste kjente risikofaktoren for Alzheimers sykdom. Anslagsvis 40 - 80 prosent av pasientene med Alzheimer har arvet denne varianten fra minst en av sine foreldre. Hvis genet er overført fra én av foreldrene, tredobles risikoen, og hvis genet er arvet fra begge foreldrene 11-dobles risikoen (Schipper, 2011).

ApoE4 fører til stor ansamling av beta-amyloid $\mathrm{i}$ hjernen før alzheimerssymptomer oppstår (Polvikoski, 1995). Så langt har ApoE4 primært blitt knyttet til Alzheimer. Resultater som er beskrevet i en oversiktsartikkel, tyder imidlertid på at dette genet er en like sterk risikofaktor for vaskulær demens (Liu, 2012). I tillegg til ApoE4 finnes det rundt 20 andre gener som koder for demens, men ingen med tilnærmet like sterk effekt (Lambert, 2013).

$\varnothing$ vrige sannsynlige risikofaktorer for demens generelt er depresjon og manglende kognitiv trening og stimulering (Plassman, 2010). Som nevnt er det også knyttet $ø$ kt risiko til lav utdannelse (Sosial og helsedirektoratet, 2007).
Tvillingstudier viser at gener er litt viktigere enn samlede miljøfaktorer som forklaring på Alzheimer (Bergem, 1997; Gatz, 2006). Det finnes ikke tilsvarende forskningsresultater for andre demenstyper.

\section{Konsekvenser av demens}

Den som får demens, vil ofte opplever mye lidelse knyttet til tapet av kognitive funksjoner, og vil før eller siden dø av eller med sykdommen.

Også blant pårørende, spesielt ektefelle eller barn, medfører sykdommen store belastninger. Opplevelsen av gradvis å miste sin nærmeste er en smertefull og ofte langvarig prosess. I tillegg er selve omsorgsbyrden ofte tung og slitsom.

\section{Forebygging}

Fra et forebyggings-synspunkt ser det heldigvis ut til at vegen til et demensfritt liv er omtrent den samme som til god helse for øvrig. Siden risikoen for demens øker med økende tilstopping av blodårer, kan tiltak som tar sikte på å redusere forekomsten av hjerte- og karsykdommer også påvirke forekomsten av demens. Eksempler er økt fysisk aktivitet, redusert tobakksrøyking og «hjertevennlig» kosthold. Se også kapittel hjerte- og karsykdommer.

\section{Referanser}

Bergem, A. L., K. Engedal and E. Kringlen (1997). The role of heredity in late-onset Alzheimer disease and vascular dementia. A twin study. Arch Gen Psychiatry 54(3): 264-270.

Bornebroek, M. and M. M. B. Breteler (2004). Epidemiology of non-AD dementias. Clinical Neuroscience Research 3(6): 349-361.

Caamano-Isorna, F., M. Corral, A. Montes-Martinez and B. Takkouche (2006). Education and dementia: a metaanalytic study. Neuroepidemiology 26(4): 226-232.

Christensen, K., M. Thinggaard, A. Oksuzyan, T. Steenstrup, K. Andersen-Ranberg, B. Jeune, M. McGue and J. W. Vaupel (2013). Physical and cognitive functioning of people older than 90 years: a comparison of two Danish cohorts born 10 years apart. Lancet 382(9903): 1507-1513.

European Alzheimer's Disease, I., Genetic, D. Environmental Risk in Alzheimer's, C. Alzheimer's Disease Genetic, H. Cohorts for and E. Aging Research in Genomic (2013). Meta-analysis of 74,046 individuals identifies 11 new susceptibility loci for Alzheimer's disease. Nat Genet 45(12): 1452-1458.

Ferri, C. P., M. Prince, C. Brayne, H. Brodaty, L. Fratiglioni, M. Ganguli, K. Hall, K. Hasegawa, H. Hendrie, Y. Huang, A. Jorm, C. Mathers, P. R. Menezes, E. Rimmer, M. Scazufca and I. Alzheimer's Disease (2005). Global prevalence of dementia: a Delphi consensus study. Lancet 366(9503): 2112-2117. 
Gatz, M., C. A. Reynolds, L. Fratiglioni, B. Johansson, J. A. Mortimer, S. Berg, A. Fiske and N. L. Pedersen (2006). Role of genes and environments for explaining Alzheimer disease. Arch Gen Psychiatry 63(2): 168-174.

Grysiewicz, R. A., K. Thomas and D. K. Pandey (2008). Epidemiology of ischemic and hemorrhagic stroke: incidence, prevalence, mortality, and risk factors. Neurol Clin 26(4): 871-895, vii.

Jellinger, K. A. and J. Attems (2010). Prevalence of dementia disorders in the oldest-old: an autopsy study. Acta Neuropathol 119(4): 421-433.

Liu, X., L. Li, F. Liu, S. Deng, R. Zhu, Q. Li and Z. He (2012). ApoE gene polymorphism and vascular dementia in Chinese population: a meta-analysis. J Neural Transm 119(3): 387-394.

Lobo, A., L. J. Launer, L. Fratiglioni, K. Andersen, A. Di Carlo, M. M. Breteler, J. R. Copeland, J. F. Dartigues, C. Jagger, J. Martinez-Lage, H. Soininen and A. Hofman (2000). Prevalence of dementia and major subtypes in Europe: $\mathrm{A}$ collaborative study of population-based cohorts. Neurologic Diseases in the Elderly Research Group. Neurology 54(11 Suppl 5): S4-9.

Matthews, F. E., A. Arthur, L. E. Barnes, J. Bond, C. Jagger, L. Robinson, C. Brayne, F. Medical Research Council Cognitive and C. Ageing (2013). A two-decade comparison of prevalence of dementia in individuals aged 65 years and older from three geographical areas of England: results of the Cognitive Function and Ageing Study I and II. Lancet 382(9902): 1405-1412.

Ott, A., M. M. Breteler, F. van Harskamp, J. J. Claus, T. J. van der Cammen, D. E. Grobbee and A. Hofman (1995). Prevalence of Alzheimer's disease and vascular dementia: association with education. The Rotterdam study. BMJ 310(6985): 970-973.

Polvikoski, T., R. Sulkava, M. Haltia, K. Kainulainen, A. Vuorio, A. Verkkoniemi, L. Niinisto, P. Halonen and K. Kontula (1995). Apolipoprotein E, dementia, and cortical deposition of beta-amyloid protein. N Engl J Med 333(19): 1242-1247.
Qiu, C., D. De Ronchi and L. Fratiglioni (2007). The epidemiology of the dementias: an update. Curr Opin Psychiatry 20(4): 380-385.

Reitz, C., C. Brayne and R. Mayeux (2011). Epidemiology of Alzheimer disease. Nat Rev Neurol 7(3): 137-152.

Schipper, H. M. (2011). Apolipoprotein E: implications for $A D$ neurobiology, epidemiology and risk assessment. Neurobiol Aging 32(5): 778-790.

Sosa-Ortiz, A. L., I. Acosta-Castillo and M. J. Prince (2012). Epidemiology of dementias and Alzheimer's disease. Arch Med Res 43(8): 600-608.

Sosial- og helsedirektoratet, 2007. Glemsk, men ikke glemt!: om dagens situasjon og framtidas utfordringer for å styrke tjenestetilbudet til personer med demens. Oslo, Sosial- og helsedirektoratet. Avdeling omsorg og tannhelse: 122 s. : ill. (2007).

Statistisk sentralbyrå (SSB). Statistikkbanken. Tilgjengelig fra $\underline{\text { SSB. }}$. Hentet juni 2014.

Tolppanen, A. M., A. Solomon, H. Soininen and M. Kivipelto (2012). Midlife vascular risk factors and Alzheimer's disease: evidence from epidemiological studies. J Alzheimers Dis 32(3): 531-540.

Zaccai, J., C. McCracken and C. Brayne (2005). A systematic review of prevalence and incidence studies of dementia with Lewy bodies. Age Ageing 34(6): 561-566.

\section{FORFATTERE}

Kristian Tambs, Bjørn Heine Strand og Vegard Skirbekk 


\section{Diabetes}

- Diabetes er en av de store folkesykdommene og er forbundet med alvorlige komplikasjoner.

- Vel 200000 personer (4 prosent av befolkningen) anslås å ha diagnosen diabetes. Disse behandles med blodsukkersenkende legemidler (165 000) og/eller kost og mosjon. I tillegg kommer et betydelig antall tilfeller av udiagnostisert diabetes.

- Antall som lever med diabetesdiagnosen har økt, men antall nye brukere av blodsukkersenkende legemidler per år har flatet ut de siste årene.

- Type 2-diabetes kan i stor grad forebygges med økt fysisk aktivitet og vektreduksjon.

\section{Hva er diabetes?}

Personer med diabetes har for høyt blodsukker. Type 1- og type 2-diabetes er de to vanligste formene. Type 2-diabetes er betydelig hyppigere enn type 1-diabetes. Type 1-diabetes er den vanligste formen for diabetes blant barn, men oppstår også hos voksne.

Personer med type 1- og type 2-diabetes har økt dødelighet og risiko for senkomplikasjoner fra hjerte- og karsystemet, nyrer, øyne og nerver. Komplikasjoner kan i stor grad forebygges med god behandling (Helsedirektoratet, 2009).

Svangerskapsdiabetes er forbudet med økt risiko for komplikasjoner i svangerskapet for mor og barn.

\section{Vel 4 prosent av befolkningen har diagnosen diabetes}

I Norge har vi ikke landsdekkende undersøkelser av antall personer (prevalens) med diagnostisert diabetes eller med ukjent diabetes (dvs nyoppdaget diabetes etter «screening»). Ved å kombinere data fra Reseptregisteret, Helseundersøkelsene i Nord-Trøndelag, Tromsø og enkelte andre undersøkelser, kan vi likevel danne oss et rimelig bilde av diabetessykeligheten i Norge.

Data fra Reseptregisteret viser at 165000 personer (3,3 prosent av befolkningen) brukte blodsukkersenkende legemidler i 2013.

\section{Hva er diabetes?}

Type 1-diabetes: Kroppen danner ikke hormonet insulin. Insulin regulerer blodsukkeret.

Alle må behandles med insulininjeksjoner.

Type 2-diabetes: Kroppen danner insulin, men for lite, kombinert med nedsatt effekt av insulin.

Behandles med livsstilsendring og/eller blodsukkersenkende legemidler. Dette er i første omgang tabletter, men mange trenger etter hvert insulininjeksjoner.

Svangerskapsdiabetes: $\varnothing \mathrm{kt}$ blodsukker som påvises første gang i svangerskapet. I mange tilfeller blir blodsukkeret normalt etter fødsel, men ikke hos alle.

Behandles primært med livsstilsendring, de alvorligste tilfellene trenger insulininjeksjoner.

\section{Type 1- og type 2-diabetes}

De fleste befolkningsbaserte studier skiller ikke mellom type 1- og type 2-diabetes. Basert på beregninger fra Reseptregisteret i Norge, kan vi anslå at 28000 personer ( 0,6 prosent av befolkningen) har type 1-diabetes (Strøm, 2014). Det vil si at 2,7 prosent av befolkningen har type 2-diabetes som behandles med blodsukkersenkende legemidler. 
I tillegg behandles et ukjent antall pasienter med type 2-diabetes med kost og mosjon. Tall fra representative fastlegepraksiser i 2005 viste at 28 prosent av pasienter med type 2-diabetes ble behandlet kun med kost og/eller mosjon (Cooper, 2009). Om vi legger dette til grunn, kan vi anslå at drøyt 53000 personer har type 2-diabetes som behandles kun med kost og/eller mosjon, og at totalt 190000 (3,8 prosent av befolkningen) har diagnostisert type- 2 diabetes. Vi kan dermed anslå at omlag 218000 (4,3 prosent) har diagnostisert diabetes. Upubliserte data fra Helseundersøkelsene i Nord-Trøndelag (HUNT1-3) antyder at andelen av pasienter med type 2-diabetes som behandles kun med kost og mosjon har gått ned, og anslaget på 28 prosent som er angitt ovenfor, må tolkes med forsiktighet (Kristian Midthjell, personlig meddelelse).

\section{Ukjente tilfeller av diabetes kommer i tillegg}

Internasjonale studier og upubliserte data fra Norge tyder på at det er mange i befolkningen som har diabetes uten å vite om det. Enkelte undersøkelser antyder at for hver 100 pasienter med kjent diabetes, kan det være mellom 50 og 100 med uoppdaget diabetes i befolkningen, men metodeproblemer gjør det vanskelig å anslå et sikkert tall (Hutchinson, 2012; Smith, 2007; Stene, 2004).

- Les blogginnlegg med detaljerte beregninger på http://www.fhi.no/artikler/?id=111380

\section{Utvikling over tid}

\section{Stadig flere lever med diabetes}

Data fra Helseundersøkelsene i Nord-Trøndelag (HUNT) viser at andelen voksne (alder 20 år og over) med diabetes økte fra 2,9 prosent til 4,3 prosent i perioden 1984-2008. Data fra Reseptregisteret viser også at antallet som bruker blodsukkersenkende legemidler har økt for hvert år fra cirka 110000 (2,5 prosent) i 2004 til rundt 165000 personer (3,3 prosent av befolkningen) i 2013, se figur 1 .

En slik økning kan i teorien skyldes at det blir flere nye tilfeller per år (insidens), at flere diagnostiseres eller at de som har diabetesdiagnosen lever lengre, se figur 2 som viser faktorer som kan påvirke prevalensen.

\section{Antallet med nyoppdaget diabetes kan ha flatet ut}

Rundt 15 000-16 000 nye pasienter starter med blodsukkersenkende legemidler hvert år. Antallet har ikke økt i perioden 2006-2011 (Strøm, 2014). Dette antyder at antallet nyoppdagede med type 2-diabetes per år ikke lenger øker.

Vi har ikke andre landsdekkende tall som kan vise hvor mange personer som får diabetes hvert år (insidens). Et unntak er type 1-diabetes hos barn. Omkring 300 nye personer under 15 års alder får type 1-diabetes hvert år i Norge. Dette tallet har vært stabilt fra 2004 (Skrivarhaug, 2014).

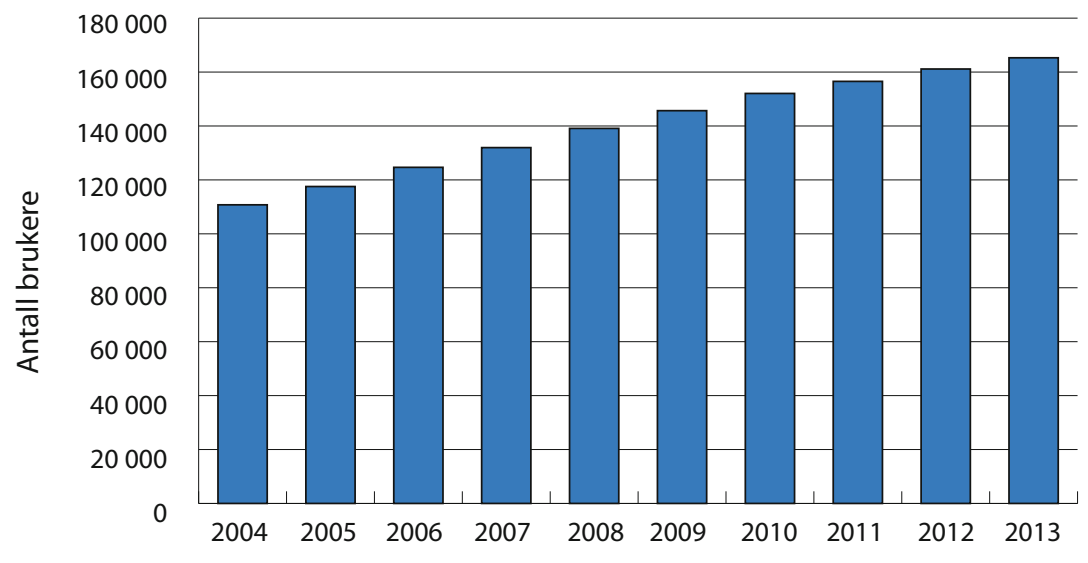

Figur 1: Antall brukere av blodsukkersenkende legemidler i Norge, 2004-2013. Kilde: Reseptregisteret, Folkehelseinstituttet. 


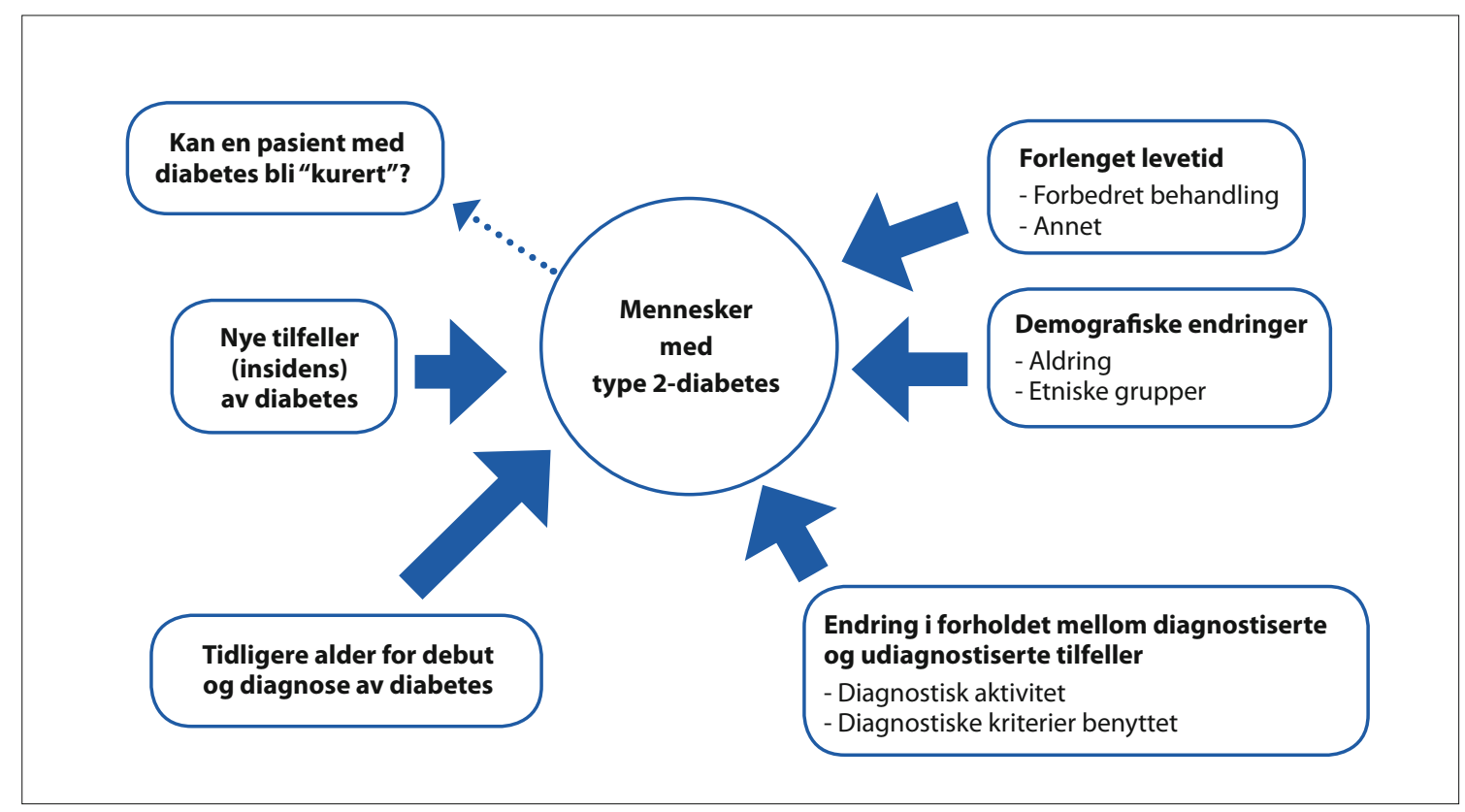

Figur 2: Påvirkningsfaktorer for utbredelse av type 2-diabetes. Kilde: Ma \& Tong, 2010.

\section{Forskjeller mellom ulike grupper i befolkningen}

\section{Flere menn enn kvinner har diabetes}

Totalt er det flere menn enn kvinner som har diabetes, gjennomsnittlig er det åtte kvinner med diabetes for hver tiende mann med diabetes i Norge. Det er noe variasjon i kjønnsforskjellene med alder og etnisk gruppe.

\section{Én av ti 80-åringer har diabetes- diagnosen}

Både prevalens og insidens av type 2-diabetes øker kraftig med alderen, til en topp omkring 80 år. 12012 brukte nesten 11 prosent i aldersgruppen over 80 år blodsukkersenkende legemidler.

\section{Sosioøkonomiske forskjeller}

De fleste studier, både fra Norge (Joseph, 2010) og andre land, viser at type 2-diabetes er vanligere i grupper med lav utdanning enn i grupper med høyere utdanning (Agardh, 2011).

\section{Geografiske variasjoner}

Andelen som bruker blodsukkersenkende legemidler ser ut til å være høyest i Hedmark, Nord-Trøndelag og Østfold, og lavest i Rogaland, Akershus, Hordaland og Oslo. Det kan være flere mulige forklaringer på fylkesforskjellene, og man bør derfor være forsiktig med å tolke dette. Når det gjelder type 1-diabetes, har Finnmark og de nordligste fylkene i mange år hatt noe lavere insidens blant barn, mens Vest-Agder og AustAgder har hatt relativt høy insidens.

\section{Noen innvandrergrupper er særlig utsatt}

Innvandrere med opprinnelse fra det indiske subkontinent har høyere forekomst av type 2-diabetes. Disse får ofte type 2-diabetes i yngre alder enn det etniske nordmenn gjør. En undersøkelse i bydelene Romsås og Furuset i Oslo viste at i aldersgruppen 30-59 år, hadde 14 prosent av mennene og 28 prosent av kvinnene fra Pakistan, India og Sri Lanka kjent eller nyoppdaget diabetes, mot henholdsvis seks og tre prosent av dem med norsk bakgrunn (Jenum, 2005).

Når det gjelder type 1-diabetes, er det sannsynligvis lavere insidens blant innvandrere fra India og Pakistan (og en del andre land i Asia og Sør-Amerika), i alle fall blant barn. Vi har ikke norske data, men detter er dokumentert i Sverige (Ji, 2010).

\section{Internasjonale forskjeller}

- Norge har relativt lav prevalens av diagnostisert diabetes i aldersgruppen 20-79 år, sammen med blant annet de andre skandinaviske landene og Storbritannia.

- India, Mexico og USA er blant land med høyere forekomst av diagnostisert diabetes i følge http://www.idf.org/diabetesatlas (merk at ikke alle tall i Diabetes Atlas er sammenlignbare).

Norge er, sammen med Finland og Sverige, blant landene i verden som topper statistikken for nye årlige tilfeller av type 1-diabetes hos barn. 


\section{Livsstilen påvirker risikoen for type 2-diabetes}

Både type 1- og type 2-diabetes skyldes i en viss grad arvelige faktorer, men arv alene er sjelden nok til å utvikle diabetes. Et unntak er sjeldne genetiske former for diabetes.

Foreløpig vet vi svært lite om påvirkbare risikofaktorer for type 1-diabetes.

Blant de viktigste påvirkbare risikofaktorene for type 2-diabetes, er:

- overvekt og fedme

- fysisk inaktivitet

- røyking

Det er vist at personer med kroppsmasseindeks (KMI) rundt 30 hadde mer enn 20 ganger høyere risiko for å utvikle type 2-diabetes i løpet av en 11-års periode, sammenlignet med «normalvektige» med kroppsmasseindeks på cirka 22 kg/m² (Midthjell, 2001). For en person som er $175 \mathrm{~cm}$ høy, vil en vekt på ca 92 kg gi en KMI på 30 mens en vekt på ca 67 kg gir en KMI på $22 \mathrm{~kg} / \mathrm{m}^{2}$. Stor midjeomkrets («bukfedme») er forbundet med spesielt høy risiko for type 2-diabetes.

\section{Svangerskapsdiabetes}

I en undersøkelse hvor et utvalg av alle gravide fra Groruddalen i Oslo ble testet, hadde over 10 prosent av de gravide svangerskapsdiabetes (Jenum, 2012). Groruddalen er ikke representativt for Oslo eller resten av landet med hensyn til sammensetning av etniske grupper eller sosio-økonomisk status, men det var omtrent 10 prosent med svangerskapsdiabetes også blant etnisk norske. Landsdekkende tall fra Medisinsk fødselsregister viser betraktelig lavere forekomst av diagnostisert svangerskapsdiabetes, cirka 2 prosent i 2011. Forskjellen skyldes sannsynligvis i stor grad at ikke alle gravide undersøkes systematisk for svangerskapsdiabetes.

Av kvinner registrert med svangerskapsdiabetes i Medisinsk fødselsregister, brukte 1 av 5 blodsukkersenkende legemidler fem år etter fødselen (Engeland, 2011). Dette viser at kvinner med svangerskapsdiabetes har betydelig økt risiko for senere å utvikle type 2-diabetes. Risikofaktorene for å utvikle svangerskapsdiabetes er i stor grad de samme som for type 2-diabetes, inkludert etnisitet og alder.

\section{Forebygging og utfordringer}

Type 1-diabetes kan foreløpig ikke forebygges. Dersom antall nye, årlige tilfeller av diabetes skal kunne reduseres, må tiltak rettes mot de viktigste risikofaktorer for type 2-diabetes.

Intervensjonsstudier fra Finland, USA og Kina har vist at bedre kosthold, mosjon og vektreduksjon reduser antall nye tilfeller av type 2-diabetes i høyrisikogrupper. Derimot er det en utfordring å finne hvilke tiltak som er mest effektive for å skape livsstilsendringer, og som er praktisk gjennomførbare på befolkningsnivå. Les mer om forebygging i kapittel Hjerte- og karsykdommer.

I Mosjon på Romsås (MORO)-studien ble det gjennomført en rekke tiltak i bydelen, som for eksempel opplyste stier, organiserte treningsgrupper og informasjonsplakater. Tiltakene ga økt fysisk form og redusert vektoppgang hos deltakerne tre år senere (Jenum, 2006). Konklusjonen fra studien er at det kan være mulig å bremse vektøkningen med befolkningsrettede tiltak, men at dette krever koordinert og målrettet innsats fra alle relevante aktører. For å kunne evaluere og dokumentere eventuelle effekter av tiltak som kan redusere sykeligheten av diabetes, trengs det nøye overvåkning og rutinemessig registrering av data. I Norge har vi i dag ikke data som er gode nok for dette formålet.

\section{Referanser}

Agardh E, Allebeck P, Hallqvist J, Moradi T, \& Sidorchuk A (2011): Type 2 diabetes incidence and socio-economic position: a systematic review and meta-analysis. Int J Epidemiol 40, 804-818.

Cooper JG, Claudi T, Jenum AK, Thue G, Hausken MF, Ingskog W, \& Sandberg S (2009): Quality of care for patients with type 2 diabetes in primary care in Norway is improving: results of cross-sectional surveys of 33 general practices in 1995 and 2005. Diabetes Care 32, 81-83.

Engeland A, Bjorge T, Daltveit AK, Skurtveit S, Vangen S, Vollset SE, \& Furu K (2011): Risk of diabetes after gestational diabetes and preeclampsia. A registry-based study of 230,000 women in Norway. Eur J Epidemiol 26, 157-163.

Helsedirektoratet. Nasjonal faglig retningslinje med anbefalinger om forebygging, diagnostikk og behandling av diabetes. IS-1674. Oslo: Helsedirektoratet, 2009.

Helse- og omsorgsdepartementet. NCD-strategi 2013-2017 for forebygging, diagnostisering, behandling og rehabilitering av fire ikke-smittsomme folkesykdommer; hjerte- og karsykdommer, diabetes, kols og kreft. Oslo: Helse- og omsorgsdepartementet, (2013). 
Hutchinson MS, Joakimsen RM, Njølstad I, Schirmer H, Figenschau Y, \& Jorde R (2012): Glycated hemoglobin in diagnosis of diabetes mellitus and pre-diabetes; validation by oral glucose tolerance test. The Tromso OGTT Study. J Endocrinol Invest 35, 835-840.

Jenum AK, Anderssen SA, Birkeland KI, Holme I, GraffIversen S, Lorentzen C, Ommundsen Y, Raastad T, Odegaard AK, \& Bahr R (2006): Promoting physical activity in a low-income multiethnic district: effects of a community intervention study to reduce risk factors for type 2 diabetes and cardiovascular disease: a community intervention reducing inactivity. Diabetes Care 29, 1605-1612.

Jenum AK, Holme I, Graff-Iversen S, \& Birkeland KI (2005): Ethnicity and sex are strong determinants of diabetes in an urban Western society: implications for prevention. Diabetologia 48, 435-439.

Jenum AK, Mørkrid K, Sletner L, Vangen S, Torper JL, Nakstad B, Voldner N, Rognerud-Jensen OH, Berntsen S, Mosdøl A, Skrivarhaug T, Vårdal MH, Holme I, Yajnik CS, \& Birkeland KI (2012): Impact of ethnicity on gestational diabetes identified with the WHO and the modified International Association of Diabetes and Pregnancy Study Groups criteria: a population-based cohort study. Eur J Endocrinol 166, 317-324.

Ji J, Hemminki K, Sundquist J, \& Sundquist K (2010): Ethnic differences in incidence of type 1 diabetes among secondgeneration immigrants and adoptees from abroad. J Clin Endocrinol Metab 95, 847-850.

Joseph J, Svartberg J, Njølstad I, \& Schirmer H (2010): Incidence of and risk factors for type-2 diabetes in a general population: the Tromsø Study. Scand J Public Health 38, 768-775.

Krokstad, S. and M. S. Knudtsen Folkehelse i endring: Helseundersøkelsen Nord-Trøndelag : HUNT 1 (1984-86) - HUNT 2 (1995-97) - HUNT 3 (2006-08). Levanger, HUNT forskningssenter. (2011).
Midthjell K (2001): Diabetes in adults in Nord-Trøndelag: epidemiological and public health aspects of diabetes mellitus in a large, non-selected Norwegian population (Thesis). Verdal: NTNU.

Skrivarhaug T, Stene LC, Drivvoll AK, Strøm H, \& Joner G (2014): Incidence of type 1 diabetes in Norway among children aged 0-14 years between 1989 and 2012: has the incidence stopped rising? Results from the Norwegian Childhood Diabetes Registry. Diabetologia 57, 57-62.

Smith JP (2007): Nature and causes of trends in male diabetes prevalence, undiagnosed diabetes, and the socioeconomic status health gradient. Proc Natl Acad Sci U S A $104,13225-13231$.

Soderstrom, U., J. Aman and A. Hjern (2012). "Being born in Sweden increases the risk for type 1 diabetes - a study of migration of children to Sweden as a natural experiment." Acta Paediatrica 101(1): 73-77.

Stene LC, Midthjell K, Jenum AK, Skeie S, Birkeland KI, Lund E, Joner G, Tell GS, \& Schirmer H (2004): Hvor mange har diabetes mellitus i Norge? Tidsskr Nor Lægeforen 124, 1511-1514.

Strøm H, Selmer R, Birkeland KI, Schirmer H, Berg TJ, Jenum AK, Midthjell K, Berg C, \& Stene LC (2014): No increase in new users of blood glucose-lowering drugs in Norway 2006-2011: a nationwide prescription database study. BMC Public Health 14:520 (pdf).

\section{FORFATTERE}

Lars Christian Stene, Hanne Strøm og Hanne Lovdal Gulseth 


\section{Hjerte-og karsykdommer}

- Dødeligheten av hjerte- og karsykdom synker i alle aldersgrupper.

- Nye tilfeller av hjerteinfarkt har gått ned i aldersgrupper over 65 år.

- Det er en bekymringsfull økning i sykehusinnleggelser for førstegangs hjerteinfarkt blant yngre voksne.

- Antall syke forventes å stige på bakgrunn av en økende andel eldre i befolkningen, samt bedre overlevelse etter akutt sykdom.

- Hjerte og karsykdommer er fortsatt den sykdomsgruppen som fører til flest dødsfall når vi ser på alle aldersgrupper samlet.

- Det har vært en nedgang i kolesterol, blodtrykk og røyking, men flere er overvektige.

- Små endringer i livsstil og kosthold kan bety mye for forebygging.

\section{Om hjerte- og karsykdommer}

Hjerte- og karsykdommer består av flere sykdommer, med angina pectoris, hjerteinfarkt, hjertesvikt og hjerneslag som viktige hovedgrupper. Sykeligheten er i hovedsak knyttet til aterosklerose, en prosess som gir innsnevring og tilstopping av blodårer.

\section{Dagens situasjon for hjerte- og karsykdommer i Norge}

Dødeligheten og forekomsten av hjerte- og karsykdommer er her analysert ved hjelp av statistikk fra Dødsårsaksregisteret og Hjerte- og karregisteret.

Tabell 1: Antall pasienter med poliklinisk konsultasjon i spesialisthelsetjenesten eller innleggelse i sykehus i 2012 for utvalgte hoveddiagnoser innen hjerte- og karsykdommer. Kilde: FHI, 2014.

\begin{tabular}{|l|l|}
\hline & $\begin{array}{l}\text { Antall pasienter med } \\
\text { hoveddiagnose }\end{array}$ \\
\hline Hjertesvikt & 7550 \\
\hline Hjerneslag & 10672 \\
\hline Akutt Hjerteinfarkt & 11888 \\
\hline $\begin{array}{l}\text { Hjerteinfarkt og } \\
\text { hjertekramper til sammen }\end{array}$ & 26102 \\
\hline $\begin{array}{l}\text { Hjerteinfarkt og hjertekrampe } \\
\text { behandlet med utblokking av } \\
\text { kransårene i hjertet }\end{array}$ & $10304(40 \%)$ \\
\hline
\end{tabular}

Utviklingen i sykelighet av hjerteinfarkt er basert på et forskningsprosjekt som bruker utskrivingsdiagnoser fra alle landets sykehus.

I 2012 fikk 66029 personer en poliklinisk konsultasjon eller sykehusinnleggelse med iskemisk hjertesykdom (hjerteinfarkt eller hjertekrampe) som hoved- eller bidiagnose. Av disse hadde 26102 pasienter dette som hoveddiagnose, se tabell 1. Pasienter med hjerte- og karsykdommer utgjør en stor andel av polikliniske konsultasjoner og innleggelser i sykehus.

Aldersfordelingen blant pasientene med hjerteinfarkt eller hjertekrampe går fram av figur 1.

\section{De fleste sykehusinnlagte med akutt hjerteinfarkt overlever}

- 28 dager etter innleggelse for akutt hjerteinfarkt var 99 prosent av pasientene under 50 år fortsatt i live, mens overlevelsen var 97 prosent for aldersgruppen 50 til 70 år og 84 prosent for de over 70 år. (FHI, 2014).

- Vel 20 prosent av de som rammes av førstegangs hjerteinfarkt, dør før de kommer til sykehus (Sulo, 2014a). 
Tabell 2: Antall døde av hjerte- og karsykdommer i Norge i 2000 og 2012. Kilde: Norgeshelsa/Dødsårsaksregisteret, 2013.

\begin{tabular}{|c|c|c|}
\hline$\AA ̊ 丿$ & $\begin{array}{c}\text { Antall døde av hjerte- og } \\
\text { karsykdommer, menn }\end{array}$ & $\begin{array}{c}\text { Antall døde av hjerte- og } \\
\text { karsykdommer, kvinner }\end{array}$ \\
\hline 2000 & 8659 & 9532 \\
\hline 2012 & 5975 & 7035 \\
\hline
\end{tabular}

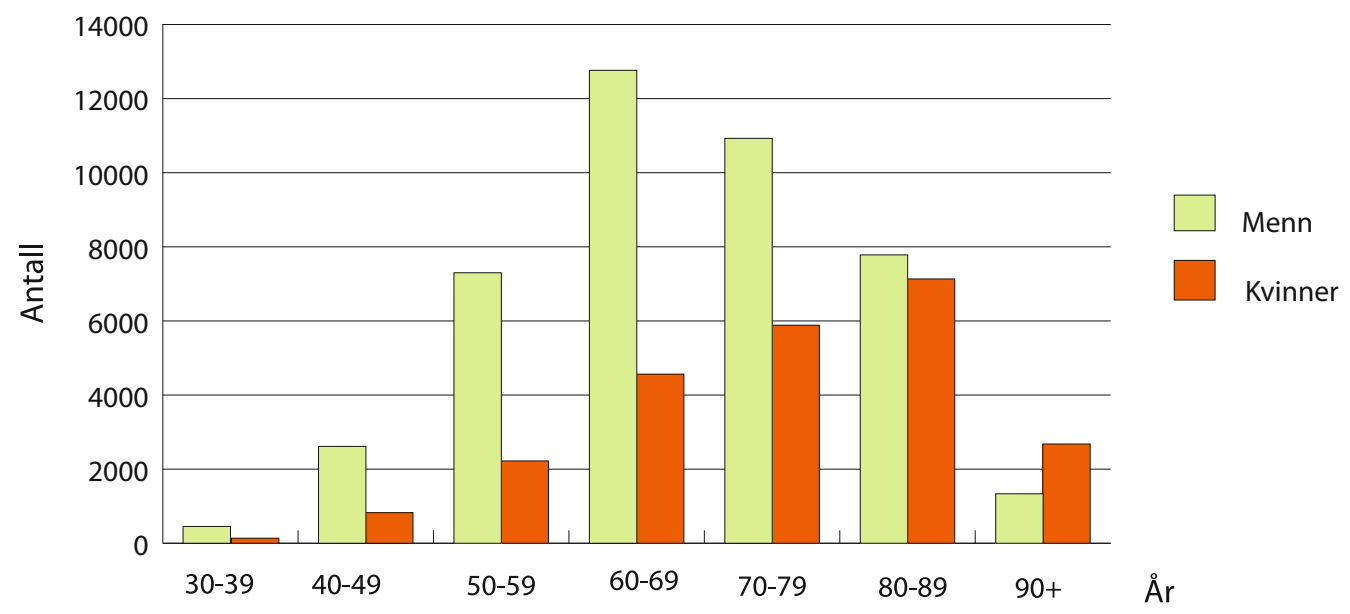

Figur 1: Antall pasienter undersøkt poliklinisk eller innlagt i spesialisthelsetjenesten 2012 med iskemisk hjertesykdom (hjerteinfarkt eller hjertekrampe) som hoved- eller bidiagnose. Kilde: FHI, 2014.

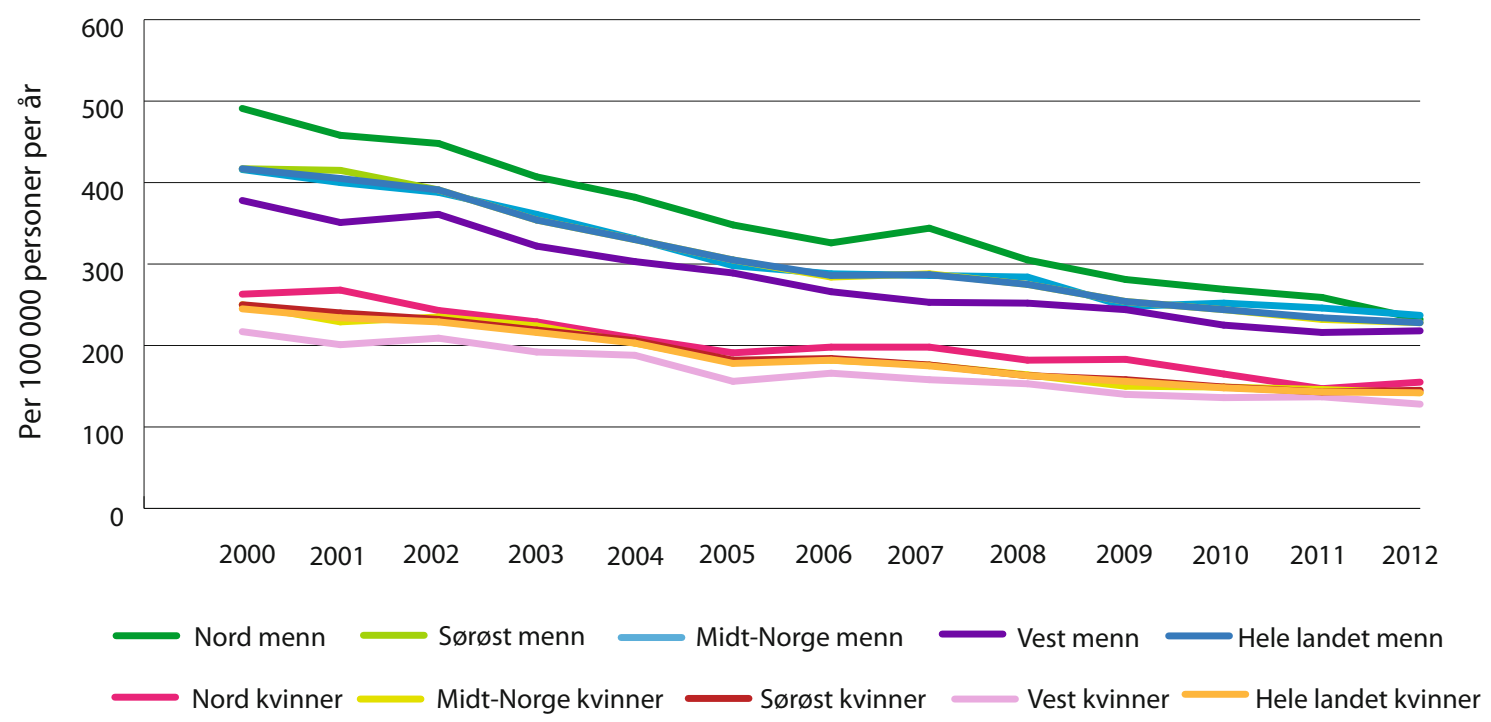

Figur 2: Dødelighet av hjerte- og karsykdommer 2000-2012. Aldersjusterte rater per 100000 personer per år. Kilde: Dødsårsaksregisteret.

\section{Mange dødsfall}

Hjerte- og karsykdommer er den sykdomsgruppen som fører til flest dødsfall når vi ser på alle aldersgrupper samlet. Mange av dem som dør, dør i høy alder, særlig kvinner. I 2012 døde 5975 menn og 7035 kvinner av hjerte- og karsykdommer i Norge, se tabell 2.

\section{Utvikling over tid}

Vi ser følgende utvikling:

- Dødeligheten av hjerte- og karsykdommer har gått ned de siste 40 årene.

- For akutt hjerteinfarkt ser vi en bekymringsfull trend blant yngre voksne, målt etter antall førstegangstilfeller innlagt i sykehus, per 100000.

- Blant eldre har antall førstegangstilfeller gått ned. 
- Antall syke forventes totalt sett å stige på grunn av en økende andel eldre i befolkningen, samt bedre overlevelse etter akutt sykdom.

\section{Sterk nedgang i hjerte- og} kardødelighet i alle deler av landet

Dødeligheten av hjerte- og karsykdommer nådde toppen i Norge i 1970-årene og har senere sunket. Denne utviklingen har fortsatt, og fra 2000 og fram til i dag er dødeligheten nesten halvert, se figur 2.

\section{Bekymringsfull trend for akutt hjerteinfarkt blant yngre voksne}

Når det gjelder førstegangstilfeller av akutt hjerteinfarkt har det for alle aldersgrupper samlet sett vært en nedgang på 24 prosent fra 2001 til 2009 (Sulo, 2014a). Nedgangen skjuler imidlertid forskjeller i ulike aldersgrupper, se figur $3 a-b$.

I aldersgruppen 25-44 år er det ingen nedgang fra 2001, se figur $3 a$.

En nærmere analyse viser at det var en nedgang i antall infarktdødsfall utenfor sykehus i alle aldersgrupper,

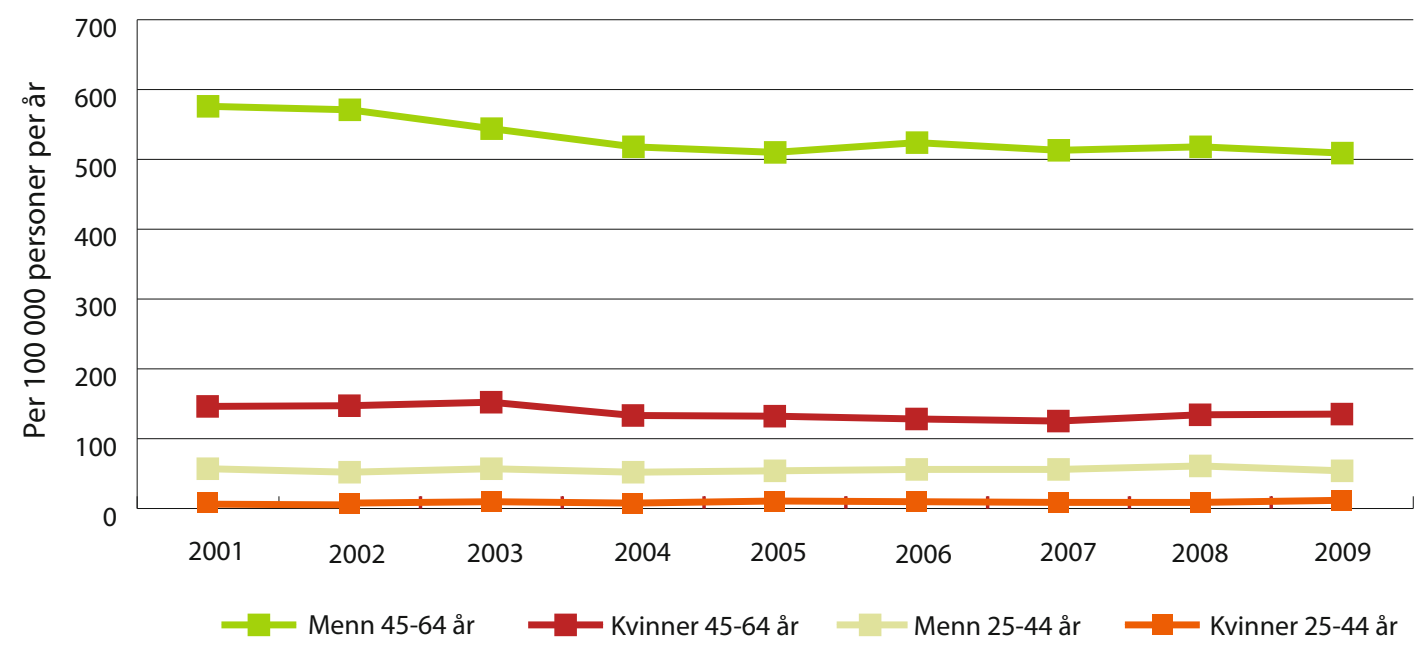

Figur 3a: Aldersjusterte insidensrater for akutt hjerteinfarkt per år fordelt på kjønn og aldersgruppene 25-44 år og 45-64 år. Datakilde: Sulo, 2014a.

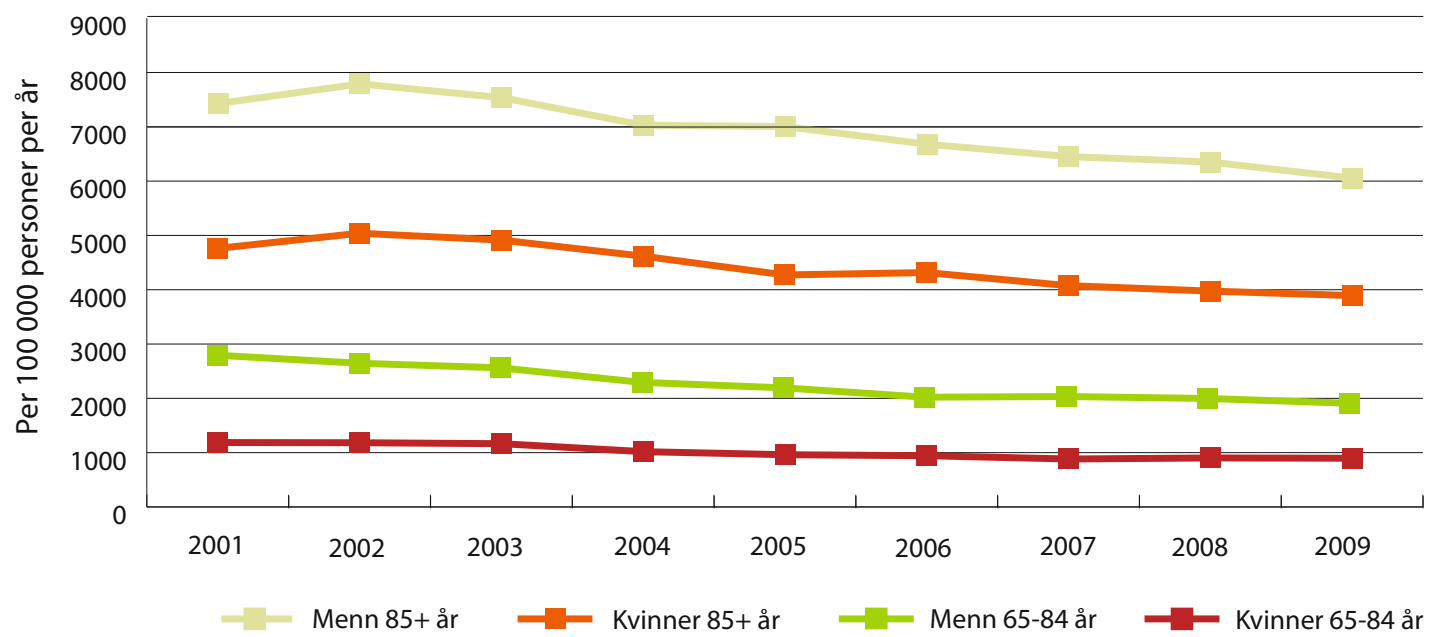

Figur 3b: Aldersjusterte insidensrater for akutt hjerteinfarkt per år fordelt på kjønn og aldersgruppene 65-84 år og 85+ år. Datakilde: Sulo, 2014a. 
også i aldersgruppen 25 til 44 år, men her økte antallet sykehusinnleggelser for førstegangs hjerteinfarkt med 11 prosent fra 2001 til 2009 (Sulo, 2014a) (ikke vist i figur).

Dette tyder på at nedgangen i dødelighet hos de yngre voksne skyldes at flere overlever sine infarkter, trolig på grunn av mer effektiv behandling, og fordi infarktene har blitt mindre alvorlige over tid. Bekymringen er at sykeligheten ikke har sunket, slik den har gjort hos de eldre.

Endringer i trender for hjerte- og karsykdom har tidligere vist seg først hos de yngre voksne, derfor er tallene i denne aldersgruppen så viktige.

En analyse som inkluderer gjentatte infarkter bekrefter bekymringen for utviklingen under 65 år (Sulo, 2014b).

Diagrammene på forrige side viser fire ulike aldersgrupper.

\section{Forskjeller i befolkningen}

\section{Geografiske forskjeller avtar}

Historisk sett har Nord-Norge og særlig Finnmark ligget høyt, mens hjerte- og kardødeligheten har vært lavest på Vestlandet. Dette har i dag jevnet seg mer ut, og i 2012 var det små forskjeller mellom regionene, se figur 2.

\section{Kjønnsforskjeller avtar}

På hvert alderstrinn har menn høyere dødelighet enn kvinner, men kjønnsforskjellene har avtatt siden 2000, se figur 2 .

\section{Stor sosial ulikhet i dødelighet av hjerte- og karsykdommer}

Den sosiale ulikheten i dødelighet av hjerte- og karsykdommer er markert, og gapet har økt de siste tiårene. Dette skyldes en særlig bratt nedgang i dødeligheten blant personer med høy utdanning (Strand, 2010).

\section{Etniske forskjeller}

Noen grupper av innvandrere har lavere risiko for hjerte- og karsykdommer enn etniske nordmenn, men bildet er sammensatt (Kumar, 2009). Blant kvinner i flere innvandrergrupper er det få som røyker og få som har forhøyet blodtrykk, men i noen grupper motvirkes dette av økt tendens til overvekt, fysisk inaktivitet og diabetes (Rabanal, 2013).

\section{Hvert fjerde dødsfall globalt skyldes hjerteinfarkt eller hjerneslag}

I 1970-årene var hjerte- og kardødeligheten i Norge blant de høyeste i verden. Dette bildet har forandret seg drastisk. Nå ligger Norge på nivå med middelhavslandene, se figur $4 a-b$.

Hjerte- og karsykdommer er den viktigste årsaken til tap av uførejusterte leveår (DALY) og for tidlig død globalt (Murray, 2012; Lozano, 2012). Hvert fjerde dødsfall globalt skyldes hjerteinfarkt eller hjerneslag. Dødeligheten av hjerte- og karsykdommer faller i de fleste europeiske land, men er fortsatt betydelig høyere i Sentral- og Øst-Europa enn i resten av Europa (Nichols, 2012).

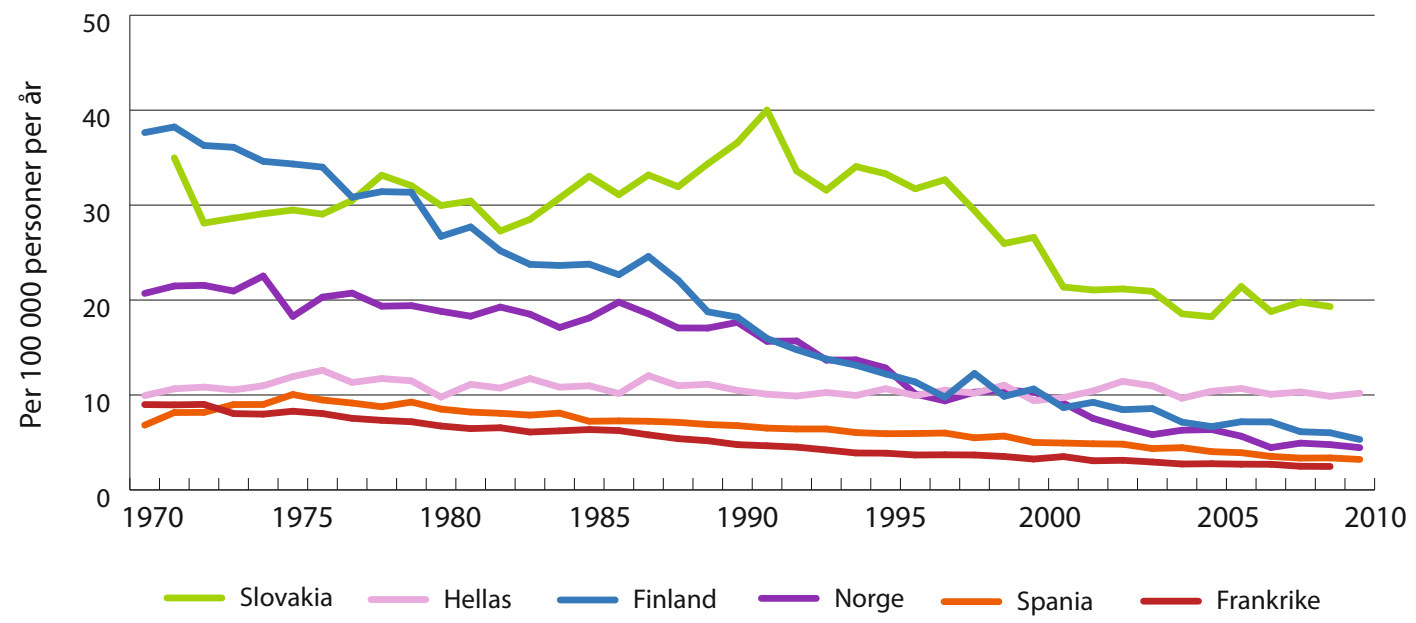

Figur 4a: Kvinner. Dødelighet av iskemisk hjertesykdom i noen europeiske land, kvinner 0-64 år. Kilde: WHO-HFA databasen. 


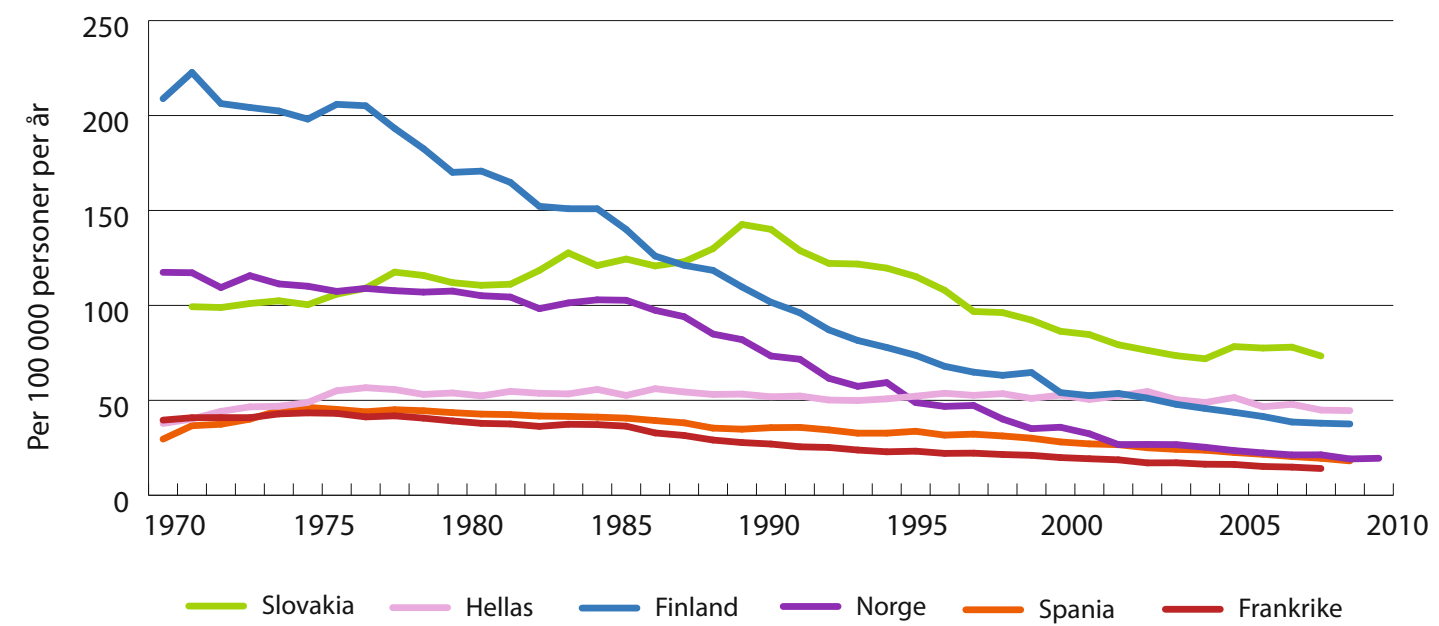

Figur 4b: Menn. Dødelighet av iskemisk hjertesykdom i noen europeiske land, menn 0-64 år. Kilde: WHO-HFA databasen.

\section{Risikofaktorer for hjerte- og karsykdommer}

Risikofaktorer for hjerte- og karsykdommer er blant annet vurdert av et utvalg i Verdens helseorganisasjon som oppsummerte forskningsbasert kunnskap (WHO 2011, Ezzati, 2012). WHOs rapport ble fulgt opp av Helsedirektoratet i 2013. De viktigste risikofaktorene for hjerteinfarkt er (Helsedirektoratet, 2013):

- tobakksrøyking

- kost med mye mettet fett og transfett (som øker blodkolesterolet) og høyt inntak av sukkerholdig drikke
- høyt saltinntak (som øker blodtrykket) og lavt inntak av frukt og grønnsaker

- fysisk inaktivitet

- diabetes og overvekt

- høyt alkoholinntak

Små endringer i kosthold og livsstil kan ha stor betydning over tid. Et kosthold med lite sukker, lite rødt kjøtt, og med hyppig inntak av fisk, hvitt kjøtt, frukt, grønnsaker, belgfrukter, nøtter og olivenolje, førte til lavere forekomst hjerte- og karsykdom i en studie (Estruch 2013).

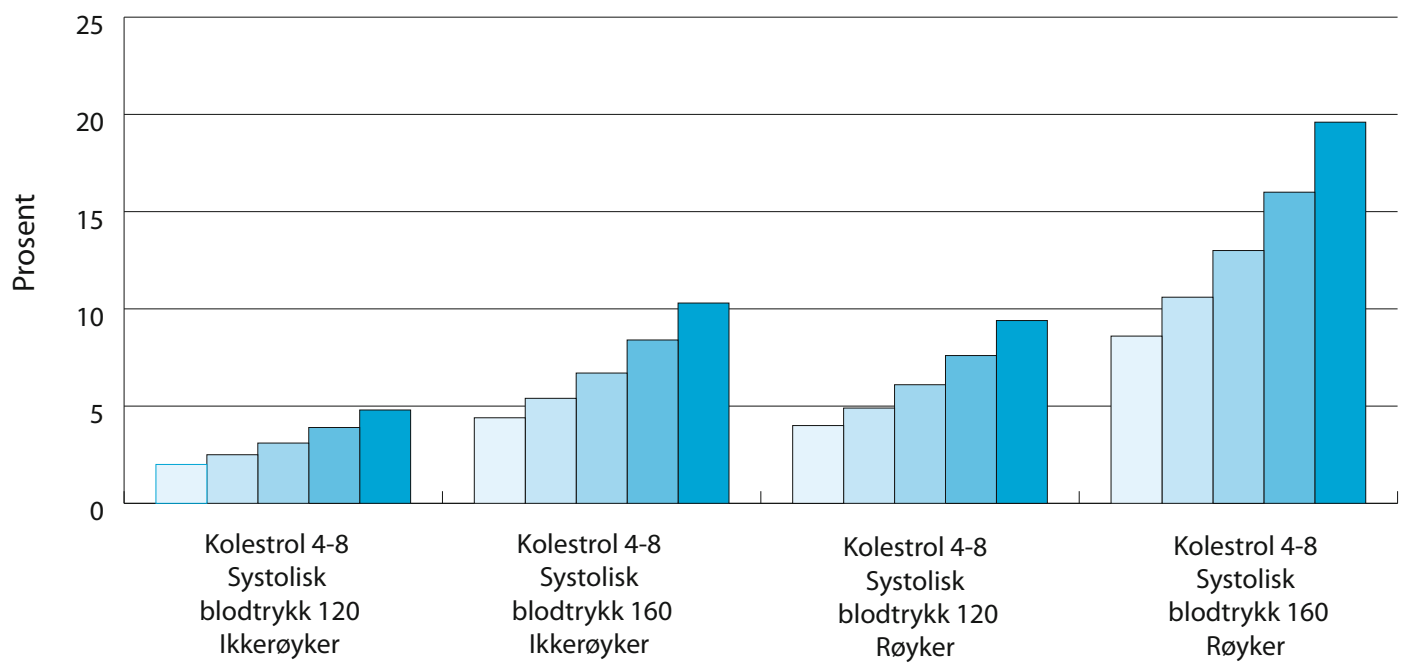

Figur 5a: Menn. 10-års risiko for død av hjerte- og karsykdom basert på risikomodellen NORRISK, menn 60 år. Kilde: Selmer, 2008; Helsedirektoratet, 2009. 


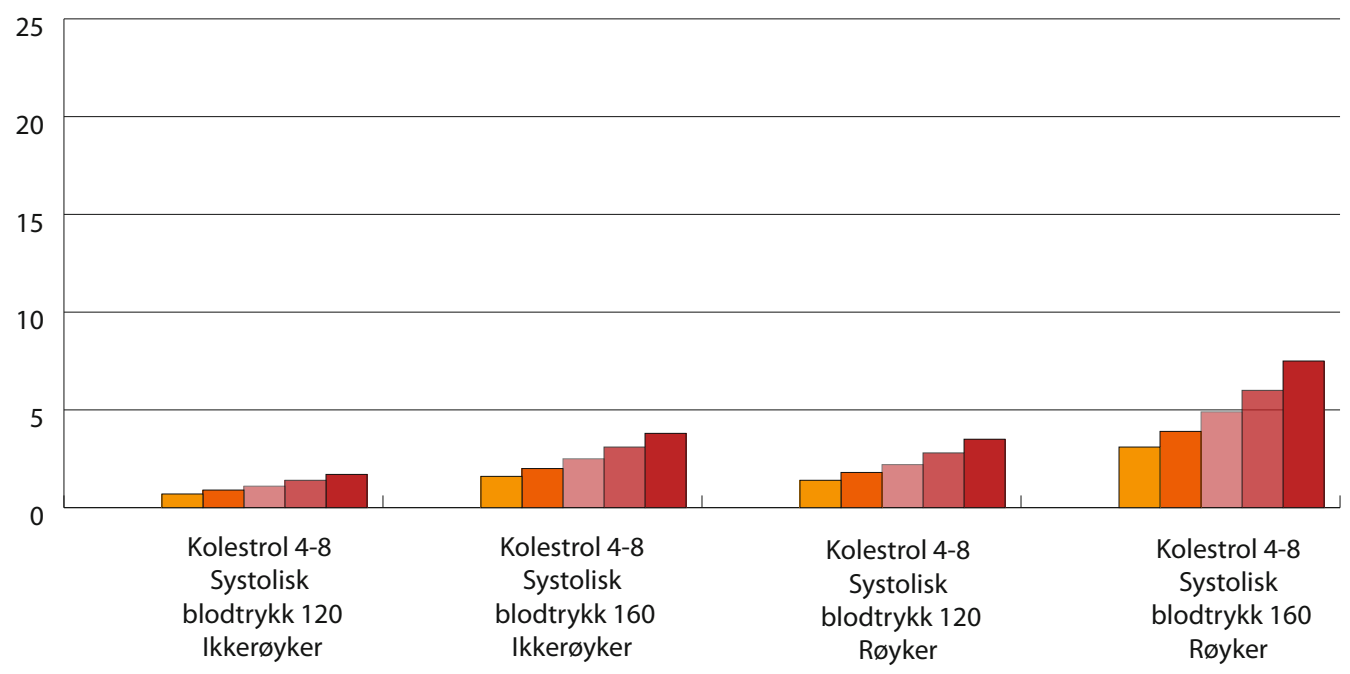

Figur 5b: Kvinner. 10-års risiko for død av hjerte- og karsykdom basert på risikomodellen NORRISK, kvinner 60 år. Kilde: Selmer, 2008; Helsedirektoratet, 2009.

Når flere risikofaktorer opptrer samtidig, øker risikoen langt mer enn summen skulle tilsi, se figur $5 a-b$.

Risikofaktorene for hjerneslag er langt på vei de samme som for hjerteinfarkt, men for denne sykdommen har blodtrykk og atrieflimmer en viktigere rolle.

\section{Nedgang i viktige risikofaktorer, men ikke i overvekt og diabetes}

Beregninger fra Sverige har konkludert med at nedgang i blodkolesterol, blodtrykk og røyking er hovedårsaken til nedgangen i dødeligheten av hjerteinfarkt fra 1986 til 2002 (Björck, 2009).

Fra 1974 til 2002 gikk blodtrykk- og blodkolesterolnivåene ned over hele landet (Jenum, 2007) og undersøkelser i Nord-Trøndelag (Krokstad, 2011) og Tromsø (Eggen, 2014) viser fortsatt nedgang fra 1990-årene til rundt 2008. Den gunstige utviklingen blir imidlertid motarbeidet av en uheldig utvikling $\mathrm{i}$ kroppsvekt, lav fysisk aktivitet og av at en økende andel av befolkningen har type 2 diabetes.

Det er holdepunkter for at depresjon (Hare, 2013) og visse typer luftforurensning øker risikoen for hjerteog karsykdom, og spesielt kan bidra til forverring hos personer som allerede er rammet. Et høyt alkoholinntak øker risikoen, mens et regelmessig, lavt inntak ser ut til å beskytte mot hjerte- og karsykdommer.

\section{Primær- og sekundær- forebygging}

\section{Hjerte- og karsykdommer kan forebygges på ulike måter:}

Primærforebygging består i tiltak for å hindre nye sykdomstilfeller. Hvis dette lykkes, gir det lavere utgifter for samfunnet og lavere helsetap for innbyggerne. Det er vel dokumentert at fravær av tobakksrøyking, sunn kost, fysisk aktivitet og lavt alkoholkonsum er egnet til å forebygge både hjerte- og karsykdom, KOLS, type-2 diabetes og utbredte kreftformer (Helsedirektoratet, 2013).

- Det mest effektive er strukturelle tiltak som gjelder alle, uavhengig av den enkeltes risiko (Helsedirektoratet, 2013; Ezzati, 2012). Lovgivningen om tobakk er et eksempel, introduksjonen av lettmelk et annet, og forbud mot transfett et tredje. Slike tiltak omfatter «folk flest», den store gruppen med lav til moderat risiko, en gruppe som på grunn av størrelsen har potensial til å rekruttere de fleste av morgendagens syke. Strukturelle tiltak motvirker sosial ulikhet ved å være uavhengig av den enkeltes overskudd til å «tenke helse».

- Også pedagogiske tiltak er viktig i forebyggingen.

- En tredje type primærforebygging består $\mathrm{i}$ tilpasset hjelp til personer med særlig høy risiko.

Sekundærforebygging består i tilpasset hjelp for å hindre nye tilfeller eller forverring etter at sykdom har debutert. Det er viktig å få hjelp til rehabilitering dersom funksjonsevnen er truet. 


\section{Forebygging og utfordringer}

\section{Årsaker til nedgangen i dødelighet: Bedre behandling eller nedgang i risikofaktorer?}

Nedgangen i dødelighet kan skyldes færre nye sykdomstilfeller (sunnere levekår og forebygging), mer effektiv behandling, eller begge deler samtidig. Se nedenfor om nedgang i noen risikofaktorer som kan forklare nedgang i dødelighet og sykelighet.

Medisinske og teknologiske framskritt har utvilsomt hatt betydning for nedgangen i dødelighet av hjerteog karsykdommer. I tillegg har det vært en sterk reduksjon i viktige risikofaktorer for hjerte- og karsykdommer fra 1970-tallet.

Beregninger over de ulike faktorenes tallmessige rolle for fallet i hjerte- og kardødelighet har ikke vært utført i Norge. Beregninger i Sverige konkluderte at mer enn halvparten av nedgangen i dødelighet mellom 1986 og 2002 kunne tilskrives en nedgang i de viktigste risikofaktorene, spesielt serum totalkolesterol.

Vi vet ikke hvor mye av nedgangen på 2000-tallet som skyldes endring i risikofaktorene og hvor mye som skyldes forebyggende legemiddelbruk og bedre medisinsk behandling, som for eksempel utblokking av hjertets kransarterier.

I 2013 brukte 40 prosent i aldersgruppen 70 til 79 år kolesterolsenkende medisiner, mens 70 prosent av 80-89-åringene brukte medisiner som i hovedsak brukes ved høyt blodtrykk. En studie fra 2010 viste at rundt 85 prosent fikk medisinene for diagnosen hypertensjon (Blix, 2012).

Andel brukere av blodtrykksmedisiner og kolesterolsenkende midler økte i perioden 2005-2013.

Med det nye hjerte-karregisteret får vi et utmerket hjelpemiddel til å studere trender i sykelighet. For å si noe om betydningen av forebyggingstiltak er det viktig å følge utviklingen også i risikofaktorer for hjerte- og karsykdom. Vi mangler nå landsrepresentative data for de viktigste risikofaktorene.

\section{Fortsatt et stort folkehelse- problem}

Hjerte- og karsykdommer er fortsatt et stort folkehelseproblem, selv om det har vært en gunstig utvikling i dødeligheten. Det er forventet at antallet vil $ø$ ke når etterkrigsgenerasjonen eldes. Bedret overlevelse ventes også å øke både antall og andel som lever med sykdommen, slik det er vist i Danmark (Koch, 2013).

Et uttrykk for denne sykdomsbyrden er at 7550 pasienter hadde over 10000 sykehusopphold på grunn av hjertesvikt i 2012 (FHI, 2014). Hjertesvikt er en livstruende og plagsom tilstand der hjertets pumpefunksjonen er nedsatt. Gjennomgått hjerteinfarkt er den vanligste årsaken.

Det er ikke opplagt hvordan kolesterol- og blodtrykksnivåene vil utvikle seg, og hvor lenge vektøkningen vil fortsette. En studie fra Finland og en fra Sverige viser en økning i serum totalkolesterol etter 2007, i Sverige også en økning i inntak av mettet fett (Vartiainen, 2012; Johansson, 2012).

$\varnothing$ kningen i sykehusinnleggelser for akutt hjerteinfarkt blant yngre voksne er en påminnelse om behovet for forebygging. Dr. Hans Stam, president for European Heart Network, kommenterer dette slik:

- I dag er storparten av offentlige helseutgifter knyttet til behandling. For å bedre folkehelsen i Europa og demme opp for de sosio-økonomiske følgene haster det å investere i forebyggende arbeid* (The European Society of Cardiology, 2012).

*Today most public health expenses are linked to treatment. It is urgent to invest in prevention in order to improve the health of European population and stem the socio-economic consequences

\section{Referanser}

Bjorck, L., A. Rosengren, K. Bennett, G. Lappas and S. Capewell (2009). Modelling the decreasing coronary heart disease mortality in Sweden between 1986 and 2002. Eur Heart J 30(9): 1046-1056. Pubmed.

Blix, H. S., K. Landmark, R. Selmer and A. Reikvam (2012). Forskrivning av antihypertensive legemidler 1975-2010. Tidsskr Nor Laegeforen 132(10): 1224-1228. Pubmed.

Eggen, A. E., E. B. Mathiesen, T. Wilsgaard, B. K. Jacobsen and I. Njolstad (2014). Trends in cardiovascular risk factors across levels of education in a general population: is the educational gap increasing? The Tromso study 1994-2008. J Epidemiol Community Health [Epub ahead of print]. Pubmed.

Estruch, R., E. Ros, J. Salas-Salvado, M. I. Covas, D. Corella, F. Aros, E. Gomez-Gracia, V. Ruiz-Gutierrez, M. Fiol, J. Lapetra, R. M. Lamuela-Raventos, L. Serra-Majem, X. Pinto, J. Basora, M. A. Munoz, J. V. Sorli, J. A. Martinez, M. A. MartinezGonzalez and P. S. Investigators (2013). Primary prevention of cardiovascular disease with a Mediterranean diet. N Engl J Med 368(14): 1279-1290. Pubmed.

Ezzati, M. and E. Riboli (2012). Can noncommunicable diseases be prevented? Lessons from studies of populations and individuals. Science 337(6101): 1482-1487. Pubmed, Science. 
FHI, 2014. Hjerte- og karregisteret - rapport for 2012. Oslo/ Bergen, Folkehelseinstituttet.

FHI, Folkehelseinstituttet, 2013. Statistikk fra Norgeshelsa. [hentet 1/12/2014].

Hare, D. L., S. R. Toukhsati, P. Johansson and T. Jaarsma (2013). Depression and cardiovascular disease: a clinical review. Eur Heart J. Pubmed.

Helsedirektoratet. Nasjonale retningslinjer for individuell primærforebygging av hjerte- og karsykdommer. Oslo, Helsedirektoratet. (2009). Helsedirektoratet.

Helsedirektoratet. Reduksjon i ikke-smittsomme sykdommer - nasjonal oppfølging av WHOs mål. Oslo, Helsedirektoratet (2013). www.helsedirektoratet.no

Jenum, A. K., S. Graff-Iversen, R. Selmer and A. J. Sogaard (2007). Risikofaktorer for hjerte- og karsykdommer og diabetes gjennom 30 år. Tidsskr Nor Laegeforen 127(19): 2532-2536. Pubmed.

Johansson I, Nilsson LM, Stegmayr B, Boman K, Hallmans G, Winkvist A. Associations among 25-year trends in diet, cholesterol and BMI from 140,000 observations in men and women in Northern Sweden. Nutrition Journal 2012 11: 40. doi:10.1186/1475-2891-11-40 Nutrition Journal.

Koch, M. B., M. Davidsen, L. V. Andersen, K. Juel and G. B. Jensen (2013). Increasing prevalence despite decreasing incidence of ischaemic heart disease and myocardial infarction. A national register based perspective in Denmark, 1980-2009. Eur J Prev Cardiol. Pubmed.

Krokstad, S. and M. S. Knudtsen Folkehelse i endring: Helseundersøkelsen Nord-Trøndelag : HUNT 1 (1984-86) - HUNT 2 (1995-97) - HUNT 3 (2006-08). Levanger, HUNT forskningssenter. (2011). HUNT, rapport 2011.

Kumar, B. N., R. Selmer, A. S. Lindman, A. Tverdal, K. Falster and H. E. Meyer (2009). Ethnic differences in SCORE cardiovascular risk in Oslo, Norway. Eur J Cardiovasc Prev Rehabil 16(2): 229-234. Pubmed.

Lozano, R., M. Naghavi, K. Foreman, S. Lim, K. Shibuya et al. (2012). Global and regional mortality from 235 causes of death for 20 age groups in 1990 and 2010: a systematic analysis for the Global Burden of Disease Study 2010. Lancet 380(9859): 2095-2128. Pubmed.

Murray, C. J., T. Vos, R. Lozano, M. Naghavi, A. D. Flaxman et al. (2012). Disability-adjusted life years (DALYs) for 291 diseases and injuries in 21 regions, 1990-2010: a systematic analysis for the Global Burden of Disease Study 2010. Lancet 380(9859): 2197-2223. Pubmed.
Nichols, M., N. Townsend, P. Scarborough and M. Rayner European Cardiovascular Disease Statistics 2012, European Heart Network, European Society of Cardiology: 125 s., ill. (2012). Pubmed.

Rabanal, K. S., A. S. Lindman, R. M. Selmer and G. Aamodt (2013). Ethnic differences in risk factors and total risk of cardiovascular disease based on the Norwegian CONOR study. Eur J Prev Cardiol 20(6): 1013-1021. Pubmed.

Selmer, R., A. S. Lindman, A. Tverdal, J. I. Pedersen, I. Njolstad and M. B. Veierod (2008). Modell for estimering av kardiovaskulaer risiko i Norge. Tidsskr Nor Laegeforen 128(3): 286-290. Tidsskrift for Den norske legeforening.

Strand, B. H., E. K. Groholt, O. A. Steingrimsdottir, T. Blakely, S. Graff-Iversen and O. Naess (2010). Educational inequalities in mortality over four decades in Norway: prospective study of middle aged men and women followed for cause specific mortality, 1960-2000. BMJ 340: c654. Pubmed.

Sulo, G., J. Igland, O. Nygard, S. E. Vollset, M. Ebbing and G. S. Tell (2014a). Favourable trends in incidence of AMI in Norway during 2001-2009 do not include younger adults: a CVDNOR project. Eur J Prev Cardiol, 21(11): 1358-64. Pubmed.

Sulo, G., S. E. Vollset, O. Nygard, J. Igland, G. M. Egeland, M. Ebbing and G. S. Tell (2014b). Trends in Acute Myocardial Infarction Event Rates and Risk of Recurrences After an Incident Event in Norway 1994 to 2009 (from a Cardiovascular Disease in Norway Project). Am J Cardiol 113:17771781. Pubmed.

Vartiainen E,Borodulin K, Sundvall J et al. Finriski-tutkimus: Väestön kolesterolitaso on vuosikymmenien laskun jälkeen kääntynyt nousuun (Cholesterol levels in Finnish population have increased after decades of decline). Soumen Lääkärilehti 2012;35:2364-8. Summary in English: Finnish Medical Journal.

WHO. European Health for All database (HFA-DB) World Health Organization. Hentet 30/5/2014, fra WHO.

WHO. Global status report on noncommunicable diseases 2010. Geneva, World Health Organization. (2011). www. who.int

\section{FORFATTERE}

Randi Selmer, Grace Egeland Hovda, Sidsel Graff-Iversen og Solveig Sakshaug 
- Alvorlige smittsomme sykdommer er mindre vanlig i Norge enn i de fleste andre land.

- Situasjonen kan endre seg raskt. Økt smittepress gjennom internasjonal handel med matvarer og dyr, migrasjon og reising kan få konsekvenser for folkehelsen, også i Norge.

- Hver 20. pasient i helseinstitusjoner rammes av en «sykehusinfeksjon».

- Cirka 20000 personer er kroniske bærere av hepatitt B, de fleste er smittet før de kom til Norge.

- Cirka 20000 personer er bærere av hepatitt C, de fleste er smittet gjennom sprøyter.

- Antall nye tilfeller av tuberkulose har økt til om lag 400 tilfeller i året.

- Antibiotikaresistens er et økende problem.

- Høy vaksinasjonsdekning, godt smittevern og effektivt overvåkingssystem er fortsatt viktig for å holde infeksjonssykdommene under kontroll.

\section{Infeksjonssykdommer i Norge i dag}

Infeksjonssykdommer er sykdommer forårsaket av mikroorganismer som bakterier, virus, sopp eller parasitter.

Infeksjonssykdommene rammer hvert år et stort antall mennesker i Norge, men de er sjelden livstruende. De står i dag for 2,4 prosent av dødsårsakene i Norge.

Under avsnittet «Status og utfordringer» nedenfor gjennomgås situasjonen for flere av de infeksjonssykdommene som overvåkes gjennom Meldingssystem for smittsomme sykdommer (MSIS) eller andre systemer.

Se kapittel Mat og vannbårne infeksjoner.

\section{Utvikling over tid}

Til langt utpå 1900-tallet var epidemier og infeksjonssykdommer de dominerende folkesykdommene i Norge. Det er særlig fire forhold som har bidratt til at infeksjoner har blitt et mindre folkehelseproblem:

- Høyere levestandard med innføring av moderne kloakksystemer, trygg drikkevannsforsyning, bedre ernæring, bedre boliger og mindre trangboddhet

- Generelt hygienearbeid

- Vaksiner

- Antibiotika og andre antimikrobielle midler Se også kapittel Folkehelse i Norge 1814-2014.

\section{Risikogrupper i befolkningen}

Noen grupper har økt risiko for å bli smittet med en infeksjonssykdom, eller økt risiko for at sykdommen får et alvorlig forløp:

- Personer i noen innvandrergrupper har økt risiko for å bli smittet med en alvorlig infeksjonssykdom når de besøker slektninger og venner i sitt tidligere hjemland.

- Menn som har sex med menn, er mer utsatt for seksuelt overførbare infeksjoner, for eksempel hiv-infeksjon.

- Injiserende stoffmisbrukere er mer utsatt for blodsmittesykdommer som hepatitt A, B og C, samt infeksjoner med sporedannende bakterier som botulisme.

Hvor alvorlig en infeksjonssykdom blir, vil ofte avhenge av om immunforsvaret på forhånd er svakt. 
- Omtrent halvparten av kikhostetilfellene forekommer hos voksne over 19 år, men det er bare hos barn under ett år det noen ganger registreres dødsfall.

- Risikoen for alvorlig influensasykdom er størst blant eldre, personer med hjerte- og karsykdommer, lungesykdommer, gravide og personer med nedsatt immunforsvar. De fleste dødsfallene skjer hos eldre.

\section{God status i Norge, men noen særtrekk}

Antall nye tilfeller av infeksjonssykdommer er lavere i Norge enn i andre europeiske land. Det viser statistikk fra meldingssystem for smittsomme sykdommer (MSIS). Det er imidlertid noen unntak:

- De siste årene har antall meldte tilfeller av kikhoste i Norge vært blant de høyeste i Europa.

- Et spesielt trekk ved situasjonen i Norge er at personer smittet før innvandring til Norge utgjør enn større andel av de som lever med enkelte kroniske infeksjoner som hivinfeksjon, tuberkulose og hepatitt B enn man ser i andre europeiske land.

\section{Globalisering øker smittefaren i Norge}

$\varnothing \mathrm{kt}$ internasjonal reisevirksomhet, internasjonal handel med matvarer og avlsdyr, endrede matvaner og høyt forbruk av antibiotika gir utfordringer for framtidige infeksjonssykdommer og utbrudd. Vi må også være forberedt på nye influensapandemier.

Situasjonen i andre land påvirker sykdomspanoramaet i Norge. En forholdsvis stor andel av de meldte tilfellene av infeksjonssykdommer i Norge, er smittet ved utenlandsreiser. De siste årene har denne andelen vært cirka 20 prosent, viser statistikk fra MSIS.

Eksempler på smitte utenlands er seksuelt overførbare infeksjoner og vann- og matbårne infeksjoner (se kapittel Mat og vannbårne infeksjoner).

Med økende mobilitet i verdens befolkning er det også en utfordring å opprettholde lavere forekomst av tuberkulose innenfor Norges grenser. En stor andel av både tuberkulosetilfellene og hepatittilfellene er smittet før ankomst til Norge.

\section{Status og utfordringer for de enkelte smittsomme sykdommene}

Nedenfor følger omtale av de viktigste smittsomme sykdommene. Se eget kapittel når det gjelder Mat- og vannbårne infeksjoner.

\section{Barnesykdommene: fortsatt god vaksinasjonsdekning viktig}

Innføringen av vaksiner har vært et av de mest effektive tiltakene i forebyggingen av infeksjonssykdommer.

Meldte tilfeller: I Norge er det få sykdomstilfeller av de sykdommene vi vaksinerer mot i barnevaksinasjonsprogrammet. Et unntak er kikhoste. Fra 1997 er det observert en betydelig økning i antall kikhostetilfeller, særlig hos eldre barn og unge. Forklaringen er sannsynligvis at vaksinens effekt avtar etter fem- seks år. I barnevaksinasjonsprogrammet er det derfor innført en oppfriskningsdose ved 7 og 15 års alder.

Utbrudd: I miljøer med dårlig vaksinasjonsdekning opptrer det noen ganger mindre utbrudd av barnesykdommer. I 2011 var det et meslingutbrudd med utgangspunkt i en bydel i Oslo, hvor vaksinasjonsdekningen for MMR-vaksinen (meslinger, røde hunder og kikhoste) lå klart under landsgjennomsnittet, med bare 85 prosent dekning for barn født i 2008. En relativt høy andel av de smittede var barn fra et innvandrermiljø, hvor skepsisen til MMR-vaksine var særlig høy.

Vaksinasjonsdekning: Vaksiner tilbys som en del av det nasjonale barnevaksinasjonsprogrammet.

Vaksinasjonsdekningen for vaksinene i barnevaksinasjonsprogrammet ligger mellom 90 og 95 prosent. For vaksine mot human papillomavirus (HPV) er dekningen noe lavere, fordi denne vaksinen først ble innført i 2009.

Utfordringer: Vaksinasjonsdekningen i Norge er høy når det gjelder barnesykdommene. Dette viser tall fra Nasjonalt vaksinasjonsregister (SYSVAK). Å beholde en vedvarende høy vaksinasjonsdekning i befolkningen er viktig for å opprettholde den gode situasjonen Norge er i.

Avhengig av sykdommens smittsomhet er det nødvendig med en vaksinasjonsdekning på 80-95 prosent for å holde sykdommen under kontroll.

Kriger og intern uro, med svekkelse av vaksinasjonsprogrammer i andre land kan gi økt risiko for import av «gamle» infeksjonssykdommer. Det er derfor viktig 
å ha en kontinuerlig overvåking som fanger opp endringer mht. de sjeldne infeksjonssykdommene. (FHI, 10 års rapport barnevaksinasjonsprogrammet).

\section{Hepatitt B og C: behov for bedre forebygging}

Hepatitt B og C er viktige årsaker til alvorlig leversykdom.

Meldte tilfeller: Cirka 20000 personer er kroniske bærere av hepatitt B, de fleste er innvandrere og asylsøkere smittet før ankomst Norge. Antall meldte tilfeller av akutt hepatitt B er lavt i Norge.

Omlag 20000 personer lever med hepatitt C i dag, og infeksjonen rammer i hovedsak injiserende stoffmisbrukere. Fremdeles smittes mange hvert år.

Vaksinasjon: Bare barn og unge under 25 år, med foreldre som er født i land med høy forekomst av hepatitt B, tilbys i dag vaksine mot hepatitt B igjennom barnevaksinasjonsprogrammet. Flere forhold sett samlet, blant annet økende smittepress i befolkningen og lav vaksinasjonsdekning i risikogrupper, taler for å innføre hepatitt B vaksinasjon til alle barn i Norge. Det finnes ingen vaksine mot Hepatitt $C$.

Utfordringer: Norge er et av de svært få land i verden som ikke tilbyr hepatitt B-vaksine til alle barn i barnevaksinasjonsprogrammet. I tillegg er det ikke allmenn screening av gravide for hepatitt B. Slike tiltak kan på sikt være svært viktige for å forebygge hepatitt B-smitte.
Injisering av rusmidler er vanligere i Norge enn $\mathrm{i}$ mange andre europeiske land, og prevalensen av hepatitt $\mathrm{C}$ blant injiserende stoffmisbrukere høyere. Tiltak for å redusere injiserende stoffmisbruk samt tilgang på rene sprøyter og annet brukerutstyr er viktig for å forebygge nye tilfeller av hepatitt $C$.

Behandlingsmuligheter for kronisk hepatitt B og C er forbedret. Dersom antallet pasienter med hepatitt B og $C \varnothing k e r$, vil behandlingen $\mathrm{i}$ årene framover medføre en betydelig utfordring både med hensyn på kostnader og ressursbruk.

\section{Influensa: risikoen for en ny pandemi}

Hvert år rammes den nordlige halvkule av influensaepidemi i vintersesongen (sesonginfluensa).

Opptil 10 prosent blir hvert år syke av sesonginfluensa i Norge, se figur 1 . Som figuren viser varierer utbruddets størrelse fra år til år. I tillegg starter utbruddet på ulike tidspunkt.

Dødsfall: Årlig dør flere hundre personer av sesonginfluensa eller komplikasjoner etter influensa. Dette er i hovedsak personer som tilhører risikogruppene. En sjelden gang blir også personer utenfor risikogruppen alvorlig syke og $\mathrm{d} ø$.

Vaksinasjonsdekning: Anbefaling fra WHO er at minst 75 prosent av risikogruppene (se under risikogrupper ovenfor) bør vaksiner seg. I Norge blir under 50 prosent i risikogruppene vaksinert, og for ansatte i helsevesenet er vaksinasjonsdekningen ofte enda lavere.

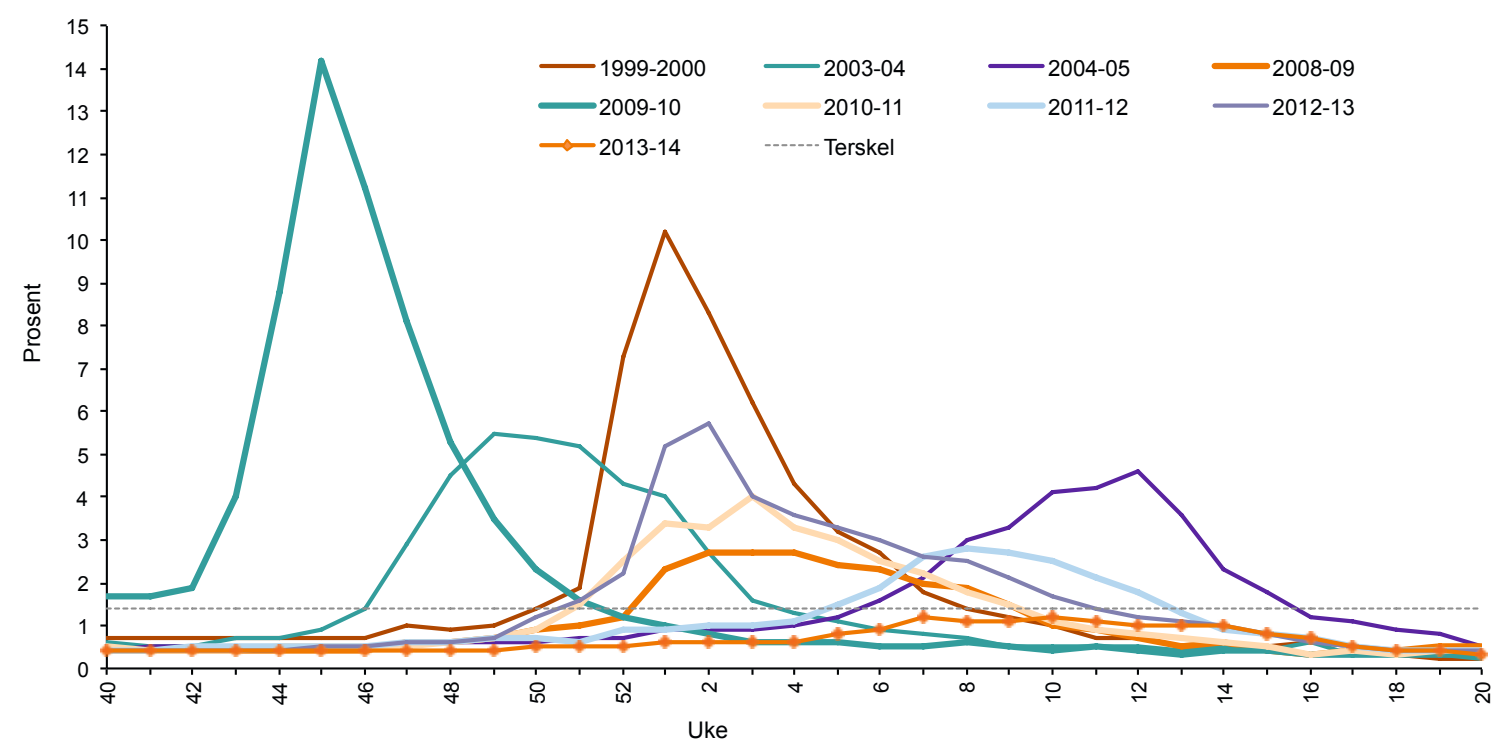

Figur 1: Andel av pasientene som har vært hos lege og fått diagnosen influensaliknende sykdom i 1998-2010. Kilde: Folkehelseinstituttet. 
Norge har gjennom Folkehelseinstituttet et system for å overvåke influensasykdom, og rapporterer data inn i internasjonale overvåkingssystem (ECDC og WHO). Ved en framtidig pandemi vil et godt overvåkingssystem både i primær- og spesialisthelsetjenesten være svært viktig for å vurdere alvorligheten av utbruddet, dimensjonere helsetjenesten og optimalisere vaksineanbefalingene i henhold til den aktuelle situasjonen.

Under «svineinfluensa-pandemien» i 2009-2010 ble 2,2 millioner (45 prosent) av befolkningen vaksinert. Man vet ikke nøyaktig hvor mange som ble smittet av viruset. En studie utført av Folkehelseinstituttet viste imidlertid at nesten 60 prosent av befolkningen i Norge ved begynnelsen av 2010 hadde målbar immunitet mot viruset som forårsaket «svineinfluensaen (A (H1N1)). Denne immuniteten ble oppnådd gjennom vaksinasjon eller gjennomgått sykdom.

Utfordringer: For influensa er vaksinasjonsdekningen lavere enn ønskelig. Alle i risikogruppene for alvorlig influensasykdom får årlig tilbud om influensavaksine. $\varnothing$ kt kunnskap om vaksinasjonsdekning og holdninger til vaksinasjon er nødvendig for å øke andelen som vaksinerer seg mot sesonginfluensa. Folkehelseinstituttet jobber også for å få bedre overvåking av alvorlig influensasykdom på sykehus.

\section{Seksuelt overførbare infeksjoner: høyere tall enn ønskelig}

De vanligste seksuelt overførbare infeksjonene i Norge i dag er klamydiainfeksjoner, genital herpes og humant papillomavirusinfeksjoner (HPV).
Klamydia: Antall årlig diagnostiserte tilfeller av klamydiainfeksjoner i Norge økte gjennom en 10-årsperiode fram til 2008, og har siden da vært stabilt høyt (om lag 22000 tilfeller årlig). Det er særlig personer i alderen 15-25 år som smittes. Klamydiainfeksjoner gir sjelden plager, og mange infeksjoner blir aldri oppdaget.

Ubehandlet kan klamydiainfeksjon hos et fåtall av de smittede føre til redusert fruktbarhet.

Genital herpes og HPV: Genital herpes og HPV-infeksjonene er ikke meldingspliktige til MSIS i dag. Den reelle forekomsten er derfor ikke kjent, men flere tusen smittes av disse infeksjonene hvert år. Fra 1.juli 2014 er HPV infeksjon som har forårsaket kreft eller forstadier til kreft meldingspliktig til MSIS.

HPV er en viktig årsak til livmorhalskreft. Siden 2009 har 12årige jenter i Norge fått tilbud om vaksine som en del av barnevaksinasjonsprogrammet. Studier pågår for å kartlegge endringer i forekomst av HPV.

Hiv: Hiv er fortsatt en alvorlig og livslang infeksjon, selv om behandling og prognose er klart forbedret de siste årene. Det påvises nå årlig 250-300 hivtilfeller i Norge, se figur 2:

- Om lag halvparten av tilfellene er blant asylsøkere og familieinnvandrere fra land med høy forekomst av hiv.

- Blant menn som har seksuell kontakt med menn, har forekomsten av hiv økt betydelig siden årtusenskiftet.

- Forekomsten er stabilt lav blant heteroseksuelle, sprøytemisbrukere og unge.

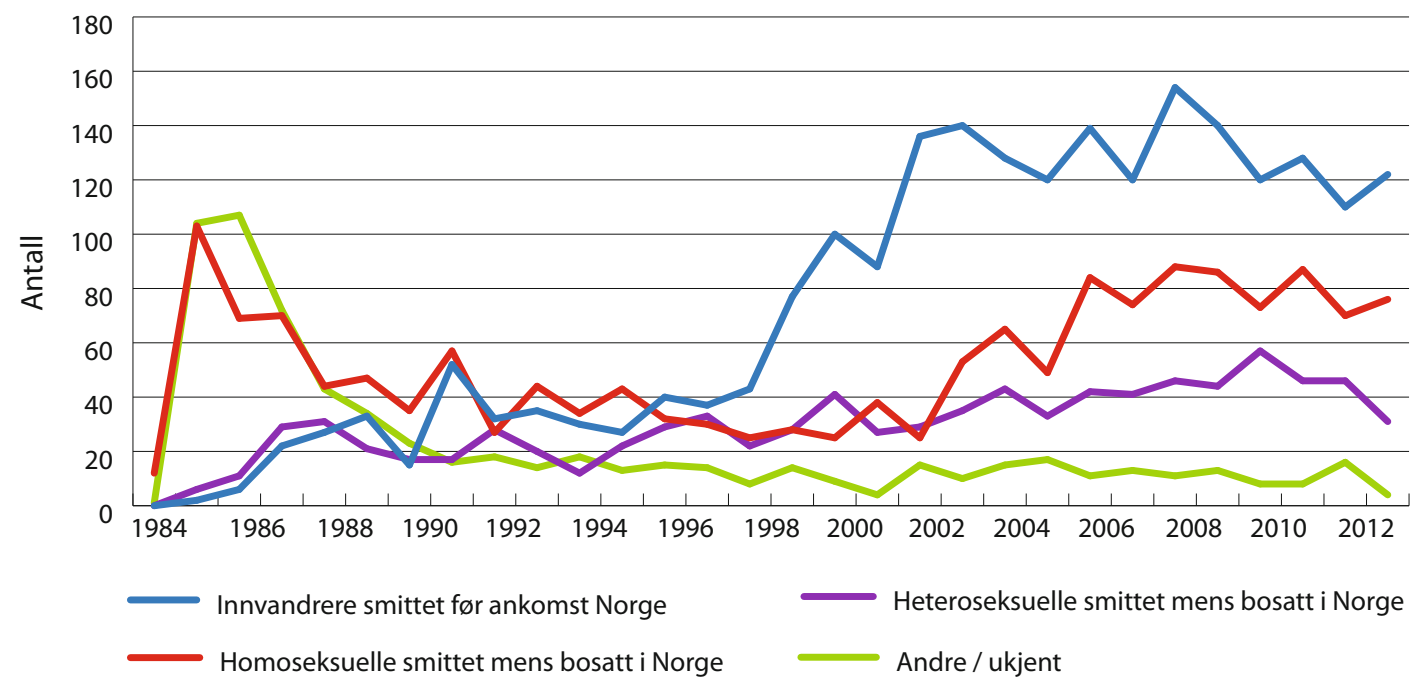

Figur 2: Antall tilfeller av hiv i perioden 1984-201, fordelt på ulike risikogrupper. Kilde: MSIS/Folkehelseinstituttet. 
Gonoré og syfilis: Det er få tilfeller av gonoré og syfilis i den generelle befolkningen. Mest utsatt er menn som har seksuell kontakt med andre menn, og menn som har seksuell kontakt i utlandet. Gonorébakteriens evne til å utvikle motstandskraft (resistens) mot antibiotika er et økende problem i behandlingen av sykdommen.

- Kapittel Antibiotikaresistens

\section{Utfordringer}

Antall nye tilfeller av seksuelt overførbare infeksjoner er høyere enn ønskelig. En kombinasjon av tiltak i og utenfor helsetjenesten er nødvendig for å nå fram til utsatte grupper med forebyggende tiltak. For eksempel er det behov for å øke kondombruken og tilby mer målrettet, tidlig diagnostikk, samt lavterskeltilbud for undersøkelse og behandling.

\section{Tuberkulose: mest smitte utenlands}

Tuberkulose kan ramme alle organer i kroppen, men lungetuberkulose er den vanligste formen. I praksis er det bare ubehandlet lungetuberkulose som smitter andre.

Forekomst og utvikling over tid: Insidensen har økt fra cirka 200 tilfeller i 1997 til cirka 400 tilfeller i 2013, se figur 3. Tuberkulose er fortsatt en sjelden sykdom i Norge, spesielt blant norskfødte.

- De fleste som får tuberkulose i Norge i dag, er smittet utenfor Norge.

- Bare om lag 5 prosent av de som er smittet vil noen gang bli syke av tuberkulose.

- Andelen smittede som blir syke er høyere i enkelte risikogrupper, for eksempel de som har nedsatt immunforsvar.

- Smittede tilbys forebyggende medikamentell behandling. Rundt 750 personer får årlig slik behandling.
Resistens: Noen typer tuberkulose er resistent mot minst to av de viktigste medikamentene mot tuberkulose, såkalt multiresistent tuberkulose. Årlig blir det meldt om fem til åtte slike tilfeller i Norge. Behandlingen av multiresistent tuberkulose kan ta over to år, og er krevende. Se også kapittel Antibiotikaresistens.

Vaksinasjon: BCG-vaksinasjon mot tuberkulose tilbys til barn av foreldre fra land med høy forekomst av tuberkulose. Begrunnelsen er at de sannsynligvis vil ha kontakt med familie og venner fra foreldrenes fødeland i løpet av livet, og at deres livstidsrisiko derfor er høyere enn andre norske barns. Dessuten anbefales BCG vaksine til helsepersonell, spesielt smitteutsatte, og som reisevaksine.

Utfordringer og forebyggende tiltak: Det viktigste enkelttiltaket for å forebygge tuberkulose i Norge er tidlig diagnose av smittsomme tilfeller. Rundt hvert tilfelle av lungetuberkulose gjøres det også rutinemessig smitteoppsporing for å fange opp personer som kan være smittet. Ofte kreves det mye arbeid for å nå fram til de som er mest smitteutsatte.

Nesten en tredjedel av verdens befolkning er smittet av tuberkulose. Personer som kommer fra land med høy forekomst av tuberkulose og som skal være i Norge i mer enn tre måneder, har plikt til å la seg undersøke for tuberkulose. Det er imidlertid ikke uvanlig at dette glipper. Dette skyldes blant annet at det er mange involverte instanser, og fordi undersøkelsen forutsetter gjentatte oppmøter fra den som skal undersøkes. Det planlegges en forenkling av undersøkelsen for latent tuberkulose fra høsten 2014 for å høyne oppslutningen.

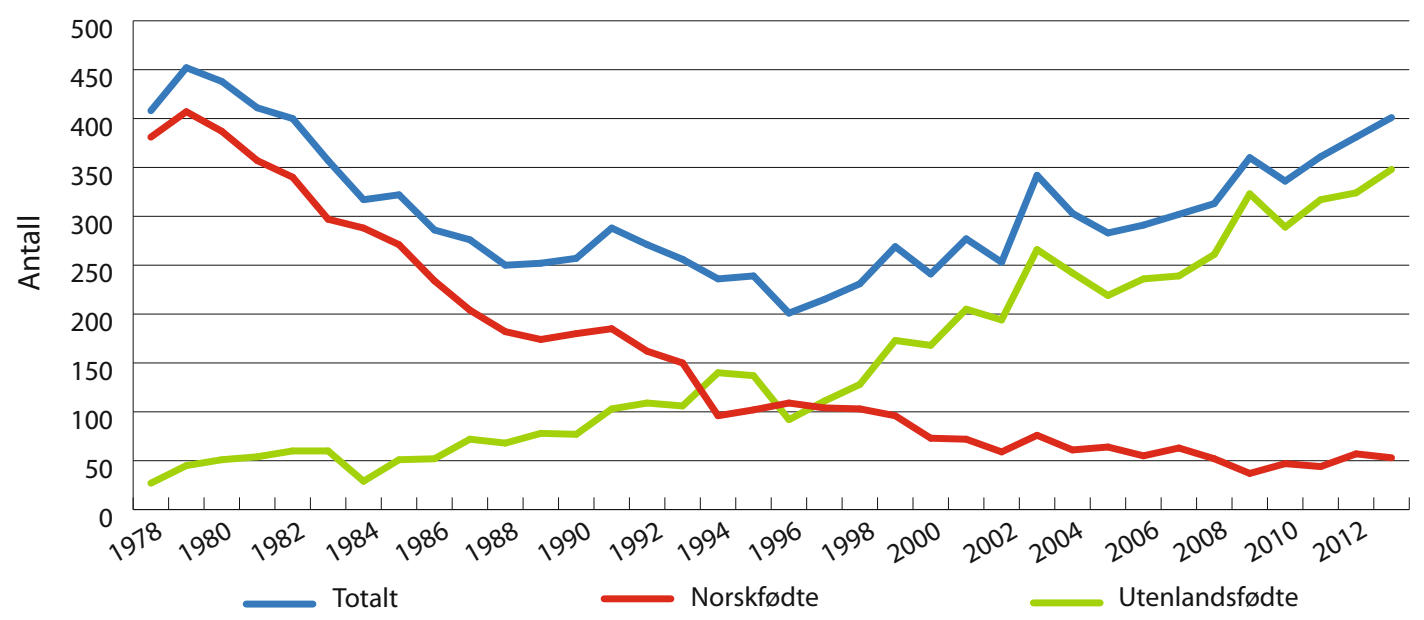

Figur 3. Antall meldte tilfeller av tuberkulose i Norge etter fødested. Utvikling i perioden 1979-2013. Kilde: MSIS og tuberkuloseregisteret. 


\section{Sykehusinfeksjoner: hver 20. pasient rammes}

Helsetjenesteassosierte infeksjoner (sykehusinfeksjoner) er infeksjoner som oppstår i forbindelse med et opphold i en helseinstitusjon. Typiske infeksjoner er infeksjoner i forbindelse med bruk av urinveiskatetre og infeksjoner i operasjonsområde.

Forekomst: Til enhver tid har fem til seks prosent av pasientene i norske sykehus en helsetjenesteassosiert infeksjon, det vil si hver 20. pasient. Eldre, svekkede og personer med nedsatt immunforsvar er mest utsatt.

Utfordringer og forebyggende tiltak: Helseinstitusjonene er i økende grad også utsatt for mikrober som er motstandsdyktige mot antibiotika.

Helsetjenesteassosierte infeksjoner er dyre for samfunnet, og kan få alvorlige konsekvenser for pasientene. Pasientene trenger ekstra pleie, ligger lengre i sykehuset og må behandles med antibiotika, med økt risiko for bivirkninger og resistensutvikling. Det kan også oppstå komplikasjoner, som i verste fall kan føre til døden.

Det antas at opp mot én tredjedel av helsetjenesteassosierte infeksjoner kan forebygges, blant annet gjennom gode rutiner og smitteverntiltak.

Infeksjoner i helseinstitusjoner overvåkes nasjonalt gjennom Norsk overvåkingssystem for antibiotikabruk og helsetjenesteassosierte infeksjoner (NOIS). Tilbakemeldinger til institusjonene om resultater av overvåkingen kan medvirke til å opprettholde gode smitteverntiltak.

\section{Beredskap og overvåking}

God overvåking og beredskap mot smittsomme sykdommer er viktig for å holde infeksjonssykdommene under kontroll. Med effektiv overvåking kan endringer i sykdomsbilder oppdages raskt, og tiltak kan kjapt iverksettes når det oppstår utbrudd.

\section{$\varnothing$ kende antibiotikaresistens}

Det er et økende og svært alvorlig problem at mikrober utvikler motstandsdyktighet (resistens) mot antibiotika. Selv om det har vært en økning av resistens også i Norge, er problemet foreløpig mindre her enn i de fleste andre land.

Den viktigste årsaken til utvikling av resistens er bruk av antibiotika hos mennesker og dyr.

Den økende forekomst av antibiotika-resistens globalt er en av de største truslene for fremtidig medisinsk behandling. En økt forekomst av resistente bakterier vil medføre at:

- Inngrep som i dag gjennomføres med lav risiko, for eksempel innsettelse av leddproteser eller kreftbehandling, vil få en betydelig høyere risiko for alvorlige komplikasjoner.

- Det vil ta lengre tid å bli frisk i forbindelse med infeksjoner og sykehusopphold blir forlenget

- Det kan bli nødvendig å bruke dyrere medikamenter med flere bivirkninger enn vanlig sersom pasienten har infeksjon med en resistent bakterie. I verste fall risikerer pasienten å få infeksjon med en bakterie som er resistent mot alle tilgjengelige antibiotika. Slike tilfeller rapporteres med økende hyppighet internasjonalt, også i Europa.

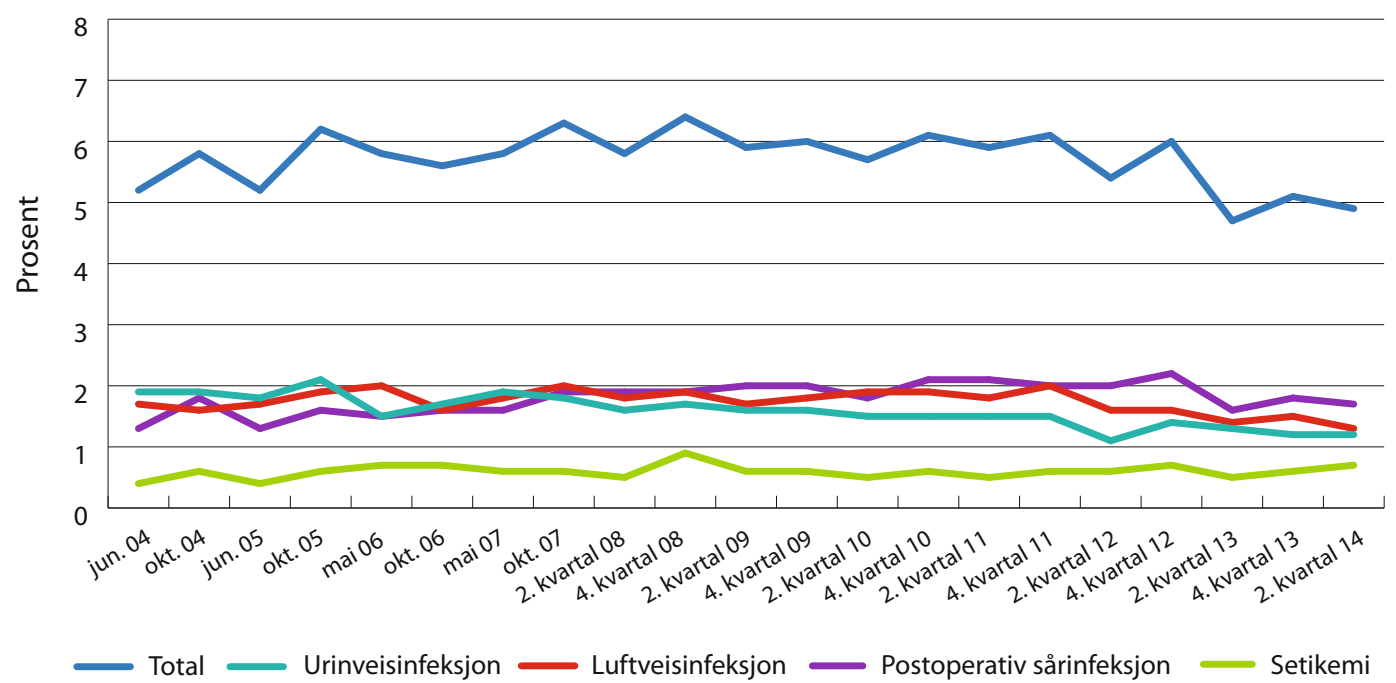

Figur 4. Forekomst av infeksjoner i sykehus 2004 - 2013, fordelt på infeksjonstype. Prosent. Forekomsten er stabil over tid. Forkortelser: Sept = blodforgiftning, SI =sårinfeksjoner, NIvi = lungebetennelse, UVI = urinviesinfeksjoner. Kilde: Norsk overvåkingssystem for antibiotikabruk og helsetjenesteassosierte infeksjoner (NOIS)/Folkehelseinstituttet. 
- Forebygging av antibiotikaresistens gjøres gjennom å:

- samarbeide internasjonalt om å begrense spredning av resistente bakterier

- redusere antibiotika-forbruket i alle deler av samfunnet

- begrense forurensning av miljøet med antibiotika

- utvikle nye antibiotika for at helsetjenesten også i fremtiden skal kunne levere avansert medisinsk behandling på en trygg måte

Se også kapittel Antibiotikaresistens.

\section{Referanser}

Arnesen, T. M. Tuberkulose i Norge 2012: med behandlingsresultater for 2011. Oslo, Folkehelseinstituttet. (2013).

Blystad, H., H. Kløvstad, V. Kostova, Ø. Nilsen, S. Sandbu, K. Stene-Johansen, M. Steinbakk, P. K. Svendsen and I. S. Samdal Vik Blod- og seksuelt overførbare sykdommer. Årsrapport 2012 for sykdomsprogrammet, Folkehelseinstituttet. (2013).
The Difference Between Latent TB Infection and TB Disease. Centers for Disease Control and Prevention. Hentet 19/6/2014, fra http://www.cdc.gov/tb/publications/factsheets/general/ltbiandactivetb.htm.

European Centre for Disease Prevention and Control Chlamydia control in Europe: literature review. Stockholm, European Centre for Disease Prevention and Control: 82 (pdf). (2014).

Pedersen, A. G. Dødelighetsmønstret i endring: Fra infeksjoner til livsstil. Historisk helsestatistikk. Dødsårsaker 1850-2004.

Sandbu, S. Anbefalinger for bruk av hepatitt B-vaksine i Norge. Oslo, Nasjonalt folkehelseinstitutt. 2008:9: (2009).

Stene-Larsen, G. (2006). 1880-2005 - fra fattigdomssykdommer til overflodslidelser. Tidsskrift for den Norske Legeforening 126(1): 38-43.

Tuberculosis. Fact sheet No.104. World Health Organization. Hentet 19/6/2014, fra $\underline{\text { WHO}}$.

\section{FORFATTERE}

Siri Seterelv, Trude Arnesen, Hans Blystad, Siri Hauge, Hilde Kløvstad, Karin Nygård og Line Vold 
- 30000 nye krefttilfeller ble diagnostisert i Norge i 2012 (16 500 menn og 13500 kvinner)

- Det ventes en ytterligere økning i antall krefttilfeller

- Spesielt ventes det en økning i antall tilfeller av føflekkreft

- 5800 menn og 5100 kvinner døde av kreft i 2012

- Forekomsten av kreft er omtrent 40 prosent høyere og dødeligheten mer enn 50 prosent høyere blant menn enn blant kvinner

- Med dagens kreftforekomst og -dødelighet vil omlag hver tredje nordmann få diagnostisert kreft før de blir 75 år gamle

\section{Om kreft}

Kreft er en fellesbetegnelse for en hel rekke sykdommer som kan ha forskjellige risikofaktorer og ulik sykdomsutvikling. Felles er at de starter med ukontrollert celledeling, og at kreftcellene kan spre seg via blod eller lymfesystemet til andre deler av kroppen og lage nye kreftsvulster (metastaser) (Kreftregisteret, 2014)

\section{Om lag 30000 nye tilfeller i 2012}

Nye tilfeller av kreft er her hovedsakelig analysert/ vurdert ved hjelp av statistikk fra Kreftregisteret. I tillegg er det benyttet tall fra Dødsårsaksregisteret og fra en nordisk database over kreftforekomst i de nordiske land (NORDCAN).

Litt over 30000 nye krefttilfeller ble diagnostisert i Norge i 2012 (om lag 16500 menn og 13500 kvinner) (Kreftregisteret, 2014). Tykktarmskreft, lungekreft og kreft i bryst (kvinner) og prostata (menn) er de største kreftformene.

\section{Om lag 225000 lever med kreft}

I 2012 var det i underkant av 225000 personer i Norge som hadde fått en kreftsykdom tidligere (Kreftregisteret, 2014). Spesielt var det mange som hadde fått prostata- eller brystkreft, henholdsvis 37000 og 40 000. Det var i overkant av 20000 som hadde fått diagnosen føflekkreft.
Om lag 11000 døde av kreft i 2012 I underkant av 11000 døde av kreft i 2012, om lag 5800 menn og 5100 kvinner (Kreftregisteret, 2014). Lungekreft var den kreftformen som tok flest liv, om lag 1250 menn og 950 kvinner. Også tykktarmskreft tok mange liv, om lag 600 menn og 600 kvinner.

\section{Utvikling over tid}

Antall nye krefttilfeller hvert år har økt fra ca. 4000 tilfeller rundt 1960 til om lag 30000 nye tilfeller i 2012 (Kreftregisteret, 2014).

\section{Nye tilfeller vil øke}

Tabell 1 viser antall krefttilfeller totalt og for noen utvalgte kreftformer i 2011 (Engholm, 2013). Fra 2011 til 2016 vil årlig antall nye krefttilfeller øke med 14 prosent for menn og 10 prosent for kvinner. En stor del av økningen vil skyldes flere eldre i befolkningen, se tabell 1. Denne tabellen viser også hvor stor andel av de forventede endringene som vil skyldes endringer $i$ befolkningsstrukturen.

- Antall krefttilfeller for menn forventes å øke med 14 prosent, 11 prosent bare p.g.a. endringer i befolkningssammensetningen.

- Antall krefttilfeller for kvinner forventes å øke med 10 prosent, 6 prosent bare p.g.a. endringer i befolkningssammensetningen.

Den store økningen som har vært i forekomsten av prostatakreft skyldes bl.a. økt testing med prostata spesifikt antigen (PSA). PSA-testen har ført til at det diagnostiseres flere tilfeller av prostatakreft som 
Tabell 1: Forventet utvikling i årlig antall nye krefttilfeller fra 2011 til 2016, totalt og for utvalgte kreftformer. Det er også beregnet hvor mye av økningen fra 2011 til 2016 som kan tilskrives endringer i befolkningsstrukturen, og hvor mye som kan tilskrives endringer i risiko. Tallene for prostata- og brystkreft er beheftet med stor usikkerhet grunnet endringer $\mathrm{i}$ diagnostisering og screening. Kilde: Engholm, 2013.

\begin{tabular}{|l|c|c|c|c|c|c|c|c|c|c|}
\hline \multirow{2}{*}{} & \multicolumn{9}{|c|}{ Menn } & \multicolumn{5}{c|}{ Kvinner } \\
\cline { 2 - 14 } & \multicolumn{2}{|c|}{ År } & \multicolumn{2}{c|}{ Endring (prosent) } & \multicolumn{2}{c|}{ År } & \multicolumn{3}{c|}{ Endring (prosent) } \\
\hline $\begin{array}{l}\text { Kreft } \\
\text { lokalisasjon }\end{array}$ & 2011 & 2016 & Totalt & Risiko & Befolkning & 2011 & 2016 & Totalt & Risiko & Befolkning \\
\hline Prostata & 4977 & 5574 & 12 & 0 & 12 & & & & & \\
\hline $\begin{array}{l}\text { Tykk- og } \\
\text { endetarm }\end{array}$ & 1910 & 2217 & 16 & 4 & 12 & 1934 & 2120 & 10 & 3 & 6 \\
\hline Bryst & 1609 & 1761 & 9 & -2 & 11 & 1221 & 1578 & 29 & 21 & 8 \\
\hline Lunge & 854 & 1062 & 24 & 14 & 10 & 862 & 1142 & 32 & 26 & 6 \\
\hline Føflekkreft & 794 & 983 & 24 & 14 & 10 & 732 & 870 & 19 & 15 & 4 \\
\hline $\begin{array}{l}\text { Annen type } \\
\text { hudkreft }\end{array}$ & 960 & 1026 & 7 & -4 & 11 & 370 & 425 & 15 & 9 & 6 \\
\hline Blære & 15852 & 18040 & 14 & 3 & 11 & 13430 & 14787 & 10 & 4 & 6 \\
\hline Totalt & & & & & & 3078 & 3263 & 6 & 0 & 6 \\
\hline
\end{tabular}

tidligere ikke ville ha blitt påvist. Beregning av antall tilfeller framover (prediksjon) for denne kreftformen er basert på dagens rater.

For kvinner ventes en stor økning i forekomsten av lungekreft, noe som hovedsakelig skyldes at røyking økte kraftig blant kvinner i perioden 1927-1970.

Det ventes også en stor økning i forekomsten av føflekkreft både for kvinner og menn.

Blant menn forventes det en økning på 24 prosent og blant kvinner på 32 prosent. Endringer i befolkningsstrukturen antas å stå for 11 prosent av økningen blant menn og 6 prosent blant kvinner.

\section{Flere vil leve med kreft}

Antall nordmenn som har overlevd eller lever med sin kreftsykdom har økt kraftig i Norge de siste årene. I 2001 var det 150000 i Norge som hadde fått en kreftsykdom (Kreftregisteret, 2014). Dette tallet har økt med 50 prosent til 225000 i 2012. Dette skyldes både at antall diagnostiserte krefttilfeller har økt, men også at folk lever lenger etter en kreftdiagnose. Dette vil imidlertid variere fra kreftform til kreftform.

\section{Dødeligheten av kreft har vært relativt stabil}

Selv om kreftforekomsten er økende, har dødeligheten av kreft de siste tiårene samlet sett vært relativt stabil (for menn under 70 år, og for kvinner generelt). Dette skyldes en kombinasjon av tidligere diagnostisering og bedre behandling. Omtrent 70 prosent overlever nå minst 5 år etter en kreftdiagnose.

Selv om bildet samlet sett er nokså konstant, har dødeligheten for flere kreftformer endret seg betydelig, f.eks. har dødeligheten av kreft i magesekken avtatt, mens dødeligheten av føflekkreft har økt. Siden rundt 1970 har man sett en nedgang i dødeligheten i aldersgruppen under 50 år, og sterkest i de yngste aldersgruppene (barn og voksne under 30 år) (FHla, 2012).

\section{Forskjeller i befolkningen}

\section{Høyest forekomst av kreft blant menn}

Forekomsten av kreft er totalt sett omtrent 40 prosent høyere og dødeligheten mer enn 50 prosent høyere blant menn enn blant kvinner (Engholm, 2013) Dødeligheten er relativt lik for menn og kvinner opp til ca. 60-års-alderen. Etter 60-årsalderen har menn den høyeste dødeligheten.

De vanligste kreftformene blant menn er kreft i prostata, lunge og tykktarm, samt føflekkreft. Blant kvinner er brystkreft, lungekreft, tykktarmskreft og føflekkreft de vanligste kreftformene.

\section{Risikoen for å få kreft øker med alderen}

For de fleste kreftformene øker risikoen kraftig med alderen. Derfor oppstår flesteparten av krefttilfellene (mer enn 85 prosent hos kvinner og 90 prosent hos menn) etter 50 års alder, se tabell 2 (3). Likevel er kreft 
Tabell 2: De vanligste kreftformene i ulike aldersgrupper i femårsperioden 2007-2011. Kilde: Kreftregisteret, 2013.

\begin{tabular}{|l|l|l|l|l|}
\hline \multicolumn{3}{|l|}{ Menn } & \multicolumn{2}{l|}{ Kvinner } \\
\hline Alder (år) & $\begin{array}{l}\text { Årlig } \\
\text { antall }\end{array}$ & Hyppigste kreftlokalisasjoner/sykdom & $\begin{array}{l}\text { Årlig } \\
\text { antall }\end{array}$ & Hyppigste kreftlokalisasjoner/sykdom \\
\hline $0-14$ & 50 & Sentralnervesystemet, leukemi & 50 & Sentralnervesystemet, leukemi \\
\hline $15-24$ & 40 & Testikkel & 10 & Sentralnervesystemet \\
\hline $25-49$ & 200 & Testikkel & 600 & Bryst \\
\hline $50-69$ & 2300 & Prostata & 1500 & Bryst \\
\hline $70+$ & 2300 & Prostata & 2000 & Tykk og endetarm, bryst \\
\hline
\end{tabular}

den hyppigste dødsårsaken blant dem som dør før 65 års alder.

Med dagens kreftforekomst og -dødelighet vil om lag hver tredje nordmann få diagnostisert kreft før de blir 75 år gamle. Dette skyldes også nedgang i dødelighet $\mathrm{i}$ hjerte- og karsykdommer i aldersgruppen under 75 år.

\section{Sosioøkonomiske forskjeller}

Kreftrisikoen er større hos personer med lav utdanning og inntekt enn hos personer med høy utdanning og inntekt. Et unntak er brystkreft blant kvinner der kvinner med høy utdanning har større risiko for brystkreft enn kvinner med lav utdanning. En del av forklaringen på dette er trolig at kvinner med høy utdanning er eldre når de får sitt første barn, og at de får færre barn. Tidlig første fødsel og flere fødsler beskytter mot brystkreft (Adami, 2008).

- Se mer om sosioøkonomsike forskjeller i: Fakta om kreft

\section{Geografiske forskjeller}

I Norge er kreftrisikoen (rater for nye krefttilfeller) høyest i helseregion Helse Vest, både for kvinner og menn. Det er imidlertid relativt små forskjeller i kreftrisiko mellom helseregionene i Norge.

\section{Nordiske forskjeller i kreft- forekomst}

Norge har den høyeste kreftforekomsten i Norden blant menn, mens forekomsten blant kvinner er omtrent som gjennomsnittet for Norden. Norge og Danmark har verdens høyeste forekomst av testikkelkreft.

Dødeligheten av kreft er høyest i Danmark for begge kjønn. I alle de nordiske landene har det vært en nedgang i kreftdødeligheten de siste tiårene, både for menn og kvinner, se figur 2 og figur 3, en nedgang som forventes å fortsette.

Norge har høy forekomst og dødelighet av prostatakreft sammenlignet med Vest-Europa for øvrig. Også forekomsten av tykk- og endetarmskreft er høy (GLOBOCAN, 2014).

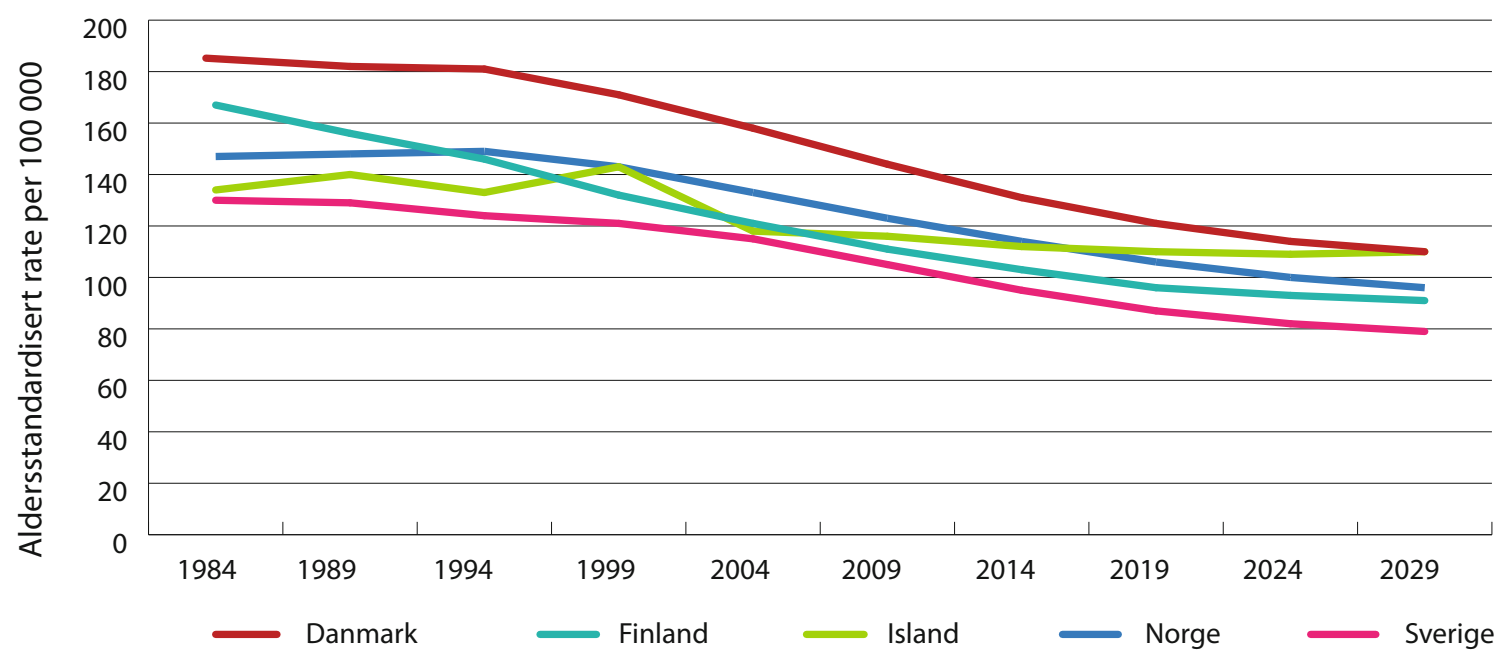

Figur 2: Aldersjustert dødelighet av kreft i de nordiske land, menn. Observert 1982-2011, predikert 2012-2031. Kilde: Engholm, 2013. 


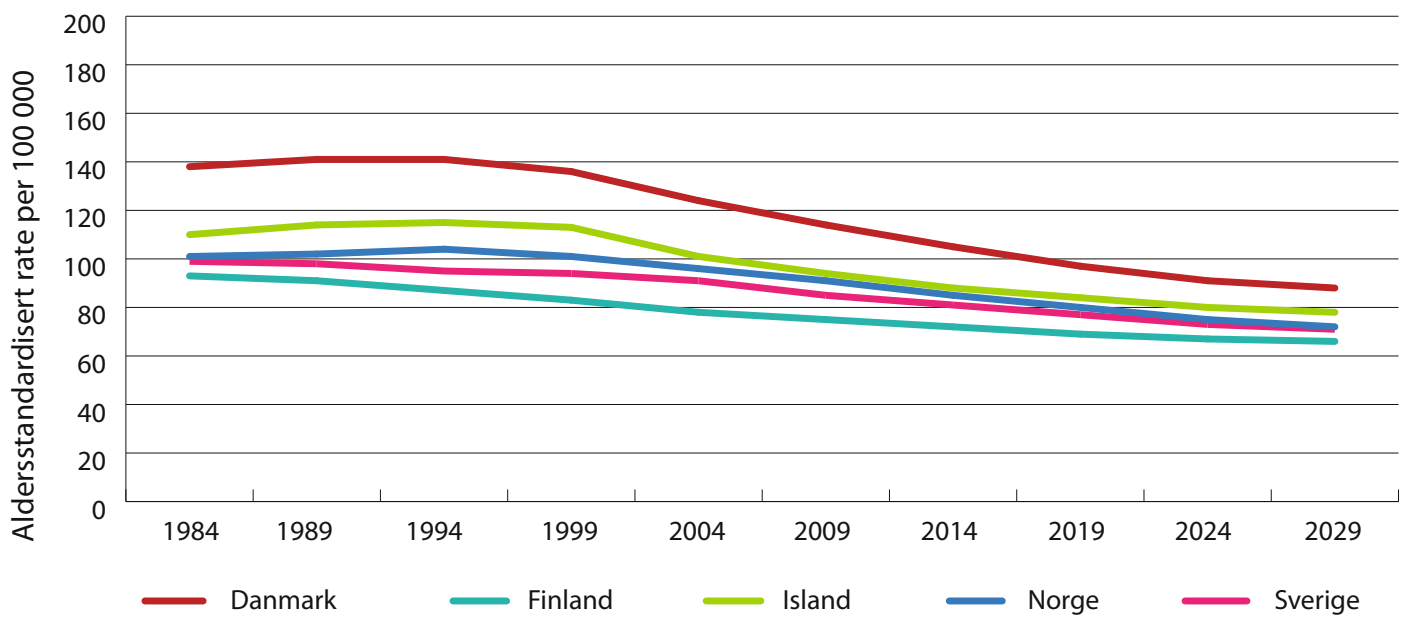

Figur 3: Aldersjustert dødelighet av kreft i de nordiske land, kvinner. Observert 1982-2011, predikert 2012-2031. Kilde: Engholm, 2013.

\section{Risikofaktorer for kreft}

Her er noen av de vanligste faktorene som påvirker risikoen for å få kreft (FHIb, 2013).

Tobakk. Bruk av tobakk er en viktig risikofaktor for kreft, særlig lungekreft, men også kreft i munnhule, strupe, svelg, spiserør, urinblære, nyre og bukspytt kjertel.

Alkohol. Stort alkoholkonsum øker risikoen for kreft i munnhule, spiserør, bryst og tykk og endetarm (Ekspertgruppe, 2007).

Infeksjoner. Kroniske infeksjoner øker risikoen for flere kreftformer. Livmorhalskreft skyldes for eksempel i stor grad humant papillomvirus (HPV). Hepatitt B øker risikoen for leverkreft, mens Helicobacter pylori er en bakterie som er assosiert med økt forekomst av kreft i magesekken.

Hormonelle forhold. Tidspunktet for første fødsel og antall barn har betydning for brystkreftrisikoen. Amming reduserer risikoen for brystkreft og kanskje også for eggstokkreft.

Kosthold. Enkelte matvarer som kornprodukter og grønnsaker kan være med på å minske risikoen for kreft i fordøyelsessystemet. Inntak av fiber, frukt og grønnsaker reduserer, mens høyt forbruk av rødt kjøtt og kjøttprodukter øker risikoen for tykk og endetarmskreft (FHIb, 2013; Ekspertgruppe, 2007).

Fedme. Fedme gir økt risiko for kreft i nyre, livmor, bryst (etter menopause), tykk og endetarm, bukspyttkjertel og spiserør. Det er beregnet at 40-50 prosent av tilfellene av kreft i nyre og livmor og 20 prosent av brystkreft og tykktarmskreft kan tilskrives overvekt og fedme (Calle, 2004).

Fysisk aktivitet. Fysisk aktivitet reduserer risikoen for kreft i tykk og endetarm, trolig også i bryst og livmor (FHIb, 2013; Ekspertgruppe, 2007).

Faktorer i miljøet/omgivelsene. Lang tids eksponering for kjemikalier i miljøet (via mat, forurenset luft eller gjennom hudeksponering) er ansvarlig for en andel av krefttilfellene, men det er usikkert hvor stor andelen er (5 - 70 prosent). Omlag100 enkeltstoffer er klassifisert som sikkert kreftfremkallende for mennesker, mens ytterligere 200 er antatt å være kreftfremkallende blant annet utfra at de gir kreft til dyr. Lav eksponering kan være forbundet med en lav risiko for kreft, men flere stoffer i kombinasjon kan samlet sett gi en høyere risiko enn forventet. Et eksempel er risikoen for lungekreft, som stiger betydelig når man både røyker og blir utsatt for asbest, radonstråling, svevestøv eller nikkelstøv.

Soling. Overdreven soling kan føre til føflekkreft.

Arv/genetikk. Noen familier har større risiko for å få kreft enn andre på grunn av feil ved det genetiske materialet. Ved brystkreft er 5-10 prosent av alle tilfellene arvelig betinget.

\section{Forebygging og utfordringer}

Å bekjempe tobakksrøyking er det viktigste man kan gjøre for å få ned kreftforekomsten. Tiltak som kan få flere til å mosjonere, øke forbruket av frukt og grønnsaker og unngå overvekt og overdreven soling, 


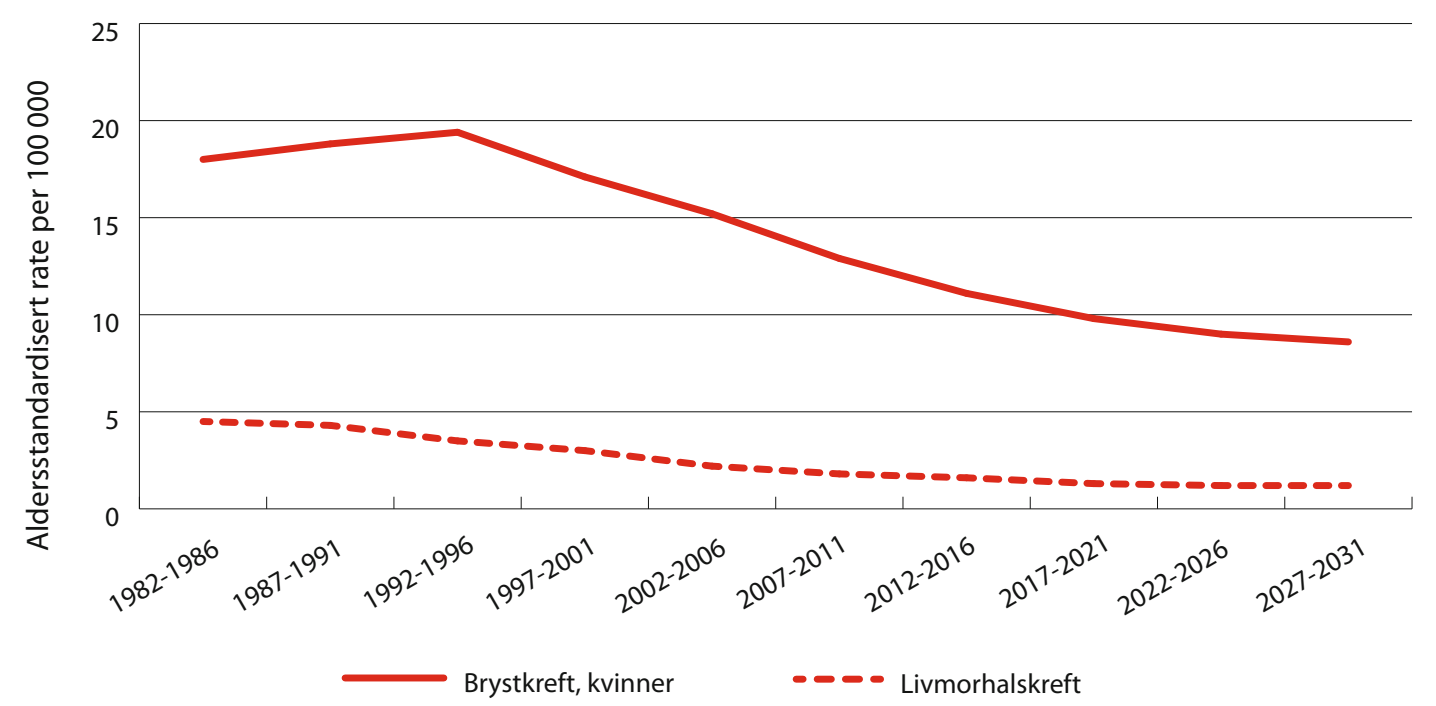

Figur 4: Aldersjustert dødelighet av bryst- (kvinner) og livmorhalskreft. Observert 1982-2011, predikert 2012-2031. Kilde: Engholm, 2013.

er også viktig. Det samme er tiltak i arbeidslivet for å beskytte ansatte mot kreftfremkallende stoffer som for eksempel asbest. Vurdering av risiko fra kjemikalier - både enkeltvis og i blanding - er nødvendig for å kunne redusere eksponering og forebygge sykdom.

Det antas at vaksine mot HPV kan forebygge kreftutvikling i livmorhalsen. I 2009 ble HPV-vaksinasjon innført i barnevaksinasjonsprogrammet i Norge for jenter på 7. klassetrinn. Man regner med at vaksinen på sikt vil føre til en reduksjon i forekomsten av sykdommen.

For å få ned antall dødsfall av kreft er det viktig å oppdage krefttilfellene så tidlig som mulig.

- Etter at screeningprogrammet for livmorhalskreft ble innført her i landet, er forekomsten av denne sykdommen blitt redusert med 25 prosent og dødeligheten halvert.

- I Norge får alle kvinner mellom 50 og 69 år også tilbud om røntgenundersøkelse av brystene (mammografi) annethvert år. Dødeligheten av både bryst- og livmorhalskreft har vært avtagende de siste tiårene, og denne trenden forventes å fortsette, se figur 4. Hvor mye av nedgangen som skyldes masseundersøkelser og behandling, er omdiskutert.

- Siden forekomster av tykk- og endetarmskreft i Norge er høy, er det nå startet et prøveprosjekt med screening mot tarmkreft.

\section{Referanser}

Adami HO, Hunter D, Trichopoulos D (red). Textbook of cancer epidemiology. Second edition. Oxford, University Press (2008).

Calle EE, Kaaks R. Overweight, obesity and cancer: epidemiological evidence and proposed mechanisms. Nat.Rev. Cancer 2004;4:579-591. http://www.ncbi.nlm.nih.gov/ pubmed/15286738.

Ekspertgruppe om ernæring og kreft fra World Cancer Research Fund (WCRF). Food, Nutrition and the Prevention of Cancer: A global perspective, andre utgave 2007. 2007.

Engholm G, Ferlay J, Christensen N, et al. NORDCAN: Cancer Incidence, Mortality, Prevalence and Survival in the Nordic Countries, Version 6.0 (2013). Association of the Nordic Cancer Registries.

FHla (Folkehelseinstituttet). Dødelighet og dødsårsaker i Norge gjennom 60 år 1951-2010. FHI-rapport 2012:4 (2012).

FHIb (Folkehelseinstituttet). Fakta om kreft, 2013.

GLOBOCAN 2012, 2014.

Kreftregisteret. Cancer in Norway 2012 (2014).

NORDCAN - database for kreft i Norden.

http://www.fhi.no/artikler/?id=110413

\section{FORFATTERE}

Anders Engeland, Tone Bjørge og Gunnar Brunborg 


\section{Kronisk obstruktiv lungesykdom (KOLS)}

- KOLS er en vanlig tilstand i den voksne delen av befolkningen og andelen av befolkningen som har plager øker med alderen.

- Symptomene og alvorlighetsgraden av symptomene på KOLS varierer i stor grad.

- KOLS er en hyppig dødsårsak.

- Antall personer som lever med KOLS vil trolig øke i årene framover fordi antallet eldre øker.

- Røyking er hovedårsaken til to av tre KOLS-tilfeller

\section{Om KOLS}

Kronisk obstruktiv lungesykdom (KOLS) er en sykdom som kan gi betydelig funksjonshemming.

Kronisk hoste og oppspytt om morgenen er de første tegnene på KOLS. Ved fysisk anstrengelse blir en tungpusten og får hoste. Ved mer alvorlige tilstander kan en få problemer også i hvile. Symptomene skyldes hevelser og unormalt mye slimproduksjon med påfølgende trange forhold i de små bronkiegrenene. Dette kan hemme luftstrømmen.

De fleste personer som har KOLS har mer eller mindre emfysem, noe som innebærer at lungeblærene er skadet og redusert i antall. Dette reduserer evnen til å ta opp oksygen. KOLS-pasienter kan også få astmatiske anfall, fordi slimhinnene er betente og reaktive.

\section{Forekomst usikker, mange tilfeller trolig ikke rapportert}

Forekomsten av KOLS må beregnes fra helseundersøkelser og andre relevante kilder. Beregningene baseres på rapportering av luftveissymptomer og målinger av lungefunksjon. Ulik vurdering av symptomer, lungefunksjon og hvilke utvalg en undersøker vil kunne føre til betydelig variasjon i beregninger av forekomst av KOLS i en befolkning. Vi har ikke hatt registre som kan benyttes til direkte beregning av antall KOLS-tilfeller i Norge.

En befolkningsundersøkelse fra Hordaland i 1996-97 viste at om lag sju prosent av befolkningen i alderen
26-82 år hadde KOLS (Johannessen, 2005). Undersøkelsen ble gjennomført etter de såkalte GOLDkriteriene og inkluderte en grundig undersøkelse av lungefunksjon på et stort antall personer. Maksimalt utåndingsvolum ble testet etter bruk av et luftveisutvidende middel. Undersøkelsen viste at mer enn ni av ti av de som hadde KOLS, hadde sykdommen i mild eller moderat form.

Mange av deltagerne i Hordalandundersøkelsen ble undersøkt på nytt i 2003-05 (Waatevik, 2013). Funnene tyder på at forekomsten av KOLS hadde $ø$ kt til 14 prosent i perioden fra første undersøkelse. I tillegg kunne funnene tyde på en betydelig underrapportering av KOLS.

En undersøkelse basert på opplysninger fra Reseptregisteret viser at 62882 personer med en KOLSdiagnose hadde fått forskrevet lungemedisiner i 2009 (Halvorsen, 2014). Det er trolig at dette tallet i hovedsak representerer den andelen som er mest plaget av sin KOLS.

\section{Forekomsten av KOLS vil øke}

Forekomsten av KOLS øker med økende alder, og økningen i antall eldre vil føre til at antall personer som lever med KOLS vil øke. Reduksjonen i antall røykere vil kunne motvirke økningen.

\section{Dødelighet øker blant kvinner}

KOLS var den 3. hyppigste registrerte dødsårsaken i 2012, etter død på grunn av sykdommer i sirkulasjonsorganene og kreft (Dødsårsaksregisteret). Dette stemmer godt med tall fra andre vestlige land. 


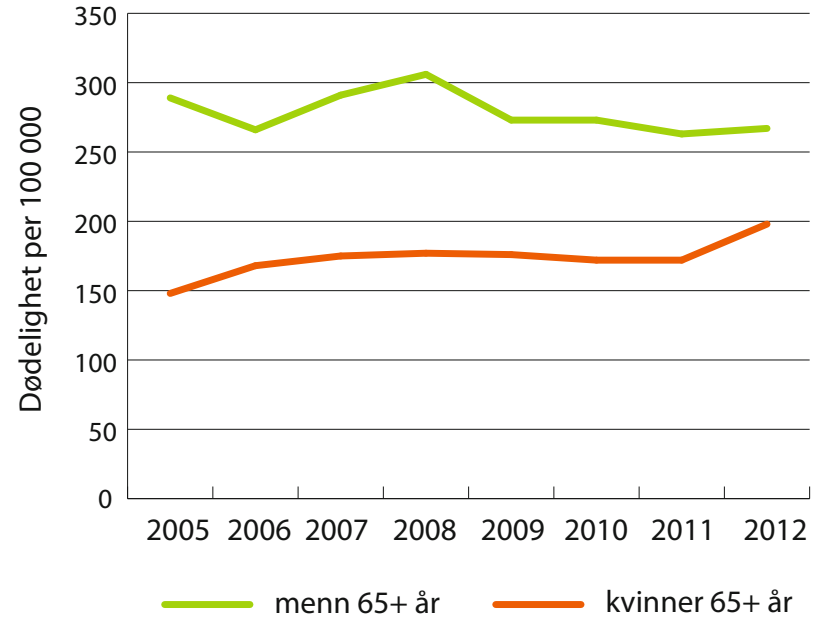

Figur 1: Dødelighet per 100000 for KOLS/emfysem/ astma/kronisk bronkitt (J40-J47) for kvinner og menn i perioden 2005-2012. Kilde: Dødsårsaksregisteret.

Tabell 1 viser at dødeligheten i de senere årene har vært økende blant kvinner. I aldersgruppen over 65 år øte dødeligheten blant kvinner fra 148 per $100000 \mathrm{i}$ 2005 til 195 per 100000 i 2012 (se figur 1). Blant menn har den vært omtrent stabil og høyere enn for kvinner.

En studie fra de nordiske land (inkludert Norge), viser at én av fem som legges inn i sykehus med akutt KOLSforverring (eksaserbasjon), dør i løpet av to år. (Hallin, 2007)

\section{Forskjeller mellom ulike grupper i befolkningen}

\section{Kjønnsforskjeller}

Helseundersøkelsen i Nord Trøndelag i 1995-1997 viste at 11 prosent av de undersøkte kvinnene og 19 prosent av de undersøkte mennene hadde KOLS (Leivseth, 2013). Kjønnsforskjellene i KOLS er imidlertid i ferd med å bli mindre. Ulike røykevaner over tid er en av årsakene til dette, se nedenfor.

\section{Sosioøkonomiske forskjeller i KOLS}

Personer med grunnskoleutdanning har tre ganger høyere risiko for KOLS enn personer med universitetsutdanning. Dette gjelder også når en tar hensyn til røykevaner og yrke. En kjenner ikke de underliggende årsakene, men forhold gjennom livsløpet som varierer med sosioøkonomisk status kan ha betydning for utvikling av KOLS, for eksempel lav fødselsvekt, luftveisinfeksjoner og miljøfaktorer som kosthold, luftforurensing og boligstandard (Bakke, 1995; Johannessen, 2005; Næss, 2004).

\section{Internasjonalt}

Rapporter fra andre land i Europa og Nord-Amerika tyder på en lignende forekomst og økning i forekomst som den vi har sett i Norge (Mannino, 2007; Buist, 2007).

\section{Røyking er vanligste årsak}

Røyking er den vanligste årsaken til KOLS, og forklarer to av tre tilfeller. Risikoen øker med økende tobakksforbruk og antall røykeår. Sammenlignet med ikke-røykere har røykere i gjennomsnitt 4,2 ganger og eks-røykere 3,6 ganger økt odds for å utvikle KOLS (Johannessen, 2005).

Kvinner begynte tidsmessig å røyke seinere enn menn, og ligger derfor etter i tid når det gjelder utvikling av kroniske lungesykdommer. Mange kvinner som har røykt i mange år, har nå kommet i en alder hvor risikoen for KOLS øker. Selv om det i dag er en nedgang i røyking både blant menn og kvinner, vil skadene av tidligere røyking kunne forklare mye av den observerte økningen i forekomst og død av KOLS blant kvinner.

\begin{tabular}{|l|c|c|c|c|c|c|c|c|c|}
\hline & & $\mathbf{2 0 0 5}$ & $\mathbf{2 0 0 6}$ & $\mathbf{2 0 0 7}$ & $\mathbf{2 0 0 8}$ & $\mathbf{2 0 0 9}$ & $\mathbf{2 0 1 0}$ & $\mathbf{2 0 1 1}$ & $\mathbf{2 0 1 2}$ \\
\hline Menn & $0-44$ år & - & - & - & - & - & - & - & - \\
\hline & $45-64 a ̊ r$ & 13 & 17 & 16 & 18 & 19 & 14 & 16 & 14 \\
\hline & $65+a ̊ r$ & 289 & 266 & 291 & 306 & 273 & 273 & 263 & 267 \\
\hline Kvinner & $0-44$ år & - & - & - & - & - & - & - & - \\
\hline & $45-64 a ̊ r$ & 15 & 17 & 18 & 19 & 16 & 16 & 17 & 16 \\
\hline & $65+a ̊ r$ & 148 & 168 & 175 & 177 & 176 & 172 & 172 & 198 \\
\hline
\end{tabular}

Tabell 1: Dødelighet per 100000 for KOLS/emfysem/astma/kronisk bronkitt (J40-J47) i perioden 2005-2012. Kilde: Dødsårsaksregisteret 
Personer som arbeider i et miljø med bl.a. kvartsstøv og metallholdige gasser, eller som arbeider i gruver og tunneler, har også økt risiko for KOLS. Det er også mulig at utendørs forurensing, fysisk inaktivitet og kostholdsfaktorer kan påvirke risikoen, men her er det mangelfull kunnskap (Bakke, 1991).

\section{$\varnothing$ øt risiko for flere sykdommer samtidig}

KOLS-pasienter har økt risiko for å få flere andre sykdommer samtidig (Rabe, 2013). Eksempler er hjerte- og karsykdom, lungekreft, depresjon og beinskjørhet.

Sammenhengen mellom KOLS og andre sykdommer har flere årsaker:

- Røyking er en viktig felles årsak til både KOLS og flere av sykdommene som lungekreft, hjerte- og karsykdom og beinskjørhet.

- KOLS kan gi høyt trykk i lungekretsløpet, som i neste omgang kan gi hjertesykdom.

- Mange KOLS-pasienter blir sosialt isolert og lite fysiske aktive pga. tung pust og hoste med oppspytt, noe som igjen kan medvirke til depresjon og hjertesykdom.

- Medikamenter mot KOLS som for eksempel prednison kan gi beinskjørhet og hjerte- og karsykdom.

- Betennelsesstoffer fra lungene kan også renne over til blodkretsløpet og påvirke andre organer.

\section{Behandling kan ikke reparere}

Har man først utviklet KOLS, kan ikke behandling reparere den tapte lungefunksjonen. Røykestopp kan bremse forverring av sykdommen og ytterligere tap av lungefunksjon (Eagan, 2004). Legemidler og ulike tiltak kan lindre symptomene. Tiltakene virker best dersom sykdommen diagnostiseres tidlig i forløpet.

\section{Referanser}

Bakke, P. S., V. Baste, R. Hanoa and A. Gulsvik (1991). “Prevalence of obstructive lung disease in a general population: relation to occupational title and exposure to some airborne agents." Thorax 46(12): 863-870. Pubmed.

Bakke, P. S., R. Hanoa and A. Gulsvik (1995). “Educational level and obstructive lung disease given smoking habits and occupational airborne exposure: a Norwegian community study." Am J Epidemiol 141(11): 10801088. Pubmed.

Buist, A. S., M. A. McBurnie, W. M. Vollmer, S. Gillespie, P. Burney, D. M. Mannino, A. M. Menezes, S. D. Sullivan, T. A. Lee, K. B. Weiss, R. L. Jensen, G. B. Marks, A. Gulsvik, E. Nizankowska-Mogilnicka and B. C. R. Group (2007). "International variation in the prevalence of COPD (the BOLD Study): a population-based prevalence study." Lancet 370(9589): 741-750. Pubmed.

Eagan, T. M., A. Gulsvik, G. E. Eide and P. S. Bakke (2004). "Remission of respiratory symptoms by smoking and occupational exposure in a cohort study." Eur Respir J 23(4): 589-594. Pubmed.

Dødsårsaker, 2012." SSB. Retrieved 15/5/2014, fra SSB.

Halvorsen, T. and P. E. Martinussen (2014). “The geography of chronic obstructive pulmonary disease: A populationbased study of Norway." Soc Sci Med 111: 25-34. Sciencedirect.

Johannessen, A., E. R. Omenaas, P. S. Bakke and A. Gulsvik (2005). "Implications of reversibility testing on prevalence and risk factors for chronic obstructive pulmonary disease: a community study." Thorax 60(10): 842-847. Pubmed.

Leivseth, L. (2013). Chronic obstructive pulmonary disease: lung function, respiratory symptoms, and mortality : the HUNT Lung Study 1995-97. Doktoravhandling, Norges teknisk-naturvitenskapelige universitet. Doktoravhandling.

Mannino, D. M. and A. S. Buist (2007). “Global burden of COPD: risk factors, prevalence, and future trends." Lancet 370(9589): 765-773. Pubmed.

Naess, O., B. Claussen, D. S. Thelle and G. Davey Smith (2004). "Cumulative deprivation and cause specific mortality. A census based study of life course influences over three decades." J Epidemiol Community Health 58(7): 599-603. Pubmed.

Nielsen, R., A. Johannessen, B. Benediktsdottir, T. Gislason, A. S. Buist, A. Gulsvik, S. D. Sullivan and T. A. Lee (2009). "Present and future costs of COPD in Iceland and Norway: results from the BOLD study." Eur Respir J 34(4): 850-857. Pubmed.

Rabe, K. F., J. A. Wedzicha and E. F. M. Wouters (2013). "COPD and Comorbidity Introduction." Copd and Comorbidity (59): IX-X. E-bok.

Waatevik, M., T. D. Skorge, E. Omenaas, P. S. Bakke, A. Gulsvik and A. Johannessen (2013). "Increased prevalence of chronic obstructive pulmonary disease in a general population." Respir Med 107(7): 1037-1045. Pubmed.

\section{FORFATTER}

Per Nafstad 


\section{Langvarige smertetilstander}

- Rundt 30 prosent av befolkningen har til enhver tid langvarig smerte.

- Kvinner rammes mer enn menn.

- Beregninger tyder på at langvarige smertetilstander koster samfunnet minst 125 milliarder kroner årlig.

- Behov for økt kunnskap om omfang, årsaker, forebygging og behandling.

\section{Om langvarig smerte}

Langvarig smerte defineres oftest som smerter med varighet på tre måneder eller mer (se Faktaboks). De fleste sykdommer og skader kan føre til langvarig smerte. Vanligst er smerte i muskler og skjelett, men smerter i mage og tarm, samt hodepine, forekommer også hyppig.

Forskning og behandling har tradisjonelt vært rettet mot de enkelte sykdommene og skadene. Det er imidlertid generelt dårlig sammenheng mellom den objektive vevsskaden og graden av smerte. Mye tyder på at dette skyldes forskjeller i nervesystemet som gir seg utslag i stor individuell variasjon i smertefølsomhet (Nielsen, 2009). Tvillingforskning viser at risikofaktorene i stor grad er felles for de fleste smertetilstander.

\section{Én av tre har langvarig smerte}

Smerter er trolig den vanligste grunnen til at pasienter oppsøker helsevesenet (Bell, 2009). Vi har ikke tall for dette i Norge, men i Sverige har 28 prosent av pasientene i allmennpraksis en eller flere medisinsk definerte smertetilstander (Hasselstrom, 2002).

Tilsvarende resultater er funnet i Danmark (Eriksen, 2003). Der er det også vist at pasienter med langvarig smerte har fire til fem ganger flere liggedøgn på sykehus enn befolkningen forøvrig (Becker, 1997).

Rundt 30 prosent av den voksne befolkningen i Norge oppgir at de har langvarig smerte (Breivik, 2006; Landmark, 2012; Olsen, 2013; Rustoen, 2004). Ifølge sykdomsbyrdestudien 2010 er migrene, rygg- og nakkesmerter, og andre muskel- og skjelettlidelser blant de tilstander som fører til flest leveår med tapt funksjonsevne (Vos, 2012).

\section{Smerter og smertestillende midler}

Det er vanlig å skille mellom tre hovedtyper langvarig smerte:

- Smerte som skyldes påvisbar vevsskade (nosiseptiv smerte)

Eksempler: artroser, leddgikt, psoriasis.

- Smerte som skyldes skade eller dysfunksjon i nervesystemet (nevropatisk smerte)

Eksempler: langvarige smerter knyttet til diabetes, multippel sklerose, og en del kirurgi.

- Smerte med ukjent årsak (idiopatisk smerte) Eksempler: fibromyalgi, irritabel tarmsyndrom, spenningshodepine.

\section{Smertestillende legemidler omfatter:}

- Ikke opioidholdige legemidler Eksempler: paracetamol, NSAIDs

- Svake opioider Eksempler: kodein, tramadol

- Sterke opioider Eksempler: morfin, oxycodon, fentanyl, buprenorfin

Smertestillende legemidler er blant våre mest brukte medikamenter. De brukes i behandling av både akutte og langvarige smerter.

- I 2013 fikk i overkant av 1,2 millioner nordmenn utlevert et smertestillende legemiddel på resept.

- I 2013 fikk over 520000 utlevert minst ett opioid på apotek. 


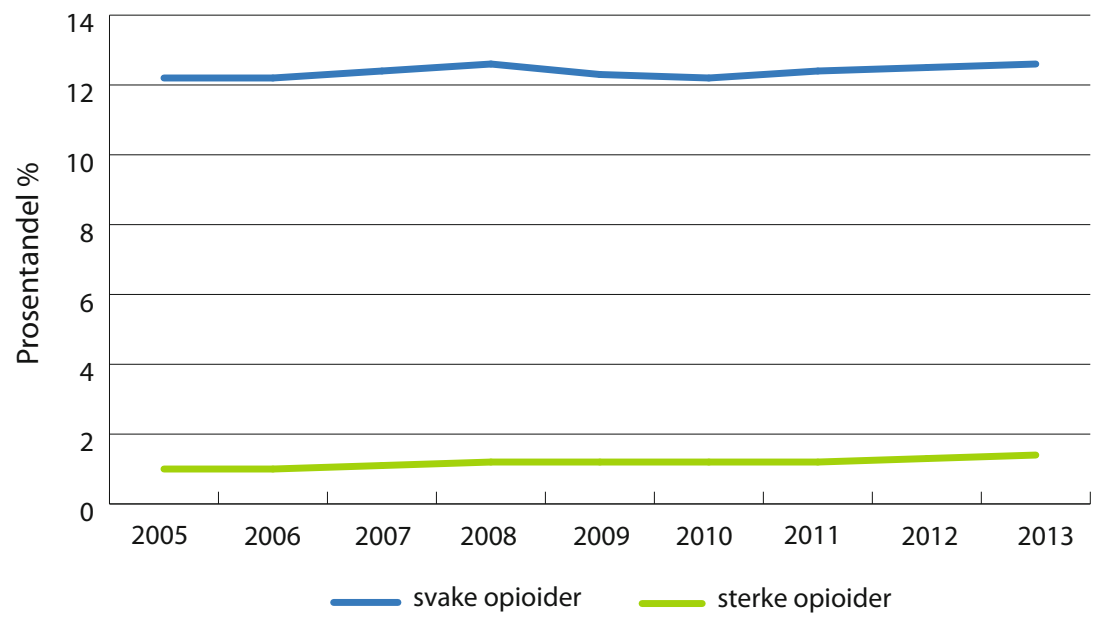

Figur 1. Andel i befolkningen som har fått utlevert minst et opioid på apotek per år i perioden 2005-2013. Kilde: Reseptregisteret.

- De fleste som bruker opioider får svake opioider i små pakninger for kortvarig behandling. Blant pasienter som starter opp behandling med kodein, utvikler imidlertid en veldig liten andel $(<0,1$ prosent) et problematisk bruk (Skurtveit, 2011).

\section{Svak økning over tid}

Data fra helseundersøkelsen i Nord-Trønderlag tyder på en svak økning i forekomst fra 1995-1997 til 20062008 (Hagen 2011). Flere faktorer kan bidra til at denne negative utviklingen vil fortsette fremover. Dette gjelder blant annet økning av fedme og inaktivitet, og et økende antall overlevende etter kreft og alvorlige ulykker.

Andelen i befolkningen som bruker smertestillende legemidler har vært forholdsvis stabil siden 2004, bortsett fra for sterke opioider der det vært en svak økning i antall brukere de siste årene, se figur 1 .

\section{Forskjeller mellom ulike grupper i befolkningen}

\section{Kvinner rammes mest}

Langvarige smerter er mer utbredt blant kvinner enn menn (Fillingim, 2000). Kjønnsforskjellene er moderate når det gjelder smerte generelt, men betydelig større for mer uttalte smerter, særlig smerter som er utbredt flere steder i kroppen, se figur 2. neste side.

Kjønnsforskjellene er også vist når forsøkspersoner blir påført smerte i laboratorieforsøk, og de er vist hos enkelte forsøksdyr. Dette gir holdepunkter for at det er biologiske mekanismer bak kjønnsforskjellene. Forskjellen mellom kjønnene gjenspeiles også i uførestatistikken. Mer enn dobbelt så mange kvinner som menn har en muskel- eller skjelettlidelse som hoveddiagnose (NAV, 2010).

Kjønnsforskjeller i smerte sees også i legemiddelstatistikken. Flere kvinner enn menn bruker smertestillende legemidler, se figur 3. 
1. Langvarig smerte generelt

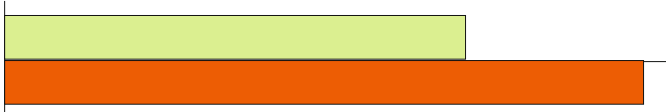

2. Sterk langvarig smerte

3. Utbredt langvarig smerte

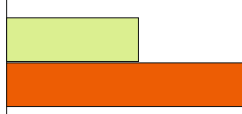

4. Lav toleranse kuldesmerte

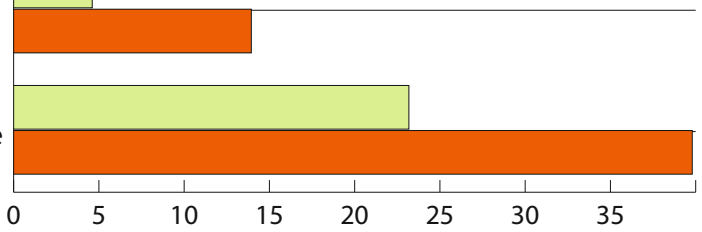

Forholdstall kvinner/menn

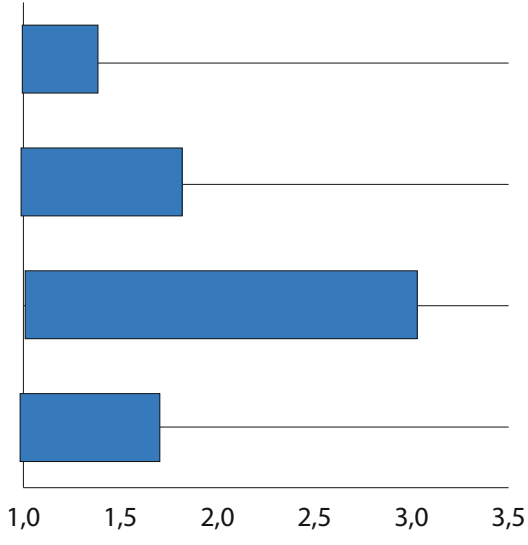

Forholdstall kvinner/menn

$\square$ menn kvinner

Figur 2: Kjønnsforskjeller i langvarig smerte. Kilde: Tromsøundersøkelsen 2008.

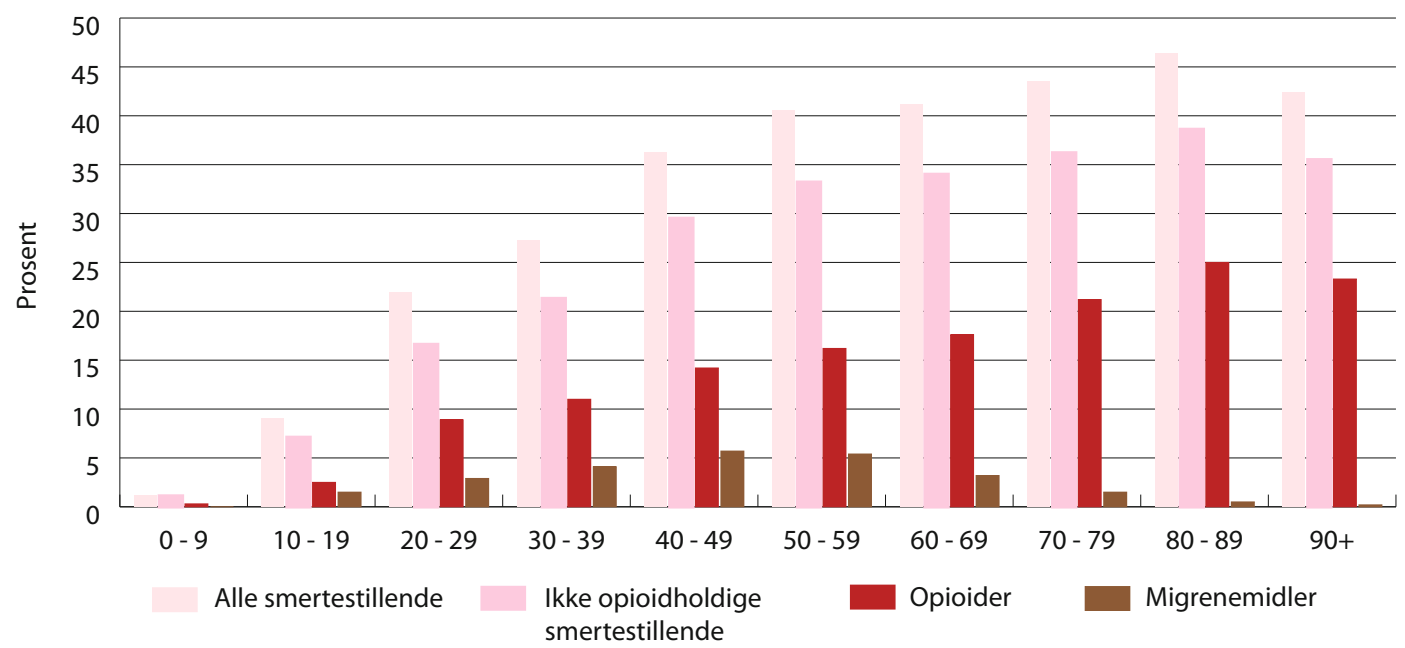

Figur 3a: Andel kvinner som fikk utlevert ulike typer smertestillende legemidler på resept fordelt etter alder, 2013. Kilde: Reseptregisteret.

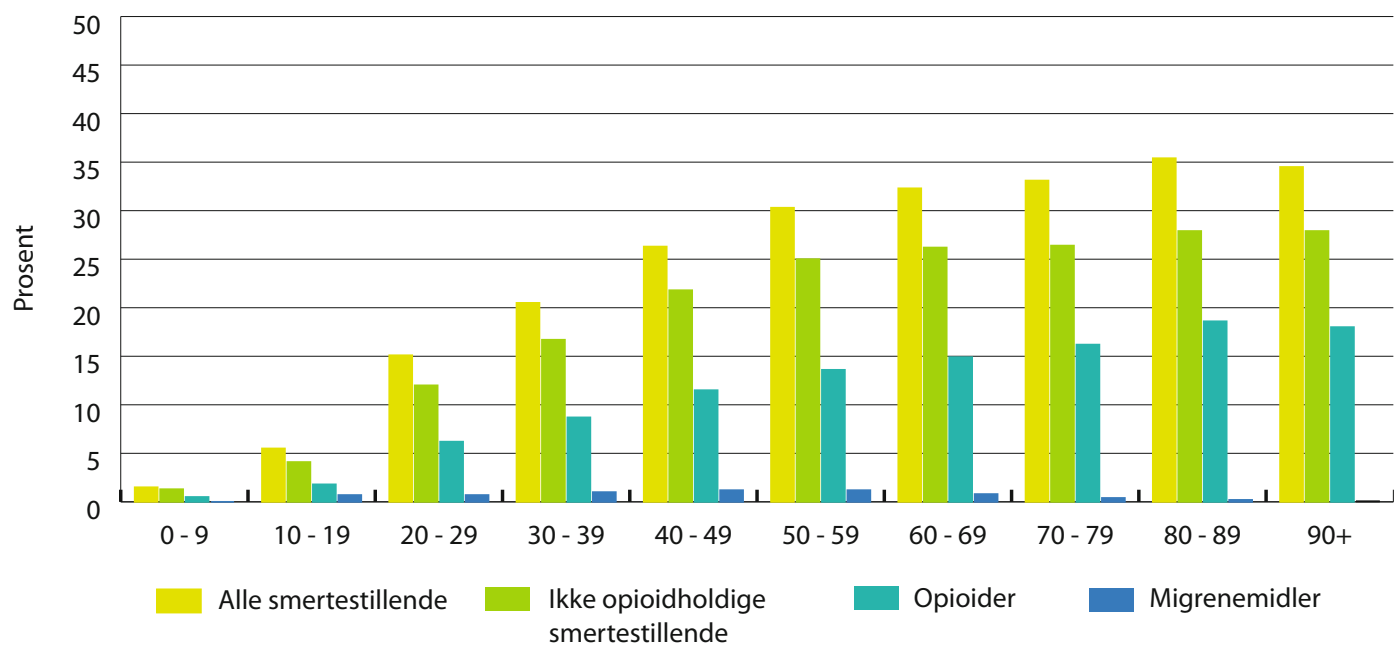

Figur 3b: Andel menn som fikk utlevert ulike typer smertestillende legemidler på resept fordelt etter alder, 2012. Kilde: Reseptregisteret. 


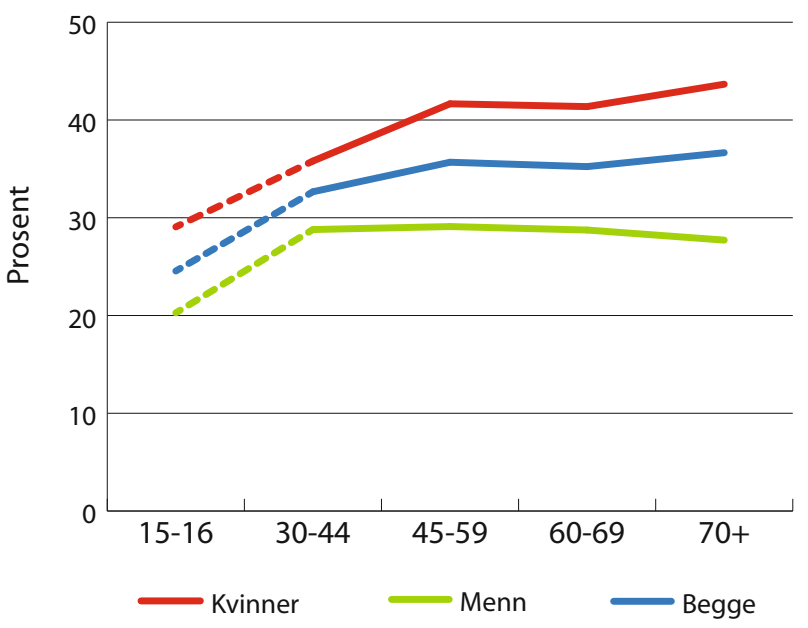

Figur 4: Andel av befolkningen med langvarig smerte fordelt etter alder. Kilde: Fit Futures i 2010 (15-16 åringer) og Tromsøundersøkelsen i 2008 (30 år og eldre).

\section{Forekomsten øker med alderen, men er også høy blant unge}

Forekomsten av langvarig smerte og forbruk av smertestillende legemidler på resept øker med økende alder, se figur 3 og 4 .

Selv om det er holdepunkter for at forekomsten av smerte ligger noe lavere hos ungdom enn hos voksne, er forskjellen trolig liten. Sammenlikning er vanskelig på grunn av at det er brukt forskjellige metoder i de ulike undersøkelsene. I Tromsø, der både ungdommer og voksne har besvart samme spørreskjema, var forekomsten 25 prosent hos ungdommer, mot 32 prosent hos voksne, se figur 4.

\section{Sosioøkonomiske forskjeller}

Det er en klar sammenheng mellom langvarige smerter og sosioøkonomiske faktorer som lav utdanning, inntekt, og yrkesstatus (Bonathan, 2013). Årsaker og mekanismer bak denne sammenhengen er usikker. På den ene siden kan yrkesbelastninger og livsstil hos de med lav inntekt og utdanning bidra til smerte, på den andre siden kan langvarig smerte føre til frafall fra utdanning og arbeidsliv.

\section{Geografiske forskjeller}

Når det gjelder bruk av sterke smertestillende legemidler er det til dels store forskjeller mellom fylker. Det er usikkert om dette skyldes forskjeller i sykelighet eller foreskrivingspraksis blant legene. Se figur i webversjonen av rapporten: på www.fhi.no/folkehelserapporten

\section{Store forskjeller mellom nordiske land}

Norge hadde høyest forekomst av langvarig smerte i en direkte sammenlikning av 15 europeiske land. Mens forekomsten av langvarig smerte i Norge lå på rundt 30 prosent, var tilsvarende tall i våre skandinaviske naboland 16-19 prosent, se figur 6. Årsaken til disse store forskjellene er ukjent.

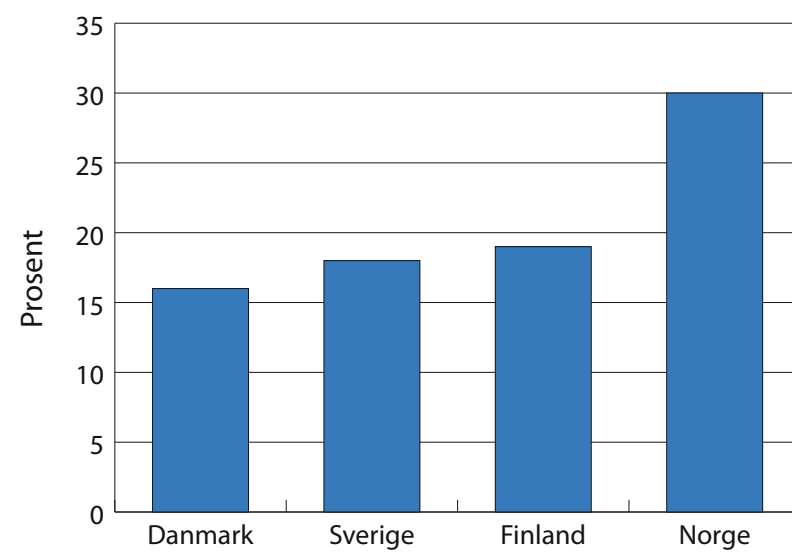

Figur 6: Andel av befolkningen med langvarig smerte i Danmark, Sverige, Finland og Norge. Kilde: Breivik et al 2006.

\section{Risikofaktorer}

Risikofaktorene for utvikling av langvarig smerte ser i stor grad ut til å være felles for de vanligste smertetilstandene. Det bør presiseres at det gjelder risikofaktorer for smerte, ikke nødvendigvis for de lidelsene som forårsaker smerte.

Genetikk: Flere gener som har betydning for utvikling av langvarig smerte og for smertefølsomhet er identifisert (Sorge, 2011; Sorge, 2012). Det er også funnet gener som har kjønnsspesifikke effekter (Mogil, 2011).

Tvillingforskning tyder på at gener som disponerer for langvarige smerte i stor grad er de samme for forskjellige smertetilstander. For eksempel viste en tvillingstudie at 95 prosent av risikoen for å utvikle muskel- og skjelettsmerter skyldes de samme genetiske og miljømessige risikofaktorene, uavhengig av hvor på kroppen smertene var (Kato, 2009; Williams, 2010). Dette bidrar trolig sterkt til forklaringen på at personer med én type smerte har høy risiko for å utvikle flere typer smerte.

Fibromyalgi og migrene er blant de smertetilstandene som har høyest arvelighet, rundt 50-60 prosent (Nielsen, 2012). Andre tilstander, for eksempel irritabel 
tarm, ser ut til å være langt mindre arvelig og derfor mer avhengig av miljøfaktorer.

\section{Miljøfaktorer:}

- Skader eller belastninger over tid kan gi langvarig smerte. For eksempel er smerter i korsryggen vanligst blant yrkesgrupper som utfører tungt fysisk arbeid (Tynes, 2008).

- Langvarig smerte kan også være en bivirkning av behandling, som kirurgi, strålebehandling eller legemiddelbruk.

- For enkelte kirurgiske prosedyrer utvikler opptil halvparten av pasientene langvarig nevropatisk smerte (Kehlet, 2006).

- Det mangler kunnskap blant annet om effekter av miljøforurensning.

Fedme: Overvekt gir økt belastning på skjelettet og således økt risiko for en rekke smertetilstander i muskel- og skjelettsystemet. Det er også holdepunkter for at fedme påvirker smerte gjennom inflammatoriske mekanismer (Arranz, 2014). Se kapittel Muskel-og skjelettsykdommer og -plager.

\section{Levevaner:}

- Mens nikotin har en svak kortvarig smertestillende effekt, er daglig røyking trolig forbundet med økt risiko for langvarig smerte (Ditre, 2011).

- Høyt alkoholforbruk over lang tid kan disponere for utvikling av nevropatiske smerter, men det er usikkert om moderat forbruk øker eller minsker risiko for langvarig smerte (Ferreira, 2013).

- Fysisk aktivitet virker forebyggende på langvarig smerte, og er også helt sentralt i behandling av mange smertetilstander (Mork, 2013).

\section{Psykiske faktorer:}

- Psykiske faktorer ser også ut til å ha betydning for utvikling av langvarig smerte, og kanskje særlig for hvor godt smerten mestres når den foreligger. Pasienter som har høy grad av angst før operative inngrep, opplever i snitt sterkere akutt smerte etter inngrepet (Katz , 2005).

- Angst og depresjon gir trolig også noe økt risiko for å utvikle langvarige smerter, men effekten ser ut til å være beskjeden sammenliknet med effekten av smerte på psykisk helse (Lien, 2011).

- Data fra reseptregisteret viser at pasienter som bruker antidepressiva eller angstdempende/ sovemidler, har et høyere forbruk av sterke smertestillende legemidler.

\section{Konsekvenser}

Langvarig smerte er blant våre største helseutfordringer både i Norge og globalt.

Langvarig smerte kan ha innvirkning på:

- Arbeidsevne og fysisk funksjon:

- I følge den globale sykdomsbyrdestudien er fire av de ti ledende årsaker til nedsatt funksjonsevne smertetilstander (Vos., 2012).

- I Norge kan halvparten av uførhetstilfellene tilskrives langvarig smerte (Landmark., 2013; Nielsen, 2013).

- Smertetilstander er også den ledende årsaken til langtidssykefravær. Tall fra NAV viser at muskel- og skjelettlidelser alene utgjorde 40 prosent av sykefraværsdagene dekket av Folketrygden i 2013 (NAV, 2013).

- Psykisk helse og livskvalitet:

- Forekomsten av angst og depresjon er to til fire ganger høyere hos personer med smerte enn hos personer uten smerte (McWilliams, 2004).

- Risikoen for selvmord er minst doblet (Tang, 2006).

- Søvn:

- Det er funnet at forekomsten av søvnvansker er 18 ganger høyere hos pasienter med langvarig ryggsmerte enn hos befolkningen for øvrig. (Tang, 2007).

- Dødelighet:

- Personer med langvarig smerte har 20-30 prosent økt dødelighet av hjerteog karsykdommer og enkelte krefttyper (McBeth, 2003; McBeth, 2009; Torrance, 2010). Årsaken til den økte dødeligheten er ukjent.

\section{Samfunnskostnader}

Samlet kostnadsanalyse for langvarige smertetilstander er ikke gjennomført i Norge. En grundig analyse i USA konkluderte med at langvarig smerte koster samfunnet minst 4,3 prosent av brutto nasjonalprodukt årlig (Institute of Medicine (US), 2011). Overført til norske forhold tilsvarer dette minst 125 milliarder kroner årlig. Høy forekomst av langvarig smerte, se figur 6 , samt et mer generøst trygdesystem gjør det sannsynlig at dette anslaget er for lavt. 
I Norge er det anslått at muskel- og skjelettskader, sykdommer og plager alene koster 70 milliarder årlig i behandling og trygdeutgifter (Lærum, 2013). Indirekte kostnader er da ikke tatt med.

\section{Muligheter for forebygging}

Forebygging av langvarig smerte må i første rekke rettes mot forebygging av sykdommer og skader som gir smerte. Det er også holdepunkter for at allmenne helsefremmende tiltak som reduksjon av fedme, økning av fysisk aktivitet og reduksjon av nikotinbruk vil virke positivt.

I noen tilfeller kan langvarige smerter fjernes helt ved å behandle sykdommen eller skaden som gir smerte. For eksempel blir mange med hofteartrose helt smertefrie etter innsettelse av hofteprotese.

For mange diagnoser finnes det imidlertid ikke helbredende behandling, og hos mange pasienter kjenner man ikke den medisinske årsaken til smertetilstanden. Behandling av symptomer blir da avgjørende for å opprettholde funksjon og livskvalitet. Mestring, aktivisering og tilbakeføring til arbeidsliv og aktiviteter er viktige elementer ved siden av den rent medisinske behandlingen.

\section{Referanser}

Arranz, L. I., M. Rafecas and C. Alegre (2014). Effects of obesity on function and quality of life in chronic pain conditions. Curr Rheumatol Rep 16(1): 390.

Becker, N., A. Bondegaard Thomsen, A. K. Olsen, P. Sjogren, P. Bech and J. Eriksen (1997). Pain epidemiology and health related quality of life in chronic non-malignant pain patients referred to a Danish multidisciplinary pain center. Pain 73(3): 393-400.

Bell, R. Retningslinjer for smertelindring: utarbeidet av en arbeidsgruppe med Rae Frances Bell. Oslo: Den norske legeforening; 2009.

Bonathan, C., L. Hearn and A. C. Williams (2013). Socioeconomic status and the course and consequences of chronic pain. Pain Manag 3(3): 159-162.

Breivik, H., B. Collett, V. Ventafridda, R. Cohen and D. Gallacher (2006). Survey of chronic pain in Europe: prevalence, impact on daily life, and treatment. Eur J Pain 10(4): 287-333.

Ditre, J. W., T. H. Brandon, E. L. Zale and M. M. Meagher (2011). Pain, nicotine, and smoking: research findings and mechanistic considerations. Psychol Bull 137(6): 10651093.

Eriksen, J., M. K. Jensen, P. Sjogren, O. Ekholm and N. K. Rasmussen (2003). Epidemiology of chronic non-malignant pain in Denmark. Pain 106(3): 221-228.
Ferreira, PH, Pinheiro, MB, Machado, GC \& Ferreira, ML. Is alcohol intake associated with low back pain? A systematic review of observational studies. Man Ther 2013; 18(3): 183-90.

Fillingim, R. B. (2000). Sex, gender, and pain: women and men really are different. Curr Rev Pain 4(1): 24-30.

G. B., P. R. Romundstad, J. A. Zwart and M. Rygg (2011). Chronic idiopathic pain in adolescence - high prevalence and disability: the young HUNT Study 2008. Pain 152(10): 2259-2266.

Hagen, K, Linde, M, Heuch, I, Stovner, LJ \& Swart, JA. Increasing prevalence of chronic musculoskeletal complaints. A large 11-year follow-up in the general population (HUNT 2 and 3). Pain Med 2011; 12(11): 1657-66.

Hasselstrom, J., J. Liu-Palmgren and G. Rasjo-Wraak (2002). Prevalence of pain in general practice. Eur J Pain 6(5): 375-385.

Institute of Medicine (US): Relieving pain in America: a blueprint for transforming prevention, care, education, and research. Washington, The National Academies Press. (2011).

Kato, K., P. F. Sullivan, B. Evengard and N. L. Pedersen (2009). A population-based twin study of functional somatic syndromes. Psychol Med 39(3): 497-505.

Katz, J., E. L. Poleshuck, C. H. Andrus, L. A. Hogan, B. F. Jung, D. I. Kulick and R. H. Dworkin (2005). Risk factors for acute pain and its persistence following breast cancer surgery. Pain 119(1-3): 16-25.

Kehlet, H, Jensen, TS \& Woolf, CJ. Persistent postsurgical pain: risk factors and prevention. Lancet 2006; 367(9522): 1618-25. Landmark, T., P. Romundstad, O. Dale, P. C. Borchgrevink and S. Kaasa (2012). Estimating the prevalence of chronic pain: validation of recall against longitudinal reporting (the HUNT pain study). Pain 153(7): 1368-1373.

Landmark, T., P. Romundstad, O. Dale, P. C. Borchgrevink, L. Vatten and S. Kaasa (2013). Chronic pain: One year prevalence and associated characteristics (the HUNT pain study). Scand J Pain 4(4): 182-187.

Lien, L., K. Green, M. Thoresen and E. Bjertness (2011). Pain complaints as risk factor for mental distress: a three-year follow-up study. Eur Child Adolesc Psychiatry 20(10): 509-516.

Lærum, E. Et muskel- og skjelettregnskap: forekomst og kostnader knyttet til skader, sykdommer og plager i muskel- og skjelettsystemet. Oslo: FORMI, Klinikk for kirurgi og nevrofag, Oslo universitetssykehus, Ullevål; 2013, rapport: 1/2013.

McBeth, J., A. J. Silman and G. J. Macfarlane (2003). Association of widespread body pain with an increased risk of cancer and reduced cancer survival: a prospective, population-based study. Arthritis Rheum 48(6): 1686-1692.

McBeth, J., D. P. Symmons, A. J. Silman, , m fl (2009). Musculoskeletal pain is associated with a long-term increased risk of cancer and cardiovascular-related mortality. Rheumatology (Oxford) 48(1): 74-77. 
McWilliams, L. A., R. D. Goodwin and B. J. Cox (2004). Depression and anxiety associated with three pain conditions: results from a nationally representative sample. Pain 111(1-2): 77-83.

Mogil, J. S., R. E. Sorge, M. L. LaCroix-Fralish, S. B. , $m$ fl (2011). Pain sensitivity and vasopressin analgesia are mediated by a gene-sex-environment interaction. Nat Neurosci 14(12): 1569-1573.

Mork, PJ, Holtermann, A \& Nilsen, TI. Physical exercise, body mass index and risk of chronic arm pain: longitudinal data on an adult population in Norway. Eur J Pain 2013; 17(8): 1252-8.

NAV, 2010. Mottakere av uførepensjon etter diagnose, alder og kjønn. Pr. 31.12.2010. Hentet 30.06.14 fra: https:// www.nav.no/Statistikk+og+analyse.348858.cms

NAV, 2013. Legemeldte sykefraværsdager 3 kv 2004-2013 Diagnose og kjønn. Hentet 30.06.14 fra: https://www.nav. no/Statistikk+og+analyse.348858.cms

Nielsen, C. S., G. P. Knudsen and O. A. Steingrimsdottir (2012). Twin studies of pain. Clin Genet 82(4): 331-340.

Nielsen, C. S., R. Staud and D. D. Price (2009). Individual differences in pain sensitivity: measurement, causation, and consequences. J Pain 10(3): 231-237.

Nielsen, C. S., A. Stubhaug, D. D. Price, O. Vassend, N. Czajkowski and J. R. Harris (2008). Individual differences in pain sensitivity: genetic and environmental contributions. Pain 136(1-2): 21-29.

Norbury, T. A., A. J. MacGregor, J. Urwin, T. D. Spector and S. B. McMahon (2007). Heritability of responses to painful stimuli in women: a classical twin study. Brain 130(Pt 11): 3041-3049.

Olsen, R. B., S. Bruehl, C. S. Nielsen, $m \mathrm{fl}$ (2013). Hypertension prevalence and diminished blood pressure-related hypoalgesia in individuals reporting chronic pain in a general population: the Tromso study. Pain 154(2): 257-262.

Rustoen, T., A. K. Wahl, B. R. Hanestad, , $m$ fl (2004). Prevalence and characteristics of chronic pain in the general Norwegian population. Eur J Pain 8(6): 555-565.

Skurtveit S, Furu K, Borchgrevink P, Handal M, Fredheim O. To what extent does a cohort of new users of weak opioids develop persistent or probable problematic opioid use? Pain. 2011;152(7):1555-1561.
Sorge, R. E., M. L. LaCroix-Fralish, A. H. Tuttle, S. G., m fl (2011). Spinal cord Toll-like receptor 4 mediates inflammatory and neuropathic hypersensitivity in male but not female mice: edited version. J Neurosci 31(43): 1545015454.

Sorge, R. E., T. Trang, R. Dorfman, $\mathrm{m}$ fl (2012). Genetically determined P2X7 receptor pore formation regulates variability in chronic pain sensitivity. Nat Med 18(4): 595-599.

Tang, N. K. and C. Crane (2006). Suicidality in chronic pain: a review of the prevalence, risk factors and psychological links. Psychol Med 36(5): 575-586.

Tang, N. K., K. J. Wright and P. M. Salkovskis (2007). Prevalence and correlates of clinical insomnia co-occurring with chronic back pain. J Sleep Res 16(1): 85-95.

Torrance, N., A. M. Elliott, A. J. Lee and B. H. Smith (2010). Severe chronic pain is associated with increased 10 year mortality. A cohort record linkage study. Eur J Pain 14(4): 380-386.

Tynes, T., T. Eiken, T. K. Grimsrud, T. Sterud and S. Aasnæss Arbeidsmiljø og helse: slik norske yrkesaktive opplever det : hovedrapport. Oslo, STAMI, Statens arbeidsmiljøinstitutt. 16/2008: 135.

Vos, T., A. D. Flaxman, M. Naghavi, R., $m$ fl (2012). Years lived with disability (YLDs) for 1160 sequelae of 289 diseases and injuries 1990-2010: a systematic analysis for the Global Burden of Disease Study 2010. Lancet 380(9859): 21632196.

Williams, F. M., T. D. Spector and A. J. MacGregor (2010). Pain reporting at different body sites is explained by a single underlying genetic factor. Rheumatology (Oxford) 49(9): 1753-1755.

\section{FORFATTERE}

Christopher S. Nielsen, Marte Handal, Svetlana Skurtveit og Ólöf A. Steingrímsdóttir 


\section{Mat- og vannbårne infeksjoner}

- Hvert år blir det registrert flere tusen tilfeller av mat- og vannbårne infeksjoner eller "matforgiftninger". De registrerte tilfellene er bare toppen av et isfjell.

- En stor andel av de registrerte tilfellene er smittet i utlandet.

- Økt import av matvarer fra land med en annen epidemiologisk situasjon enn i Norge, gir økt smittepress og kan gi økt forekomst av mat- og vannbårne infeksjoner i årene framover.

- Norovirus er trolig årsaken til en stor andel av mat- og vannbårne sykdomstilfeller som er smittet innenlands.

- Blant bakteriene er Campylobacter vanligst. På 1990-tallet var det en kraftig økning i hele den vestlige verden. Antall meldte tilfeller øker i Norge fortsatt, og var i 2013 høyere enn noen gang tidligere.

- Infeksjoner med Salmonella har gått tilbake siden 2009 på grunn av redusert smitte i utlandet.

- Vannforsyningen i Norge har spesielle utfordringer med spredt befolkning, mange små vannverk og mye dårlig ledningsnett.

- Situasjonen er likevel generelt god i Norge sammenliknet med resten av Europa.

\section{Om mat- og vannbårne infeksjoner}

En rekke bakterier, virus og parasitter kan forårsake sykdom som smitter gjennom mat og vann. Alvorlighetsgraden og varigheten av sykdommene varierer betydelig.

Overvåkingen ved Folkehelseinstituttet viser at de vanligste årsakene til mat- og vannbårne infeksjoner $\mathrm{i}$ Norge er (FHI, 2014a,b; Vold, 2014; Guzman, 2014):

- Norovirus

- Campylobacter

- Salmonella

- Shigella

- E. coli

- Listeria

- Yersinia

\section{Mat- og vannbårne infeksjoner i Norge i dag}

En rekke mat- og vannbårne infeksjoner skal meldes til Meldingssystem for smittsomme sykdommer (MSIS) ved Folkehelseinstituttet. Hvert år blir det registrert flere tusen sykdomstilfeller, men de registrerte tilfellene er bare toppen av isfjellet, fordi mange ikke går til lege, noe det vanligvis heller ikke er behov for, eller legen tar ikke prøve av pasienten.

Vi har derfor ikke nøyaktige tall for hvor mange som blir syke av mat- og vannbårne infeksjoner, men vi kan følge utviklingen gjennom meldingene til MSIS. Disse viser at en stor andel av de registrerte tilfellene er smittet $i$ utlandet. Nedenfor følger en oversikt over status for de vanligste mat- og vannbårne infeksjonene:

\section{Norovirus-infeksjon}

Næringsmidler kan være smittekilde for flere forskjellige virus, som alle smitter direkte eller indirekte fra menneskets avføring (FHI, 2014a). Enkelte virus kan også smitte gjennom oppkast. 
Norovirus er den vanligste årsaken til virusbetinget mage-tarminfeksjon («omgangssyke»). Det er grunnlag for å mene at norovirus er ansvarlig for en stor andel av de næringsmiddelbårne, særlig vannbårne, infeksjonssykdommene både i Norge og i andre industrialiserte land. Se tabell 1 neste side.

\section{Campylobacteriose}

Campylobacter er den vanligste bakterielle årsaken til diarésykdom som registreres i Norge. Omtrent halvparten smittes utenlands (FHI, 2014b; Vold, 2014;). I Norge er bakterien vanlig i tarmen hos en lang rekke pattedyr og fugler, både viltlevende dyr og husdyr.

De fleste og største, kjente utbruddene av campylobacteriose i Norge har vært forårsaket av forurenset drikkevann, av og til med flere enn tusen syke (Guzman, 2014; FHI, 2014c).

Se tabell 1 neste side.

\section{Salmonellose}

De fleste nordmenn som får salmonellose, er smittet i utlandet (FHla,b; Vold, 2014). Salmonella er sjelden i norskprodusert mat og blant norske husdyr. Enkelte varianter av bakterien har imidlertid etablert seg i norsk, viltlevende fauna, særlig blant småfugl og piggsvin. Disse Salmonella-stammene forårsaker hvert år utbrudd av sykdom i befolkningen.

De fleste utbruddene i Norge skyldes importerte matvarer (Guzman, 2014; FHI, 2014c).

Se tabell 1 neste side

\section{Sykdommer forårsaket av $E$. coli}

Flere varianter av E. coli kan smitte gjennom mat og vann (FHI, 2014a; Vold, 2014). Enkelte av dem kan gi alvorlig sykdom, av og til død, særlig hos barn, eldre og personer med svekket immunforsvar.

Antall meldte tilfeller er beskjedent, se tabell 1. Sykdommen er betydelig underdiagnostisert.

E. coli kan forårsake store og alvorlige utbrudd. Det mest kjente utbruddet i Norge skjedde i 2006, da minst 17 personer ble syke etter å ha spist morrpølse med kontaminert sauekjøtt. Ti av de syke fikk alvorlig nyresvikt (HUS), og ett barn døde (Schimmer, 2008).

\section{Shigellose}

Bakterier som tilhører slekten Shigella, er nummer tre blant årsakene til de registrerte tilfellene av bakteriell diarésykdom i Norge (Vold, 2014). I de siste ti årene har Folkehelseinstituttet årlig fått melding om 120-190 tilfeller av shigellose, hvorav de fleste (60-90 prosent) er smittet utenlands, se tabell 1.

Reservoaret er mennesket, og smitte kan skje direkte fra person til person, eller indirekte via vann eller andre næringsmidler forurenset fra smittebærende personer.

Det er påvist flere utbrudd i Norge der importerte grønnsaker eller urter som ikke varmebehandles har vært smittekilden (FHI, 2014c; Guzman, 2014), se tabell 1.

\section{Yersiniose}

I Norge blir yersiniose forårsaket av bakterien Yersinia enterocolitica, som er vanlig hos slaktegris. Etter omlegging av slakteprosessen på midten av 1990-tallet, er forekomsten av sykdommen vesentlig redusert, til cirka 50 registrerte tilfeller hvert år. Mellom 20 og 60 prosent er smittet utenlands, se tabell 1.

De medisinske og samfunnsøkonomiske konsekvensene av yersiniose er langt større enn antall sykdomstilfeller skulle tilsi. Årsaken er at Y. enterocolitica kan forårsake alvorlige og til dels langvarige komplikasjoner, oftere enn de fleste andre tarmbakterier (FHI, 2014a).

Vi har hatt flere utbrudd, blant annet flere der julesylte laget av hodekjøtt fra svin var smittekilden, og ett som skyldtes importert, forurenset salat.

\section{Listeriose}

Listeriose er en svært alvorlig sykdom med betydelig dødelighet, som hovedsakelig rammer gravide og personer med svekket immunforsvar (FHI, 2014a).

Antall tilfeller som årlig meldes til MSIS, er under 100, og langt de fleste smittes i Norge, se tabell 1.

\section{Hepatitt A}

Hepatitt A er en virusinfeksjon som kan forårsake leverbetennelse («gulsott»).

Siden 1950-tallet har de fleste tilfellene i Norge blitt importert etter opphold i land der sykdommen er vanlig, med enkelte sekundærtilfeller etter hjemkomst til Norge. De siste par årene har vi hatt utbrudd med hepatitt A i Norge knyttet til importerte fryste bær. Se tabell 1.

Med økt import av grønnsaker, ferske krydderurter, salater, frukt og bær fra land hvor hepatitt A er vanlig, vil vi forvente flere utbrudd og enkelttilfeller av denne sykdommen i årene som kommer. 
Tabell 1. Oversikt over meldte tilfeller av mat- og vannbårne infeksjoner, andelen som er smittet utenlands og vanlige smittekilder i Norge (FHI, 2014b; Vold, 2014; Guzman, 2014; FHI, 2014c). Datakilde: MSIS, Folkehelseinstituttet.

\begin{tabular}{|c|c|c|c|}
\hline Smittestoff & $\begin{array}{l}\text { Meldte tilfeller } \\
\text { per år }\end{array}$ & $\begin{array}{l}\text { Herav } \\
\text { smittet } \\
\text { utenlands }\end{array}$ & Vanlige smittekilder i Norge * \\
\hline Norovirus & $\begin{array}{l}\text { Ikke } \\
\text { meldingspliktig }\end{array}$ & Ukjent & $\begin{array}{l}\text { Gjenstander, mat og drikkevann som er forurenset } \\
\text { av tarminnhold eller oppkast fra smittebærende } \\
\text { personer }\end{array}$ \\
\hline Campylobacter & $2300-3000$ & $50-55 \%$ & $\begin{array}{l}\text { Drikkevann, } \\
\text { kylling, } \\
\text { grillmat, } \\
\text { kontakt med dyr }\end{array}$ \\
\hline Salmonella & $1000-1500$ & $80 \%$ & $\begin{array}{l}\text { Småfugl, } \\
\text { piggsvin, } \\
\text { drikkevann, } \\
\text { importerte matvarer }\end{array}$ \\
\hline E. coli: EHEC & $50-100$ & $20-30 \%$ & $\begin{array}{l}\text { Kjøtt og kjøttprodukter fra småfe eller storfe } \\
\text { Andre næringsmidler kontaminert fra smittebærende } \\
\text { dyr eller personer, inkludert uvaskete grønnsaker } \\
\text { Drikkevann }\end{array}$ \\
\hline Yersinia & $40-130$ & $20-60 \%$ & $\begin{array}{l}\text { Svinekjøttprodukter, } \\
\text { drikkevann }\end{array}$ \\
\hline Shigella & $100-150$ & $>90 \%$ & $\begin{array}{l}\text { Importerte matvarer } \\
\text { Gjenstander, mat og drikkevann som er forurenset av } \\
\text { tarminnhold fra smittebærende personer }\end{array}$ \\
\hline Listeria & $15-50$ & (liten andel) & $\begin{array}{l}\text { Rakefisk, gravet fisk, røkt fisk } \\
\text { Kokt kjøttpålegg } \\
\text { Myke modningsoster inkludert muggoster }\end{array}$ \\
\hline $\begin{array}{l}\text { Hepatitt } \\
\text { A-virus }\end{array}$ & Ca. 50 & $40-50 \%$ & $\begin{array}{l}\text { Importerte matvarer, særlig grønnsaker, ferske } \\
\text { krydderurter, salat, frukt og bær }\end{array}$ \\
\hline
\end{tabular}

* Foruten spesifikke smittekilder som er nevnt i tabellen, vil kontakt med smittebærende dyr eller personer være en smittekilde for alle mat- og vannbårne infeksjoner.

\section{Et økende problem}

I løpet av de siste 40 årene har mat- og vannbårne infeksjonssykdommer igjen blitt et økende helseproblem også i den industrialiserte del av verden. Dette er hovedsakelig en konsekvens av forandringer i husdyrhold, næringsmiddelproduksjon og handelsmønstre som skjøt fart etter at siste verdenskrig ble avsluttet i 1945.

Også i Norge har forekomsten av mat- og vannbårne infeksjoner steget kraftig. Økningen skyldes for en stor del at flere blir smittet i utlandet gjennom økt reisevirksomhet til land med større smittepress. Også internasjonal handel med matvarer har gitt seg utslag i flere enkelttilfeller og utbrudd av slike sykdommer. I de siste årene har vi hatt en rekke utbrudd der smittekilden har vært importerte grønnsaker og bær (Guzman, 2014; FHI, 2014C).

Salmonellose: Til tross for den økningen vi har sett for salmonellose blant nordmenn siden 1980-tallet, er det fra 2009 registrert færre meldte tilfeller av denne sykdommen sammenlignet med tidligere år, se figur 1. Dette skyldes i hovedsak en betydelig reduksjon i utenlandssmitte. Nedgangen knyttes til redusert forekomst av Salmonella i fjørfebesetninger og egg i mange europeiske land. 


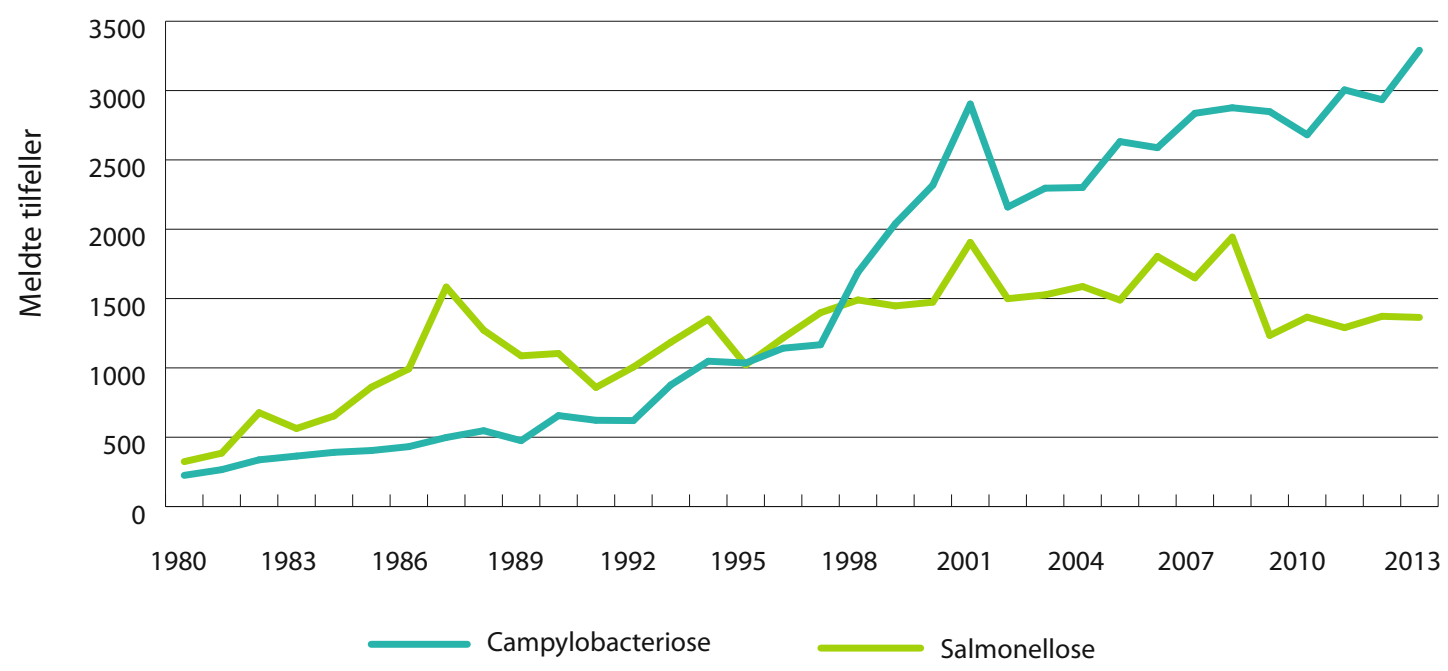

Figur 1. Antall pasienter med campylobacteriose og salmonellose som er meldt til MSIS årlig. Kilde: MSIS, Folkehelseinstituttet $1980-2013$.

Campylobacteriose: På 1990-tallet ble det registret en kraftig økning av campylobacteriose i hele den vestlige verden, også i vårt land. Antall meldte tilfeller øker i Norge fortsatt, i likhet med ellers i Europa. Antallet var i 2013 høyere enn noen gang tidligere, se figur 1. Årsaken er ukjent.

E.coli-infeksjon: Infeksjoner med enterohemoragisk E. coli (EHEC) og andre tarmpatogene E. coli, viser en økende tendens (FHI, 2014b; Vold, 2014). Noe av denne økningen kan forklares med bedre diagnostiske metoder, økt prøvetaking og analyse, samt større oppmerksomhet om sykdommen i forbindelse med utbrudd. Men det kan også være en reell økning i forekomst av sykdommen.

Listeriose: Over et lengre tidsperspektiv viser også listeriose en økende tendens, parallelt med utviklingen i andre europeiske land. Årsaken til økningen er ikke kjent, men kan skyldes at det er flere mottakelige personer i befolkningen, særlig eldre og personer med svekket immunforsvar. Antallet tilfeller hos gravide ser ikke ut til å øke (FHI, 2014b; Vold, 2014).

Yersiniose: Antallet tilfeller av yersiniose ble betydelig redusert etter 1994-1995, da det ble innført nye slakteteknikker for svin ved norske slakterier, noe som reduserte forurensningen av slakteskrottene (FHI, 2014b; Vold, 2014). Grisen er det eneste kjente reservoaret for patogene varianter av bakterien.

Epidemiologiske undersøkelser viser at forbruk av svinekjøtt og svinekjøttprodukter, og bruk av ikkedesinfisert drikkevann, er de viktigste årsakene til yersiniose i Norge. I tillegg til bedret slaktehygiene er det mulig at også redusert forbruk av svinekjøtt og en generell bedring av drikkevannskvaliteten, kan være en medvirkende årsak til nedgangen i denne sykdommen.

\section{Norge har lav forekomst sammenliknet med andre land}

Smittsomme sykdommer som overføres fra mat og vann, er blant de vanligste årsakene til sykdom og død på verdensbasis.

Norge har fremdeles en av Europas laveste forekomster av smitte fra matvarer og dyr. Dette har sammenheng med at forekomsten av de fleste smittestoffer er relativt beskjeden i norske husdyr og norskproduserte matvarer.

Spesielt er Norge i en særlig gunstig situasjon når det gjelder Salmonella, fordi disse bakteriene er svært sjeldne i norskproduserte matvarer og husdyr.

Årsaken til Norges gunstige status er målrettet, effektiv bekjempelse av smittestoffer blant husdyr gjennom en over 100-årig tradisjon, et godt utbygd mattilsyn og et sterkt importvern som begrenser importen av kjøtt, levende dyr og dyrefôr (Kapperud, 2007).

For enkelte smittestoffer er det imidlertid en betydelig forekomst også hos norske husdyr. Dette gjelder særlig Toxoplasma hos sau og gris, tarmpatogene E. coli hos sau, Listeria i røket, gravet og raket fisk, Yersinia hos gris og Campylobacter hos fiørfe, storfe, gris og sau.

Når det gjelder infeksjoner fra drikkevann, antas sykdomsbyrden i Norge å være høyere enn i sammenliknbare land. Dette skyldes at en del av befolkningen bruker ikke-desinfisert overflatevann, blant annet på 
hytter, feriehus og i naturen, og at det til dels er dårlig kvalitet på ledningsnettet.

\section{Konsekvenser av mat- og vannbårne infeksjoner}

Mat- og vannbårne infeksjonssykdommer viser seg oftest som diaré krever sykehusinnleggelse eller antibiotikabehandling bare unntaksvis. Slike infeksjoner er sjelden dødelige i den industrialiserte delen av verden, i motsetning til i fattige land. Alvorligere sykdommer og dødsfall kan imidlertid forekomme, og særlig hos spesielt utsatte grupper som små barn, skrøpelig eldre, gravide, fostre og personer med nedsatt immunforsvar (Kapperud, 2007).

Mat- og vannbårne infeksjoner kan være årsak til alvorlige og av og til kroniske, følgetilstander. Eksempler på dette er sykdom forårsaket av parasitten Toxoplasma gondii, samt bakteriene Listeria monocytogenes, Clostridium botulinum, Yersinia enterocolitica og enterohemoragisk E. coli.

Siden bare et mindretall av sykdomstilfellene blir registrert i MSIS, er de medisinske og samfunnsøkonomiske konsekvensene av mat- og vannbårne infeksjoner langt større enn antall registrerte sykdomstilfeller skulle tilsi. Se også kapittel Drikkevann.

\section{Utfordringer og forebygging}

Det kan hevdes at maten og drikkevannet i Norge aldri har vært tryggere når det gjelder forekomst av smittestoffer. På den annen side opplever vi en globalisering av matmarkedet og økning i både lovlig og ulovlig import av mat fra land der smittepresset er større enn i Norge. Konsekvensene av en hygienesvikt kan dermed bli langt mer omfattende enn tidligere.

Selv om drikkevannet generelt er av god kvalitet $\mathrm{i}$ Norge, har vannforsyningen spesielle utfordringer ved at vi har en spredt befolkning med mange små vannverk, utstrakt bruk av overflatevann, og stort behov for oppgradering av gammelt eller dårlig ledningsnett. Vi har begrenset med informasjon om hvor mange som blir syke på grunn av forurensning i drikkevannet knyttet til dette. Se også kapittel

Drikkevann.
Andre viktige utfordringer i Norge er :

- Økende forekomst av antibiotikaresistente bakterier blant kjøttproduserende husdyr.

- Mer mat tilberedes på storkjøkken, slik at konsekvensene av en hygienebrist blir større.

- Manglende kunnskap om kjøkkenhygiene og håndhygiene, både i serveringsbransjen og blant folk flest (Mattilsynet, 2009a; Jacobsen, 2011).

- Mangelfull kjøkkenhygiene i helseinstitusjoner (Mattilsynet, 2009b).

- Mer økologisk produksjon, småskalaproduksjon og lokal mat, der det kan være problemer med å opprettholde en stabil internkontroll.

- Mer ferdigmat, og mer importerte råvarer, som nordmenn ikke sjelden tilbereder på en annen måte enn tiltenkt i produksjonslandet, for eksempel spiser vi ferske krydderurter uten varmebehandling.

- Demografiske endringer: Flere skrøpelige eldre, langtidssyke og immunsvekkete, som er mer mottagelige, og for hvem sykdommene kan få alvorligere konsekvenser.

\section{Forebyggende tiltak}

Utfordringene kan møtes med forebyggende tiltak, slik som å:

- Overvåke omfanget av mat- og vannbårne infeksjonssykdommer i befolkningen og gjennomføre studier for å kartlegge reell sykdomsbyrde knyttet til smitte gjennom vann og mat.

- Overvåke forekomsten av smittestoffer i husdyr, mat og vann.

- Utbedre små vannverk og oppgradere gamle og dårlige vannledningsnett.

- Etablere tverrfaglig samarbeid som sikrer at smitte mellom mennesker og dyr, gjennom mat og vann, blir behandlet i et helhetlig perspektiv («One Health»).

- Opprettholde god beredskap for å kunne oppdage og oppklare sykdomsutbrudd og identifisere utviklingstendenser.

\section{Referanser}

FHI; Folkehelseinstituttet. (2014a). Smittevernveileder for helsepersonell. Hentet juni 2014.

FHI; Folkehelseinstituttet. (2014b). Meldingssystem for smittsomme sykdommer. Hentet juni 2014

FHI; Folkehelseinstituttet. (2014c). Vevbbasert system for utbruddsvarsling. Oversikt over større utbrudd over smittsomme sykdommer. Hentet juini 2014. 
Guzman HB, Arnesen TM, Berg TC, Bjørnholt JV, Elstrøm P, Kacelnik O, Kapperud G, Lange H, MacDonald E, Vold L, Nygård K. Årsrapport: Utbrudd av smittsomme sykdommer i Norge i 2013. Vevbasert system for utbruddsvarsling. Folkehelseinstituttet 2014.

Jacobsen E, Lavik R. Kjøkkenpraksis og mathygiene litteraturgjennomgang og web-survey. Fagrapport nr. 3 (pdf) (2011). Statens institutt for forbruksforskning, SIFO.

Kapperud G. Næringsmiddelbårne infeksjoner og intoksikasjoner - Forekomst og betydning. I Granum PE (red.): Matforgiftning. Næringsmiddelbårne infeksjoner og intoksikasjo $\neg$ ner, pp. 27-47. Høyskoleforlaget, Kristiansand 2007.

Mattilsynet. (2009a). Det er servert. En tilstandsbeskrivelse av serveringsbransjen. Områdeanalyse av serveringsbransjen - delrapport 1. Mattilsynet.
Mattilsynet. (2009b). Institusjonskjøkken. Rapport nasjonalt tilsynsprosjekt 2008-2009.

Schimmer B, Nygård K, Eriksen HM, Lassen J, Lindstedt B-A, Brandal LT, Kapperud G, Aavitsland P. Outbreak of haemolytic uraemic syndrome in Norway caused by stx2positive Escherichia coli 0103:H25 traced to cured mutton sausages. BMC Infectious Diseases (pdf) 2008: 8:41.

Vold L, Nygård K, Guzman HB, Stene-Johansen K, Dao P, Dahle U, Kapperud G. Årsrapport: Mat- og vannbårne infeksjoner 2013. Folkehelseinstituttet 2014.

\section{FORFATTERE}

Line Vold, Georg Kapperud, Karin Nygård 


\section{Muskel-og skjelettsykdommer}

- De fleste vil i løpet av livet ha sykdommer eller plager knyttet til muskel- og skjelettapparatet.

- Diagnosegruppen muskel- og skjelettsykdommer er den vanligste årsaken til sykefravær og uføretrygd.

- Et stort antall hofte-, ryggvirvel og håndleddsbrudd skyldes osteoporose.

Antallet vil øke med flere eldre i befolkningen.

- Legemidler kan forebygge nye osteoporotiske brudd, men et mindretall bruker slike legemidler.

- Omtrent hver femte gravide kvinne får bekkenleddsmerter.

- Fysisk aktivitet og redusert røyking kan forebygge flere typer muskel- og skjelettsykdom.

\section{Om muskel- og skjelett- sykdommer}

Muskel- og skjelettskader, sykdommer og plager omfatter en lang rekke ulike tilstander som har det til felles at de er forbundet med smerte og eventuelt nedsatt funksjon knyttet til muskel- og skjelettsystemet. Her er det valgt å omtale følgende fire grupper:

- Rygg-og nakkeplager

- Osteoporose og osteoporotiske brudd

- Revmatiske sykdommer

- Svangerskapsrelaterte bekkenleddsmerter

Se også kapittel Langvarig smerte samt kapittel Skader og ulykker.

\section{Mange rammes, store kostnader}

Samlet sett er muskel- og skjelettsykdommer den diagnosegruppen som «plager flest og koster mest», selv om de fleste tilstandene ikke medfører betydelig overdødelighet (Lærum, 2013).

I Norge er diagnosegruppen muskel- og skjelettsykdommer de vanligste årsakene til sykefravær og uførhet (Lindbøl, 2012).

\section{Rygg- og nakkeplager}

- På et gitt tidspunkt har 15-20 prosent av alle voksne ryggplager (Lærum, 2013).

- Man antar at 60-80 prosent vil være plaget av ryggsmerter i løpet av livet (Lærum, 2013).

- Nakkesmerter er omtrent like vanlig som ryggplager. I større befolkningsundersøkelser rapporterer mellom 30 og 50 prosent å ha vært plaget i løpet av den siste måneden. (Lærum, 2013; Ihlebæk 2010).

\section{Osteoporose og osteoporotiske brudd} Osteoporose (benskjørhet) er karakterisert ved redusert knokkelstyrke på grunn av redusert benmasse og/eller endret benkvalitet. Osteoporose er i seg selv symptomfri, men utgjør en betydelig risikofaktor for brudd, særlig i hofte, ryggrad og håndledd. Av disse er hoftebruddene mest alvorlige. I Norge har vi omkring 9000 hoftebrudd per år (Omsland, 2012).

Risikoen for å dø de første tre månedene etter et hoftebrudd er tidoblet blant menn og seksdoblet blant kvinner sammenlignet med normalbefolkningen. Overdødeligheten vedvarer i minst 10 år (Omsland, 2014).

Vi mangler landsdekkende tall for andre typer brudd enn hoftebrudd. Undersøkelser fra Tromsø og Oslo tyder på at om lag 1 av 5 personer over 70 år har et sammenfallsbrudd i ryggraden (Waterloo, 2012), mens det blant voksne skjer om lag 14000 håndleddsbrudd i året. 


\section{Revmatiske sykdommer}

Inflammatoriske revmatiske sykdommer inkluderer mange ulike tilstander, der revmatoid artritt (leddgikt), ankyloserende spondylitt (tidligere Bekhterevs sykdom) og psoriasisartritt er blant de best kjente.

Artrose (tidligere feilaktig betegnet «slitasjegikt») hører tradisjonelt til i den ikke-inflammatoriske gruppen.

Fibromyalgi eller langvarige utbredte muskelsmerter, klassifiseres ofte som en revmatisk sykdom. Diagnosen har vært omdiskutert, blant annet fordi tilstanden i liten grad er forbundet med objektive funn.

Både inflammatoriske og ikke-inflammatoriske revmatiske sykdommer påvirker livskvalitet og funksjonsevne negativt, med langvarige smerter og tretthet som sentrale komponenter i sykdomsbildet.

Inflammatoriske revmatiske sykdommer er hver for seg relativt sjeldne. Forekomsten av revmatoid artritt er for eksempel under 1 prosent (Kvien, 1997). Resultater fra internasjonale undersøkelser tyder på at rundt 8 prosent rammes av en eller annen form for inflammatorisk revmatisk lidelse i løpet av livet (Crowson, 2011).

Artrose er ganske vanlig. Over 10 prosent av den voksne befolkningen har artrose i minst ett ledd (Slatkowsky-Christensen, 2008). Forekomsten av fibromyalgi er omkring 3 prosent (Gran, 2003).

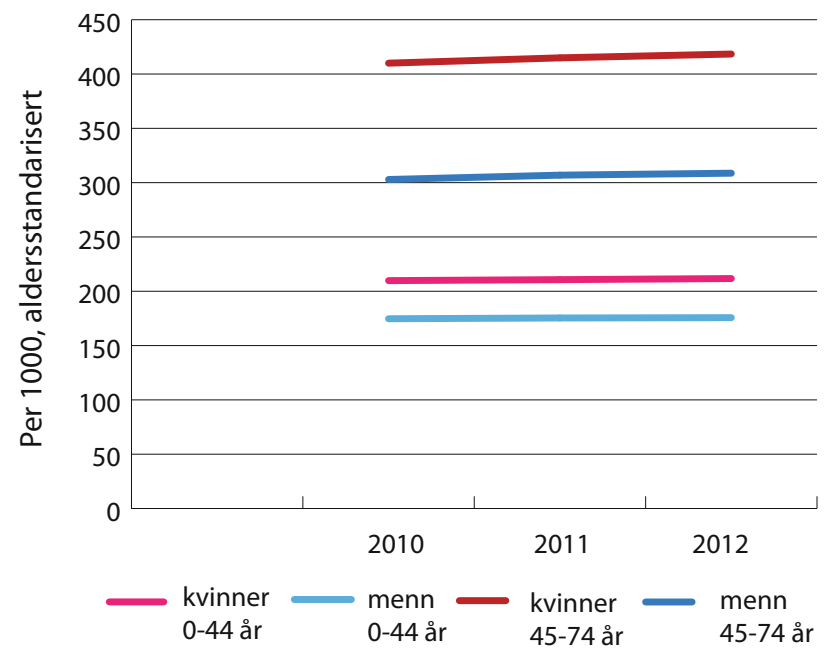

Figur 1: Brukere av primærhelsetjenesten for muskel- og skjelettplager, 2010-2012. Kilde: KUHR.

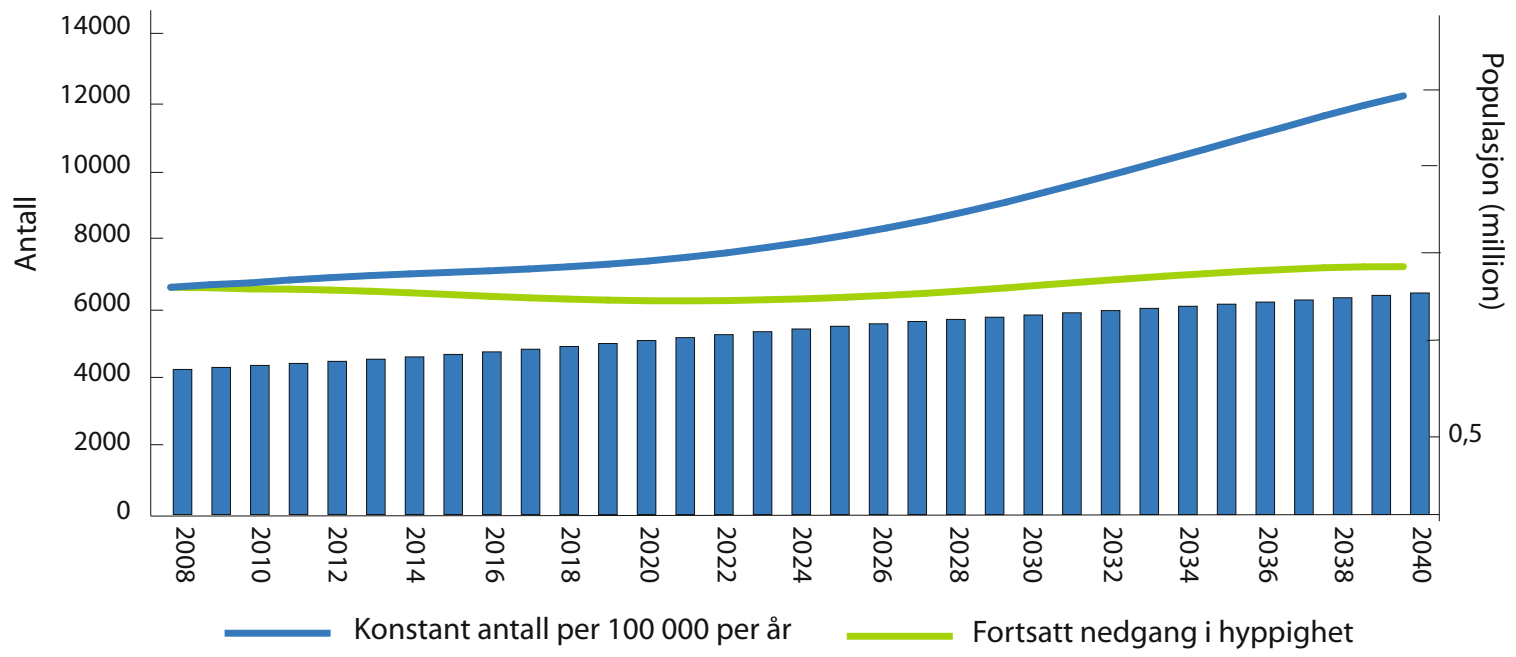

Figur 2: Fremskriving av hoftebrudd i Norge, kvinner alder 65+, i perioden 2008-2040. Kilde: Omsland 2014. 


\section{Svangerskapsrelaterte bekkenledd- smerter}

Bekkenleddsmerter («bekkenløsning») rammer hver femte gravide kvinne (Vleeming, 2008) og er en viktig årsak til sykemelding i svangerskapet (Dørheim, 2013). Omtrent 7 prosent av alle gravide har betydelige funksjonsbegrensninger og må bruke krykker (Bjelland, 2010; Robinson, 2006).

Kort tid etter fødselen blir de fleste symptomfrie, men 2-3 prosent av alle gravide rapporterer betydelige smerter etter ett år (Bjelland, 2013, Albert, 2001).

\section{Utvikling over tid}

Resultater fra helseundersøkelsene i Nord-Trøndelag viser at blant personer 20 år og eldre hadde andelen med muskel- og skjelettplager økt ved målinger i 2006-2008 sammenlignet med samme aldersgrupper 11 år tidligere (Hagen, 2011). Den største økningen var hos de yngste voksne (20-29 år). Dette kan være et viktig tegn på at endret atferd hos barn og ungdom kan ha betydning for fremtidig utvikling av muskel- og skjelettlidelser. Overvekt hos ungdom, som kan følge av lite fysisk aktivitet eller endret kosthold, har for eksempel vist seg å øke risikoen for knesmerter ved 45 års alder (Macfarlane, 2011).

I primærhelsetjenesten var det i perioden 2010 til 2012 en stabil, eventuelt svakt stigende andel besøkende på grunn av muskel- og skjelettplager, se figur 1.

Andre undersøkelser viser at:

- Forekomsten av ryggsmerter ser ut til å være relativt stabil over tid (Lærum, 2013).

- Selv om forekomsten av hoftebrudd i Norge har gått noe ned de siste årene, er antall hoftebrudd forventet å øke i fremtiden på grunn av økt andel eldre i befolkningen (Omsland, 2014), se figur 2. De samme tendensene ser man i andre vestlige land.

- Forekomsten av artrose ser ut til å være økende, også uavhengig av at befolkningen blir eldre (Slatkowsky-Christensen, 2008).

\section{Forskjeller mellom ulike grupper i befolkningen}

\section{Aldersforskjeller}

Muskel- og skjelettsykdommer og -plager er samlet sett mer vanlige hos middelaldrende og eldre. Det er imidlertid store forskjeller mellom diagnosegruppene: Nakkesmerter er for eksempel mest vanlig hos yngre kvinner, mens hoftebrudd er mest vanlig hos de aller eldste og øker sterkt med alderen etter 75 år (Lærum, 2013).

\section{Forskjell mellom kvinner og menn}

Muskel- og skjelettsykdommer og -plager er samlet sett mer vanlige blant kvinner enn blant menn.

Ryggsmerter er omtrent like vanlig hos begge kjønn (Lærum, 2013). Kvinner har oftere nakkesmerter enn menn.

Om lag 70 prosent av de årlige 9000 hoftebrudd skjer blant kvinner (Omsland, 2012).

\section{Sosioøkonomiske forskjeller}

Muskel- og skjelettsykdommer er vanligere hos personer med lav sosioøkonomisk status. Tall fra levekårsundersøkelser i Norge tyder på at denne sammenhengen har økt de siste 30 årene (Dahl, 2014).

Det er funnet en sammenheng mellom lav sosioøkonomisk status og uførepensjonering på grunn av ryggplager (Hagen, 2000).

\section{Geografiske forskjeller}

Det er store fylkesvise forskjeller i bruk av primær- og spesialisthelsetjeneste for tilstander knyttet til muskelog skjelettlidelser, se figur 3 a og b. Osteoporose diagnostiseres ved at benmassen måles i en DXAmaskin (Dual energy X-ray Absorptiometry). Variasjon i tilbudet på undersøkelser med DXA-maskin kan bidra til geografiske forskjeller i diagnostisert osteoporose.

\section{Internasjonalt}

Ifølge Global Burden of Disease-undersøkelsen, en verdensomspennende studie av sykdomsbyrde, er ryggsmerter den ledende årsaken til leveår med nedsatt funksjon i Norge (Institute for Health Metrics and Evaluation, 2013). Nakkesmerter og andre muskelog skjelettsykdommer ligger også høyt på listen.

Norge er sammen med resten av Skandinavia på verdenstoppen i hoftebrudd, uten at vi sikkert vet hvorfor. 


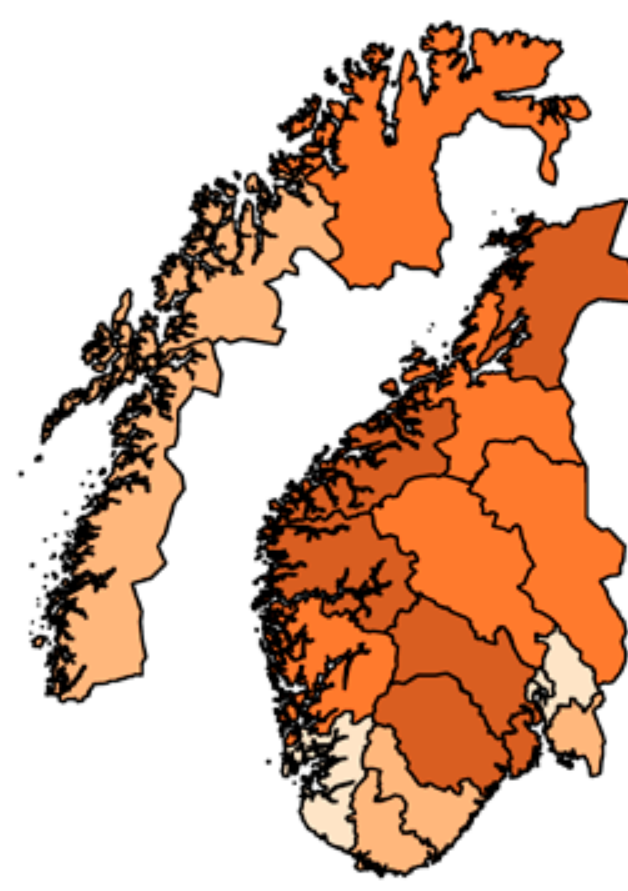

per 1000, standardisert

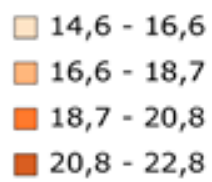

Figur 3a: Bruk av spesialisthelsetjeneste for tilstander knyttet til muskel- og skjelettlidelser, variasjon mellom fylkene, 2012. Kilde: Helsedirektoratet/Norgeshelsa.

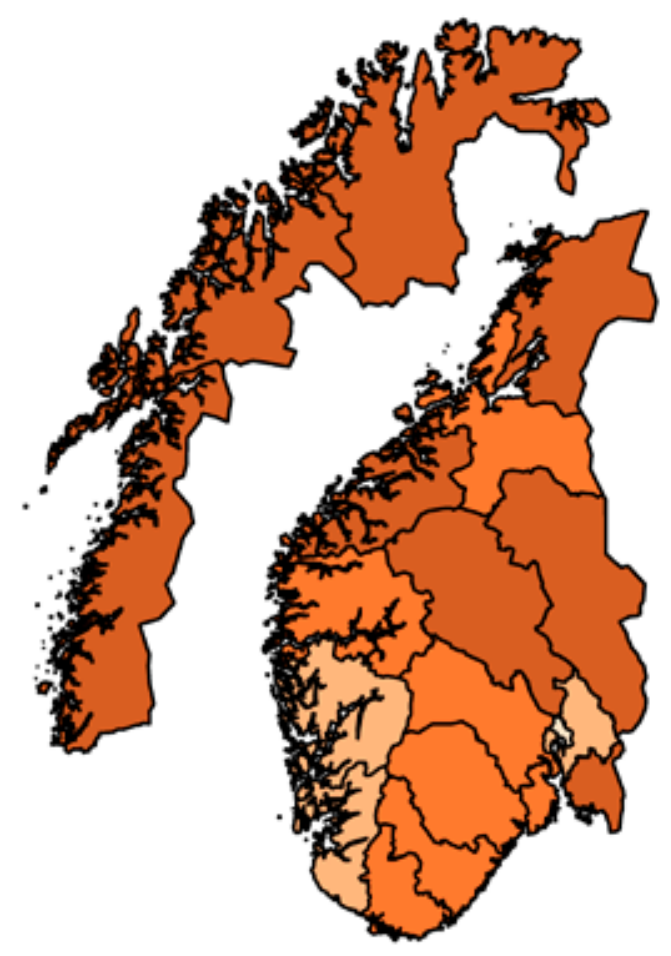

per 1000, standardisert

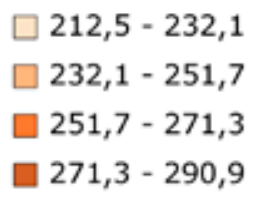

Figur 3b: Bruk av primærhelsetjenesten for tilstander knyttet til muskel- og skjelettlidelser, variasjon mellom fylkene, 2012. Kilde: Helsedirektoratet/Norgeshelsa.

Geografiske variasjoner i diagnostisering av osteoporose kan føre til ulikt behandlingstilbud, ikke bare innad i Norge, men også sammenliknet med andre land. Norge er blant landene i Europa med færrest DXA-maskiner per innbygger (Devold, 2012; Kanis, 2013). 


\section{Konsekvenser av muskel- og skjelettlidelser}

\section{Uføretrygding}

Rygg- og nakkesmerter fører til store helseplager og redusert livskvalitet (Ihlebæk, 2010). Blant nye uføretrygdede med muskel- og skjelettlidelser utgjør rygglidelser den største undergruppen (Lindbøl, 2012).

Artrose er en relativt vanlig årsak til uførhet, men da først og fremst hos eldre (Lindbøl, 2012). Pasienter med håndartrose ser ut til å ha minst like mye plager som pasienter med leddgikt (Slatkowsky-Christensen, 2007), og dette kan også gjelde for andre typer artrose.

Mange med revmatiske sykdommer faller ut av arbeidslivet. I en norsk studie av pasienter med revmatoid artritt var 40 prosent av deltakerne uføretrygdet (Ødegård, 2005), og tilsvarende funn er gjort for Bekhterevs sykdom (Bakland, 2011). Bedre medikamentell behandling fører sannsynligvis til at færre pasienter får behov for uføretrygd (Halpern, 2009).

\section{Hoftebrudd for 4,5 milliarder per år}

Osteoporotiske brudd, især hoftebrudd, medfører smerter, funksjonstap og redusert livskvalitet (Osnes, 2004). Hoftebrudd anslås å koste samfunnet 4,5 milliarder kroner per år det første året etter bruddet (Hektoen, 2014). Når det gjelder andre typer brudd mangler vi norske beregninger, men analyser av danske forhold tilsier at osteoporotiske brudd til sammen koster om lag 10 milliarder kroner i året i Norge (Hansen, 2013).

\section{Risikofaktorer og muligheter for forebygging}

Risikofaktorer, og dermed også mulighetene for forebygging, avhenger av diagnose. Sett under ett har mange typer muskel- og skjelettsykdommer og - plager sammenheng med økende alder, stillesittende livsstil og til dels også overvekt.

Risikofaktorer for smerter i rygg og nakke er sammensatte og delvis ukjente. Både arbeidsmiljø, psykososiale forhold og sosioøkonomisk status ser ut til å ha betydning, samt at en del smertetilstander oppstår som følge av skader i muskel og skjelett. Arbeidstilsynet har publisert en egen veiledning for å forebygge arbeidsrelaterte muskel- og skjelettlidelser (Arbeidstilsynet, 2007).

Det er mye som tyder på at barn som får muskel- og skjelettplager under oppveksten, har økt risiko for å få slike plager også som voksne (Kashikar-Zuck 2014;
Jones, 2009). Hvis dette er riktig, støtter det at forebyggingsarbeidet bør begynne ved ung alder.

Tiltak som forebygger skader og ulykker kan også være viktige bidrag for å redusere omfanget av smertetilstander i muskel- og skjelett.

\section{Genetikk, overvekt og røyking}

Årsakene til ulike typer revmatiske sykdommer er delvis ukjente, men genetiske faktorer ser ut til å spille en betydelig rolle.

Røyking ser ut til å disponere for revmatoid artritt (Uhlig, 1999). Tall fra Sverige antyder at 20 prosent av nye tilfeller kunne vært unngått dersom man klarte å eliminere røyking helt (Källberg, 2011).

Overvekt har stor betydning for artrose, særlig for kneartrose. Røyking ser ikke ut til å øke risikoen for artrose.

Det har skjedd en betydelig utvikling i den medikamentelle behandlingen av revmatiske sykdommer de siste 10-15 årene, spesielt revmatoid artritt. Dette har ført til betydelig færre plager og bedre funksjon hos denne pasientgruppen (Uhlig, 2008).

\section{Osteoporose: Brudd nummer to kan forebygges}

Det finnes en rekke kjente risikofaktorer for osteoporose - blant annet høy alder, lav kroppsmasseindeks og røyking. Blant dem som brekker hoften vil 20-25 prosent få et nytt brudd i løpet av de nærmeste fem årene (Omsland, 2013).

Bruk av bisfosfonater kan redusere risikoen for nye brudd med omkring 50 prosent (Wells, 2008). I Norge bruker bare 16 prosent slike medikamenter etter et hoftebrudd (Devold, 2012).

Internasjonalt er det lansert en aksjon for å forhindre brudd nummer to. Dette innebærer en koordinert og systematisk oppfølging av bruddpasienter (International Osteoporosis Foundation, 2013; Eisman, 2012).

Bruk av hoftebeskyttere blant beboere på sykehjem i Oslo reduserte risikoen for hoftebrudd med opptil 60 prosent (Bentzen, 2008), mens det er funnet at den forebyggende effekten hos hjemmeboende eldre er mer beskjeden (Gillespie, 2010). 


\section{Tilrettelegging kan forebygge bekkenleddsmerter}

Årsakene til svangerskapsrelaterte bekkenleddsmerter er ikke kjent, men hormonelle og mekaniske faktorer antas å spille en rolle (Vleeming, 2008). Antall svangerskap, høy kroppsmasseindeks, tungt arbeid, samt psykologiske og sosiodemografiske forhold ser også ut til å ha betydning (Bjelland, 2010; Biering, 2011; Juhl, 2005).

Tiltak for å redusere overvekt hos kvinner i fertil alder, samt tilrettelegging av gravides arbeidsplass kan derfor bidra til å forebygge svangerskapsrelaterte bekkenleddsmerter.

\section{Referanser}

Ahmed, L. A., J. R. Center, A. Bjornerem, D. Bluic, R. M. Joakimsen, L. Jorgensen, H. E. Meyer, N. D. Nguyen, T. V. Nguyen, T. K. Omsland, J. Stormer, G. S. Tell, T. A. van Geel, J. A. Eisman and N. Emaus (2013). Progressively increasing fracture risk with advancing age after initial incident fragility fracture: the Tromso study. J Bone Miner Res 28(10): 2214-2221.

Albert, H., M. Godskesen and J. Westergaard (2001). Prognosis in four syndromes of pregnancy-related pelvic pain. Acta Obstet Gynecol Scand 80(6): 505-510.'

Arbeidstilsynet. Veiledning: Hvordan forebygge yrkesrelaterte muskel- og skjelettlidelser 2007. 15/3/2007. Report No.: 538 http://www.arbeidstilsynet.no/veiledning. html?tid=92844.

Bakland, G., J. T. Gran, A. Becker-Merok, B. Y. Nordvag and J. C. Nossent (2011). Work disability in patients with ankylosing spondylitis in Norway. J Rheumatol 38(3): 479-484.

Bentzen, H., A. Bergland and L. Forsen (2008). Risk of hip fractures in soft protected, hard protected, and unprotected falls. Inj Prev 14(5): 306-310.

Biering, K., E. A. Nohr, J. Olsen, A. M. Andersen, N. H. Hjollund and M. Juhl (2011). Pregnancy-related pelvic pain is more frequent in women with increased body mass index. Acta Obstet Gynecol Scand 90(10): 1132-1139.

Bjelland, E. K., A. Eskild, R. Johansen and M. Eberhard-Gran (2010). Pelvic girdle pain in pregnancy: the impact of parity. Am J Obstet Gynecol 203(2): 146.e141-146.

Bjelland, E. K., B. Stuge, B. Engdahl and M. Eberhard-Gran (2013). The effect of emotional distress on persistent pelvic girdle pain after delivery: a longitudinal population study. Bjog 120(1): 32-40.

Crowson, C. S., E. L. Matteson, E. Myasoedova, C. J. Michet, F. C. Ernste, K. J. Warrington, J. M. Davis, 3rd, G. G. Hunder, T. M. Therneau and S. E. Gabriel (2011). The lifetime risk of adult-onset rheumatoid arthritis and other inflammatory autoimmune rheumatic diseases. Arthritis Rheum 63(3): 633-639.

Dahl, E., H. Bergli and K. A. Wel Sosial ulikhet i helse: en kunnskapsoversikt. [Oslo], Høgskolen i Oslo og Akershus: 366 s. +362 vedlegg : ill. (2014).
Devold, H. M. (2012). The epidemiology of anti-osteoporosis drug use in Norway. Doktoravhandling, University of Oslo, Faculty of Medicine.

Dørheim, S. K., B. Bjorvatn and M. Eberhard-Gran (2013). Sick leave during pregnancy: a longitudinal study of rates and risk factors in a Norwegian population. Bjog 120(5): 521-530.

Eisman, J. A., E. R. Bogoch, R. Dell, J. T. Harrington, R. E. McKinney, Jr., A. McLellan, P. J. Mitchell, S. Silverman, R. Singleton and E. Siris (2012). Making the first fracture the last fracture: ASBMR task force report on secondary fracture prevention. J Bone Miner Res 27(10): 2039-2046.

Gillespie, W. J., L. D. Gillespie and M. J. Parker (2010). Hip protectors for preventing hip fractures in older people. Cochrane Database Syst Rev(10): Cd001255.

Gran, J. T. (2003). The epidemiology of chronic generalized musculoskeletal pain. Best Pract Res Clin Rheumatol 17(4): 547-561.

Hagen, K., Linde, M., Heuch, I., Stovner, L. J. and Zwart, J. A. (2011). "Increasing prevalence of chronic musculoskeletal complaints. A large 11-year follow-up in the general population (HUNT 2 and 3)." Pain Med 12(11): 1657-1666.DOI: 10.1111/j.1526-4637.2011.01240.x.

Hagen, K. B., H. H. Holte, K. Tambs and T. Bjerkedal (2000). Socioeconomic factors and disability retirement from back pain: a 1983-1993 population-based prospective study in Norway. Spine (Phila Pa 1976) 25(19): 2480-2487.

Halpern, M. T., Cifaldi, M. A. and Kvien, T. K. (2009). "Impact of adalimumab on work participation in rheumatoid arthritis: comparison of an open-label extension study and a registry-based control group." Ann Rheum Dis 68(6): 930-937.DOI: 10.1136/ard.2008.092734. http://ard.bmj. com/content/68/6/930.full.pdf.

Hansen, L., Mathiesen, A. S., Vestergaard, P., Petersen, K. D. and Ehlers, L. H. Den økonomiske byrde af osteoporotiske frakturer ligger primært i kommunerne (The economic burden of osteoporotic fractures lies primarily with the municipalities). Annual Meeting of the Danish Endocrine Society (DES). Aalborg, Denmark. (2013).

Hektoen, L. F. (2013) Kostnadsberegning av hoftebrudd hos eldre personer [konferanseforedrag]. Landskonferanse: Fall og brudd, 201306 sep., Høgskolen i Oslo og Akershus.

Ihlebaek, C., S. Brage, B. Natvig and D. Bruusgaard (2010). Forekomst av muskel- og skjelettlidelser i Norge. Tidsskr Nor Laegeforen 130(23): 2365-2368.

Institute of Health Metrics and Evaluation, IHME. The Global Burden of Disease Study 2010. Country profile: Norway. Hentet 1.06.2014, fra http://www.healthmetricsandevaluation.org/gbd/country-profiles.

Fracture Liaison Services. International Osteoporosis Foundation. Retrieved 04/04/2014, from http://www.capturethe-fracture.org/fracture-liaison-services.

Jones GT et al. Adverse events in childhood and chronic widespread pain in adult life: Results from 1958 British Cohort Study Pain 2009;143:92-6 
Juhl, M., P. K. Andersen, J. Olsen and A. M. Andersen (2005). Psychosocial and physical work environment, and risk of pelvic pain in pregnancy. A study within the Danish national birth cohort. J Epidemiol Community Health 59(7): 580-585.

Kanis, J. A., E. V. McCloskey, H. Johansson, C. Cooper, R. Rizzoli and J. Y. Reginster (2013). European guidance for the diagnosis and management of osteoporosis in postmenopausal women. Osteoporos Int 24(1): 23-57.

Kashikar-Zuck et al (2014). Adolescents with juvenile-onset fibromyalgia in early adulthood. Pediatrics 133:e592-600.

Kvien, T. K., A. Glennas, O. G. Knudsrod, L. M. Smedstad, P. Mowinckel and O. Forre (1997). The prevalence and severity of rheumatoid arthritis in Oslo. Results from a county register and a population survey. Scand J Rheumatol 26(6): 412-418.

Källberg, H., B. Ding, L. Padyukov, C. Bengtsson, J. Ronnelid, L. Klareskog and L. Alfredsson (2011). Smoking is a major preventable risk factor for rheumatoid arthritis: estimations of risks after various exposures to cigarette smoke. Ann Rheum Dis 70(3): 508-511.

Lindbøl, M. Utviklingen i uførediagnoser per 31. desember 2011 [Notat]. Oslo, NAV. Arbeids- og velferdsdirektoratet, Seksjon for statistikk. (2012).

Lærum, E., S. Brage, C. Ihlebæk, K. Johnsen, B. Natvig and E. Aas Et muskel- og skjelettregnskap: forekomst og kostnader knyttet til skader, sykdommer og plager i muskel- og skjelettsystemet: MST-rapport 1/2013. Oslo, Oslo universitetssykehus - Ullevål, Muskel og Skjelett Tiåret (MST). (2013).

Macfarlane, GJ, de Silva, V \& Jones, GT (2011). The relationship between body mass index across the life course and knee pain in adulthood: results from the 1958 birth cohort study. Rheumatology (Oxford) 50(12): 2251-6.

Omsland, T. K., N. Emaus, G. S. Tell, L. A. Ahmed, J. R. Center, N. D. Nguyen, C. G. Gjesdal, S. Forsmo, B. Schei, A. J. Sogaard and H. E. Meyer (2013). Ten-year risk of second hip fracture. A NOREPOS study. Bone 52(1): 493-497.

Omsland, T. K., N. Emaus, G. S. Tell, J. H. Magnus, L. A. Ahmed, K. Holvik, J. Center, S. Forsmo, C. G. Gjesdal, B. Schei, P. Vestergaard, J. A. Eisman, J. A. Falch, A. Tverdal, A. J. Sogaard and H. E. Meyer (2014). Mortality following the first hip fracture in Norwegian women and men (19992008). A NOREPOS study. Bone 63c: 81-86.

Omsland, T. K., K. Holvik, H. E. Meyer, J. R. Center, N. Emaus, G. S. Tell, B. Schei, A. Tverdal, C. G. Gjesdal, G. Grimnes, S. Forsmo, J. A. Eisman and A. J. Sogaard (2012). Hip fractures in Norway 1999-2008: time trends in total incidence and second hip fracture rates: a NOREPOS study. Eur J Epidemiol 27(10): 807-814.
Osnes, E. K., C. M. Lofthus, H. E. Meyer, J. A. Falch, L. Nordsletten, I. Cappelen and I. S. Kristiansen (2004). Consequences of hip fracture on activities of daily life and residential needs. Osteoporos Int 15(7): 567-574

Robinson, H. S., A. Eskild, E. Heiberg and M. Eberhard-Gran (2006). Pelvic girdle pain in pregnancy: the impact on function. Acta Obstet Gynecol Scand 85(2): 160-164.

Slatkowsky-Christensen, B. and M. Grotle (2008). Artrose i Norge. Norsk Epidemiol 18(1): 99-106.

Slatkowsky-Christensen, B., P. Mowinckel, J. H. Loge and T. K. Kvien (2007). Health-related quality of life in women with symptomatic hand osteoarthritis: a comparison with rheumatoid arthritis patients, healthy controls, and normative data. Arthritis Rheum 57(8): 1404-1409.

Uhlig, T., K. B. Hagen and T. K. Kvien (1999). Current tobacco smoking, formal education, and the risk of rheumatoid arthritis. J Rheumatol 26(1): 47-54.

Vleeming, A., H. B. Albert, H. C. Ostgaard, B. Sturesson and B. Stuge (2008). European guidelines for the diagnosis and treatment of pelvic girdle pain. Eur Spine J 17(6): 794-819.

Waterloo, S., Ahmed, L. A., Center, J. R., Eisman, J. A., Morseth, B., Nguyen, N. D., Nguyen, T., Søgaard, A. J. and Emaus, N. (2012). "Prevalence of vertebral fractures in women and men in the population-based Tromsø Study." BMC Musculoskelet Disord 13: 3.DOI: 10.1186/14712474-13-3. http://www.ncbi.nlm.nih.gov/pmc/articles/ PMC3273434/pdf/1471-2474-13-3.pdf.

Wells, G. A., A. Cranney, J. Peterson, M. Boucher, B. Shea, V. Robinson, D. Coyle and P. Tugwell (2008). Alendronate for the primary and secondary prevention of osteoporotic fractures in postmenopausal women. Cochrane Database Syst $\operatorname{Rev}(1)$.

$\varnothing$ degard, S., A. Finset, T. K. Kvien, P. Mowinckel and T. Uhlig (2005). Work disability in rheumatoid arthritis is predicted by physical and psychological health status: a 7-year study from the Oslo RA register. Scand J Rheumatol 34(6): 441-447.

\section{FORFATTERE}

Ragnhild Ørstavik, Kristin Holvik, Ólöf Anna Steingrímsdóttir og Anne Johanne Søgaard. Elisabeth Bjelling (om bekkenløsning). Takk til Kåre Birger Hagen for gjennomlesing av manuskript. 


\section{Psykisk helse hos barn og unge}

- Personer med psykiske vansker i barne- eller ungdomsårene har økt risiko for å oppleve psykiske plager og psykiske lidelser senere i livet.

- Komplikasjoner i svangerskap og fødsel, mishandling og traumer i barndom, samt senere faktorer, slik som mobbing, tapsopplevelser og bruk av rusmidler, kan øke risiko for både utbrudd og tilbakefall av psykiske lidelser.

\section{Mange barn og unge rammes av psykiske plager og psykiske lidelser}

Psykiske plager og lidelser er et stort helseproblem hos barn og unge i Norge i dag. Til enhver tid regner vi med at:

- 15-20 prosent av barn og unge mellom 3 og 18 år har nedsatt funksjon på grunn av psykiske plager som angst, depresjon og atferdsproblemer.

- Omtrent åtte prosent av barn og unge har så alvorlige problemer at det tilfredsstiller kriteriene til en psykisk lidelse (Heiervang, 2007, Wichstrøm, 2012, Mykletun, 2009).

- Se tabell 1 for oversikt over utbredelse av de vanligste psykiske lidelsene blant barn og unge, samt internasjonale sammenligninger.

\section{Psykiske plager er oftest forbigående}

For de fleste barn og unge er psykiske plager forbigående, men hos noen vedvarer plagene. En fjerdedel av barn som ved 18 måneders alder har betydelige psykiske plager, har det også ved 4 års alder (Mathiesen, 2009). Blant fireåringer vil 40 prosent av de med betydelige psykiske plager fremdeles ha dette som 10-åringer (Koot, 1992).

\section{Flere psykiske lidelser samtidig}

Det er vanlig at flere psykiske lidelser opptrer samtidig:

- Om lag fire av fem fireåringer med depresjon og atferdsforstyrrelser har en annen psykisk lidelse i tillegg (Wichstrøm, 2012). Emosjonelle lidelser (angst- og depresjonslidelser) og atferdslidelser opptrer ofte samtidig.

- Ved 8-10 års alder har mange barn med ADHD, atferdslidelse eller emosjonell lidelse en annen psykisk lidelse i tillegg. Man regner med at mellom 3 og 5 prosent av barn og unge under 18 år har ADHD (Helsedirektoratet, 2007). Det er vanligst at atferdsforstyrrelsene opptrer sammen med ADHD eller angst- og depresjonslidelser (Heiervang, 2007).

- I ungdomstiden (13-18 års alder) har man funnet at om lag 40 prosent av ungdommene som lider av en gruppe av psykiske lidelser (f.eks. stemningslidelser) også tilfredsstiller kriteriene for en annen gruppe av psykiske lidelser (f.eks. atferdsforstyrrelser) (Merikangas, 2010). Dette gjelder særlig for stemningslidelser.

\section{Utvikling over tid}

Tall fra tre større ungdomsundersøkelser i Oslo (Ung i Oslo 1996, 2006 og 2012) viser en tendens til økning i depresjonsplager og nedgang i atferdsvansker blant elever i 9 og 10 klasse samt i 1. klasse videregående fra 2006 til 2012 (Øуа, 2012). Det har vært uvisst hvorvidt dette er et enkeltstående funn eller del av en større utviklingstrend. Den norske levekårsundersøkelsen sammen med nye tall fra reseptregisteret kan tyde på at dette er en utviklingstrend.

For aldersgruppen 15-19 år viser tall fra Reseptregisteret at det var en sterk økning i antallet som brukte antidepressiver i perioden fra 2004 til 2013, se figur 1. Blant unge gutter økte antallet fra cirka 1300 til 1800 brukere (44 prosent økning) og blant unge jenter fra cirka 2800 til 4100 brukere (48 prosent økning) (Reseptregisteret, 2014). Blant de som var 20 år og eldre var økningen på 11 prosent (kvinner) og 13 prosent (menn). 
For aldersgruppen 16-24 år viser tall fra Levekårsundersøkelsene at andelen med høy skåre (over 1,75) på psykiske plager økte fra 1998 til 2012, se figur 2. Økningen var sterkest blant unge kvinner der 13 prosent hadde høy skåre i 1998 og 23 prosent i 2012. For unge menn var de tilsvarende tallene 7 prosent og 12 prosent (Norgeshelsa, 2014).

$\varnothing$ kningen i psykiske plager som er vist gjennom Reseptregisteret og ulike helseundersøkelser kan skyldes ulike feilkilder, slik som synkende deltagelse i helseundersøkelser, økt rapporteringsvillighet om psykiske plager eller at leger i økende grad skriver ut resepter på antidepressiver til unge. Det er imidlertid ikke urimelig å anta at deler av den rapporterte økningen i psykiske plager er reell, og at den økte bruken av antidepressiver blant ungdom gjenspeiler en reell økning i depresjon.

\section{Forskjeller mellom grupper $\mathrm{i}$ befolkningen}

\section{Forekomsten varierer med alder og kjønn}

Psykiske plager og lidelser har forskjellig uttrykk på ulike alderstrinn og varierer med kjønn.

- Hos de yngste barna ser man oftest utfordringer med å regulere biologiske funksjoner som søvn, spising og renslighet, og enkelte utfordringer knyttet til regulering av oppmerksomhet, følelser og atferd.

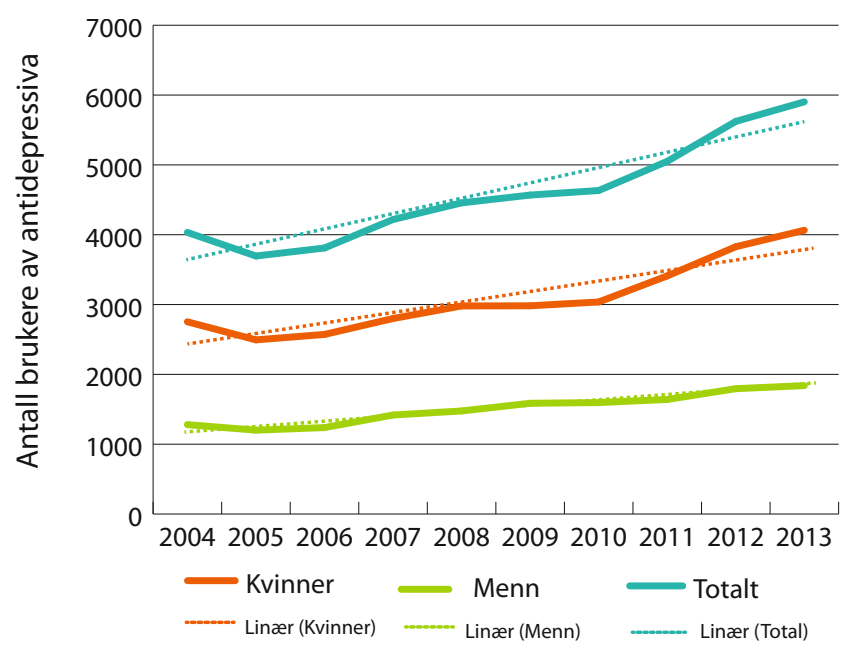

Figur 1: Antall brukere av antidepressiva i aldersgruppen 15-19 år, 2004-2013. Kilde: FHI/Reseptregisteret, 2014.
- Hos barn og ungdom er angst- og depresjonsplager, samt atferdsvansker de vanligste psykiske plagene. Aggressiv og opposisjonell atferd er vanlig i småbarnsalderen (Wakschlag, 2010), men de fleste barn lærer alternativer til fysisk aggresjon før skolestart (Tremblay, 2006).

- Flere gutter enn jenter har problemer med fysisk aggresjon (Moffitt, 2001), mens stjeling og lyving samt såkalt relasjonell aggresjon (der man rammer en annen gjennom å manipulere eller skade den andres sosiale relasjoner) er mer likt fordelt mellom kjønnene (Crick, 1995, Tiet, 2001).

Resultater fra ulike studier viser at:

- Separasjonsangst, spesifikke fobier og sosial angst er de vanligste angstlidelsene i barneårene (Heiervang, 2007; Wichstrøm, 2012), mens generalisert angst og andre angstlidelser forekommer oftere fra puberteten av (Merikangas, 2005).

- Depresjon forekommer også i barneårene, men forekomsten øker vesentlig i ungdomsalderen (Hankin, 1998; Merikangas, 2010).

- Blant ungdommer har dobbelt så mange jenter som gutter angst- og depresjonsplager (Wichstrøm, 1999; Merikangas, 2010).

- Alvorlige atferdslidelser er mest utbredt blant gutter (Moffitt, 2001).

- Spiseforstyrrelser starter som regel i løpet av ungdomsårene, og anoreksi og bulimi forekommer hyppigere hos jenter enn gutter (Fairburn, 2003, Striegel-Moore, 2007).

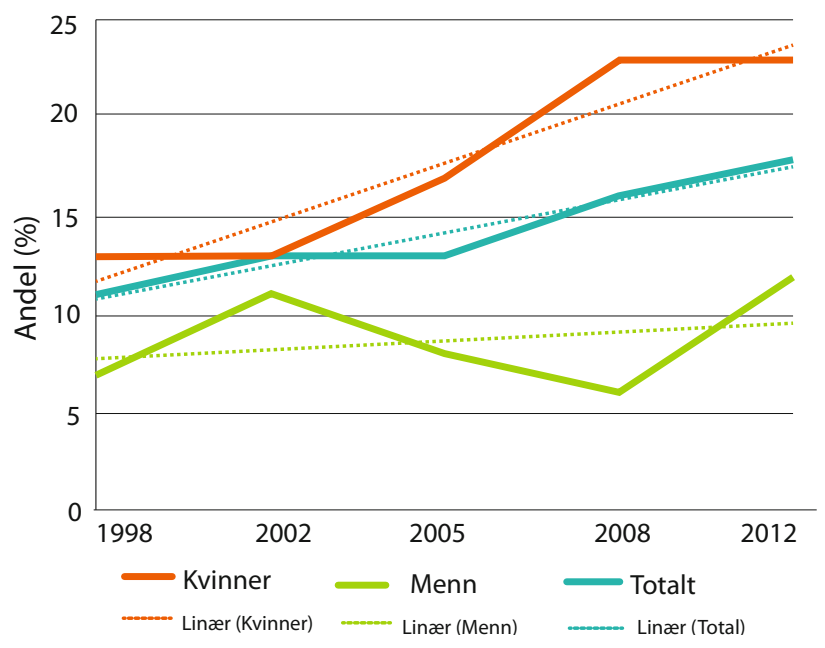

Figur 2: Andelen (i prosent) med høy skåre på HSCL-25 i aldersgruppen 16-24 år, 1998-2012. Kilde: FHI/Norgeshelsa, 2014. 


\section{Sosiale og geografiske forskjeller}

Lav sosioøkonomisk status hos foreldre har sammenheng med dårligere psykisk helse hos barna (Bradley, 2002, Poulton, 2002). En norsk studie fra 2012 viste mer atferdsvansker og hyperaktivitet/uoppmerksomhet blant barn fra familier med lavere sosioøkonomisk status sammenlignet med barn fra familier med høyere sosioøkonomisk status (Bøe, 2012).

Noen studier finner geografiske/regionale forskjeller i omfanget av psykiske helseproblemer. Det er blant annet funnet en høyere andel av atferdsproblemer i Oslo sammenlignet med andre deler av landet (Wichstrøm, 1996). Dette er ikke nødvendigvis et uttrykk for forskjeller i psykisk helse, men kan også skyldes ulik tilgjengelighet til psykiske helsetjenester, eller ulik diagnosepraksis i de ulike regionale helsetjenestene (Surén, 2013).

\section{Internasjonale sammenligninger}

Atferdslidelser er mindre vanlig hos norske barn ((4-åringer; Wichstrøm, 2012) og (8-10-åringer; Heiervang, 2007)) enn hos barn i andre vestlige land. Det samme gjelder depresjonsplager i ungdomsårene (Wichstrøm, 1999; Kessler, 2001 ). Dette kan komme av kulturelle forskjeller i forståelsen og rapporteringen av problematisk atferd og psykiske lidelser hos barn og unge (Heiervang, 2008).

Forekomsten av diagnostiserbare atferdsforstyrrelser blant norske barn og unge under 18 år er beregnet til å være 1,7 prosent for alvorlig atferdsforstyrrelse (kjennetegnes av voldelig og aggressiv atferd) og 1,8 prosent for opposisjonell atferdsforstyrrelse (kjennetegnes av sinneutbrudd, hyppig krangling med voksne og mangel på å følge voksnes ønsker og regler) (Skogen, 2013).

\section{Risikofaktorer}

\section{Samspill mellom psykososiale og biologiske (genetiske) faktorer}

Psykososiale og biologiske (genetiske) risikofaktorer for psykiske vansker blant barn og unge virker i et samspill. Sentrale risikofaktorer er:

- Vansker på skolen.

- Mobbing.

- Sosial isolasjon.

- Foreldrekonflikt/skilsmisse.

- Forhold i familien som psykiske vansker, rusmisbruk, mishandling og overgrep.
- Flykninger og innvandrere med traumatiske opplevelser og/eller utfordringer knyttet til det å etablere seg i nytt land og ny kultur.

- Biologisk og genetisk sårbarhet.

\section{Konsekvenser og utfordringer}

\section{Psykiske lidelser har vidtrekkende konsekvenser}

Psykiske lidelser i barne- og ungdomsårene ser ut til å ha mer vidtrekkende negative konsekvenser enn somatisk sykdom (Goodman, 2011; Delaney, 2012).

Psykiske plager og lidelser i barne- og ungdomsårene øker risikoen for (McCarty, 2008, Odgers, 2008, Goodman, 2011):

- Frafall i skolen, løsere tilknytning til arbeidsmarkedet, økonomiske vansker og vansker i nære relasjoner.

- Dårlig psykisk og fysisk helse senere i livet.

- Rusmisbruk.

\section{$\varnothing \mathbf{k t}$ risiko for andre sykdommer}

Barn og unge med psykiske lidelser har en økt risiko for å få ulike kroppslige plager og sykdommer. Dette gjelder særlig barn og unge med ADHD som har en økt risiko for søvnforstyrrelser (Owens, 2008), overvekt (Kim, 2014), hodepine (Parisi, 2014), forstoppelse (McKeown, 2013), astma, allergier, autoimmune sykdommer (Chen, 2013) og nevrologiske forstyrrelser (Surén, 2012).

Kroppslige sykdommer kan på sin side disponere for eller forverre psykiske lidelser. Barn med kroniske sykdommer har økt risiko for emosjonelle og atferdsmessige plager, særlig har barn med nevrologiske lidelser hyppigere forekomst av psykisk lidelser (Hysing, 2009). Kronisk sykdom i kombinasjon med funksjonshemming gir økt risiko for psykiske lidelser (Cadman, 1987).

\section{Forebygging}

\section{Tidlig intervensjon og inkluderende nærmiljø}

Barn som viser tegn til psykiske plager, eller som er eksponert for alvorlige risikoforhold bør fanges opp på et tidlig tidspunkt. Helsestasjon, barnehage og skole er sentrale arenaer hvor det kan arbeides med universelle, grupperettede, familierettede og individuelt rettede tiltak.

- Les mer i rapport fra Folkehelseinstituttet: Rapport 2011:1 Bedre føre var 


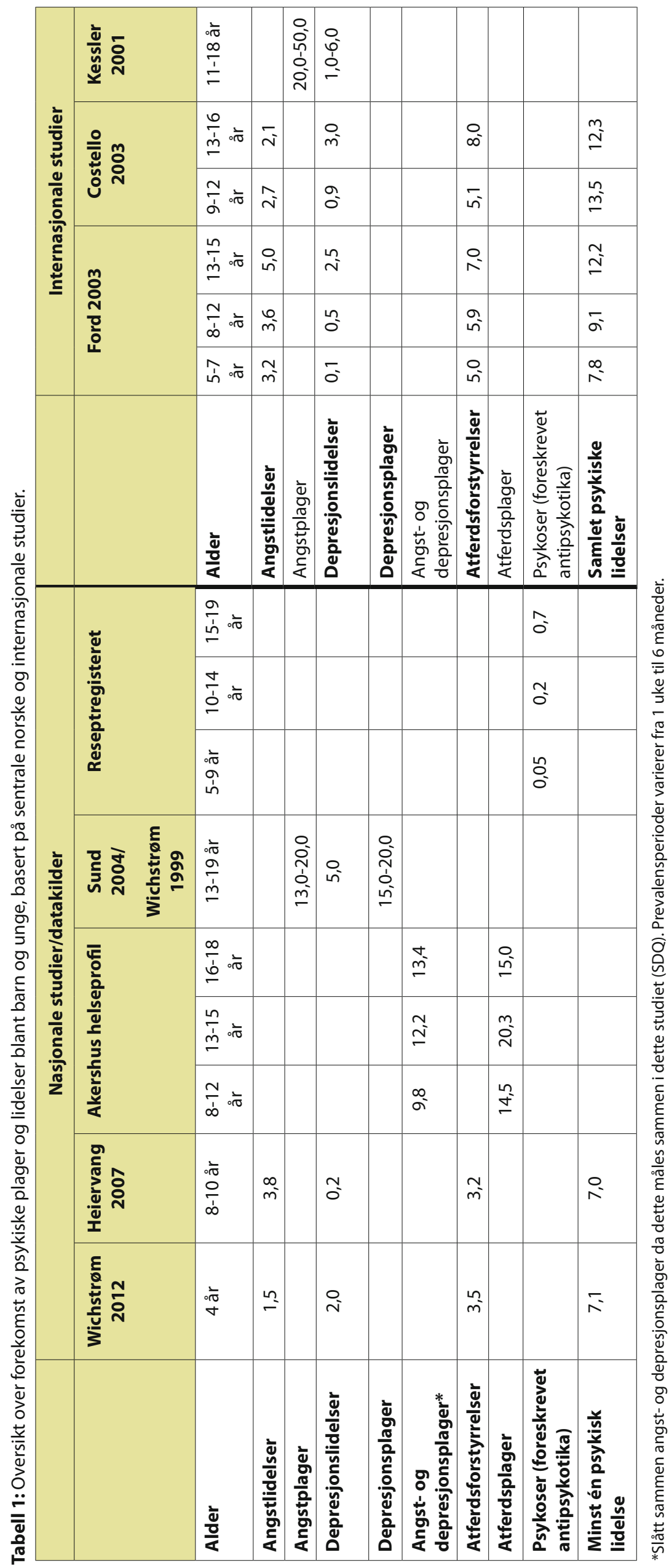




\section{Referanser tabell 1:}

Akershus helseprofil (2002). Jocelyne Clench-Aas, personlig kommunikasjon april 2014.

Costello, E.J., Mustillo, S., Erkanli, A., Keeler, G. and Angold, A. (2003). Prevalence and development of psychiatric disorders in childhood and adolescence. Archives of General Psychiatry, 60(8): p. 837-844.

Ford, T., Goodman, R. and Meltzer, H. (2003). The British child and adolescent mental health survey 1999: The prevalence of DSM-IV disorders. Journal of the American Academy of Child and Adolescent Psychiatry, 42(10): p. 1203-1211.

Heiervang, E., Stormark, K. M., Lundervold, A. J., Heimann, M., Goodman, R., Posserud, M.-B., Ullebø, A. K., Plessen, K. J., Bjelland, I., Lie, S. A., Gillberg, C. (2007).Psychiatric disorders in Norwegian 8-to 10-years-olds: An epidemiological survey of prevalence, risk factors, and service use. Journal of the American Academy of Child \& Adolescent Psychiatry, 26(4), 438-447.

Kessler, R. C., Avenevoli, S., Ries Merikangas K. (2001). Mood disorders in children and adolescents: an epidemiologic perspective. Biol Psychiatry, 49, 1002-1014.

Sund, A.M. (2004). Development of Depressive Symptoms in Early Adolescence. The Youth and Mental Health Study. NTNU: Trondheim.

Wichstrøm, L. (1999). The emergence of gender difference in depressed mood during adolescence: The role of intensified gender socialization. Developmental Psychology, 35(1), 232-245.

Wichstrøm, L., Berg-Nilsen, T. S., Angold, A., Egger, H. L., Solheim, E., Sveen, T.H. (2012). Prevalence of psychiatric disorders in pre-schoolers. The Journal of Child Psychology \& Psychiatry, 53(6), 695-705

\section{Referanser}

Bradley, R. H. and R. F. Corwyn (2002). "Socioeconomic status and child development." Annu Rev Psychol 53: 371-399.

Bøe, T., S. Øverland, A. J. Lundervold and M. Hysing (2012). «Socioeconomic status and children»s mental health: results from the Bergen Child Study.» Soc Psychiatry Psychiatr Epidemiol 47(10): 1557-1566.

Cadman, D., Boyle, M., Szatmari, P., \& Offord, D.R. (1987). Chronic illness, disability, and mental health and social well-being: Findings of the Ontario Child Health Study. Pediatrics, 79 (5), 1987.

Chen MH, Su TP, Chen YS, Hsu JW, Huang KL et al. (2013). Comorbidity of Allergic and Autoimmune Diseases Among Patients With ADHD: A Nationwide Population-Based Study. J Atten Disord. Feb 11. [Epub ahead of print]

Crick, N. R. and J. K. Grotpeter (1995). «Relational aggression, gender, and social-psychological adjustment.» Child Development 66(3): 710-722.

Delaney, L. and J. P. Smith (2012). «Childhood Health: Trends and Consequences over the Life Course.» The Future of Children 22(1): 43-63, from http://www.jstor.org/ stable/41475646.
Fairburn, C. G. and P. J. Harrison (2003). “Eating disorders.” Lancet 361(9355): 407-416.

Goodman, A., R. Joyce and J. P. Smith (2011). "The long shadow cast by childhood physical and mental problems on adult life." Proceedings of the National Academy of Sciences 108(15): 6032-6037, from http://www.pnas.org/ content/108/15/6032.abstract.

Hankin, B. L., L. Y. Abramson, T. E. Moffitt, P. A. Silva, R. McGee and K. E. Angell (1998). "Development of depression from preadolescence to young adulthood: Emerging gender differences in a 10-year longitudinal study." Journal of Abnormal Psychology 107(1): 128-140. http://informahealthcare.com/doi/abs/10.3109/14659891.2011.580415

Heiervang, E., A. Goodman and R. Goodman (2008). “The Nordic advantage in child mental health: separating health differences from reporting style in a cross-cultural comparison of psychopathology." J Child Psychol Psychiatry 49(6): 678-685.

Heiervang, E., K. M. Stormark, A. J. Lundervold, M. Heimann, R. Goodman et al. (2007). "Psychiatric disorders in Norwegian 8- to 10-year-olds: An epidemiological survey of prevalence, risk factors and service use." Journal of the American Academy of Child and Adolescent Psychiatry 46(4): 438-447.

Helsedirektoratet (2007), Veileder i diagnostikk og behandling av AD/HD. IS-1244.

Hysing, M., Elgen, I., Gillberg, C. \& Lundervold, A.J. (2009). Emotional and behavioural problems in subgroups of children with chronic illness: Results from a large-scale population study. Child: care, health and development, 35 (4), 527-533.

Kessler, R. C., S. Avenevoli and K. Ries Merikangas (2001). "Mood disorders in children and adolescents: an epidemiologic perspective." Biological Psychiatry 49(12): 10021014, from http://www.sciencedirect.com/science/article/ pii/S0006322301011295.

Kim EJ, Kwon HJ, Ha M, Lim MH, Oh SY, Kim JH, Yoo SJ, Paik KC (2014). Relationship among attention-deficit hyperactivity disorder, dietary behaviour, and obesity. Child: Care Health Dev, Jan 20. Doi: 10.1111/cch.12129 [epub ahead of print].

Koot, H. M. and F. C. Verhulst (1992). "Prediction of Children's Referral to Mental Health and Special Education Services from Earlier Adjustment." Journal of Child Psychology and Psychiatry 33(4): 717-729, from http://dx.doi. org/10.1111/j.1469-7610.1992.tb00907.x.

Major, E. F., O. S. Dalgard, K. S. Mathisen, E. Nord, S. Ose, M. Rognerud and L. E. Aarø (2011). Bedre føre var ... Psykisk helse: Helsefremmende og forebyggende tiltak og anbefalinger. Oslo, Nasjonalt folkehelseinstitutt.

Mathiesen, K., A. Sanson, M. Stoolmiller and E. Karevold (2009). "The Nature and Predictors of Undercontrolled and Internalizing Problem Trajectories Across Early Childhood." Journal of Abnormal Child Psychology 37(2): 209-222, from http://dx.doi.org/10.1007/s10802-008-9268-y. 
McCarty, C. A., W. A. Mason, R. Kosterman, J. D. Hawkins, L. J. Lengua and E. McCauley (2008). "Adolescent School Failure Predicts Later Depression Among Girls." Journal of Adolescent Health 43(2): 180-187, from http://www.sciencedirect.com/science/article/pii/S1054139X08000864.

McKeown C, Hisle-Gorman E, Eide M, Gorman GH, Nylund CM (2013). Association of constipation and fecal incontinence with attention-deficit/hyperactivity disorder. Pediatrics, Nov; 132(5). Epub 2013 Oct 21.

Merikangas, K. R. (2005). "Vulnerability factors for anxiety disorders in children and adolescents." Child Adolesc Psychiatr Clin N Am 14(4): 649-679, vii.

Merikangas, K. R., J.-p. He, M. Burstein, S. A. Swanson, S. Avenevoli et al. (2010). "Lifetime Prevalence of Mental Disorders in U.S. Adolescents: Results from the National Comorbidity Survey Replication-Adolescent Supplement (NCS-A)." Journal of the American Academy of Child and Adolescent Psychiatry 49(10): 980-989, from http://www.sciencedirect.com/science/article/pii/ S0890856710004764.

Moffitt, T. E., A. Caspi, M. Rutter and P. A. Silva (2001). Sex differences in antisocial behaviour: Conduct disorder, juvenile delinquency, and violence in the Dunedin Longitudinal Study. Cambridge, England, Cambridge University Press.

Mykletun, A., A. K. Knudsen and K. S. Mathisen ( 2009). Psykiske lidelser i Norge: Et folkehelseperspektiv. Oslo, Nasjonalt Folkehelseinstitutt.

Owens JA (2008). Sleep disorders and attention-deficit/ hyperactivity disorder. Curr Psychiatry Rep, 10 (5), 439-44.

Odgers, C. L., T. E. Moffitt, J. M. Broadbent, N. Dickson, R. J. Hancox et al. (2008). "Female and male antisocial trajectories: From childhood origins to adult outcomes." Development and Psychopathology 20(02): 673-716, from http:// dx.doi.org/10.1017/S0954579408000333.

Parisi P, Verrotti A, Paolino MC, Ferretti A, Raucci U, Moavero R, Villa MP, Curatolo p (2014) Headache and attention deficit and hyperactivity disorder in children: Common condition with complex relation and disabling consequences. Epilepsy Behav, Mar; 32C:72-75. Epub 2014 Feb 2.

Poulton, R., A. Caspi, B. J. Milne, W. M. Thomson, A. Taylor, M. R. Sears and T. E. Moffitt (2002). "Association between children's experience of socioeconomic disadvantage and adult health: a life-course study." Lancet 360(9346): 16401645.

Skogen, J. C. and F. A. Torvik (2013). Atferdsforstyrrelser blant barn og unge i Norge: Beregnet forekomst og bruk av hjelpetiltak. Rapport 2013:4. Folkehelseinstituttet.
Striegel-Moore, R. H. and C. M. Bulik (2007). "Risk factors for eating disorders." American Psychologist 62(3): 181-198, from http://psycnet.apa.org/journals/amp/62/3/181/.

Surén, P., I. J. Bakken, S. Schjølberg, H. Aase, T. ReichbornKjennerud et al. (2013). "Fylkesvise forskjeller i registrert forekomst av autisme, AD/HD, epilepsi, cerebral parese i Norge 2012."Tidskrift for den Norske Legeforening 18: 1929-1934.

Surén P, Bakken IJ, Aase H, Chin R, Gunnes N, Lie KK et al. Autism Spectrum Disorder, ADHD, Epilepsy, and Cerebral Palsy in Norwegian Children. Pediatrics 2012, 130(1):e152e158.

Tiet, Q., G. Wasserman, R. Loeber, L. McReynolds and L. Miller (2001). “Developmental and Sex Differences in Types of Conduct Problems." Journal of Child and Family Studies 10(2): 181-197, from http://dx.doi.org/10.1023/ A\%3A1016637702525.

Tremblay, R. (2006). “Prevention of Youth Violence: Why not Start at the Beginning?" Journal of Abnormal Child Psychology 34(4): 480-486, from http://dx.doi.org/10.1007/ s10802-006-9038-7.

Wakschlag, L. S., P. H. Tolan and B. L. Leventhal (2010). “Research Review: 'Ain't misbehavin': Towards a developmentally-specified nosology for preschool disruptive behavior." Journal of Child Psychology and Psychiatry 51(1): 3-22, from http://dx.doi.org/10.1111/j.14697610.2009.02184.x.

Wichstrøm, L., K. Skogen and T. Osia (1996). “Increased Rate of Conduct Problems in Urban Areas: What Is the Mechanism?" Journal of the American Academy of Child \& Adolescent Psychiatry 35(4): 471-479, from: http://www.sciencedirect.com/science/article/pii/ $\underline{\text { S0890856709635176. }}$

Wichstrøm, L. (1999). "The emergence of gender difference in depressed mood during adolescence: The role of intensified gender socialization." Developmental Psychology 35(1): 232-245.

Wichstrøm, L., T. S. Berg-Nielsen, A. Angold, H. L. Egger, E. Solheim and T. H. Sveen (2012). "Prevalence of psychiatric disorders in preschoolers." Journal of Child Psychology and Psychiatry 53(6): 695-705, from http://dx.doi.org/10.1111/ j.1469-7610.2011.02514.x.

Øya, T. (2012). “Ung i Oslo 2012, Nøkkeltall.” Norsk Institutt for oppvekst, velferd og aldring. Notat $\mathrm{nr} 7 / 12$.

\section{FORFATTERE}

Jens Christoffer Skogen, Anne Kjeldsen, Ann Kristin Knudsen, Ingri Myklestad, Ragnar Nesvåg, Anne Reneflot, Ellinor Major 


\section{Psykisk helse hos voksne}

- Mellom en av tre og en av to vil bli rammet av en psykisk lidelse i løpet livet.

- Psykiske lidelser og ruslidelser opptrer ofte samtidig.

- Vi vet lite om enkeltårsakene, men både genetiske og miljømessige faktorer kan øke risikoen for å utvikle psykiske lidelser.

\section{Psykiske plager og lidelser blant voksne}

\section{Psykiske plager blant voksne}

Tall fra Statistisk sentralbyrås levekårsundersøkelse i 2008 viser at om lag 8-10 prosent av den voksne befolkningen i Norge har betydelige psykiske plager (Nes, 2011). Omfanget av betydelige psykiske plager i befolkningen synes dog å variere over relative korte tidsrom.

\section{Mellom 30 og 50 prosent vil få en psykisk lidelse i løpet av livet}

Norske og internasjonale studier viser at 30-50 prosent av den voksne befolkningen vil få en psykisk lidelse i løpet av livet (Kessler, 2005a, Mykletun, 2009).

- 30 prosent får en angstlidelse. Hyppigst er spesifikk fobi og sosial fobi.

- 25 prosent får en stemningslidelse (hovedsakelig depresjon).

- 10-20 prosent får en ruslidelse.

- Rundt 1-2 prosent får schizofreni eller en annen psykoselidelse.

Se tabell 1a og 1b for oversikt over utbredelse av de vanligste psykiske lidelsene blant voksne, samt internasjonale sammenligninger.

\section{Halvparten med psykiske lidelser har minst to psykiske lidelser}

I løpet av ett år vil 10-30 prosent av den voksne befolkningen ha psykiske plager som fyller kriteriene for minst én psykisk lidelse, og av disse vil halvparten fylle kriteriene for minst to lidelser (Kessler, 2005b). De lidelsene som oftest opptrer sammen er angst og depresjon, samt ruslidelser og andre stemningslidelser.
Personer som rammes av flere psykiske lidelser har sterkere funksjonsnedsettelse og dårligere prognose enn de som rammes av én lidelse (Kessler, 2005b). For eksempel kan personlighetsforstyrrelser vanskeliggjøre behandling av angst og depresjon (Skodol, 2011). Den totale sykdomsbyrden kan slik bli større enn summen av hver lidelse for seg.

\section{Mange med psykiske lidelser opplever rusmiddelproblemer}

Bruk av rusmidler er vanligere blant personer med psykiske lidelser enn ellers i befolkningen (Regier, 1990). Blant personer med depresjon og bipolar lidelse har rundt 20 prosent også problemer med misbruk eller avhengighet av alkohol eller andre rusmidler. Rusmisbruk er spesielt utbredt blant personer med psykoselidelser som for eksempel schizofreni (Hartz, 2014). Cannabis og amfetamin er de hyppigst brukte rusmidlene blant personer med schizofreni.

\section{Mange er ikke i kontakt med helse- tjenesten}

Mange som rammes av en psykisk lidelse kommer aldri i kontakt med helsetjenesten. I 2008 oppsøkte rundt 12 prosent av den voksne befolkningen primærlege for psykiske plager (Helsedirektoratet, 2010), og i perioden 2008-2012 mottok rundt 3 prosent behandling $\mathrm{i}$ psykisk helsevern, se figur 1 og 2.

Andelen kvinner og menn som bruker legemidler for psykiske lidelser har vært forholdsvis stabil de siste årene. Et unntak er legemidler for ADHD, der andelen er doblet fra 2004 til 2012, se figur 3. 


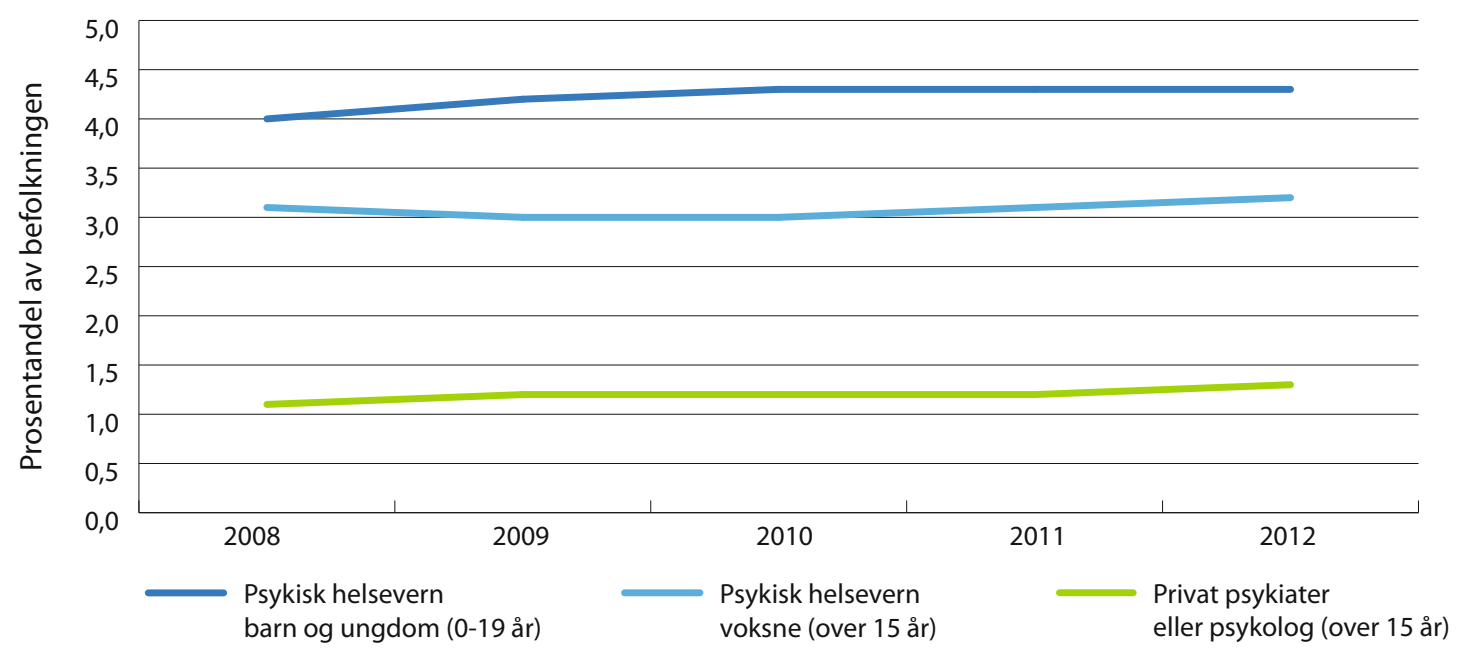

Figur 1: Andel av befolkningen i aldersgruppene 0-19 år og > 15 år som var i kontakt med spesialisthelsetjenesten i 2008-2012. Kilde: NPR/Helsedirektoratet.

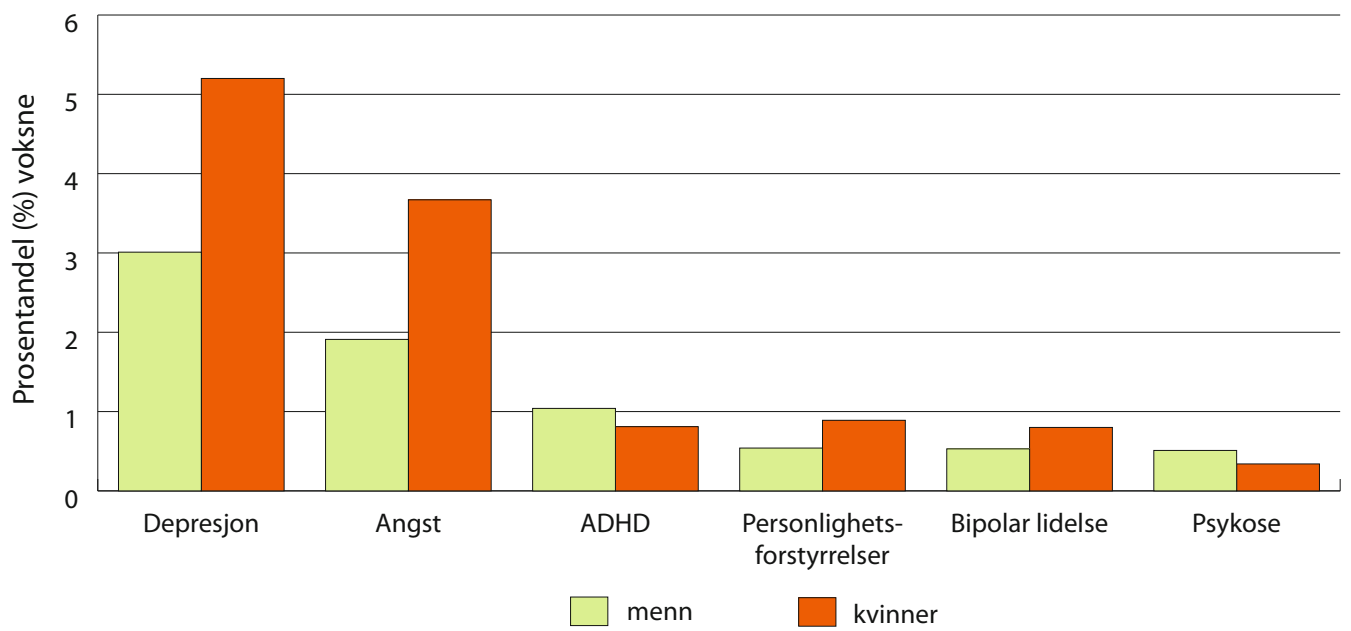

Figur 2: Andel av den voksne befolkningen som var i behandling i spesialisthelsetjenesten i 2008-2012, etter ulike diagnosegrupper. Kilde: NPR/Helsedirektoratet.

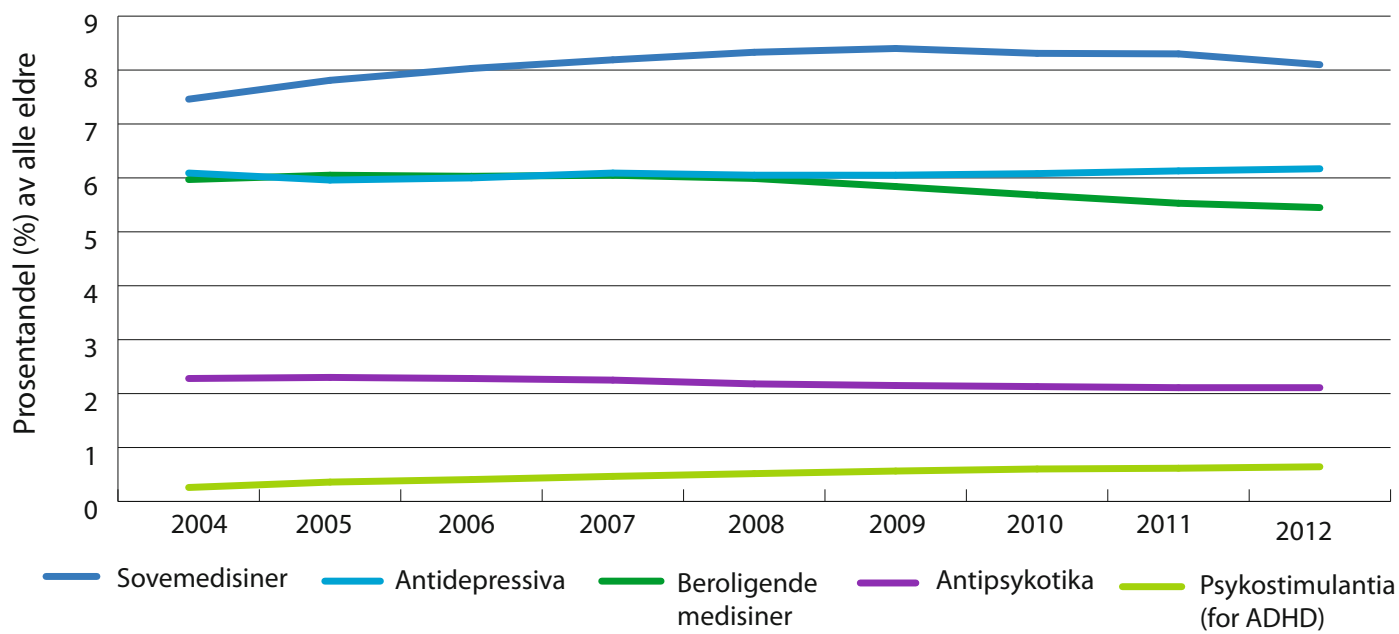

Figur 3: Andel i befolkningen (alle aldre) som bruker legemidler mot psykiske lidelser. Kilde: Reseptregisteret. 


\section{Utvikling over tid}

\section{Utvikling mellom 1998 og 2012 i psykiske plager}

Tall fra den norske levekårsundersøkelsen viser at andelen personer med psykiske plager gikk ned fra 1998 til 2005, men økte igjen fram mot 2012, se den oransje kurven figur 4. Det er vanskelig å si noe om utviklingen av psykiske lidelser, siden vi mangler presise og oppdaterte data om forekomsten i den norske befolkningen. I takt med en stadig eldre befolkning, må man imidlertid forvente økt behov for helsetjenester for psykiske lidelser fremover.

\section{Forskjeller mellom grupper i befolkningen}

\section{De fleste psykiske lidelser debuterer $\mathrm{i}$ ung voksen alder}

Livstidsforekomsten av psykiske lidelser er totalt sett mellom 30 - 50 prosent for begge kjønn, men det er betydelige kjønnsforskjeller i forekomst av enkeltlidelser (Kringlen, 2001).

Forekomsten av depresjon og angstlidelser er dobbelt så høy hos kvinner sammenlignet med menn, mens ruslidelser og schizofreni er hyppigere hos menn.

De fleste psykiske lidelser debuterer i ung voksen alder. Angstlidelser starter ofte i tenårene, ruslidelser mellom 20 og 30 år og stemningslidelser mellom 30 og 40 års alder (Kessler, 2005a).

\section{Sosial ulikhet og geografi}

Det er godt vitenskapelig grunnlag for å hevde at det er en sammenheng mellom sosioøkonomisk status og risikoen for psykiske lidelser (se blant annet Hiilamo, 2014). Flere studier har blant annet funnet en sammenheng mellom lav sosioøkonomisk status og depresjon (Lorant, 2003). Mekanismene bak sammenhengen mellom sosioøkonomisk status og risiko for psykiske lidelser er derimot ikke åpenbare (Hiilamo, 2014).

I Oslo er livstidsforekomsten av psykiske lidelser over 50 prosent (Kringlen, 2001), mens den er rundt 30 prosent i Sogn og Fjordane (Kringlen, 2006). Internasjonale studier har vist at forekomsten av schizofreni er høyest i byer.

\section{Risikofaktorer}

\section{Genetisk sårbarhet og miljøfaktorer}

Genetiske faktorer forklarer opp mot 80 prosent av variasjonen i sårbarhet for schizofreni og bipolar lidelse. For øvrig er det mangelfull kunnskap om spesifikke årsaker til psykiske plager og lidelser. Både tidlige faktorer, for eksempel infeksjoner i svangerskapet, komplikasjoner ved fødsel, traumer i barndom, og senere faktorer, som tapsopplevelser og bruk av rusmidler kan øke risikoen for både utbrudd og tilbakefall av psykiske helseplager og lidelser (AjdacicGross, 2014)

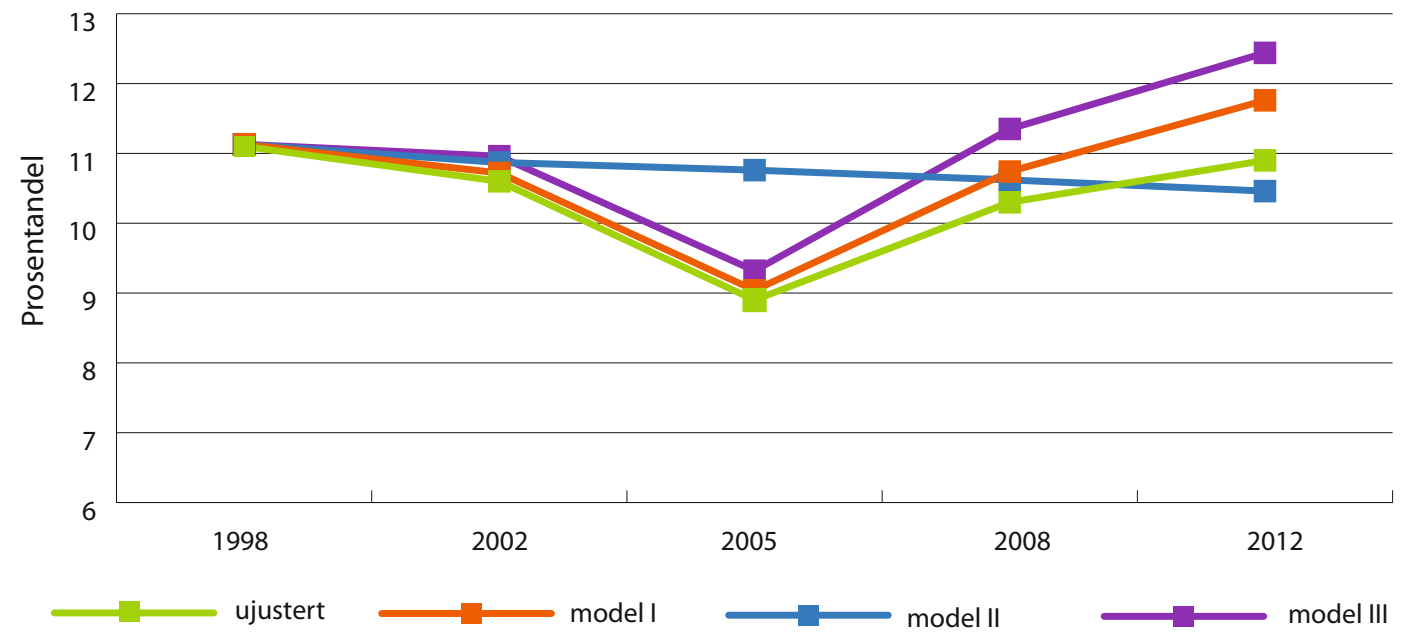

Figur 4: Utvikling i andelen med psykiske plager i perioden 1998-2012. Kilde: Statistisk sentralbyrå, Levekårsundersøkelsen 1998, 2002, 2005, 2008 og 2012. Det mest pålitelige estimatet er oransje kurve som viser andel justert for alder, utdanning og kjønn. Grønn kurve er ujusterte tall. Blå kurve er den utviklingen man ville forvente dersom all utvikling i psykiske plager kunne forklares av demografiske endringer (endringer i alder, utdanning, kjønn i befolkningen). Lilla kurve er det man kunne forvente dersom ingenting kunne forklares av demografiske endringer. 


\section{Konsekvenser og utfordringer}

\section{Psykiske lidelser øker risikoen for syke- fravær og uførhet}

Hos om lag tre av fire pasienter med psykiske lidelser starter sykdommen før 25 års alder (Kessler, 2005a), og de fleste har tilbakevendende plager gjennom livet. En betydelig andel av personer med psykiske lidelser står derfor i fare for å bli sykmeldt eller motta uførestønad.

Én av hundre arbeidsdager tapes på grunn av sykmelding for psykiske lidelser, og en økende andel tilskrives lettere psykiske lidelser (Brage, 2012). I 2011 var hver tredje uførepensjon tilskrevet en psykisk lidelse. Over halvparten av de som fikk uførepensjon før 40 års alder, fikk uførepensjon begrunnet i en psykisk lidelse (NAV, 2014).

\section{Kortere levealder}

Pasienter med psykiske lidelser har høyere forekomst av kroppslige sykdommer og lever kortere enn befolkningen for øvrig (Laursen, 2013). Blant pasienter med schizofreni er levealderen redusert med om lag 20 år i gjennomsnitt. Den økte dødeligheten kan tilskrives genetiske og sosioøkonomiske forhold, samt usunn livsstil, selvmord og bruk av legemidler. Pasienter med samtidig rusmisbruk er særlig utsatt for ulykker, voldsskader og tidlig død.

\section{Risiko for andre sykdommer}

Sviktende egenomsorg ved psykiske lidelser kan øke sårbarheten for både smittsomme og ikke-smittsomme sykdommer. Evnen til oppfølging av sykdom er gjerne også svekket. Ved diabetes er det i stor grad pasientens ansvar å kontrollere blodsukker, møte til legetimer og tilpasse kostholdet, og det er vist at depresjon kan påvirke mestring av diabetes (Johnson, 2012).
Bivirkninger av medisiner kan gi økt risiko for andre sykdommer. Medikamentell behandling av schizofreni leder for eksempel ofte til økt kroppsvekt (Baptista, 2002), noe som igjen øker risikoen for andre sykdommer.

\section{Sykdomsbyrde}

I 2010 var psykiske lidelser og ruslidelser internasjonalt den største årsaken til tap av leveår med nedsatt helse (YLDs), hvorav depresjon (40 prosent) og angstlidelser (15 prosent) var de to største bidragsyterne (Whiteford, 2013). Den totale sykdomsbyrden av psykiske lidelser og ruslidelser har økt med 38 prosent fra 1990 til 2010, noe som for psykiske lidelser begrunnes i befolkningsmessige endringer, blant annet økende andel eldre.

\section{Forebygging}

For å forebygge psykiske lidelser i befolkningen bør tiltakene søke å motvirke risikofaktorer og styrke beskyttelsesfaktorer (WHO, 2004). Forebygging av psykiske lidelser bør starte tidlig og krever en koordinert innsats på flere nivå i samfunnet. Folkehelseinstituttet ga i 2011 ut en rapport som oppgav de 50 viktigste tiltakene for å forebygge psykiske lidelser (Major, 2011).

Les mer i rapport fra Folkehelseinstituttet: $\underline{\text { Bedre føre }}$ var FHI-rapport 2011:1. 
Tabell 1a: Livstidsprevalens. Oversikt over de største norske og de viktigste internasjonale studiene angående forekomst av psykiske lidelser i befolkningen. Alle studiene er basert på såkalte strukturerte kliniske intervjuer utviklet av Verdens helseorganisasjon. Kilde: Nasjonalt folkehelseinstitutt, Rapport 2009:8, s. 18.

\begin{tabular}{|c|c|c|c|c|c|c|c|}
\hline \multirow[b]{2}{*}{ Lidelse } & \multicolumn{7}{|c|}{ Livstidsprevalens } \\
\hline & Tvilling & Oslo & $\begin{array}{l}\mathrm{S} \text { og } \\
\mathrm{Fj}\end{array}$ & NCS & NCS-R & NEMESIS & ESEMeD \\
\hline Angstlidelser & 26,7 & & & 24,9 & 28,8 & 19,3 & 13,6 \\
\hline Spesifikk fobi & 18,6 & 14,4 & 6,5 & 11,3 & 12,5 & 10,1 & 7,7 \\
\hline Sosial fobi & 4,0 & 13,7 & 7,3 & 13,3 & 12,1 & 7,8 & 2,4 \\
\hline Agorafobi & $4,8^{*}$ & 6,1 & 3,6 & 5,3 & 1,4 & 3,4 & 0,9 \\
\hline Panikklidelse & 2,8 & 4,5 & 2,6 & 3,5 & 4,7 & 3,8 & 2,1 \\
\hline Generalisert angstlidelse & 2,0 & 4,5 & 3,4 & 5,1 & 5,7 & 2,3 & 2,8 \\
\hline Tvangslidelse & 0,7 & 1,6 & 0,6 & & 1,6 & 0,9 & \\
\hline $\begin{array}{l}\text { Depressive lidelser og bipolar } \\
\text { lidelse }\end{array}$ & & & & 19,3 & 20,8 & 19,0 & 14,0 \\
\hline Alvorlig depresjon & 14,0 & 17,8 & 8,3 & 17,1 & 16,6 & 15,4 & 12,8 \\
\hline Dystymi & 1,7 & 10,0 & 6,3 & 6,4 & 2,5 & 6,3 & 4,1 \\
\hline Bipolar lidelse & & 1,6 & 0,2 & & 3,9 & 1,8 & \\
\hline Rusrelaterte lidelser & & & & 26,3 & 14,6 & 18,7 & \\
\hline Alkoholmisbruk/avhengighet & 9,4 & 22,7 & 9,4 & & & & 5,2 \\
\hline Alkoholmisbruk & & 14,0 & 6,9 & 9,4 & 13,2 & 11,7 & \\
\hline Alkoholavhengighet & & 8,8 & 2,4 & 14,1 & 5,4 & 5,5 & \\
\hline Stoffmisbruk/avhengighet & 1,8 & 3,4 & 0,4 & & & 1,0 & \\
\hline Stoffmisbruk & & 1,5 & 0,1 & 4,4 & 7,9 & 1,5 & \\
\hline Stoffavhengighet & & 1,9 & 0,1 & 7,5 & 3,0 & 1,8 & \\
\hline \multicolumn{8}{|l|}{ Andre lidelser } \\
\hline Somatoform lidelse & & 3,7 & 3,4 & & & & \\
\hline Spiseforstyrrelser & 1,7 & 1,8 & 0,5 & & & 0,7 & \\
\hline Minst en av ovenstående lidelser & 45,9 & 52,4 & 30,9 & 48,0 & 46,4 & 41,2 & 25,0 \\
\hline
\end{tabular}

Tvilling = Tvillingstudien ved Nasjonalt folkehelseinstitutt. S og Fj = Sogn og Fjordane. NCS = National Comorbidity Survey, NCS-R = National Comorbidity Survey Replication, NEMESIS = The Netherlands Mental Health Survey and Incidence Study, $\mathrm{ESEMeD}=$ European Study of the Epidemiology of Mental Disorders project. *Agorafobi uten panikkanfall 
Tabell 1b: 12-månedersprevalens. Oversikt over de største norske og de viktigste internasjonale studiene angående forekomst av psykiske lidelser i befolkningen. Alle studiene er basert på såkalte strukturerte kliniske intervjuer utviklet av Verdens helseorganisasjon. Kilde: Nasjonalt folkehelseinstitutt, Rapport 2009:8, s. 18.

\begin{tabular}{|c|c|c|c|c|c|c|c|}
\hline \multirow[b]{2}{*}{ Lidelse } & \multicolumn{7}{|c|}{ 12-måneders prevalens (\%) } \\
\hline & Oslo & $\begin{array}{l}\text { Sog } \\
\mathrm{Fj}\end{array}$ & NCS & NCS-R & NEMESIS & ESEMeD & Health \\
\hline Angstlidelser & & & 17,2 & 18,1 & 12,4 & 6,0 & 4,2 \\
\hline Spesifikk fobi & 11,1 & 5,0 & 8,8 & 8,7 & 7,1 & 3,5 & \\
\hline Sosial fobi & 7,9 & 5,0 & 7,9 & 6,8 & 4,8 & 1,2 & 1,0 \\
\hline Agorafobi & 3,1 & 1,6 & 2,8 & 0,8 & 1,6 & 0,4 & 1,2 \\
\hline Panikklidelse & 2,6 & 1,2 & 2,3 & 2,7 & 2,2 & 0,8 & 1,9 \\
\hline Generalisert angstlidelse & 1,9 & 1,1 & 3,1 & 3,1 & 1,2 & 1,0 & 1,3 \\
\hline Tvangslidelse & 0,7 & 0,3 & & 1,0 & 0,5 & & \\
\hline $\begin{array}{l}\text { Depressive lidelser og bipolar } \\
\text { lidelse }\end{array}$ & & & 11,3 & 9,5 & 7,6 & 4,2 & 6,5 \\
\hline Alvorlig depresjon & 7,3 & 3,7 & 10,3 & 6,7 & 5,8 & 3,9 & 4,9 \\
\hline Dystymi & 3,8 & 1,6 & 2,5 & 1,5 & 2,3 & 1,0 & 2,5 \\
\hline Bipolar lidelse & 0,9 & 0,1 & & 2,6 & 1,1 & & \\
\hline Rusrelaterte lidelser & & & 11,3 & 3,8 & 8,9 & & \\
\hline Alkoholmisbruk/avhengighet & 10,6 & 3,1 & & & & 1,0 & 4,3 \\
\hline Alkoholmisbruk & & 2,3 & 2,5 & 3,1 & 4,6 & & 0,3 \\
\hline Alkoholavhengighet & & 0,8 & 7,2 & 1,3 & 3,7 & & 3,9 \\
\hline Stoffmisbruk/avhengighet & 0,9 & 0,0 & & & & & \\
\hline Stoffmisbruk & & 0,0 & 0,8 & 1,4 & 0,5 & & \\
\hline Stoffavhengighet & & 0,0 & 2,8 & 0,4 & 0,8 & & \\
\hline \multicolumn{8}{|l|}{ Andre lidelser } \\
\hline Somatoform lidelse & 2,1 & 2,2 & & & & & \\
\hline Spiseforstyrrelser & 0,7 & 0,1 & & & 0,4 & & \\
\hline Minst en av ovenstående lidelser & 32,8 & 16,5 & 29,5 & 26,2 & 23,2 & 9,6 & 12,3 \\
\hline
\end{tabular}

Tvilling = Tvillingstudien ved Nasjonalt folkehelseinstitutt. S og Fj = Sogn og Fjordane. NCS = National Comorbidity Survey, NCS-R = National Comorbidity Survey Replication, NEMESIS = The Netherlands Mental Health Survey and Incidence Study, $\mathrm{ESEMeD}=$ European Study of the Epidemiology of Mental Disorders project, Health = Health 2000 Study. 


\section{Referanser}

Ajdacic-Gross, V. (2014). “The prevention of mental disorders has a bright future." Frontiers in Public Health2, from http://www.frontiersin.org/Journal/Abstract. aspx?s=1473\&name=public mental health\&ART DOI=10.3389/fpubh.2014.00060.

Baptista T, Araujo de Baptista E, Ying Kin NMKN, Beaulieu S, Walker D, Joober R, Lalonde J, Richard D: Comparative effects of the antipsychotics sulpiride or risperidone in rats: I: Bodyweight, food intake, body composition, hormones and glucose tolerance. Brain Res 2002, 957(1):144-151.

Brage, S., J. P. Nossen, I. C. Kann and O. Thune (2012). "Sykefravær med diagnose innen psykiske lidelser 2000-2011." NAV: Arbeid og velferd (3).

Hartz, S. M., C. N. Pato, H. Medeiros and et al. (2014). "Comorbidity of severe psychotic disorders with measures of substance use." JAMA Psychiatry 71(3): 248-254, from http://dx.doi.org/10.1001/jamapsychiatry.2013.3726.

Helsedirektoratet ( 2010). Rapport IS-1808. Data fra allmenlegetjenesten.

Hiilamo, H. (2014). “Is Income Inequality ‘Toxic for Mental Health'? An Ecological Study on Municipal Level Risk Factors for Depression." PLoS ONE 9 (3): e92775, from http://dx.doi.org/10.1371\%2Fjournal.pone.0092775.

Johnson J, Al Sayah F, Wozniak L, Rees S, Soprovich A, Chik C, Chue P, Florence P, Jacquier J, Lysak P et al: Controlled trial of a collaborative primary care team model for patients with diabetes and depression: Rationale and design for a comprehensive evaluation. BMC Health Services Research 2012, 12(1):258.

Kessler, R. C., P. Berglund, O. Demler, R. Jin and E. E. Walters (2005a). “Lifetime prevalence and age-of-onset distributions' of DSM-IV disorders in the national comorbidity survey replication." Archives of general psychiatry 62(6): 593-602.

Kessler, R. C., W. T. Chiu, O. Demler and E. E. Walters (2005b). "Prevalence, severity, and comorbidity of 12-month DSM-IV disorders in the National Comorbidity Survey Replication." Archives of general psychiatry 62(6): 617-627.

Kringlen, E., S. Torgersen and V. Cramer (2001). "A Norwegian psychiatric epidemiological study." American Journal of Psychiatry 158(7): 1091-1098.

Kringlen, E., S. Torgersen and V. Cramer (2006). "Mental illness in a rural area: A Norwegian psychiatric epidemiological study." Social Psychiatry and Psychiatric Epidemiology 41(9): 713-719, from http://www.ncbi.nlm.nih.gov/ pubmed/16732397.

Laursen, T. M., K. Wahlbeck, J. Hallgren, J. Westman, U. Osby, H. Alinaghizadeh, M. Gissler and M. Nordentoft (2013). "Life expectancy and death by diseases of the circulatory system in patients with bipolar disorder or schizophrenia in the Nordic countries." PLoS One 8(6): e67133, from http://www.ncbi.nlm.nih.gov/pubmed/23826212.
Lorant, V., D. Deliège, W. Eaton, A. Robert, P. Philippot and M. Ansseau (2003). "Socioeconomic Inequalities in Depression: A Meta-Analysis." American Journal of Epidemiology157(2): 98-112, from http://aje.oxfordjournals.org/ content/157/2/98.abstract.

Major, E. F., O. S. Dalgard, K. S. Mathisen, E. Nord, S. Ose, M. Rognerud and L. E. Aarø (2011). Bedre føre var...Psykisk helse: Helsefremmende og forebyggende tiltak og anbefalinger. Oslo, Nasjonalt folkehelseinstitutt.

Mykletun, A., A. K. Knudsen and K. S. Mathisen ( 2009). Psykiske lidelser i Norge: Et folkhelseperspektiv. Oslo, Nasjonalt folkehelseinstitutt.

NAV. (2014). "Tall og analyse." Hentet 10.02.2014, fra nav. no

Nes, R. B. and J. Clench-Aas (2011). Psykisk helse i Norge: Tilstandsrapport med internasjonale sammenligninger, Nasjonalt folkehelseinstitutt. Rapport 2011: 2.

Regier, D. A., M. E. Farmer, D. S. Rae and et al. (1990). "Comorbidity of mental disorders with alcohol and other drug abuse: Results from the epidemiologic catchment area (eca) study." JAMA 264(19): 2511-2518, from http:// dx.doi.org/10.1001/jama.1990.03450190043026.

Skodol, A. E., Grilo, C. M., Keyes, K. M., Geier, T., Grant, B. F., \& Hasin, D. S. (2011). Relationship of personality disorders to the course of major depressive disorder in a nationally representative sample. The American Journal of Psychiatry, 168(3), 257-64. Doi:10.1176/appi.ajp.2010.10050695.

Whiteford, H. A., L. Degenhardt, J. Rehm, A. J. Baxter, A. J. Ferrari, H. E. Erskine, F. J. Charlson, R. E. Norman, A. D. Flaxman, N. Johns, R. Burstein, C. J. L. Murray and T. Vos (2013). "Global burden of disease attributable to mental and substance use disorders: findings from the Global Burden of Disease Study 2010." The Lancet 382(9904): 1575-1586, from http://linkinghub.elsevier.com/retrieve/ pii/S0140673613616116.

WHO (2004). Prevention of mental disorders: effective interventions and policy options: summary report. World Health Organization, World Health Organization Dept. of Mental Health and Substance Abuse; in collaboration with the Prevention Research Centre of the Universities of Nijmegen and Maastricht.

\section{FORFATTERE}

Jens Christoffer Skogen, Inger Johanne Bakken, Jocelyne Clench-Aas, Rune Johansen, Ann Kristin Knudsen, Ragnar Nesvåg, Leila Torgersen 
- Mellom 10 og 20 prosent av befolkningen får en ruslidelse i løpet av livet.

- Skadelig bruk eller avhengighet av alkohol er den hyppigst forekommende ruslidelsen i Norge.

- Ruslidelser er en betydelig helseutfordring og medfører omfattende kostnader for enkeltindivider og samfunnet forøvrig.

- Pasienter med ruslidelser har ofte også andre psykiske lidelser og kroppslige sykdommer.

- Antallet personer under legemiddelassistert rehabilitering (LAR) for opiatavhengighet øker.

- Både arv og miljø er viktige risikofaktorer.

\section{Ruslidelser og rusavhengighet}

Ruslidelser kan brukes som en samlebetegnelse på skadelig bruk av rusmidler og rusmiddelavhengighet.

- Skadelig bruk kalles ofte misbruk og innebærer bruk av rusmidler i et mønster som gir fysisk eller psykisk helseskade.

- Rusmiddelavhengighet kjennetegnes vanligvis av at bruker har et sterkt ønske om å ta rusmiddelet, vansker med å kontrollere bruken av det, fortsatt bruk til tross for skadelige konsekvenser og at stoffbruken får prioritet foran andre aktiviteter og forpliktelser. Ved rusmiddelavhengighet vil man også se en toleranseutvikling (tilvenning, behov for økende doser) hos personen, og noen ganger avvenningssymptomer (abstinenser). Disse symptomene varierer mellom type rusmidler i uttrykk, alvorlighetsgrad og varighet.

Vi har valgt å omtale følgende fem grupper:

1. Alkoholavhengighet og alkoholmisbruk

2. Avhengighet av opioider

3. Avhengighet av cannabis

4. Avhengighet av amfetamin og metamfetamin

5. Avhengighet av vanedannende legemidler

\section{Livstidsforekomst på 10-20 prosent}

Vi mangler oppdaterte og presise tall på den faktiske forekomsten av ruslidelser i Norge. Basert på det tilgjengelige datamaterialet er derfor omfanget av ruslidelser i Norge usikkert, men det er grunn til å tro at omfanget er betydelig med en antatt livstidsforekomst på 10-20 prosent med store variasjoner på landsbasis. Det vil si at mellom én av ti og én av fem får slike problemer i løpet av livet.

Dette er basert på:

- Tidligere intervjustudier av et tilfeldig utvalg $\mathrm{i}$ befolkningen har vist at livstidsforekomsten for alkoholmisbruk/alkoholavhengighet er om lag 22,7 prosent i Oslo og om lag 9,4 prosent i Sogn og Fjordane (Kringlen, 2001, Kringlen 2006).

- Livstidsforekomsten for andre ruslidelser enn alkoholmisbruk/alkoholavhengighet er om lag 3,4 prosent i Oslo og om lag 0,4 prosent (misbruk/avhengighet) i Sogn og Fjordane (Kringlen, 2001; Kringlen, 2006).

Tall fra den norske Tvillingstudien, hvor man har intervjuet et utvalg av unge norske tvillingpar, har beregnet forekomsten av andre ruslidelser (misbruk/avhengighet) til om lag 1,8 prosent (Kendler, 2006). Dette er lavere enn tallene fra Oslo, og kan delvis forklares ved at ruslidelser er mer vanlig i urbane enn i landlige områder.

Se tabell 1a-b for mer detaljert informasjon. 
Tabell 1a: Oversikt over de tre største norske studiene og de fem viktigste internasjonale studiene angående forekomst av ruslidelser i befolkningen. Alle studiene er basert på såkalte strukturerte kliniske intervjuer utviklet av Verdens helseorganisasjon. Kilde: Folkehelseinstituttet, Rapport 2009:8, s. 18

\begin{tabular}{|l|l|l|l|l|l|l|l|}
\hline & \multicolumn{7}{|c|}{ Livstidsprevalens } \\
\hline Lidelse & Tvilling & Oslo & $\begin{array}{l}\text { S og } \\
\text { Fj }\end{array}$ & NCS & NCS-R & NEMESIS & ESEMeD \\
\hline Alkoholmisbruk/avhengighet & 9,4 & 22,7 & 9,4 & & & & 5,2 \\
\hline Alkoholmisbruk & & 14,0 & 6,9 & 9,4 & 13,2 & 11,7 & \\
\hline Alkoholavhengighet & & 8,8 & 2,4 & 14,1 & 5,4 & 5,5 & \\
\hline Stoffmisbruk/avhengighet & 1,8 & 3,4 & 0,4 & & & 1,0 & \\
\hline Stoffmisbruk & & 1,5 & 0,1 & 4,4 & 7,9 & 1,5 & \\
\hline Stoffavhengighet & & 1,9 & 0,1 & 7,5 & 3,0 & 1,8 & \\
\hline
\end{tabular}

Tabell 1b: Oversikt over de tre største norske studiene og de fem viktigste internasjonale studiene angående forekomst av ruslidelser i befolkningen. Alle studiene er basert på såkalte strukturerte kliniske intervjuer utviklet av Verdens helseorganisasjon. Kilde: Folkehelseinstituttet, Rapport 2009:8, s. 18

\begin{tabular}{|l|l|l|l|l|l|l|l|}
\hline & \multicolumn{7}{|c|}{ 12-måneders prevalens (\%) } \\
\hline Lidelse & Oslo & $\begin{array}{l}\text { S og } \\
\text { Fj }\end{array}$ & NCS & NCS-R & NEMESIS & ESEMeD & Health \\
\hline Alkoholmisbruk/avhengighet & 10,6 & 3,1 & & & & 1,0 & 4,3 \\
\hline Alkoholmisbruk & & 2,3 & 2,5 & 3,1 & 4,6 & & 0,3 \\
\hline Alkoholavhengighet & & 0,8 & 7,2 & 1,3 & 3,7 & & 3,9 \\
\hline Stoffmisbruk/avhengighet & 0,9 & 0,0 & & & & & \\
\hline Stoffmisbruk & & 0,0 & 0,8 & 1,4 & 0,5 & & \\
\hline Stoffavhengighet & & 0,0 & 2,8 & 0,4 & 0,8 & & \\
\hline
\end{tabular}

Tabell 1a-b: Tvilling = Tvillingstudien ved Nasjonalt folkehelseinstitutt, $\mathrm{S}$ og $\mathrm{Fj}=\mathrm{Sogn}$ og Fjordane, NCS = National Comorbidity Survey, NCS-R = National Comorbidity Survey Replication, NEMESIS = The Netherlands Mental Health Survey and Incidence Study, ESEMeD = European Study of the Epidemiology of Mental Disorders project, Health = Health 2000 Study.

\section{Mange har problemer med flere rusmidler}

For perioden 2008-2012 ble om lag 71000 menn og 33000 kvinner i aldersgruppen 23-62 år behandlet for en ruslidelse i spesialisthelsetjenesten, se figur 1 neste side. Skadelig bruk eller avhengighet av alkohol var de hyppigst registrerte ruslidelsene for begge kjønn, dernest flerbruksproblematikk.

Bruk av ulike rusmidler eller kombinasjoner av rusmidler og vanedannende legemidler er vanlig blant misbrukere. Én ruslidelse øker sannsynligheten for misbruk av andre rusmidler (Compton, 2007).

Alkohol er det mest brukte rusmiddelet i Norge, og ruslidelser knyttet til alkohol utgjør de hyppigst forekommende ruslidelsene (Kringlen, 2001; Kringlen, 2006).

Cannabis er det mest brukte illegale rusmidlet i Norge. Misbruk av amfetamin og metamfetamin er økende på verdensbasis, og vi finner også utstrakt misbruk i Norge. Se også kapittel Alkohol og andre rusmidler.

\section{Utvikling over tid: lite tallgrunnlag}

Vi mangler data om forekomsten av ruslidelser i Norge over tid. På verdensbasis ser vi en økning i forekomst av ruslidelser (Whiteford, 2013), og det er grunn til å tro at også forekomsten i Norge har økt. Forbruket av alkohol og andre rusmidler er en viktig risikofaktor. Omsetningen av alkohol har økt fra 3,6 liter ren alkohol per innbygger per år i 1970 til 5,2 liter i 2010. Data fra SIRUS viser at beslag av cannabis og amfetamin har økt sterkt de siste årene (Edland-Gryt, 2012). Se også kapittel Alkohol og andre rusmidler. 


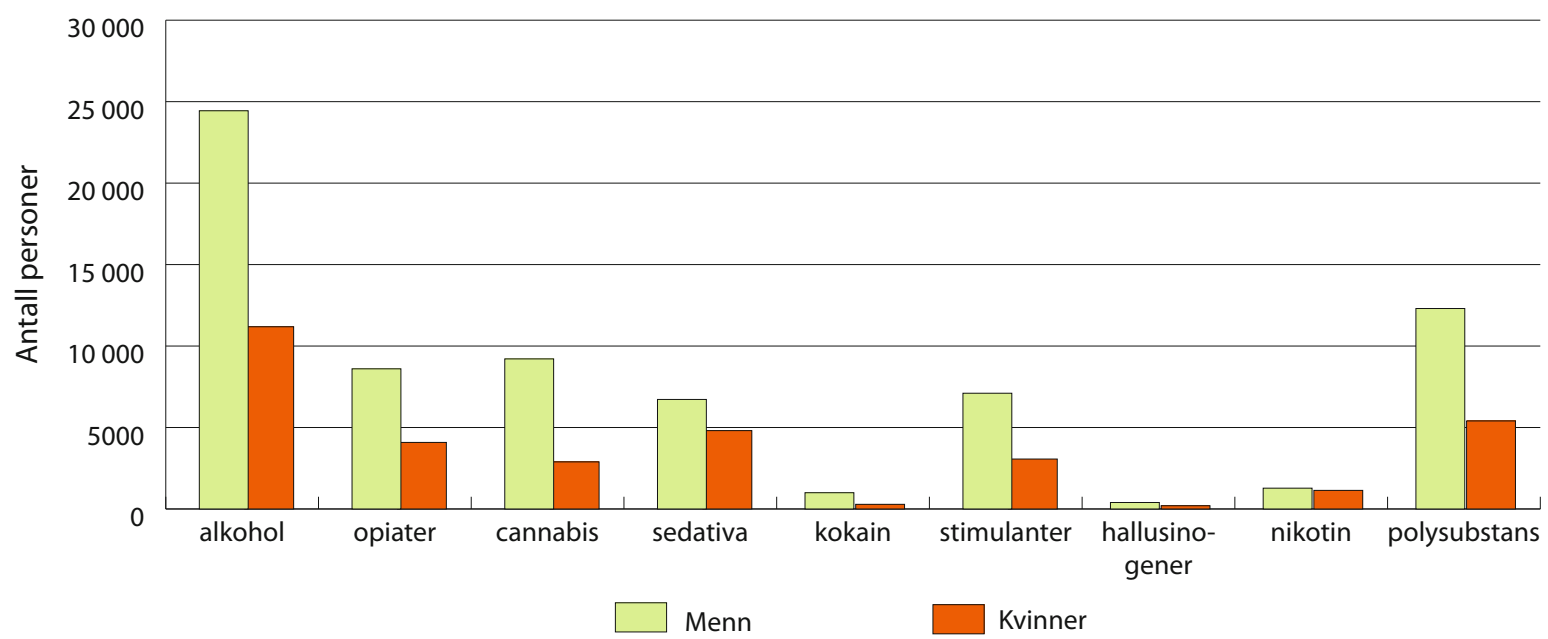

Figur 1: Antall personer i aldersgruppen 23-62 år registrert med ruslidelsesdiagnose 2008-2012.

Sedativa: sedativa/hypnotika (beroligende midler og sovemidler), Polysubstans: ruslidelse knyttet til flere ulike rusmidler. Kilde: Norsk pasientregister (NPR).

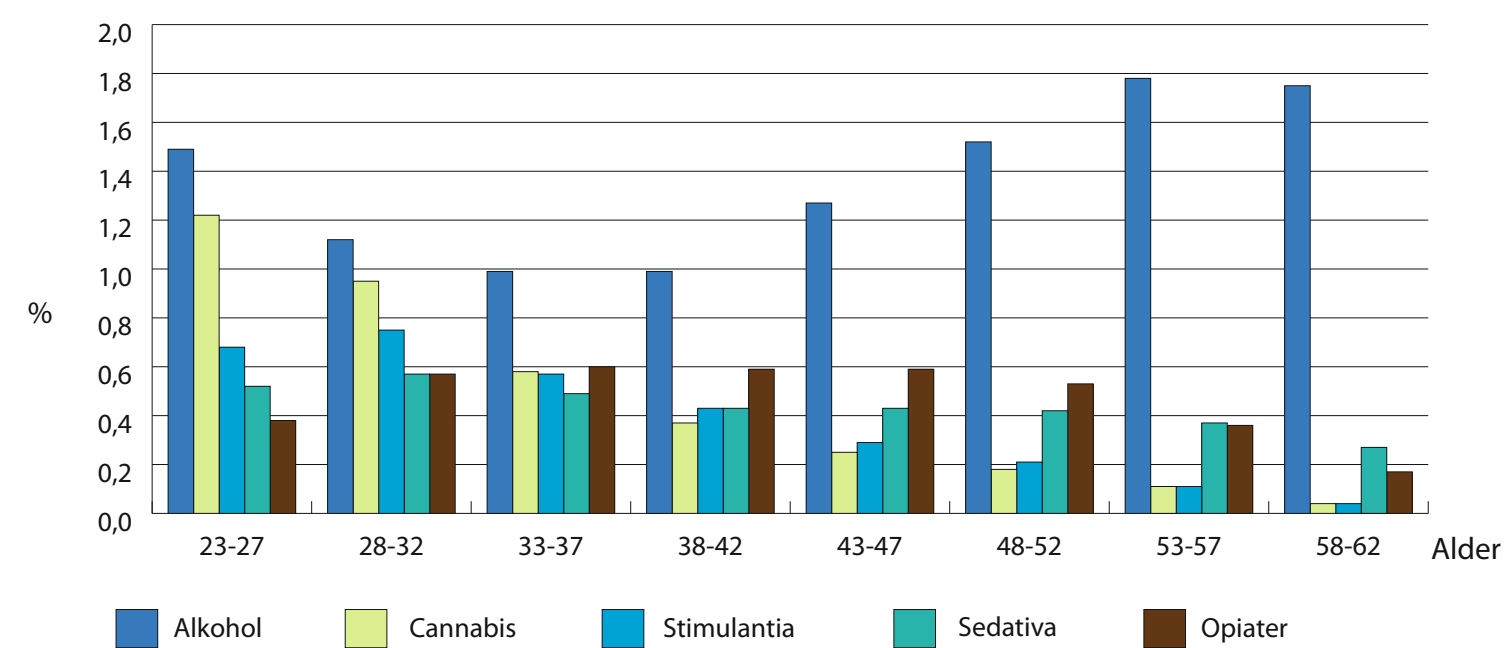

Figur 2: Andel av befolkningen i aldersgruppen 23-62 år registrert med en ruslidelse i perioden 2008-2012, fordelt på rusmiddel og alder. Sedativa: sedativa/hypnotika. Kilde: Norsk pasientregister (NPR).

\section{Flere får behandling med LAR-tiltak}

Ifølge tall fra Reseptregisteret har antall personer i LAR-behandling (legemiddelassistert rehabilitering) $ø$ kt fra 5000 i 2008 til 7500 i 2013. Slik behandling tilbys personer som er avhengige av heroin eller andre opioider. LAR er en tverrfaglig spesialisert behandling der substitusjonsbehandling med legemidler inngår som et tiltak i et helhetlig rehabiliteringsforløp. Legemidlene som benyttes er metadon og buprenorfin. $\varnothing$ kningen av pasienter i LAR-tiltak kan være et uttrykk for at det er enklere å komme inn i behandling, og at terskelen for utskrivning har økt (Waal, 2013).

\section{Forskjeller i befolkningen}

\section{Kjønnsforskjeller minker}

Generelt finner man en høyere andel unge menn blant personer med ruslidelser (Kringlen, 2001; Degenhardt, 2013), men kjønnsforskjellene ser ut til å minke (Zilberman, 2004; Keyes, 2008).

Tall fra Norsk pasientregister (NPR) for perioden 2008 til 2012 viser at foruten alkohol og flerbruksproblematikk var ruslidelser knyttet til bruk av cannabis og opiater vanlig for menn, og sedativa og opiater vanlig for kvinner, se figur 1. 


\section{Aldersforskjeller}

Blant pasienter som har vært i kontakt med spesialisthelsetjenesten i perioden 2008-2012, ser man at:

- Misbruk og avhengighet knyttet til alkohol er hyppigst blant eldre.

- Misbruk og avhengighet av cannabis og stimulantia (for eksempel amfetamin) er mest hyppig blant de yngste.

Ruslidelser knyttet til bruk av sedativa (for eksempel. benzodiazepin) og opiater (for eksempel. heroin) er mer jevnt fordelt over aldersgruppene, se figur 2 .

\section{Sosioøkonomiske forskjeller i ruslidelser}

Alkoholkonsum og hyppighet av alkoholinntak øker med økende utdanning og inntekt (Clench-Aas, 2009). Likevel er det færre som blir alkoholavhengige i disse gruppene sammenlignet med personer med lav utdanning og inntekt. Det samme mønsteret ser ut til å gjelde for andre rusmidler også.

\section{Høyere forekomst i storbyer}

Forekomsten av alkoholavhengighet er høyere i storbyene sammenlignet med småbyer og landsbygden (Clench-Aas, 2009). Det samme mønsteret finner man i forhold til bruk av hasj, marihuana og andre narkotiske stoffer.

\section{Mindre problem i enkelte innvandrer- grupper}

Funn fra Helseundersøkelsen i Oslo gjennomført i 2000-2001, tyder på at alkoholbruk er langt mindre utbredt blant innvandrere fra Afrika og Asia enn blant etniske nordmenn (Kumar, 2008).

\section{Risikofaktorer for utvikling av ruslidelser}

Tilgang til rusmidler er en forutsetning for å utvikle en ruslidelse (Se kapittel om alkohol og andre rusmidler). Genetiske, psykososiale og sosioøkonomiske forhold er også av betydning for utviklingen av en ruslidelse (Galea, 2004). Vi har mangelfull kunnskap om hvordan betydningen av de ulike faktorene samvirker og varierer over livsløpet, men generelt vil genetisk sårbarhet, negativ påvirkning fra familie og nærmiljø, psykososiale utfordringer og lavere sosioøkonomisk status bidra til å øke risikoen for å utvikle en ruslidelse (Galea, 2004).

Tall fra den norske Tvillingstudien viser at på befolkningsnivå er arvelighet en betydelig årsaksfaktor for utvikling av ruslidelser (Kendler, 2006).
Gjentatt bruk av sterke smertestillende og beroligende midler/sovemidler forskrevet av lege, henger sammen med økende alder, kjønn (kvinne), opioidbruk hos mor og lav sosioøkonomisk status hos unge voksne (Hartz, 2011; Log, 2013; Svendsen, 2014). I tillegg øker røyking sannsynligheten for gjentatt opioidbruk (Log, 2011).

\section{Ruslidelser og andre psykiske lidelser opptrer sammen}

Det er stor grad av samsykelighet mellom ruslidelser og andre psykiske lidelser (Conway, 2006). Dette inkluderer samsykelighet med stemningslidelser, angst, personlighetsforstyrrelser og psykoselidelser.

Det er også en overhyppighet av somatisk sykdom blant personer med ruslidelser. Dette kan skyldes de direkte skadelige virkningene av rusmisbruket (van Amsterdam, 2013) eller sviktende egenomsorg, som disponerer for både smittsomme og ikke-smittsomme sykdommer gjennom mangelfull ernæring, fysisk inaktivitet og sosial isolasjon. Evnen til oppfølging av somatisk sykdom er gjerne også svekket.

\section{Konsekvenser og utfordringer}

Alkoholrelaterte ruslidelser er knyttet både til andre psykiske lidelser, somatisk sykdom og tidlig død (Rehm, 2010), og alkoholbruken har ofte svært negative konsekvenser for personens forhold til familie og venner. Utvikling fra bruk via misbruk til avhengighet kan være en langvarig og gradvis prosess, og ofte erkjenner man ikke at alkoholbruken er blitt problematisk før langt ut i forløpet.

Bruk av opioider (heroin, morfin) som rusmiddel er etter gjentatte inntak sterkt avhengighetsskapende. Livstruende overdoser er mer vanlig ved misbruk av visse typer opioider (som heroin) enn for andre vanlige rusmidler. Faren for overdoser øker ved flerbruksproblematikk, spesielt i kombinasjon med sedativa eller alkohol. Langvarig bruk av opioider øker risikoen for psykiske lidelser, sosiale og økonomiske problemer, samt somatiske komplikasjoner.

LAR-behandling i Norge fører til en betydelig reduksjon i kriminalitet (Bukten, 2012; Bukten, 2013a; Bukten, 2013b) og dødelighet (Clausen, 2009) og bedre svangerskapsomsorg og helse for gravide (Lund, 2012; Lund, 2013).

Cannabis antas å være mindre avhengighetsskapende enn andre rusmidler. Avhengigheten kan likevel oppleves som sterk. Ved utvikling av cannabisavhengighet, kan risikoen for bruk av andre avhengighetsskapende stoffer øke. Langvarig bruk kan påvirke 
kroppens immunforsvar, og øke risikoen for angst og depresjonssymptomer, samt komplisere behandlingen av eventuelle samtidige psykiske lidelser.

Amfetaminmisbruk over kort tid kan i noen tilfeller utløse langvarige perioder med psykiske lidelser, selv etter avbrutt inntak av stoffene. Ved overdose eller omfattende misbruk av amfetamin og metamfetamin kan det oppstå somatiske tilstander eller psykoser som må behandles i sykehus.

Vanedannende legemidler brukes $i$ behandling av pasienter med både somatiske og psykiske lidelser. Brukt på en forsvarlig måte kan de være til stor nytte, men de kan også misbrukes, ofte i kombinasjon med alkohol og/eller illegale rusmidler, og gjentatt bruk kan føre til avhengighet.

Som vanedannende legemidler regnes: sterke smertestillende midler (opioider), sovemidler, angstdempende midler, enkelte legemidler mot epilepsi, sentralstimulerende midler (ADHD legemidler), enkelte typer hostestillende, anestesimidler.

\section{Forebygging av ruslidelser}

Forebygging av ruslidelser i befolkningen innebærer å motvirke risikofaktorene og styrke beskyttelsesfaktorene (WHO, 2004). Effektiv forebygging av ruslidelser krever koordinerte tiltak på internasjonalt, nasjonalt og regionalt nivå.

Ettersom tilgjengelighet av rusmidler er en forutsetning for å utvikle en ruslidelse, vil strukturelle tiltak som reduserer tilgangen til alkohol (gjennom økt pris, begrensninger i åpningstider og utsalgsteder) og andre rusmidler i seg selv virke forebyggende.

Utover strukturelle tiltak vil tiltak som søker å redusere etterspørselen av rusmidler også bidra til å redusere omfanget av ruslidelser. Forebygging bør omfatte hele livsløpet, men med et spesielt fokus på ungdomstiden, og finne sted i samarbeid med nærmiljøet, som skole og arbeidsplass.

\section{Se også kapitlene om:}

- Alkohol og andre rusmidler - forebygging av skadelig bruk av alkohol og andre rusmidler

- Psykisk helse - forebygging av psykiske lidelser

\section{Referanser}

Bukten, A., A. Herskedal, S. Skurtveit, J. G. Bramness and T. Clausen (2013a). Driving under the influence (DUI) among patients in opioid maintenance treatment (OMT): a registry-based national cohort study. Addiction 108(11): 1954-1961.

Bukten, A., J. Roislien, S. Skurtveit, H. Waal, M. Gossop and T. Clausen (2013b). A day-by-day investigation of changes in criminal convictions before and after entering and leaving opioid maintenance treatment: a national cohort study. BMC Psychiatry 13: 262.

Bukten, A., S. Skurtveit, M. Gossop, H. Waal, P. Stangeland, I. Havnes and T. Clausen (2012). Engagement with opioid maintenance treatment and reductions in crime: a longitudinal national cohort study. Addiction 107(2): 393-399.

Clausen, T., H. Waal, M. Thoresen and M. Gossop (2009). Mortality among opiate users: opioid maintenance therapy, age and causes of death. Addiction 104(8): 13561362.

Clench-Aas, J., O. S. Dalgard and M. Rognerud Psykisk helse i Norge: levekårsundersøkelsen 2005 : tilstandsrapport med internasjonale sammenligninger. Oslo, Nasjonalt folkehelseinstitutt. 2009:6: 78 s.: ill. (2009).

Compton, W. M., Y. F. Thomas, F. S. Stinson and B. F. Grant (2007). Prevalence, correlates, disability, and comorbidity of DSM-IV drug abuse and dependence in the United States: results from the national epidemiologic survey on alcohol and related conditions. Arch Gen Psychiatry 64(5): 566-576. DOI: http://dx.doi.org/10.1001/archpsyc.64.5.566.

Conway, K. P., W. Compton, F. S. Stinson and B. F. Grant (2006). Lifetime comorbidity of DSM-IV mood and anxiety disorders and specific drug use disorders: results from the National Epidemiologic Survey on Alcohol and Related Conditions. J Clin Psychiatry 67(2): 247-257.

Degenhardt, L., H. A. Whiteford, A. J. Ferrari, A. J. Baxter, F. J. Charlson, W. D. Hall, G. Freedman, R. Burstein, N. Johns, R. E. Engell, A. Flaxman, C. J. L. Murray and T. Vos (2013). Global burden of disease attributable to illicit drug use and dependence: findings from the Global Burden of Disease Study 2010. Lancet 382(9904): 1564-1574. ScienceDirect

Edland-Gryt, M. (red). Rusmidler i Norge 2012. Oslo, Statens institutt for rusmiddelforskning. (2012). SIRUS (pdf-versjon).

Galea, S., A. Nandi and D. Vlahov (2004). The social epidemiology of substance use. Epidemiol Rev 26: 36-52. Oxford Journals.

Hartz, I., R. Selmer, A. Tverdal, E. Skille and S. Skurtveit (2011). Does patterns of maternal use of potential addictive drugs reproduce in their children? [sammendrag] Abstracts. Pharmacoepidemiol Drug Saf 20: (S1-S364): 265.

Kendler, K. S., S. H. Aggen, K. Tambs and T. ReichbornKjennerud (2006). Illicit psychoactive substance use, abuse and dependence in a population-based sample of Norwegian twins. Psychol Med 36(7): 955-962.

Keyes, K. M., B. F. Grant and D. S. Hasin (2008). Evidence for a closing gender gap in alcohol use, abuse, and dependence in the United States population. Drug and Alcohol Dependence 93(1-2): 21-29. ScienceDirect. 
Kringlen, E., S. Torgersen and V. Cramer (2006). Mental illness in a rural area: a Norwegian psychiatric epidemiological study. Soc Psychiatry Psychiatr Epidemiol 41(9): 713-719. Pubmed

Kringlen, E., S. Torgersen and V. Cramer (2001). A Norwegian psychiatric epidemiological study. Am J Psychiatry 158(7): 1091-1098.

Kumar, B. N., L. Grøtvedt, H. E. Meyer, A. J. Søgaard and B. H. Strand (2008). The Oslo Immigrant Health Profile. Rapport 2008:7, Folkehelseinstituttet.

Log, T., I. Hartz, M. Handal, A. Tverdal, K. Furu and S. Skurtveit (2011). The association between smoking and subsequent repeated use of prescribed opioids among adolescents and young adults--a population-based cohort study. Pharmacoepidemiol Drug Saf 20(1): 90-98.

Log, T., S. Skurtveit, R. Selmer, A. Tverdal, K. Furu and I. Hartz (2013). The association between prescribed opioid use for mothers and children: a record-linkage study. Eur J Clin Pharmacol 69(1): 111-118.

Lund, I. O., S. Skurtveit, M. Sarfi, B. Bakstad, G. Welle-Strand and E. Ravndal (2013). A 2-year prospective study of psychological distress among a national cohort of pregnant women in opioid maintenance treatment and their partners. Journal of Substance Use 18(2): 148-160. OvidSP.

Lund, I. O., S. Skurtveit, M. Sarfi, B. Bakstad, G. Welle-Strand and E. Ravndal (2012). Substance use during and after pregnancy among a national cohort of pregnant women in opioid maintenance treatment and their partners. Journal of Substance Use 17(3): 277-286.

Rehm, J., D. Baliunas, G. L. Borges, K. Graham, H. Irving, T. Kehoe, C. D. Parry, J. Patra, S. Popova, V. Poznyak, M. Roerecke, R. Room, A. V. Samokhvalov and B. Taylor (2010). The relation between different dimensions of alcohol consumption and burden of disease: an overview. Addiction 105(5): 817-843. DOI: http://dx.doi.org/10.1111/j.13600443.2010.02899.x.
Svendsen, K., O. M. Fredheim, P. Romundstad, P. C. Borchgrevink and S. Skurtveit (2014). Persistent opioid use and socio-economic factors: a population-based study in Norway. Acta Anaesthesiol Scand 58(4): 437-445.

van Amsterdam, J., E. Pennings, T. Brunt and W. van den Brink (2013). Physical harm due to chronic substance use. Regul Toxicol Pharmacol 66(1): 83-87.

Waal, H., K. Bussesund, T. Clausen, A. Håseth and P. H. Lillevold (2013). Statusrapport 2012: LAR som det vil bli fremover? Senter for rus- og avhengighetsforskning (SERAF).

Whiteford, H. A., L. Degenhardt, J. Rehm, A. J. Baxter, A. J. Ferrari, H. E. Erskine, F. J. Charlson, R. E. Norman, A. D. Flaxman, N. Johns, R. Burstein, C. J. L. Murray and T. Vos (2013). Global burden of disease attributable to mental and substance use disorders: findings from the Global Burden of Disease Study 2010. Lancet 382(9904): 15751586. ScienceDirect.

WHO (2004). Prevention of mental disorders: effective interventions and policy options: summary report. World Health Organization, World Health Organization Dept. of Mental Health and Substance Abuse; in collaboration with the Prevention Research Centre of the Universities of Nijmegen and Maastricht.

Zilberman, M., H. Tavares and N. el-Guebaly (2003). Gender similarities and differences: The prevalence and course of alcohol- and other substance-related disorders. Journal of Addictive Diseases 22(4): 61-74. DOI: http://dx.doi. org/10.1300/J069v22n04 06 .

\section{FORFATTERE}

Jens Christoffer Skogen, Marte Handal, Ragnar Nesvåg, Svetlana Skurtveit 


\section{Selvmord og selvmordsforsøk}

- De siste 20 årene har forekomsten av selvmord vært nesten konstant.

- Menn har rundt 3 ganger høyere risiko for selvmord enn kvinner.

- Mange selvmord er vanskelige å forklare og er ofte en kombinasjon av mange årsaksforhold.

- Selvmordsfare er knyttet til rusmisbruk, livskriser og mental sykdom.

- Mange selvmord kan forebygges.

- Det er rundt 10 ganger så mange selvmordsforsøk som selvmord, men Norge mangler nasjonal statistikk for dette.

\section{Om selvmord og selvmords- forsøk}

Selvmord (også kalt selvdrap eller suicid) er resultatet av en selvpåført skade og et villet ønske om å dø.

Selvmordsforsøk og selvskading er som oftest ulike fenomener. Ved et selvmordsforsøk foreligger det en intensjon om å dø, selv om intensjonen kan variere i styrke.

Selvskading er ikke nødvendigvis forbundet med dødsintensjon, men mer knyttet til å påføre seg selv en fysisk smerte for å endre en intens negativ tanke, følelse eller en vanskelig relasjon ( $\varnothing$ verland, 2006).

\section{Stabile selvmordstall}

I 2012 var det 369 menn og 146 kvinner som begikk selvmord i Norge (til sammen 515 selvmord). Året før var det 598 selvmord.

Det kan være mange skjulte selvmord i gruppen ulykker. Rundt 5-10 prosent av alle dødsulykker i trafikken som blir undersøkt av Statens vegvesen sine ulykkesanalysegrupper, er selvmord. De aller fleste møteulykker med trailere på rett vei er selvmord (Assum, 2010).

Vi har ingen nasjonal oversikt over selvmordsforsøk og selvskading. Det betyr at vi ikke har nasjonale tall på forekomst og utviklingen over tid. Dette svekker mulighetene for å evaluere effekten av forebyggende tiltak.

Når det gjelder selvmordsforsøk er det vanlig i store deler av verden å stipulere omfanget til å være 7-15 ganger så høyt som antall selvmord. Omfanget av selvskading med liten eller ingen suicidal intensjon er usikkert, men sannsynligvis høyere enn omfanget av selvmordsforsøk.

I perioden 1969 til 1988 doblet risikoen for selvmord seg for begge kjønn, se figur 1. Årsaken til denne økningen er ukjent, men det har vært spekulert i at dette skyldes en økt rapportering av selvmord og lavere mørketall.

I perioden 1991-1996 falt forekomsten av selvmord blant menn, for deretter å flate ut. Forekomsten av selvmord blant kvinner har vært stabil de siste 20 årene.

\section{Forskjeller i befolkningen}

\section{Kjønnsforskjeller}

For menn utgjør selvmord rundt 16 prosent av alle dødsfall i gruppen voldsomme dødsfall (ulykker, selvmord og drap). Tilsvarende andel for kvinner er 8 prosent. De siste 10 årene har risikoen for selvmord vært rundt 15 per 100000 for menn og rundt 6 per 100000 for kvinner. 


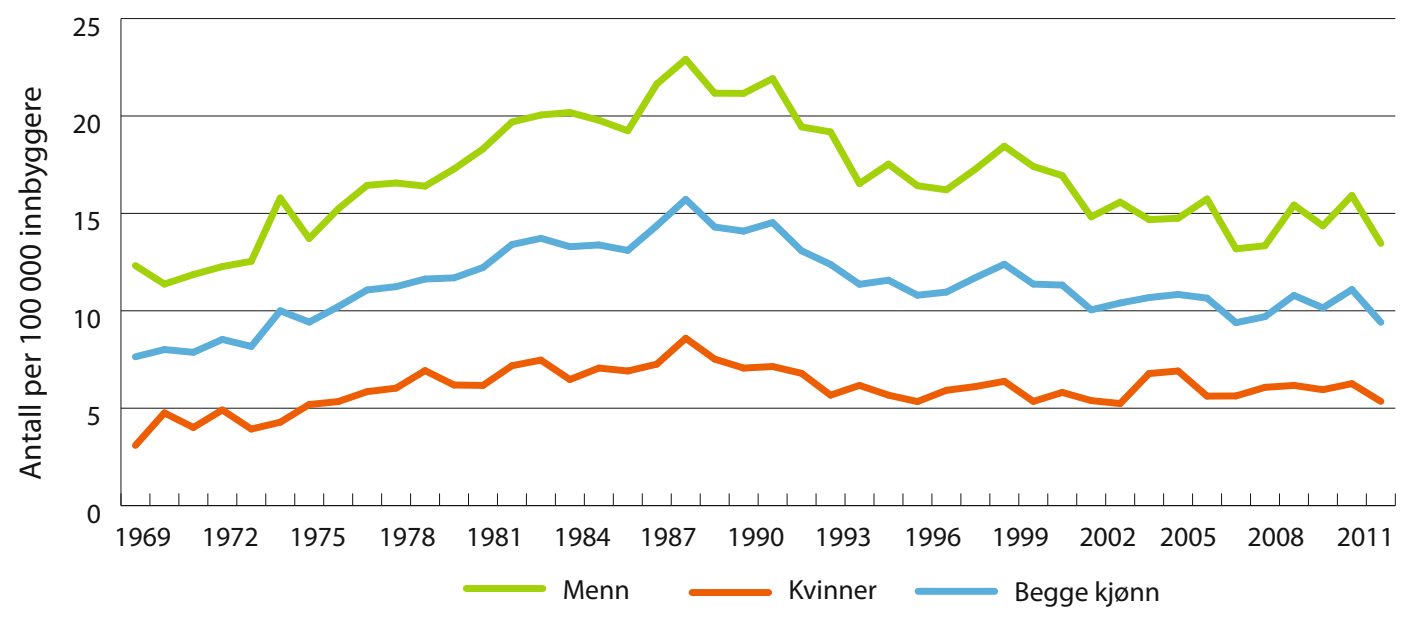

Figur 1: Antall selvmord per 100000 innbyggere. Menn, kvinner og begge kjønn for perioden 1969-2012. Kilde: Dødsårsaksregisteret.

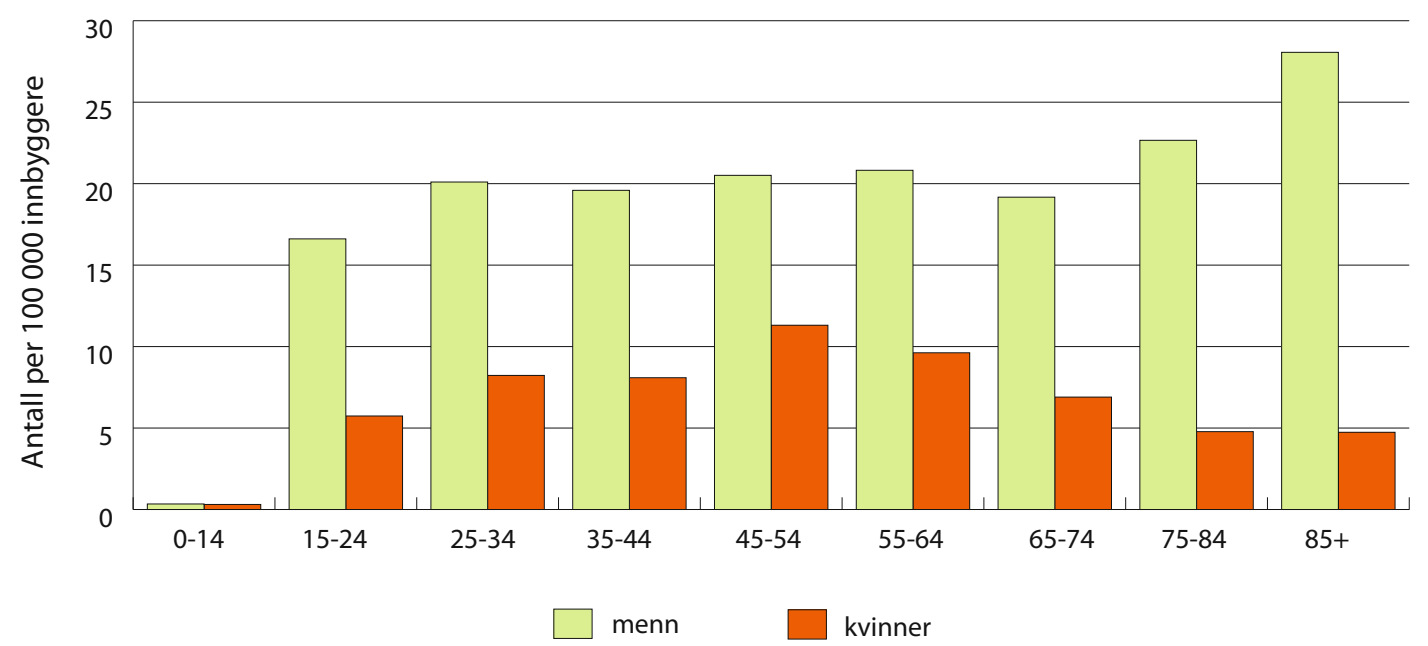

Figur 2: Antall selvmord per 100000 innbyggere for menn og kvinner, basert på selvmordstall for 2008-12. Kilde: Dødsårsaksregisteret.

Det har skjedd store endringer i hvilke metode som benyttes for å ta livet av seg. De siste 20 årene er bruk av skytevåpen og sprengstoff mer enn halvert blant menn. I dag er hengning og kvelning den vanligste selvmordsmetoden blant menn, etterfulgt av skytevåpen og sprengstoff og bruk av gift (hovedsakelig legemidler).

Tidligere var forgiftning den vanligste selvmordsmetoden blant kvinner, men i dag er bruk av gift og henging/kvelning omtrent like vanlig. Drukning er den tredje vanligste selvmordsmetoden blant kvinner.

\section{Aldersforskjeller}

Selvmordsrate etter alder og kjønn er gitt i figur 2 . Ratene er i hovedsak konstante for aldersgruppen 20-75 år; den varierer mellom 17 og 21 for menn og mellom 6 og 11 for kvinner. Hvis 550 tar livet sitt hvert år, og de i gjennomsnitt er 40 år, så medfører dette rundt 22000 tapte leveår som følge av selvmord. Dette er omtrent like mange tapte leveår som for prostatakreft og brystkreft til sammen.

Villet egenskade knyttes først og fremst til ungdom, mens selvmordsforsøk er knyttet til alle aldersgrupper. I mange studier av villet egenskade er det uklart om ungdommene har skadet seg selv ut fra suicidal hensikt eller ikke. Det er derfor knyttet stor usikkerhet til estimater av villet egenskade med ulik grad av suicidal intensjon.

I en norsk studie av 4000 norske ungdommer, oppgav rundt 11 prosent at de hadde skadet seg med vilje (Ystgaard, 2003). Det var omtrent tre ganger så mange jenter som gutter som oppgav at de hadde skadet seg med vilje. De fleste (74 prosent) hadde kuttet seg selv på kroppen (Ystgaard, 2003). 


\section{Sosioøkonomiske forskjeller}

Det er en statistisk signifikant høyere selvmordsrate for menn med lav utdanning enn for dem med høy utdanning, men ikke for kvinner (Strand, 2010).

\section{Geografiske forskjeller}

Det er ikke gjort noen systematiske studier av forskjeller i forekomst av selvmord i Norge etter geografi eller urbanitet de siste årene. I Norge har det vært mer selvmord i rurale strøk, mens $i$ andre land er det mer selvmord i urbane strøk, og det meste av denne forskjellen kan forklares med andre risikovariabler. Det er heller ikke gjort noen systematiske registerstudier av selvmord blant innvandrere.

\section{Internasjonale forskjeller}

I perioden 1969-2000 var det store forskjeller i forekomst av selvmord mellom de nordiske landene. I dag har Norge, Sverige og Danmark helt like selvmordsrater (rundt 11 per 100 000), mens Finland har fremdeles vesentlig høyere forekomst av selvmord enn de andre nordiske landene (nesten 20 per 100 000). Selvmordsraten i Norge ligger omtrent likt med resten av Europa, Nord-Amerika og Australia. I Øst-Europa, Russland, Kina, Japan og i andre land i Asia med pålitelig statistikk ligger selvmordsraten på 20-30 per 100000 (Värnik, 2012). Kjønnsratioen varier også betraktelig fra 1,5 i Asia til rundt 6-8 i Syd-Europa.

\section{Risikofaktorer}

Det er vist at risikoen for selvmord er forhøyet ved:

- Psykiske lidelser som alvorlig depresjon, schizofreni, borderlinetilstander og alvorlige personlighetsforstyrrelser og sterk angst

- Alkohol/rusmiddelmisbruk

- Tidligere selvmordsforsøk

- Impulsivitet

- Selvmord i nær familie

- Alvorlig somatisk sykdom (spesielt med sterke smerter)

En psykisk lidelse i seg selv er vanligvis ikke en tilstrekkelig årsak til selvmord. Det må alltid gjøres en vurdering av både person og situasjon. Livstidsrisikoen for selvmord ved alvorlig depresjon er 4-6 prosent (Blair-West, 1997; Inskip, 1998), og ved schizofreni 4-5 prosent (Inskip, 1998).

Nyere studier har vist at selvmord også kan forekomme uten at det med rimelighet kan knyttes til en psykisk lidelse (Judd, 2012). Både akutt og langvarig stress, selvmord i nærmiljøet og lett tilgang til gift og skytevåpen kan øke risikoen.

En rekke faktorer virker beskyttende:

- God kontakt med familie og venner

- Løsningsorientert personlighet

- Et helsevesen som fanger opp og behandler psykiske lidelser på en slik måte at selve det suicidale blir bearbeidet

Typiske tegn som tyder på at folk tenker på selvmord er når de

- Snakker om selvmord

- Føler seg alvorlig ydmyket

- Føler stor håpløshet

- Har problemer med å kontrollere sin aggressive atferd i situasjoner der de kan føle seg krenket

\section{Forebygging av selvmord}

\section{God psykisk helse og mestring i befolkningen er et overordnet mål} Generelt vil tiltak for å styrke befolkningens psykiske helse og generelle levevilkår også kunne virke selvmordsforebyggende. Intervensjonsstudier har vist at når man begrenser tilgang på våpen og gift, så reduseres antall selvmord. Sikring av broer, mindre sensasjonspregete presseoppslag, opplysningsprogram på skoler og arbeidsplasser, samt kunnskapsformidling om selvmordsatferd til den alminnelige befolkning er også viktig.

\section{Målrettede tiltak mot risikogrupper}

En annen viktig strategi for å forebygge selvmord er å fange opp og gi adekvat intervensjon til risikogrupper. Dette er mennesker i selvmordsfare knyttet til psykiske problemer og/eller rusavhengighet, selvmordsforsøkere, etterlatte ved selvmord, og individer i livskriser der mestringsevnen ikke er tilstrekkelig.

Individuell oppfølging av personer som har forsøkt å begå selvmord reduserer risikoen for nye selvmordsforsøk, gitt at intervensjonen er tilpasset det suicidale både ved personen og situasjonen.

En viktig oppgave etter selvmord er oppfølging av etterlatte, både for å støtte pårørende og for å forbygge nye selvmord i nær familie. Etterlatte ved selvmord er en gruppe med forhøyet fare for egen selvmordsatferd, og tiltak må være tilpasset deres spesielle situasjon, der både profesjonell bistand og legmannsstøtte bør være tilgjengelige (Helsedirektoratet, 2011). 


\section{Pålitelige selvmordstall}

Det er større variasjon i antall selvmord fra år til år enn hva man kan forvente ut fra rene statistiske tilfeldigheter. Dette tyder på at man i tillegg til statistiske svingninger i antall selvmord fra år til år, også har forandring i rutiner for klassifisering av selvmord som dødsårsak over tid. Det er behov for mer pålitelig selvmordsstatistikk. Det er spesielt stort behov for å finne skjulte selvmord i gruppen ulykker og forgiftninger slik man har gjort for trafikkulykker.

\section{Referanser}

Assum, T. and M. W. J. Sørensen 130 dødsulykker med vogntog. Gjennomgang av dødsulykker i 2005-2008 gransket av Statens vegvesens ulykkesanalysegrupper. Oslo, Transportøkonomisk institutt: 70. (2010).

Blair-West, G. W., G. W. Mellsop and M. L. Eyeson-Annan (1997). Down-rating lifetime suicide risk in major depression. Acta Psychiatr Scand 95(3): 259-263.

Helsedirektoratet. Etter selvmordet: veileder om ivaretakelse av etterlatte ved selvmord. Oslo, Helsedirektoratet, Avdeling psykisk helse og rus. (2011).

Inskip, H. M., E. C. Harris and B. Barraclough (1998). Lifetime risk of suicide for affective disorder, alcoholism and schizophrenia. Br J Psychiatry 172: 35-37.

Judd, F., H. Jackson, A. Komiti, R. Bell and C. Fraser (2012). The profile of suicide: changing or changeable? Soc Psychiatry Psychiatr Epidemiol 47(1): 1-9.

Ystgaard, M. (2003). Villet egenskade blant ungdom: nye forskningsresultater og konsekvenser for forebyggende arbeid. Suicidologi 8(2): 7-10.

$\varnothing$ verland, S. Selvskading: en praktisk tilnærming. Bergen, Fagbokforl. (2006).

\section{FORFATTERE}

Per Henrik Zahl og Gudrun Dieserud 


\section{Skader og ulykker}

- Antall dødsfall som følge av ulykker har blitt kraftig redusert de siste 40 årene, særlig i transportsektoren.

- Ulykker er likevel den viktigste årsaken til dødsfall for unge personer - blant menn under 25 år skyldes 1 av 5 dødsfall ulykker.

- Ulykker og skader er fremdeles en stor utfordring for folkehelsen med om lag 550000 skadepasienter i året.

- Skader kan i stor grad forebygges, og en reduksjon av ulykker vil kunne gi en solid helsegevinst i befolkningen.

\section{Om skader og ulykker}

En ulykke er en ufrivillig hendelse karakterisert ved en hurtigvirkende kraft eller påvirkning som kan ytre seg i skade på kroppen (NOMESCO, 2007). Mennesker pådrar seg skader i mange typer ulykker, for eksempel i brannulykker, drukningsulykker, trafikkulykker, forgiftningsulykker og fallulykker.

Skader varierer i alvorlighetsgrad og dekker et vidt spekter fra bagatellmessige skrubbsår til mer omfattende skader som kan medføre innleggelse på sykehus, varige mén eller i ytterste konsekvens død.

Det er vanlig å skille mellom skader som skjer utilsiktet (ulykkesskader) og skader som påføres med hensikt (voldsskader eller selvpåførte skader).

Selv om det ofte kan være vanskelig å fastslå årsaken til en skade, omhandler dette kapittelet i hovedsak skader og dødsfall forårsaket av ulykker. For mer om selvpåførte skader, se kapittel Selvmord og selvmordsforsøk.

\section{Det totale skadebildet: 10 prosent av befolkningen skades hvert år}

Om lag 10 prosent av befolkningen, i underkant av 550000 personer, blir behandlet for skader årlig (FHI, 2014).

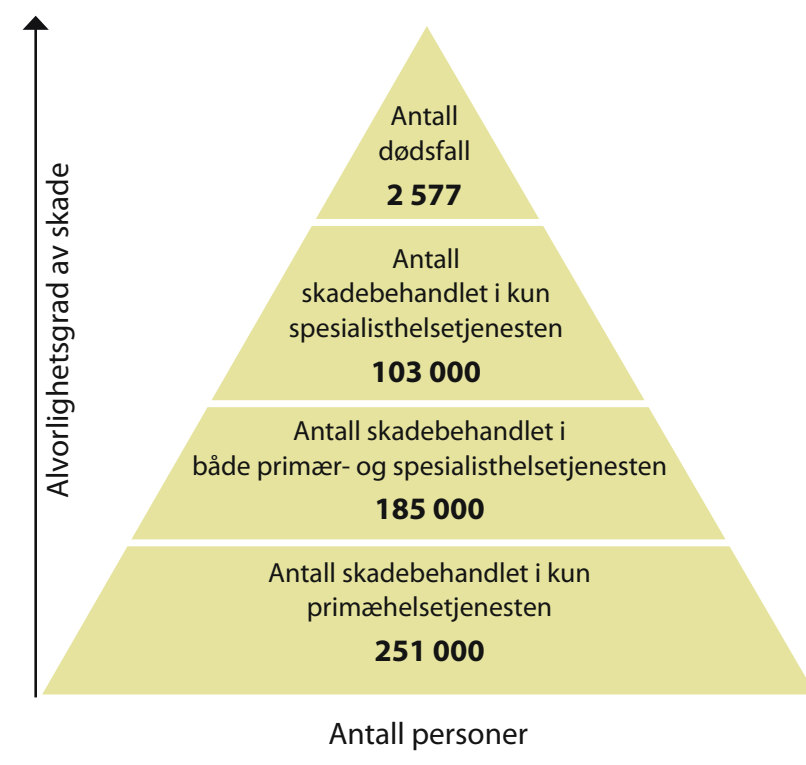

Figur 1: Det totale skadebildet per år i gjennomsnitt i perioden 2009-2011: (1) antall dødsfall pga. ulykker, drap og selvmord, (2) antall skadepasienter behandlet direkte på sykehus, (3) antall individer behandlet for skade i både primærhelsetjenesten og i spesialisthelsetjenesten, og (4) antall skadepasienter ferdigbehandlet av lege i primærhelsetjenesten. Kilde: Dødsårsaksregisteret (DÅR), Norsk pasientregister (NPR), Kontroll og utbetaling av helserefusjoner (KUHR).

Figur 1 viser at i overkant av 100000 personer rammes årlig av skader som behandles direkte på sykehus, mens den største gruppen av pasienter har skader som ferdigbehandles i primærhelsetjenesten. 


\section{Hver tiende sykehusinnleggelse gjelder personskader}

Ulykker forårsaker hvert år et stort antall skader som kan påføre stor belastning, både for den enkelte og for samfunnet. Tall fra Norsk pasientregister (Helsedirektoratet, 2014) viser at hver tiende sykehusinnleggelse skyldes behandling av en personskade.

De vanligste skadene som krever sykehusbehandling er:

- Brudd

- Overflateskader

- Forstuing, dislokasjon («ute av ledd») og forstrekking

Primærhelsetjenesten (for eksempel fastlege, kommunale legevakter, fysioterapeuter og kiropraktikere) behandler årlig cirka 560000 skader hos 440000 personer (FHI, 2014). Om lag halvparten av disse skyldes forstuing/forstrekning/ute av ledd og stikk, kutt eller bitt (penetrasjonsskader).

En liten andel ( 2 prosent) av sykehusinnleggelsene gjelder forgiftninger. Bruk av legemidler er den hyppigste årsaken til forgiftning, men også alkohol og narkotiske stoffer forårsaker mange slike skader.

\section{0 personer dør i ulykker hvert år}

Totalt dør hvert år i underkant av 2000 personer av ulykkesskader i Norge (SSB, 2013a). De viktigste enkeltårsakene til ulykkesdødsfall er transport, fall og forgiftninger.

I 2012 døde 187 personer i transportulykker (SSB, 2013b), et historisk lavt antall.
I gjennomsnitt døde 425 personer hvert år i fallulykker i perioden 2008-2012 (SSB, 2013a), de fleste over 70 år. Et vanlig utfall av fallulykker blant eldre er hoftebrudd, som er forbundet med en sterk overdødelighet (se kapittel Muskel- og skjelettsykdommer og -plager).

I perioden 2010-2012 ble det registrert 321 forgiftningsdødsfall i gjennomsnitt per år (SSB, 2013c). Det kan ofte være vanskelig å fastslå om slike dødsfall er ulykker eller tilsiktet. Av disse forgiftningsdødsfallene skyldtes:

- 48 prosent forgiftning av narkotika og hallusinogener (overdosedødsfall)

- 12 prosent forgiftning av alkohol

- 40 prosent forgiftninger av andre og uspesifiserte kjemikalier og giftige stoffer

For overdosedødsfall er gjennomsnittsalderen rundt 40 år, og 4 av 5 døde er menn (Simonsen, 2011).

\section{Utvikling over tid}

Dødelighet som følge av ulykker har blitt betydelig redusert de siste årene, særlig hos barn, ungdom og unge voksne.

Figur 2 viser utviklingen i dødelighet fra 1951 til 2012 for aldersgruppene 0-17 år og 18-24 år. Nedgangen har vært mest markant for gutter og unge menn, og hovedsakelig fra begynnelsen av 1970-tallet.

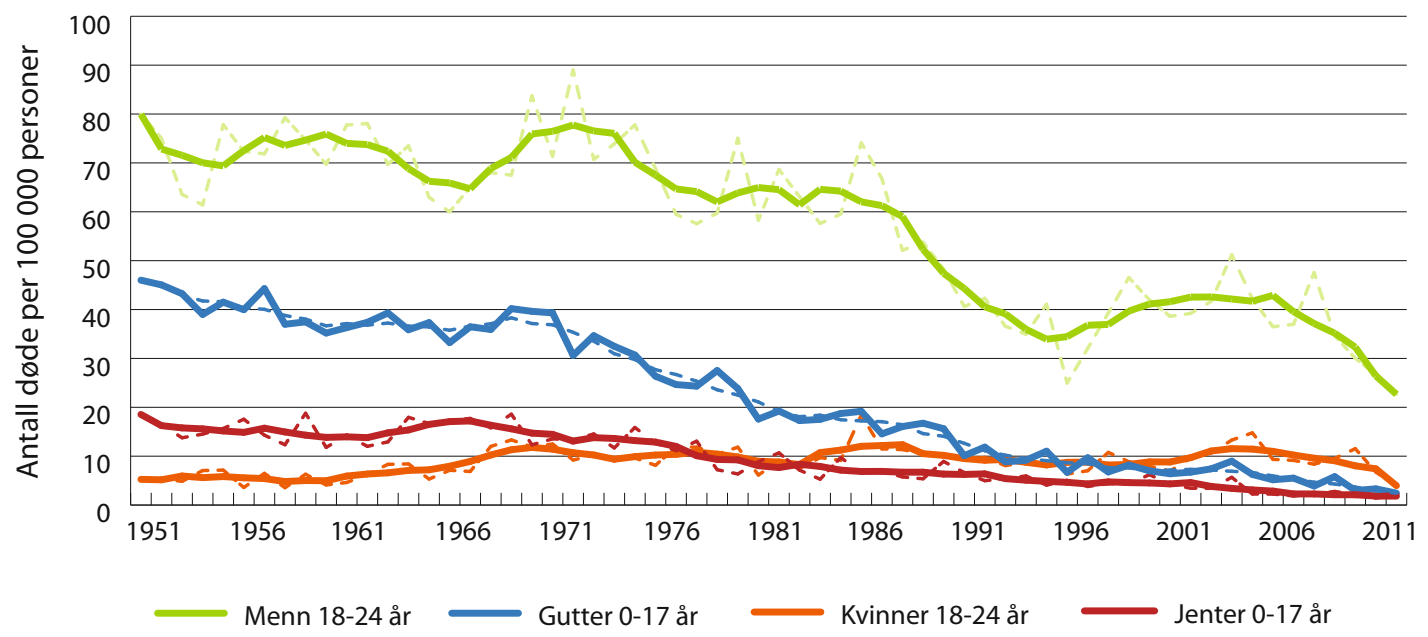

Figur 2: Utvikling i dødsfall etter ulykker i aldersgruppene 0-17 år og 18-24 år, fordelt etter kjønn. Antall døde per 100000 personer per år, 1951-2012. 5-årig glidende gjennomsnitt (heltrukken linje) og årlige rater (stiplet linje). Kilde: Dødsårsaksregisteret. 


\section{Færre dør i trafikken}

Den positive utviklingen i dødelighet skyldes blant annet en kraftig reduksjon i trafikkdødsfall. Mens 469 personer døde i trafikkulykker i 1986, var tilsvarende tall i 2012 redusert til 140 (SSB, 2013a). Nedgangen har vært spesielt kraftig blant menn, men fortsatt dør langt flere menn enn kvinner i trafikkulykker.

\section{Forskjeller i befolkningen}

\section{Personskader: vanligst blant ungdom, unge voksne og eldre}

Årlig behandles om lag 300000 pasienter for en skadediagnose på sykehus (FHI, 2014; SSB, 2014). Figur 3 viser at skader forekommer mest hyppig blant ungdom og unge voksne, samt i den eldre delen av befolkningen. Særlig etter 80 år øker hyppigheten av skader kraftig.

Figuren viser også at menn skader seg oftere enn kvinner fram til omtrent 50 års alderen, deretter blir skader mer hyppig blant kvinner.

Bruddskader (særlig i hofte og lår) er en hyppig skadetype for personer over 65 år, ofte på grunn av fallulykker og med benskjørhet (osteoporose) som medvirkende årsak. For mer om benskjørhet og hoftebrudd, se kapittel Muskel- og skjelettsykdommer og -plager.

Vanlige skader blant ungdom er overflate- og forstuingsskader, særlig i ankel/fot og hånd/arm. Små barn (0-4 år) er spesielt utsatt for brannskader og skolding.
Forgiftningsulykker rammer primært voksne i alderen 20-64 år. Kvinner har oftere legemidler som forgiftningsagens, mens menn i større grad pådrar seg forgiftningsskader etter bruk av rusmidler (Bergan, 2010).

\section{Dødsfall etter ulykker særlig høy etter 80 års alder}

Forekomst av ulykkesdødsfall henger sterkt sammen med alder og kjønn (se figur 4):

- Dødelighet etter ulykker øker med alder, og er særlig høy for eldre over 80 år

- Flere menn enn kvinner dør av ulykkesskader, i alle aldersgrupper

- Kjønnsforskjellen i dødelighet er størst blant voksne i aldersgruppen 20-64 år og mindre utpreget blant barn, ungdom og for personer 65 år og eldre

Når det gjelder antallet, er det flest ulykkesdødsfall hos de eldste, se figur 4. Når man derimot ser på andelen av alle dødsfall som skyldes ulykker, er den betydelig høyere blant de unge.

- Ulykker er den viktigste årsaken til dødsfall for personer under 45 år, og blant menn under 25 år skyldes hele 20 prosent av dødsfallene ulykker

- Eldre mennesker dør hovedsakelig av andre årsaker - i aldersgruppen 65 år og eldre utgjør ulykkesdødsfall kun 4 prosent av alle dødsfall

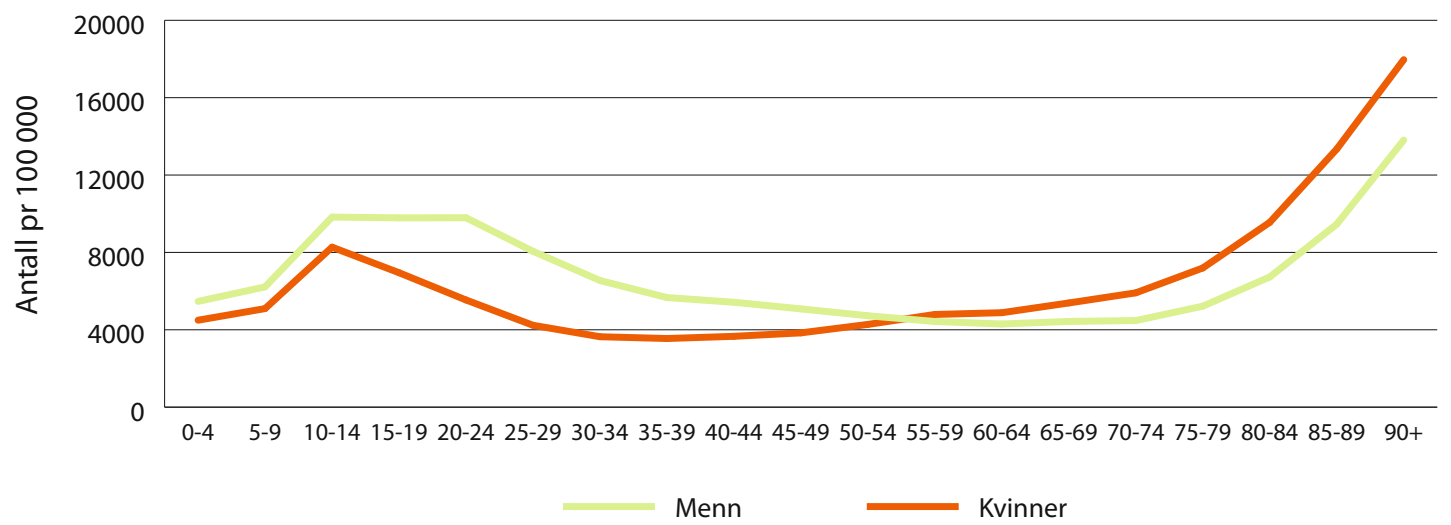

Figur 3: Personer behandlet i spesialisthelsetjenesten for skader etter alder og kjønn. Antall per 100000 innbyggere, gjennomsnitt per år i perioden 2009-2011. Kilde: Norsk pasientregister. 


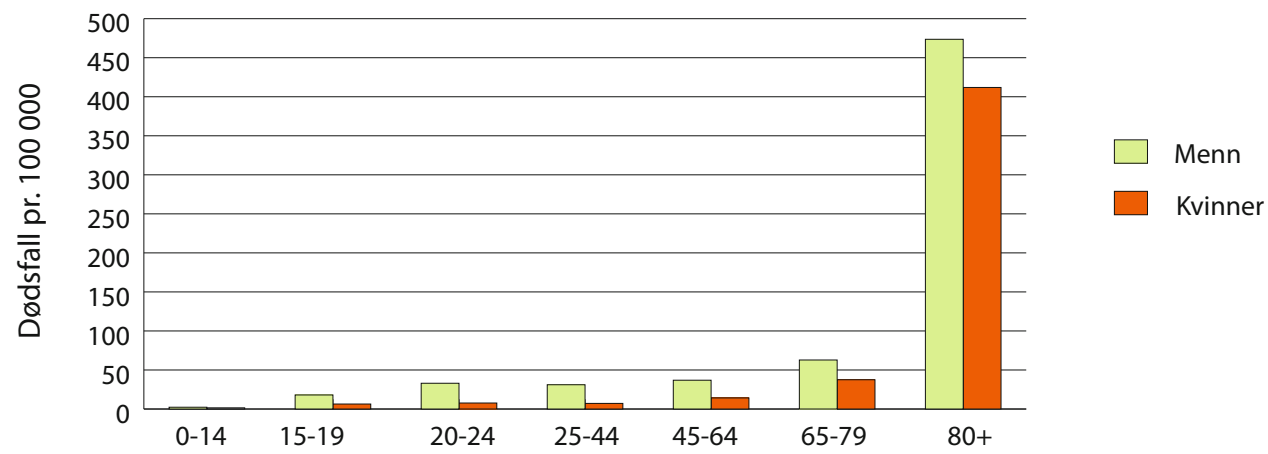

Figur 4: Antall som dør av ulykker per 100000 personer per år, gjennomsnitt for perioden 2008-2012, fordelt etter aldersgrupper og kjønn. Kilde: Dødsårsaksregisteret.

\section{Sosioøkonomiske og geografiske forskjeller}

Det finnes både sosioøkonomiske og geografiske forskjeller i ulykkesdødelighet (FHI, 2009; FHI, 2014; Laflamme, 2009):

- Dødeligheten er høyere for personer med grunnskoleutdanning enn for personer med utdanning fra videregående skole eller universitets-og høgskolenivå

- Finnmark og Østfold har høyere ulykkesdødelighet, mens Akershus, Sogn og Fjordane, samt fylkene i Midt-Norge skiller seg positivt ut

\section{Internasjonale forskjeller}

Internasjonale sammenligninger viser at Norge ligger i midtsjiktet når man rangerer land etter dødelighet av ulykker (FHI, 2014). Aldersjusterte dødelighetsrater er høyere i Norge enn i våre naboland Sverige og Danmark.

Sammenliknet med andre land ligger Norge relativt bra an for dødsfall i trafikken, men kommer relativt dårlig ut for forgiftningsdødsfall (WHO, 2008). Særlig overdosetallene er høye i Norge, noe som kan skyldes flere forhold:

- I Norge er det tradisjon for å sette heroin, metadon og andre sløvende stoffer intravenøst, mens sniffing og røyking er mer vanlig $i$ andre land

- Norge har hyppige obduksjoner og god kartlegging av slike dødsfall

I følge nye analyser har utviklingen i ulykkesdødeligheten for den yngre delen av befolkningen vært dårligere i Norge enn i OECD-landene for øvrig. Hva som ligger bak denne utviklingen er foreløpig ikke kjent, men det er mulig at det høye antall forgiftningsdødsfall i Norge bidrar til dette (se kapittel Levealder)

\section{Utfordringer og muligheter for forebygging av ulykker}

Bruk av rusmidler er ofte en medvirkende faktor $\mathrm{i}$ ulykker og øker risikoen for mange typer skader (se faktaboks).

\section{FAKTA}

\section{Rusmidler hos skadepasienter innlagt på sykehus}

En undersøkelse av om lag 1300 pasienter som ble innlagt ved akuttmottaket på Oslo universitetssykehus med en ulykkesskade fant hyppig bruk av rusmidler (Bogstrand, 2011).

Nesten halvparten av disse pasientene fikk påvist rusmidler i blodet.

Alkohol var det vanligste brukte rusmiddelet (påvist i 27 prosent av prøvene), men også legemidler (21 prosent) og narkotika (9 prosent) forekom ofte.

\section{Analysene påviste videre rusmidler i blodet hos: \\ - 2 av 3 menn i aldersgruppen 18-35 år \\ - 9 av 10 pasienter skadd på bar/restaurant \\ - 5 av 10 pasienter skadd i hjemmeulykker}

Rusmidler er en av de viktigste årsakene til trafikkulykker. Ifølge analyser hos Statens vegvesen var rus en medvirkende årsak i 24 prosent av dødsulykkene langs norske veier i 2012 (Haldorsen, 2013).

En undersøkelse av blodprøver fra omkomne bilførere i perioden 2001-2010 viste videre at 40 prosent hadde alkohol, narkotika eller legemidler i konsentrasjoner høyere enn forbudsgrensene (Christophersen, 2014). 


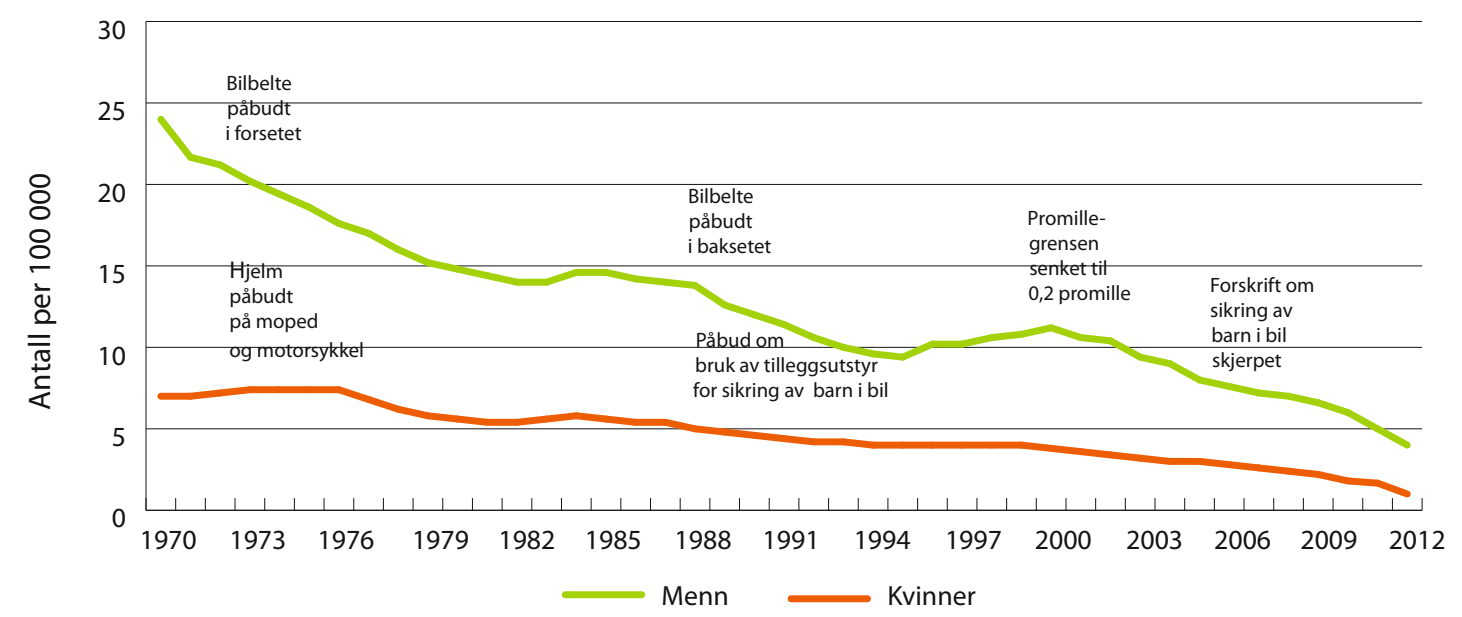

Figur 5: Antall dødsfall per 100000 i trafikkulykker, fordelt på kjønn, med tiltak, 1970-2012. Kilde: Dødsårsaksregisteret.

Tilsvarende tall blant førere som omkom i eneulykker var hele 64 prosent.

For mer om rusmidler, se kapitler Ruslidelser og Alkohol og andre rusmidler.

Ulykkesskader kan i stor grad forebygges og det finnes flere eksempler på ulykkes- og skadeforebyggende tiltak som har gitt dokumenterbar effekt:

- Strukturelle tiltak (lovendringer, produkt-og miljøendringer o.I.) har vist seg å være spesielt effektive

- Atferdsendrende tiltak som trening og belønningssystemer har også vist seg å gi effekt

- Holdningsendrende tiltak (brosjyrer, opplysningskampanjer o.l.) gir sjelden effekt alene

Særlig innenfor trafikksikkerhet har det ulykkesforebyggende arbeidet kommet langt, se figur 5 . Mange ulike tiltak har til sammen bidratt til en kraftig reduksjon i omfanget og konsekvensene av trafikkulykker (TØI, 2012), for eksempel:

- Bedre veier og sikrere biler

- Fartskontroll og lavere promillegrenser

- Bedre føreropplæring

- Bruk av bilbelte og bedre sikring av barn i bil

- Bedre akuttbehandling av trafikkskader

Ulykkesforebyggende arbeid er en del av miljørettet helsevern og reguleres av Folkehelseloven (Lov om folkehelsearbeid). Ansvaret for miljørettet helsevern ligger hos kommunen.

\section{Referanser}

Bergan, Il. Akutte forgiftninger ved norske sykehus i 2008. En epidemiologisk undersøkelse basert på epikriser med fokus på ungdom, [masteroppgave i farmasi]. Det matematisk-naturvitenskapelige fakultet, Universitet i Oslo, 2010.

Bogstrand ST, Normann PT, Rossow I, Larsen M, Mørland J, Ekeberg O. Prevalence of alcohol and other substances of abuse among injured patients in a Norwegian emergency department. Drug and Alcohol Dependence 2011; 117: 132-138.

Christophersen AS, Gjerde H. Prevalence of alcohol and drugs among car and van drivers killed in road accidents in Norway: an overview from 2001 to 2010. Traffic Injury Prevention 2014:15(6): 523-531. Tilgjengelig fra: http:// dx.doi.org/10.1080/15389588.2013.848981

FHI, Folkehelseinstituttet, 2009. Alver, $\varnothing$ Hesselberg and H Lyshol. Sosioøkonomiske forskjeller i ulykkesskader: en oppsummering av nordisk litteratur. Oslo, Nasjonalt folkehelseinstitutt. 2009:9.

FHI, Folkehelseinstituttet, 2014. I Myklestad, K Alvær, C Madsen et al. Skadebildet i Norge: Hovedvekt på personskader i sentrale registre. Oslo, Folkehelseinstituttet. 2014:2.

Haldorsen I. Dybdeanalyser av dødsulykker i veitrafikken 2012. Oslo: Statens vegvesen; 2013, rapport 196.

Helsedirektoratet, 2014. Aktivitetsdata - somatikk. [oppdatert 2014; nedlastet 11 April 2014].

Laflamme L, Burrows S, Hasselberg M. Socioeconomic differences in injury risk: a review of findings and a discussion of potential countermeasures. København: WHO Regional Office for Europe; 2009.

NOMESCO, 2007. NOMESCO Classification of External Causes of Injuries. Fourth revised edition. København: Nordic Medico-Statistical Committee, 2007.

Simonsen K, Normann P, Ceder G, Vuori E, Thordardottir S, Thelander G, Hansen A, Teige B, Rollmann D. Fatal poisoning in drug addicts in the Nordic countries in 2007. Forensic Science International 2011; 207: 170-176. 
SSB, Statistisk sentralbyrå, 2013a. Dødsårsaker. [oppdatert 2013a; nedlastet 11 April 2014]. Tilgjengelig fra: http:// www. ssb.no/helse/statistikker/dodsarsak Statistikkbanktabell 08873.

SSB, Statistisk sentralbyrå, 2013b. Dødsårsaker. [oppdatert 2013b; nedlastet 11 April 2014]. Tilgjengelig fra: http:// www. ssb.no/helse/statistikker/dodsarsak Statistikkbanktabell 08880 .

SSB, Statistisk sentralbyrå, 2013c. Dødsårsaker. [oppdatert 2013c; nedlastet 11 April 2014]. Tilgjengelig fra: http:// www. ssb.no/helse/statistikker/dodsarsak Statistikkbanktabell 06208.

SSB, Statistisk sentralbyrå, 2014. Pasienter på somatisk sykehus [internett]. [oppdatert 2014; nedlastet 11 April 2014]. Tilgjengelig fra <http://www.ssb.no/helse/statistikker/pasient Statistikkbanktabell 10261>.
TØI, Transportøkonomisk institutt, 2012. Trafikksikkerhetshåndboken. 4. utg. Oslo: Transportøkonomisk institutt; 2012.

WHO (2008).Disease and injury country estimates [lest 21.11.2013]. Tilgjengelig fra: http://www.who.int/healthinfo/global_burden_disease/estimates_country/en/ index.html.

\section{FORFATTERE}

Eyvind Ohm, Kari Alver, Gunnar Brunborg, Hallvard Gjerde og Ingri Myklestad 


\section{Sykdomsbyrde i den norske befolkningen}

- Sykdomsbyrdeberegninger gir oversikt over dødelighet og helsetap på grunn av sykdommer, skader eller risikofaktorer. Typisk vises også endringer over tid, og etter geografisk område, alder og kjønn.

- Det benyttes fire hovedmål for å beskrive sykdomsbyrde: dødsfall, tapte leveår, helsetap og summen av de to siste som kalles DALY.

- Tapte leveår: De fem største årsakene til tapte leveår i den norske befolkningen er iskemisk hjertesykdom, hjerneslag, lungekreft, tykk- og endetarmskreft og KOLS, i følge beregninger fra det globale sykdomsbyrdeprosjektet 2010 (GBD 2010).

- Helsetap: De fem ledende årsakene til helsetap i Norge er korsryggsmerter, alvorlig depresjon, angstlidelser, nakkesmerter og fallulykker, i følge beregninger fra GBD 2010.

- Risikofaktorer for sykdomsbyrde: De sentrale risikofaktorene i den norske befolkningen er usunt kosthold, røyking, høyt blodtrykk, høy kroppsmasseindeks, høyt kolesterol- og fastende blodsukkernivå, høyt alkoholforbruk og fysisk inaktivitet, i følge beregninger fra GBD 2010.

- GBD 2010 har gjort sykdomsbyrdeberegninger for 187 land for perioden 1990 - 2010. Det arbeides med å styrke datagrunnlaget og metodene for sykdomsbyrdeberegninger.

\section{Hva er sykdomsbyrde?}

Sykdomsbyrdeberegninger viser hvordan ulike sykdommer, skader og risikofaktorer rammer en befolkning i form av helsetap og dødelighet.

Beregning av sykdomsbyrde kan:

- Identifisere hvilke sykdommer og skader som bidrar mest til helsetap og dødelighet i befolkningen.

- Identifisere bidraget fra ulike risikofaktorer på helsetap og dødelighet.

I tillegg kan norske sykdomsbyrdeberegninger benyttes til å:

- Følge utviklingen i befolkningens helsetilstand og i risikofaktorer over tid.

- Gjøre internasjonale sammenlikninger, blant annet for å avdekke felles utfordringer mellom land, eller spesielle utfordringer i enkeltland. For Norge vil det for eksempel være nyttig å sammenlikne seg med de andre nordiske landene.

- Styrke helsemyndighetenes arbeid med planlegging av helsetjenester.

- Som grunnlag for utforming og evaluering av forebyggende tiltak.

\section{Hvorfor trenger vi sykdomsbyrdeberegninger?}

En del av Folkehelseinstituttets mandat er å gi en oversikt over befolkningens helsetilstand. En fullstendig oversikt må inkludere informasjon:

- Om dødelighet/dødsårsaker.

- Om helsetap grunnet sykdommer eller skader som kan utgjøre en stor belastning for den enkelte og samfunnet, men som ikke nødvendigvis er forbundet med økt dødelighet.

Dødsårsaksregisteret inneholder opplysninger om dødsfall og dødsårsaker fra og med 1951 (FHI, 2014). Folkehelseinstituttet har derfor et godt datagrunnlag 
for å kunne ha oversikt over dødeligheten $\mathrm{i}$ befolkningen. Vi har lang tradisjon for å beskrive denne delen av sykdomsbyrden (FHI, 2012).

For sykdomsbyrde fra sykdommer som sjelden eller aldri registreres som dødsårsak, for eksempel sykdommer i muskel- og skjelettsystemet eller psykiske lidelser, har Folkehelseinstituttet langt dårligere datagrunnlag og statistikk å støtte seg til. Det er i Norge ingen helhetlig tradisjon for rapportering og oppdatering av data på ikke-dødelige sykdommer. Norge mangler også et system for regelmessig oppdatering av data på forekomst av viktige risikofaktorer. Også internasjonalt er det mangelfulle data på ikke-dødelige sykdommer og risikofaktorer.

For selve beregningene av sykdomsbyrde, er det relativt uproblematisk å komme fram til en rangering av sykdomsbyrden for de sykdommene som bidrar til den norske befolkningens dødelighet. Data om antall dødsfall som skyldes ulike sykdommer og skader, samt ved hvilken alder dødsfallene skjer, kan hentes fra Dødsårsaksregisteret. Når disse opplysningene legges til grunn, gir beregningene et godt bilde av dødelighetsbyrden i den norske befolkningen. Tilsvarende vil være tilfelle for andre land med gode dødsårsaksregistre.

Beregning av sykdomsbyrde som følge av ikke-dødelige sykdommer er derimot mer utfordrende, fordi ulike sykdommer har ulike karakteristika og ulik alvorlighetsgrad. I tillegg er kunnskaps- og datagrunnlaget for mange av disse tilstandene ofte fragmentert og av varierende kvalitet.

Det er derfor behov for en metode og et system som kan sammenlikne sykdomsbyrde som skyldes til dels svært ulike sykdommer og skader. Et slikt system krever at man må kunne tallfeste hvor alvorlig helsetapet ved de ulike sykdommene og skadene er, og man må kunne veie dødsfall ved forskjellig alder mot det å leve med en lettere eller alvorlig sykdom over kortere eller lengre tid.

Det finnes ikke noe fasitsvar på hvordan man bygger et slikt system. Det internasjonale Global Burden of Disease-prosjektet (GBD) ble utviklet som et svar på disse utfordringene.

\section{Det internasjonale Global Burden of Disease-prosjektet (GBD)}

Det internasjonale sykdomsbyrdeprosjektet Global Burden of Disease (GBD) er det mest omfattende prosjektet for sykdomsbyrdeberegninger. GBD startet som et Verdensbank-prosjekt tidlig på 1990-tallet, og de første globale oversikter over dødelighet, helsetap og risikofaktorer i verdens befolkning ble publisert i 1993 (The World Bank, 1993). Prosjektet ble videreført i regi av WHO mot slutten av 1990-tallet, med publisering av The World Health Report i 2002 (WHO, 2002). Denne rapporten ble oppdatert i 2004.

Siden 2007 har GBD vært koordinert fra Institute for Health Metrics and Evaluation (IHME) ved University of Washington, Seattle, USA. Samme år ble det hittil største GBD-prosjektet startet opp i samarbeid med nesten 500 forskere fra over 300 institusjoner i 50 land. GBD 2010-prosjektet resulterte i:

- Beregning av sykdomsbyrde som følge av dødelighet og helsetap fra 235 dødsårsaker, 289 sykdommer, 1160 følgetilstander (sekveler) og 67 risikofaktorer.

- Beregning av utviklingen i sykdomsbyrde fra 1990 til 2010.

- Estimering av sykdomsbyrde globalt, etter 7 superregioner og 21 regioner.

- Estimering av sykdomsbyrde for 187 enkeltland (publisert i 2013) i korte, oppsummerende rapporter på IMHEs nettsider; www.healthdata. org.

Resultatene fra GBD 2010 har blitt publisert i en rekke vitenskapelige artikler, først og fremst i et spesialnummer av The Lancet i desember 2012, og på internett i 2012 - 2013. Se for eksempel Lim, 2012; Lozano, 2012; Vos, 2012; Murray, 2012a; Salomon, 2012a.

Fra og med 2014 er det planlagt årlige oppdateringer av beregningene for global og nasjonal sykdomsbyrde, først med GBD 2013-prosjektet som vil levere estimater for perioden 1990-2013.

I tillegg til GBD-prosjektet fra IHME, har WHO også nylig publisert sykdomsbyrdeestimater etter en metodikk som bygger på og til dels henter tall fra GBD 2010. De siste WHO-estimatene gir dødelighet, tapte leveår, helsetap og DALY for 172 WHO medlemsland for årene 2000 og 2012 (WHO, 2014). 


\section{Beregning av sykdomsbyrde i GBD}

\section{Tapte leveår, helsetap og helsetaps- justerte leveår (DALY)}

Tabell 1 gir en oversikt over viktige begreper for sykdomsbyrdeberegninger i GBD.

Samlemålet på sykdomsbyrde i GBD er DALY (disability adjusted life years; på norsk: "helsetapsjusterte leveår"). DALY er summen av tapte leveår ved dødsfall og helsetap fra ikke-dødelige sykdommer (eller helsetap i sykdomsforløpet av dødelige sykdommer).

Noe forenklet kan man si at DALY viser til tapte leveår grunnet død eller helsetap. For eksempel utgjør ti tapte leveår grunnet død en byrde på 10 DALY. Byrden ved tid levd med sykdom anslås også i DALY. Det å leve med sykdom i ett år teller som en brøkdel av det å miste et leveår. Brøken er større jo verre sykdommen er å leve med, og kalles en alvorlighetsvekt ("disability weight (DW)" på engelsk). Beregning av alvorlighetsvekter er beskrevet senere i kapitlet.

Sykdomsbyrden i en befolkning beregnes for et kalenderår. Man teller opp antall dødsfall i det aktuelle året og anslår hvor mange leveår som gikk tapt i forbindelse med disse dødsfallene, basert på alder ved dødsfall. Her bruker man en standardisert dødelighetstabell. Videre anslår man hvor mange mennesker som levde dette året med sykdommer av ulike slag. Hvert av disse levde årene multipliseres med en tilhørende alvorlighetsvekt for den aktuelle sykdommen eller skaden.

Nedenfor gis noen eksempler for beregning av sykdomsbyrde i Norge i 2013. Forutsetningene i GBD 2010 innebærer for eksempel at ett dødsfall av brystkreft hos en 67-åring ble regnet som like byrdefullt som at 53 personer levde ett år med alvorlig KOLS, eller at 285 personer levde ett år med epilepsi som er kontrollert gjennom legemidler.

\section{Eksempel 1:}

650 kvinner døde av brystkreft. Gjennomsnittsalder ved død var 67 år. Tapte leveår anslås i GBD 2010 til 20 år per person. Det gir 650 x $20=13000$ DALY.

\section{Eksempel 2:}

20000 personer levde med alvorlig KOLS. Alvorlighetsvekten i følge GBD 2010 er 0.38. Det gir $20000 \times 0,38$ $=7600$ DALY

\section{Eksempel 3:}

20000 personer levde med epilepsi behandlet med legemidler slik at personene ikke fikk anfall. Alvorlighetsvekten i følge GBD 2010 er 0,07. Det gir $20000 \times 0,07=1400$ DALY.

Sum for eksempel 1, 2 og 3: Til sammen 22000 DALY

Tabell 1: Norsk og engelsk terminologi for sentrale sykdomsbyrdemål og begreper i GBD 2010. Forkortelsene er basert på den engelske betegnelsen.

\begin{tabular}{|l|l|}
\hline $\begin{array}{l}\text { Betegnelse } \\
\text { Norsk (engelsk) - forkortelse }\end{array}$ & Beskrivelse \\
\hline $\begin{array}{l}\text { Alvorlighetsvekter } \\
\text { (Disability Weights) - DW }\end{array}$ & $\begin{array}{l}\text { Kvantifisering av helsetap ved ulike helsetilstander. Helsetapet for } \\
\text { sykdom, skade eller følgetilstand ("sekvele") angis som et tall mellom } \\
\text { (intet helsetap) og } 1 \text { (død). Mål på helsetap er beregnet ut fra } \\
\text { spørreundersøkelser i den generelle befolkningen. }\end{array}$ \\
\hline $\begin{array}{l}\text { Tapte leveår } \\
\text { (Years of Life Lost) - YLL }\end{array}$ & $\begin{array}{l}\text { Tapte leveår beregnes fra en standard dødelighetstabell. For } \\
\text { eksempel bidrar et dødsfall hos en nyfødt med } 86 \text { tapte leveår, } \\
\text { dødsfall hos en 50-åring med 37 tapte leveår, og dødsfall hos en } \\
90 \text {-åring med 5 tapte leveår. }\end{array}$ \\
\hline Helsetap & $\begin{array}{l}\text { Beregnes ved å multiplisere forekomst (prevalens) av sykdommer, } \\
\text { skader og følgetilstander med tilhørende alvorlighetsvekter (DW). }\end{array}$ \\
\hline Years Lived with Disability) - YLD & $\begin{array}{l}\text { Samlemålet på sykdomsbyrde i GBD-prosjektet. DALY er summen av } \\
\text { tapte leveår og helsetap. }\end{array}$ \\
\hline (Disability Adjusted Life Years) - DALY & \\
\hline
\end{tabular}

Kilde for engelske betegnelser og forkortelser er hentet fra The Lancet GBD Special Issue, 2012. 


\section{Beregning av alvorlighetsvekter}

Sammenlikninger er en sentral del av sykdomsbyrdeberegningene i GBD. Prosjektet gir et godt grunnlag for dette fordi man benytter de samme definisjonene på dødsårsaker og sykdommer, og de samme analysene for alle land og over tid (Murray, 2012b).

Det er behov for et system som kan kvantifisere helsetap på en slik måte at også bidraget fra sykdommer og skader med ikke-dødelige utfall kan måles og sammenliknes. Ulike former for alvorlighetsvekter har vært i bruk i de forskjellige rundene av GBD, og etter en omfattende revisjon ble nye alvorlighetsvekter for 220 helsetilstander utviklet til GBD 2010 (Salomon, 2012b). Disse ble igjen revidert til GBD 2013, ved å legge til resultater fra spørreundersøkelser i flere vesteuropeiske land.

For å bestemme alvorlighetsvektene gikk man fram på følgende måte: Det ble utviklet lettfattelige beskrivelser av ulike helsetilstander som var ment å tilsvare visse sykdommer og skader av ulik alvorlighet. Et utvalg fra den generelle befolkningen i ulike verdensdeler fikk så en rekke parvise beskrivelser av personer med disse helsetilstandene, og ble bedt om å angi hvilken av de to personene de mente hadde best helse. Forskerne "oversatte" så helsetilstandene tilbake til de sykdommene og skadene de var ment å representere. Basert på respondentenes svar ble det endelig utviklet alvorlighetsvekter med kvantifisering av helsetap forbundet med sykdommene og skadene på en skala fra 0 (intet helsetap) til 1 (død).

De fleste sykdommer har i siste versjon av GBD alvorlighetsvekter mellom 0,1 og 0,5. Lavest vekt ble gitt til milde former for anemi (jernmangel), hørselstap og infeksjon (alle 0,005). Høyest vekt ble gitt til akutt episode av schizofreni $(0,756)$ (Salomon, 2012b). Omregnet til sykdomsbyrde betyr dette at 1,3 år levd med schizofreni tilsvarer ett tapt leveår.

\section{Det norske sykdomsbyrde- prosjektet}

I 2013 kom GBD med de første tallene på sykdomsbyrde i den norske befolkningen, se nedenfor. Dette er resultater fra GBD 2010 (IHME, 2013a; IHME, 2013b), men tallene skal etter planen oppdateres årlig. Oppdateringene vil publiseres fortløpende. De første oppdateringene er forventet å komme sent i 2014 og betegnes GBD 2013.

Sykdomsbyrderesultatene fra GBD gir en ny type helhetlig oversikt over helsetilstanden i den norske befolkningen og er derfor av stor interesse. Men både datagrunnlaget og metodene bak beregningen av sykdomsbyrdeestimater for Norge må gjennomgås av fagpersoner med kunnskap om norske forhold.

GBDs beregninger av sykdomsbyrdeestimater for Norge stammer fra følgende hovedkilder:

- Vitenskapelige artikler og rapporter med informasjon om prevalens, insidens, remisjon, varighet og overdødelighet knyttet til sykdommer/skader/sekveler og risikofaktorer.

- Data fra Dødsårsaksregisteret (DÅR), Kreftregisteret og Norsk Pasientregister (NPR) som er publisert i WHOs European Hospital Morbidity Database.

- Noe data fra norske spørreundersøkelser, for eksempel Helse- og levekårsundersøkelsene.

Folkehelseinstituttet (FHI) er i ferd med å bygge opp et nasjonalt sykdomsbyrdeprosjekt, som skal etablere nasjonal ekspertise på norsk sykdomsbyrde. Det norske sykdomsbyrdeprosjektet skal bidra med:

- Grundig gjennomgang av estimatene fra GBD for å få oversikt over norsk sykdomsbyrde.

- Grundig gjennomgang av datakildene og metodene bak GBD-estimatene for Norge; identifisering og utvikling av nye og bedre datakilder.

- Egne analyser, blant annet mer detaljerte beregninger for sykdomsbyrde i Norge etter for eksempel fylke og sosioøkonomisk status.

\section{Hvilke sykdommer betyr mest for tapte leveår og helsetap i Norge?}

Tabell 2 gir en oversikt over den beregnede sykdomsbyrden i GBD 2010 fra de største hovedgruppene sykdommer og skader i den norske befolkningen, mens tallene for de enkelte sykdommer nedenfor er hentet fra IHMEs hjemmesider (www.healthdata.org).

På grunn av metodeusikkerheten betrakter vi disse tallene som foreløpige. Arbeid med validering og eventuell justering av tallene pågår. Resultatene gir likevel en god illustrasjon på hva GBD-prosjektet kan tilføre folkehelsearbeidet. 


\section{Tapte leveår: Hjerte- og karlidelser og kreft er de viktigste årsakene}

Tall fra GBD 2010 viser at 2 av 3 tapte leveår (YLL) i Norge er forårsaket av kreftsykdommer eller hjerte- og karlidelser. De fem største årsakene til tapte leveår i den norske befolkningen er ifølge GBD 2010:

- Hjerteinfarkt, angina pectoris og annen iskemisk hjertesykdom (15,0 prosent av YLL)

- Hjerneslag (6,9 prosent av YLL)

- Lungekreft (6,4 prosent av YLL)

- Tykk- og endetarmskreft (4,5 prosent av YLL)

- $\mathrm{KOLS}(4,3$ prosent av YLL)

\section{Helsetap: Psykiske lidelser, rygg- og nakkesmerter bidrar sterkt}

I følge GBD 2010 er de fem ledende årsakene til helsetap (YLD) i Norge:

- Korsryggsmerter (20,2 prosent av YLD)

- Alvorlig depresjon (9,3 prosent av YLD)

- Angstlidelser (5,2 prosent av YLD)

- Nakkesmerter (4,8 prosent av YLD)

- Fallulykker (for eksempel fall med hoftebrudd) $(4,7$ prosent av YLD)

Til sammen står disse fem tilstandene for om lag 45 prosent av helsetapet i den norske befolkningen.

\section{Summen av helsetap og tapte leveår (DALY): Smerter og psykiske lidelser står for $\mathbf{2 5}$ prosent}

Når helsetap og tapte leveår summeres til DALY i GBD 2010, finner vi at Norge har høy samlet sykdomsbyrde fra ikke-dødelige sykdommer. De viktigste er er:

- Korsryggsmerter (11,1 prosent av DALYs)

- Alvorlig depresjon (5,1 prosent av DALYs)

- Diabetes (3,2 prosent av DALYs)

- Angstlidelser (2,8 prosent av DALYs)

- Nakkesmerter (2,6 prosent av DALYs)

Til sammen står disse fem årsakene for en fjerdedel av den norske sykdomsbyrden målt i DALYs. Til sammenlikning står de fem største årsakene til tapte leveår (iskemisk hjertesykdom, hjerneslag, lungekreft, tykk og endetarmkreft og KOLS) for vel 20 prosent av DALYs.

\section{Hvilke risikofaktorer veier tyngst i beregningene for Norge?}

GBD 2010 beregnet bidraget fra 67 risikofaktorer på sykdomsbyrden. Noen av disse risikofaktorene, slik som urent vann, dårlige sanitærforhold og innendørs forurensing er viktige risikofaktorer i lavinntektsland og bidrar dermed sterkt til global sykdomsbyrde. Disse faktorene er imidlertid lite aktuelle for Norge. De ti viktigste risikofaktorene for dødelighet i form av antall dødsfall i Norge vises i figur 1.

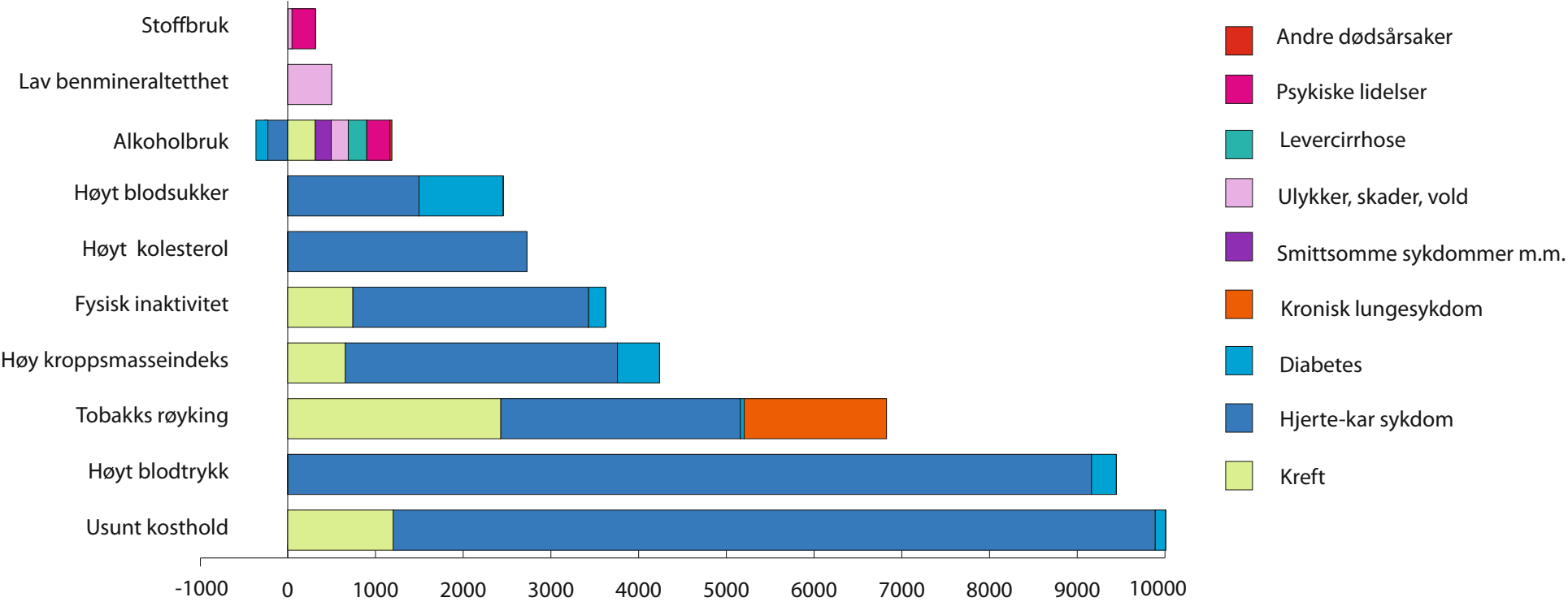

Figur 1: De 10 største risikofaktorene for dødelighet i Norge. Antall dødsfall som kan tilskrives den enkelte risikofaktor etter dødsårsak. Begge kjønn, alle aldre. Tall fra GBD 2010. 
Risikofaktoren med høyest bidrag til den norske sykdomsbyrden, enten man ser på helsetap, dødelighet eller summen av disse (DALY), er ifølge GBD 2010 usunt kosthold. Usunt kosthold er også blant de viktigste risikofaktorene for sykdomsbyrde i resten av Vest-Europa.

Samlebetegnelsen "usunt kosthold" er satt sammen av 14 kostholdskomponenter. Det er spesielt lavt inntak av frukt, grønnsaker, nøtter og frø som bidrar til betydningen av denne risikofaktoren, men også høyt saltinntak og lavt inntak av omega-3 fettsyrer spiller inn. Usunt kosthold betyr spesielt mye for sykdommer som forårsaker både mye helsetap og høy dødelighet, slik som hjerteinfarkt og andre hjerte- og kar sykdommer, visse krefttyper og diabetes.

På andreplass over sentrale risikofaktorer for norsk dødelighet kommer høyt blodtrykk, fulgt av røyking, høy kroppsmasseindeks, fysisk inaktivitet, høyt kolesterol, høyt blodsukker og alkoholforbruk.

\section{Endringer i den norske sykdoms- byrden fra 1990 til 2010}

GBD har også sett på endringer i den norske sykdomsbyrden fra 1990 til 2010 (IHME 2013a, IHME 2013b). Til tross for at hjertesykdom er blant de viktigste årsakene til sykdomsbyrde i 2010, har betydningen av denne falt betraktelig fra 1990 til 2010. Dette skyldes blant annet store fremskritt i behandling av kardiovaskulære sykdommer de siste tiårene (se kapittel om hjerte- og karsykdommer i Norge). Også betydningen av hjerneslag og lungeinfeksjoner falt fra 1990 til 2010. KOLS og nakkesmerter er nå blant de 10 ledende årsakene til sykdomsbyrde. Som følge av stadig økende levealder har også betydningen av Alzheimers sykdom steget betraktelig fra 1990 til 2010.

\section{Kan vi stole på resultatene fra det internasjonale GBD- prosjektet?}

Mange vil spørre om vi kan stole på resultatene fra GBD-prosjektet. Dette er et omfattende spørsmål, og svaret avhenger av hvilke resultater man ser på.

Kvaliteten på sykdomsbyrdeestimatene fra GBD er helt avhengig av kvaliteten på de underliggende dataene som kommer inn i prosjektet.

Dødelighet og dødsårsaker. Resultatene for dødelighet og dødsårsaker er de mest pålitelige. Dette gjelder både Norge og andre land med velfungerende dødsårsaksregistrering. Slike land er i mindretall på global basis. I land uten generell dødsårsaksregistering, benyttes data fra stikkprøve-undersøkelser og spørreundersøkelser av pårørende ved dødsfall («verbal autopsy»).

Datagrunnlaget for Norge når det gjelder dødsårsaker vil bli gjennomgått i det norske sykdomsbyrdeprosjektet for å sikre at data er oppdatert og av best mulig kvalitet

Forekomst av ikke-dødelige sykdommer. Data om forekomst av ikke-dødelige sykdommer er mer usikre. For norske forhold er for eksempel usikkerheten høy når det gjelder forekomst av sykdommer i muskel- og skjelettsystemet og psykiske lidelser. Norge har ingen helhetlig tradisjon for rapportering og oppdatering av slike data. Der GBD mangler oppdaterte norske data, slik som for psykiske lidelser og rus, bygger beregningene delvis på data fra Norden og andre vestlige, sammenliknbare land. Dette må tas i betraktning når de norske sykdomsbyrdeestimatene fortolkes.

\section{Beregning av alvorlighetsvekter. Måten GBD} beregner alvorlighet på, har vært kritisert. For eksempel er det argumentert for at en overraskende lav vekting av blindhet, døvhet, amputasjoner og lammelser i ben kan skyldes at disse tilstandene ikke nødvendigvis blir forstått som helsetilstander.

Videre har det blitt argumentert for at man ikke uten videre kan sammenlikne svært ulike helsetilstander mot hverandre, og at det som måles med alvorlighetsvektene ikke er helsetap i seg selv, men hvilke verdier man tillegger ulike typer helsetilstander (Nord, 2013). Kritikken mot alvorlighetsvektingen ved bestemte helsetilstander har ført til at de aktuelle vektene ble endret i Verdens helseorganisasjons sykdomsbyrdeberegninger (WHO, 2013).

Det vil bli vurdert om det er behov for å gjøre norske DALY-beregninger med alternative alvorlighetsvekter. På tross av svakhetene er imidlertid alvorlighetsvektene som brukes av GBD og WHO nyttige fordi de gir muligheter for internasjonale sammenlikninger.

Beregning av helsetap som følge av risikofaktorer. Norge mangler et system for regelmessig oppdatering av data om forekomst av viktige risikofaktorer. $\AA$ beregne hvor stor sykdomsbyrde som kan tilskrives ulike risikofaktorer, krever full oversikt over den epidemiologiske litteraturen som beregner risiko for sykdom eller død etter forskjellige nivåer av risikofaktorer. På enkelte områder, for eksempel røyking, er disse estimatene solide og basert på store tall- 
materialer fra mange undersøkelser. For andre risikofaktorer, for eksempel kosthold, er kunnskapen mer kontroversiell og bygger på et svakere grunnlag.

Rangeringen av risikofaktorer er også avhengig av om man ser på sammensatte variabler (for eksempel kosthold) eller ikke, hva man definerer som referanseverdier, og hvordan man tar hensyn til at risikofaktorer samvarierer. For eksempel kan ikke tallene i figur 1 summeres for å gi den totale byrden av disse faktorene; da denne summen vil bli for høy, det vil si overstige $100 \%$. Tallene kan kun benyttes for innbyrdes sammenlikning mellom faktorene.

Det er grunn til å regne med at noen av risikofaktorresultatene vil endre seg både gjennom utvikling av bedre datagrunnlag, nye kunnskapsoppsummeringer og nye metoder.

En viktig oppgave for det norske sykdomsbyrdeprosjektet vil være å sikre og videreutvikle den norske datakvaliteten, blant annet ved å supplere den eksisterende kunnskapen med nye analyser, samt identifisere områder hvor det norske datagrunnlaget er svakt og hvor det er behov for forbedringer.

Verken GBD 2010 eller GBD 2013 (som trolig publiseres sent i 2014) kan derfor ses på som et sluttresultat. Før 2013 hadde det aldri vært publisert detaljert helsestatistikk for verdens land. Tallene vil endre seg i årene som kommer ved at metodikken forbedres og korrigeres, men de største forbedringene kan bare komme gjennom at det enkelte land bedrer innsamlingen av data om helsetilstand og risikofaktorer.

\section{Beregning av sykdomsbyrde peker på folkehelseutfordringer}

Ikke-smittsomme sykdommer forårsaker nesten 90 prosent av den totale sykdomsbyrden i Norge, enten man måler byrden i form av helsetap, tapte leveår eller DALY. Sykdomsbyrden som forårsakes av ikke-smittsomme sykdommer i Norge er sammenliknbar med andre høyinntektsland, og er også et vesentlig bidrag for sykdomsbyrden i lavinntektsland. Ikke-smittsomme sykdommer utgjør dermed en betydelig byrde for den globale befolkningshelsen. Dette eksempelet viser at mange helseproblemer og risikofaktorer i større grad i dag enn for 20 år siden representerer en felles utfordring for alle land $i$ verden.

De globale og regionale resultatene fra GBD 2010 viser at Norge i stor grad har de samme helseproblemene som andre høyinntektsland, men at vi har høyere sykdomsbyrde knyttet til rygg og nakkesmerter, samt psykiske lidelser (spesielt angst og depresjon) enn Vest-Europa generelt. Disse forskjellene kan være uttrykk for reelle forskjeller mellom Norge og andre høyinntektsland, men kan også være et resultat av varierende datakvalitet og GBD-metodikken.

Den store fordelen ved GBD-systemet er at det er blitt til gjennom omfattende faglige diskusjoner, er basert på et betydelig empirisk grunnlag og at man benytter den samme metodikken for alle de 187 landene. Gjennom GBD har det blitt utviklet ny demografisk og statistisk metodikk for å kunne utnytte data best mulig, og for å kunne sammenstille data fra ulike kilder, og som er samlet inn på ulike måter.

Prosjektet har også videreutviklet modeller for å kunne beregne helsetilstand og risikofaktorer i land med svake eller manglende data.

GBD vil kunne være nyttig som et rammeverk for en helhetlig helsestatistikk på nasjonalt nivå, både i Norge og $\mathrm{i}$ andre land.

\section{Referanser}

FHI (2012): Dødelighet og dødsårsaker i Norge gjennom 60 år: 1951-2010. FHI-rapport 2012:4. Oslo: Nasjonalt Folkehelseinstitutt.

FHI (2014). Dødsårsaksregisteret. http://www.fhi. no/eway/default.aspx?pid=239\&trg=Main_6157\& Main_6157=6261:0:25,6744 (Lastet ned 26.08.2014).

IHME ( 2013a). The Global Burden of Disease: Generating Evidence, Guiding Policy - European Union and European Free Trade Association Regional Edition. Seattle, WA: Institute for Health Metrics and Evaluation.

IHME (2013b). GBD Profile: Norway. http://www.healthmetricsandevaluation.org/sites/default/files/country-profiles/ GBD Country Report - Norway.pdf. (Lastet ned 26.08.2014).

Lim, S. S., Vos, T., Flaxman, A. D., Danaei, G., Shibuya, K., et al. (2012). A comparative risk assessment of burden of disease and injury attributable to 67 risk factors and risk factor clusters in 21 regions, 1990-2010: a systematic analysis for the Global Burden of Disease Study 2010. The Lancet 380(9859): 2224-2260.

Lozano, R., Naghavi, M., Foreman, K., Lim, S., Shibuya, K., et al. (2012). Global and regional mortality from 235 causes of death for 20 age groups in 1990 and 2010: a systematic analysis for the Global Burden of Disease Study 2010. The Lancet 380(9859): 2095-2128.

Murray, C., Vos, T., Lozano, R., Naghavi, M., Flaxman, A., D., et al. (2012a). Disability-adjusted life years (DALYs) for 291 diseases and injuries in 21 regions, 1990-2010: a systematic analysis for the Global Burden of Disease Study 2010. The Lancet 380(9859): 2197-2223. 
Murray, C.J.L., et al. (2012b). Comprehensive Systematic Analysis of Global Epidemiology: Definitions, Methods, Simplification of DALYs, and Comparative Results from the Global Burden of Disease Study 2010. Supplement to Murray C.J.L., Ezzati, M., Flaxman, A. D., et al. (2012). GBD 2010: design, definitions, and metrics. The Lancet 380(9859): 2063-2066.

Nord, E. (2013). Disability weights in the Global Burden of Disease 2010: Unclear meaning and overstatement of international agreement. Health Policy 111(1): 99-104.

Salomon, J. A., Wang, H., Freeman, M. K., Vos, T., Flaxman, A. D., et al. (2012a). Healthy life expectancy for 187 countries, 1990-2010: a systematic analysis for the Global Burden Disease Study 2010. The Lancet 380(9859): 2144-2162.

Salomon, J. A., Vos, T., Hogan, D.R., Gagnon, M.; Naghavi, M., et al. (2012b). Common values in assessing health outcomes from disease and injury: disability weights measurement study for the Global Burden of Disease Study 2010. The Lancet 380(9859): 2129-2143.

The Lancet GBD Special Issue (2012). The Global Burden of Disease Study 2010. The Lancet 380(9859):2053-2260.

The World Bank, 1993. World Development Report 1993 Investing in Health. New York: Oxford University Press.
Vos, T., Flaxman, A. D., Naghavi, M., Lozano, R., Michaud, C., et al. (2012). Years lived with disability (YLDs) for 1160 sequelae of 289 diseases and injuries 1990-2010: a systematic analysis for the Global Burden of Disease Study 2010. The Lancet 380(9859): 2163-2196.

WHO (2002). World Health Report 2002. Reducing Risks, Promoting Healthy Life. Geneva, Switzerland, World Health Organization.

WHO (2013). WHO methods and data sources for global burden of disease estimates 2000-2011. Geneva, Switzerland, Department of Health Statistics and Information Systems, World Health Organization.

WHO (2014) Estimates for 2000-2012. Geneva, Switzerland, Department of Health Statistics and Information Systems, World Health Organization. http://www.who.int/healthinfo/global_burden_disease/estimates/en/index2.html (Lastet ned 26.08, 2014).

\section{FORFATTERE}

Ann Kristin Knudsen, Jonas Minet Kinge, Erik Nord, Vegard Skirbekk, Richard White, Stein Emil Vollset 


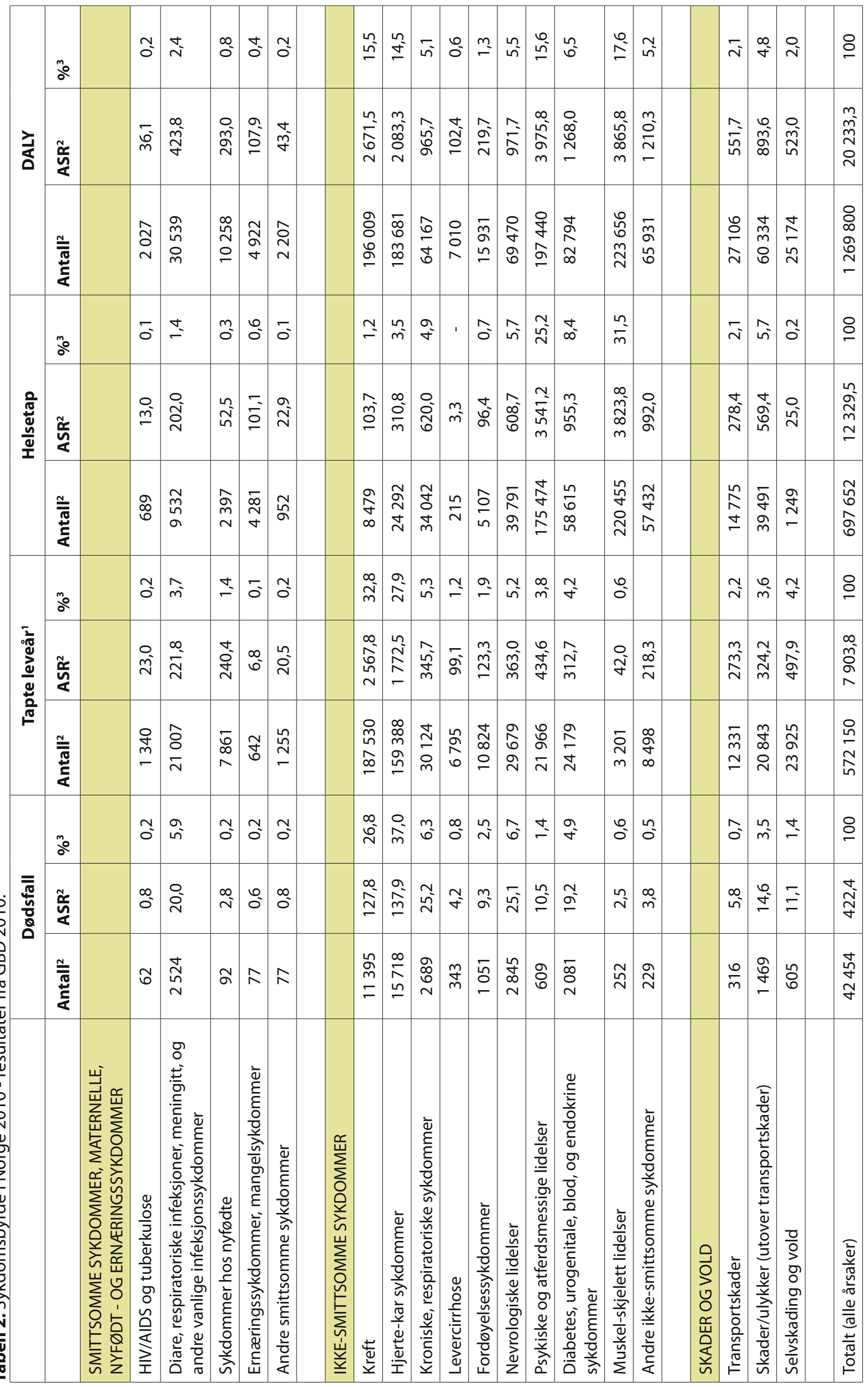

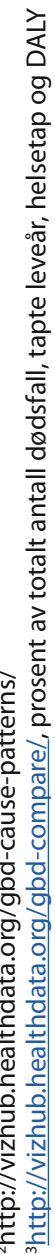




\section{Søvnvansker}

- Én av sju voksne har kronisk insomni (søvnvansker), og om lag én av tre har ukentlige søvnvansker.

- Forekomsten av insomni har økt betraktelig i Norge det siste tiåret.

- Ungdom sover mindre enn tidligere.

- Bruk av elektroniske medier før sengetid er forbundet med senere leggetid og kortere søvnlengde hos barn og ungdom med søvnvansker.

- Insomni øker risikoen for utvikling av helseplager og frafall fra arbeidslivet.

- Insomni har betydelige samfunnsøkonomiske konsekvenser.

- Sovemedisiner er fortsatt vanligste behandling i Norge, selv om kognitiv atferdsterapi har bedre og mer varig effekt.

\section{Én av sju voksne har insomni}

Kjernesymptomene ved insomni er problemer med innsovning, hyppige oppvåkninger eller å oppleve såkalt ikke-restituerende søvn, som medfører nedsatt funksjonsevne på dagtid. Undersøkelser fra en rekke land viser at:

- Nærmere en tredjedel av befolkningen rapporterer ukentlige søvnvansker, og nærmere 70 prosent av pasienter i primærhelsetjenesten rapporterer søvnvansker (Shochat 1999).

- Rundt 10 prosent av den voksne befolkningen i den vestlige verden oppfyller de diagnostiske kriteriene for insomni (Ohayon, 2002).

- Man regner med at søvnproblemene som ikke er forårsaket av en kjent somatisk eller psykisk lidelse (primær insomni) utgjør rundt 20-25 prosent av insomni-tilfellene.

\section{Forekomsten av søvnvansker har økt}

Ferske tall fra Norge viser at forekomsten av insomni blant voksne økte fra 11,9 prosent til 15,5 prosent i perioden 2000 til 2010 (Pallesen, 2014). Økningen var spesielt tydelig hos middelaldrende kvinner. Økningen gjaldt først og fremst problemer med innsovningen (fra 13,1 til 15,2 prosent), misnøye med søvnen (fra 8,2 til 13,6 prosent), og nedsatt funksjon på dagtid pga. dårlig søvn (fra 14,8 til 18,8 prosent). Økningen var ikke relatert til andre helseutfall.

\section{Forskjeller i befolkningen}

\section{Flest kvinner med søvnvansker}

Insomni forekommer hyppigere hos kvinner (Sivertsen, 2009). Spesielt eldre kvinner rapporterer ofte insomni (Pallesen, 2013), men kjønnsforskjellen er til stede allerede i ungdomsalderen (Hysing, 2013).

\section{Vanlig i alle aldersgrupper}

Søvnvansker er vanlig i alle aldersgrupper. Ferske tall fra Norge viser at:

- Hyppige oppvåkninger om natten er svært vanlig blant småbarn (Hysing, 2014).

- 1 av 5 førskolebarn har en diagnostiserbar søvnvanske, hvor insomni er den mest utbredte (Steinbekk, 2013.

- Insomni er også utbredt hos ungdom, der hver fjerde ungdom tilfredsstiller de diagnostiske kriteriene for insomni (Hysing, 2013).

- Insomni øker med alderen blant voksne; til opp mot 25 prosent hos personer over 60 år. 


\section{Voksne sover like lenge som før, mens ungdom får for lite søvn}

I den voksne befolkningen har den gjennomsnittlige søvntiden vært relativ stabil de siste tiårene (6 timer, 52 minutter for menn og 7 timer, 11 minutter for kvinner) (Ursin, 2005), men nye norske tall viser at vi har forskjøvet døgnet betraktelig siden 1980 (Sivertsen, 2011).

Mange norske ungdommer ser ut til å få for lite søvn, noe som ble vist i en stor norsk undersøkelse der ungdommer i gjennomsnitt sov to timer mindre på ukedagene enn anbefalt. De sov 6 timer og 25 minutter mot anbefalt 8 -9 timer (Hysing, 2013).

Det er mange fellestrekk for utvikling av søvnvansker på tvers av aldersgrupper, men også noen aldersspesifikke trekk. Hos små barn er høy grad av foreldreinvolvering ved barnets leggerutiner uheldig for utvikling av et godt søvnmønster, siden barnet da i mindre grad tilegner seg evnen til å regulere søvn og våkenhet på egen hånd (Sadeh, 2010). Samsoving er relatert til hyppige natteoppvåkinger i sped- og småbarnsalderen (Hysing, 2014).

I ungdomstiden kan forskjøvet døgnrytme, som ofte oppstår som følge av biologiske og sosiale årsaker, bidra til eller forverre insomni-symptomene (Pallesen, 2011).

\section{Sosioøkonomiske forskjeller i søvnvansker}

I en stor norsk undersøkelse var symptomer på insomni mer enn dobbelt så vanlig blant personer med lav utdanning (19 prosent) sammenlignet med personer med universitets- eller høyskoleutdanning (9 prosent) (Sivertsen, 2009). Denne sammenhengen er til stede også hos barn, der barn fra familier med dårlig familieøkonomi har langt større grad av søvnvansker (28 prosent) sammenlignet med barn fra familier med god familieøkonomi (10 prosent) (Boe, 2012).

\section{Risikofaktorer}

Vi vet lite om de underliggende fysiologiske mekanismene ved insomni, men både underliggende, utløsende og opprettholdende faktorer ser ut til å påvirke utviklingen (Spielman, 1991).

For eksempel kan akutt insomni utløses av en sykdom eller annen negativ livshendelse, mens kognitive og atferdsmessige faktorer er viktig for at søvnvanskene opprettholdes og eventuelt forverres. Vedvarende søvnrelatert bekymring og dårlig nattesøvn fører ofte til økt soving på dagtid, noe som igjen bidrar til å opprettholde vanskene. Det å "sove ut" i helgene bidrar ytterligere til å forstyrre kroppens egen døgnrytme som kontrollerer våre behov for søvn og våkenhet.

\section{Elektronikk og sosiale medier som «søvntyv»}

Et av de utviklingstrekkene som kan ha påvirket søvnmønsteret vårt er den økte bruken av elektroniske gjenstander og sosiale medier. Tall fra USA viser at 95 prosent av befolkningen nå benytter seg av elektroniske medier (mobiltelefon, nettbrett, videospill osv.) den siste timen før de legger seg.

En stor litteraturgjennomgang viste at bruk av elektroniske medier før sengetid var relatert til senere leggetid og kortere søvnlengde hos barn og ungdom med søvnvansker (Cain, 2010). En studie av norske studenter fant nylig at mobiltelefonbruk i sengen var assosiert med økt forekomst av insomni (Fossum, 2013).

\section{Forebygging av søvnvansker}

Selv om det finnes gode forskningsdata på behandling av søvnvansker, har få studier til nå undersøkt effekten av forebyggende tiltak mot søvnvansker. Flere tverrsnittstudier i den generelle befolkningen har vist at bruk av søvnhygieneråd henger sammen med god søvnkvalitet (Yang, 2010). Man antar derfor gjerne at god søvnhygiene vil kunne virke forebyggende mot utvikling av søvnvansker.

De fleste personer med søvnvansker (cirka 80 prosent) har som regel samtidige psykiske eller kroppslige plager. Det har derfor vært vanlig å se på forebygging av søvnvansker som en del av tiltakene i forbindelse med disse tilstandene.

Selv om forebygging av for eksempel angst og depresjon også trolig vil ha en overførbar effekt på søvnvansker, er det likevel et stort behov for framtidige studier for å undersøke effekten av forebyggingstiltak som er mer spisset mot søvnvansker.

\section{Konsekvenser og utfordringer}

Søvnvansker både påvirker og påvirkes av vår somatiske og psykiske helse (Sivertsen, 2012).

- Hos barn er søvnvansker forbundet med både dårligere skolefunksjon (Dewald, 2010) og utvikling av somatiske og mentale helseplager (Shochat, 2014).

- Hos voksne har søvnvansker en negativ påvirkning på helsen på en rekke områder 
(Sivertsen, 2013). Søvnvansker er også assosiert med redusert arbeidskapasitet, og dobler risikoen for å bli sykemeldt og uføretrygdet (Sivertsen, 2009b; Sivertsen, 2006).

- I USA er de økonomiske kostnadene knyttet til insomni anslått å beløpe seg til over 90 milliarder dollar i året. Det inkluderer både direkte medisinske kostnader, og indirekte kostnader som søvnrelaterte ulykker og tapt arbeidskapasitet (Kessler, 2011). Det finnes ingen tilsvarende tall for Norge.

\section{Feil behandling kan øke vanskene}

Halvparten av pasientene i primærhelsetjenesten og psykisk helsevern rapporter symptomer på søvnvansker (Reigstad, 2010; Shochat, 1999), men kun et fåtall av disse blir fanget opp av helsepersonell (Sivertsen, 2010). I tillegg vet vi at 2 av 3 personer med insomni har ingen eller dårlig kunnskap om tilgjengelige behandlingsmuligheter (Ancoli-Israel, 1999). Mange benytter alkohol og helsekostprodukter i forsøk på å bedre søvnen sin.

Benzodiazepiner (med virkestoffer som alprazolam, diazepam, klonazepam, midazolam, nitrazepam og oxazepam) har vært mest benyttet for behandling av søvnvansker. Sammenhengende bruk er imidlertid forbundet med utvikling av bivirkninger, tilbakefall av symptomer, og avhengighet av medikamentet (Ashton, 1994).

Nyere benzodiazepinlignende sovemidler (med virkestoffer som zopiclon, zolpidem) har vist seg å være like effektive for behandling av akutt insomni, som tradisjonelle benzodiazepiner. Ved kortvarig bruk har de nye legemidlene også noe færre bivirkninger, og de endrer ikke søvnmønsteret i samme grad som de eldre legemidlene. Likevel er det i dag generell enighet om at denne typen sovemidler må benyttes med forsiktighet hos pasienter med kronisk insomni, og langvarig bruk utover 3-4 uker bør unngås (National Institute of Health, 2005).

Foreskriving av alimemazin (antihistamin) til barn mellom 0 og 3 år er ikke uvanlig i Norge (Slordal, 2008), til tross for betydelig risiko for bivirkninger og manglende dokumentasjon på effekt. Bruk av sovemidler hos voksne personer har også vist seg å være relatert til bruk av tilsvarende sovemidler hos deres sped- og småbarn, uavhengig av barnet helse (Holdo, 2013).

\section{Alternativer til legemiddelbehandling}

Medikamentell behandling er fortsatt mest benyttet $\mathrm{i}$ behandling av insomni (Sivertsen, 2010). Dette til tross for at ikke-medikamentell behandling, for eksempel kognitiv atferdsterapi (KAT) har vist seg å være mer effektiv, både på kort og lang sikt. KAT er en behandlingsform som inkluderer flere faktorer, som opplæring i søvnhygiene (psykoedukasjon), søvnrestriksjon, stimuluskontroll, kognitiv terapi og avslapningsteknikker. Flere kunnskapsoppsummeringer viser at 8 av 10 pasienter blir bedre om de fullfører en slik behandling (Morin, 1994; Pallesen, 1998).

Det er viktig at behandlingstilbudet for personer med kronisk insomni i større grad inkluderer ikke-medikamentelle alternativer som kognitiv atferdsterapi, og at legemiddelbehandling begrenses til kortvarig bruk ved akutt insomni.

\section{Referanser}

Ancoli-Israel, S., \& Roth, T. (1999). Characteristics of insomnia in the United States: results of the 1991 National Sleep Foundation Survey. I. Sleep, 22 Suppl 2, S347-353. http://www.ncbi.nlm.nih.gov/pubmed/10394606.

Ashton, H. (1994). Guidelines for the rational use of benzodiazepines. When and what to use. Drugs, 48(1), 25-40. http://www.ncbi.nlm.nih.gov/pubmed/7525193.

Blunden, S. L., Chapman, J., \& Rigney, G. A. (2012). Are sleep education programs successful? The case for improved and consistent research efforts. Sleep Med Rev, 16(4), 355-370. http://www.ncbi.nlm.nih.gov/pubmed/22104441.

Boe, T., Hysing, M., Stormark, K. M., Lundervold, A. J., \& Sivertsen, B. (2012). Sleep problems as a mediator of the association between parental education levels, perceived family economy and poor mental health in children. $J$ Psychosom Res, 73(6), 430-436. http://www.ncbi.nlm.nih. gov/pubmed/23148810.

Cain, N., \& Gradisar, M. (2010). Electronic media use and sleep in school-aged children and adolescents: A review. Sleep Med, 11(8), 735-742. http://www.ncbi.nlm.nih.gov/ pubmed/20673649.

Cain, N., Gradisar, M., \& Moseley, L. (2011). A motivational school-based intervention for adolescent sleep problems. Sleep Med, 12(3), 246-251. http://www.ncbi.nlm.nih.gov/ pubmed/21292553.

Dewald, J. F., Meijer, A. M., Oort, F. J., Kerkhof, G. A., \& Bogels, S. M. (2010). The influence of sleep quality, sleep duration and sleepiness on school performance in children and adolescents: A meta-analytic review. Sleep medicine reviews, 14(3), 179-189. http://www.ncbi.nlm.nih.gov/ pubmed/20093054. 
Espie, C. A., Kyle, S. D., Williams, C., Ong, J. C., Douglas, N. J., Hames, P., et al. (2012). A Randomized, Placebo-Controlled Trial of Online Cognitive Behavioral Therapy for Chronic Insomnia Disorder Delivered via an Automated Media-Rich Web Application. Sleep, 35(6), 769-781. http://www.ncbi. nlm.nih.gov/pubmed/22654196.

Fossum, I. N., Nordnes, L. T., Storemark, S. S., Bjorvatn, B., \& Pallesen, S. (2013). The Association Between Use of Electronic Media in Bed Before Going to Sleep and Insomnia Symptoms, Daytime Sleepiness, Morningness, and Chronotype. Behavioral Sleep Medicine, Oct 24. [Epub ahead of print]. http://www.ncbi.nlm.nih.gov/pubmed/24156294.

Holdo, I., Handal, M., Skurtveit, S., \& Bramness, J. G. (2013). Association between prescribing hypnotics for parents and children in Norway. Archives of Disease in Childhood, 98(9), 732-736. http://www.ncbi.nlm.nih.gov/ pubmed/23845695.

Hysing M., Torgersen L, Ystrøm E., Harvey AG., ReichbornKjennerud T., Sivertsen B (2014). Trajectories and predictors of nocturnal awakenings and short sleep duration in infants from 6 to 18 months. Journal of Developmental \& Behavioral Pediatrics, 35:309-316. http://www.ncbi.nlm. nih.gov/pubmed/24906032.

Hysing M., Pallesen S., Stormark K.M., Lundervold A.J., Sivertsen B (2013). Sleep patterns and insomnia among adolescents: a population-based study. Journal of Sleep Research, 22: 549-6. http://www.ncbi.nIm.nih.gov/ pubmed/23611716.

Kessler, R. C., Berglund, P. A., Coulouvrat, C., Hajak, G., Roth, T., Shahly, V., et al. (2011). Insomnia and the Performance of US Workers: Results from the America Insomnia Survey. Sleep, 34(9), 1161-1171. http://www.ncbi.nlm.nih.gov/ pubmed/21886353.

Manber, R., Edinger, J. D., Gress, J. L., San Pedro-Salcedo, M. G., Kuo, T. F., \& Kalista, T. (2008). Cognitive behavioral therapy for insomnia enhances depression outcome in patients with comorbid major depressive disorder and insomnia. Sleep, 31(4), 489-495. http://www.ncbi.nlm.nih. gov/pubmed/18457236.

Morin, C. M., Culbert, J. P., \& Schwartz, S. M. (1994). Nonpharmacological interventions for insomnia: a meta-analysis of treatment efficacy. Am J Psychiatry, 151(8), 1172-1180. http://www.ncbi.nlm.nih.gov/pubmed/8037252.

National Institute of Health. (2005). State of the Science Conference statement on Manifestations and Management of Chronic Insomnia in Adults, June 13-15, 2005. Sleep, 28(9), 1049-1057. http://www.ncbi.nlm.nih.gov/ pubmed/16268373.

Ohayon, M. M. (2002). Epidemiology of insomnia: What we know and what we still need to learn. Sleep Med Rev, 6, 97-111. http://www.ncbi.nlm.nih.gov/pubmed/12531146.

Pallesen, S., Nordhus, I. H., \& Kvale, G. (1998). Nonpharmacological interventions for insomnia in older adults: $A$ meta-analysis of treatment efficacy. Psychotherapy, 35(4), 472-482. http://psycnet.apa.org/journals/pst/35/4/472/.
Pallesen, S., Saxvig, I. W., Molde, H., Sorensen, E., Wilhelmsen-Langeland, A., \& Bjorvatn, B. (2011). Brief report: behaviorally induced insufficient sleep syndrome in older adolescents: prevalence and correlates. Journal of adolescence, 34(2), 391-395. http://www.ncbi.nlm.nih.gov/ pubmed/20303581.

Pallesen S, Sivertsen B, Nordhus IH, Bjorvatn B. A 10-year trend of insomnia prevalence in the adult Norwegian population. Sleep Medicine 2014, 15:173-179. http://www. ncbi.nlm.nih.gov/pubmed/24382513

Reigstad, B., Jorgensen, K., Sund, A. M., \& Wichstrom, L. (2010). Prevalences and correlates of sleep problems among adolescents in specialty mental health services and in the community: what differs? Nord J Psychiatry, 64(3), 172-180. http://www.ncbi.n/m.nih.gov/pubmed/19883190.

Ritterband, L. M., Thorndike, F. P., Gonder-Frederick, L. A., Magee, J. C., Bailey, E. T., Saylor, D. K., et al. (2009). Efficacy of an Internet-based behavioral intervention for adults with insomnia. Archives of General Psychiatry, 66(7), 692-698. http://www.ncbi.nlm.nih.gov/pubmed/19581560.

Sadeh, A., Tikotzky, L., \& Scher, A. (2010). Parenting and infant sleep. Sleep Med Rev, 14(2), 89-96. http://www.ncbi. nlm.nih.gov/pubmed/19631566.

Shochat, T., Cohen-Zion, M., \& Tzischinsky, O. (2014). Functional consequences of inadequate sleep in adolescents: a systematic review. Sleep Med Rev, 18(1), 75-87. http://www. ncbi.nlm.nih.gov/pubmed/23806891.

Shochat, T., Umphress, J., Israel, A. G., \& Ancoli-Israel, S. (1999). Insomnia in primary care patients. Sleep, 22 Supp/ 2, S359-365. http://www.ncbi.nlm.nih.gov/ pubmed/10394608.

Sivertsen, B., Krokstad, S., Overland, S., \& Mykletun, A. (2009a). The epidemiology of insomnia: associations with physical and mental health. The HUNT-2 study. $J$ Psychosom Res, 67(2), 109-116. http://www.ncbi.nlm.nih. gov/pubmed/19616137.

Sivertsen, B., Lallukka, T., Salo, P., Pallesen, S., Hysing, M., Krokstad, S., et al. (2013). Insomnia as a risk factor for ill health. Results from the large population-based prospective HUNT study in Norway. Journal of Sleep Research, Oct 30. [Epub ahead of print]. http://www.ncbi.nlm.nih.gov/ pubmed/24635564.

Sivertsen, B., Nordhus, I. H., Bjorvatn, B., \& Pallesen, S. (2010). Sleep problems in general practice: a national survey of assessment and treatment routines of general practitioners in Norway. Journal of Sleep Research, 19(1 Pt 1), 36-41. http://www.ncbi.nlm.nih.gov/ pubmed/19732316.

Sivertsen, B., Overland, S., Bjorvatn, B., Maeland, J. G., \& Mykletun, A. (2009b). Does insomnia predict sick leave? The Hordaland Health Study. J Psychosom Res, 66(1), 67-74. http://www.ncbi.nlm.nih.gov/pubmed/19073296.

Sivertsen, B., Overland, S., Neckelmann, D., Glozier, N. Krokstad, S., Pallesen, S., et al. (2006). The long-term effect of insomnia on work disability: the HUNT-2 historical cohort study. Am J Epidemiol, 163(11), 1018-1024. http:// www.ncbi.nlm.nih.gov/pubmed/16611665. 
Sivertsen, B., Salo, P., Mykletun, A., Hysing, M., Pallesen, S., Krokstad, S., et al. (2012). The bidirectional association between depression and insomnia: the HUNT study. Psychosom Med, 74(7), 758-765. http://www.ncbi.nlm.nih. gov/pubmed/22879427.

Sivertsen, B., Øverland, S., \& Pallesen, S. (2011). Trends in timing of sleep in the general population of Norway: 1980 to 20001. Percept Mot Skills, 113(2), 509-518. http://www. ncbi.nlm.nih.gov/pubmed/22185065.

Slordal, L., \& Bramness, J. G. (2008). [ls alimemazine a suitable sleeping agent for children?]. Tidsskr Nor Laegeforen, 128(19), 2194-2196. http://www.ncbi.nlm.nih.gov/ pubmed/18846144.

Spielman, A. J., \& Glovinsky, P. (1991). The varied nature of insomnia. I P. J. Hauri (Red.), Case studies in insomnia (s. 1-15). New York: Plenum Press.
Steinsbekk, S., Berg-Nielsen, T. S., \& Wichstrom, L. (2013). Sleep disorders in preschoolers: prevalence and comorbidity with psychiatric symptoms. J Dev Behav Pediatr, 34(9), 633-641. http://www.ncbi.nlm.nih.gov/pubmed/24217030.

Ursin, R., Bjorvatn, B., \& Holsten, F. (2005). Sleep duration, subjective sleep need, and sleep habits of 40- to 45-yearolds in the Hordaland Health Study. Sleep, 28(10), 12601269. http://www.ncbi.n/m.nih.gov/pubmed/16295211. Yang, C. M., Lin, S. C., Hsu, S. C., \& Cheng, C. P. (2010). Maladaptive sleep hygiene practices in good sleepers and patients with insomnia. J Health Psychol, 15(1), 147-155. http://www.ncbi.nlm.nih.gov/pubmed/20064894.

\section{FORFATTER}

Børge Sivertsen 


$$
\begin{aligned}
& \text { DEL } 4 \\
& \text { Risiko- og beskyttande faktorar }
\end{aligned}
$$

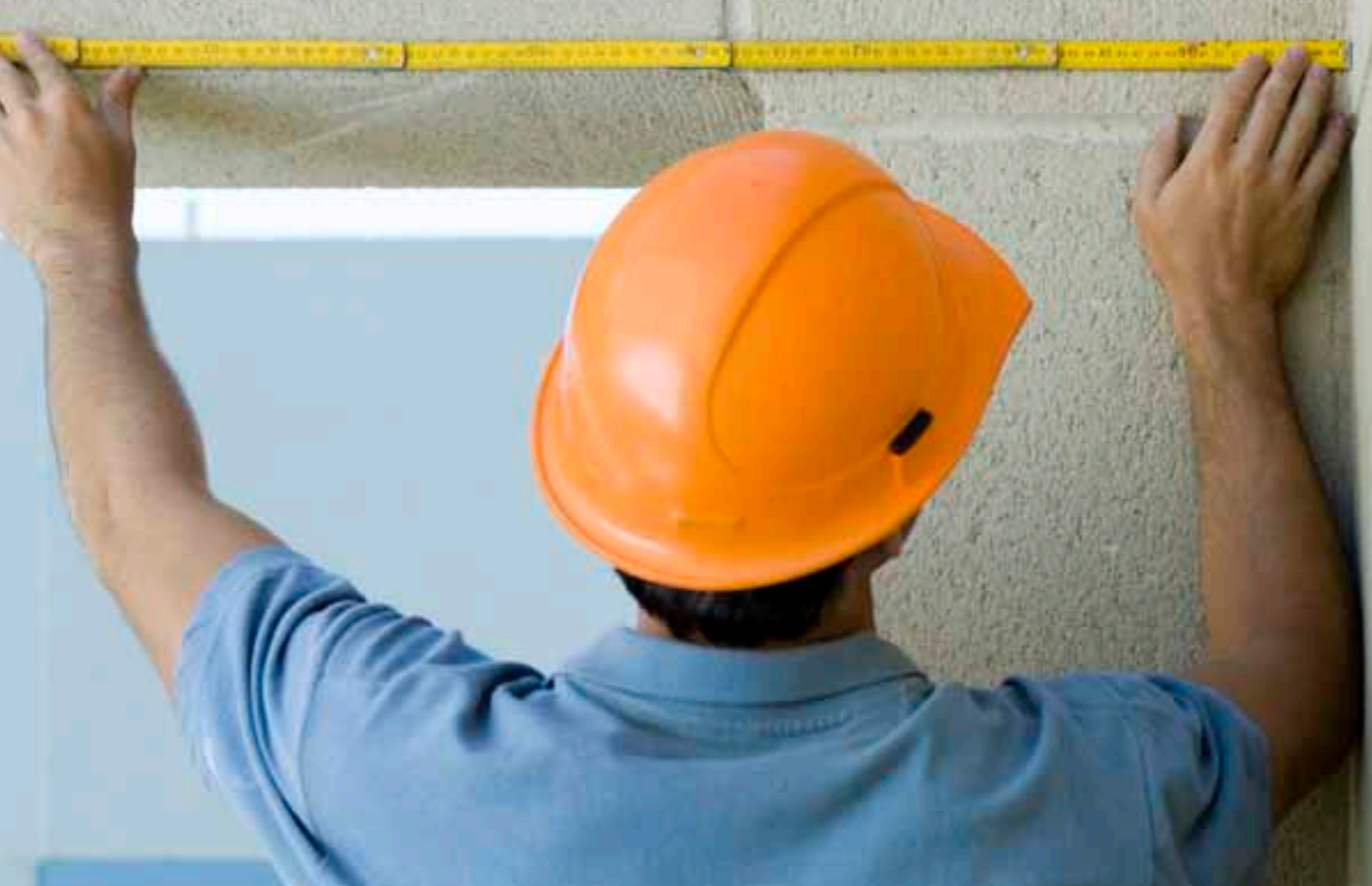




\section{Alkohol og andre rusmiddel}

- I gjennomsnitt drikk nordmenn over 15 år cirka 8 liter rein alkohol per år.

- Sidan tidleg på 1990-talet har alkoholforbruket auka med cirka 40 prosent, og mest blant kvinner og eldre.

- Utanom alkohol er cannabis og amfetamin dei mest brukte rusmidla.

- Nye syntetiske rusmiddel har til dels ukjende verknader og er ei utfordring for helsetenesta.

- Talet på bilførarar som er tekne for køyring under påverknad av cannabis eller metamfetamin, har auka kraftig de siste fem åra.

\section{Rusmiddel er dempande, stimulerande eller hallusinogene}

Som rusmiddel reknar vi alkohol, vanedannande legemiddel og ulovlege rusmiddel (narkotika) som blant anna cannabis, amfetamin, heroin og kokain.

Vanedannande legemiddel er hovudsakleg roande middel og sovemiddel av typen benzodiazepinar. Ein stor del av tablettane i den illegale marknaden er ikkje framstilte av godkjende legemiddelprodusentar. Ulovlege middel inneheld ofte ei høgare mengde verkestoff samanlikna med registrerte preparat som blir selde på apotek (Kripos, 2014).

Benzodiazepinar blir ofte misbrukte i kombinasjon med narkotiske stoff som blant anna amfetamin, cannabis og heroin.

Effekten av rusmiddel kan delast inn i tre hovudgrupper: Dempande, stimulerande og hallusinogene, sjå figur 1. Fleire rusmiddel har ei blanding av desse effektane, sjå for eksempel alkohol og ecstasy.

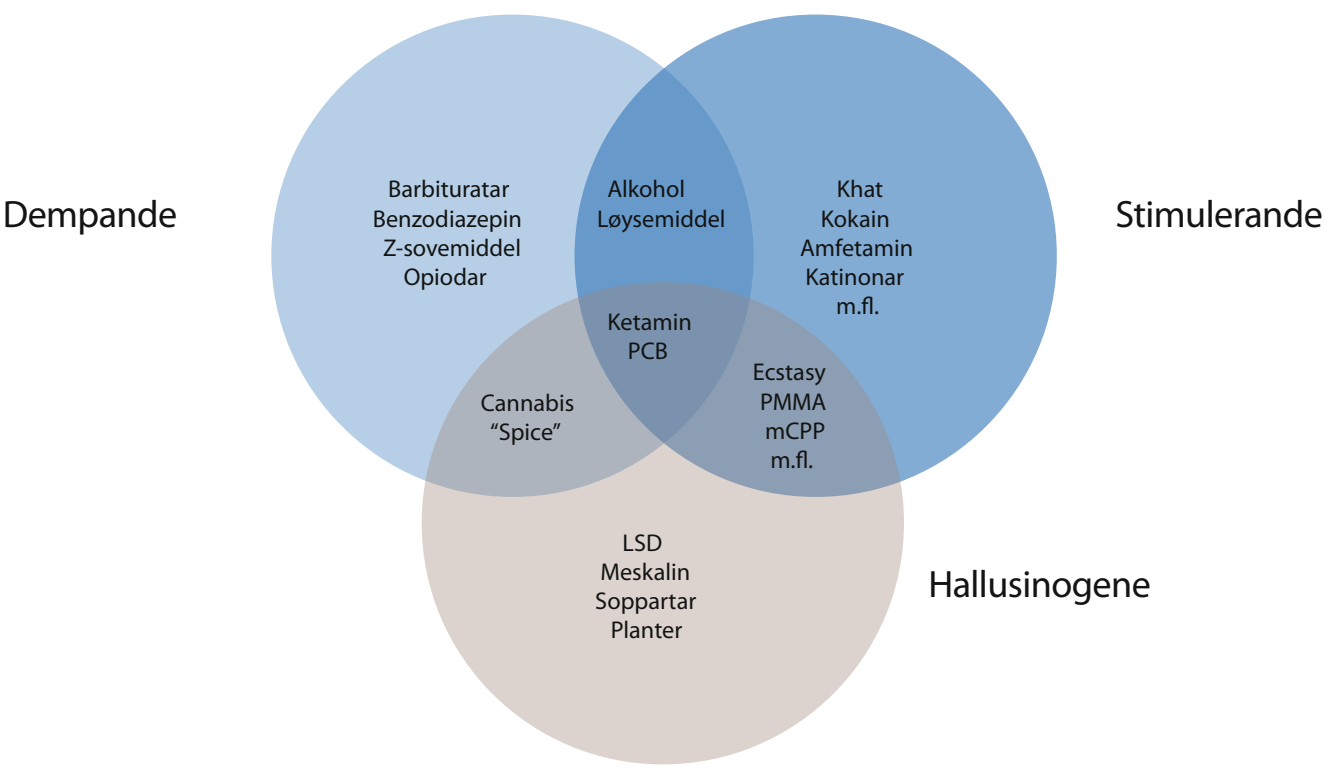

Figur 1: Rusmiddel kan vere dempande, stimulerande eller Hallusinogene. Fleire rusmiddel har ei blanding av desse effektane. Figur: Folkehelseinstituttet. 


\section{Bruk av alkohol og andre rusmiddel i Noreg i dag}

\section{Nesten 8 liter alkohol per person i året}

I 2012 blei det omsett 6,21 liter rein alkohol per innbyggjar over 15 år. I tillegg kjem uregistrert forbruk frå grensehandel med Sverige og avgiftsfri («tax free») handel på norske flyplassar, som er rekna ut til å vere 1,6 liter (Sirus, Rusmiddeltatistikk).

I tillegg til grensehandel og avgiftsfri handel på flyplassar omfattar det uregistrerte forbruket også anna «turistimport», alkoholinntak under opphald $\mathrm{i}$ utlandet, heimeproduksjon av øl, vin og brennevin, og smugling.

Utrekningar av det uregistrerte forbruket gir usikre anslag, særleg for det forbruket som stammar frå heimeproduksjon, smugling, utanlandsopphald og turistimport utanom grensehandelen og den avgiftsfrie handelen på norske flyplassar.

Avgiftsfritt sal på flyplassar (taxfree). I perioden 2010- 2012 auka det avgiftsfrie salet av alkohol på norske flyplassar med 29 prosent for både øl og svakvin og med 129 prosent for heitvin. Brennevinssalet gjekk ned med 11 prosent (SIRUS: Avgiftsfritt sal av alkohol).

Grensehandel. Utviklinga i grensehandelen med Sverige viser at salet var nesten åtte gonger større i 2011 samanlikna med 1995. Det viser ei kartlegging der ein tok for seg salet omrekna til rein alkohol. Auken var størst for øl og vin (SIRUS: Grensehandelen).
Undersøkingar av alkoholforbruket

Ei nyare undersøking blant tilfeldige bilførarar i normal trafikk viser at 2 av 1000 førarar (0,2 prosent) er påverka av alkohol (Gjerde, 2013).

Undersøkinga "Ung i Oslo 2012" viser at cirka 45 prosent av elevane i 1. trinn på vidaregåande skule hadde drukke seg tydeleg rusa minst éin gong. For heile aldersgruppa (15-17 år) var talet 29 prosent. Det var ein høgare andel jenter enn gutar. Det var liten forskjell i alkoholbruk mellom unge i Oslo og unge i resten av landet (Øia, 2012).

\section{Alkoholforbruket har auka med cirka 40 prosent på 20 år}

Alkoholforbruket i Noreg aukar og er i dag cirka 40 prosent høgare enn forbruket tidleg på 1990-talet - dersom vi samanliknar registrert årleg forbruk tidleg på 1990-talet og registrert årleg forbruk dei siste åra (Sirus, 2013).

Uregistrert forbruk frå blant anna grensehandel og avgiftsfri handel på flyplassar kjem i tillegg og har i perioden sannsynlegvis auka meir enn det registrerte forbruket. Sjå avsnittet «bruk av alkohol».

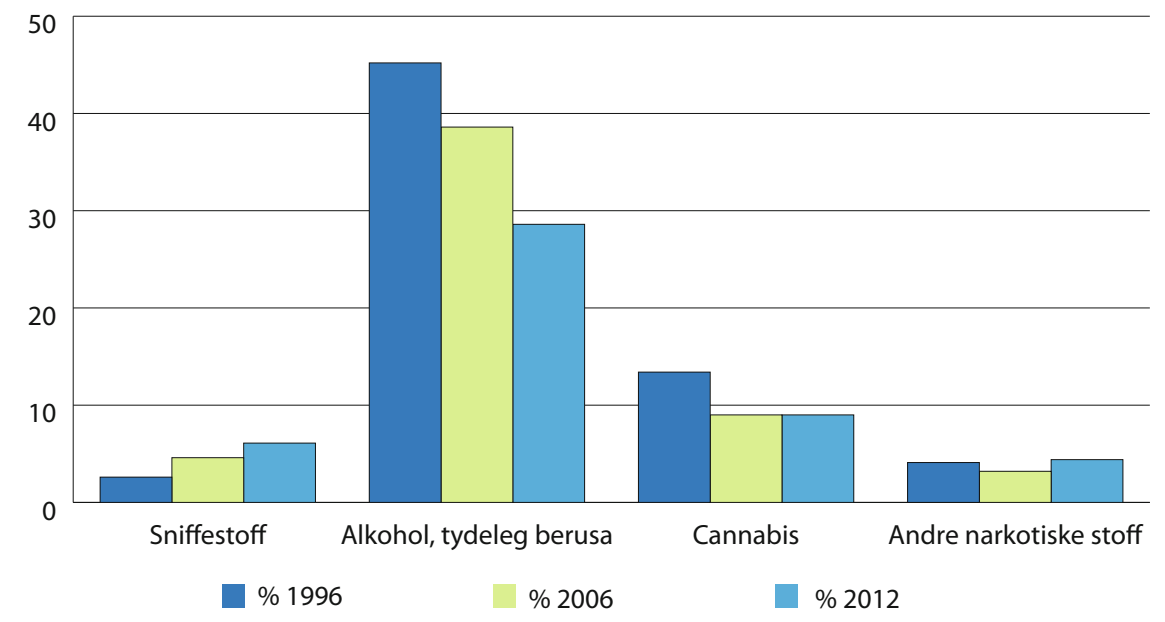

Figur 2: Endring av rusmiddelbruk blant ungdom i Oslo frå 1996 til 2006 og 2012 (Øia, 2012). 


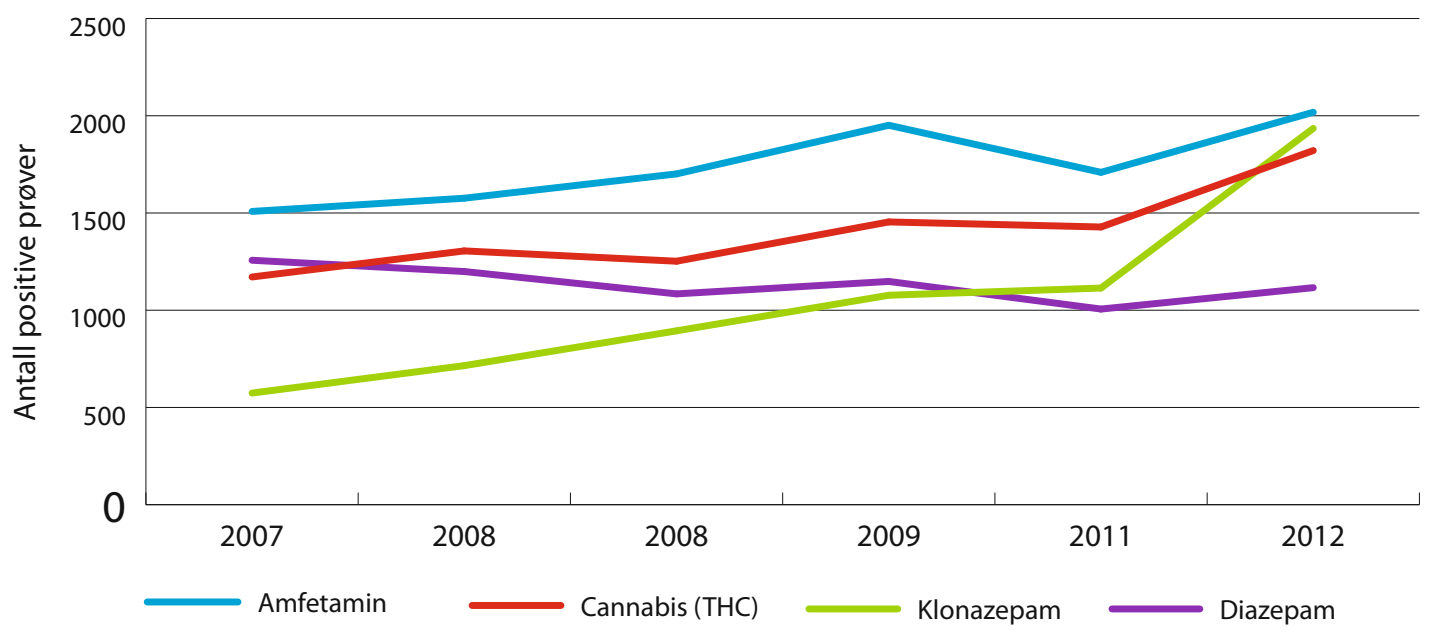

Figur 3: Talet på positive prøver frå bilførarar som blei arresterte for påverka køyring i perioden 2007 til 2012. Figuren viser dei fire vanlegaste stoffa utanom alkohol. Datakjelde: Folkehelseinstituttet.

At alkoholforbruket aukar blant vaksne blir støtta av følgjande undersøkingar:

- Menn drikk framleis meir enn kvinner, med unntak av vin, men det er fleire kvinner som drikk alkohol i dag enn for få år sidan (Sirus, 2013).

- I løpet av perioden 1997-2008 auka andelen eldre over 70 år med problematisk alkoholforbruk frå under 0,5 prosent til 4,5 prosent (Støver, 2012).

- Ein studie som omfatta sjølvrapportert alkoholforbruk i Noreg for perioden 1973-2004, viste både auke i talet på stordrikkarar og auka alkoholbruk i befolkninga generelt fram til 2004 (SIRUS; Rossow, 2014). Det er ikkje gjort tilsvarande undersøkingar dei siste 10 åra.

Alkoholbruken blant unge har derimot gått ned, sjå figur 2 (Øia, 2012). Det viser tal frå undersøkinga «Ung i Oslo 2012», samanlikna med tilsvarande undersøkingar i 1999 og 2006.

\section{Forskjellar i befolkninga}

\section{Menn drikk mest}

Menn drikk mest, men kvinners alkoholforbruk aukar mest (Støver, 2012).

\section{Mindre alkohol i nokre innvandrar- grupper}

Alkoholbruken blant unge med innvandrarbakgrunn er lågare enn hos andre elevar i første klasse i vidaregåande skule; 37 prosent mot 12 prosent. Det viser undersøkinga Ung i Oslo i 2012. Også alkoholbruken blant innvandrarforeldre er betydeleg lågare enn blant etnisk norske foreldre (Øia, 2012).

\section{Bruk av andre rusmiddel enn alkohol}

\section{Cannabis og amfetamin er dei mest brukte ulovlege rusmidla}

Beslag hos Kripos og analysar av blodprøver hos personar som er mistenkte for påverka køyring, gir eit bilete av kva rusmiddel som er vanlegast i Noreg i dag. Prøver frå tilfeldige bilførarar i normaltrafikk og arbeidstakarar i bedrifter gir i tillegg eit bilete av kor hyppig rusmiddelbruken er i den vaksne befolkninga.

Cannabis, metamfetamin og amfetamin er dei vanlegaste ulovlege rusmidla. Ecstasy har nesten vore borte frå marknaden, men Kripos melder om ein auke i beslag (Kripos, 2014).

Kokain blir hovudsakleg brukt i meir lukka miljø. I enkelte ungdomsmiljø har bruk av GHB vore populært dei siste 10 åra.

\section{1-2 prosent av bilførarane er påverka}

Blant tilfeldige bilførarar i normal trafikk reknar ein med at 0,6 prosent er påverka av narkotika og 1,3 prosent av legemiddel (Gjerde, 2013).

Analyse av spyttprøver frå bilførarar i normaltrafikk og arbeidstakarar i ulike bedrifter viser at cirka 1 prosent hadde brukt cannabis i løpet av dei siste to døgna. Blant menn under 30 år var talet 4 prosent (Gjerde, 2013). 


\section{Bruken av ulovlege rusmiddel aukar}

Utviklinga i beslagstatistikk frå Kripos er den same som utviklinga i analysefunn knytt til mistanke om påverka køyring, valdsepisodar eller andre straffbare forhold (Kripos, 2014; FHI; Bogstrand, 2011a,b; Gjerde, 2014).

Trendar frå forskjellige studiar og årsstatistikk frå politiet viser at bruken av cannabis, amfetamin og kokain har auka, mens bruken av heroin har gått ned i perioden 2008/2009-2011/2013 (Kripos, 2014; Gjerde, 2011; FHI, 2013). Sjå figur 3, som viser ei markert auke i funn av cannabis, amfetamin og beroligande middel hos bilførarar som blir arresterte for påverka køyring.

Andre rusmiddel enn alkohol er oftare enn tidlegare i søkjelyset ved mistanke om påverka køyring. I 2013 gjaldt halvparten av sakene andre rusmiddel enn alkohol.

\section{Mest narkotika i større byar}

- Ei samanlikning av rusmiddelbruk hos ungdom i Oslo med ungdom i same aldersgruppe frå distriktskommunar viser at bruk av cannabis og andre narkotiske stoff er mest vanleg i Oslo (Øia, 2012).

- Bruk av narkotiske stoff er vanlegare i område rundt storbyane enn i distrikta (Gjerde, 2011). Det viser ei undersøking av rusmiddelbruk hos bilførarar i normaltrafikk frå område i Søraust-, Vest-, Midt- og Nord-Noreg.

- I Oslo varierer bruken av cannabis mellom bydelane, frå cirka 11-16 prosent i sentrum og vestlege bydelar til 6-8 prosent i austlege bydelar (Øia, 2012). Andre narkotiske stoff er vanlegast i sentrumsbydelane (6-8 prosent) (Øia, 2012).

\section{Sosioøkonomiske forskjellar i rusmiddelbruk}

Alkoholbruk og hyppigheit for alkoholinntak aukar i takt med høgare utdanning og inntekt, men færre i denne gruppa blir alkoholavhengige enn i grupper med låg inntekt og utdanning (Clench-Aas, 2009). Personar som ikkje lever i parforhold, har også høgare alkoholforbruk enn personar med partnar (Clench-Aas, 2009).

Prosentdelen som rusar seg på hasj og tablettar, er høgast blant dei med låg sosioøkonomisk status. Rusmiddelbruk er også vanlegare i grupper med problemåtferd og for eksempel hos elevar som ofte skulkar skulen (Rødje, 2004).

Personar med høg sosial status har oftare prøvd narkotiske stoff enn personar med låg sosial status, mens langvarig misbruk er vanlegast hos den siste gruppa.

\section{Internasjonal samanlikning}

Den registrerte alkoholomsetninga i Noreg er lågare enn i dei fleste andre europeiske land, sjå figur 4 (WHO, 2011). Data frå WHO viser at alkoholbruken i fleire europeiske land har gått ned, mens omsetninga i Noreg har auka. Omfanget av uregistrert alkoholomsetning kan vere usikker og vanskeleg å samanlikne.

\section{Konsekvensar av rusmiddelbruk}

Bruk av alkohol og andre rusmiddel er forbunde med ei rekke sosiale og helsemessige konsekvensar i form av sjukdommar, skadar og psykiske plager og lidingar.

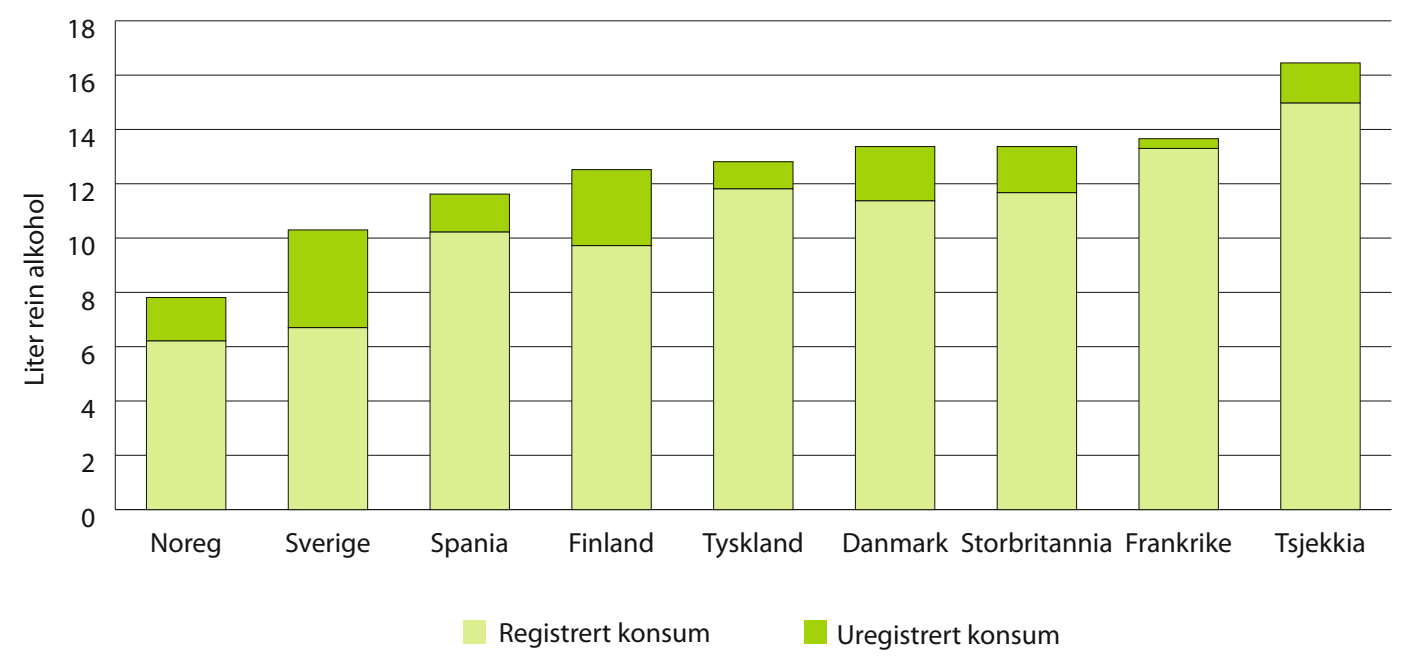

Figur 4: Alkoholbruk i ulike europeiske land, 2010. Datakjelde: OECD, 2010. 
Både for alkohol og andre rusmiddel er dei sosiale og helsemessige konsekvensane generelt avhengige av type rusmiddel og dose, om dei er brukt éin gong eller over lengre tid.

Det totale alkoholforbruket er ein viktig faktor (determinant) for alkoholrelaterte sjukdommar og skadar i befolkninga. Når det totale forbruket i samfunnet aukar, aukar både andelen storforbrukarar og andelen som ligg i «gråsona» mot eit helseskadeleg forbruk.

Risikoen for kroniske sjukdommar knytt til alkoholbruk aukar gradvis. Hos storforbrukarar er risikoen høg. For enkeltpersoner $\mathbf{i}$ «gråsone-gruppa» er risikoen lågare, men fordi denne gruppa er stor, vil den likevel bidra med mange personar til dei samla helseproblema i samfunnet.

Helseskadane ved alkohol blir først og fremst bestemt av den totale mengda alkohol som kroppen blir utsett for, sjå nedanfor. Alkoholskadar kan derfor utvikle seg sjølv om ein person ikkje har vore synleg berusa. Skadar som skuldast ulykker og vald er ofte knytt til sporadisk stordrikking, utan at det ligg føre eit generelt storforbruk.

\section{Tilrådingar for inntak av alkohol}

Helsedirektoratet tilrår at alkoholinntaket blir avgrensa og ikkje er høgare enn 10 gram (12,5 ml rein alkohol) om dagen for kvinner og ikkje meir enn 20 gram (25 $\mathrm{ml}$ ) for menn. 10 gram svarar til litt under eit glas vin eller nesten 3 desiliter øl, sjå tabell 1 (Helsedirektoratet, 2014).

Gravide, kvinner som ammar, barn og ungdom blir rådde til å avstå heilt frå alkohol.

Tilrådinga er basert på at auka inntak av alkohol aukar risikoen for blant anna brystkreft, hjerneslag og fosterskadar, og at bruk av alkohol også har sosiale følgjer. Norske og nordiske ekspertrapportar ligg til grunn for tilrådingane.

\section{Alkoholrelaterte sjukdommar og skadar}

Psykiske plager og lidingar. Eit langvarig og høgt

alkoholkonsum kan auke risikoen for avhengigheit og andre psykiske lidingar.

Kroppslege sjukdommar. Eit langvarig og høgt alkoholforbruk aukar risikoen for hjerte- og karsjukdommar, i tillegg til andre sjukdommar som leversvikt, betennelse i bukspyttkjertelen og lungesjukdommar (Parry, 2011).

Eit moderat alkoholforbruk aukar risikoen for kreft i fordøyelsesorgana, lever, bryst og enkelte andre kreftformer. Talet på krefttilfelle som kan tilskrivast alkohol er ikkje estimert for Noreg. For Europa er slike estimat gjort. Ein fann at hos menn kan 10 prosent av krefttilfella tilskrivast alkohol, mens andelen hos kvinner er 3 prosent (Schutze, 2011).

Store enkeltinntak av alkohol gir auka risiko for hjerneslag og hjerteinfarkt, og risikoen aukar med frekvensen av slike episodar (Parry, 2011). Det er også haldepunkt for at alkoholbruk, allereie ved moderat forbruk, aukar risikoen for atrieflimmer (Larsson, 2014).

Høgt forbruk av medikament kombinert med alkohol er spesielt skadeleg (SIRUS, 2012).

Alkohol er ei medverkande årsak til meir enn 60 somatiske sjukdommar og den 3. største årsaka til sjukdom og tapte leveår i den vestlege verda (WHO, 2011).

Skadar og ulykker. 27 prosent av ulykkesrelaterte akuttinnleggingar ved Ullevål sjukehus i løpet av 1 år var alkoholrelaterte (Bogstrand, 2011b).

Legevakta i Bergen fann at 70 prosent av pasientane som blei behandla for valdsskadar, var alkoholpåverka (Sten og Hundskar, 1997).

Innlegging på sjukehus. Talet på sjukehusinnleggingar med alkoholrelaterte hovuddiagnosar har auka betydeleg dei siste åra, frå 4131 innleggingar i 2004 til

Tabell 1: Mengda vin, øl, lettøl og brennevin som gir $10 \mathrm{~g}$ og $20 \mathrm{~g}$ alkohol per dag. *(Helsedirektoratet, 2014).

\begin{tabular}{|l|l|l|l|l|}
\hline $\begin{array}{l}\text { Anbefaling for } \\
\text { alkoholinntak* }\end{array}$ & $\begin{array}{l}\text { Tilsvarar i vin } \\
(12 \text { volum\% })\end{array}$ & $\begin{array}{l}\text { Tilsvarar } \mathbf{i} \text { øl, pils } \\
(4,5 \text { volum\% })\end{array}$ & $\begin{array}{l}\text { Tilsvarar i lettøl } \\
(1,5 \text { volum\% })\end{array}$ & $\begin{array}{l}\text { Tilsvarar i brennevin } \\
(40 \text { volum\% })\end{array}$ \\
\hline $\begin{array}{l}\text { Kvinner: bør ikkje } \\
\text { overstige } 10 \mathrm{~g} / \mathrm{dag}\end{array}$ & $104 \mathrm{ml}(1 \mathrm{dl})$ & $278 \mathrm{ml}(0,3$ liter $)$ & $833 \mathrm{ml}(0,8$ liter $)$ & $31 \mathrm{ml}(3 \mathrm{cl})$ \\
\hline $\begin{array}{l}\text { Menn: } \text { bør ikkje } \\
\text { overstige } 20 \mathrm{~g} / \mathrm{dag}\end{array}$ & $208 \mathrm{ml}(2 \mathrm{dl})$ & $556 \mathrm{ml}(0,6$ liter $)$ & $1666 \mathrm{ml}(1,7 \mathrm{liter})$ & $62 \mathrm{ml}(6 \mathrm{cl})$ \\
\hline
\end{tabular}


6064 i 2012. Talet har vore vesentleg høgare for menn enn for kvinner. I 2012 var talet for innleggingar 4083 for menn og 1981 for kvinner (Helsedirektoratet).

\section{Alkoholrelaterte dødsfall}

Totalt sett er talet på alkoholrelaterte dødsfall er betydeleg høgare enn det som blir registrert i

Dødsårsaksregisteret.

- Ifølgje data frå Dødsårsaksregisteret er det dei siste 15 åra årleg registrert cirka 320-420 dødsfall som skuldast direkte eller indirekte alkoholbruk. Dei høgaste enkelttala er knytt til ulike psykiske lidingar og åtferdsforstyrringar, alkoholisk leversjukdom og alkoholforgifting (SSB).

- Alkoholrelaterte dødsulykker i trafikken (Christophersen \& Gjerde, 2014), alkoholrelaterte drukningsdødsfall og andre typar dødsulykker er ikkje med i oversikta frå Dødsårsaksregisteret. Sjå også kapittel om Skader og ulykker.

\section{Konsekvensar ved bruk av andre rusmiddel enn alkohol}

Forbruk av andre rusmiddel enn alkohol gir også auka risiko for skadar og sjukdommar:

- overdosar

- ulykker og skadar

- smittsame sjukdommar som hepatitt og hiv ved sprøytebruk

Auken i rusmiddelbruk som vi har sett dei siste åra, fører også til auke i kriminalitet, vald og aggressiv åtferd. Over ein tredel av dødsulykkene i trafikken og mange av ulykkene med personskade skjer under påverknad av alkohol, illegale rusmiddel eller rusgivande legemiddel (Christophersen \& Gjerde, 2014).

\section{Nye syntetiske rusmiddel har ukjende verknader}

Utviklinga av rusmiddel har dei siste åra gitt mange nye stoff på den illegale marknaden, og dette kan bli ei utfordring for helsevesenet. Eksempel på nye rusmiddel er syntetiske cannabinoidar «spice», amfetamin- og ecstasy-liknande stoff og katinonar, sjå figur 1. Dei siste åra er det registrert mange titalls nye variantar av nye rusmiddel. Ofte blir fleire stoff kombinerte. Vi veit lite eller ingenting om dei helsemessige konsekvensane ved bruk av nye, syntetiske rusmiddel. Det er rapportert om følgjande:

- Høgt blodtrykk og hjarteinfarkt hos tenåringar som har brukt syntetiske cannabinoider.
- Tap av medvit, krampar, angst, agitasjon, akutte psykosar og forverring av tidlegare psykisk sjukdom.

Dei langsiktige verknadene veit vi ingenting om.

- Dei nye stoffa kan også medføre dødsfall. Brukarane veit ikkje kva dei får i seg, stoffa har ukjent styrke og dei kan innehalde restar av kjemikaliar og blandingar av fleire liknande stoff.

Eit eksempel er PMMA, som dukka opp på marknaden i Noreg for 3-4 år sidan. Frå juli 2010 til og med august 2012 blei det registrert over 29 dødsfall der PMMA var hovudårsaka eller ei medverkande årsak (AI-Samarraie, 2013). I løpet av to år fann Folkehelseinstituttet PMMA i blodprøver frå 130 rusa bilførarar.

\section{Risiko for fosterskadar under graviditeten}

Både alkohol og andre rusmiddel kan skade fosteret i alle fasar av graviditeten.

- Alkohol: Alkohol er skadeleg for fosteret gjennom heile fosterlivet, og ein kjenner ikkje til nokon trygg nedre grense for alkoholbruk i svangerskapet (O'Leary, 2013; Lewis, 2012; Willford, 2006). Ved stort alkoholbruk i svangerskapet aukar risikoen for føtalt alkohol syndrom (FAS) og føtal alkoholeffekt (FAE). Barn med FAS og FAE er født med dårleg fostervekst og hjerneskade, som gir psykomotoriske utviklingsforstyrringar og lærevanskar. Barn med FAS har også karakteristiske ansiktstrekk (Sosial- og helsedirektoratet, 2005; Cayetanot, 2009; Kuczkowski, 2007; Lewis, 2012; O'Leary, 2013; Willford, 2006;).

- Kokain, cannabis og amfetaminar: Risiko for morkakeløysing, fosterdød, redusert fostervekst, for tidleg fødsel, pusteproblem etter fødsel, krybbedød, og seinare oppmerksomheits- og atferdsvansker (Schempf, 2007; Accornero, 2007).

- Beroligande/sovemiddel: Kan gi redusert fostervekst og abstinenssymptom etter fødsel (Jain, 2005).

- Opiater/opioidar: Auka risiko for morkakeløysing, fosterdød, redusert fostervekst, for tidleg fødsel og seinare konsentrasjons/åtferdsproblem. Ofte uttalte behandlingstrengande abstinenssymptom etter fødselen (Cayetanot, 2009, Shankaran, 2007). Nyare, norske studiar har vist at metadon- og buprenorfinbehandling $\mathrm{i}$ svangerskapet gir liten risiko for barnet. Kombinasjonen buprenorfin og naloxon (Suboxone) utgjer ikkje nokon spesiell risiko (Lund, 2012; Welle-Strand, 2013). 


\section{Sosiale problem}

Høg alkoholbruk har samband med sosiale problem som ofte rammar andre enn dei som drikk. Sosiale problem inkluderer alt frå vanskar i arbeidslivet til kriminalitet, inkludert vald i nære relasjonar (Steen \& Hunskår, 1997; Pape, 2003; Sirus 2009).

\section{Moglegheiter for å førebyggje alkoholskadar}

Vi kan førebyggje skadar av alkoholbruk ved å påverke pris og tilgjengelegheit. Ei systematisk oversikt viser at både strukturelle og individuelt retta tiltak har effekt. Eksempel kan vere alkoholavgifter, reklame, promillegrenser og spesielle tiltak for personar med alkoholproblem (Anderson, 2009).

\section{Kunnskap om rusmiddelbruk}

For å følgje utviklinga i rusmiddelbruk over tid, både for dei mest kjende rusmidla og nye rusmiddel, er det viktig å ha standardiserte protokollar for kartleggingsstudiar, nært samarbeid mellom dei ulike fagmiljøa og å bruke både biologiske prøver og spørjeskjema. I planlegginga av det førebyggande arbeidet er det spesielt viktig å få truverdige data som er baserte på flest mogleg deltakarar i kartleggingsstudiar (Gjerde, 2014).

\section{Referansar}

Accornero, VH, Amado, AJ, Morrow, CE, Xue, L, Anthony, $\mathrm{JC}$ et al. Impact of prenatal cocaine exposure on attention and response inhibition as assessed by continuous performance tests. J Dev Behav Pediatr 2007; 28(3): 195-205.

Al-Samarraie, MS, Vevelstad, M, Nygaard, IL, Bachs, L \& Morland, J. Forgiftning med parametoksymetamfetamin. Tidsskr Nor Laegeforen 2013; 133(9): 966-9.

Anderson, P, Chisholm, D \& Fuhr, DC. Effectiveness and cost-effectiveness of policies and programmes to reduce the harm caused by alcohol. Lancet 2009; 373(9682): 223446.

Bogstrand, ST, Middelkoop, G \& Christophersen, AS. Trends in amphetamine and benzodiazepine use among drivers arrested for drug impaired driving in Norway 2000-2009. Norsk epidemiol 2011a; 21(1): 61-66.

Bogstrand, ST, Normann, PT, Rossow, I, Larsen, M, Morland, $J$ et al. Prevalence of alcohol and other substances of abuse among injured patients in a Norwegian emergency department. Drug Alcohol Depend 2011b; 117(2-3): 132-38.

Cayetanot, F, Larnicol, N \& Peyronnet, J. Antenatal environmental stress and maturation of the breathing control, experimental data. Respir Physiol Neurobiol 2009; 168(12): $92-100$.
Christophersen, AS \& Gjerde, H. Prevalence of alcohol and drugs among car and van drivers killed in road accidents in Norway: an overview from 2001 to 2010. Traffic Inj Prev 2014; 15(6): 523-31.

Clench-Aas J, M Rognerud and OS Dalgard. Levekårsundersøkelsen 2005 : Psykisk helse i Norge. Oslo: Folkehelseinstituttet; 2009, rapport: 2009:6

FHI, Folkehelseinstituttet. Rusmiddelstatistikk: funn i blodprøver hos bilførere mistenkt for påvirket kjøring 2012. Folkehelseinstituttet, Divisjon for rettsmedisin og rusmiddelforskning; 2013.

FHI. Fakta om rusmidlenes virkning på hjernen - faktaark. Hentet: 30.04.2014 på www.fhi.no/faktaark

Gjerde, H. Bruk av alkohol, narkotika og trafikkfarlege legemiddel blant bilførarar i normal trafikk: norske og europeiske resultat frå DRUID-prosjektet. Oslo: Folkehelseinstituttet; 2011, rapport: 2011:6.

Gjerde, H, Christophersen, AS, Normann, PT, Assum, T, Oiestad, EL et al. Norwegian roadside survey of alcohol and drug use by drivers (2008-2009). Traffic Inj Prev 2013; 14(5): 443-52.

Gjerde, H, Christophersen, AS, Øiestad, EL \& Vindenes, V. Bruk av biologiske prøver til kartlegging av rusmiddelbruk: foredrag ved Forskningsrådets konferanse. I "Psykisk helse og rusmiddelforskning - Sammen om fremtidens forskning!", Trondheim, 3-5. februar 2014., Forskningsrådet; 2014.

Helsedirektoratet. Alkoholrelaterte hoveddiagnoser ved innleggelser og polikliniske konsultasjoner ved somatiske sykehus. Hentet 1.09.2014 fra www.helsedirektoratet.no.

Helsedirektoratet. Anbefalinger om kosthold, ernæring og fysisk aktivitet. Oslo: Helsedirektoratet; 2014, rapport: IS-2170.

Jain, AE \& Lacy, T. Psychotropic drugs in pregnancy and lactation. J Psychiatr Pract 2005; 11(3): 177-91.

Kripos. Narkotika- og dopingstatistikk. Oslo: Kripos; 2014.

Kuczkowski, KM. The effects of drug abuse on pregnancy. Curr Opin Obstet Gynecol 2007; 19(6): 578-85.

Larsson, SC, Drca, N \& Wolk, A. Alcohol consumption and risk of atrial fibrillation: a prospective study and doseresponse meta-analysis. J Am Coll Cardiol 2014; 64(3): 281-9.

Lewis, SJ, Zuccolo, L, Davey Smith, G, Macleod, J, Rodriguez, $\mathrm{S}$ et al. Fetal Alcohol Exposure and IQ at Age 8: Evidence from a Population-Based Birth-Cohort Study. PLoS One 2012; 7(11): e49407.

Lund, IO, Skurtveit, S, Sarfi, M, Bakstad, B, Welle-Strand, $G$ et al. Substance use during and after pregnancy among a national cohort of pregnant women in opioid maintenance treatment and their partners. Journal of Substance Use 2012; 17(3): 277-86.

O'Leary, CM, Taylor, C, Zubrick, SR, Kurinczuk, JJ \& Bower, C. Prenatal Alcohol Exposure and Educational Achievement in Children Aged 8-9 Years. Pediatrics 2013.

OECD. OECD Factbook 2013: Economic, Environmental and Social Statistics: Organisation for Economic Cooperation and Development; 2014. 
Pape, H. Vold og krenkelser i unge menneskers parforhold. Tidsskr Nor Lægeforen 2003; 123(15): 2016-20.

Parry, CD, Patra, J \& Rehm, J. Alcohol consumption and non-communicable diseases: epidemiology and policy implications. Addiction 2011; 106(10): 1718-24.

Rossow, I, Mäkeli, P \& Kerr, W. Addiction. 2014.

Rødje, K, Clench-Ass, J, van Roy, B, Holmboe, O \& Müller, AM. Helseprofil for barn og ungdom i Akershus: ungdomsrapport. Oslo: Nasjonalt kunnskapssenter for helsetjenesten; 2004.

Schempf, AH. Illicit drug use and neonatal outcomes: a critical review. Obstet Gynecol Surv 2007; 62(11): 749-57.

Schutze, M, Boeing, H, Pischon, T, Rehm, J, Kehoe, T et al. Alcohol attributable burden of incidence of cancer in eight European countries based on results from prospective cohort study. BMJ 2011; 342: d1584.

Shankaran, S, Lester, BM, Das, A, Bauer, CR, Bada, HS et al. Impact of maternal substance use during pregnancy on childhood outcome. Semin Fetal Neonatal Med 2007; 12(2): 143-50.

SIRUS; Statens Institutt for Rusmiddelforskning. Avgiftsfritt salg av alkohol og tobakk på norske flyplasser i 2012. Hentet 1/9/2014 fra sirus.no.

SIRUS: EK Bye, EJ Amundsen and M Lund. Bruk av tobakk, rusmidler og vanedannende legemidler i Norge: hovedfunn fra SIRUS' befolkningsundersøkelse i 2012. Oslo: Statens Institutt for Rusmiddelforskning; 2013.

SIRUS; Statens Institutt for Rusmiddelforskning. Grensehandelen med sterke alkoholdrikker fra Sverige. Hentet 1/9/2014 på sirus.no.

SIRUS: I Rossow, H Natvig and IS Moan. Nære pårørende av alkoholmisbrukere: hvor mange er de og hvordan berøres de? Oslo: Statens Institutt for Rusmiddelforskning; 2009, rapport: 9/2009.

SIRUS; Statens Institutt for Rusmiddelforskning. Rusmiddelstatistikk på nett. Hentet 28/4/2014 fra sirus.no.
SIRUS. Rusmidler i Norge. Oslo: Statens institutt for rusmiddelforskning; 2012, rapport: 978-82-7171-387-4.

Sosial- og helsedirektoratet. Alkohol og graviditet. Hva er farlig for fosteret? Hvordan forebygge og behandle? Rapport fra en ekspertgruppe. Oslo: Helsedirektoratet; 2005, rapport: IS-1284.

SSB; Statistisk sentralbyrå. Dødsfall som skyldes bruk av alkohol, narkotika og medikamenter, etter underliggende dødsårsak. Hentet 11/4/2014 fra ssb.no.

Steen, K \& Hunskår, S. Vold i Bergen : et ettårsmateriale fra Bergen legevakt. Tidsskr Nor Laegeforen 1997; 17(2): 226-29.

Støver, M. Bruk av alkohol og medikamenter blant eldre $(60+)$ i Norge: Helseundersøkelsen Nord-Trøndelag rapport. Levanger: HUNT forskningssenter; 2012, rapport: 978-82-91725-09-3.

Welle-Strand, GK, Skurtveit, S, Jones, HE, Waal, H, Bakstad, $B$ et al. Neonatal outcomes following in utero exposure to methadone or buprenorphine: a National Cohort Study of opioid-agonist treatment of Pregnant Women in Norway from 1996 to 2009. Drug Alcohol Depend 2013; 127(1-3): 200-6.

WHO. Global status report on alcohol and health. Geneve: World Health Organization; 2011.

Willford, J, Leech, S \& Day, N. Moderate prenatal alcohol exposure and cognitive status of children at age 10. Alcoh

Øia, T. Ung i Oslo 2012: nøkkeltall: Notat nr. 7/2012. Oslo: Norsk institutt for forskning om oppvekst, velferd og aldring; 2012.

\section{FORFATTARAR}

Asbjørg S. Christophersen, Hallvard Gjerde, Ragnar Nesvåg og Eivind Ystrøm. Bidrag frå: Sidsel Graff-Iversen. 
- Arbeid gir tilgang til viktige helsefremmande ressursar som sosiale relasjonar, identitet og personleg vekst, og økonomisk tryggleik.

- Høg sysselsetting og arbeid for personar med redusert arbeidsevne vil vere positivt for folkehelsa.

- Kvinner har høgare sjukefråvære enn menn.

- Tiltak for å hindre lange sjukemeldingar kan vere viktige for å førebygge overgang til uføretrygd.

- Blant medlemslanda i OECD har Noreg det høgaste sjukefråværet.

\section{Arbeidslivet i Noreg i dag}

I Noreg er ei brei deltaking i arbeid prioritert (Dahl, 2014), og dei fleste vaksne i landet er tilknytt arbeidslivet.

- I august 2014 vart 71 prosent av befolkninga i Noreg rekna som del av arbeidsstyrken, som består av alle sysselsette og arbeidsledige personar i aldersgruppa 15-74 år. Andelen var høgast i aldersgruppa 35-39 år (89\%) (SSB, 2014).

- I forhold til gjennomsnittet i OECD er sysselsettinga i Noreg høg blant begge kjønn, og i alle aldersgrupper, sjå figur 1 (OECD, 2013a).
Det er stor variasjon i korleis dei ulike europeiske landa organiserer arbeidslivet. Sett opp mot gjengs standard i EU, har norske arbeidstakarar oftare jobb i offentlig sektor, oftare fast arbeidskontrakt, eit meir robust vern mot oppseiing, og full lønn under sjukefråvære.

Personar som er inkluderte i arbeidsstyrken kan likevel ha kortare og lengre periodar utanfor arbeidslivet på grunn av tilhøve som oppseiingar og helsevanskar.

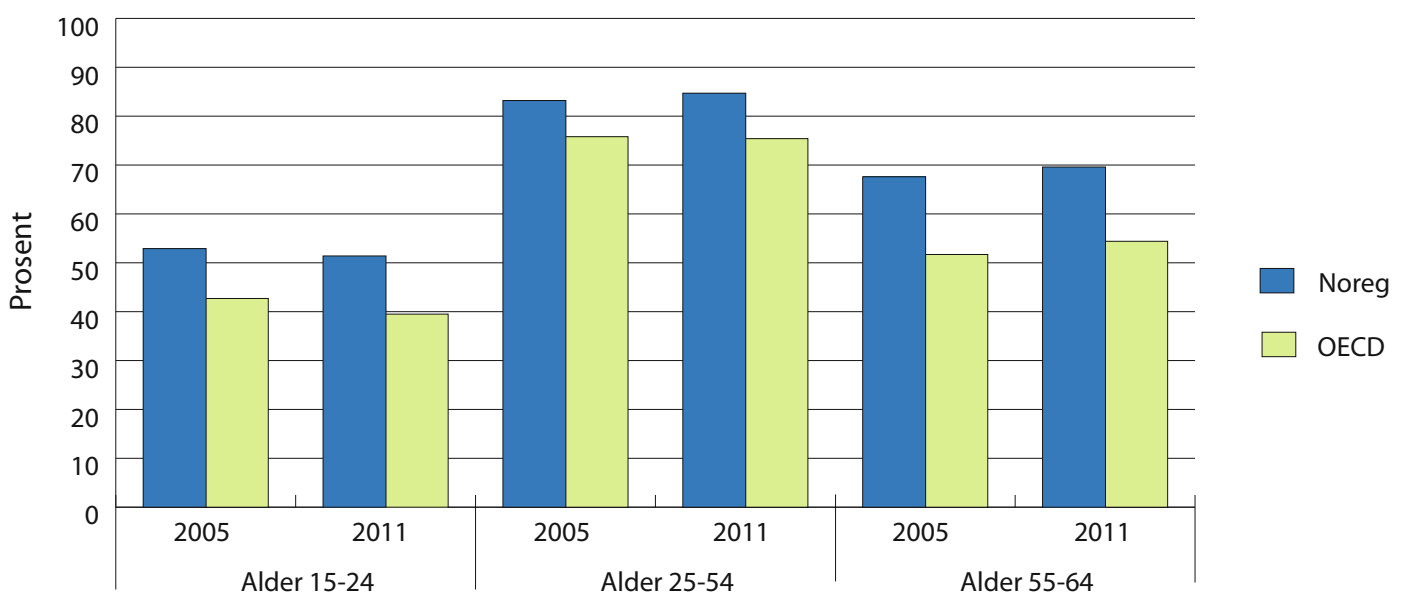

Figur 1. Arbeidsdeltakinga i Noreg og OECD i tre aldersgrupper for åra 2005 og 2011. Prosent av den totale befolkninga i kvar aldersgruppe. Kjelde: Basert på tal frå OECD (2013a). 


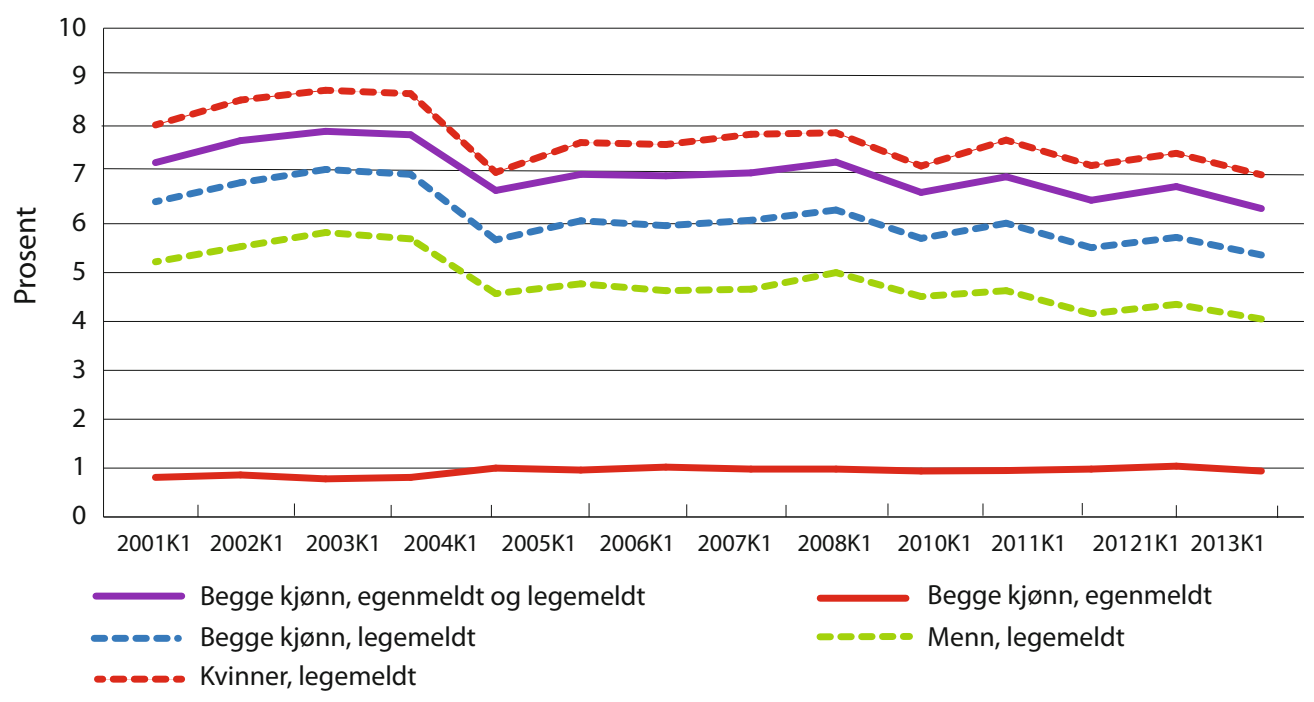

Figur 2: Legemeldt og eigenmeldt sjukefråvære, sesong- og influensajustert. 1. Kvartal 2001-2014. Prosent. Kjelde: Basert på tal frå SSB Statistikkbanken (2014).

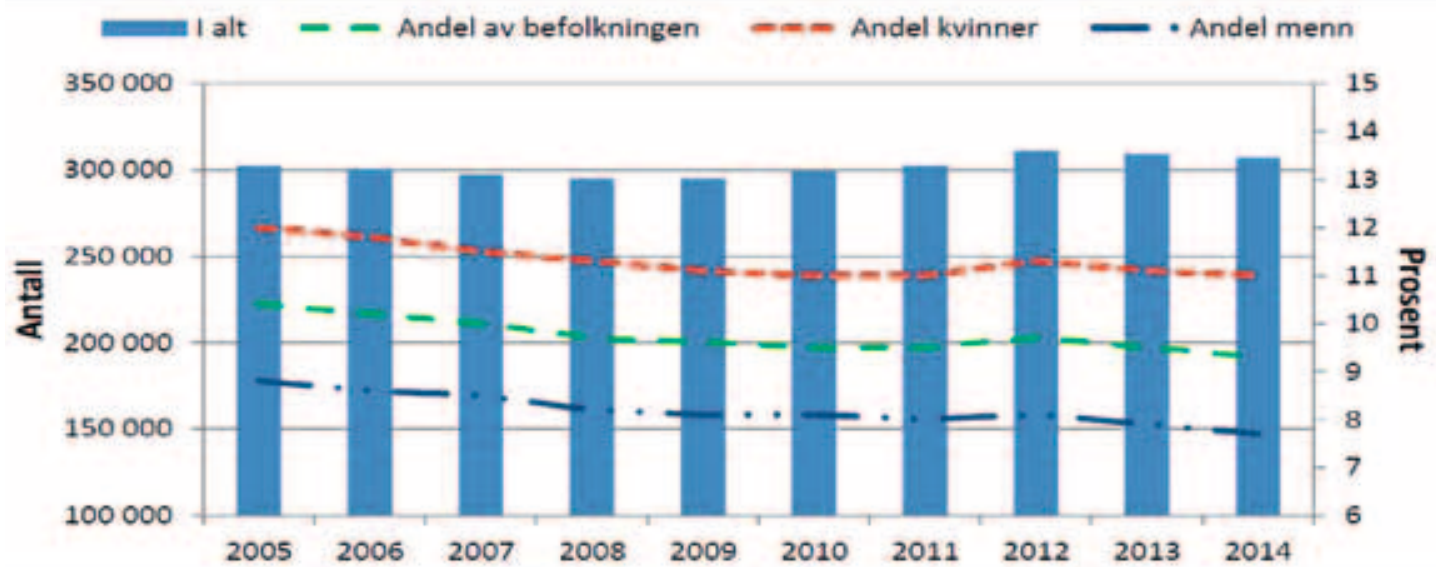

Figur 3. Menn og kvinner som får uførepensjon. Søylediagram viser totaltal, og stipla line viser andel i befolkninga. Kjelde: NAV, 2014.

\section{Sjukefråvære og uførepensjon i Noreg i dag}

Sjukefråvære: Statistikk for sjukefråvære syner kor stor del av alle dagsverk som går tapt gjennom sjukefråvære. Sjølv om mange fleire er borte frå jobb med korttidsfråvære og eigenmeldingsdagar, er det langtidsfråværet som utgjer det store volumet, sjå figur 2 .

Uførepensjon: Per 31. mars 2014 fekk 307400 personar eller 9,3 prosent av befolkninga uførepensjon, sjå figur 3 (NAV, 2014). I 2013 fekk 3,5 prosent uførepensjon heilt eller delvis på grunn av yrkesskade.
Årsaker til fråvære: Fleirtalet av sjukmeldingar og langvarige trygdestønader vert gitt for muskel- og skjelettlidingar og vanlege psykiske lidingar som angst og depresjon (NAV, 2012). Dette er vanlege helseplager i befolkninga, også blant dei som ikkje er sjukmelde eller får trygd (Ihlebæk, 2010; Wittchen, 2011).

Grunnane til at folk ikkje er i arbeid, er mange og samansette.

Arbeidsmiljøfaktorar er ein av fleire faktorar som bidreg til å forklare sjukefråvære og uføretrygd. I snitt hadde om lag 6 prosent av norske arbeidstakarar 
arbeidsrelatert sjukefråvær som varte to veker eller meir i 2009, men talet varierte mellom bransjar og yrke, og var høgast blant reinhaldarar, der 15 prosent oppgav slikt arbeidsrelatert fråvær (St. meld nr 29 (2010-2011)).

\section{Utvikling over tid}

Sjukefråværet og andelen som får uføretrygd har vore relativt stabilt dei siste åra, og det er tendens til ein nedgang, sjå figur 2 og 3. Det er likevel venta ei auke i andelen uføretrygda framover, etterkvart som mottakarar av tidsavgrensa arbeidsavklaringspengar ikkje lenger kan stå på denne ordninga (NAV, 2014).

\section{Skilnadar i befolkninga}

\begin{abstract}
Alder
Noreg har ein høgare andel av befolkninga i arbeid enn gjennomsnittet i OECD: Det gjeld alle aldersgrupper, sjå figur 1 (OECD, 2013a). Sjukefråværsprosenten stig med aukande alder for både menn og kvinner.
\end{abstract}

\section{Høgare sjukefråvære blant kvinner}

Figur 2 viser skilnaden i sjukefråvære blant kvinner og menn. Menn og kvinner følgjer i hovudsak dei same svingingane i sjukefråværet over tid.

Det er utilstrekkeleg kunnskap om kva som kan forklare skilnadane i sjukefråvære mellom menn og kvinner, og kva som kan vere effektive tiltak for å redusere skilnaden (FHI, 2013).

Aktuelle faktorar som kan forklare skilnadane er:

- Som for andre land i Europa er det framleis store skilnader i kvar menn og kvinner arbeider, sjå figur 4.

- Det er fleire menn enn kvinner i leiande stillingar (Eurofound, 2012).

- I en ny norsk studie forklarte psykososiale arbeidslivsfaktorar meir enn 20 prosent av skilnaden i sjukefråvære mellom kvinner og menn (Sterud, 2014a). Det er likevel ikkje klare konklusjonar på i kva grad kjønnsskilnader i yrke kan forklare det høgare sjukefråværet hjå kvinner (Laaksonen, 2010; Mastekaasa, 2014).

Figur 4: Andel kvinner blant sysselsette i 30 utvalde yrke. 1996 og 2010. Kjelde: NOU 2012:15.

Se figur i webversjonen av rapporten: på www.fhi.no/ folkehelserapporten

\section{Sosioøkonomiske skilnadar}

Det er sosioøkonomiske skilnader i sjukefråvære og uføretrygd.

- Uføretrygd på grunn av muskel- og skjelettlidingar er til dømes langt vanlegare blant lågt utdanna enn høgt utdanna (Bruusgaard, 2010). Skilnaden kan dels forklarast med at risikofaktorar for sjukefråvære og uføretrygd er hyppigare i jobbar med lågare løn og krav til utdanning (Falkstedt, 2014). Dette gjeld til dømes hardt fysisk arbeid, tunge løft med vriding av ryggen, krevjande arbeidsstillingar, heilkroppsvibrasjonar, monotont arbeid, lite kontroll over arbeidsoppgåvene og lite fleksibilitet i arbeidstida (Foss, 2011; Haukenes, 2011; Sterud, 2013).

- Mekaniske og psykososiale arbeidsmiljøfaktorar forklarte meir enn 40 prosent av skilnaden i langtidssjukefråværet mellom høgt og lågt utdanna arbeidstakarar i ei nyare norsk studie (Sterud, 2014b).

- På arbeidsplassar med lågare krav til utdanning vil det oftare vere vanskeleg å tilpasse arbeidssituasjonen til helsevanskar (Johansson, 2009).

- Arbeidstakarar med lågare utdanning kan og ha større vanskar med å finne nytt arbeid dersom helsevanskar krev eit skifte av arbeidsoppgåver.

\section{Type arbeid og fråvere blant innvandrarar}

Innvandrarar frå låg-inntektsland er oftare tilsette i ufaglærte og låglønna stillingar med større innslag av fysisk og manuelt arbeid, samt i stillingar der sjukefråværet er høgare.

Det vert diskutert om risikofaktorar ved arbeidet kan forklare skilnadane i uførepensjon mellom landsgjennomsnittet og innvandrarar frå låg-inntektsland, men funna er ikkje eintydige (Claussen, 2009; Hansen, 2014).

\section{Høgare sjukefråvære i Noreg enn i andre OECD-land}

Noreg har det høgaste sjukefråværet blant medlemslanda i OECD. Andelen av befolkninga som får andre langvarige stønader som arbeidsavklaringspengar (AAP) og uføretrygd er også høgast i Noreg (OECD 2013b). 
Høg sysselsetting kan bidra til å heve sjukefråværet i Noreg samanlikna med andre land, ved at grupper med svakare band til arbeidslivet i større grad er inkludert i arbeidsstyrken (Dahl, 2014).

\section{Arbeid som helsefremjande faktor}

Når arbeidsmiljøet er tilfredsstillande, har deltaking i arbeid i seg sjølv positiv effekt på helsa (Waddel, 2006).

- Tap av arbeid gjev dårlegare psykisk helse (Gathergood, 2013), mens retur til arbeid påverkar psykisk helse i positiv retning (van der Noordt, 2014).

- Arbeid er for mange ei viktig kjelde til helsefremmande sosiale relasjonar, personlig vekst og økonomisk tryggleik (Dahl, 2014).

- Arbeid strukturerer kvardagen, gir meining og er ein viktig del av den sosiale identiteten for mange (Dahl, 2014).

Ei undersøking fann likevel at arbeidstakarar som rapporterte om dårleg arbeidsmiljø, oppgav betre helse etter at dei gjekk av med pensjon (Westerlund, 2009). Ein systematisk litteraturgjennomgang har óg funne støtte for betra psykisk helse etter pensjonering (van der Heide, 2013).

\section{Arbeid som risikofaktor for helse}

Arbeidsplassen kan vere ei kjelde til skader, sjukdom og helsevanskar knytt til både kjemiske, fysiske, mekaniske og psykososiale/organisatoriske belastningar. Mange av desse risikofaktorane har også samanheng med risiko for sjukefråvære og uførepensjon (Wang, 2014; Foss, 2011; Stattin, 2005; Labriola, 2009).

Psykososiale arbeidsmiljøfaktorar, som til dømes rollekonflikt, jobbusikkerheit, uheldige kombinasjonar av krav og kontroll i arbeidet, mobbing, samt vold og trugsmål, gir høgare risiko for angst og depresjon (Johannessen, 2013; Stansfeld, 2006) og muskel- og skjelettlidingar (Christensen, 2010). Arbeid prega av høge krav og lite kontroll er og ein risikofaktor for hjerte- og karsjukdom (Kivimäki, 2012).

Organisatoriske faktorar som lange arbeidsveker, skiftarbeid, manglande opplæring og midlertidige arbeidskontraktar er knytt til auka risiko for arbeidsskader (Benavides, 2006; Chau, 2008; Dembe, 2009; Piha, 2013).
Tungt fysisk arbeid og uheldige arbeidsstillingar aukar risikoen for muskel- og skjelettlidingar (Sterud, 2013).

Fysiske arbeidsmiljøfaktorar som vibrasjonar og støynivå kan medføre helseskade og hørselsskade (Bonvenzi, 2010; Ramsden, 2010; STAMI, 2011).

Kjemiske arbeidsmiljøfaktorar som inhalering av støv, røyk, gass og damp, samt hudkontakt med kjemikaliar er knytt til ei rekke alvorlige sjukdommar som kreft, sjukdommar i nervesystemet, lungesjukdom og hudsjukdom (STAMI, 2011).

\section{Førebygging for å sikre høg arbeidsdeltaking og lågt sjukefråvære}

Arbeidsmiljø: Det pågår eit kontinuerleg arbeid med å identifisere helserisiko på arbeidsplassane, særleg i samband med innføring av nye arbeidsformer og ny teknologi (Baxter, 2010). Arbeidsmiljølova lovfester dette arbeidet, og forpliktar både arbeidsgjevarar, arbeidstakarar, bedriftshelseteneste og tilsynmyndigheiter til å bidra.

Tiltak for å halde arbeidstakarar med helseproblem i arbeid: Arbeidsplassane er ein viktig arena for helsefremmande arbeid og førebygging, men det er ikkje eit eintydig forhold mellom helsevanskar og arbeidsdeltaking. Faktorar knytt både til helse og arbeid vil ha betydning for om ein arbeidstakar med gitt helseproblem kan halde fram i arbeid eller ikkje.

Verk og smerter, psykiske plager og lidingar utgjer store helseutfordringar i arbeidslivet, og desse kan oftast ikkje eintydig knyttast til enkelte risikofaktorar og sjukdomar med kjent årsak (Baxter, 2010). Eit «inkluderande arbeidsliv» betyr at arbeidsplassane skal tilpassast den enkelte sine helseproblem. På nokre arbeidsplassar kan små justeringar vere nok, mens det på andre arbeidsplasser vil krevje omfattande tilrettelegging og eventuelt omplassering til anna arbeid. I nokre tilfelle vil det vere svært vanskeleg å legge til rette for fortsatt arbeidsdeltaking.

Det er behov for å utvikle meir og betre kunnskap om kva som kan gjerast for å redusere sjukefråvære (Odeen, 2013) og førebygge at arbeidstakarar utviklar helsevanskar på arbeidsplassen (Van Oostrom, 2009).

Gradert sjukmelding har vore eit tydeleg satsingsområde i avtalen om inkluderande arbeidsliv (FHI, 2013). Ordninga er basert på kunnskap om at dei fleste ikkje 
er "heilt friske eller heilt sjuke", og at ein kan nytte den arbeidsevna ein har, trass sjukdom. Arbeid, aktivitet og kontakt med arbeidsplassen kan gje helsegevinst, redusere barrierar mot seinare retur til arbeid, og dermed førebygge varig utstøyting frå arbeidslivet (FHI, 2013).

Det er observert ein nedgang i sjukefråværet parallelt med at bruken av gradert sjukmelding har gått opp. (FHI, 2013). Finske forskingsresultat tyder på at gradert sjukmelding kan redusere lengda på sjukefråvære og førebygge uføretrygding (Kausto, 2013).

\section{Høg yrkesdeltaking og folkehelse}

Låg arbeidsledigheit og høg yrkesdeltaking vil inkludere fleire i det sosiale fellesskapet som arbeidsplassen kan gi. Det er grunn til å tru at dette vil bidra til å fremme folkehelsa generelt og førebygge psykiske lidingar spesielt.

Tiltak for å hindre lange sjukemeldingar kan vere viktig for å førebygge overgang til uføretrygd. Gode velferdsordningar kan redusere belastningane ved å vere utan arbeid (Ferrarini, 2014).

\section{Referansar}

Barne- likestillings- og inkluderingsdepartementet. $\mathrm{NOU}$ 2012:15. Politikk for likestilling

Baxter, PJ, Aw, T-C, Cockroft, A, Durrington, P \& Harrington, $J M$, Eds. Hunter's Diseases of Occupations. The changing face of occupational disease. London, Hodder Arnold; 2010.

Benavides, FG, Benach, J, Muntaner, C, Delclos, GL, Catot, $\mathrm{N}$ et al. Associations between temporary employment and occupational injury: what are the mechanisms? Occup Environ Med 2006; 63(6): 416-21.

Bovenzi, M \& Palmer, K. Whole body vibration. I: PJ Baxter and D Hunter (Eds.). Hunter's diseases of occupations. 10. utgave. London: Hodder Arnold; 2010.

Bruusgaard, D, Smeby, L \& Claussen, B. Education and disability pension: a stronger association than previously found. Scand J Public Health 2010; 38(7): 686-90.

Chau, N, Bourgkard, E, Bhattacherjee, A, Ravaud, JF, Choquet, $M$ et al. Associations of job, living conditions and lifestyle with occupational injury in working population: a population-based study. Int Arch Occup Environ Health 2008; 81(4): 379-89.

Christensen, JO \& Knardahl, S. Work and neck pain: a prospective study of psychological, social, and mechanical risk factors. Pain 2010; 151(1): 162-73.
Claussen, B, Dalgard, OS \& Bruusgaard, D. Disability pensioning: can ethnic divides be explained by occupation, income, mental distress, or health? Scand J Public Health 2009; 37(4): 395-400

Dahl, E, Bergsli, H \& van der Wel, KA. Sosial ulikhet i helse: En norsk kunnskapsoversikt (Hovedrapport). Oslo: Høgskolen i Oslo og Akershus; 2014.

Dembe, AE, Delbos, R \& Erickson, JB. Estimates of injury risks for healthcare personnel working night shifts and long hours. Qual Saf Health Care 2009; 18(5): 336-40.

Eurofound. 2012. Fifth European Working Conditions Survey, Publications Office of the European Union, Luxembourg.

Falkstedt, D, Backhans, M, Lundin, A, Allebeck, P \& Hemmingsson, T. Do working conditions explain the increased risks of disability pension among men and women with low education? A follow-up of Swedish cohorts. Scand J Work Environ Health 2014.

Ferrarini, T, Nelson, K \& Sjoberg, O. Unemployment insurance and deteriorating self-rated health in 23 European countries. J Epidemiol Community Health 2014.

FHI, Folkehelseinstituttet, 2013. A, Mykletun and B, Brinchmann. Effekter av tiltak under IA-avtalen: rapport fra forskermøte på oppdrag fra Arbeidsdepartementet. Oslo: Folkehelseinstituttet; 2013.

Foss, L, Gravseth, HM, Kristensen, P, Claussen, B, Mehlum, IS et al. The impact of workplace risk factors on long-term musculoskeletal sickness absence: a registry-based 5-year follow-up from the Oslo health study. J Occup Environ Med 2011; 53(12): 1478-82.

Gathergood, J. An instrumental variable approach to unemployment, psychological health and social norm effects. Health Econ 2013; 22(6): 643-54.

Hansen, H-T, Holmås, TH, Islam, MK \& Naz, G. Sickness Absence Among Immigrants in Norway: Does Occupational Disparity Matter? European Sociological Review 2014.

Haukenes, I, Mykletun, A, Knudsen, AK, Hansen, HT \& Maeland, JG. Disability pension by occupational class-the impact of work-related factors: the Hordaland Health Study Cohort. BMC Public Health 2011; 11: 406.

Ihlebæk, C, Brage, S, Natvig, B \& Bruusgaard, D. Forekomst av muskel- og skjelettlidelser i Norge. Tidsskr Nor Laegeforen 2010; 130(23): 2365-8.

Johannessen, HA, Tynes, T \& Sterud, T. Effects of occupational role conflict and emotional demands on subsequent psychological distress: a 3-year follow-up study of the general working population in Norway. J Occup Environ Med 2013; 55(6): 605-13.

Johansson, G \& Lundberg, I. Components of the illness flexibility model as explanations of socioeconomic differences in sickness absence. Int J Health Serv 2009; 39(1): 123-38.

Kausto, J. Effect of partial sick leave on work participation - people and work research reports. Helsinki: Finnish Institute of Occupational Health; 2013, rapport: 102. 
Kivimäki, M, Nyberg, ST, Batty, GD, Fransson, El, Heikkilä, K et al. Job strain as a risk factor for coronary heart disease: $a$ collaborative meta-analysis of individual participant data. The Lancet 2012; 380(9852): 1491-97.

Laaksonen, M, Mastekaasa, A, Martikainen, P, Rahkonen, O, Piha, $\mathrm{K}$ et al. Gender differences in sickness absence--the contribution of occupation and workplace. Scand J Work Environ Health 2010; 36(5): 394-403.

Labriola, M, Feveile, H, Christensen, KB, Stroyer, J \& Lund, T. The impact of ergonomic work environment exposures on the risk of disability pension: Prospective results from DWECS/DREAM. Ergonomics 2009; 52(11): 1419-22.

NAV. 2012. Utviklingen i uførediagnoser per 31. desember 2011 [Notat]. Oslo: NAV. Arbeids- og velferdsdirektoratet, Seksjon for statistikk.

Mastekaasa, A. The gender gap in sickness absence: longterm trends in eight European countries. The European journal of public health 2014; 24(4): 656-662.

NAV. 2014. Uførepensjon: Uviklingen i uførepensjon, 31. mars 2014. [Notat]. Oslo: Nav. Arbeids- og velferdsdirektoratet, Statistikkseksjonen.

Odeen, M, Magnussen, LH, Maeland, S, Larun, L, Eriksen, $\mathrm{HR}$ et al. Systematic review of active workplace interventions to reduce sickness absence. Occup Med (Lond) 2013; 63(1): 7-16.

OECD. 2013a. "Employment rates by age group" in OECD Factbook 2013: Economic, Environmental and Social Statistics, OECD Publishing. http://dx.doi.org/10.1787/factbook2013-52-en.

OECD. 2013b, Mental Health and Work: Norway, OECD Publishing. http://dx.doi.org/10.1787/9789264178984-en

Piha, K, Laaksonen, M, Martikainen, P, Rahkonen, O \& Lahelma, E. Socio-economic and occupational determinants of work injury absence. Eur J Public Health 2013; 23(4): 693-8.

Ramsden, RT \& Saeed, SR. Sound, noise and the ear. I: PJ Baxter and D Hunter (Eds.). Hunter's diseases of occupations. 10. utgave. London: Hodder Arnold; 2010.

SSB. 2014. Statistikkbanken. Tabell: 03777: Personer i arbeidsstyrken, etter kjønn og alder. https://www.ssb.no/ statistikkbanken [Hentet 01/12/2014].

Stansfeld, S \& Candy, B. Psychosocial work environment and mental health--a meta-analytic review. Scand J Work Environ Health 2006; 32(6): 443-62.

Statens arbeidsmiljøinstitutt (STAMI). Faktabok om arbeidsmiljø og helse 2011 - Status og utviklingstrekk. Oslo: Statens arbeidsmiljøinstitutt; 2011.
Stattin, M \& Jarvholm, B. Occupation, work environment, and disability pension: a prospective study of construction workers. Scand J Public Health 2005; 33(2): 84-90.

Sterud, T. Work-related gender differences in physiciancertified sick leave: a prospective study of the general working population in Norway. Scand J Work Environ Health 2014a; 40(4): 361-9.

Sterud, T \& Johannessen, HA. Do work-related mechanical and psychosocial factors contribute to the social gradient in long-term sick leave: a prospective study of the general working population in Norway. Scand J Public Health 2014b; 42(3): 329-34.

Sterud, T \& Tynes, T. Work-related psychosocial and mechanical risk factors for low back pain: a 3-year follow-up study of the general working population in Norway. Occup Environ Med 2013; 70(5): 296-302.

St.meld nr. 29 (2010-2011). Felles ansvar for eit godt og anstendig arbeidsliv -Arbeidsforhold, arbeidsmiljø og sikkerheit. Oslo: Arbeidsdepartementet.

van der Heide, I, van Rijn, RM, Robroek, SJ, Burdorf, A \& Proper, KI. Is retirement good for your health? A systematic review of longitudinal studies. BMC Public Health 2013; 13: 1180.

van der Noordt, M, ljzelenberg, H, Droomers, M \& Proper, KI. Health effects of employment: a systematic review of prospective studies. Occup Environ Med 2014.

van Oostrom, SH, Driessen, MT, de Vet, HC, Franche, RL, Schonstein, E et al. Workplace interventions for preventing work disability. Cochrane Database Syst Rev 2009;(2).

Waddell, G \& Burton, AK. Is work good for your health and well-being? London: TSO; 2006.

Wang, M-J, Mykletun, A, Møyner, El, Øverland, S, Henderson, $\mathrm{M}$ et al. Job Strain, Health and Sickness Absence: Results from the Hordaland Health Study. PLoS One 2014; 9(4): e96025.

Wittchen, HU, Jacobi, F, Rehm, J, Gustavsson, A, Svensson, $M$ et al. The size and burden of mental disorders and other disorders of the brain in Europe 2010. Eur Neuropsychopharmacol 2011; 21(9): 655-79.

\section{FORFATTARAR}

Simon Øverland

Takk til Inger Haukenes, Arnstein Mykletun og Statens arbeidsmiljøinstitutt for gjennomlesing og bidrag til kapitlet 
- Talet på vassverk som leverer utilfredsstillande drikkevatn, har blitt kraftig redusert dei siste 20 åra.

- Vi har mangelfulle opplysningar om private brønnar og andre små, private anlegg som leverer vatn til i alt 600000 innbyggjarar.

- Store og alvorlege vassborne sjukdomsutbrot er sjeldne.

- Arbeidet med å skifte ut og reparere dårlege vassleidningar går så seint at problemet med forureina drikkevatn høgst truleg kjem til å auke i åra framover.

\section{Om drikkevatn og drikke- vasskjelder}

Reint vatn er livsnødvendig for alle levande organismar, og det daglege væsketapet bør i stor grad erstattast med reint drikkevatn.

Noreg har god tilgang på gode vasskjelder som det er mogleg å verne mot forureinande aktivitetar. Nivået av miljøgifter, plantevernmiddel, tungmetall og andre uønskte stoff i vasskjeldene er lågt og utgjer ikkje noko helsemessig problem i dei vasskjeldene som blir brukte til produksjon av drikkevatn.

Godkjenningspliktige vassverk er kommunale, interkommunale eller private vassverk som forsyner minst 50 personar eller 20 husstandar. Totalt har vi 1600 slike anlegg i landet. Dei leverer i all hovudsak vatn med god kvalitet.

Private brønnar og andre mindre vassforsyningskjelder krev ikkje godkjenning. Slike kjelder forsyner cirka 600000 personar med drikkevatn. Vi har ikkje oversikt over vasskvaliteten i desse.

\section{9 av 10 får vatn frå vassverk}

I 2010 fekk 90 prosent av innbyggjarane i Noreg (cirka 4,3 millionar personar) drikkevatn frå eit av dei cirka 1600 registrerte vassverka her i landet.

Blant dei 1600 anlegga var det 10 prosent som henta vatn frå grunnvasskjelder og 90 prosent frå innsjøar, tjern, elver og bekkar. Grunnvatn er som regel hygienisk trygt i seg sjølv, mens vatn frå overflatevasskjelder alltid må desinfiserast. Per 2010 var det berre 9800 personar i Noreg som fekk ikkje-desinfisert vatn frå overflatevasskjelder (i alt cirka 60 små anlegg).

Enkelte grunnvassbrønnar for enkelthusanlegg og små fellesanlegg har noko høge verdiar av radon og/eller fluorid. Vi har ikkje oversikt over kor mange dette gjeld.

\section{Betring dei siste 20 åra}

Vassbehandlingsanlegga i Noreg har blitt mykje betre dei siste 20 åra, spesielt i perioden 1995-2001, der effektane av det statlege programmet for vassforsyning gjorde seg gjeldande.

I starten av programmet var det om lag 1000 vassverk som ikkje oppfylte dei gjeldande krava i drikkevassforskrifta. Desse vassverka forsynte cirka 1,3 millionar menneske i Noreg. I løpet av seks år blei vassforsyninga frå 350 vassverk, tilsvarande 800000 menneske, utbetra. Figur 1 viser at talet på vassverk som distribuerer udesinfisert overflatevatn, har blitt kraftig redusert sidan 1994. Nedgangen var spesielt stor fram til og med 2001.

Sjølv om vassbehandlingsanlegga har blitt mykje betre, har leidningsnettet framleis store svakheiter. Store delar av leidningsnettet blei bygd i gjenreisingstida etter andre verdskrig, og dette er no i dårleg forfatning. Ifølgje data frå Vannverksregisteret blir om lag 300 km av leidningsnettet fornya årleg. 


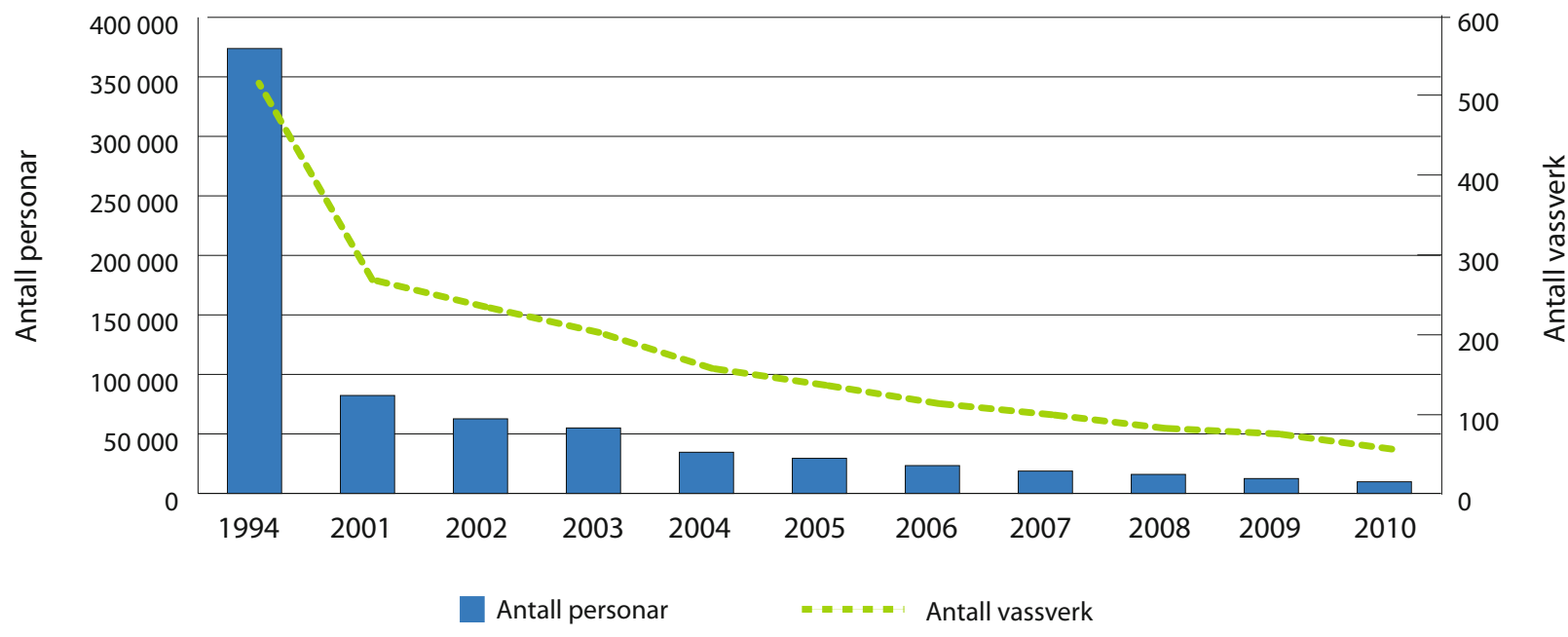

Figur 1: Trend - tal på vassverk/personar forsynt med udesinfisert overflatevatn i perioden 1994-2010. Datakjelde: Folkehelseinstituttet (Myrstad, 2014).

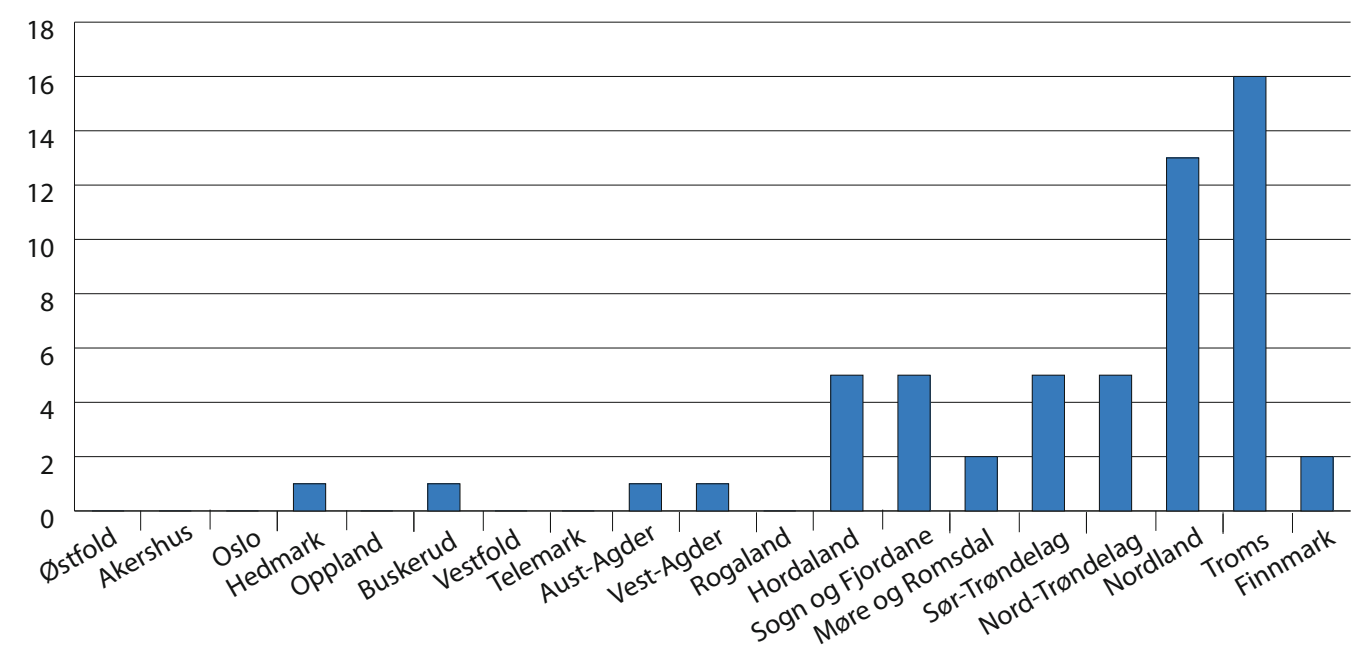

Figur 2: Fylkesvis fordeling av talet på vassverk som leverte udesinfisert overflatevatn i 2010 Datakjelde: Folkehelseinstituttet (Myrstad, 2014).

I 2009 blei det rapportert 4223 leidningsbrot. Talet på leidningar som har blitt skifta ut, har auka jamt frå 4 prosent i 2003 til 13 prosent i 2009. Det er estimert at det kjem til å ta cirka 200 år før heile leidningsnettet er utbetra og har tilfredsstillande kvalitet.

\section{Geografiske forskjellar}

Det er geografiske forskjellar i kvaliteten på norsk vassforsyning. Figur 2 viser ei fylkesvis fordeling av talet på vassverk som leverte udesinfisert overflatevatn i 2010. Vi ser av figuren at dei nordlege fylka gjennomgåande har fleire vassverk som leverte udesinfisert overflatevatn. Forskjellane reflekterer i stor grad forskjellar i busetnadsstrukturen.
Generelt har fylka i nord og nordvest spreidd busetnad og blir forsynte av mange små vassverk som har dårlegare føresetnader for å byggje og drive tilfredsstillande vassforsyning.

\section{Internasjonale forskjellar}

Internasjonalt er forureina drikkevatn ei av dei viktigaste kjeldene til dårleg helse. FN har rekna ut at om lag 880 millionar menneske manglar tilgang på trygt drikkevatn, og at 2,7 milliardar menneske ikkje har tilfredsstillande sanitære forhold. WHO estimerer at eitt av tre sjukdomstilfelle i verda kjem av dårlege miljøforhold, spesielt forureina vatn. Over 40 prosent av tilfella gjeld barn under 5 år (WHO/UNICEF, 2012). 
Om lag 6000 barn døyr dagleg av sjukdom forårsaka av utrygt drikkevatn og dårleg hygiene- og sanitærforhold. Berre i Europa bur 140 millionar menneske i ein heim utan innlagt vatn. Ein reknar med at så mykje som 13000 personar under 14 år i Europa og SentralAsia døyr årleg som følgje av diaré (UNECE, 2012).

\section{Drikkevatn og helserisiko}

\section{Fluor og radon}

Enkelte stader kan fluor og radon finnast i høge konsentrasjonar i grunnvatn.

Drikkevatn som har for høgt radonnivå, kan forureine innelufta og bør derfor luftast for radon før det blir teke inn i huset. Radon er forbunde med auka risiko for lungekreft.

Høgt fluoridnivå i drikkevatn kan verke inn på danninga av tenner og bør derfor ikkje brukast til matlaging eller drikke for spedbarn og gravide.

\section{Bakterieforureina drikkevatn gir magetarmsjukdom}

I 2010 var det 52 registrerte vassverk som i periodar leverte drikkevatn med utilfredsstillande bakteriologisk kvalitet. Desse forsynte til saman 25600 personar. Det blei ikkje rapportert om sjukdom blant folket i samband med desse episodane.

Vi har ikkje tal for små private vassverk som ikkje er registreringspliktige.

- Sidan 2000 har vi hatt to større sjukdomsutbrot forårsaka av drikkevatn frå registreringspliktige vassverk:

- giardiautbrotet i Bergen i 2004 med om lag 6000 sjuke

- campylobacterutbrotet i Røros i 2007 med om lag 1500 sjuke

- I tillegg blir det kvart år registrert eit varierande tal små utbrot forårsaka av drikkevatn frå enkelthusanlegg eller små fellesforsyningar, det vil seie vassforsyningar som ikkje er registreringspliktige til Vannverksregisteret. I perioden 2003-2012 blei det registrert 28 slike utbrot med til saman 8060 sjuke (Guzman Herrador, 2013).

Sjå òg kapittelet Mat og vassborne infeksjonar.

\section{Vatn i naturen ikkje alltid trygt}

Tularemi (harepest) er ein sjukdom som kan smitte via vatn. Dette skjer særleg i «lemenår» når mange smågnagarar døyr i naturen. Ei anna smittekjelde for tularemi er brønnvatn, for eksempel på hytta, der vatnet ikkje har vore tilstrekkeleg verna mot forureining frå gnagarar, kombinert med at ein ikkje desinfiserer vatnet.

\section{Dårleg leidningsnett eit stort problem} Leidningsnettet er i dag det svake punktet til vassverka. Meir enn om lag 31 prosent av alt vatnet lekk ut før det når forbrukarane. Det er langt meir enn i dei fleste land vi elles samanliknar oss med. Fordi drikkevassleidningen vanlegvis ligg i same grøft som avløpsleidningen, som òg lekk ganske mykje, er det stor fare for forureining ved leidningsbrot eller reparasjonar.

Arbeidet med å skifte ut og reparere dårlege vassleidningar går så seint at problemet med forureina drikkevatn høgst truleg kjem til å auke i åra framover. Av ulike årsaker blir som regel ikkje utbrot av sjukdom forårsaka av dårlege leidningar oppklarte, men vi veit at det er ein altfor stor førekomst av akutt magetarmsjukdom etter forbigåande fall i vasstrykket (Nygård, 2007).

Når trykket i vassleidningen fell, kan grøftevatn som er forureina av kloakk, bli soge inn i leidningen. I Canada har dei påvist at rundt 14 til 40 prosent av alle tilfella av magetarmsjukdom kom av denne typen problem med drikkevatnet (Payment, 1997).

\section{Infeksjonar og sjukefråvær}

Sjølv om drikkevatnet generelt er av god kvalitet i Noreg, har vassforsyninga i Noreg spesielle utfordringar ved at vi har ein spreidd busetnad med mange små vassverk, omfattande bruk av overflatevatn og stort behov for oppgradering av gamalt eller dårleg leidningsnett. Vi har lite informasjon om kor mange som blir sjuke på grunn av forureina drikkevatn.

\section{Referansar}

Bjorland, J., V. Lund and L. S. Bakketeig Mage-tarminfeksjoner i norske husstander: en befolkningsundersøkelse. SIFF vann rapport. Oslo, Statens institutt for folkehelse, Avdeling for vannhygiene. 61: 26 bl. (1987).

Guzman Herrador, B., Lund, V., MacDonald, E., Vold, L., Nygård, K.: Waterborne outbreaks in Norway 1992-2012 (unpublished report)

Kuusi, M., P. Aavitsland, B. Gondrosen and G. Kapperud (2003). Incidence of gastroenteritis in Norway--a population-based survey. Epidemiol Infect 131(1): 591-597. PMC

Myrstad, L., C. F. Nordheim and B. Einan Vannrapport 121. Rapport fra Vannverksregisteret - Drikkevannsstatus (data 2009 og 2010) Folkehelseinstituttet: 117. (2014). FHI 
Nygard, K., E. Wahl, T. Krogh, O. A. Tveit, E. Bohleng, A. Tverdal and P. Aavitsland (2007). Breaks and maintenance work in the water distribution systems and gastrointestinal illness: a cohort study. Int J Epidemiol 36(4): 873-880. Oxford Journals

Payment, P., J. Siemiatycki, L. Richardson, G. Renaud, E. Franco and M. Prevost (1997). A prospective epidemiological study of gastrointestinal health effects due to the consumption of drinking water. International Journal of Environmental Health Research 7(1): 5-31. Taylor and Francis Online
United Nations Economic Commission for Europe (UNECE), 2012. Protocol on Water and Health. UNECE

WHO and UNICEF. Joint Monitoring Program (JMP)

Progress on drinking water and sanitation: 2012 update

2012 [cited 201322 November]. Available from: $\underline{\mathrm{WHO}}$

\section{FORFATTAR}

Wenche Fonahn 


\section{Fysisk aktivitet}

- Reduksjonen i fysisk aktivitetsnivå startar allereie tidleg i barneåra.

- Om lag 90 prosent av seksåringane tilfredsstiller tilrådingane om fysisk aktivitet, men blant vaksne er andelen redusert til om lag 30 prosent.

- Blant barn er det fleire gutar enn jenter som oppfyller tilrådingane, men blant vaksne er kjønnsforskjellen motsett.

- Vaksne bruker i gjennomsnitt ni timar per dag på stillesitting.

\section{Om fysisk aktivitet og stillesitting}

Fysisk aktivitet er definert som ein kvar kroppsleg bevegelse initiert av skjelettmuskulatur som resulterer i ein auke i energiforbruket utover kvilenivå.

Fysisk aktivitet blir ofte delt inn i lett, moderat og hard intensiv fysisk aktivitet, etter kor stor energiomsetning aktiviteten krev.

Stillesittande åtferd vil vere i den enden av skalaen der ein bruker minst energi (sjå figur 1), og kan definerast som den delen av den vakne tida ein sit eller ligg, og der mesteparten av muskulaturen i kroppen er i kvile.

Fysisk aktivitet er ei kompleks åtferd det er vanskeleg å måle. Vi treng derfor både aktivitetsmålarar og spørjeskjema når vi skal kartleggje fysisk aktivitetsnivå i befolkninga. Aktivitetsmålarar er viktig for å kartleggje mengda fysisk aktivitet og stillesitting, og spørjeskjema gir nyttig informasjon om mellom anna type aktivitet og i kva kontekst aktiviteten blir utøvd.

\section{Fysisk aktivitet i ulike aldersgrupper}

\section{Barn og unge}

Barn har eit unikt aktivitetsmønster som ofte er kjenneteikna av periodiske og spontane aktivitetar.

Tal frå kartlegginga av fysisk aktivitet blant barn og unge i 2011 inkluderte målingar frå 6-, 9- og 15-åringar. Dette var første gong 6-åringane blei inkluderte. Fysisk aktivitet i denne studien blei registrert med aktivitetsmålarar (Kolle, 2012).

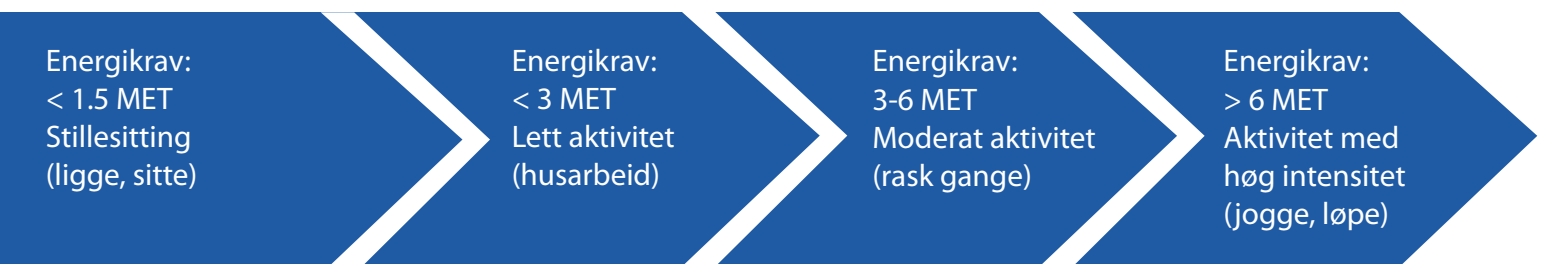

Figur 1: Energiforbruket under fysisk aktivitet utgjer eit kontinuum der enkelte aktivitetar krev lite energi, mens andre krev ei mangedobling av energiforbruket.Forholdet mellom energiforbruket under kvile og under fysisk aktivitet kallar vi MET (metabolic equivalent). Kjelde: Nerhus 2011. 
Tabell 1: Gjennomsnittleg (SD) tid (min/dag) brukt på inaktivitet, lett, moderat og hard fysisk aktivitet per dag fordelt på kjønn og aldersgrupper $(n=3218)$ (Kolle, 2012).

\begin{tabular}{|l|l|l|l|l|l|l|}
\hline & \multicolumn{2}{|c|}{ 6-åringar } & \multicolumn{2}{c|}{ 9-åringar } & \multicolumn{2}{c|}{ 15-åringar } \\
\hline & $\begin{array}{l}\text { Jenter } \\
(\mathrm{n}=507)\end{array}$ & $\begin{array}{l}\text { Gutar } \\
(\mathrm{n}=486)\end{array}$ & $\begin{array}{l}\text { Jenter } \\
(\mathrm{n}=686)\end{array}$ & $\begin{array}{l}\text { Gutar } \\
(\mathrm{n}=637)\end{array}$ & $\begin{array}{l}\text { Jenter } \\
(\mathrm{n}=449)\end{array}$ & Gutar $(\mathrm{n}=453)$ \\
\hline Inaktivitet (min/dag) & $392(48.9)$ & $376(50,4)$ & $470(53,8)$ & $450(59,3)$ & $571(61,1)$ & $558(71,3)$ \\
\hline Lett FA (min/dag) & $247(34,4)$ & $254(33,9)$ & $223(34,6)$ & $225(34,9)$ & $148(32,3)$ & $164(37,9)$ \\
\hline Moderat FA (min/dag) & $73(17,4)$ & $91(21,4)$ & $64(18,2)$ & $82(23,3)$ & $52(18,6)$ & $60(21,9)$ \\
\hline Hard FA (min/dag) & $9,7(7,4)$ & $9,6(7,5)$ & $7,3(6,2)$ & $9.3(8,1)$ & $5,5(5,7)$ & $8,3(7,3)$ \\
\hline
\end{tabular}

Tabell 1 viser gjennomsnittleg tal på minuttar brukt på inaktivitet, lett, moderat og hard fysisk aktivitet dagleg.

- Barn: I gjennomsnitt bruker 6-årige jenter og gutar høvesvis 73 og 91 minutt på moderat fysisk aktivitet dagleg, mens 9-årige jenter og gutar i gjennomsnitt bruker 64 og 82 minutt.

- Unge: 15-årige jenter og gutar er i gjennomsnitt moderat aktive i høvesvis 52 og 60 minutt dagleg.

I alle aldersgruppene bruker gutar meir tid på fysisk aktivitet totalt sett (lett, moderat og hard samanlagt) enn jenter. Innanfor dei ulike aldersgruppene er det elles stor variasjon i gjennomsnittleg tal på minutt brukt på inaktivitet og fysisk aktivitet.

Blant 6-åringane bruker jenter og gutar like mange minutt på hard fysisk aktivitet.

I gjennomsnitt bruker 15-åringane mest tid på inaktivitet målt i tal på minutt per dag.

Tilrådingar: Helsedirektoratet tilrår at barn og unge bør delta i fysisk aktivitet med moderat eller høg intensitet i minimum 60 minutt kvar dag. I tillegg bør barn og unge utføre aktivitetar med høg intensitet minst tre gonger i veka, inkludert aktivitetar som gir større muskelstyrke og styrkjer skjelettet (Helsedirektoratet, 2014a).

Status for tilrådingane: Om lag 90 prosent av seksåringane, 80 prosent av niåringane og halvparten av 15-åringane oppfyller tilrådingane om fysisk aktivitet. I alle tre aldersgruppene er det fleire gutar enn jenter som oppfyller tilrådingane, sjå figur 2 (Kolle, 2012).

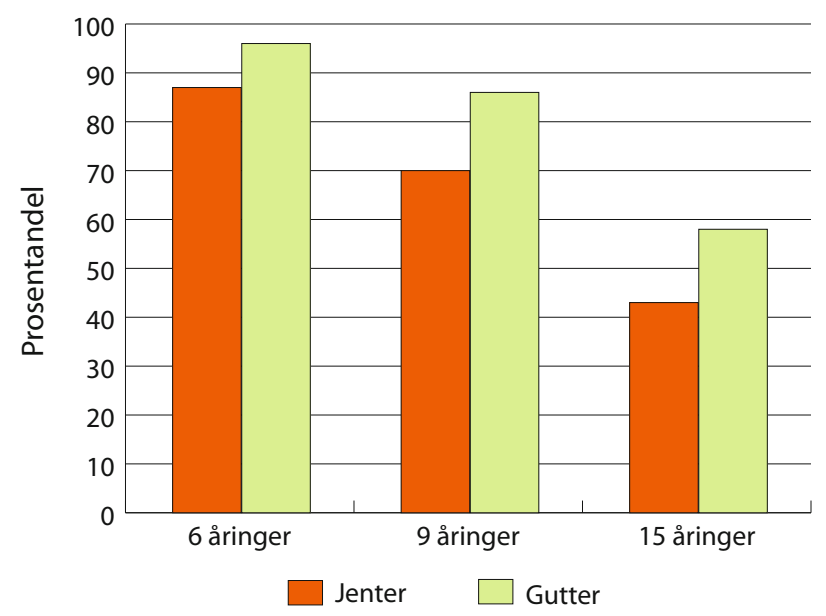

Figur 2: Delen av 6-, 9- og 15-åringar som tilfredsstiller tilrådingane om 60 minutt moderat fysisk aktivitet dagleg fordelt på kjønn. Kjelde: Kolle, 2012.

\section{Vaksne}

Tilrådingar: Helsedirektoratet tilrår at vaksne er moderat fysisk aktive i minst 150 minutt per veke. Det vil seie å utføre aktivitetar som gir raskare pust enn vanleg, for eksempel ved rask gange. Tilrådinga kan òg oppfyllast med minst 75 minutt aktivitet med høg intensitet per veke, eller ein kombinasjon av moderat og høg intensitet. Det er vidare tilrådd å redusere tida ein bruker i ro, og unngå langvarig stillesitting (Helsedirektoratet, 2014a).

Status for tilrådingane: Om lag 30 prosent av vaksne oppfyller dei nye tilrådingane når fysisk aktivitet er registrert med ein aktivitetsmålar. Denne prosentdelen er lågare enn tal frå studiar som har registrert fysisk aktivitet ved hjelp av spørjeskjema (50 prosent) (Helsedirektoratet, 2014b).

Vaksne bruker i gjennomsnitt ni timar per dag på stillesitting. Menn bruker i snitt meir tid på stillesittande aktivitetar enn kvinner (Anderssen, 2009). 


\section{Gravide}

Tilrådingar: Friske gravide blir tilrådde å delta i fysisk aktivitet av moderat intensitet i minst 150 minutt i veka dersom dei ikkje var fysisk aktive før svangerskapet. Kvinner som har vore regelmessig fysisk aktive før svangerskapet, bør halde fram med å delta i fysisk aktivitet på omtrent same nivå, eventuelt med tilpassingar (Helsedirektoratet, 2014a).

Status for tilrådingane: Vi manglar tal som viser kor mange gravide kvinner i Noreg som oppfyller dagens tilrådingar om fysisk aktivitet. Ein norsk studie frå 2012 viste at om lag 15 prosent av kvinnene var moderat fysisk aktive i minst 60 minutt i veka i første del av svangerskapet (Gjestland, 2013). Fysisk aktivitet blei her registrert ved hjelp av spørjeskjema, og prosentdelen gravide som oppfylte tilrådingane kan derfor vere endå lågare. Aktivitetsnivået ser òg ut til å minske frå før ein blir gravid og fram til siste delen av svangerskapet (Owe, 2009).

\section{Utvikling over tid}

Tal frå både undersøkingar ved hjelp av spørjeskjema og undersøkingar der fysisk aktivitet blir målt ved hjelp av aktivitetsmålarar, viser at

- vi blir mindre fysisk aktive dess eldre vi blir

- vi bruker stadig meir tid på stillesittande aktivitetar i bilen, på jobb eller heime framfor ein skjerm (Anderssen, 2009)

- færre har kroppsarbeid no enn tidlegare (Graff-Iversen, 2001)

Barn: Blant 9- og 15-åringar fann ein inga endring i total fysisk aktivitet frå 2005/2006 til 2011, men 9- og 15-åringar sat meir stille i løpet av dagen i 2011 (Kolle, 2012).

Vaksne: Det finst ikkje gode nok data i dag til å kunne seie noko om utviklinga i fysisk aktivitet og stillesitting blant vaksne over tid. Ei ny landsomfattande kartlegging av fysisk aktivitetsnivå blant vaksne og eldre er sett i gang, og denne kan gi oss viktig informasjon om utviklinga i fysisk aktivitetsnivå blant vaksne. Gravide inngår ikkje i denne kartlegginga, og vi manglar data for å kunne seie om gravide kvinner er meir eller mindre aktive no enn tidlegare, eller om aktivitetsmønsteret hos gravide har endra seg dei seinare åra.

\section{Forskjellar i befolkninga}

\section{Aldersforskjellar}

Blant vaksne er 30-åringane minst aktive og 60-åringane mest aktive. Både kvinner og menn reduserer aktivitetsnivået etter 70 -årsalderen, og for kvinner er denne reduksjonen spesielt tydeleg etter fylte 75 år (Anderssen, 2009).

\section{Kjønnsforskjellar}

Hos barn er gutane meir fysisk aktive enn jentene. Dette går fram av figur 2, som viser prosentdelen gutar og jenter som oppfyller tilrådingane om fysisk aktivitet (Kolle, 2012). Kjønnsforskjellen i gjennomsnittleg aktivitetsnivå er størst blant 9-åringane (20 prosent) og minst blant 6 -åringane (12 prosent).

Fleire kvinner ( 35 prosent) enn menn ( 28 prosent) i alderen 20-64 år oppfyller tilrådingane om fysisk aktivitet, men kjønnsforskjellen er nesten viska ut blant eldre over 65 år (28 og 29 prosent) (Helsedirektoratet, 2014b).

\section{Geografiske forskjellar}

Tal frå 2008 viste at vaksne i Nord-Noreg har lågare totalt aktivitetsnivå enn vaksne i Trøndelag og på Aust- og Vestlandet (Anderssen, 2009).

\section{Sosioøkonomiske forskjellar}

Vaksne med minst 4 års høgskule- eller universitetsutdanning har eit høgare gjennomsnittleg aktivitetsnivå enn personar med berre grunnskuleutdanning. Samtidig bruker personar med grunnskule som høgaste fullførte utdanning mindre tid på inaktivitet samanlikna med personar som har minst 4 års utdanning ved høgskule eller universitet.

\section{Etniske forskjellar}

Barn og unge med ikkje-vestleg bakgrunn er mindre fysisk aktive enn barn med vestleg bakgrunn. Det er derimot ingen forskjell i tal på skritt per dag mellom vestlege og ikkje-vestlege barn og unge, viser tal frå 2011 (Kolle, 2012).

Ettersom vi manglar data, kan vi ikkje seie noko om korleis fysisk aktivitet hos vaksne varierer med etnisk bakgrunn. 


\section{Internasjonal samanlikning}

\section{Barn:}

- Norske 9-åringar er noko meir aktive enn barn på same alder i Europa og USA.

- Norske 15-åringar har eit aktivitetsnivå tilsvarande det ein ser hos jamnaldrande europearar, og noko høgare enn 12-19-åringar i USA (Kolle, 2012).

\section{Vaksne:}

- Norske kvinner og menn i alderen 20 til 69 år har tilnærma same fysiske aktivitetsnivå som svenske menn og kvinner (Anderssen, 2009).

- Amerikanske menn i alderen 20 til 50 år har eit høgare gjennomsnittleg aktivitetsnivå enn norske menn på same alder. Frå 60-årsalderen er norske menn derimot meir aktive enn dei amerikanske.

- Norske kvinner har eit høgare aktivitetsnivå enn amerikanske, og forskjellen aukar med alderen.

\section{Kva fysisk aktivitet har å seie for folkehelsa}

Både mengda fysisk aktivitet og mengda stillesitting verkar inn på helsa.

Det er i dag godt dokumentert at fysisk aktivitet fremjar helse, gir overskot og kan brukast til førebygging og behandling av over 30 ulike diagnosar og tilstandar (Bahr, 2009).

\section{Helsegevinstar ved tilstrekkeleg aktivitet}

Helsegevinstane ved å vere i regelmessig fysisk aktivitet gjeld for alle aldersgrupper.

- Fysisk aktivitet gir fleire leveår med god helse (kvalitetsjusterte leveår), både lengre levetid og auka livskvalitet, samanlikna med inaktivitet. Dersom vi aukar aktivitetsnivået utover tilrådingane, kan det gi oss endå fleire kvalitetsjusterte leveår (Helsedirektoratet, 2014c).

- Mindre total tid med inaktiv åtferd og hyppige, korte bolkar med ståing, samt fysisk aktivitet mellom inaktive periodar, gir helsegevinst. Dette gjeld òg for personar som allereie er fysisk aktive.

\section{Fysisk aktivitet nødvendig for at barn skal vekse og utvikle seg}

Regelmessig fysisk aktivitet er nødvendig for å oppnå normal vekst og utvikling, og for å kunne utvikle motorisk kompetanse, muskelstyrke og kondisjon.

For barn er det vist at TV-titting før fylte 3 år kan vere negativt for merksemda, språkutviklinga og den kognitive utviklinga til barna ved skulestart (Tremblay, 2010).

\section{Fysisk aktivitet i barneåra positivt for helsa i vaksen alder}

Fysisk aktivitet er viktig for yteevna og helsa i unge år og seinare.

Fleire studiar har vist at regelmessig fysisk aktivitet $\mathrm{i}$ barneåra er viktig for om ein blir regelmessig fysisk aktiv som vaksen, sjølv om aktivitetsnivået varierer noko frå barn til ungdom og frå ungdom til vaksen (Telema, 2009).

\section{Konsekvensar og helserisiko ved inaktivitet}

Fysisk inaktivitet er ein sjølvstendig risikofaktor for å få dårleg helse. Verdas helseorganisasjon (WHO) har slege fast at fysisk inaktivitet (her definert som å ikkje oppfylle dagens tilrådingar for fysisk aktivitet) er den fjerde største risikofaktoren for ikkje-smittsame sjukdomar, og at inaktivitet er ein større risikofaktor enn høgt blodtrykk og høgt blodsukker (Lee, 2012).

Lengre periodar med inaktivitet eller stillesitting er sterkt knytte til dette:

- fedme

- diabetes

- metabolsk syndrom

- enkelte former for kreft

- hjarte- og karsjukdomar

- tidleg død

Det er òg vist at det er ein samanheng mellom stillesitting og funksjonsnedsetting hos heimebuande over 60 år (Dunlop, 2014).

Tal frå Helseundersøkelsene i Nord-Trøndelag (HUNT) har vist at total tid brukt på stillesittande aktivitetar er knytt til høgare dødelegheit av alle dødsårsaker samla og dødelegheit som kjem av hjarte- og lungesjukdomar (Chau, 2012).

Det er urovekkjande at ein stor del av befolkninga i dag, uavhengig av alder, er i ro store delar av dagen 
og ikkje bruker tilstrekkeleg med tid på fysisk aktivitet. Fysisk aktivitet må aukast for å redusere stillesittinga, noko som vil vere svært viktig for folkehelsa generelt.

Risikoen for å utvikle hjarte- og karsjukdom minskar med aukande fysisk aktivitet. Sjølv dei som ikkje oppfyller tilrådingane om fysisk aktivitet, men som er noko aktive, har ein redusert risiko samanlikna med dei som er heilt inaktive (Sattelmair, 2011).

Dersom vi får jamna ut forskjellane slik at fleire blir fysisk aktive, kan dette truleg også bidra til å jamne ut sosiale forskjellar når det gjeld livsstilssjukdomar som kan tilskrivast manglande fysisk aktivitet.

\section{Utfordringar når det gjeld å fremje fysisk aktivitet}

Det er viktig å leggje til rette for meir fysisk aktivitet og mindre stillesitting. Gode aktivitetsvanar som varer, tileigner vi oss i barneåra, og barn er derfor ei viktig målgruppe.

Det finst i dag mykje kunnskap om helseeffektane av fysisk aktivitet hos menn og kvinner i ulike aldersgrupper. Vi har mindre kunnskap om korleis vi bør gå fram for å auke aktivitetslysta og aktivitetsnivået, spesielt hos dei som er inaktive eller ikkje tilstrekkeleg fysisk aktive.

Ein rapport frå Kunnskapssenteret viser at både befolkningsretta og individretta tiltak kan auke det fysiske aktivitetsnivået. Eksempel på befolkningsretta tiltak er tiltak som gjer det enklare for alle å vere fysisk aktive, for eksempel å ta trappa i staden for heisen eller rulletrappa. Eksempel på individretta tiltak er rådgiving, trening og andre tiltak som er retta mot enkeltpersonar (Denison, 2010).

\section{Referansar}

Anderssen, S. Fysisk aktivitet blant voksne og eldre i Norge: resultater fra en kartlegging i 2008 og 2009. IS-2183. Oslo, Helsedirektoratet. (2009).

Bahr, R. (red). Aktivitetshåndboken: fysisk aktivitet i forebygging og behandling. Oslo, Helsedirektoratet. (2009).

Chau, J. Y., A. Grunseit, K. Midthjell, J. Holmen, T. L. Holmen, A. E. Bauman and H. P. Van der Ploeg (2013). Sedentary behaviour and risk of mortality from all-causes and cardiometabolic diseases in adults: evidence from the HUNT3 population cohort. Br J Sports Med. May 10 [epub].

Denison, E. Effekter av tiltak utenfor helsetjenesten for å øke fysisk aktivitet hos voksne: systematisk kunnskapsoversikt. Oslo, Nasjonalt kunnskapssenter for helsetjenesten. 19-2010: 68 s. : digital, PDF-fil. (2010).
Dunlop, D., J. Song, E. Arnston, P. Semanik, J. Lee, R. Chang and J. M. Hootman (2014). Sedentary Time in U.S. Older Adults Associated With Disability in Activities of Daily Living Independent of Physical Activity. J Phys Act Health. DOI: http://dx.doi.org/10.1123/jpah.2013-0311. Feb [Epub].

Gjestland, K., K. Bo, K. M. Owe and M. Eberhard-Gran (2013). Do pregnant women follow exercise guidelines? Prevalence data among 3482 women, and prediction of low-back pain, pelvic girdle pain and depression. $\mathrm{Br} J$ Sports Med 47(8): 515-520.

Graff-Iversen, S., S. Skurtveit, A. Nybo and G. B. Ross (2001). [Trends when it comes to occupational physical activity among Norwegians aged 40-42 years during the period 1974-94]. Tidsskr Nor Laegeforen 121(22): 2584-2588.

Helsedirektoratet (2014a). Anbefalinger om kosthold, ernæring og fysisk aktivitet. Oslo, Helsedirektoratet.

Helsedirektoratet (2014b). Fysisk aktivitetsnivå blant voksne og eldre i Norge. Oppdaterte analyser basert på nye nasjonale anbefalinger i 2014. Oslo, Helsedirektoratet IS-2183.

Helsedirektoratet (2014c). Kunnskapsgrunnlag fysisk aktivitet: innspill til departementets videre arbeid for økt fysisk aktivitet og redusert inaktivitet i befolkningen. Oslo, Helsedirektoratet.

Kolle, E. Fysisk aktivitet blant 6-, 9- og 15-åringer i Norge: resultater fra en kartlegging i 2011. Oslo, Helsedirektoratet. (2012).

Lee, I. M., E. J. Shiroma, F. Lobelo, P. Puska, S. N. Blair and P. T. Katzmarzyk (2012). Effect of physical inactivity on major non-communicable diseases worldwide: an analysis of burden of disease and life expectancy. Lancet 380(9838): 219-229.

Nerhus, K. A. (2011). Sentrale begreper relatert til fysisk aktivitet : forslag til bruk og forståelse Norsk epidemiol 20(2): 149-152

Owe, K. M., W. Nystad and K. Bo (2009). Correlates of regular exercise during pregnancy: the Norwegian Mother and Child Cohort Study. Scand J Med Sci Sports 19(5): 637-645.

Sattelmair, J., J. Pertman, E. L. Ding, H. W. Kohl, W. Haskell and I. M. Lee (2011). Dose Response Between Physical Activity and Risk of Coronary Heart Disease A Meta-Analysis. Circulation 124(7): 789-U784.

Sosial- og helsedirektoratet. Fysisk aktivitet og helse: anbefalinger. Oslo, Sosial- og helsedirektoratet (2002).

Telama, R. (2009). Tracking of physical activity from childhood to adulthood: a review. Obes Facts 2(3): 187-195.

Tremblay, M. S., R. C. Colley, T. J. Saunders, G. N. Healy and N. Owen (2010). Physiological and health implications of a sedentary lifestyle. Appl Physiol Nutr Metab 35(6): 725-740.

\section{FORFATTARAR}

Katrine M. Owe, Anstein Mykletun, Wenche Nystad og Lisa Forsen 


\section{Klimaendringar og helse}

- Klimaendringar i form av temperaturauke og forureiningar påverkar helsa vår både direkte og indirekte.

- I Noreg kan temperaturauke påverke utbreiinga av flåttborne sjukdomar.

- Endringar i utbreiinga av pollenproduserande plantar kan påverke førekomsten av pollenallergi.

- Når polisen smeltar, kan det frigjere miljøgifter og auke mengda miljøgifter i fisk og skaldyr.

- Klimaendringane bidreg til auka sjukdomsbyrde på global basis.

\section{Om klimaendringar}

Klimaendringar kan gi auka temperatur og auka luftforureining. Klimaendringane har stor innverknad på helse og trivsel. Helsa kan påverkast både direkte og indirekte.

I den nyaste rapporten beskriv Intergovernmental Panel on Climate Change korleis endringar i klima fortset å utvikle seg (IPCC, 2014). Temperaturen globalt har auka omtrent i takt med $\mathrm{CO}_{2}$-konsentrasjonen og enkelte andre gassar i atmosfæren, og ein reknar med at han vil auke i kommande tiår dersom ikkje utsleppa blir reduserte. Nokre område på kloden kan bli ubebuelege.

\section{Klimaendringar og direkte følger for folkehelsa}

Klimaendringar kan påverke helsa direkte gjennom auka dødelegheit, skader, sjukdomar og helseplager som følge av:

- hetebølgjer

- tørkeperiodar

- ekstremvêr

Den observerte auka av naturkatastrofar, for eksempel ekstremvêr i samband med auka temperaturar, er i tråd med modellane til forskarane (IPCC, 2014). Det er forventa at effektane blir forsterka når temperaturen stig ytterlegare.

\section{Befolkningsendringar}

Som følge av at nokre område kan bli ubebuelege, kan ein vente auka migrasjon. Vi reknar med at dette får liten innverknad på Noreg (Miljø- og klimadepartementet, 2010).

\section{Indirekte effektar av klima- endringar}

I Noreg kan klimaendringar:

- Endre vilkåra for flått, som igjen kan auke førekomsten av flåttborne sjukdomar, sjå nedanfor

- Påverke utbreiinga av eksisterande og nye pollenproduserande planter, som kan auke førekomsten av pollenallergi, sjå nedanfor.

Klimaendringane kan også auke førekomsten av infeksjonar og gjennom meir ekstremvêr forverre vilkåra for matproduksjonen og drikkevassforsyninga.

\section{Flåttborne infeksjonar}

I åra framover vil temperaturauke truleg påverke livsvilkåra for flått og dermed auke førekomsten av sjukdomar som blir overførte av flått.

Noreg utgjer den nordlege utbreiingsgrensa i Europa for flåtten Ixodes ricinus. Nyleg publiserte studiar (Jore, 2011) viser likevel at flått no finst både lengre nord og høgare opp i fjellet enn tidlegare. Dette betyr auka fare for smitte og sjukdom hos menneske og dyr i nye område av landet. 


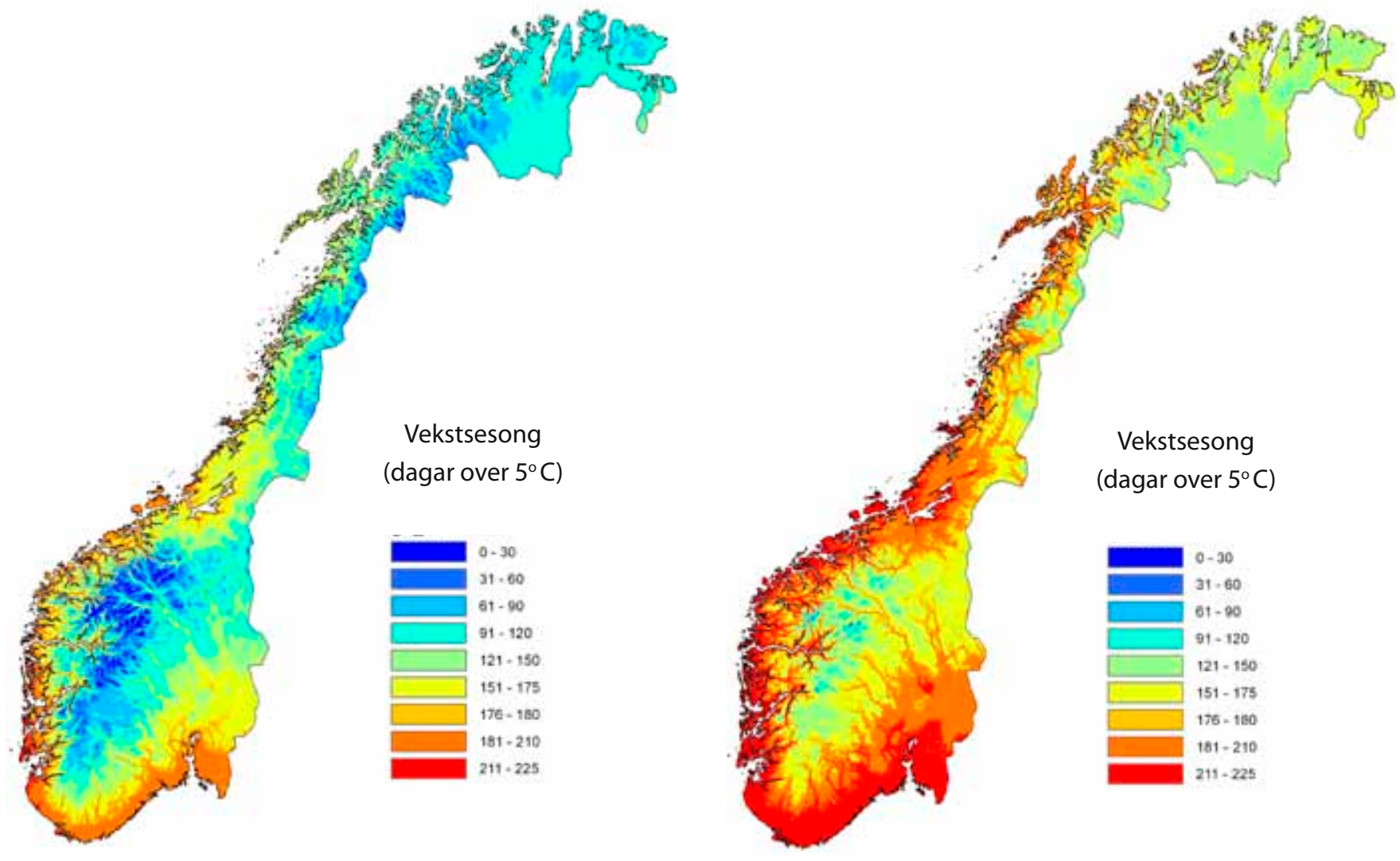

Kartet til venstre viser lengda på vekstsesongen i perioden 1961-90. Utbreiinga til flåtten i dag samsvarar med ein vekstsesong på 176-180 døger, markert på kartet med oransje til raud farge. I modellen Hadley A2 til høgre er vekstsesongen framskriven til 2071-2100. Ifølgje desse berekningane vil stort sett alle låglandsområda i Noreg ha ein vekstsesong på 176 - 180 døger i 2071-2100. Unntaket er områda lengst i nord. Kartet er produsert av Meteorologisk institutt, Oslo.

Borreliose: Kvart år blir det meldt mellom 250 og 300 tilfelle av Lyme borreliose i Noreg, sjå tabell 1. Sjukdomen er vanlegast i kystområda på begge sider av Ytre Oslofjord, Telemark, Agderfylka og Vestlandet.
Lyme borreliose er ein bakteriesjukdom som kan gi langvarige og alvorlege nevrologiske plager. Sjukdomen kan behandlast med antibiotika. Det finst ingen vaksine.

Tabell 1. Flåttborne infeksjonar i Noreg, melde tilfelle i perioden 2008-2013. Kjelde: FHI/MSIS (2014).

\begin{tabular}{|l|r|r|r|r|r|r|r|r|}
\hline Diagnose & $\mathbf{2 0 0 8}$ & $\mathbf{2 0 0 9}$ & $\mathbf{2 0 1 0}$ & $\mathbf{2 0 1 1}$ & $\mathbf{2 0 1 2}$ & $\mathbf{2 0 1 3}$ & IR 2013* & Smitta i Noreg 2013 \\
\hline Lyme borreliose & 346 & 273 & 288 & 247 & 256 & 315 & 6,2 & $78 \%$ \\
\hline Skogflåttencefalitt (TBE) & 11 & 10 & 11 & 14 & 7 & 6 & 0,1 & $83 \%$ \\
\hline
\end{tabular}

*IR = Insidensrate; antall tilfelle per 100000 innbyggarar. 
Skogflåttencefalitt har sidan 1998 etablert seg i kystområda i Agderfylka, Telemark, Vestfold og Østfold. Kvart år blir det meldt om 6-14 tilfelle av skogflåttencefalitt, sjå tabell 1 (FHI/MSIS, 2014). Skogflåttencefalitt er ein virussjukdom som kan gi infeksjon i sentralnervesystemet. Ein vaksine kan førebygge sjukdomen.

\section{Andre infeksjonar som blir overførte via insekt}

Ved klimaendringar kan også nye insektoverførte sjukdomar etablerast i Noreg.

- Vestnilfeber blir overført av mygg som finst i Noreg, men med dagens klima klarer ikkje viruset å modnast lenger nord enn Mellom-Europa.

- Asiatisk tigermygg spreier seg raskt i Europa. Med dei forventa klimaendringane kan myggen etablere seg i kystområde i Sør-Noreg. Han kan spreie ei rekke ulike virus, blant anna sjukdomane denguefeber og chikungunyafeber.

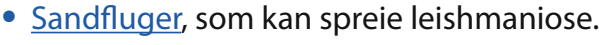

- Dagens klima gjer at også malaria kan etablere seg på våre breiddegradar. Dagens helsetilbod er likevel tilstrekkeleg til å halde befolkninga fri for smitte.

\section{Vatn- og matborne infeksjonar}

Andre infeksjonssjukdommar vil truleg ikkje auke, kanskje med unntak av visse mage- og tarmsjukdomar som salmonellose og campylobacteriose, for eksempel som følge av varmare somrar. I varmt sommarvêr er det mange som grillar mat ute, noko som er knytt til auka risiko for matborne infeksjonar. Bakteriane blir overførte når steikt kjøtt blir lagt tilbake på same tallerken som det rå stykket kom frå. Sjå kapittel om mat-og vannborne sjukdomar.

\section{Pollenallergi}

Temperaturauke vil endre vekstvilkåra for pollenproduserande tre og planter. Dette kan føre til at pollensesongen blir forlenga og at planter etablerer seg i område der dei ikkje veks i dag. Ein reknar derfor med at klimaendringar vil gi auka førekomst av kjente pollenallergiar.

Nye planteartar kan også føre til endringar i pollentypar og dermed også endringar i førekomsten av "nye" allergiar. Forureiningar kan i tillegg forsterke allergiplager (Eriksson, 2004; Madsen, 2005; Nordic Council of Ministers, 2009; D'Amato, 2013).

Pollenallergi inneber både høysnue og pollenrelatert matallergi (såkalla kryssreaksjonar). Kryssreaksjoner kjem av at allergena i pollen liknar på proteina i maten.
Les meir i kapittel om luftforureining og kapittel om astma og allergi.

\section{Auka luftforureining}

Komponentar i luftforureininga som ozon og sotpartiklar bidreg til klimaendringar, men klimaendringar kan også bidra til auka luftforureining. Klimaendringar kan for eksempel gi høgare nivå av ozon, som i sin tur kan gi forverring av sjukdom (luftveis- og hjerte- og karlidingar) og auka førekomst av for tidleg død i befolkninga. Luftforureiningar kan utløyse astmaanfall og forsterke kroppens reaksjonar på luftvegsallergen hos personar som allereie har astma eller høysnue (rhinitt).

\section{Frigjering av miljøgifter}

Med auka nedsmelting i Arktis ventar ein å få auka frigjering av miljøgifter, som igjen vil kunne føre til auka forureining av fisk og skaldyr. Auka inntak av miljøgifter via matvarer kan auke belastninga av slike stoff i befolkninga, og det kan gi auka førekomst av sjukdom.

\section{Førebygging og overvaking}

Prognosar for utslepp av klimagassar gjer det lite truleg at vi kan nå målet om ei begrensa temperaturauke på 2 gradar. Den viktigaste utfordringa er å få til globale kutt i utslepp av klimagassar.

Ein kan førebygge og lindre helseplager og sjukdom gjennom overvaking og varsling/informasjon til befolkninga:

- Ozonnivåa blir overvaka på ei rekke stasjonar i forskjellige delar av landet. Når nivåa overskrid visse grenser, skal befolkninga informerast/ varslast.

- Folkehelseinstituttet overvaker flåttførekomst og flåttborne infeksjonar, samt førekomsten av andre infeksjonar.

- Eit matallergiregister registrerer førekomsten av alvorlege allergiar.

- Førekomsten av miljøgifter i befolkninga blir følgt gjennom oppbygginga av ein human miljøbiobank. 


\section{Referansar}

D'Amato, G, Baena-Cagnani, CE, Cecchi, L, Annesi-Maesano, I, Nunes, $C$ et al. Climate change, air pollution and extreme events leading to increasing prevalence of allergic respiratory diseases. Multidiscip Respir Med 2013; 8(1).

Eriksson, NE, Moller, C, Werner, S, Magnusson, J, Bengtsson, $\mathrm{U}$ et al. Self-reported food hypersensitivity in Sweden, Denmark, Estonia, Lithuania, and Russia. J Investig Allergol Clin Immunol 2004; 14(1): 70-9.

FHI/MSIS; Folkehelseinstituttet/Meldingssystem for smittsomme sykdommer. MSIS-statistikk. [hentet 20/6/2014].

IPCC. Fifth Assessment Report. Geneva, Switzerland: Intergovernmental Panel on Climate Change; 2014.

Jore, S, Viljugrein, $\mathrm{H}$, Hofshagen, $M$, Brun-Hansen, $H$, Kristoffersen, $A B$ et al. Multi-source analysis reveals latitudinal and altitudinal shifts in range of Ixodes ricinus at its northern distribution limit. Parasit Vectors 2011; 4: 84.
Madsen, C. Prevalence of food allergy: an overview. Proc Nutr Soc 2005; 64(4): 413-7.

Miljø- og klimadepartementet. NOU 2010: 10; Tilpassing til eit klima i endring, kap. 11.3.2 Migrasjon. 2010.

Nordic Council of Ministers. Signs of Climate Change in Nordic Nature. Copenhagen: Nordic council of ministers; 2009. Tilgjengelig fra: http://norden.diva-portal.org/ smash/get/diva2:702674/FULLTEXT01.pdf

\section{FORFATTARAR}

Per Schwarze, Berit Granum, Preben Ottesen og Arnulf Soleng 
- Norsk kosthald inneheld framleis for mykje metta feitt, sukker og salt og for lite grove kornprodukt, grønsaker, frukt og fisk.

- Det er framleis eit altfor høgt brusforbruk i den norske befolkninga.

- Kosttilskot med D-vitamin, folat og jern kan vere nødvendig for å sikre næringsstoffinntaket for enkelte grupper i befolkninga.

- Det er teikn til at særleg unge kvinner får mindre jod gjennom kosthaldet enn tidlegare.

- Vi ser ein samanheng mellom utdanningslengd og kosthald.

- Forskjellane mellom kosthaldet i Noreg og andre europeiske land er truleg mindre i dag enn for berre nokre tiår sidan.

- Livsstilssjukdomar kan førebyggjast med eit meir plantebasert kosthald.

\section{Dei nasjonale kostråda}

I 2011 publiserte Helsedirektoratet nye nasjonale kostråd som byggjer på ein systematisk gjennomgang av ei rekkje forskingsresultat. Desse råda gjeld spesielt for førebygging av ikkje-smittsame sjukdomar, men vi har òg teke omsyn til at ein skal førebyggje ernæringsmanglar og miljøbelastingar. Råda er oppdaterte og samsvarer med dei felles nordiske kosthaldstilrådingane frå 2013.

I det vidare presenterer vi statusen for norsk kosthald med omsyn til kostråda og tilrådingane for dagleg inntak av vitamin og mineral samt statusen for miljøgifter i norsk kost.

- Råd 1: Vi tilrår eit kosthald som hovudsakleg er plantebasert, og som inneheld mykje grønsaker, frukt, bær, fullkorn og fisk og lite mengder raudt kjøt, salt, tilsett sukker og energirike matvarer.

- Råd 2: Vi tilrår å sørgje for å ha balanse mellom energiinntak og energiforbruk.

- Råd 3: Et minst fem porsjonar grønsaker, frukt og bær kvar dag.

- Råd 4: Et minst fire porsjonar fullkornprodukt kvar dag.
- Råd 5: Et fisk tilsvarande 2-3 middagsporsjonar i veka.

- Råd 6: Vi tilrår å innta magre meieriprodukt dagleg.

- Råd 7: Vi tilrår å velje magert kjøt og magre kjøtprodukt og ete mindre raudt kjøt og bearbeidd kjøt.

- Råd 8: Vi tilrår å velje matoljer, flytande margarin eller mjuk margarin.

- Råd 9: Vi tilrår vatn som drikke.

- Råd 10: Reduser inntaket av tilsett sukker.

- Råd 11: Reduser inntaket av salt.

- Råd 12: Kosttilskot kan vere nødvendig for å sikre næringsstoffinntaket for enkelte grupper i befolkninga.

- Råd 13: Vi tilrår at alle dagleg er i fysisk aktivitet i minst 30 minutt.

\section{Status og utvikling for norsk kosthald}

Vi tilrår eit kosthald som hovudsakleg er plantebasert, og som inneheld mykje grønsaker, frukt, bær, fullkorn og fisk og lite mengder raudt kjøt, salt, tilsett sukker og energirike matvarer (nøkkelråd 1). I tillegg 
har vi utforma nøkkelråd for ulike matvaregrupper (nøkkelråd 2-12).

Status for kosthaldet i Noreg med omsyn til kostråda:

- Det gjennomsnittlege inntaket av grønsaker, frukt, bær, fullkorn og fisk er langt lågare enn ønskjeleg.

- Forbruket av feite, salte og søte matvarer med låg ernæringskvalitet er langt høgare enn ønskjeleg.

- Trass i fleire positive utviklingstrekk dei siste åra har kosthaldet til store delar av befolkninga framleis klare ernæringsmessige svakheiter som bidreg til utvikling av hjarte- og karsjukdomar, kreft, overvekt, type 2-diabetes, forstopping, tannråte og jernmangel (Helsedirektoratet, 2013).

\section{Feitt}

Feittet i kosten er ei viktig energikjelde og dessutan heilt nødvendig for at kroppen skal ta opp dei feittløyselege vitamina A, D, E og K.

Vi tilrår at den totale mengda energi som kjem frå feitt, utgjer mellom 25 og 40 energiprosent, og av dette bør ikkje det harde feittet (metta feitt og transfeitt) utgjere meir enn 10 energiprosent. For transfeitt er det sett ei ny grense på 2 prosent av feittet i ei matvare.

For å nå dette målet tilrår vi å velje magre meieriprodukt, magre kjøtprodukt og å velje matoljer, flytande margarin eller mjuk margarin (nøkkelråd 6, 7 $\operatorname{og} 8)$.

Status for inntak av feitt: I 2012 blei 16 prosent av energibehovet i det norske kosthaldet dekt gjennom hardt feitt. Dette er det same høge inntaket som vi hadde i 1975. I år 2000 var energiinntaket frå metta feitt det lågaste i nyare tid, på 14,7 prosent, men etter dette har forbruket auka igjen, mest fordi vi har ete meir kjøtvarer og feite ostar (Helsedirektoratet, 2013).

Det er derfor langt igjen før det gjennomsnittlege feittforbruket i Noreg er nede på det tilrådde nivået, som er 10 energiprosent frå metta feitt. Energiinntaket frå transfeitt har sidan 2000 lege stabilt på cirka 0,7 prosent av energibehovet.

Ei positiv utvikling i norsk kosthald er at vi har begynt å bruke meir raps- og olivenolje, både i margarinprodukt og som olje i matlaging. Desse oljetypane inneheld lite metta feitt.

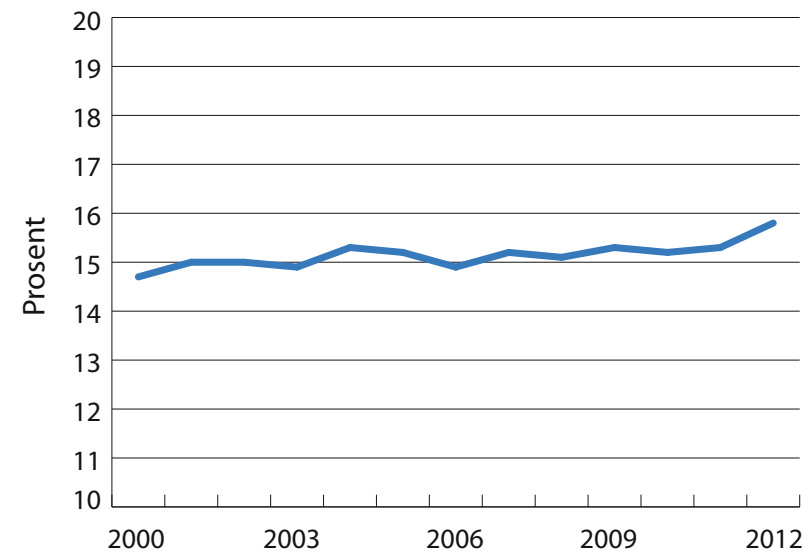

Figur 1: Energiinntak frå metta feitt sidan år 2000. Kjelde: Helsedirektoratet, 2013.

\section{Sukker}

Vi tilrår at sukker utgjer maksimalt 10 prosent av energiinntaket. For å kunne nå dette målet tilrår vi å velje vatn som drikke og redusere inntaket av tilsett sukker (nøkkelråd 9 og 10).

Status: Brus og godteri er dei største sukkerkjeldene i kosthaldet. Dette er dessutan matvarer som inneheld svært lite andre næringsstoff, og som derfor kan fjernast frå kosthaldet utan at det får uheldige ernæringsmessige følgjer.

Forbruket av sukker og sukkervarer på engrosnivå har minska kvart år sidan 2001 og minska òg i 2012 (sjå figur 2). I 2012 var forbruket av sukker per innbyggjar på 29 kg per år. Tilsvarande tal i 1999 var 44 kg (Helsedirektoratet, 2013). I same periode blei innhaldet av tilsett sukker i kosten redusert frå 17 til 13 prosent av det totale energiinnhaldet i kosten. Dette er likevel framleis høgare enn det tilrådde nivået på maksimalt 10 energiprosent. Med tilsett sukker meiner vi sukker som blir tilsett i for eksempel brus, godteri, yoghurt, is og ketsjup.

Omsetninga av sukkerhaldig brus auka frå 1970-åra til det var på det høgaste nivået i 1997, med 93 liter per innbyggjar per år. Omsetninga har minska dei to siste åra og var i 2012 på 59 liter per innbyggjar (Helsedirektoratet, 2013).

Det er framleis eit altfor høgt brusforbruk i den norske befolkninga.

Forbruket av sjokolade og anna godteri har auka kraftig over lang tid og var på det høgaste nivået, $15 \mathrm{~kg}$ per innbyggjar, i 2008. Forbruket har etter dette gått litt ned og var i 2012 på 14 kg per innbyggjar (Helsedirektoratet, 2013). Nedgangen blir vist i figur 2, 
der ein ser korleis nedgangen i inntaket av sukker blir synleg i mengd energiprosent frå sukker.

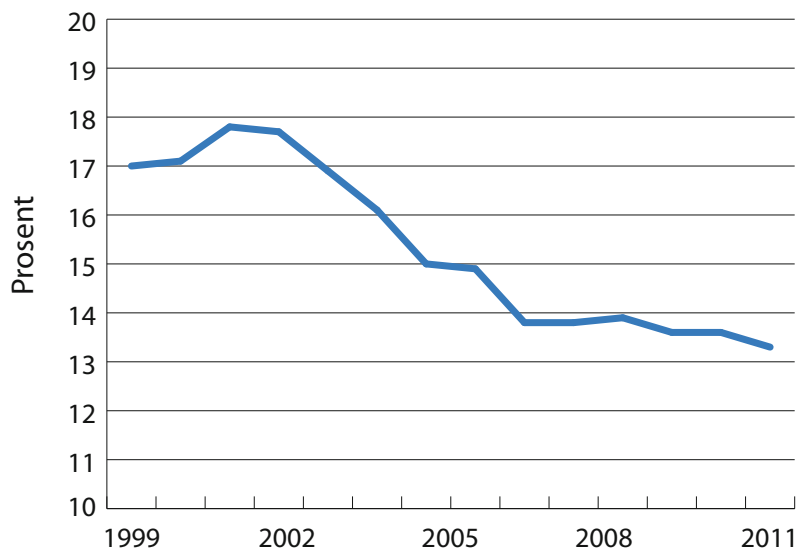

Figur 2. Energiprosent frå sukker per person per år. Kjelde: Helsedirektoratet, 2013.

Høgare sukkerinntak blant barn og unge Konsumet av sukkerhaldige drikkevarer er i stor grad høgare blant unge i alderen 16-24 år enn i andre aldersgrupper (Helsedirektoratet, 2013).

\section{Salt}

Vi tilrår å vere forsiktig med inntaket av salt (nøkkelråd 11).

Status: Det gjennomsnittlege saltinntaket i Noreg er estimert til ca. 10 gram per person per dag (Helsedirektoratet, 2013). Dette er dobbelt så høgt som tilrådd. Ein reknar med at omtrent tre firedelar av saltet kjem frå ferdigmat.

\section{Fullkorn, frukt og grønsaker og fisk}

Vi tilrår å ete minst fem porsjonar grønsaker, frukt og bær kvar dag (nøkkelråd 3), minst fire porsjonar fullkornprodukt kvar dag (nøkkelråd 4), fisk tilsvarande 2-3 middagsporsjonar i veka (nøkkelråd 5), og at magre meieriprodukt inngår i det daglege kosthaldet (nøkkelråd 6).

Status: Norkost 3 er ei landsomfattande kosthaldsundersøking blant menn og kvinner i alderen 18 til 70 år. Kosthaldet blei kartlagt i eit utval med 862 menn og 925 kvinner i løpet av 2010 og 2011. Denne undersøkinga kan seie noko om konsumet av matvaregrupper på individnivå (Helsedirektoratet, 2012). Det er viktig å nemne at det er noko usikkerheit knytt til prosentdelane, ettersom utrekningane er baserte på berre 2 dagars registrering per person:
Rundt ein fjerdedel av deltakarane åt grønsaker, frukt, bær og fullkorn i samsvar med kostråda.

- Omtrent ein tredjedel av deltakarane låg innanfor tilrådinga for inntak av fisk.

Den norske mor og barn-undersøkinga gir unik innsikt i korleis gravide i Noreg et. I eit utval på 47000 deltakarar (von Ruesten, 2014) kom det fram at

- under 10 prosent av dei gravide kvinnene hadde eit inntak av grønsaker i tråd med tilrådingane

- omtrent ein tredjedel åt nok frukt

- omtrent 60 prosent åt fullkorn i tilrådd mengd

- berre 22 prosent åt nok fisk under graviditeten

\section{Forskjellar i befolkninga}

\section{Sosioøkonomiske forskjellar når det gjeld kosthald}

Utdanning og økonomi er viktig for kva kosthald vi har, viser fleire undersøkingar:

- Ein djupnestudie av 11-åringar frå Oslo-området viste at utdanningslengda til foreldra heng saman med barna sitt forbruk av sukkerhaldige drikkevarer (Totland, 2013).

- I ein studie av over 9000 vaksne i Oslo blei det funne at dess lengre utdanning, dess større inntak av sunn mat (Kjollesdal, 2010). Personar med høg utdanning hadde høgare konsum av frukt og grønsaker enn personar med låg utdanning (Helsedirektoratet, 2013).

- Blant gravide som deltek i Den norske mor og barn-undersøkinga, er det òg vist at kvinner med lang utdanning og høg inntekt har sunnare kosthald (Englund-Ogge, 2012).

\section{Kva kosthaldet har å seie for utvikling av ikkje-smittsame sjukdomar}

Kosthaldet er viktig både for å førebyggje sjukdom og fremje god helse.

Eit balansert og fullverdig kosthald i tråd med dei offisielle kostråda kan redusere risikoen for utvikling av ikkje-smittsame sjukdomar som hjarte- og karsjukdomar, diabetes, enkelte kreftsjukdomar, overvekt, forstopping, tannråte og jernmangel.

Ernæring og kosthald er òg avgjerande når det gjeld vekst og utvikling både i fosterlivet, spedbarnsalder og barne- og ungdomsåra. I tillegg har kosthaldet i 
barnealderen mykje å seie for helsa og risikoen for å få kroniske sjukdomar seinare i livet.

Konsekvensar av høgt inntak av hardt feitt: Det er ein klar samanheng mellom høgt inntak av hardt feitt og utvikling av hjarte- og karsjukdomar. Høgt inntak av hardt feitt aukar innhaldet av kolesterol i blodet.

Konsekvensar av høgt sukkerinntak: Sukker som er tilsett i matvarene, gir auka energitettleik og er med på å auke risikoen for å få kroniske sjukdomar, spesielt overvekt og fedme. I tillegg aukar sukker og søte drikkar risikoen for å få karies og tannerosjon.

Konsekvensar av høgt saltinntak: Høgt saltinntak aukar risikoen for høgt blodtrykk og bidreg dermed til større risiko for hjarte- og karsjukdomar.

\section{Moglegheiter for å førebyggje ikkje-smittsame sjukdomar gjennom kosthaldet}

Kosthaldsundersøkingar viser at nordmenn sitt kosthald har stort potensial for å bli betre, og kunnskapsoppsummeringar konkluderer eintydig med at det er mogleg å førebyggje kroniske sjukdomar ved å betre kosthaldet.

Dersom vi følgjer tilrådingane og aukar forbruket av fullkornprodukt, frukt, grønsaker og fisk, kan vi redusere risikoen for dei fleste ikkje-smittsame sjukdomar. Den største ernæringspolitiske utfordringa i tida framover er å klare å doble forbruket av frukt og grønsaker, redusere inntaket av metta feitt og salt samt å redusere inntaket av sukker blant barn og unge (Helsedirektoratet, 2013).

Verdas helseorganisasjon (WHO) har estimert at endringar i kosthald, fysisk aktivitet og røykjevanar kan førebyggje 80 prosent av hjarteinfarkt, 90 prosent av type 2-diabetes og over 30 prosent av kreft (WHO, 2003) (Fund/ \& Research, 2007).

\section{Treng vi spesielle diettar?}

Kosthald og livsstil er eit tema som får større merksemd i media no enn nokon gong tidlegare, og vi blir dagleg utsette for ulike råd og påverknader. Det har blitt vanskeleg å vite kva ein bør ete. Råda frå styresmaktene og ulike ekspertar går ofte på tvers av kvarandre. Ofte blir resultat frå enkeltundersøkingar slegne stort opp, og tilsynelatande motstridande funn skaper usikkerheit om kva vi veit og ikkje veit.
Det som kjenneteiknar dagens motediettar, er at dei blir marknadsførde og motiverte ut frå faglege spekulasjonar henta frå genetikk, biokjemi, fysiologi, immunologi og/eller epidemiologi. Dei oppstår gjerne hos enkeltpersonar eller grupper som står i utkanten eller på sida av det etablerte fagmiljøet. Enkelte populære retningar, for eksempel den som er basert på glykemisk indeks, har eit betre vitskapeleg fundament og har vakt stor interesse i mange fagmiljø. Det er likevel eit godt stykke fram til at det denne teorien eventuelt har å seie, kan få konsekvensar for generelle kosthaldstilrådingar.

Dei fleste motediettar og populære teoriar har derimot til felles at dei fører til eit sunnare kosthald for mange av dei som er villige til å endre livsstil. At folk føler seg betre, er derfor ikkje uventa, men i seg sjølv ikkje noko kriterium som kan danne grunnlag for offisielle tilrådingar (Meltzer, 2004).

\section{Inntak av vitamin og mineral - ernæringsmanglar}

Eit kosthald i tråd med helsestyresmaktene sine tilrådingar gjer at dei fleste får i seg det dei treng av næringsstoff, inkludert vitamin og mineral, gjennom maten dei et.

I enkelte tilfelle kan det likevel vere nødvendig med kosttilskot, eksempel er personar som et lite, eller som av ulike grunnar utelèt viktige matvaregrupper frå kosthaldet.

Kosttilskot er produkt som gir ei konsentrert tilføring av eitt eller fleire næringsstoff, for eksempel vitamin og mineral. Nedanfor omtaler vi dei vitamina og minerala som det oftast oppstår mangel på i Noreg.

\section{D-vitamin}

Tilrådd dagleg inntak av D-vitamin i dei nordiske landa er $10 \mu \mathrm{g}$ (400 IE) for barn og vaksne opp til 74 år, og $20 \mu \mathrm{g}$ (800 IE) for vaksne på 75 år og eldre (Nordisk råd, 2012). Etter tilråding frå Helsedirektoratet blir smør og margarin tilsett D-vitamin.

Status: Syntese i huda ved soleksponering og feite fiskeprodukt er dei viktigaste kjeldene til D-vitamin. Feite fiskeprodukt bidreg med 40 prosent av D-vitamin i norsk kosthald.

Smør og margarin er tilsett D-vitamin, og desse matvarene bidreg med 30 prosent av D-vitamin i det norske kosthaldet (Helsedirektoratet, 2012; 2013). 
Den norske gjennomsnittskosten består av mindre D-vitamin enn tilrådd (Helsedirektoratet, 2012).

Unge jenter, institusjonaliserte eldre samt ikkjevestlege innvandrarar er i risikogruppene for å kunne mangle D-vitamin, og mange nordmenn har låge nivå i vinterhalvåret (Helsedirektoratet, 2013); (Holvik, 2008).

Konsekvensar av lågt inntak: Kronisk alvorleg D-vitaminmangel gir rakitt hos barn og osteomalaci hos vaksne med alvorlege konsekvensar for skjelettet, mens låge nivå av D-vitamin òg er ein risikofaktor for osteoporose (sjå kapittelet Muskel- og skjelettsjukdomar og -plager). Låg D-vitaminstatus er forbunde med høgare dødelegheit (Chowdhury, 2014). I mange tilfelle kan D-vitaminmangel vere ein markør for dårleg helse og ikkje direkte årsak til sjukdom.

For risikogruppa unge jenter, institusjonaliserte eldre samt ikkje-vestlege innvandrarar kan kosttilskot vere nødvendig for å klare å dekkje D-vitaminbehovet. Personar som får lite sol, og/eller som et lite fisk og matvarer tilsett D-vitamin, kan òg ha behov for D-vitamintilskot.

\section{Folat}

Tilråding for gravide: Helsedirektoratet tilrår at kvinner som planlegg å bli gravide, eller som kan rekne med å bli gravide, tek eit tilskot på $400 \mu \mathrm{g}$ folat dagleg. Tilskotet skal takast siste månaden før graviditet og dei første 2-3 månadene i graviditeten (Helsedirektoratet, 2004).

Status: Tal frå Medisinsk fødselsregister viser at berre 27 prosent av norske kvinner tek tilskot av B-vitaminet folat før dei blir gravide.

Konsekvensar av lågt inntak: Folat er eit B-vitamin som er spesielt viktig før og i starten av graviditeten. Tilskot av folat kan førebyggje ryggmargsbrokk og andre liknande alvorlege medfødde misdanningar (De-Regil, 2010).

Kvart år blir om lag 60 kvinner gravide med eit barn som har ryggmargsbrokk eller ein annan alvorleg nevralrøyrsdefekt. Talet kan truleg halverast dersom kvinner tek folattilskot allereie før dei blir gravide, og held fram med det i starten av svangerskapet (FHI, faktaark folat).

Forsking basert på Den norske mor og barn-undersøkinga tyder på at det å ta folattilskot i vekene før og i starten av svangerskapet også kan redusere risikoen for utviklingsforstyrringar hos barna (FHI, faktaark folat).

\section{Jod}

Tilrådd dagleg inntak er $150 \mu \mathrm{g} / \mathrm{dag}$ for vaksne (Helsedirektoratet, 2014). Alle som ikkje får i seg mjølkeprodukt og fisk, eller som får i seg lite mjølkeprodukt og fisk i kosthaldet, bør ta tilskot som inneheld jod. Det gjeld spesielt kvinner som planlegg å bli gravide (Brantsaeter, 2013).

Status: Mjølk og mjølkeprodukt er den viktigaste kjelda til jod i det norske kosthaldet, fordi jod som er tilsett i kraftfôr, går over i mjølka (Dahl, 2004). Eit kosthald med fisk 2-3 gonger i veka og dagleg inntak av mjølkeprodukt dekkjer behovet for jod.

I Noreg har ein til no vurdert det slik at eit vanleg kosthald gir nok jod. No ser vi derimot teikn på at vi får i oss mindre jod gjennom kosthaldet enn før, og dette gjeld spesielt unge kvinner som et lite fisk og mjølk/ mjølkeprodukt.

Konsekvensar av lågt inntak: Jod er eit grunnstoff som er sentralt for at skjoldbruskkjertelen skal fungere normalt. I mange land kan jodmangel vere ei årsak til nedsett mental utvikling hos barn.

\section{Jern}

Tilrådd dagleg inntak av jern er avhengig av alder og er høgare for kvinner (15 mg/dag) enn menn (9 mg/dag) (Helsedirektoratet, 2014).

Status: 15 prosent av norske kvinner i fertil alder har tomme jernlager (Borch-lohnsen, 2005).

Konsekvensar av lågt inntak: Jern er eit grunnstoff som er spesielt viktig for oksygentransporten i blodet, men har òg ei rekkje andre funksjonar i kroppen. Jernmangel, eller anemi, er ein tilstand som utgjer eit alvorleg helseproblem i store delar av verda. I utviklingsland kjem jernmangel hovudsakleg av underernæring, men infeksjonssjukdomar, spesielt HIVinfeksjon og gastrointestinale infeksjonar, og mange barnefødslar kan føre til store jerntap. I industrialiserte land er ikkje desse problemstillingane særleg aktuelle. Likevel kan spesielt yngre kvinner ha låg jernstatus, fordi dei får i seg lite jern og mister blod ved menstruasjon.

Kvinner med store menstruasjonsblødingar, gravide og ammande kan vere utsette for jernmangelanemi, men òg små barn og eldre som får i seg lite kaloriar, vegetarianarar samt personar med einsidig kosthald eller personar som slankar seg, står i faresona for å utvikle alvorleg jernmangel. 


\section{Treng vi andre typar kosttilskot?}

Andre typar kosttilskot er produkt som blir hevda å verke slankande eller å bidra til auka muskelmasse og prestasjonsevne. Det finst ingen vitskapelege haldepunkt for at slike kosttilskot verkar slik det blir hevda, eller at det å få i seg næringsstoff frå kosttilskot over lang tid reduserer risikoen for sjukdomar som hjarteog karsjukdomar og kreft. Tvert imot er det funne at høgt inntak av tilskot kan gi helseskader (Helsedirektoratet, 2014). Norske styresmakter åtvarar spesielt mot å kjøpe kosttilskot via Internett (Statens legemiddelverk, 2014).

\section{Miljøgifter}

I dag blir barn fødde med fleire hundre framandstoff i blodet som dei får overført frå mora under svangerskapet. Etter fødselen blir barna ytterlegare eksponerte for miljøgifter via mat og miljø.

Sjølv om nivåa er låge og for mange stoff har gått ned dei siste tiåra, dukkar det stadig opp nye stoff som vi ikkje veit korleis verkar inn på helsa (Meltzer, 2013).

Befolkningsstudiar i Noreg har vist at grupper i befolkninga som et utsette matvarer, for eksempel fiskelever og måkeegg, har høgare risiko for å få i seg for mykje av desse stoffa (Birgisdottir, 2012).

Dersom vi skal få betre oversikt over befolkninga si helse, føreset det at vi kjenner til kva slags helseskadelege sambindingar som finst i miljøet, og i kva grad menneske blir eller kan bli eksponerte for dei. Folkehelseinstituttet skal frå 2014 leie eit overvakingsprogram for miljøgifter i den norske befolkninga, der merksemda blir retta spesielt mot miljøgifter vi får i oss gjennom kosthaldet.

\section{Norsk kosthald i eit inter- nasjonalt perspektiv}

Tidlegare har det vore vanskeleg å samanlikne kosthald mellom land på grunn av ulike metodar for innhenting av data og liten standardisering. Men i dag er samordninga komme langt innanfor Europa, og ei rekkje samanliknande studiar kjem truleg til å bli publiserte i åra framover.

Så langt har dei viktigaste samanliknande studiane komme frå den store EPIC-studien (the European Prospective Investigation into Cancer and Nutrition), der ti ulike land inngår. Her har ein kunna studere forskjellar i kostmønster mellom europeiske land med same metodikk. Dette er det ein har sett:
- Dei skandinaviske landa skil seg frå land lengre sør i Europa ved at vi har eit mykje høgare konsum av kaffi og margarin.

- Det norske kosthaldet utmerkjer seg ved at vi får i oss mykje leskedrikkar, poteter og fisk, særleg mager fisk og fiskeprodukt, og ved at vi har blant dei lågaste inntaka av frukt, grønsaker, vegetabilske oljer og belgvekstar (Freisling, 2010; Slimani, 2002).

Dei fleste publikasjonane som samanliknar kosthaldet i landa innanfor EPIC, er derimot over ti år gamle, og dei norske dataa omfattar berre kvinner. Det skjer endringar i kosthaldet heile tida, og som omtala i tidlegare avsnitt har det norske konsumet av sukra leskedrikkar gått kraftig ned dei siste åra, mens forbruket av for eksempel vegetabilske oljer har auka.

- I framtidige samanliknande studiar kjem vi med høgt sannsyn til å finne mindre forskjellar mellom europeiske land enn for berre nokre tiår sidan.

\section{Utfordringar}

Kosthaldet er viktig for å førebyggje fleire kroniske sjukdomar. Vi treng både systematiske tiltak retta mot heile befolkninga, tiltak retta mot spesielle grupper samt individuelle tiltak for at befolkninga skal kunne sikrast eit balansert kosthald utan ernæringsmessige manglar.

Vi må overvake mengda helseskadelege miljøstoff i matvarene, slik at det kan utformast råd også på dette området.

\section{Referansar}

Birgisdottir, B. E., Brantsaeter, A. L., Kvalem, H. E., Knutsen, H. K., Haugen et al. (2012). Fish liver and seagull eggs, vitamin D-rich foods with a shadow: results from the Norwegian Fish and Game Study. Mol Nutr Food Res, 56(3), 388-398. Doi: 10.1002/mnfr.201100395

Borch-Iohnsen, B., Sandstad, B., \& Åsberg, A. (2005). Iron status among 3005 women aged 20-55 years in Central Norway: the Nord-Trondelag Health Study (the HUNT Study). Scand.J.Clin.Lab.Invest., 65(1), 45-54.

Brantsaeter, A. L., Abel, M. H., Haugen, M., \& Meltzer, H. M. (2013). Risk of suboptimal iodine intake in pregnant Norwegian women. Nutrients, 5(2), 424-440. Doi: 10.3390/ nu5020424

Chowdhury, R., Kunutsor, S., Vitezova, A., Oliver-Williams, C., Chowdhury, S. et al. (2014). Vitamin D and risk of cause specific death: systematic review and meta-analysis of observational cohort and randomised intervention studies. BMJ, 348, g1903. Doi: 10.1136/bmj.g1903 
Dahl, L., Johansson, L., Julshamn, K., \& Meltzer, H. M. (2004) The iodine content of Norwegian foods and diets. Public Health Nutr, 7(4), 569-576.

De-Regil, L. M., Fernandez-Gaxiola, A. C., Dowswell, T., \& Pena-Rosas, J. P. (2010). Effects and safety of periconceptional folate supplementation for preventing birth defects. Cochrane Database Syst Rev(10), Cd007950. Doi: 10.1002/14651858.CD007950.pub2

Englund-Ogge, L., Brantsaeter, A. L., Haugen, M., Sengpiel, V., Khatibi, A. et al. (2012). Association between intake of artificially sweetened and sugar-sweetened beverages and preterm delivery: a large prospective cohort study. Am J Clin Nutr, 96(3), 552-559. Doi: 10.3945/ajcn.111.031567

Freisling, H., Fahey, M. T., Moskal, A., Ocke, M. C., Ferrari, P. et al. (2010). Region-specific nutrient intake patterns exhibit a geographical gradient within and between European countries. J Nutr, 140(7), 1280-1286. Doi: 10.3945/ jn.110.121152

Fund/, W. C. R., \& Research, A. I. f. C. (2007). Food, Nutrition, Physical Activity, and the Prevention of Cancer: a Global Perspective. Washington DC: AICR.

Helsedirektoratet. (2004). Folat. Oslo, Norge: Helsedirektoratet.

Helsedirektoratet. (2012). Norkost 3. En landsomfattende kostholdsundersøkelse blant menn og kvinner i Norge i alderen 18 - 70 år, 2010-11. Oslo: Helsedirektoratet.

Helsedirektoratet. (2013). Utviklingen i norsk kosthold. Oslo: Helsedirektoratet.

Helsedirektoratet. (2014). Anbefalinger om kosthold, ernæring og fysisk aktivitet. Oslo, Norge: Helsedirektoratet.

Holvik, K., L. Brunvand, M. Brustad \& H. E. Meyer. (2008). Vitamin D status in the Norwegian population. Oslo, Norway: The Norwegian Academy of Science and Letters.

Kjollesdal, M. R., Holmboe-Ottesen, G., Mosdol, A., \& Wandel, M. (2010). The relative importance of socioeconomic indicators in explaining differences in $\mathrm{BMI}$ and waist:hip ratio, and the mediating effect of work control, dietary patterns and physical activity. Br J Nutr, 104(8), 1230-1240. Doi: 10.1017/s0007114510001868
Meltzer, H. M., Brandtzæg, P., Knutsen, H. K., Løland, B. F., Odland, J. O. et al. (2013). Benefit and risk assessment of breastmilk for infant health in Norway - opinion of the Steering Committee of the Norwegian Scientific Committee for Food Safety Vitenskapskomiteen for mattrygghet, 299.

Meltzer, H. M., Meyer, H. E., \& Klepp, K.-I. (2004). Fra hypotese til kostråd - veier, snarveier og blindveier. Tidsskr Nor Lægeforen, 124(9), 30-32.

Nordisk Ministerråd. Nordic nutrition recommendations 2012: integrating nutrition and physical activity. København: Nordisk Ministerråd; 2014.

Slimani, N., Fahey, M., Welch, A. A., Wirfalt, E., Stripp, C. et al. (2002). Diversity of dietary patterns observed in the European Prospective Investigation into Cancer and Nutrition (EPIC) project. Public Health Nutr., 5(6B), 1311-1328.

Statens legemiddelverk. (2014). Kjøp av medisiner på internett. Tilgjengelig på Legemiddelverket.no

Totland, T. H., Lien, N., Bergh, I. H., Bjelland, M., Gebremariam, M. K. et al. (2013). The relationship between parental education and adolescents' soft drink intake from the age of 11-13 years, and possible mediating effects of availability and accessibility. Br J Nutr, 110(5), 926-933. Doi: 10.1017/s0007114512005946

von Ruesten, A., Brantsaeter, A. L., Haugen, M., Meltzer, H. M., Mehlig et al. (2014). Adherence of pregnant women to Nordic dietary guidelines in relation to postpartum weight retention: results from the Norwegian Mother and Child Cohort Study. BMC Public Health, 14(1), 75. doi: 10.1186/1471-2458-14-75

WHO. Diet, nutrition and the prevention of chronic diseases. Geneva: World Health Organization; 2003, rapport: 916.

\section{FORFATTARAR}

Helle Margrete Meltzer, Anne Lise Brantsæter, Margaretha Haugen, Kristin Holvik 


\section{Overvekt og fedme}

- Eitt av seks barn har overvekt eller fedme.

- Éin av fem vaksne har fedme.

- Overvekt og fedme aukar risikoen for type 2-diabetes og ei rekkje andre kroniske sjukdomar.

- Overvekt og fedme har auka i befolkninga dei siste tiåra, men det er teikn til at utviklinga har flata ut hos barn.

\section{Om overvekt og fedme}

Kroppsmasseindeks (KMI) fungerer godt som mål for overvekt og fedme i ei befolkning og er det målet ein vanlegvis bruker for å omtale vektforhold i befolkninga. Når det blir brukt på enkeltpersonar, kan det vere misvisande, for eksempel kjem personar med mykje muskulatur og personar som har tapt kroppshøgde, til å få «for høg» KMI.

Det er ikkje likegyldig kvar på kroppen feittet sit, og bukfedme ser ut til å hengje sterkare saman med sjukdomar som type 2-diabetes og hjarte- og karsjukdomar enn generell fedme.

\section{Status for overvekt og fedme}

\section{Eitt av seks barn har overvekt eller fedme.}

Resultat frå ulike helseundersøkingar blant barn i Noreg viser at

- mellom 15 og 20 prosent av barn har overvekt/ fedme (Dvergsnes 2009, Juliusson, 2007, Kolle 2009, Barnevekststudien)

- åtte prosent av tredjeklassingane har bukfedme (Barnevekststudien)

\section{Éin av fire ungdomar er overvektige} Resultat frå Helseundersøkelsen i Nord-Trøndelag (HUNT) i 2006-2008 (Krokstad, 2011) viser at

- 22 prosent av gutane og 20 prosent av jentene i ungdomsskulen er overvektige

- 27 prosent av gutane og 25 prosent av jentene i vidaregåande er overvektige

\section{Éin av fem vaksne har fedme}

Helseundersøkingar i Noreg (figur 1) etter år 2000 med målt høgd og vekt viser dette:

- Omkring 20 prosent av mennene og 17 prosent av kvinnene i alderen 40-45 år har fedme $\left(\mathrm{KMI} \geq 30 \mathrm{~kg} / \mathrm{m}^{2}\right)$.

- Det er totalt sett fleire menn enn kvinner som har fedme, men prosentdelen med grad 2 eller grad 3 fedme $\left(\mathrm{KMl} \geq 35 \mathrm{~kg} / \mathrm{m}^{2}\right)$ er høgare hos kvinner enn hos menn (5 prosent hos kvinner og 3,5 prosent hos menn).

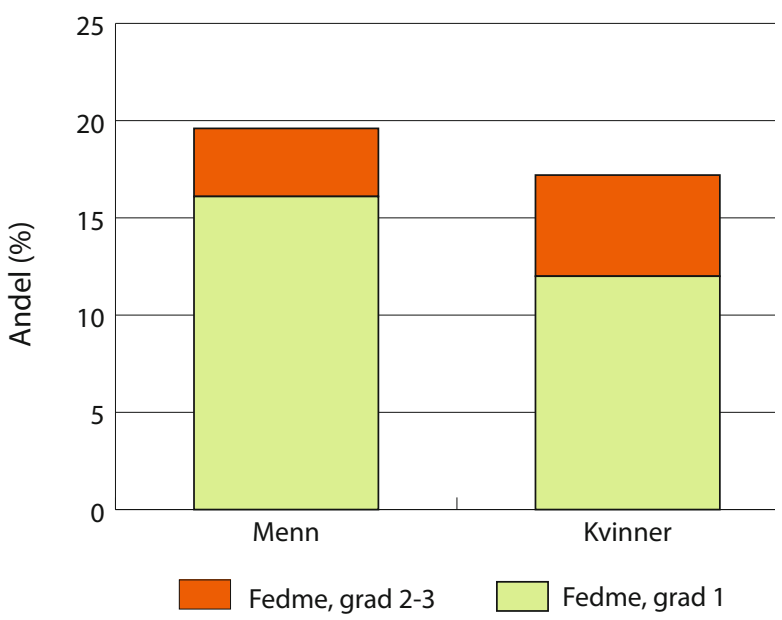

Figur 1: Prosentdel (\%) menn og kvinner 40-45 år med fedme i sju fylke. Grønt viser prosentdel med grad 1 fedme (BMI 30-34,9), og raudt viser prosentdel med grad 2 eller 3 fedme (KMI $\geq 35)$. Kjelder: Helseundersøkingane i Oslo (2000/01), Hedmark (2000/01), Oppland (2001), Troms (2001/3), Finnmark (2002/3), Tromsø (2007/8, Jacobsen, upubliserte data) og Nord-Trøndelag (2008, Midthjell, upubliserte data). 


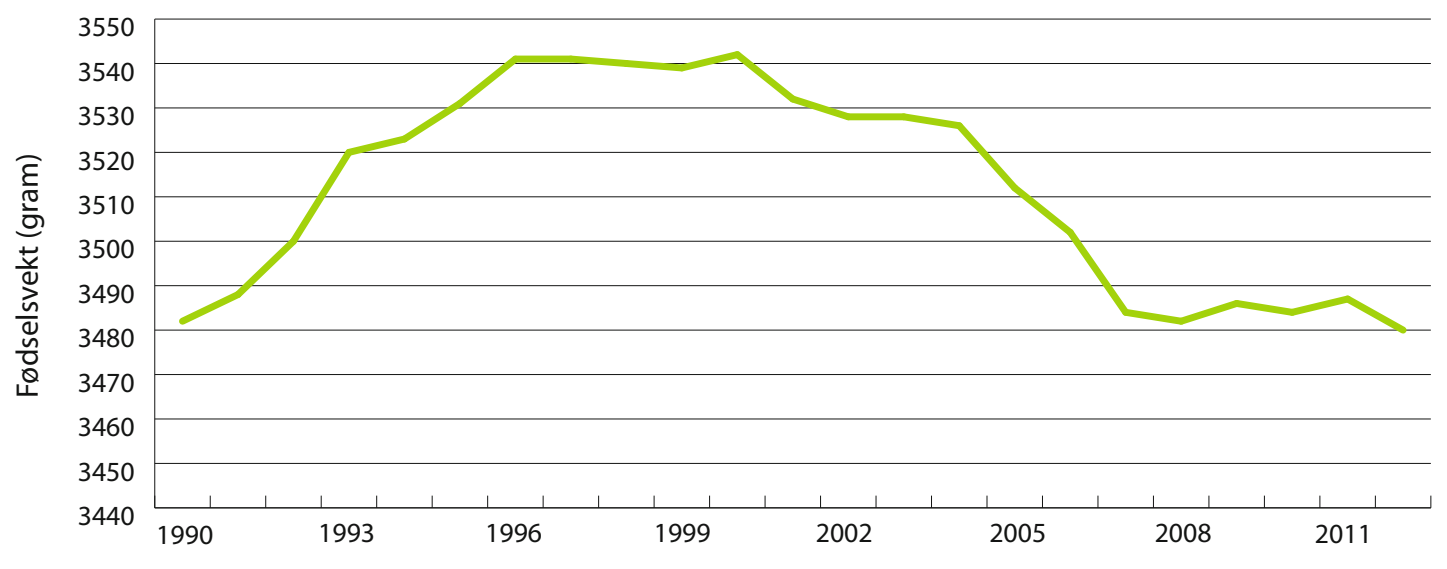

Figur 2: Gjennomsnittleg fødselsvekt 1990-2012. Datakjelde: Medisinsk fødselsregister.

- Dersom vi bruker prosentdelane over på heile befolkninga i aldersgruppa 40-49 år, har 32500 personar $\mathrm{KMI} \geq 35 \mathrm{~kg} / \mathrm{m}^{2}$ (grad 2 eller grad 3 fedme).

Data frå HUNT-studien tyder på at det blant vaksne med $\mathrm{KMI} \geq 35 \mathrm{~kg} / \mathrm{m}^{2}$ er nærmare halvparten (40-50 prosent) som har sjukleg fedme (definert som følgjesjukdomar eller $\mathrm{KMI} \geq 40 \mathrm{~kg} / \mathrm{m}^{2}$ ) (personleg kommunikasjon, Kristian Midthjell).

\section{Utvikling over tid}

\section{Barn}

Tal frå Medisinsk fødselsregister viser at den gjennomsnittlege fødselsvekta gjekk opp, med ein topp rundt år 2000, men at ho sidan har gått ned og no er tilbake på 1990-nivå (sjå figur 2).

Mykje tyder på at prosentdelen overvektige barn i stor grad auka i Noreg fram mot starten av 2000-talet (Juliusson, 2007). Det siste tiåret ser det derimot ut til at prosentdelen skulebarn med overvekt og fedme har forandra seg lite, og resultat frå Barnevekststudien ved Folkehelseinstituttet (Barnevekststudien) viser desse resultata for perioden 2008-2012:

- Prosentdelen tredjeklassingar med overvekt, inkludert fedme, har helde seg stabil, med eit gjennomsnitt på 16 prosent (sjå figur 3).

- Prosentdelen tredjeklassingar med bukfedme har endra seg lite, med eit gjennomsnitt på åtte prosent.

Nye nasjonale målingar i Barnevekststudien i 2015 kjem til å gi sikrare haldepunkt for utviklinga av overvekt og bukfedme blant norske barn.
Forsking kan tyde på at den gjennomsnittlege livvidda har auka i større grad enn den gjennomsnittlege kroppsmasseindeksen (KMI) over ein lengre tidsperiode (McCarthy, 2005), også i Noreg (Kolle, 2009).

Bukfedme (abdominal fedme) er sett i samanheng med auka risiko for metabolsk sjukdom, også hos barn (Maffeis, 2008).

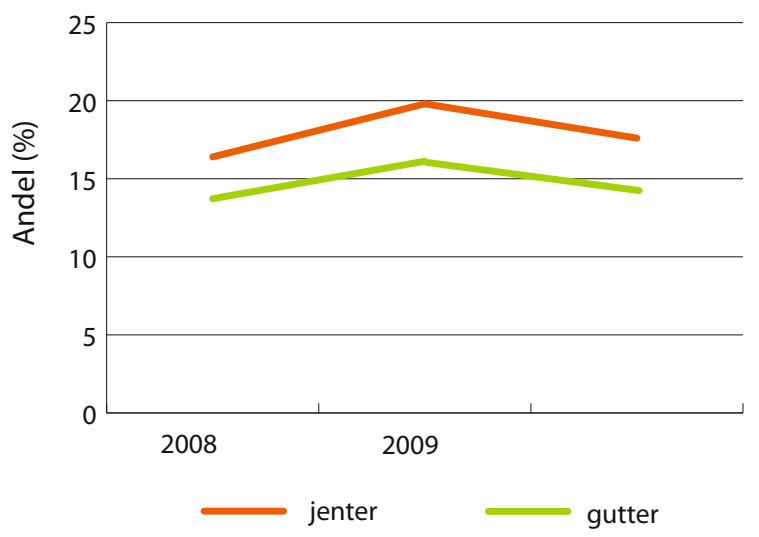

Figur 3: Prosentdel (\%) gutar og jenter i tredjeklasse (8-9-åringar) som er overvektige eller har fedme. Kjelde: Barnevekststudien 2008, 2010 og 2012, Folkehelseinstituttet.

\section{Ungdom}

Vi har ikkje systematiske nasjonale målingar som kan vise utviklinga av overvekt blant ungdom over tid. Data frå Helseundersøkelsen i Nord-Trøndelag (HUNT) rapporterer likevel om ei urovekkjande utvikling av overvekt, inkludert fedme, blant ungdom i aldersgruppa 13-18 år i perioden 1968 til 2008.

\section{Vaksne}

På slutten av 1960-talet hadde berre ca. fem prosent av norske middelaldrande menn fedme. Etter dette auka den gjennomsnittlege vekta kontinuerleg fram til tusenårsskiftet. Auken var særleg kraftig på slutten av 
1990-talet. Hos kvinner blei prosentdelen med fedme redusert frå 13 til 7 prosent i perioden frå 1960-talet til slutten av 1970-talet. Deretter har vekta auka på same måte som hos menn (Meyer \& Tverdal, 2005).

Dei siste åra har det vore utført få helseundersøkingar blant vaksne, og det er derfor vanskeleg å seie korleis vektutviklinga har vore i denne perioden. Basert på data frå Tromsøundersøkelsen ser det likevel ut til at auken i førekomsten av fedme hos menn, men ikkje hos kvinner, har vore meir moderat i perioden 2001 til 2008 samanlikna med åra før (sjå figur 4).

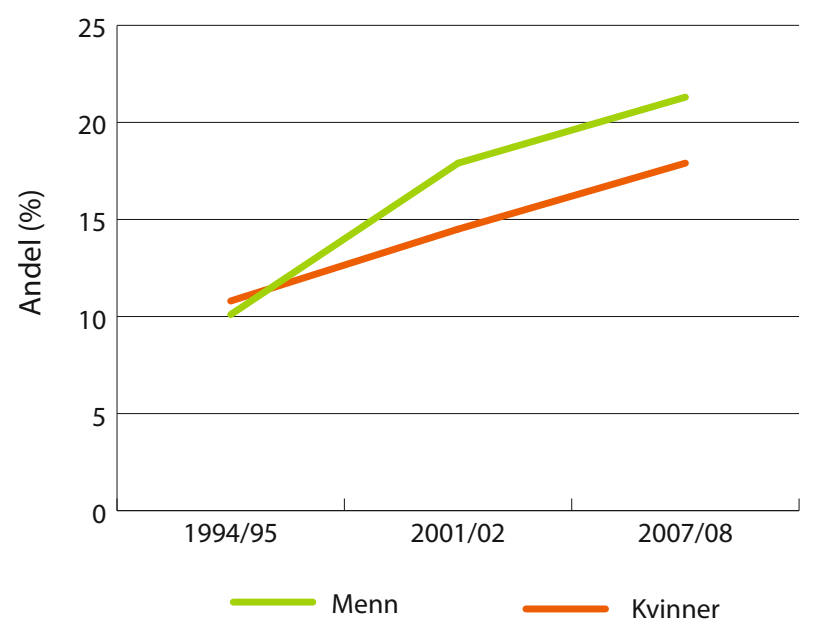

Figur 4: Prosentdel med fedme (BMI $\geq 30 \mathrm{~kg} / \mathrm{m} 2)$ i Troms $\varnothing$ undersøkelsene. Menn og kvinner 30-69 år. Aldersjusterte tal. Kjelde: Koster Jacobsen, upubliserte data.

\section{Forskjellar i befolkninga}

\section{Mindre fedme i urbane strøk}

Førekomsten av fedme er lågare i byane enn på landsbygda, særleg hos kvinner.

Data frå Barnevekststudien viser at førekomsten av overvekt er 50 prosent høgare blant barn på landsbygda samanlikna med barn i byar. Prosentdelen med bukfedme følgjer det same mønsteret (Biehl 2013). I tillegg er førekomsten av overvekt (inkludert fedme) høgast i Helseregion Nord og lågast i Helseregion Sør-Øst (Barnevekststudien).

\section{Forskjellar blant innvandrar- befolkninga}

Førekomsten av fedme er høg blant innvandrarar frå Pakistan og Tyrkia, men låg blant innvandrarar frå Vietnam. Kvinner frå Sri Lanka og Pakistan har mest bukfedme og høgast førekomst av diabetes (Jenum, 2012).

\section{Sosioøkonomiske forskjellar}

Det er sosioøkonomiske forskjellar i førekomsten av fedme og overvekt. Tidlegare norske studiar viste at prosentdelen med fedme var lågare blant 40-åringar med høg utdanning enn hos 40-åringar med lågare utdanning (Meyer \& Tverdal, 2005). I Oslo var den vaksne befolkninga tyngre i austlege enn i vestlege bydelar, særleg gjaldt dette kvinner (Helseunders $\varnothing$ kelsen i Oslo 2000-2001).

Data frå Barnevekststudien viser at det også hos barn er sosioøkonomiske skiljeliner for overvekt og fedme. Analysar av data frå Barnevekststudien 2010 viser at prosentdelen med overvekt er 30 prosent høgare blant barn av mødrer med låg utdanning enn blant barn av mødrer med høg utdanning. Prosentdelen med bukfedme følgjer det same mønsteret (Biehl 2013).

\section{Internasjonalt}

\section{Nord-sørgradient for overvekt blant barn i Europa}

Barnevekststudien ved Folkehelseinstituttet er ein del av WHO European Childhood Obesity Surveillance Initiative (Wijnhoven, 2013). Resultat frå ulike land $\mathrm{i}$ Europa viser at det går ein klar nord-sørgradient der land i sørlege delar av Europa har ein mykje større prosentdel barn med overvekt (inkludert fedme) samanlikna med barn i Noreg og andre nordiske land (sjå tabell 1).

\section{Vanskeleg å samanlikne land}

Vektauken som vi har sett blant vaksne i Noreg, er ein del av ein internasjonal trend. Ein ny rapport viser derimot ei stabilisering av vekta i perioden 2003 til 2012 i USA (Ogden, 2014).

Det er vanskeleg å rangere nøyaktig kvar Noreg ligg i det internasjonale biletet, på grunn av ulike metodar og ulik kvalitet i dei undersøkingane som ligg til grunn for samanlikningane. Det ser ut til at førekomsten av fedme blant vaksne er lågare i Noreg enn i mange andre land (OECD, 2012).

\section{Inaktivitet og høgt energiinntak aukar risikoen for overvekt og fedme}

På befolkningsnivå er det endringar i miljøforhold, og ikkje endringar i genar, som kan forklare dei store endringane vi har sett i vekta i den norske befolkninga dei seinare tiåra. Vi lever i eit samfunn som oppmuntrar til fysisk inaktivitet, og som har eit stort og freistande mattilbod. 
Tabell 1: Prosentdel gutar og jenter med overvekt (inkludert fedme) etter alder og land. (1) Basert på grenseverdiar sett av IOTF. Kjelde: (Wijnhoven, 2013).

\begin{tabular}{|c|c|c|c|}
\hline Land & Aldersgruppe & $\begin{array}{l}\text { Andel med overvekt } \\
\text { (inkludert fedme) }{ }^{1} \\
(\%)\end{array}$ & $\begin{array}{c}\text { Andel med overvekt } \\
{\text { (inkludert fedme) }{ }^{1}}^{(\%)}\end{array}$ \\
\hline & 7-åringar & Gutar & Jenter \\
\hline Sverige & & 14,6 & 17,8 \\
\hline Latvia & & 15,3 & 15,1 \\
\hline Litauen & & 16,1 & 16,2 \\
\hline Irland & & 21,1 & 22,8 \\
\hline Belgia & & 15,2 & 19,4 \\
\hline Tsjekkia & & 15,8 & 14,7 \\
\hline Slovenia & & 24,2 & 22,0 \\
\hline Bulgaria & & 20,1 & 24,2 \\
\hline \multirow[t]{2}{*}{ Portugal } & & 26,8 & 28,5 \\
\hline & 8-åringar & & \\
\hline Noreg & & 13,5 & 17,4 \\
\hline Sverige & & 17,4 & 17,9 \\
\hline Belgia & & 13,9 & 17,4 \\
\hline Slovenia & & 25,2 & 25,6 \\
\hline Italia & & 37,2 & 34,7 \\
\hline
\end{tabular}

Dette er to av forholda som bidreg til auka risiko for overvekt og fedme:

- Det er godt dokumentert at inaktivitet aukar risikoen for overvekt og fedme, og at risikoen blir redusert ved regelmessig fysisk aktivitet (NNR5, 2014).

- Mens matvarer med låg energitettleik ofte er rike på fiber og vatn (for eksempel grønsaker og mange typar frukt), inneheld matvarer med høg energitettleik oftare mykje feitt og tilsett sukker.

Dersom vi skal halde ei stabil vekt, må inntaket av mat og drikke balanserast av energiforbruket gjennom fysisk aktivitet. Det er mange forhold hos den enkelte som kan verke inn på energibalansen, m.a. arvelege forhold. Derfor har enkelte større problem med å halde vekta enn andre.

Amming reduserer risikoen for overvekt og fedme hos barn og unge, mens samanhengen mellom amming og overvekt og fedme hos vaksne er noko mindre sikker (NNR5).

\section{Samanheng mellom psykiske vanskar og overvekt}

Kunnskapsoppsummeringar av store befolkningsstudiar viser ei overhyppigheit av psykiske plager som angst og depresjon i gruppa med fedme (de Wit, 2010).
Longitudinelle studiar har vist at angst og depresjon verkar inn på risikoen for seinare overvekt, samt at fedme kan føre til angst og depresjon (Berkowitz \& Fabricatore, 2011).

Psykiske vanskar kan verke inn på både appetitt, vilje og sjølvkontroll, som alle er viktige faktorar for å forklare utviklinga av fedme. Personar som er ramma av angst, depresjon og psykosar, er òg meir sårbare for å oppleve stress og hjelpeløyse når dei møter utfordringar. Dette kan føre til trøsteeting, spesielt av smakfull mat som er rik på feitt, sukker eller salt.

Inntak av legemiddel kan òg forklare ein del av samanhengen mellom overvekt og psykiske plager. Ein av dei vanlegaste biverknadene av medisinar mot alvorlege psykiske plager er forandringar i hjernemekanismar som styrer matlyst og stoffskifte, som i sin tur kan føre til kraftig vektauke (Carlat, 2012; Ferno, 2011) 


\section{Helserisiko knytt til fedme}

Fedme hos vaksne aukar risikoen for ei rekkje sjukdomar og plager (Helsedirektoratet):

- type 2-diabetes

- hjarte- og karsjukdomar

- visse typar kreft (spiserøyr, bukspyttkjertel, tjukk- og endetarm, bryst (etter overgangsalderen), livmor, nyre)

- pustestopp om natta (søvnapné)

- slitasjegikt i hofter og kne

- stigmatisering, psykiske plager og mistrivsel

Risikoen for beinskjørheit og -brot er lågare hos overvektige enn hos tynne. Hos eldre finn vi lågast dødelegheit ved ein noko høgare BMI enn hos yngre, og hos dei eldste er låg vekt ei stor helseutfordring (Kvammet, 2011).

Det finst ei rekkje andre faktorar enn vekt og vektutvikling som kjem til å ha mykje å seie for korleis helsetilstanden utviklar seg i den norske befolkninga i åra som kjem. Eit sunt kosthald og fysisk aktivitet er førebyggjande, mens røyking utgjer ein tilleggsrisiko.

Trass i at vekta i befolkninga har gått opp, har hyppigheita av hjarte- og karsjukdomar gått ned. Ei av årsakene til dette kan vere at vi samtidig har hatt ei gunstig utvikling med omsyn til kolesterol og andre feittstoff $i$ blodet, ein nedgang i blodtrykket og færre som røyker. Heilt nye tal indikerer likevel at nedgangen i hjarte- og karsjukdomar er ferd med å snu hos dei yngste (Sulo, 2013). Dette kan tyde på at den gunstige utviklinga av dei andre risikofaktorane har stoppa opp, og at den samla (totale) risikoen har auka i denne gruppa. Sjå elles kapittelet om hjarte- og karsjukdomar.

\section{Moglegheiter for å førebyggje på befolkningsnivå}

For å kunne gjere noko med overvekt og fedme på samfunnsnivå er det viktig med både befolkningsretta og individretta tiltak. Vi treng innsats frå mange aktørar, inkludert det offentlege, matvareindustrien, tilbydarar av mat og drikke, osv. Barn og unge er spesielt utsette og prisgitt omgivnadene sine i familien, barnehagen, skulen og nærmiljøet.

Internasjonalt ser vi ein aukande diskusjon om kva folkehelsetiltak som kan og bør brukast for å klare å redusere vektauken i samfunnet. Befolkningsretta tiltak som blir diskuterte i Noreg, er betre tilrettelegging for fysisk aktivitet i skulen og samfunnet elles samt redusert tilgang på energitette, men næringsfattige matvarer, for eksempel søte drikkar. Tiltak på samfunnsnivå kan nå fleire og vere meir effektive enn det å berre satse på det mest kjente individretta tiltaket, som er å oppfordre enkeltpersonar til å halde kontroll på vekta.

\section{Referansar}

Berkowitz, R. I. and A. N. Fabricatore (2011). Obesity, psychiatric status, and psychiatric medications. Psychiatr Clin North Am 34(4): 747-764.

Biehl, A., R. Hovengen, E. K. Groholt, J. Hjelmesaeth, B. H. Strand and H. E. Meyer (2013). Adiposity among children in Norway by urbanity and maternal education: a nationally representative study. BMC Public Health 13: 842.

Carlat, D. (2012). Evidence-based somatic treatment of depression in adults. Psychiatr Clin North Am 35(1): 131-142.

Cole, T. J., M. C. Bellizzi, K. M. Flegal and W. H. Dietz (2000). Establishing a standard definition for child overweight and obesity worldwide: international survey. Bmj 320(7244): 1240-1243.

de Wit, L., F. Luppino, A. van Straten, B. Penninx, F. Zitman and P. Cuijpers (2010). Depression and obesity: a metaanalysis of community-based studies. Psychiatry Res 178(2): 230-235

Dvergsnes, K. and G. Skeie (2009). Utviklingen i kroppsmasseindeks hos fireåringer i Tromsø 1980-2005. Tidsskr Nor Laegeforen 129(1): 13-16.

Ferno, J., S. Skrede, A. O. Vik-Mo, G. Jassim, S. Le Hellard and V. M. Steen (2011). Lipogenic effects of psychotropic drugs: focus on the SREBP system. Front Biosci (Landmark Ed) 16: 49-60.

Folkehelseinstituttet. Barns vekst i Norge (Barnevekststudien). Hentet 7/4/2014. Resultater fra Barnevekststudien.

Helsedirektoratet. Nasjonal faglig retningslinje fore forebygging, utredning og behandling av overvekt og fedme hos voksne. Oslo, Helsedirektoratet. (2011).

Jenum, A. K., L. M. Diep, G. Holmboe-Ottesen, I. M. Holme, B. N. Kumar and K. I. Birkeland (2012). Diabetes susceptibility in ethnic minority groups from Turkey, Vietnam, Sri Lanka and Pakistan compared with Norwegians - the association with adiposity is strongest for ethnic minority women. BMC Public Health 12: 150. Pubmed.

Juliusson, P. B., M. Roelants, G. E. Eide, R. Hauspie, P. E. Waaler and R. Bjerknes (2007). Overweight and obesity in Norwegian children: secular trends in weight-for-height and skinfolds. Acta Paediatr 96(9): 1333-1337.

Kolle, E., J. Steene-Johannessen, I. Holme, L. B. Andersen and S. A. Anderssen (2009). Secular trends in adiposity in Norwegian 9-year-olds from 1999-2000 to 2005. BMC Public Health 9: 389.

Krokstad, S. and M. S. Knudtsen Folkehelse i endring: helseundersøkelsen Nord-Trøndelag : HUNT 1 (1984-86) - HUNT 2 (1995-97) - HUNT 3 (2006-08). Levanger, HUNT forskningssenter. (2011). 
Kvamme, J. M., J. Holmen, T. Wilsgaard, J. Florholmen, K. Midthjell and B. K. Jacobsen (2012). Body mass index and mortality in elderly men and women: the Tromso and HUNT studies. J Epidemiol Community Health 66(7): 611-617. Pubmed.

Maffeis, C., C. Banzato and G. Talamini (2008). Waist-toheight ratio, a useful index to identify high metabolic risk in overweight children. J Pediatr 152(2): 207-213.

McCarthy, H. D., K. V. Jarrett, P. M. Emmett and I. Rogers (2005). Trends in waist circumferences in young British children: a comparative study. Int J Obes (Lond) 29(2): 157-162.

Meyer, H. E. and A. Tverdal (2005). Development of body weight in the Norwegian population. Prostaglandines, Leukotrienes and Essential Fatty Acids 73(1): 3-7.

NNR5. Nordic nutrition recommendations 2012: integrating nutrition and physical activity. [København], Nordisk Ministerråd: 627 s. : fig. (2014).

OECD. Health at a Glance: Europe 2012. Overweight and obesity among adults. Hentet: juni 2014. OECD iLibrary
Ogden, C. L., M. D. Carroll, B. K. Kit and K. M. Flegal (2014). Prevalence of childhood and adult obesity in the United States, 2011-2012. JAMA 311(8): 806-814.

Sulo, G., J. Igland, O. Nygard, S. E. Vollset, M. Ebbing and G. S. Tell (2014). Favourable trends in incidence of AMI in Norway during 2001-2009 do not include younger adults: a CVDNOR project. Eur J Prev Cardiol. 21;1358-64.

Wijnhoven, T. M., J. M. van Raaij, A. Spinelli, A. I. Rito, R. Hovengen, M. Kunesova, G. Starc, H. Rutter, A. Sjoberg, A. Petrauskiene, U. O'Dwyer, S. Petrova, V. Farrugia Sant'angelo, M. Wauters, A. Yngve, I. M. Rubana and J. Breda (2013). WHO European Childhood Obesity Surveillance Initiative 2008: weight, height and body mass index in 6-9-year-old children. Pediatr Obes 8(2): 79-97.

\section{FORFATTARAR}

Haakon E. Meyer, Ragnhild Hovengen, Leila Torgersen og Margarete Vollrath 
- Nivåa av luftforureining i Noreg har det siste tiåret vore forholdsvis stabile. For svevestøv har det vore ein svak nedgang.

- Nivåa av luftforureiningar er som i andre skandinaviske land, men lågare enn i Sør-Europa.

- Luftforureining fører til at luftvegssjukdomar og hjarte- og karsjukdomar blir forverra.

- Mange luftforureinande komponentar utløyser dei same helseeffektane og verkar truleg saman.

- Det er særleg viktig å ha krav og setje inn tiltak mot trafikk og vedfyring for å kunne redusere luftforureininga.

\section{Om luftforureining}

Luftforureininga består av ei rekkje ulike stoff, avhengig av kva kjelder som bidreg til forureininga:

- svevestøv (storleiksfraksjonar)

$$
\begin{array}{ll}
\circ & \mathrm{PM}_{10} \\
\circ & \mathrm{PM}_{2,5} \text { (finfraksjon) } \\
\circ & \mathrm{PM}_{2,5-10} \text { (grovfraksjon) } \\
\circ & \mathrm{PM}_{0,1} \text { (ultrafinfraksjon) }
\end{array}
$$

- nitrogendioksid $\left(\mathrm{NO}_{2}\right)$

- bakkenær ozon

- svoveldioksid $\left(\mathrm{SO}_{2}\right)$

- karbonmonoksid (CO)

- metall som aluminium, arsen, bly, jarn, kadmium, kopar, krom, mangan, nikkel, sink og vanadium som finst i lufta bunde til svevestøv

- polysykliske aromatiske hydrokarbon (PAH) og andre organiske sambindingar som er danna ved ufullstendig forbrenning, og som kan vere bunde til svevestøv

- flyktige organiske sambindingar (VOC)

I dette kapittelet omtaler vi svevestøv, nitrogendioksid og ozon. Desse blir rekna for å vere dei viktigaste luftforureinande komponentane som fører til plager, sjukdom og død i vår del av verda.

\section{Luftforureining i Noreg i dag}

Figur 1A-B, 2A-B og 3 viser nivåa av svevestøv, $\mathrm{NO}_{2}$ og ozon dei siste åra (2004-2012) i dei mest forureina byane i Noreg.

\section{Nitrogendioksid}

Hovudkjelda til $\mathrm{NO}_{2}$ er vegtrafikk, og det er spesielt dieselbilar som har høge utslepp. Nivåa av $\mathrm{NO}_{2}$ i uteluft varierer i stor grad i løpet av dagen, ved ulike årstider og stader (FHI, 2013).

Gjennomsnittsnivåa i dei største byane i Noreg ligg over grenseverdiane for årsmiddel på $40 \mu \mathrm{g} / \mathrm{m}^{3}$ (sjå figur $1 \mathrm{~A}$ ). Maksimale timeverdiar kan òg overstige grenseverdien på $200 \mu \mathrm{g} / \mathrm{m}^{3}$ (sjå figur 1B) (tillate med sju overskridingar).

\section{Svevestøv}

Vegtrafikk bidreg vanlegvis mest til svevestøvnivåa dei fleste stadene. Vedfyring kan òg i enkelte periodar føre til høge nivå, og utslepp frå industrien kan bidra med metallhaldig svevestøv (FHI, 2013).

Årlege gjennomsnittsnivå av $\mathrm{PM}_{10}$ i fleire norske byar og tettstader ligg på mellom 15 og $30 \mu \mathrm{g} / \mathrm{m}^{3}$ (figur 2A), og for $\mathrm{PM}_{2,5}$ ligg nivåa på mellom 6 og $15 \mu \mathrm{g} / \mathrm{m}^{3}$ (figur $2 \mathrm{~B})$. Dette er under dei gjeldande grenseverdiane, men over luftkvalitetskriteria. 


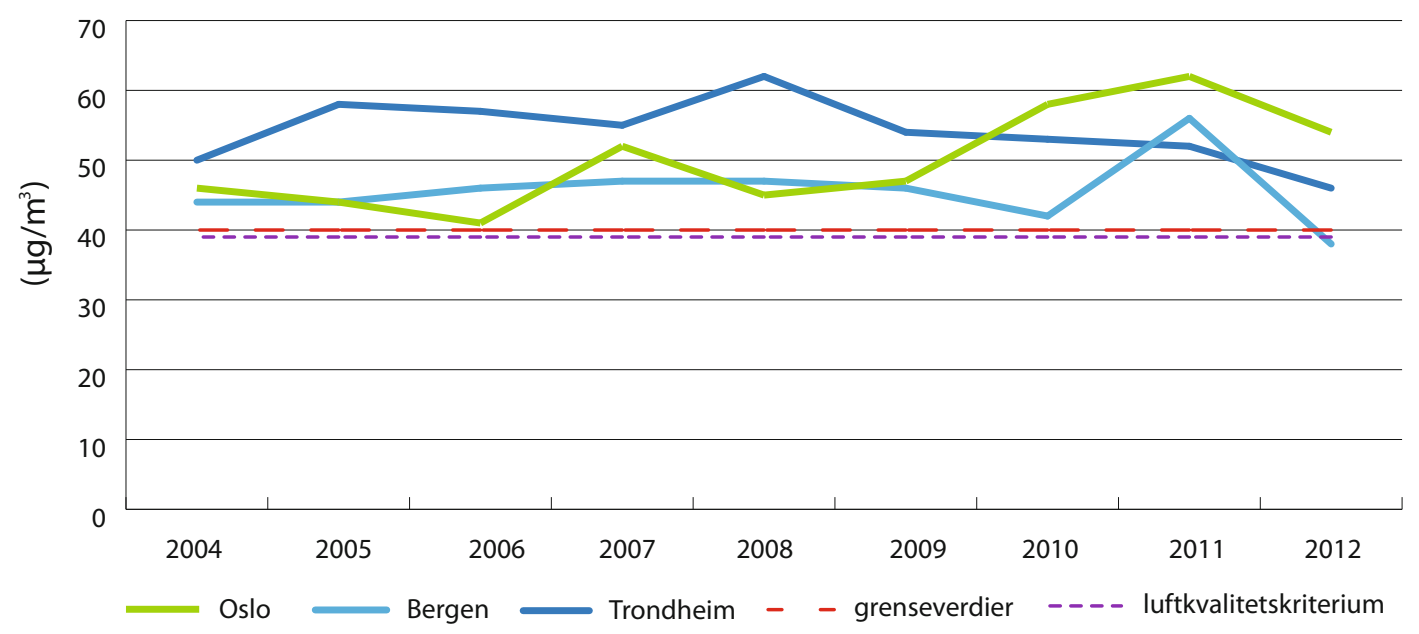

Figur 1 A: Årsmiddel av nitrogendioksid ( $\left.\mathrm{NO}_{2}\right)$ i Oslo, Bergen og Trondheim med grenseverdiar og luftkvalitetskriterium i perioden frå 2004 til 2012. Kjelde: Folkehelseinstituttet.

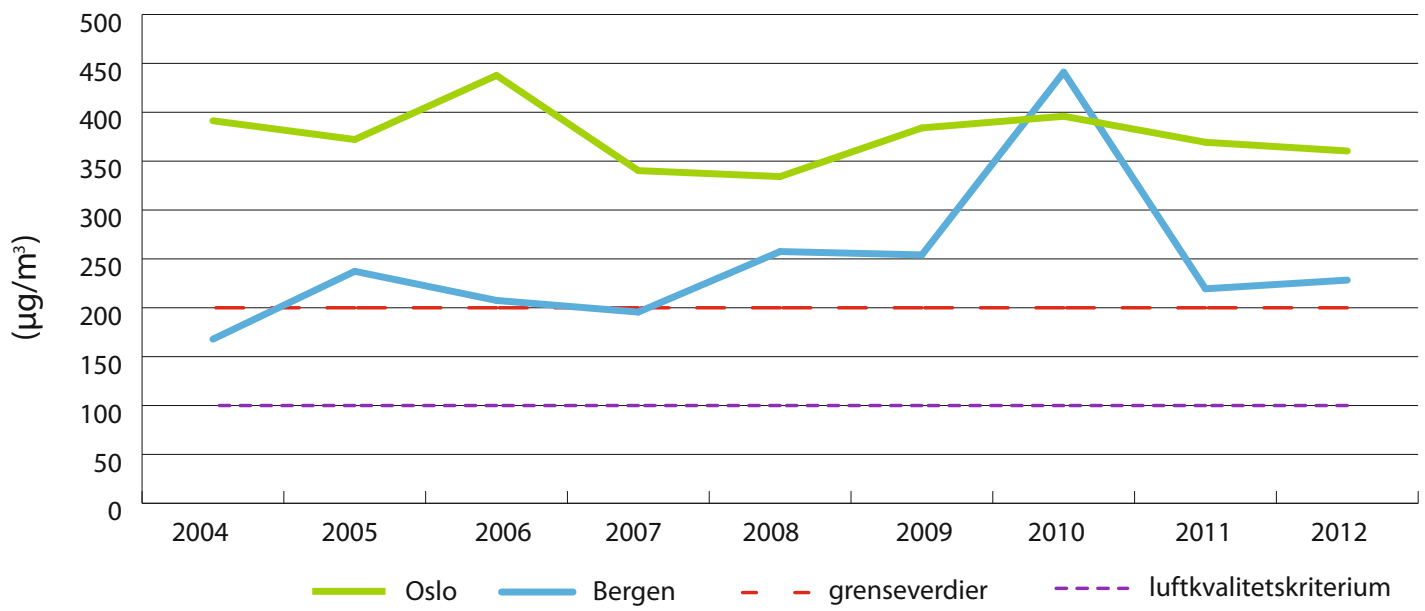

Figur 1B: Maksimal timemiddel av nitrogendioksid $\left(\mathrm{NO}_{2}\right)$ med grenseverdiar og luftkvalitetskriterium i Oslo og Bergen i perioden frå 2004 til 2012. Kjelde: Folkehelseinstituttet.

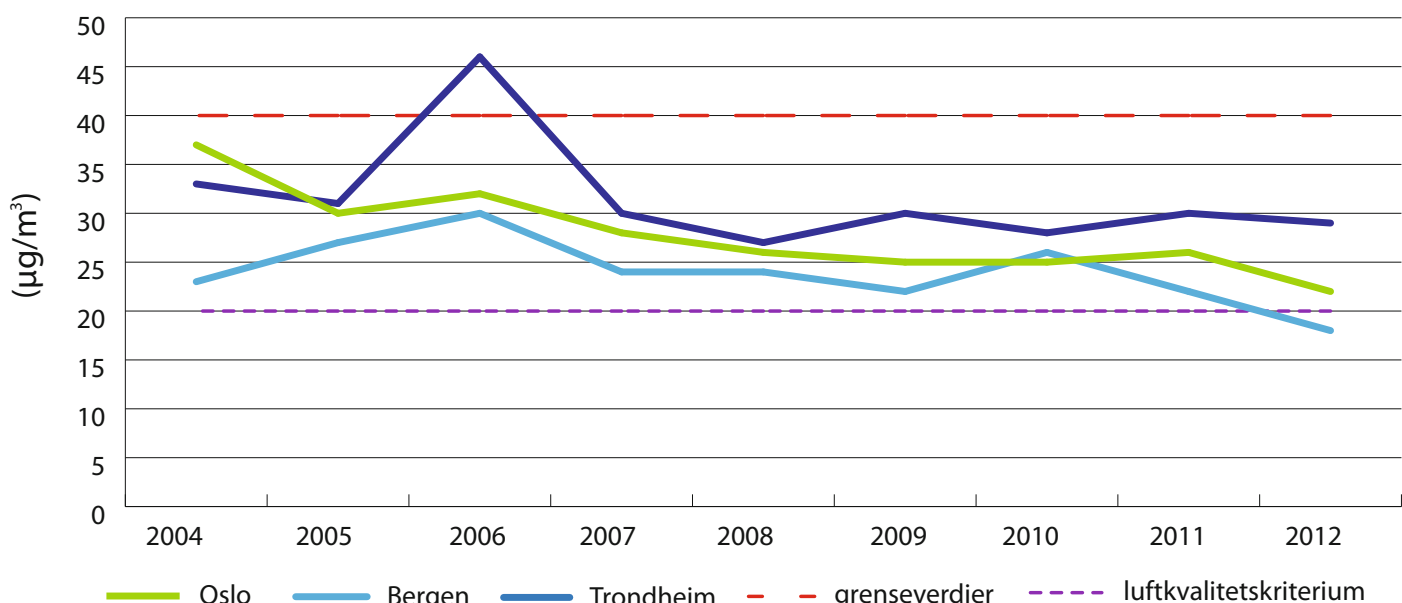

Figur 2A: Årsmiddel av svevestøv $\left(\mathrm{PM}_{10}\right)$ i Oslo, Bergen og Trondheim med grenseverdiar og luftkvalitetskriterium i perioden frå 2004 til 2012. Kjelde: Folkehelseinstituttet. 


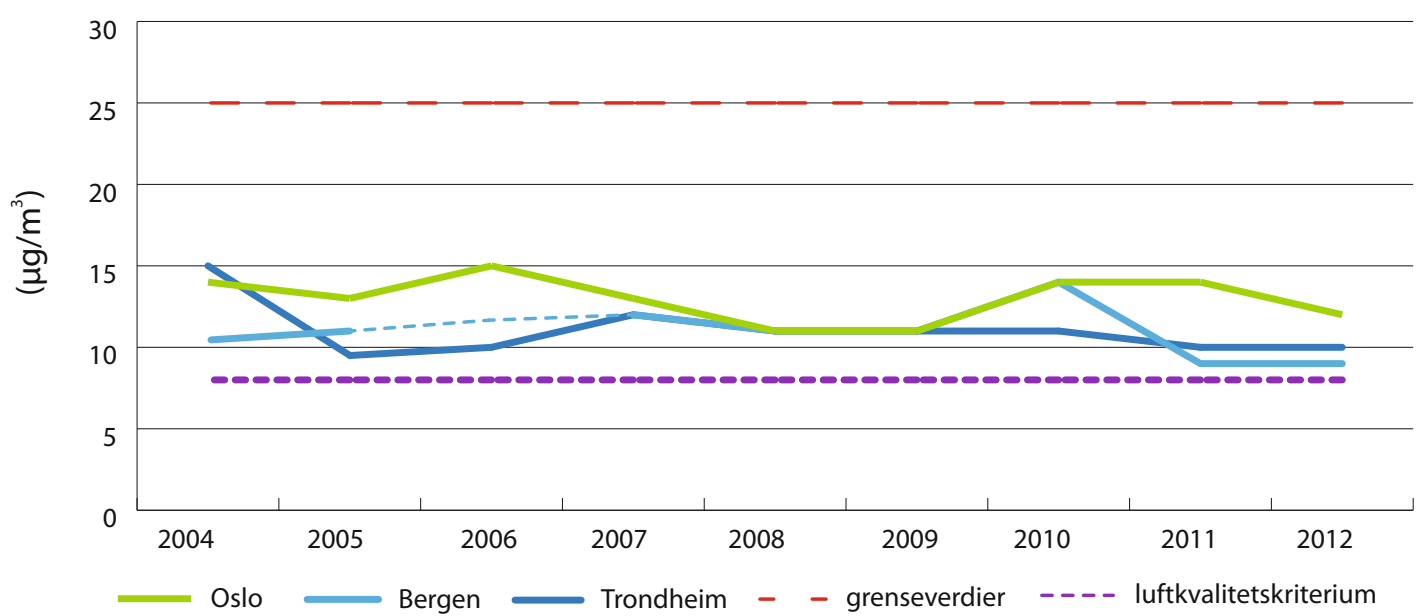

Figur 2B: Årsmiddel av svevestøv $\left(\mathrm{PM}_{2,5}\right)$ i Oslo, Bergen og Trondheim med grenseverdiar og luftkvalitetskriterium i perioden frå 2004 til 2012. Kjelde: Folkehelseinstituttet.

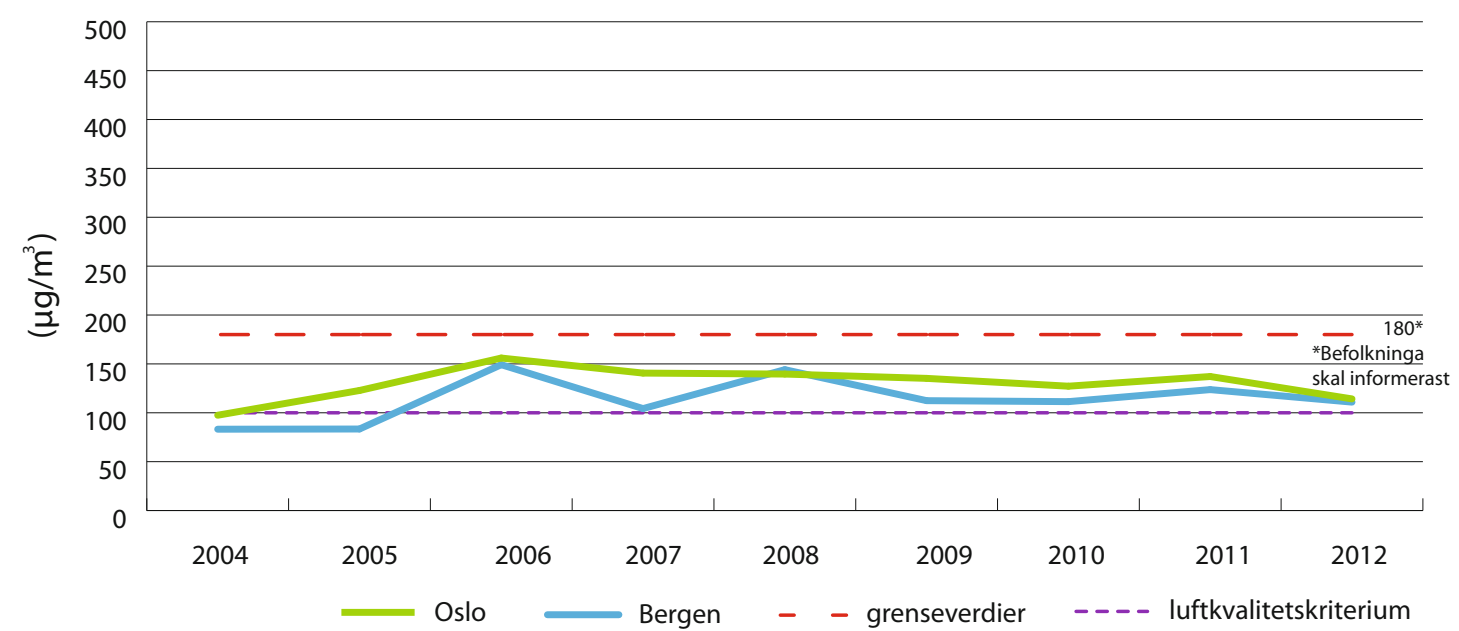

Figur 3: Maksimal timemiddel av ozon med informasjonsterskel og luftkvalitetskriterium i Oslo og Bergen i perioden frå 2004 til 2012. Kjelde: Folkehelseinstituttet.

\section{Ozon}

Ozon transportert frå kontinentet bidreg mest til ozonnivåa vi har i Noreg. Dei lokale utsleppskjeldene bidreg òg noko, men i mindre grad.

Ozonkonsentrasjonen i Noreg har i periodar nådd nivå på nærmare $150 \mu \mathrm{g} / \mathrm{m}^{3}$ dei seinare åra. Terskelen for å informere befolkninga er $180 \mu \mathrm{g} / \mathrm{m} 3$, ifølgje forureiningsforskrifta, sjå figur 3. Nivåa varierer frå årstid til årstid og stad til stad og er like høge på landsbygda som i byar (FHI, 2013).

- Svevestøvnivåa har blitt redusert noko den siste tiårsperioden, og ein forventar at dei kjem til å bli ytterlegare reduserte i åra framover, sjå figur 2A og B. Dette er fordi det har blitt innført tiltak som auka krav til utslepp frå køyretøy, piggdekkgebyr, auka støvbinding og reingjering av vegane (Miljødirektoratet, 2014).

- Grenseverdien for $\mathrm{PM}_{10}$ per døgn blei tidlegare overskriden i fleire norske byar og tettstader, men innføring av effektive tiltak har ført til at dei fleste stadene no ligg under dei gjeldande grenseverdiane.

- For nitrogendioksid har nivåa dei siste åra auka noko i Oslo, sjå figur 1A. Dette kan vere på grunn av fleire dieselbilar på vegane.

- Ozonnivåa har vore forholdsvis stabile dei siste tiåra og avheng i stor grad av utslepp på kontinentet. Dei siste hundre åra har derimot konsentrasjonane av bakkenært ozon blitt fordobla. 


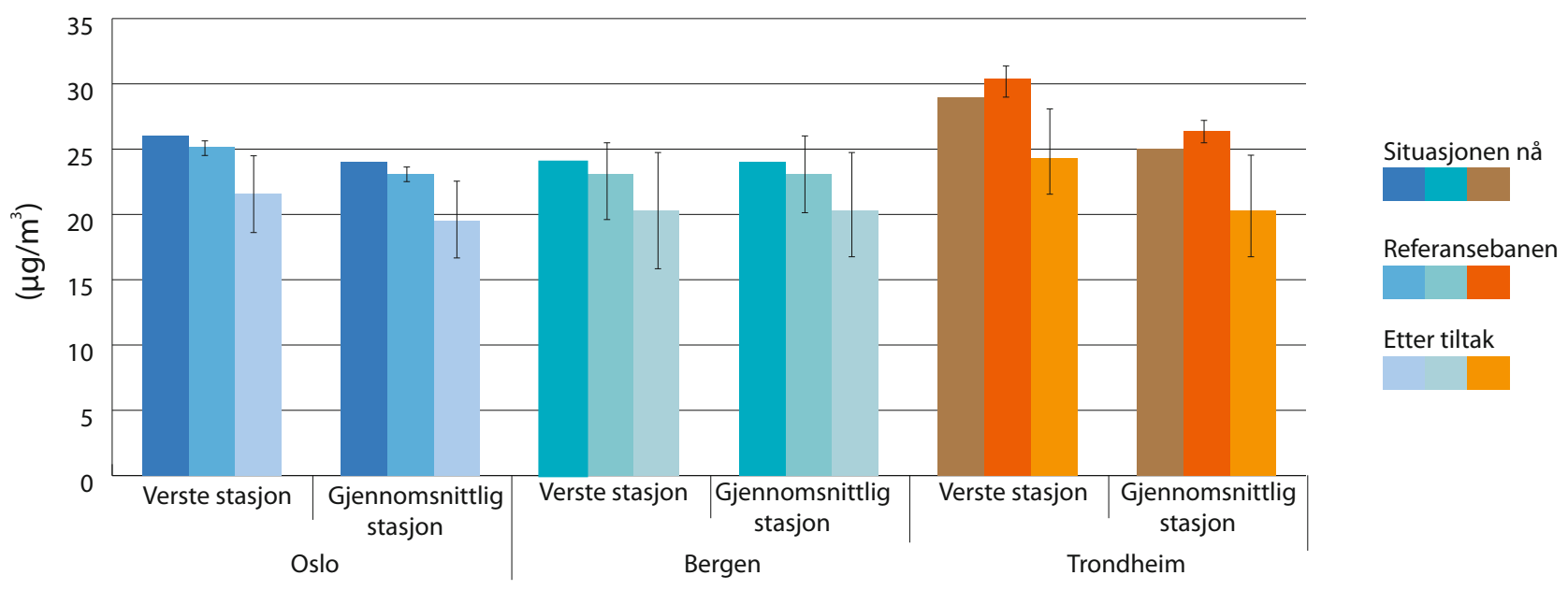

Figur 4: $\mathrm{PM}_{10}$-konsentrasjon i Oslo, Bergen og Trondheim med og utan lønsame tiltak. Kjelde: Miljødirektoratet, 2014.

\section{Forskjellar i befolkninga}

\section{Utsette grupper}

- Personar med luftvegssjukdomar (astma, KOLS, infeksjonar) og hjarte- og karsjukdomar er spesielt kjenslevare for å få helseeffektar av luftforureining.

- Barn med uferdig utvikla luftvegar er òg kjenslevare.

- Personar med diabetes og fedme ser ut til å vere utsette for uønskte effektar av luftforureining.

- Låg sosioøkonomisk status gjer òg personar disponerte for helseeffektar av luftforureining.

\section{Geografiske forskjellar}

Nivå av svevestøv og $\mathrm{NO}_{2}$ varierer svært mykje mellom bystrøk og elles i landet. Det kan òg vere store variasjonar innanfor kvar enkelt by og tettstad, avhengig av trafikk og andre utslepp. Ozonnivåa er jamnare fordelte utover landet.

\section{Internasjonale forskjellar}

Globalt sett blir luftforureining (ute og inne) sett på som den viktigaste miljøfaktoren som gir helseeffektar. WHO har rekna ut at 3,7 millionar dødsfall kan tilskrivast utandørs luftforureining i 2012, og av dette er om lag 0,5 millionar av dødsfalla tilskrivne Europa (WHO, 2014). Nivåa i dei største byane i Noreg tilsvarar nivåa i andre skandinaviske land, men er lågare enn i dei fleste større byane elles i Europa (Eeftens, 2012).

\section{Luftforureining og helserisiko}

Luftforureining utandørs kan utløyse og forverre sjukdomar, først og fremst i luftvegane og i hjarte- og karsystemet (WHO, 2000; 2006). Helseeffektane ser ut til å inntreffe ved lågare konsentrasjonar enn ein tidlegare har rekna med (FHI, 2013).

Korte opphald (timar/døgn) i forureina luft forverrar eksisterande hjarte- og lungesjukdomar, mens langvarig eksponering (månader/år) ser ut til å kunne bidra direkte til at ein utviklar sjukdom.

\section{Helserisiko ved ulike svevestøvs- fraksjonar}

Helseeffektar av svevestøv har blitt observert både i kliniske studiar og i befolkningsstudiar. Det er godt dokumentert at $\mathrm{PM}_{2,5}$ og $\mathrm{PM}_{10}$ forverrar sjukdomar i luftvegane og hjarte- og karsystemet. Og både korttids- og langtidseksponering viser samanhengar med dødelegheit og dårleg helse. Risikoen for sjukdom og død er høgare ved langvarig eksponering enn ved kortvarig eksponering.

Andre svevestøvsfraksjonar enn $\mathrm{PM}_{10}$ og $\mathrm{PM}_{2,5}$ er også forbundne med helseeffektar. Grovfraksjonen ser ut til å ha samanheng med dødelegheit og dårleg helse etter kortvarig eksponering. Datagrunnlaget for $\mathrm{PM}_{0,1}$ (ultrafine partiklar) er for tynt til at vi kan seie noko om ein årsakssamanheng.

Når det gjeld klima, har det vore fokusert mykje på svarte karbonpartiklar. Risikoestimata for desse karbonpartiklane når det gjeld dødelegheit og dårleg helse, er høgare enn for $\mathrm{PM}_{2,5}$ og $\mathrm{PM}_{10}$. Dette gjeld både ved kortvarig og langvarig eksponering.

Det er mindre klart kva for svevestøvskjelder som bidreg mest til dei observerte helseeffektane. Studiar viser at både forureining frå trafikk (eksos og vegstøv) og vedfyring er viktig. Metall som er bundne til svevestøv, kan bidra til å gi helseeffektar. Organiske sambindingar som PAH er særleg bundne til forbren- 
ningspartiklar og kan bidra til utvikling av kreft. Ein av komponentane (benzo[a]pyrene - BaP) blir brukt som ein indikator for kreftframkallande effektar av PAH.

\section{Helserisiko ved nitrogendioksid $\left(\mathrm{NO}_{2}\right)$}

Det er observert helseeffektar ved kortvarig eksponering for $\mathrm{NO}_{2}$ både i kliniske studiar og befolkningsstudiar. Effektane av langvarig eksponering er berre undersøkte i befolkningsstudiar. Dei viktigaste helseeffektane som er knytte til kortvarig $\mathrm{NO}_{2}$-eksponering, er nedsett lungefunksjon og forverring av astma og bronkitt samt høgare dødelegheit. Resultat frå befolkningsundersøkingar har òg vist at det er høgare sjukelegheit og dødelegheit av lunge- og hjartekarlidingar ved langvarig $\mathrm{NO}_{2}$-eksponering, men det er svært vanskeleg å skilje effekten av $\mathrm{NO}_{2}$ frå effekten av svevestøv i desse undersøkingane.

\section{Helserisiko ved ozon}

Nyare studiar styrkjer samanhengen mellom låge ozonnivå og helseeffektar. Ein stor del av ozonet blir teke opp i dei øvre luftvegane, men ozon trengjer òg djupt ned i luftvegane, spesielt ved høg fysisk aktivitet. Ved kortvarig eksponering for ozon er det observert betennelsesreaksjonar, redusert lungefunksjon og auka luftvegssymptom. Ozon kan gi høgare sjukelegheit og dødelegheit av luftvegssjukdomar. Det er store individuelle forskjellar når det gjeld kor kjenslevar kvar enkelt er for helseeffektar av ozoneksponering.

\section{Fleire komponentar verkar saman}

Mange luftforureinande komponentar utløyser dei same helseeffektane og verkar truleg saman. Sidan folket blir utsett for ei rekkje ulike komponentar samtidig, vil helseeffektane som blir observerte, vere eit resultat av den samla eksponeringa for luftforureining. Dette kan vere noko av grunnen til at helseeffektar blir observerte ved lågare nivå i befolkningsstudiar enn i mange eksperimentelle studiar. Vi har derimot lite kunnskap om interaksjonane og mekanismane for dette samvirket, spesielt ved låge konsentrasjonar.

\section{Førebyggjande tiltak mot luftforureining}

Ny kunnskap om helseeffektar av svevestøv gjer at Folkehelseinstituttet og Miljødirektoratet har sett strengare kriterium for luftkvalitet med omsyn til $\mathrm{PM}_{10}$ og $\mathrm{PM}_{2,5}$. Førebels har vi ikkje nok faktagrunnlag til å kunne fastsetje luftkvalitetskriterium for andre storleiksfraksjonar. Også for nitrogendioksid er luftkvalitetskriteria nyleg blitt reviderte. Desse kriteria er fastlagde slik at mesteparten av befolkninga skal bli verna mot skadelege effektar.
Dersom ein framleis skal kunne redusere svevestøv og nitrogendioksid i utelufta, må ein vidareføre tiltak mot biltrafikk, og for svevestøv også mot vedfyring og utslepp frå industrien.

Det å redusere ozonnivåa krev strengare internasjonale avtalar for å minske utslepp av flyktige organiske sambindingar og nitrogenoksid.

Ein reknar med at dei nye forslaga til grenseverdiar samt bruken av helsebaserte nasjonale mål (Miljødirektoratet, 2014) og luftkvalitetskriterium (FHI, 2013) i plansamanheng bidreg til redusert eksponering. Dermed kjem også luftforureining til å få mindre helsemessige effektar.

Det er planlagt intensiverte tiltak mot luftforureining av svevestøv frå veg og utslepp frå bilar og nye omnar (Miljødirektoratet, 2014). Vi forventar at dette skal redusere nivåa. Det er noko usikkerheit knytt til kor mykje tiltaka kjem til å redusere førekomsten av dei minste partiklane. Oppfølging av Gøteborgprotokollen og Parma Declaration on Environment and Health kan bidra til at vi får betre luftkvalitet og mindre eksponering av helseskadelege stoff.

\section{Referansar}

Eeftens, M., M. Y. Tsai, C. Ampe, B. Anwander, R. Beelen et al (2012) "Spatial variation of PM2.5, PM10, PM2.5 absorbance and PM coarse concentrations between and within 20 European study areas and the relationship with NO2 - Results of the ESCAPE project." Atmospheric Environment 62, 303-317 DOI: http://dx.doi.org/10.1016/j. atmosenv.2012.08.038

FHI, Folkehelseinstituttet (2013). Luftkvalitetskriterier: virkninger av luftforurensning på helse. Oslo, Nasjonalt folkehelseinstituttet rapport 2013:9.

Miljødirektoratet (2014). Grenseverdier og nasjonale mål: Forslag til langsiktige helsebaserte nasjonale mål og reviderter grenseverdier for lokal luftkvalitet. Rapport M-129- 2014.

Miljøverndepartementet. Forskrift om begrensning av forurensning (forurensningsforskriften). Oslo (2012).

WHO. Air quality guidelines for Europe. Copenhagen, World Health Organization, Regional Office for Europe. (2000).

WHO. Air quality guidelines: global update 2005: particulate matter, ozone, nitrogen dioxide and sulfur dioxide. Copenhagen, WHO Regional Office for Europe. (2006).

WHO. Burden of disease from household air pollution for 2012: Summary of results. World Health Organization. Retrieved 23/5/2014, from WHO.

\section{FORFATTARAR}

Marit Låg og Magne Refsnes 


\section{Røyking og snusbruk}

- I befolkninga sett under eitt bruker éin av tre tobakk, blant dei yngste vaksne er prosentdelen på rundt 40.

- Den daglege røykinga har gått ned, mens snusbruken har auka.

- Det er tydelege sosioøkonomiske forskjellar når det gjeld røyking blant vaksne, men ikkje når det gjeld bruk av snus.

- Både røyking og snusbruk kan få store negative følgjer for fosteret.

- Det har vore ein gledeleg nedgang i røyking i svangerskapet. Vi har ikkje opplysningar om snusbruk i svangerskapet.

- Dei nedovergåande trendane for røyking kjem etter kvart til å bli etterfølgt av nedovergåande trendar for sjukelegheit og dødelegheit.

\section{Om tobakk og nikotin}

Tobakk kan tyggjast, røykjast eller brukast som snus. Tobakksblada inneheld nikotin. Når tobakk blir røykt, blir det òg frigjort ei rekkje andre helseskadelege stoff.

Nikotin er sterkt avhengigheitsskapande, og ein kan bli avhengig raskt. Helseskader ved tobakks- og nikotinbruk kjem dels av nikotin og dels av andre stoff $\mathrm{i}$ tobakks- og nikotinprodukt.

\section{E-sigarettar}

E-sigarettar med nikotin er forbode å selje i Noreg, men e-sigarettar utan nikotin kan seljast med 18-årsgrense. Dei kan ikkje marknadsførast og er omfatta av oppstillingsforbodet i butikkane. E-sigarettar er ikkje nærmare omtala i dette kapittelet.

Meir informasjon: Helsedirektoratet: Om endringer i tobakksskadeloven (2013)

\section{Status for bruk av tobakk}

\section{5 prosent av befolkninga røykjer dagleg}

I 2013 brukte ein stor del av vaksne i aldersgruppa 16-74 år tobakk:

- 15 prosent av mennene og 14 prosent av kvinnene røykte dagleg, mens rundt 10 prosent røykte av og til.
- 14 prosent av mennene og 4 prosent av kvinnene brukte snus dagleg, mens det var 5 prosent av mennene og 3 prosent av kvinnene som brukte snus av og til.

\section{Éin av tre bruker tobakk som snus, røyk eller kombinasjon}

I 2012 brukte 32 prosent av den norske befolkninga tobakk, enten som eksklusive røykarar, eksklusive snusarar eller dobbeltbrukarar (Bye, 2013). Talet på dobbeltbrukarar var på 5 prosent for alle aldrar og begge kjønn samla. Den vanlegaste forma for dobbeltbruk er å snuse dagleg og røykje av og til.

\section{Passiv røyking}

I SIRUS si undersøking frå 2012 oppgav 86 prosent av dei spurte at det aldri blei røykt heime hos dei, mens sju prosent oppgav at det blei røykt inne kvar dag.

Av daglegrøykarane svarte 56 prosent at det aldri blei røykt innandørs heime hos dei.

I familiar med barn under seks år oppgav nesten ingen av dei spurte at det blei røykt inne, mens det i familiar med eldre barn var to prosent som rapporterte dagleg røyking inne (Bye, 2013). 


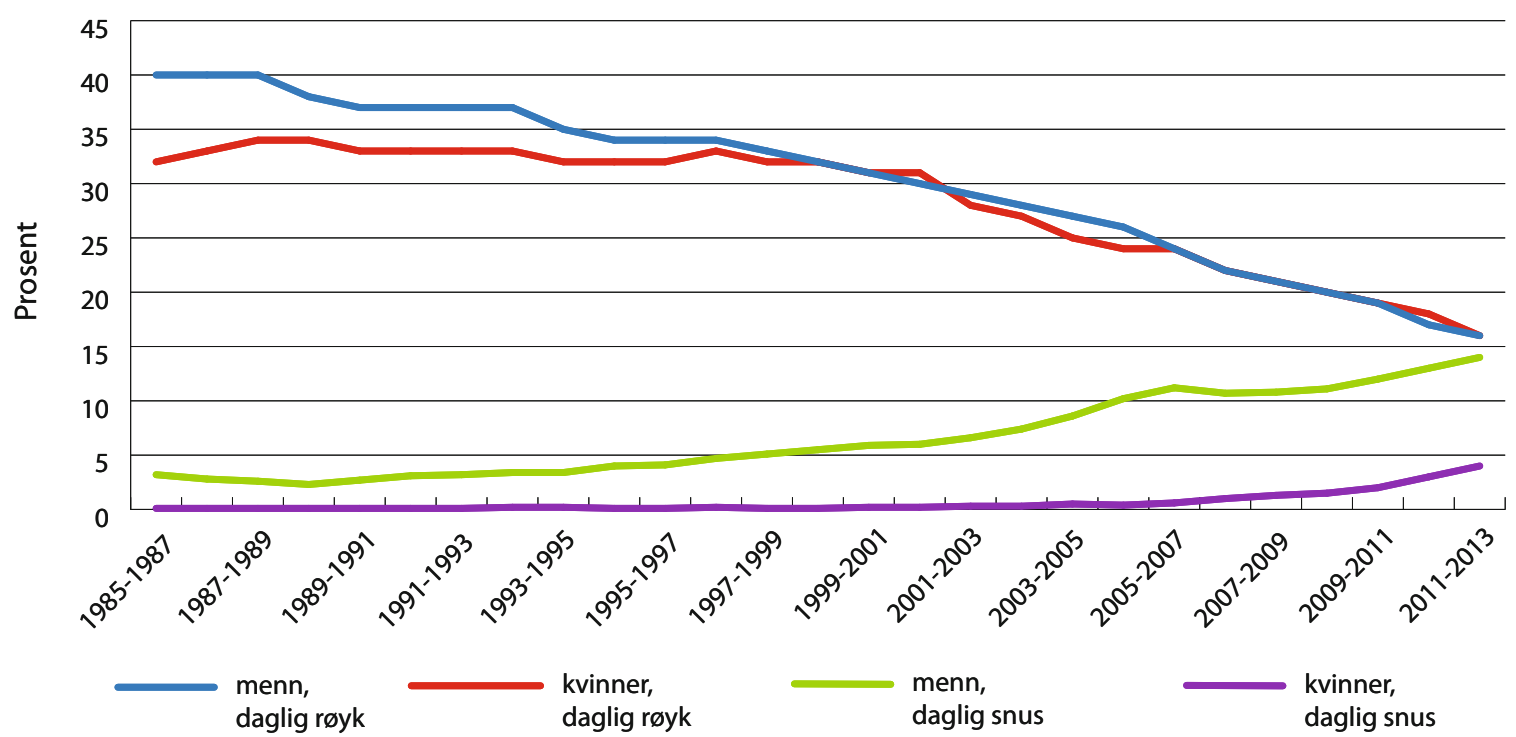

Figur 1: Dagleg røyking og snusbruk 1985-2013 blant menn og kvinner 16-74 år. Kjelde: Lindbak, 2013/ Helsedirektoratet og Norgeshelsa.

\section{Nesten 1 av 10 gravide røykjer, vi veit lite om snusbruk}

Tal frå Medisinsk fødselsregister i 2013 viser at åtte prosent av gravide kvinner røykte i starten av svangerskapet og fem prosent i slutten av svangerskapet. Ti år tidlegare, i 2003, var tilsvarande tal 20 og 12 prosent.

Vi veit lite om omfanget av snusbruk i svangerskapet. Informasjon om snusbruk kjem til å inngå i eit nytt elektronisk helsekort for gravide, som er under planlegging.

Røyking i svangerskapet er mest utbreidd (CupulUicab, 2012)

- blant yngre gravide

- blant gravide med låg utdanning

- blant gravide med eit ikkje-planlagt svangerskap

- blant døtrer av foreldre som røykjer

- blant førstegongsgravide

\section{Utvikling over tid}

Dagleg røyking. På 1950-talet røykte omtrent 70 prosent av mennene i Noreg, mens prosentdelen blant kvinnene var på mellom 25 og 30 (Engeland, 1993).

I 1973 var prosentdelane mykje lågare; 51 prosent av mennene og 32 prosent av kvinnene røykte dagleg. Frå tusenårsskiftet har vi hatt ein jamn nedgang, og kjønnsforskjellane er no små. I 2013 hadde omfanget av dagleg røyking falle til 15 prosent blant menn og 14 prosent blant kvinner (sjå figur 1).

Av og til-røykinga har lenge helde seg stabilt på omtrent 10 prosent for alle aldrar og for begge kjønn. Blant dei yngste (16-24 år) har det vore ein nedgang. Dette gjeld særleg kvinner, der prosentdelen av og tilrøykarar gjekk ned frå 18 prosent i 2004 til 10 prosent i 2010. Dei siste tre åra har vi hatt ein svak oppgang i talet på av og til-røykjande kvinner til 13 prosent i 2013 (SSB-statistikkbank).

Samtidig har dagleg snusbruk auka (sjå figur 1 og 2). I 2013 var det omtrent like vanleg for menn å bruke snus som å røykje. Dersom trendane held fram, vil det $\mathrm{i}$ åra framover vere meir vanleg for menn å snuse enn å røykje. Dette biletet er tydelegast om vi ser på 16-24-åringar i dag (sjå figur 2).

Av og til-bruk av snus har dei siste åra lege på rundt 6 prosent for menn og 3 prosent for kvinner (alle aldrar).

\section{Færre førstegongsfødande røykjer under svangerskapet}

Figur 3 viser utviklinga i dagleg røyking blant førstegongsfødande. Det er flest daglegrøykarar blant dei yngste, men prosentdelen har gått ned i alle aldersgrupper i perioden frå rundt 2000 til 2013. 


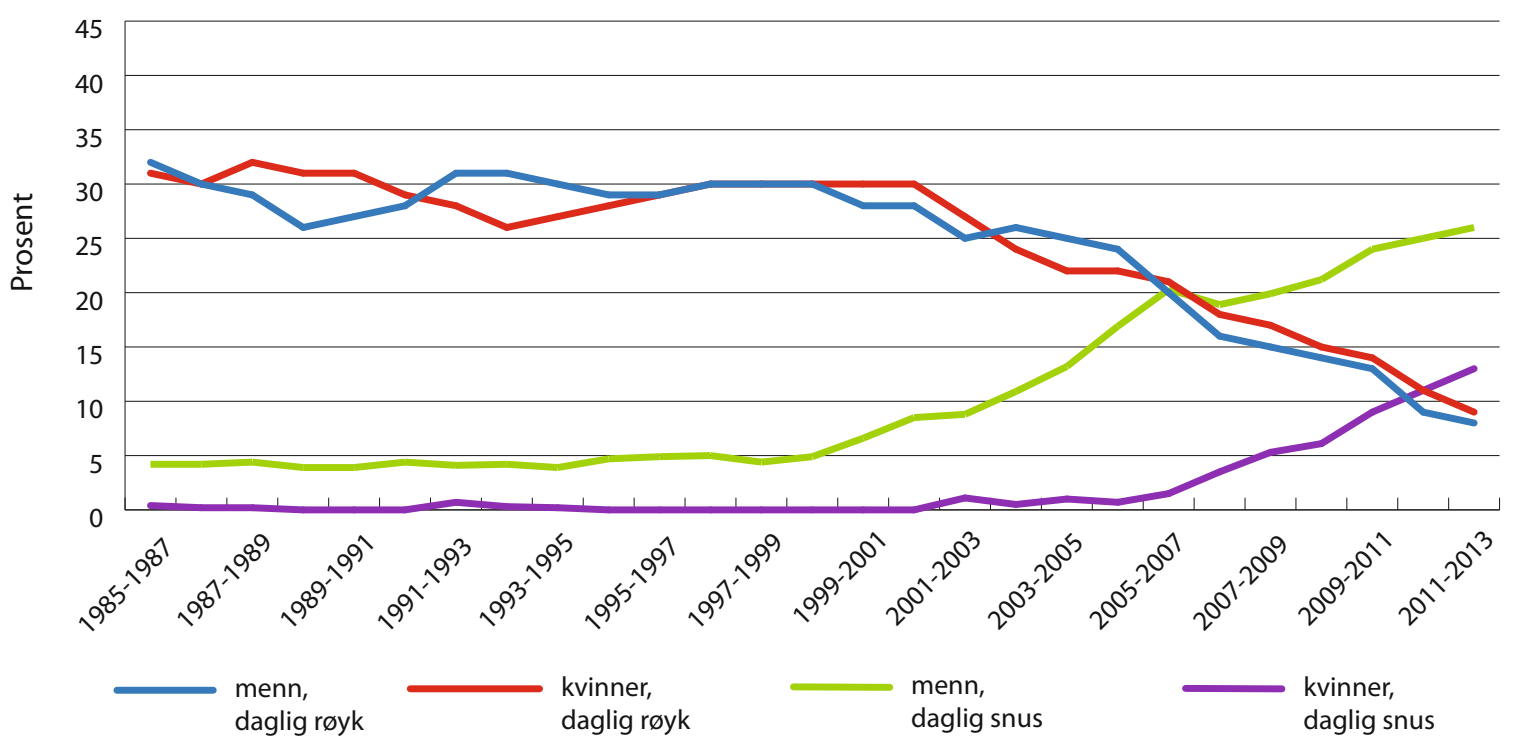

Figur 2: Dagleg røyking og snusbruk 1985-2013 blant menn og kvinner 16-24 år. Kjelde: Lindbak, 2013/ Helsedirektoratet og Norgeshelsa.

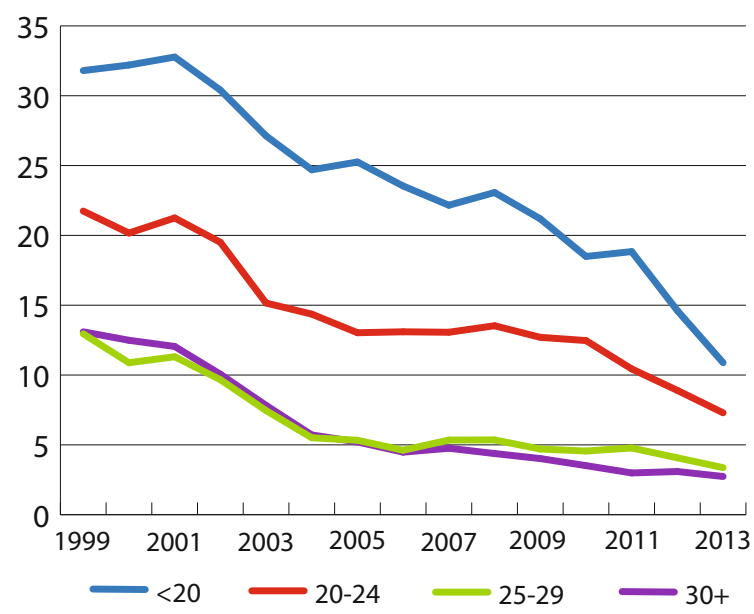

Figur 3: Dagleg røyking i slutten av svangerskapet etter alderen til mor. Kjelde: Medisinsk fødselsregister (MFR).

\section{Færre blir utsette for passiv røyking}

Nedgangen i prosentdelen røykarar har òg ført til ein nedgang i talet på personar som blir utsette for passiv røyking. Dette gjeld både røyking på arbeidsplassen og i heimen.

- Mens 25 prosent av dei yrkesaktive blei utsette for passiv røyking på jobb i 2002, gjaldt dette for 5 prosent ti år seinare.

Samtidig med nedgangen i røyking har haldningane til det å røykje innandørs endra seg, og talet på dei som blir utsette for passiv røyking i heimen, gjekk ned frå 20 prosent i 2005 til under 10 prosent i 2012 (Lindbak, 2013).

\section{Forskjellar i befolkninga}

\section{Mennene stumpa røyken først}

Nedgangen i røyking blant menn starta allereie tidleg på 1970-talet, mens røyking blant kvinner var nokså uendra fram til slutten av 1990-talet. Den tilsynelatande stabiliteten blant kvinner kom eigentleg av at det var svært få røykarar blant eldre kvinner og relativt fleire blant dei yngre kvinnene. Dei unge trakk opp gjennomsnittet for prosentdelen daglegrøykarar etter kvart som dei eldre fall ut av statistikken. Derfor blei ikkje nedgangen blant dei yngre synleg i totaltala.

Røyking er i dag nokså likt fordelt mellom kjønna og vanlegast blant middelaldrande, mens snusbruk er mest utbreidd blant unge menn (sjå figur 4 og 5).

Det er framleis usikkert korleis snusepidemien kjem til å utvikle seg. Vi veit m.a. ikkje om snusbruken blant dei unge kjem til å stabilisere seg på dagens nivå, eller om den trenden vi ser med aukande snusbruk blant unge kjem til å halde fram.

\section{Tobakk blir brukt på ulik måte i ulike aldersgrupper}

Aldersgruppa med flest røykarar er 45-64 år, der 22 prosent av både menn og kvinner røykjer dagleg (sjå figur 4). Figur 5 viser at 25 prosent av mennene og 11 prosent av kvinnene i alderen 16-24 år snusar dagleg $\mathrm{i}$ siste femårsperiode. I aldersgruppene over 45 år er det få som brukar snus. 


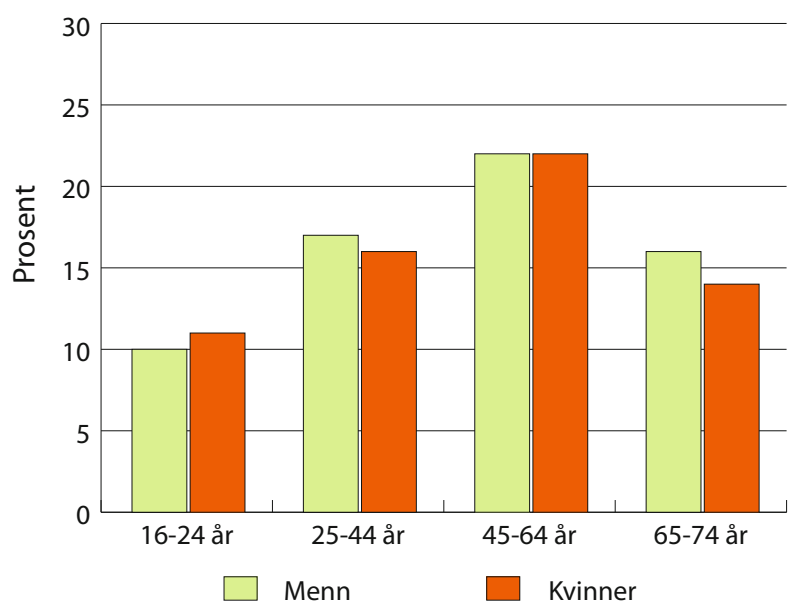

Figur 4: Dagleg røyking etter kjønn og alder. Statistikken for femårsperioden 2009-2013 er slegen saman. Kjelde: Lindbak, 2013 / Helsedirektoratet og Norgeshelsa.

I 2013 brukte heile 27 prosent av mennene og 14 prosent av kvinnene i alderen 16-24 år snus dagleg. Tilsvarande var det åtte prosent menn og seks prosent kvinner som røykte dagleg i same aldersgruppe og år.

Dersom vi ser på heile befolkninga, er prosentdelen som røykjer mykje høgare enn prosentdelen som bruker snus. Mens det var 24 prosent i aldersgruppa 16-74 år som røykte dagleg eller av og til i 2013, var tilsvarande tal for snusbruk 13 prosent (Statistisk Sentralbyrå).

Dobbeltbruk er meir utbreidd i yngre enn i eldre aldersgrupper. I perioden 2010-2012 var 16 prosent av mennene og 8 prosent av kvinnene i alderen 16-24 år

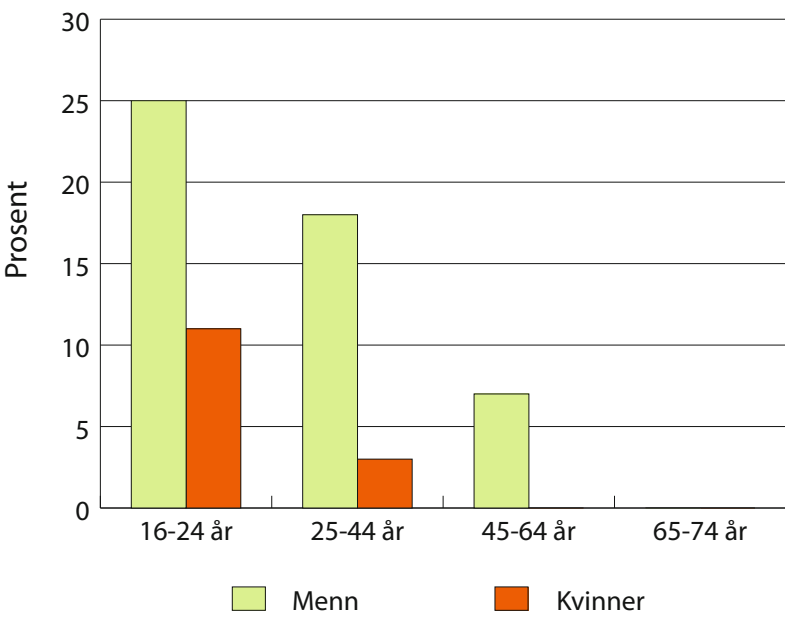

Figur 5: Dagleg bruk av snus etter kjønn og alder. Statistikken for femårsperioden 2009-2013 er slegen saman. Kjelde: Lindbak, 2013 / Helsedirektoratet og Norgeshelsa.

dobbeltbrukarar. 48 prosent av mennene og 34 prosent av kvinnene i denne aldersgruppa oppgav at dei brukte tobakk (Lindbak, 2013).

\section{Sosiale forskjellar når det gjeld røyking}

Sidan midten av 1990-åra har det vore ein nedgang i talet på daglegrøykarar i alle utdanningsgrupper (Lindbak, 2013), sjå figur 6. Men forskjellane mellom utdanningsgruppene er framleis store:

- Berre 8 prosent av dei med universitets- eller høgskuleutdanning røykjer.

- 34 prosent av personar med grunnskuleutdanning røykjer.

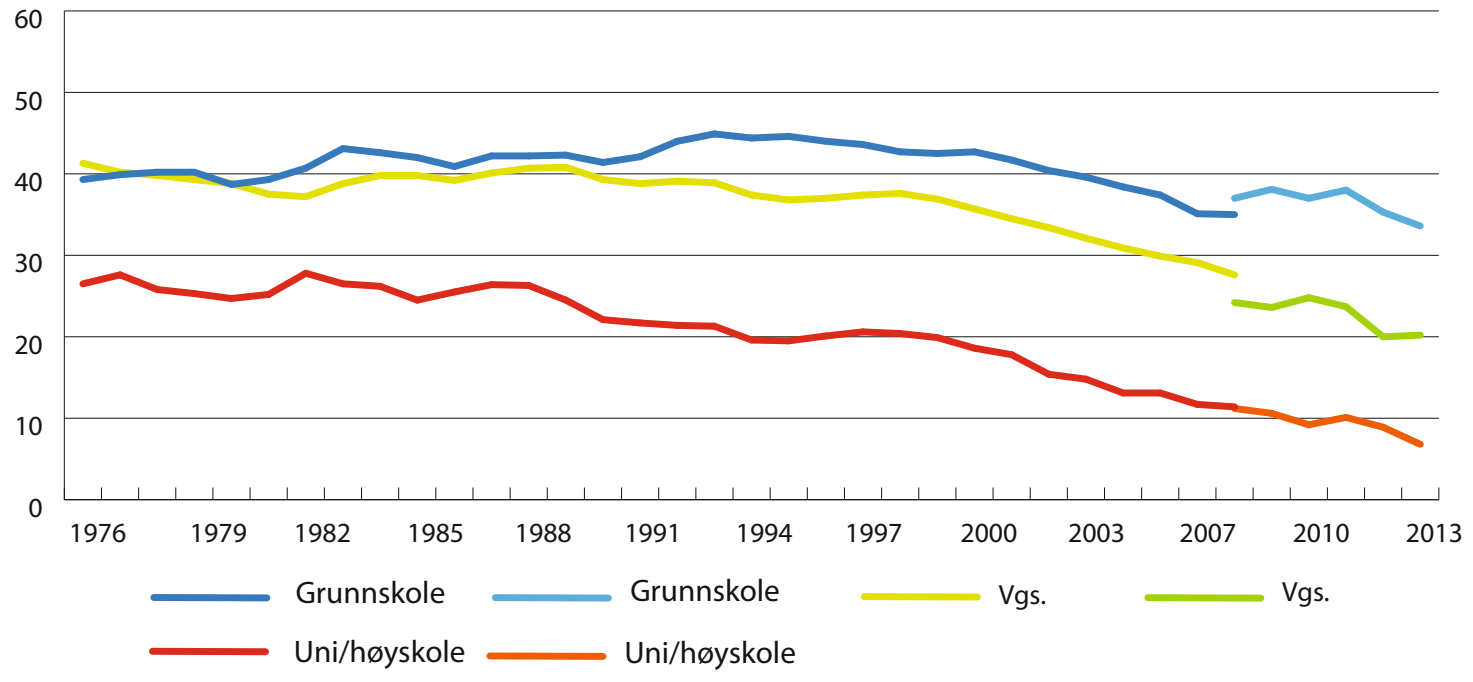

Figur 6: Dagleg røyking etter utdanning i perioden 1976-2012. Kjelde: Lindbak, 2013/SSB. Brotet i tidsseriane kjem av endra kriterium for fullført vidaregåande utdanning frå og med 2007. 


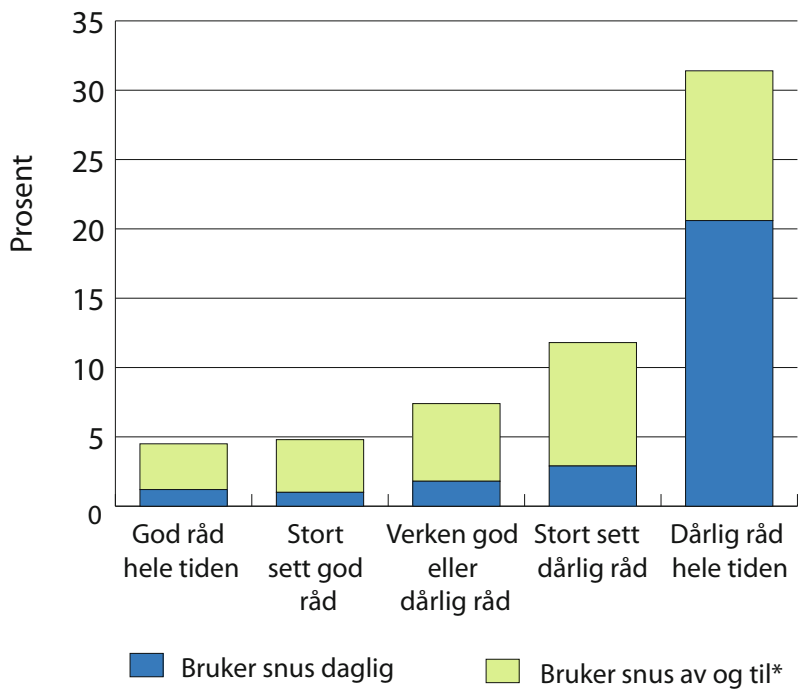

Figur 7: Røyking i grupper for sjølvrapportert familieøkonomi. Kjelde: Ungdata 2013. *Av og til tyder her ein gong i veka eller sjeldnare.

I tida rundt 1950 eller endå tidlegare var situasjonen omvendt. Då var det flest røykarar blant legar og andre høgt utdanna. Då skadeverknadene etter kvart blei kjende, var det derimot òg denne gruppa som slutta først (Lund, 1996). Det førte til at forskjellane i røykeåtferd mellom dei ulike utdanningsgruppene blei større. Av figur 6 ser vi at nedgangen i dagleg røyking dei siste 15-20 åra er tilnærma parallell i dei tre utdanningsgruppene. Det kan vere fordi ulike førebyggjande tiltak har verka inn på nedgangen i røyking i alle utdanningsgruppene, men at tiltaka ikkje har ført til at forskjellane har blitt jamna ut.

Også blant ungdom finn vi store sosioøkonomiske forskjellar når det gjeld røyking, målt gjennom korleis ungdomsskuleelevar vurderer økonomien i familien, sjå figur 7 (Ungdata 2013).

\section{Unge snusbrukarar har ofte dårleg økonomi}

På slutten av 1990-talet var snusbruken lågare i gruppa med låg utdanning enn i dei andre utdanningsgruppene, men forskjellane har jamna seg ut over tid (sjå figur 8). Snusbruken har sidan auka parallelt i alle grupper.

Samanlikna med gruppa med lågast utdanning var det fleire i gruppa med vidaregåande utdanning og universitetsutdanning som brukte snus frå slutten av 1990-talet og eit tiår framover. Dei siste åra har det vore liten forskjell på dagleg bruk av snus i dei tre utdanningsgruppene (figur 8).

Dei som begynner med snus allereie i ungdomsskulealderen, skil seg derimot ut når det gjeld sosioøkonomisk status. Sjå figur 9, som viser sosioøkonomiske forskjellar målt etter om familieøkonomien blir opplevd som god eller dårleg.

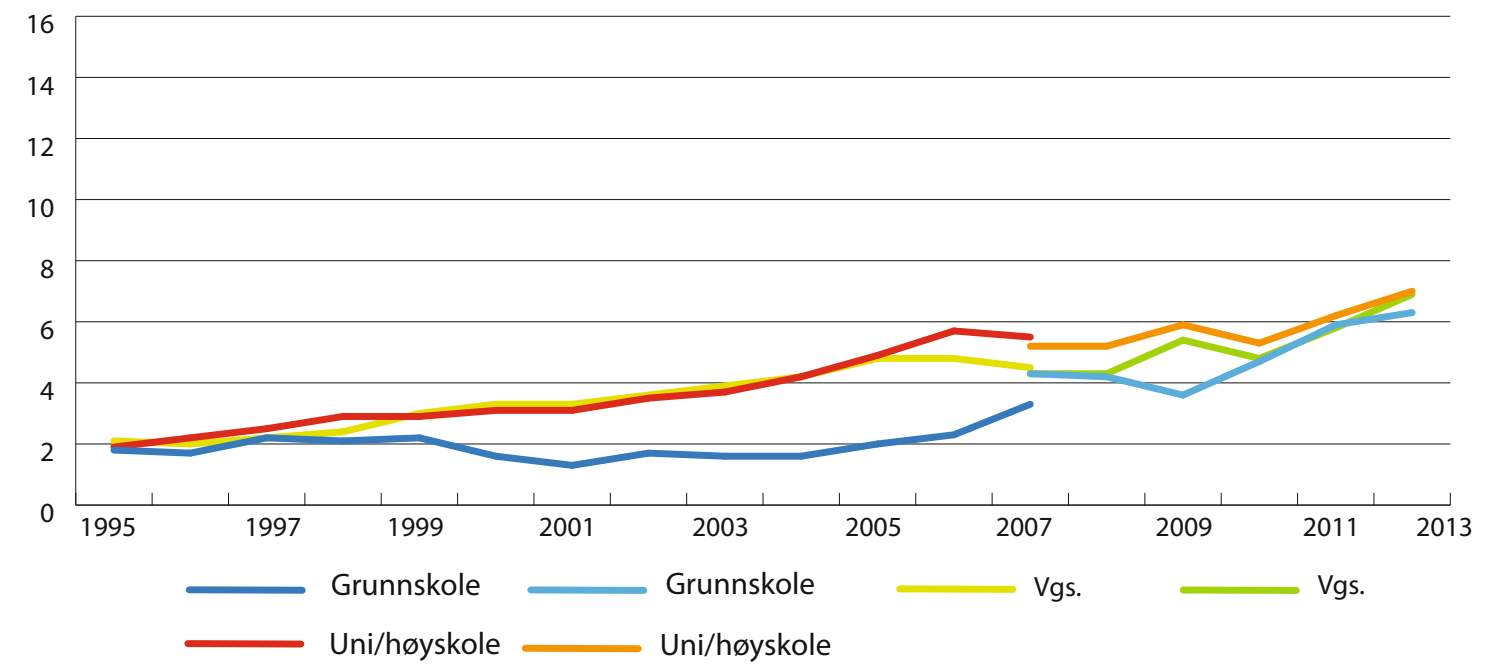

Figur 8: Dagleg bruk av snus etter utdanning i perioden 1995-2012. Kjelde: Lindbak, 2013/Helsedirektoratet. Brotet i tidsseriane kjem av endra kriterium for fullført vidaregåande utdanning frå og med 2007. 


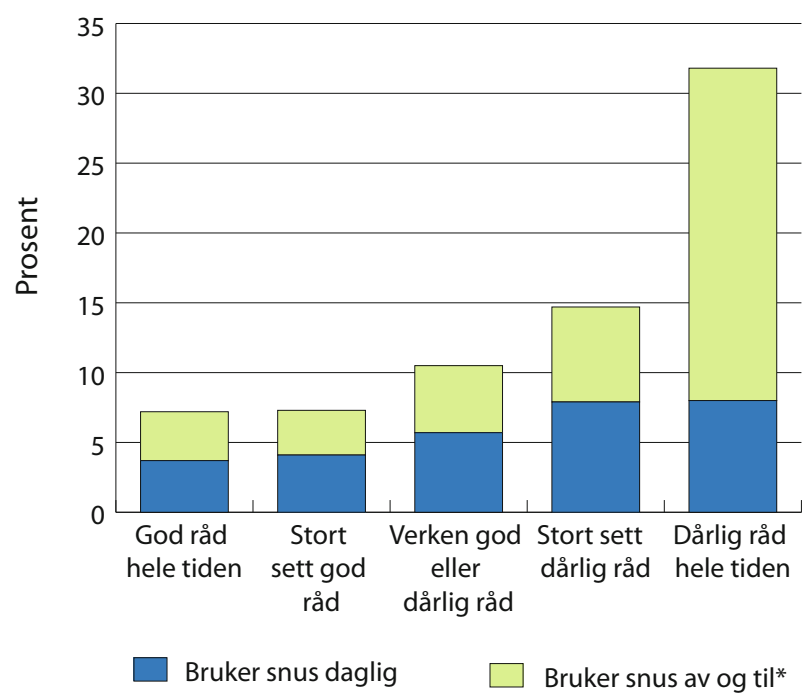

Figur 9: Bruk av snus i grupper for sjølvrapportert familieøkonomi. Kjelde: Ungdata 2013. *Av og til tyder her ein gong i veka eller sjeldnare.

\section{Geografiske forskjellar}

I perioden 2008-2012 var talet på daglegrøykarar blant vaksne 16-74 år høgast i nord (Lindbak, 2013):

- I Finnmark var 28 prosent daglegrøykarar.

- I Østfold og Telemark var høvesvis 23 og 22 prosent daglegrøykarar.

- Oslo låg lågast, med 14 prosent daglegrøykarar, men her var prosentdelen av og til-røykarar noko høgare, med 13 prosent.

Trøndelagsfylka har, ved sidan av Nordland, den høgaste prosentdelen snusbrukarar dersom ein ser på den vaksne befolkninga 16-74 år samla i perioden 2008-2012. I desse fylka brukte éin av ti snus dagleg, mens 5-6 prosent brukte snus av og til.

Finnmark, Telemark og Aust-Agder hadde lågast prosentdel snusbrukarar (Lindbak, 2013).

\section{Nordiske forskjellar mindre enn før}

Tabell 1 viser dagleg røyking i dei nordiske landa. Som det går fram av tabellen ligg Noreg på nivå med Finland og Danmark, mens Island ligg noko lågare. Sverige har den lågaste prosentdelen røykarar.

Finland har hatt den svakaste nedgangen i røykinga dei siste tiåra, men forskjellane når det gjeld prosent daglegrøykarar mellom dei nordiske landa, er no mindre enn før (Lindbak, 2013).
Tabell 1: Prosentdel daglegrøykarar i dei nordiske landa, 2012. Kjelde: Lindbak, 2013.

\begin{tabular}{|l|l|}
\hline Land & Andel dagligrøykere \\
\hline Norge & 16 \\
\hline Finland & 18 \\
\hline Danmark & 17 \\
\hline Island & 14 \\
\hline Sverige & 11 \\
\hline
\end{tabular}

\section{Helseskader knytte til tobakksbruk}

\section{Nikotinavhengigheit}

Nikotin er sterkt avhengigheitsskapande. Tre av fire daglegrøykarar har prøvd å slutte ein eller annan gong. Over halvparten av tidlegare daglegrøykarar har greidd å slutte enten på første eller andre forsøk, mens resten prøvde fleire gonger før dei lykkast (Lindbak 2013).

Det blir rekna som like vanskeleg å slutte med snus som det er å slutte å røykje.

\section{Hjarte- og karsjukdomar}

Røyking aukar risikoen for hjarte- og karsjukdomar. Dersom ein sluttar å røykje, blir risikoen raskt redusert, og allereie etter fem år ser risikoen for hjarteinfarkt ut til å vere nede på nivået for ikkje-røykarar (Tverdal, 1993) (Bakhru, 2005).

Snusbruk verkar inn på hjarte- og karsystemet ved at snusen har innverknad på blodtrykk og puls. Det er ikkje påvist at snus gir auka risiko for hjarte- og karsjukdom, men vi har haldepunkt for at snusbruk kan gi større dødelegheit for dei som har ein hjartesjukdom (SCENIHR, 2008).

\section{Kreft}

Ein stor del av lungekrefttilfella i Noreg kunne ha vore unngått dersom ingen røykte.

Det tek gjerne 20-40 år å utvikle lungekreft frå det tidspunktet ein begynner å røykje. Risikoen blir kraftig redusert når ein sluttar, og meir dess yngre ein er. Risikoen for lungekreft begynner å minske i løpet av eitt til fire år etter at ein sluttar å røykje. Meir enn ti år etter røykeslutt er risikoen for å få lungekreft framleis høgare enn for dei som aldri har røykt, men vesentleg lågare enn for røykarar. (International Agency For Research On Cancer. Tobacco Smoke and Involuntary Smoking. (IARC, 2004; Peto, 2000). 
Passiv røyking, forureining på arbeidsplassen, radon i bustaden og utandørs luftforureining kan òg bidra til auka risiko for lungekreft.

Røyking aukar òg risikoen for kreft i ei rekkje andre organ som nasehole og biholer, munnhole, strupe, svelg, spiserøyr, mage, endetarm, lever, livmorhals, eggstokkar, urinblære, nyre, bukspyttkjertel og beinmerg (leukemi). Også for slike kreftformer blir risikoen redusert etter røykeslutt.

Per i dag veit vi at sigarettrøyking gir mykje høgare risiko for kreft enn det snus gjer. Men sidan snusepidemien er på eit tidleg stadium og kreft utviklar seg over lang tid, kan vi ikkje vite om dagens snusbruk vil verke inn på kor mange krefttilfelle vi får i framtida.

\section{Kronisk obstruktiv lungesjukdom (KOLS)}

Røyking er den vanlegaste årsaka til KOLS og forklarer to av tre tilfelle. Risikoen aukar med tobakksforbruket og tal på røykjeår. Samanlikna med ikkje-røykarar har røykarar i gjennomsnitt 4,2 gonger større risiko og tidlegare røykarar 3,6 gonger større risiko for å få KOLS (Hvidsten, 2010; Helse og omsorgsdepartementet, 2006).

Astma kan oppstå som ei følgje av røyking, og personar med astma kan oppleve at sjukdomen blir forverra ved røyking (Piipari, 2004).

\section{Skader i tannkjøt og tenner}

Røyking og snusing kan vere skadeleg for tenner og tannkjøt. Mindre skader på tannkjøtet forsvinn igjen dersom ein sluttar å røykje/snuse, men tannkjøtet kan òg trekkje seg tilbake slik at ein mister støttevev rundt tennene. Det kan føre til at ein får lause tenner og endra tannstilling (Helsedirektoratet/Helsenorge.no, 2014).

\section{Skader fosteret}

Auka risiko for daudfødsel er kanskje det mest alvorlege uønskte svangerskapsutfallet for kvinner som røykjer. Risikoen aukar dess større røykedosen er, og tal frå Medisinsk fødselsregister for dei siste ti åra viser at risikoen blir dobla med 10 sigarettar per dag, og at han blir tre gonger høgare med 20 sigarettar per dag. Men den absolutte risikoen er likevel låg.

Nokre få sigarettar per dag fører til at risikoen for vekstreduksjon hos fosteret blir dobla, og med større røykedosar aukar risikoen ytterlegare (sjå figur 10). Det er elles godt dokumentert at røyking reduserer fruktbarheita hos både menn og kvinner.

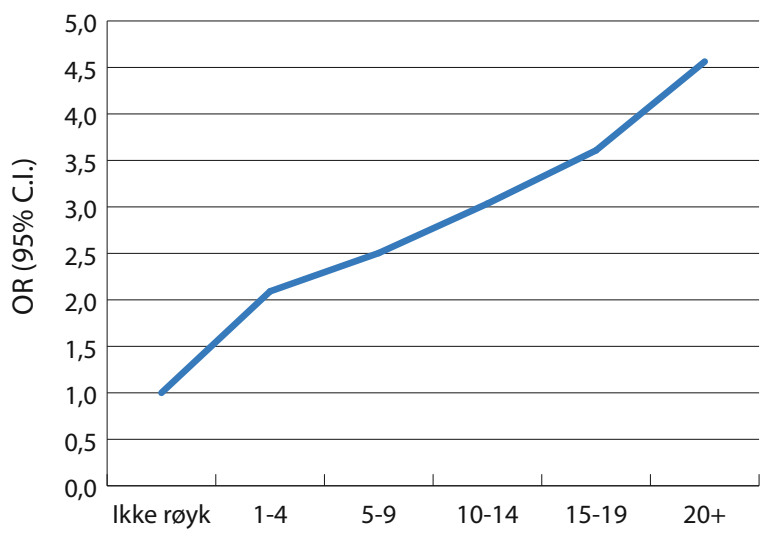

Figur 10: Samanhengen mellom dagleg røyking og redusert vekst hos fosteret 1999-2013. Kjelde: Medisinsk fødselsregister.

Fleire studiar har vist at også snus fører til daudfødsel, vekstretardasjon og for tidleg fødsel. Det er vist at risikoen for daudfødsel blir dobla, mens risikoen for vekstretardasjon og for tidleg fødsel aukar med 30-40 prosent (Wickström, 2011; Baba, 2013; Gunnerbeck, 2014).

\section{Auka risiko for krybbedød}

Det er godt dokumentert at når mor røykjer både under og etter svangerskapet, gir det auka risiko for krybbedød (Zhang \& Wang, 2013). Effekten er avhengig av dose. Det er òg vist at barnet får i seg mykje meir nikotin ved passiv røyking enn via amming, sjølv om berre mor, og ikkje far, røykjer (Fleming \& Blair, 2007; Bajanowski, 2008).

\section{Langtidseffektar av røyking under svangerskapet}

Nyare forsking viser at røyking under svangerskapet har negative effektar på helsa til barnet også etter fødselen og langt inn i vaksen alder. Data frå Den norske mor og barn-undersøkinga viser at ei kvinne som sjølv var utsett for røyking som foster, i større grad kjem til å slite med fedme, høgt blodtrykk og diabetes i vaksen alder. Studien viser òg at ho kjem til å oppleve redusert fruktbarheit, ha større risiko for å utvikle svangerskapsforgifting i eigne svangerskap samt ha større risiko for daudfødsel av eigne barn (Cupul-Uicab, 2011; Cupul-Uicab, 2012).

\section{Passiv røyking gir auka risiko for luft- vegsinfeksjonar hos barn og unge}

Barn og unge som blir eksponerte for passiv røyking, har større risiko for å få luftvegsinfeksjonar, øyreproblem og astma. Dette gjeld særleg for barn på opptil 2 år og gjeld enten det er éin eller fleire i hushaldet som røykjer. Effekten er likevel sterkast dersom det er mor som røykjer. I tillegg bidreg passiv røyking til at infeksjonane blir meir alvorlege (Burke, 2012) (Huttunen, 2011; Jones, 2011). 
Etter at forbodet mot røyking på serveringsstader tredde i kraft i 2004, fekk servitørar og restaurantarbeidarar betre helse; vi fekk ein nedgang i symptom på luftvegssjukdomar og ei betring av lungefunksjon (Eagan, 2006) (Skogstad, 2006).

Det er funne ein nedgang i nedbrytingsstoff frå nikotin i urin hos ikkje-røykjande restaurantarbeidarar (Ellingsen, 2006).

\section{Kva tobakken har å seie for folkehelsa over tid}

\section{Taper 11 leveår}

Det er rekna ut at halvparten av røykarane døyr tidlegare enn dei ville gjort som ikkje-røykarar (Peto, 1994). Norske utrekningar for 2003 viste at 6700 dødsfall årleg kunne tilskrivast røyking (Vollset, 2006). Med ein litt annan metodikk har Global Burden of Disease $\underline{2010}$ estimert at 6624 dødsfall i Noreg i 2010 kunne tilskrivast røyking. Kvar av desse har i gjennomsnitt tapt 11 leveår. Nær halvparten av storrøykarane døyr før dei fyller 70 år. Hjarte- og karsjukdom er den klart hyppigaste dødsårsaka.

Dei som har røykt sigarettar sidan tidleg i vaksenlivet, men som sluttar når dei er 30, 40 eller 50 år, vinn 10, 9 og 6 års levetid samanlikna med dei som held fram med å røykje (Jha, 2014).

\section{Hjarte- og karsjukdomar}

Dødelegheita av hjarte- og karsjukdomar har falle jamt i lang tid. Sjå kapittelet Hjarte- og karsjukdomar. Av alle som døydde av ein hjarte- og karsjukdom i 2012, utgjorde røykjerelaterte dødsfall 13 prosent. Den brattare nedgangen i dødelegheita ved hjarte- og karsjukdom for menn enn for kvinner kan skuldast at menn hadde ein raskare nedgang i røyking fram til slutten av 1990-talet.

\section{Lungekreft}

Talet på nye tilfelle av lungekreft har aldri vore så høgt som i 2012, då 2902 menn og kvinner fekk lungekreft i Noreg. Dei siste tiåra har førekomsten gått langsamt ned blant menn under 60 år og har stabilisert seg blant kvinner i same aldersgruppe. Men vi ser framleis ein auke i nye tilfelle blant kvinner over 60 år og menn over 70 år (Kreftregisteret, 2014).

Mens dødelegheita av lungekreft blant menn nådde toppunktet i 2002 og deretter fall, auka dødelegheita blant kvinner heilt fram til 2010. Det tek fleire tiår å utvikle kreft som følgje av røyking. Derfor aukar sjukelegheita og dødelegheita framleis hos kvinner, sjølv om det lenge har vore ein nedgang i prosentdelen kvinner som røykjer.

\section{Kronisk obstruktiv lungesjukdom (KOLS)}

Dødelegheita av den kroniske lungesjukdomen KOLS auka fram til slutten av 1990-talet for menn og flata deretter ut. Dødelegheita av KOLS hos kvinner aukar framleis.

\section{Førebygging av tobakksbruk}

Det førebyggjande arbeidet mot tobakksbruk i Noreg har vore basert på tre typar tiltak; dei restriktive tiltaka (lovgiving, avgifter), opplysningstiltak og hjelp til å slutte å røykje eller snuse.

Aldersgrenser: I dag er aldersgrensa 18 år for å kjøpe og selje tobakksvarer, og alle former for tobakksreklame er forbode. Det er påbode å merkje sigarettar med helseåtvaringar, og det er forbode å ha tobakksvarer synleg oppstilte på utsalsstader. Dette forbodet gjeld både røykjetobakk og røykfri tobakk (snus).

Røykfrie område og lovgiving: Frå og med 1. juli 2014 forsvinn moglegheita til å ha røykjerom eller røykje på enkeltkontor. Med nokre svært få unntak er det då totalt røykjeforbod på arbeidsplassar, transportmiddel og i lokale der allmennheita har tilgang. Samtidig blir det innført røykfrie inngangsparti til helseinstitusjonar og offentlege verksemder samt tobakksfrie skular og barnehagar både inne og ute. Elevane får heller ikkje lov til å snuse eller røykje i skuletida. Ein arbeider med å handheve aldersgrensa betre.

Avgifter: I dag er avgiftsnivået det same for all tobakk som blir røykt. Avgiftene for snus er mykje lågare. I perioden frå 1980 og fram til i dag har prisauken på sigarettar vore marginalt høgare enn utviklinga i kjøpekraft.

Hjelp til å slutte å røykje: Sidan Røyketelefonen blei etablert i 1996 og fram til i dag har denne vore ei viktig teneste til dei som ønskjer å slutte å røykje. Røyketelefonen tilbyr òg hjelp til dei som vil slutte med snus. Det blir òg gitt tilbod om røykjeavvenning gjennom helsetenestene og andre tiltak.

I Noreg er det framleis mange som røykjer, og fleire og fleire som bruker snus. Mellom anna røykjer åtte prosent av gravide, og eit ukjent tal gravide bruker snus. Førebygging av røykjerelaterte helseskader og nikotinavhengigheit er derfor framleis svært viktig folkehelsearbeid. Forsking på førebygging viser at 
individuelt retta tiltak åleine ikkje er nok, men at ulike typar tiltak bør kombinerast for å få god effekt (Rosen, 2010; Aarø, 2009).

\section{Referansar}

Aarø, L.E., Lund, K.E., Vedøy, T.F. \& Øverland, S. Evaluering av myndighetenes samlede innsats for å forebygge tobakksrelaterte sykdommer i perioden 2003 til 2007. Oslo: Statens institutt for rusmiddelforskning. SIRUSrapport 3/2009.

Baba, S., et al., Influence of Snuff and Smoking Habits in Early Pregnancy on Risks for Stillbirth and Early Neonatal Mortality. Nicotine Tob Res, 2013.

Bajanowski, T., B. Brinkmann, E. A. Mitchell, M. M. Vennemann, H. W. Leukel, K. P. Larsch, J. Beike and S. I. D. G. Ge (2008). Nicotine and cotinine in infants dying from sudden infant death syndrome. Int J Legal Med 122(1): 23-28. Pubmed.

Bakhru, A. and T. P. Erlinger (2005). Smoking cessation and cardiovascular disease risk factors: results from the Third National Health and Nutrition Examination Survey. PLoS Med 2(6): e160. Pubmed.

Burke, H., J. Leonardi-Bee, A. Hashim, H. Pine-Abata, Y. Chen, D. G. Cook, J. R. Britton and T. M. McKeever (2012). Prenatal and passive smoke exposure and incidence of asthma and wheeze: systematic review and meta-analysis. Pediatrics 129(4): 735-744. Pubmed.

Bye, E. K., E. J. Amundsen and M. Lund Bruk av tobakk, rusmidler og vanedannende legemidler i Norge: hovedfunn fra SIRUS' befolkningsundersøkelse i 2012. SIRUSrapport. Oslo, SIRUS. 6/2013: 61 s. : ill. (2013). SIRIUS.

Cupul-Uicab, L. A., D. D. Baird, R. Skjaerven, P. SahaChaudhuri, K. Haug and M. P. Longnecker (2011). In utero exposure to maternal smoking and women's risk of fetal loss in the Norwegian Mother and Child Cohort (MoBa). Hum Reprod 26(2): 458-465. Pubmed.

Cupul-Uicab, L. A., R. Skjaerven, K. Haug, K. K. Melve, S. M. Engel and M. P. Longnecker (2012). In utero exposure to maternal tobacco smoke and subsequent obesity, hypertension, and gestational diabetes among women in the MoBa cohort. Environ Health Perspect 120(3): 355-360. Pubmed.

Eagan, T. M., J. Hetland and L. E. Aaro (2006). Decline in respiratory symptoms in service workers five months after a public smoking ban. Tob Control 15(3): 242-246. Pubmed.

Ellingsen, D. G., G. Fladseth, H. L. Daae, M. Gjolstad, K. Kjaerheim, M. Skogstad, R. Olsen, S. Thorud and P. Molander (2006). Airborne exposure and biological monitoring of bar and restaurant workers before and after the introduction of a smoking ban. J Environ Monit 8(3): 362-368. Pubmed.

Engeland, A., T. Haldorsen, S. Tretli, T. Hakulinen, L. G. Horte, T. Luostarinen, K. Magnus, G. Schou, H. Sigvaldason, H. H. Storm and et al. (1993). Prediction of cancer incidence in the Nordic countries up to the years 2000 and 2010. A collaborative study of the five Nordic Cancer Registries. APMIS Suppl 38: 1-124. Pubmed.
Fleming, P. and P. S. Blair (2007). Sudden Infant Death Syndrome and parental smoking. Early Hum Dev 83(11): 721-725. Pubmed.

Gunnerbeck, A., A. K. E. Bonamy, A. K. Wikstrom, F. Granath, R. Wickstrom and S. Cnattingius (2014). Maternal Snuff Use and Smoking and the Risk of Oral Cleft Malformations - A Population-Based Cohort Study. Plos One 9(1): e84715. Pubmed.

\section{Global Burden of Disease.}

Helsedirektoratet. Munnhelse og tobakk. Helsedirektoratet. Retrieved 20/6/2014, from Helsedirektoratet.

Helsedirektoratet (2013). Tall om tobakk. Tilgjengelig på helsedirektoratet.no

Helse- og omsorgsdepartementet Nasjonal strategi for KOLS-området 2006-2011, Helse- og omsorgsdepartementet. (2006). Regjeringen.

IARC; International Agency For Research On Cancer. Tobacco Smoke and Involuntary Smoking. Lyon: International Agency for Research on Cancer, 2004

Huttunen, R., T. Heikkinen and J. Syrjanen (2011). Smoking and the outcome of infection. J Intern Med 269(3): 258-269. Pubmed.

Hvidsten, S. C., L. Storesund, T. Wentzel-Larsen, A. Gulsvik and S. Lehmann (2010). Prevalence and predictors of undiagnosed chronic obstructive pulmonary disease in a Norwegian adult general population. Clin Respir J 4(1): 13-21. Pubmed.

Jha, P. and R. Peto (2014). Global effects of smoking, of quitting, and of taxing tobacco. N Engl J Med 370(1): 60-68. Pubmed.

Jones, L. L., A. Hashim, T. McKeever, D. G. Cook, J. Britton and J. Leonardi-Bee (2011). Parental and household smoking and the increased risk of bronchitis, bronchiolitis and other lower respiratory infections in infancy: systematic review and meta-analysis. Respir Res 12: 5. Pubmed.

Kreftregisteret (2014). Historisk høye lungekrefttall tross røykekutt. Retrieved 20/6/2014, from Kreftregisteret.

Lindbak, R. L. and A. Helleve. Tal om tobakk: 1973-2012. Oslo, Helsedirektoratet. (2013). Helsedirektoratet

Lund, K. E. Samfunnsskapte endringer i tobakksbruk i Norge i det 20. århundre. Oslo, Universitetet i Oslo. (1996).

Peto, R. (1994). Smoking and death: the past 40 years and the next 40. BMJ 309(6959): 937-939. PMC.

Peto, R., S. Darby, H. Deo, P. Silcocks, E. Whitley and R. Doll (2000). Smoking, smoking cessation, and lung cancer in the UK since 1950: combination of national statistics with two case-control studies. BMJ 321(7257): 323-329. Pubmed.

Piipari, R., J. J. Jaakkola, N. Jaakkola and M. S. Jaakkola (2004). Smoking and asthma in adults. Eur Respir J 24(5): 734-739. Pubmed.

Rosen, LJ, Ben Noach M. Systematic reviews on tobacco control from Cochrane and the Community Guide: different methods, similar findings. J Clin Epidemiol. 2010;63: 596-606. doi: 10.1016/j.jclinepi.2009.09.010. 
SCENIHR; Scientific Committee on Emerging and Newly Identified Health Risks. Health Effects on Smokeless Tobacco Products. 2008.European Commision, Health and Consumer Protection, Directorate - Generale. Scientific Commitees.

Skogstad, M., K. Kjaerheim, G. Fladseth, M. Gjolstad, H. L. Daae, R. Olsen, P. Molander and D. G. Ellingsen (2006). Cross shift changes in lung function among bar and restaurant workers before and after implementation of a smoking ban. Occupational and Environmental Medicine 63(7): 482 487. PMC.

Statistisk sentralbyrå. Statistikk røykevaner. Sist oppdatert 5.2.2014.

Tverdal, A., D. Thelle, I. Stensvold, P. Leren and K. Bjartveit (1993). Mortality in relation to smoking history: 13 years' follow-up of 68,000 Norwegian men and women 35-49 years. J Clin Epidemiol 46(5): 475-487. Pubmed.

Ungdata. Nasjonale resultater 2010-2012. Norsk institutt for forskning om oppvekst, velferd og aldring. NOVA Rapport 10/13. 2013.
Vollset, S. E., S. R., A. Tverdal and H. K. Gjessing. Hvor dødelig er røyking?: rapport om dødsfall og tapte leveår som skyldes røyking. Rapport. Oslo, Nasjonalt folkehelseinstitutt. 2006:4: 24 s. : diagr. (2006). $\mathrm{FHI}$

Wikstrom, A.K., et al. Snuff during pregnancy no risk-free alternative to smoking. Lakartidningen, 2011. 108(29-31): p. $1430-3$.

Zhang, K. and X. Wang (2013). Maternal smoking and increased risk of sudden infant death syndrome: a metaanalysis. Leg Med (Tokyo) 15(3): 115-121. Pubmed.

\section{FORFATTARAR}

Liv Grøtvedt, Leif Edvard Aarø, Rolv Skjærven og Siri Hauge Opdal 
- 25 prosent er utsette for støy frå vegtrafikk og annan støy over det tilrådde nivået ved bustaden sin. Ein halv million er svært plaga.

- Delen av befolkninga som bur i område med støy over anbefalt nivå, auka med 22 prosent frå 1999 til 2011.

- Søvnforstyrringar bidreg mest til sjukdomsbyrda i befolkninga som følge av støy.

- God og heilskapleg arealplanlegging kan førebygge støyplager.

- Langvarige og kraftige støybelastningar eller svært høge kortvarige lydimpulsar kan gi permanente høyrselsskader.

- Høyrselstap kan gi øyresus. Om lag 15 prosent av befolkninga over 20 år oppgir at dei er plaga av øyresus, viser undersøkingar i Nord-Trøndelag.

\section{Kva er støy}

Støy er definert som uønskt lyd og lyd som kan gi helseskade.

Dei viktigaste kjeldene til støy i samfunnet er samferdsel, tekniske installasjonar, industri, naboaktivitetar og bygge- og anleggsverksemd.

Langvarige og kraftige støybelastningar eller svært høge kortvarige lydimpulsar kan gi permanente høyrselsskader.

\section{Tilrådde grenser}

For å unngå sterk støyplage er det anbefalt at støynivå frå trafikk ikkje bør overstige $55 \mathrm{~dB}$ utanfor bustader (WHO, 1999).

Fare for høyrselsskader oppstår ved langvarig eksponering av lydnivå over 80-85 dB eller ved eksponering av impulslyd som smell fra eksplosjonar, slaglyd, skot frå gevær, spikerpistol og liknande med støytoppar over $130-140 \mathrm{~dB}$.

\section{Førekomst av støyplager i Noreg i dag}

\section{Helseskadeleg støy}

Støy rammar mange menneske i Norge. Om lag 25 prosent av befolkninga er utsette for gjennomsnittleg utandørs støynivå på over $55 \mathrm{~dB}$ ved bustaden sin, og ein halv million menneske er svært plaga (Miljødirektoratet, 2013). Støy frå vegtrafikk er den klart dominerande kjelda til støyplager i samfunnet. Mellom 3 og 5 prosent oppgir at dei har problem med søvnen på grunn av støy.

\section{Støy som kan gi høyrselstap}

Støy i arbeidslivet utgjer den største risikoen for høyrselstap i befolkninga. Høyrselsskade som kjem av støy på arbeidsplassen, toppar Arbeidstilsynets statistikk over melde arbeidsrelaterte skader.

Av eksponering på fritida er det sannsynlegvis knytt større risiko til støy frå skyting og annan impulslyd enn til støy frå musikk og bruk av øyretelefonar.

\section{Utvikling over tid}

\section{Støyplager i samfunnet}

Vegtrafikk stod for i overkant av 80 prosent av støyplagene i 2011. Talet på folk som bur i bustader som er utsette for vegtrafikkstøy over det tilrådde nivået på 55 dB, auka med om lag 22 prosent frå 1999 til 2011. 
Årsaka til denne auka er hovudsakleg trafikkvekst og ein auka prosentdel tungtrafikk, i tillegg til befolkningsvekst i støyutsette område. Støy frå jernbane og luftfart gjekk noko ned frå 1999 til 2006, men har etter dette samla sett auka på nytt (SSB, 2013).

Den tidlegare nedgangen i støy kom av meir stillegåande tog og fly, og ein nedgang i både gods- og persontrafikk for tog. Etter 2006 har persontrafikken auka på nytt, og det er særleg større trafikk på baner gjennom folketette område som bidreg til at prosentdelen støyutsette frå tog har auka på nytt. Auka i støyutsette frå luftfart kjem også av befolkningsvekst i nær flyplassane (SSB, 2013).

På lengre sikt er det forventa at meir støysvake dekk og veidekke vil føre til mindre støyplager frå vegtrafikken. Men førebels har vi fått svært lite støyreduksjon som følge av slike tiltak. Nyare støykjelder, for eksempel nærmiljøanlegg, vindkraftanlegg og ventilasjonsanlegg, kan føre til auke i støyplager, også i område som i dag er lite støybelasta.

\section{Høyrselstap}

Talet på høyrselshemma vil i framtida sannsynlegvis auke, fordi befolkninga blir stadig eldre. Befolkningsstudiar viser at den viktigaste risikofaktoren for høyrselstap er auka alder.

Vi veit ikkje i kva grad ein reduksjon av støy i arbeidslivet og ei eventuell endring i eksponering for andre faktorar påverkar høyrselsutviklinga i befolkninga. Derfor er det behov for oppdaterte data over utbreiinga av høyrselstap i befolkninga og nye studiar av moglege risikofaktorar.

\section{Forskjellar mellom grupper i befolkninga}

Varleik for støy. Det er store individuelle forskjellar i varleik for støy, og helseverknadene av støy vil vere avhengig av ei rekke andre faktorar enn sjølve støyen. Problem knytt til støy i bumiljø, er størst i folketette område av landet, og dei som bur i område med spreidd busetnad, er minst plaga.

Høyrselstap. Førekomst av permanent høyrselstap aukar med alderen, men det er store individuelle aldersforskjellar ved start, progresjon og alvorsgrad. Høyrselstap har til ein viss grad samband med yrke, spesielt for menn over 45 år. Ei undersøking frå Folkehelseinstituttet viser at menn som er bygg-og anleggsarbeidarar, verkstadmekanikarar, linjemontørar, trearbeidarar, gruvearbeidarar, sjømenn (dekkmannskap), maskin- og motorreparatørar og offiserar har dårlegast høyrsel (Engdahl \& Thambs, 2010).

Nedsett høyrsel er vanlegare i ressursfattige delar av befolkninga enn blant folk med høg utdanning og inntekt.

\section{Helseskader og -plager som følge av støybelastning}

Støybelastningar har fleire helseeffektar:

- Støy kan gi fysiologiske endringar som er typiske for stress.

- Støy kan også påverke det fysiologiske søvnmønsteret.

- Opplevinga av å bli forstyrra under kvile, søvn og avkopling, i samtale eller i ein arbeidssituasjon, bidreg til mistrivsel, redusert velvære og helseplager.

- Nyare forsking tyder på ein samanheng mellom langvarig eksponering for trafikkstøy og auka risiko for høgt blodtrykk og hjarte- og karsjukdom. Høge nivå av flystøy ved skular har vist å ha ein negativ innverknad på barns minne og leseferdigheiter (Basner, 2014).

\section{Høyrselstap og øyresus (tinnitus)}

Støyeksponering kan skade sneglehuset i det indre øyret. Langvarige og kraftige støybelastningar eller svært høge kortvarige lydimpulsar kan gi permanente høyrselsskader. Dette er godt dokumentert.

Støy på jobben er ein viktig årsak til høyrselstap for mange middelaldrande og eldre menn, men ikkje blant yngre menn eller kvinner. Impulsstøy (smell), særleg fra skyting, har gjort nesten like mykje skade på høyrsla i befolkninga som arbeidsstøy, viser Helseundersøkelsene i Nord-Trøndelag. Støy skader høyrselsevna for lyse lydar mest.

Høyrselsskadeleg støy førekjem også i fritida.

Høyrselstap kan gi øyresus og psykiske plager:

- Høyrselstap kan gi øyresus, eller tinnitus, og dette oppfattast ofte som eit like stort problem som sjølve høyrselssvekkinga. Om lag 15 prosent av befolkninga i Nord-Trøndelag over 20 år oppgir at dei er plaga av øyresus.

- Høyrselstap kan føre til sosial isolasjon, gi vanskar i jobb og fritid og påverke livskvaliteten. Forsking ved Folkehelseinstituttet viser likevel at høyrselstap har forholdsvis lite å seie for opplevinga av angst og depresjon, sjølvkjensle og livstilfredsheit. 


\section{Internasjonalt}

Ifølge WHO bidreg støy i samfunnet med minst 1 million helsetapsjusterte leveår (DALY) årleg i VestEuropa (WHO, 2011). Det største bidraget kan tilskrivast støyrelaterte søvnforstyrringar, sjå figur 1. Også spesifikke estimat for Noreg viser at det er søvnforstyrringar som bidreg til den største delen av tapte funksjonsfriske leveår som kan tilskrivast støy (Aasvang, 2012). Vidare har WHO estimert at om lag 10 prosent av verdas befolkning er utsette for potensielt høyrselsskadelege støynivå (Oishi, 2011).

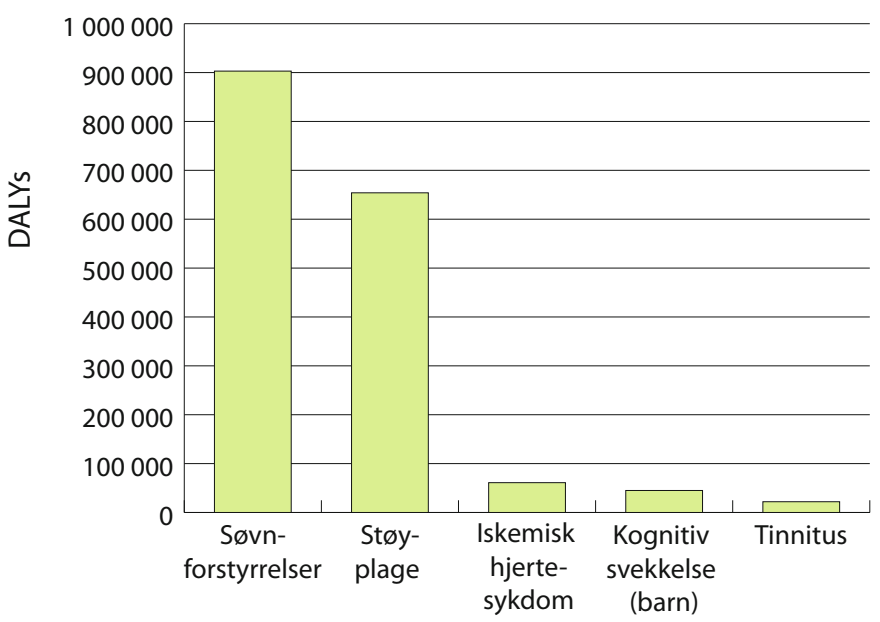

Figur 1. Estimert sjukdomsbyrde (DALYs) som følge av støy i Vest-Europa. Kjelde: WHO, 2011.

\section{Førebygging og tiltak}

Støyplager. God og heilskapleg arealplanlegging er nødvendig for å unngå nye støykonfliktar i bustadområde og for å førebygge helseplager på grunn av støy. Dette er spesielt viktig i pressområde med stor befolkningsvekst. Moglege tiltak er å sørge for at nye bustader har ein stille side der soveromma er, for å unngå søvnforstyrringar. Vidare er det viktig at grøn infrastruktur blir bevart for å gi moglegheit til restitusjon i nærmiljøet.

Høyrselsskader. Trass ei rekke tiltak for å førebygge høyrselssvekking i befolkninga, er støyeksponering framleis den vanlegaste årsaka til høyrselstap - når vi ser bort frå høyrselstap som følge av aldring. For å unngå støyinduserte høyrselsskader er det viktig å unngå eksponering for høge impulslydar og langvarig kraftig støybelastning, for eksempel ved å bruke høyrselvern. Men ein skal hugse at det er store individuelle variasjonar når det gjeld faren for å få støyskader.
Det finst førebels ingen gode metodar for å fastsette kven som har lettskadeleg høyrsel, men arv spelar ei viss rolle.

\section{Referansar}

Basner, M, Babisch, W, Davis, A, Brink, M, Clark, C et al. Auditory and non-auditory effects of noise on health. The Lancet 2014; 383(9925): 1325-32.

Engdahl, B \& Tambs, K. Occupation and the risk of hearing impairment--results from the Nord-Trøndelag study on hearing loss. Scand J Work Environ Health 2010; 36(3): 250-7. Type of occupation and the risk of hearing loss.

Engelien, E, Steinnes, M \& Haagensen, T. Støyeksponering og støyplage i Norge 1999-2011; Flere støyutsatte. SSB 2013.

Folkehelseinstituttet: GM Aasvang. Helsebelastning som skyldes veitrafikkstøy i Norge. Oslo: Folkehelseinstituttet; 2012.

Miljødirektoratet. 2013. Flere utsatt for støy. [hentet 04.06.2014].

Oishi, N \& Schacht, J. Emerging treatments for noiseinduced hearing loss. Expert Opin Emerg Drugs 2011; 16(2): 235-45.

WHO. Burden of disease from environmental noise. Quantification of healthy life years lost in Europe. Copenhagen, Denmark: WHO Regional office for Europe; 2011.

WHO: B Berglund, T Lindvall and DH Schwela. Guidelines for Community Noise. Geneva, Switzerland: World Health Organization; 1999.

\section{FORFATTARAR}

Gunn Marit Aasvang, Bo Engdahl, Norunn Hjertager Krog 


\section{Vaksinar i førebygging av infeksjonar}

- Meir enn 9 av 10 barn følger det norske barnevaksinasjonsprogrammet.

- Etter at barnevaksinasjonsprogrammet blei etablert, har sjukdomane i programmet nesten blitt borte i Noreg.

- Tilbod om rotavirusvaksine blir innført for alle spedbarn i 2014.

- Vaksinasjon er viktig også i vaksen alder.

- For influensavaksine er det eit mål å auke vaksinasjonsdekninga i risikogruppene.

- Polio er på nytt ein trussel mot internasjonal folkehelse.

-WHO har som mål å utrydde polio, meslingar og raude hundar.

\section{Kva er vaksinar?}

Vaksinar gir eit enkelt og effektivt vern mot alvorlege smittsame sjukdomar. Ved vaksinasjon får kroppen tilført svekte bakteriar eller virus, delar av slike eller noko som liknar. Det gjer at immunsystemet blir aktivert utan at vi blir sjuke. Dersom vi seinare blir smitta, kjenner immunsystemet bakterien eller viruset att, slik at vi unngår sjukdomen heilt eller får ei mildare sjukdomsutvikling.

\section{Vaksinasjon gjennom livet}

Alle vaksinar har som mål å verne enkeltpersonar. I tillegg er målet med vaksinasjonsprogramma å få kontroll med eller utrydde ein sjukdom.

Tabell 1. Barnevaksinasjonsprogrammet i Noreg, september 2014.

\begin{tabular}{|l|l|}
\hline Alder & Vaksinasjon mot \\
\hline 3 veker & Rotavirussjukdom \\
\hline 5 månader & $\begin{array}{l}\text { Rotavirussjukdom } \\
\text { Difteri, tetanus, kikhoste, polio og Haemophilus influenzae type } \\
\text { B-infeksjon } \\
\text { Pneumokokksjukdom }\end{array}$ \\
\hline 12 månader & $\begin{array}{l}\text { Difteri, tetanus, kikhoste, polio og Haemophilus influenzae type } \\
\text { B-infeksjon Pneumokokksjukdom }\end{array}$ \\
\hline 15 månader & $\begin{array}{l}\text { Difteri, tetanus, kikhoste, polio og Haemophilus influenzae type } \\
\text { B-infeksjon Pneumokokksjukdom }\end{array}$ \\
\hline 2. klasse (7 år) & Meslingar, kusma, raude hundar \\
\hline 6. klasse (11 år) & Difteri, tetanus, kikhoste, polio \\
\hline 7. klasse (12 år), jenter & Meslingar, kusma, raude hundar \\
\hline 10. klasse (15 år) & Humant papillomavirus \\
\hline Barn med foreldre frå ikkje-lågendemiske land & Difteri, tetanus, kikhoste, polio \\
\hline Barn med foreldre frå høgendemiske land & Tuberkulose* \\
\hline
\end{tabular}

* Vanlegvis vaksinasjon i spedbarnsalderen 


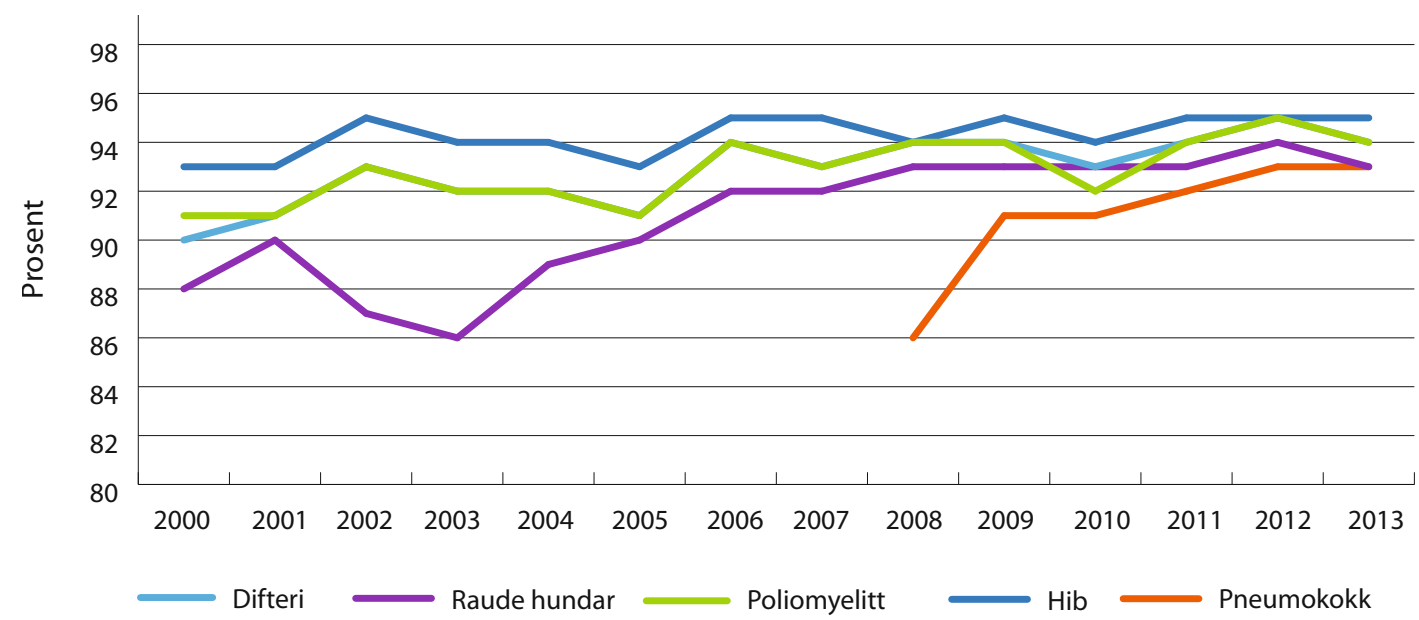

Figur 1: Vaksinasjonsdekning i Noreg. Prosentdel av 2-åringar som har fått anbefalte vaksinar 2000-2013. Kjelde: SYSVAK, Folkehelseinstituttet.

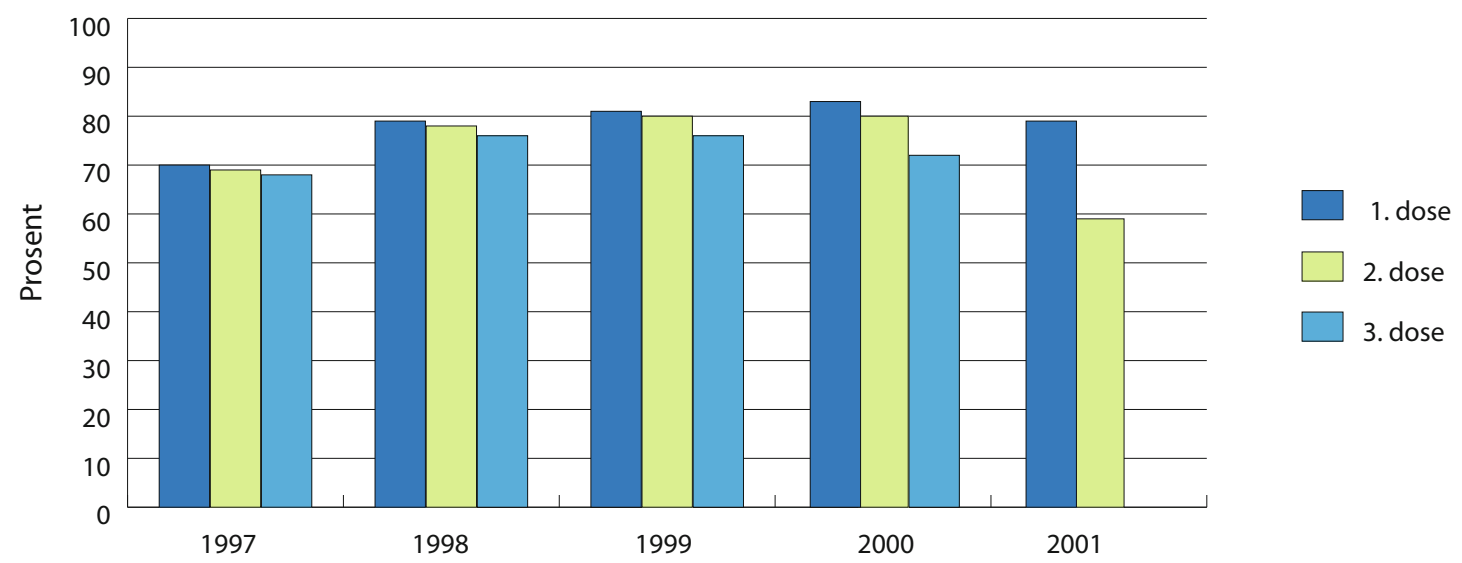

Figur 2: Prosentdel jenter i 7. klasse som har fått HPV-vaksine, etter fødselsår (1997-2001). Kjelde: SYSVAK, Folkehelseinstituttet.

\section{Det norske barnevaksinasjons- programmet}

Alle norske barn får tilbod om vaksinar som del av det norske barnevaksinasjonsprogrammet. Frå hausten 2014 inkluderer barnevaksinasjonsprogrammet vaksinar mot 11 forskjellige sjukdomar, sjå tabell 1. I tillegg får barn i definerte risikogrupper tilbod om vaksine mot tuberkulose og hepatitt B. All vaksinasjon er frivillig.

\section{Dei fleste norske barn følger vaksinasjonsprogrammet}

Det er stor oppslutning om det norske barnevaksinasjonsprogrammet. Meir enn ni av ti barn og unge fekk i 2013 dei tilrådde barnevaksinane, sjå figur 1. Eit unntak er vaksine mot humant papillomavirus (HPV-vaksine) som førebygger alvorlege forstadium til livmorhalskreft.
I Noreg får jenter i 7. klasse tilbod om HPV-vaksine. Dekninga for vaksinen har auka sidan innføringa i 2009, og i 2013 var ho på 75 prosent, sjå figur 2.

Internasjonale studiar viser god effekt av HPV-vaksine som er gitt i vaksinasjonsprogram. I land som i tillegg til å vaksinere 12-13-årige jenter også tilbyr vaksine til eldre jenter og unge kvinner, har ein sett rask reduksjon i førekomsten av kjønnsvorter og forstadium til livmorhalskreft (Blomberg, 2013; Baldur-Fjelskov, 2014; Brotherton 2011; Crowe 2014).

Det vil framleis ta tid før vi kan måle tilsvarande effekt $\mathrm{i}$ Noreg. Dette kjem først og fremst av at vi i Noreg berre har hatt tilbod om vaksinen til jenter i 7. klasse. 


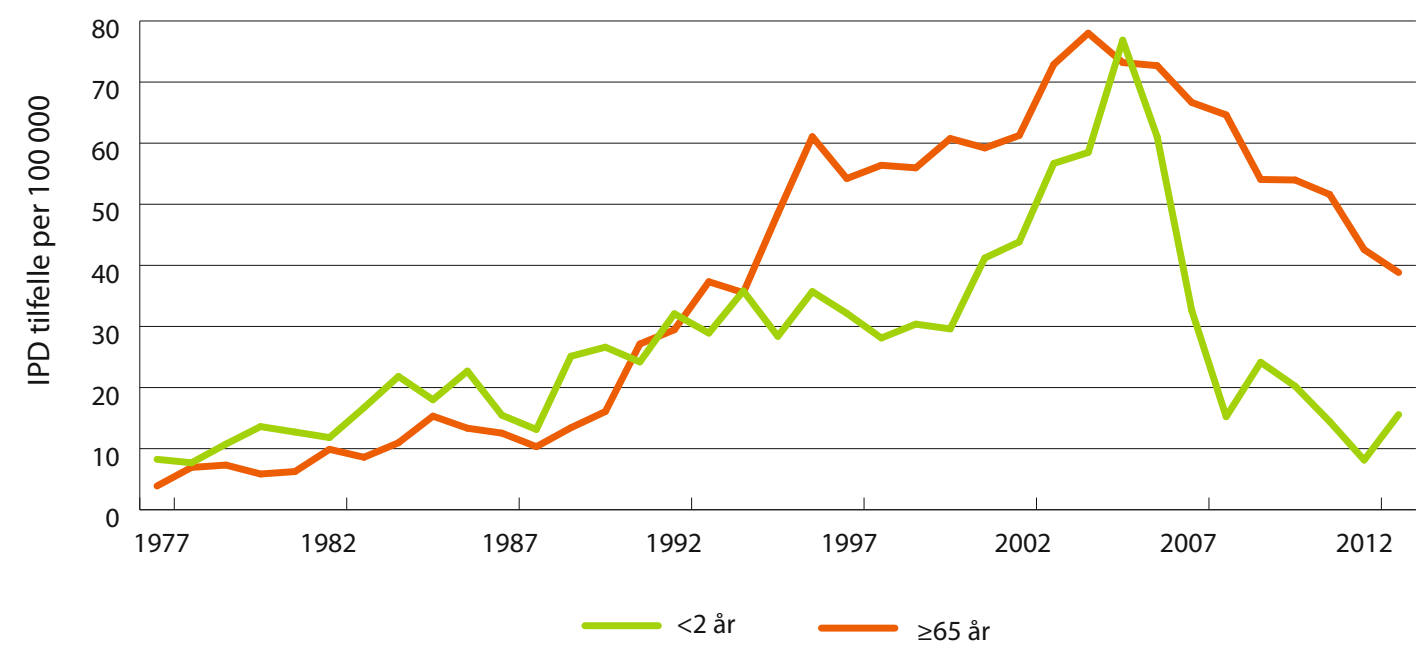

Figur 3: Invasiv pneumokokksykdom (IPD) i Noreg 1977-2013 i ulike aldersgrupper. Diagrammet viser tilfelle per 100000. Kjelde: Meldingssystem for smittsame sjukdomar (MSIS), Folkehelseinstituttet.

\section{Effekten av barnevaksinasjons- programmet}

Individuelt vern. Vaksinane i barnevaksinasjonsprogrammet gir godt vern til den som er vaksinert. Etter fullført vaksinasjon varierer det individuelle vernet frå om lag 85 prosent for kikhostevaksine til nærmare 100 prosent for difteri-, tetanus- og poliovaksine.

Flokkvern. Når ein stor del av befolkninga får vaksinasjon mot ein sjukdom, blir smittepresset redusert. Det gjer at også personar som ikkje er vaksinerte, får eit indirekte vern mot sjukdom. Dette kallar vi flokkvern.

For å få ein sjukdom under kontroll i befolkninga, må ein ha ei vaksinasjonsdekning på 80-95 prosent, avhengig av kor lett sjukdomen smittar mellom menneske. Dersom vaksinasjonsdekninga blir for låg, kan sjukdomar som vi i dag har kontroll over, komme tilbake.

Eit eksempel på effektiv flokkvern såg vi etter innføringa av pneumokokkvaksine i barnevaksinasjonsprogrammet i 2006. Pneumokokkar er bakteriar som blant anna kan gi lungebetennelse. Etter at vaksinen blei innført, har også førekomsten av alvorleg (invasiv) pneumokokkinfeksjon hos eldre falle, sjå figur 3.

Barnevaksinasjonsprogrammet har ført til at vi i Noreg har kontroll over infeksjonssjukdomar som polio, meslingar og difteri, sjølv om det blant ikkjevaksinerte framleis førekjem sporadiske, mindre utbrot av meslingar.
For at vaksinasjonsprogrammet skal gi best mogleg vern, er behovet for endringar stadig til vurdering. Desse vurderingane er først og fremst basert på den kontinuerlege overvakinga av både sjukdomane vi vaksinerer mot, og den generelle smittesituasjonen i landet. Vaksinar kan bli tekne ut eller lagde til i programmet, tidspunktet for vaksinasjon kan endrast eller oppfriskingsdosar kan bli lagde til.

\section{Behov for oppfrisking av kikhostevaksine}

Sidan 1997 har vi i Noreg observert ei stor auke i førekomsten av kikhoste, særleg hos eldre barn og unge. Hausten 2006 blei det derfor innført oppfriskingsdose av kikhostevaksine i 2 . klasse.

Vedvarande høg førekomst av kikhoste i aldersgruppa 10-19 år førte til eit tilbod om oppfriskingsdose av kikhostevaksine i 10. klasse frå hausten 2013. Fordi denne aldersgruppa blir tilrådd å ta difteri-, stivkrampe- og poliovaksine, kan ein få alle dei fire vaksinekomponentane i ein kombinasjonsvaksine.

Vi forventar at førekomsten av kikhoste i den vaksinerte aldersgruppa blir redusert, slik vi har sett etter innføringa av oppfriskingsdose i 2. klasse, sjå figur 4 neste side.

\section{Rotavirusvaksine blir innført hausten 2014}

Nesten alle barn får rotavirusinfeksjon før dei blir 5 år, og nesten 1000 barn i Noreg blir kvart år behandla på sjukehus på grunn av alvorleg uttørking som følge av rotavirusinfeksjon. 


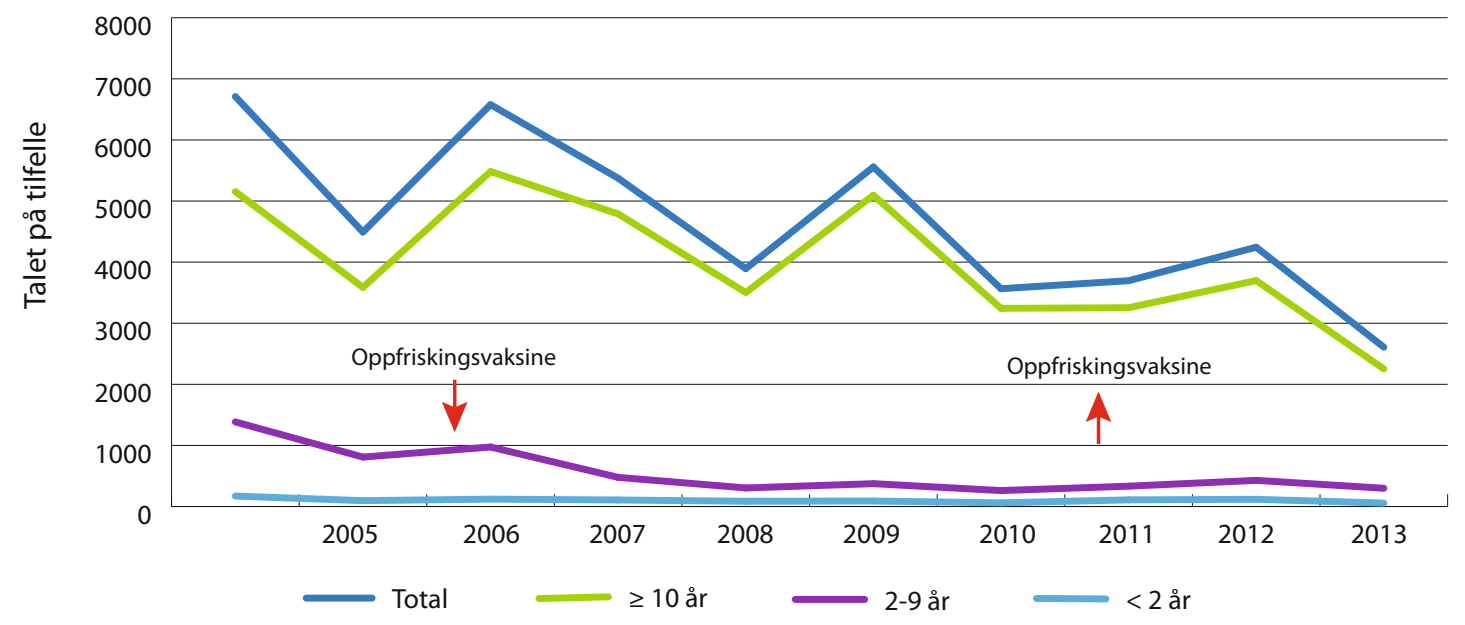

Figur 4: Talet på tilfelle som er melde til MSIS 2004-2013 etter diagnoseår og aldersgrupper. Kjelde: MSIS, Folkehelseinstituttet.

Frå hausten 2014 inngår vaksine mot sped- og småbarnsdiaré forårsaka av rotavirus i barnevaksinasjonsprogrammet. Vaksinen er ein drikkevaksine som blir gitt i dropeform i munnen til spedbarn.

\section{Vaksne treng også vaksinar}

For fleire av vaksinane som blir gitt i barnevaksinasjonsprogrammet, blir vernet etter kvart redusert. Derfor treng ein etter ei tid oppfriskingsdosar for å halde ved like ei tilstrekkeleg immunitet.

Det er ikkje etablert noko vaksinasjonsprogram for vaksne, men vi tilrår følgande:

- Oppfrisking av vaksine mot difteri, stivkrampe og kikhoste cirka 10 år etter førre vaksinasjon (FHI).

- Oppfriskingsdose mot polio ved reise til land der det førekjem poliosmitte.

Per i dag har vi ingen god oversikt over kor mange som følger desse råda.

Vaksinasjon mot andre sjukdomar er også aktuelt for personar som av ulike årsaker har auka risiko for å bli smitta (som ved reise eller yrkeseksponering), eller for å få ei spesielt alvorleg sjukdomsutvikling (FHI).

Barnevaksinasjonsprogrammet blei etablert på1950talet. Personar som er fødde før dette, kan derfor mangle vern. Vi tilrår derfor følgande:

- Grunnvaksinasjon til vaksne som ikkje har fått vaksinane som barn.

For eksempel gjaldt alle dei 7 melde tilfella av stivkrampe dei siste 10 åra personar som var eldre enn 70 år.

Det finst inga god oversikt over omfanget av vaksne som ikkje er grunnvaksinerte.

\section{Fleire bør ta sesonginfluensavaksine}

Vanlegvis blir mellom fem og ti prosent av befolkninga sjuke av influensa i løpet av ein vintersesong, og ein reknar med at influensa forårsakar i gjennomsnitt 900 dødsfall per år i Noreg (FHI, 2014). Les meir om dette i kapitlet Infeksjonssykdommer. I Noreg tilrår vi influensavaksine til personar i grupper med auka risiko for alvorleg sjukdom og død på grunn av influensa (gravide, enkelte grupper kronisk sjuke, eldre). I tillegg er det nokre grupper som vi tilrår å ta influensavaksine for å verne andre, for eksempel helsepersonell som har pasientkontakt.

For influensa har vaksinasjonsdekninga i dei ulike risikogruppene i Noreg vore på mellom 42 og 47 prosent etter 2010. WHO har ei målsetting om vaksinasjonsdekning på meir enn 75 prosent i den eldre delen av befolkninga. Sjølv om det er usikkerheit rundt dei norske estimata, er det langt igjen før dette målet frå WHO er nådd i Noreg.

Med stadig fleire eldre er det mykje å vinne ved betra helse, også med berre ei lita auke i dekningstala. Folkehelseinstituttet jobbar målretta for å nå målet til WHO.

\section{Vaksine mot smittsam hjernehinne- betennelse (meningokokksjukdom)}

Vi deler bakteriane som forårsakar smittsam hjernhinnebetennelse, meningokokkar, inn i ulike undergrupper (serogrupper). Dei fleste infeksjonane har utspring i serogruppene $A, B, C, X, W$ og Y. Dei forskjellige serogruppene gir stort sett same sjukdomsbilete.

I Noreg og andre europeiske land var serogruppene B og $C$ tidlegare årsak til om lag 90 prosent av sjukdomstilfella. Noreg hadde ein meningokokk B-epidemi som begynte på 1970-talet og avtok gradvis i 1990-åra. 
Frå 2010 blei gruppe $Y$ vanlegare, og i 2010-2012 var serogruppe $C$ og $Y$ til saman årsak til meir enn halvparten av tilfella. I seinare år har det stort sett vore meldt under 40 tilfelle i året, og i 2012 blei det til saman meldt berre 24 tilfelle.

Det finst ulike vaksinar mot sjukdomen. Dei vernar mot respektive serogruppe $B, C$ og serogruppene $A, C, W$ og $\mathrm{Y}$ i kombinasjon. Vaksine blir tilrådd til personar med auka risiko for smitte (FHI, 2014a).

\section{Utrydding av polio, meslingar og raude hundar}

Alle vaksinar har som mål å verne enkeltpersonar. Det mest ambisiøse målet for eit vaksinasjonsprogram er å utrydde sjukdomen. Dette er målet til WHO for polio, meslingar og raude hundar. For at WHO skal kunne nå desse måla, er det viktig at alle land følger opp med vaksinasjonsprogram og tilbod om reisevaksinar (WHO, 2012).

\section{Intensivert overvaking av polio}

Polio var tidlegare ein frykta sjukdom. Etter innføring av poliovaksine i vaksinasjonsprogram er polio utrydda i store delar av verda. Europa blei erklært poliofritt i 2002. I løpet av det siste året har vi på nytt sett ei kraftig auke i tilfelle av polio i Midtausten, Afrika og Asia som følge av manglande vaksinering. WHO erklærte derfor i mai 2014 at poliovirus på nytt er ein trussel mot internasjonal folkehelse.

Mange personar frå land med polio søker opphald i Noreg. FHI har intensivert overvakinga av polio, og vaksinasjonsarbeidet for personar som kjem frå desse landa, er styrkt. Eit av tiltaka er gratis poliovaksine. I tillegg tilrår vi vaksinasjon før reise til land med utbrot av polio (FHI).

\section{Meslingar - krev høg vaksinasjonsdekning}

Meslingar er den alvorlegaste barnesjukdomen og ein av dei mest smittsame sjukdomane våre. Fleire andre land, både i og utanfor Europa, har stadig store meslingutbrot, og sjukdomen er ennå ei viktig dødsårsak for barn.

I 2012 reknar WHO med at om lag 120000 barn døydde av meslingar, de fleste i låginntektsland (WHO).

Etter at vaksine mot meslingar blei ein del av barnevaksinasjonsprogrammet, har vi hatt svært få tilfelle av sjukdomen i Noreg. Dei få tilfella vi har sett det siste tiåret, har vore knytt til smitte i andre land.
Sidan meslingar er svært smittsamt, krevst det ei høg vaksinasjonsdekning for å nå målet. I Noreg er det derfor tilbod om ei kombinasjonsvaksine mot meslingar, kusma og raude hundar til personar som ikkje har hatt sjukdomane eller ikkje er vaksinerte. Vaksinen blir også sterkt tilrådd for personar som skal reise til land som har meslingutbrot.

\section{Vaksine mot raude hundar er viktig for gravide} Raude hundar (rubella) kjem av rubellavirus. Sjukdomen er vanlegvis mild, men hos gravide kan han føre til abort og alvorleg fosterskade. Infeksjon i første halvdel av svangerskapet gir 50-80 prosent risiko for abort eller fostermisdanning som døvheit, blindheit, hjartefeil, hjerneskade og anna (medfødd rubellasyndrom).

Vaksine mot raude hundar blei innført i det norske barnevaksinasjonsprogrammet i 1978. Det primære målet med vaksinasjon er å unngå medfødd rubellasyndrom som følge av infeksjon under svangerskapet.

Frå 1983 har det vore brukt ei kombinert vaksine mot meslingar, kusma og raude hundar (MMR-vaksine). Du skal ikkje ta vaksine mot raude hundar dersom du er gravid eller er i den siste månaden før planlagt graviditet. Vi tilrår at gravide tek ei screening (test) for antistoff mot raude hundar. Dersom antistoff som teikn på vaksinasjon eller tidlegare gjennomgått sjukdom ikkje kan påvisast, tilrår vi at barselavdelinga eller helsestasjonen vaksinerer mor kort tid etter fødselen.

Vaksinasjon har gjort raude hundar til ein sjeldan sjukdom i Noreg. Denne gunstige situasjonen kan vi berre halde ved lag ved å ha så høg immunitet $\mathrm{i}$ befolkninga at virus ikkje får moglegheit til å sirkulere.

\section{Nasjonalt vaksinasjonsregister (SYSVAK)}

Alle vaksinar som er gitt i barnevaksinasjonsprogrammet, skal registrerast i det nasjonale vaksinasjonsregisteret SYSVAK. Frå 2011 skal også vaksinasjonar til vaksne registrerast etter samtykke. Registreringa gir grunnlag for den nasjonale overvakinga av vaksinasjonsdekninga, og dette er avgjerande for å måle effekten av vaksinasjonsprogramma.

Gjennom tenesta Mine vaksinar kan alle over 18 år finne vaksinasjonsopplysingar for seg sjølv og eventuelle barn. Du kan hente ut vaksinasjonskort. Tenesta er nettbasert og er tilgjengeleg på helsenorge.no. 


\section{Biverknader blir overvaka}

Statens legemiddelverk overvaker biverknader etter vaksinasjon i samarbeid med Folkehelseinstituttet. Dette spontanrapporteringssystemet er basert på meldingar om mistenkte biverknader som blir sende inn av både helsepersonell og privatpersonar. Dei fleste meldingane etter vaksinar som er gitt i barnevaksinasjonsprogrammet, gjeld milde og kortvarige hendingar og samsvarer med det som allereie er kjent av biverknader for desse vaksinane.

Det kan oppstå mange hendingar i tida etter ein vaksinasjon som ikkje har anna samband med vaksinen enn tilfeldig samanfall i tid. Ei biverknadsmelding betyr ikkje nødvendigvis at det er ei årsakssamanheng mellom vaksinasjonen og symptom/sjukdom som oppstod i ettertid. Mistanke om biverknad er tilstrekkeleg for å melde.

Etter influensapandemien i 2009/2010 blei det først i Sverige og deretter i Finland oppdaga auka førekomstar av narkolepsi hos barn som var vaksinerte med pandemivaksinen Pandemrix. Narkolepsi er ein sjeldan søvnsjukdom der det vanlegvis går lang tid frå symptoma startar til diagnosen blir stilt. I Noreg er det sidan rapportert om cirka 100 tilfelle av narkolepsi hos vaksinerte barn og nokre få tilfelle hos vaksne. Mange har fått erstatning frå Norsk Pasientskadeerstatning.

Folkehelseinstituttet følger situasjonen nøye og arbeider blant anna med ein omfattande studie for å kartlegge førekomsten av narkolepsi i Noreg før og etter pandemien i 2009. Målet med studien er å sjå på kva vaksinasjon har å seie for risikoen for å utvikle narkolepsi.

\section{Vaksinasjon er framleis viktig}

Vaksinasjon er eit svært effektivt førebyggande tiltak. Etter at barnevaksinasjonsprogrammet blei etablert i Noreg, har sjukdomane i programmet nesten blitt borte.

Når kjennskap til og kunnskap om sjukdomane og konsekvensane deira forsvinn, kan behovet og forståinga for vidare vaksinasjon bli redusert. Det auka talet på poliosjuke i Midtausten, Afrika og Asia i 2014 er ein viktig illustrasjon på kva som kan skje når vaksinasjonsprogramma bryt saman. Med omfattande reising mellom land er smittsame sjukdomar ei global utfordring.
Det er avgjerande å halde ved like gode vaksinasjonsprogram og ei høg vaksinasjonsdekning for å halde førekomsten av smittsame sjukdomar låg også i framtida.

\section{Referansar}

Baldur-Felskov, B, Dehlendorff, C, Munk, C \& Kjaer, SK. (2014.) Early Impact of Human Papillomavirus Vaccination on Cervical Neoplasia-Nationwide Follow-up of Young Danish Women. J Natl Cancer Inst 106(3).

Blomberg, M, Dehlendorff, C, Munk, C \& Kjaer, SK (2013). Strongly decreased risk of genital warts after vaccination against human papillomavirus: nationwide follow-up of vaccinated and unvaccinated girls in Denmark. Clin Infect Dis 57(7): 929-34.

Brotherton, JML, Fridman, M, May, CL, Chappell, G, Saville, AM et al (2011). Early effect of the HPV vaccination programme on cervical abnormalities in Victoria, Australia: an ecological study. The Lancet 377(9783): 2085-92.

Crowe, E, Pandeya, N, Brotherton, JML, Dobson, AJ, Kisely, $S$ et al (2014). Effectiveness of quadrivalent human papillomavirus vaccine for the prevention of cervical abnormalities: case-control study nested within a population based screening programme in Australia. Br Med J 348 (1458).

FHI; Folkehelseinstituttet. 2014a. Meningokokkvaksinasjon - rettleiing for helsepersonell. Oslo: Folkehelseinstituttet.

FHI; Folkehelseinstituttet. Nye råd om poliovaksinasjon ved opphald i land med utbrot av polio. [henta 1/9/2014].

FHI; Folkehelseinstituttet. Råd til publikum om influensaførebygging og vaksine - sesongen 2013-2014. [henta $1 / 9 / 2014]$

FHI; Folkehelseinstituttet. Vaksinasjon i ulike livsfasar. [henta 1/9/2014].

FHI; Folkehelseinstituttet. Vaksinar for spesielt smitteutsette grupper. [henta 1/9/2014].

Statens legemiddelverk. Biverknadsrapport. Oslo: Statens legemiddelverk; 2013.

WHO (2012). Global Measles and Rubella - Strategic plan 2012-2020. Geneva, Switzerland: World Health Organization; 2012.

WHO. Factsheet Measles www.who.int [henta 15/9/2014].

\section{FORFATTARAR}

Lill Trogstad, Ellen Furuseth, Øystein Riise,

Marianne Bergsaker, Sara Watle 
Utgitt av Nasjonalt folkehelseinstitutt

Postboks 4404 Nydalen

0403 Oslo

Tel: +47-21 077000

E-mail: folkehelseinstituttet国fhi.no

www.fhi.no

\section{Bestilling:}

E-post: publikasjonafhi.no

Telefon: +47-21078200

Telefaks: +47-21078105

ISSN: $1503-1403$

ISBN: $978-82-8082-635-0$ trykt utgave

ISBN: 978-82-8082-636-7 elektronisk utgave

\section{www.fhi.no}

